總
㑹
演
顶

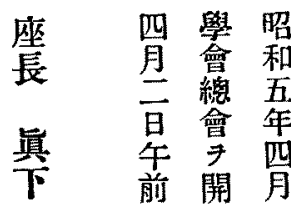

倰杂当白

開會, 夏

角

楠說 及

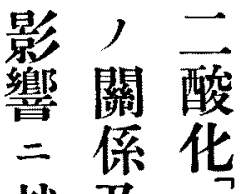

就及卜

テビリ

會討 四

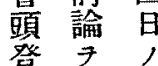

壇 位 三

簡 收 間

單 錄 犬

$\frac{11}{\text { 酸 }}$

化

a

I

$\stackrel{\sim}{*}$

網

狀

同
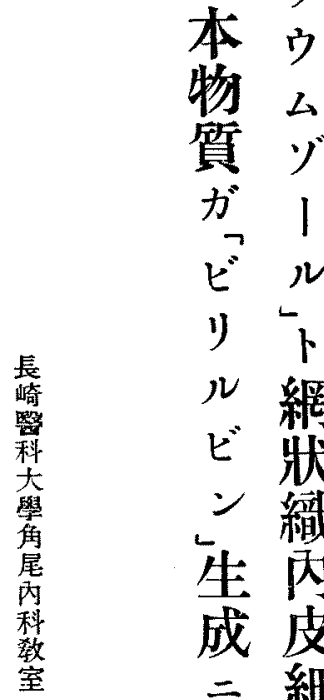

物

質 ゾ

ガ

ビ ル

リ 下

開架

會年,

铰島

F 岛

+ 央

尘

直愈

$\frac{x}{x+20 \times x \times x}$

總

祖

雷

x.

弐演

ル 細

ビ 蛙

$ン$ 綪

關尾 生

成皮

二 細

森中岩角

及 胞

ボ系

村 尾

ス 卜

尾

吾英忠

䲞夫治 晋

㸛日

和本

五科

年會

五雔

月第

十午

日卷

發第

行號 
狀.來取 こ更三カリレこ著二ト先シタレ, 昭

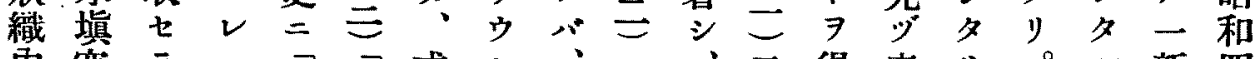

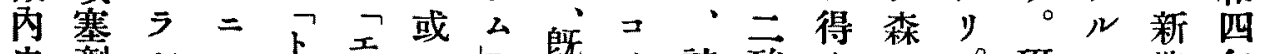

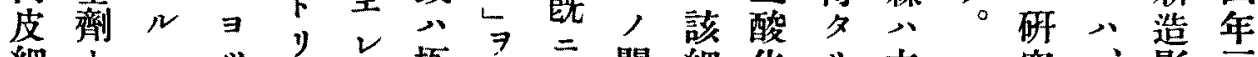

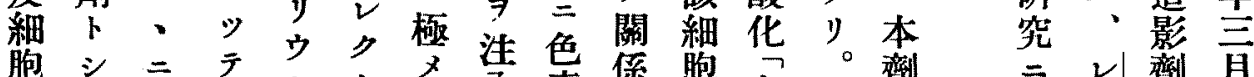

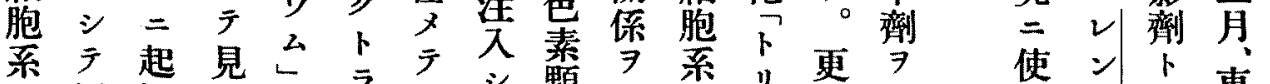
, 用因 填 塞ラN 三 入 使々, 酸ス攝生取 スウ!影家

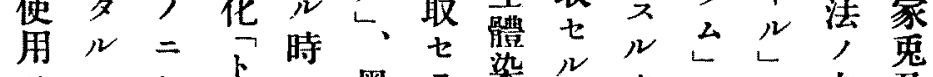

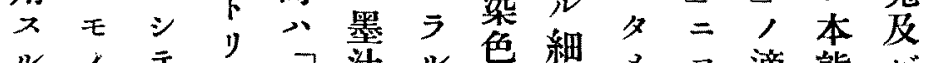
ルンテ、ウト莐ル色細メョ適態ビ

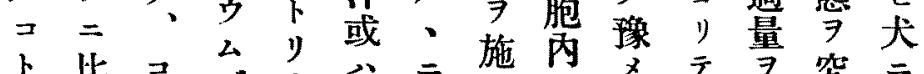

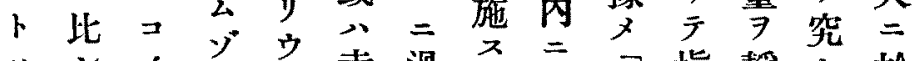
極亏點 1

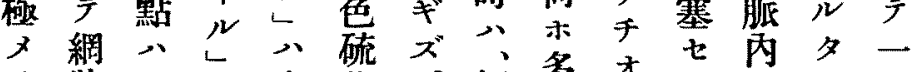

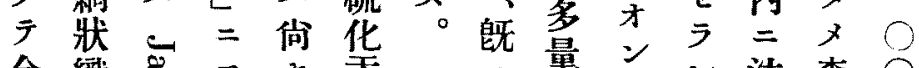

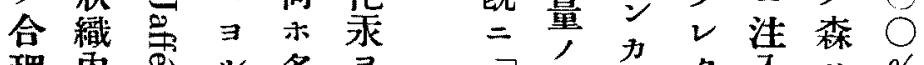

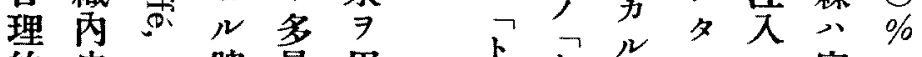
的皮邓脾量用占卜尗年家二

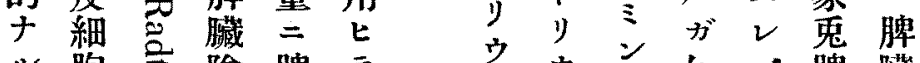
胞‡㓌脾テ方ウさ如心脾臟

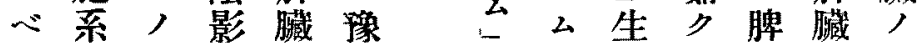

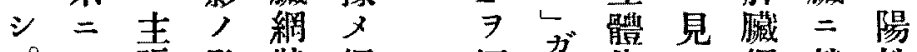
殊当張發狀網攝攝染工絧就性

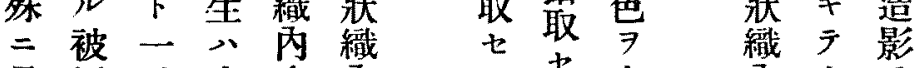
最攝致主皮內年宁完丙次 $\exists$ 乇取 ス下細皮細 今成皮, 優能。シ胞細胞得 $シ$ 細如 力佾テ丙胞丙得置胞手得 夕更本網二系 點卡狀攝丘 八大获塞

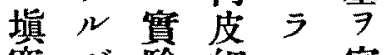

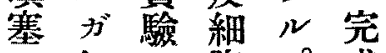
七如寻胞。成 ; $\forall=$ ᄂ。見 $\exists$ 夕從 2 , 几 阝本該 否本物物

学算等方 4 網從攝

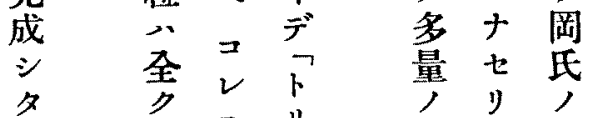
$=\mp$ 两組 $r$ 、层 $=$ 織 色点 2 的卜 素 $\exists=$ 極檢 $尹$

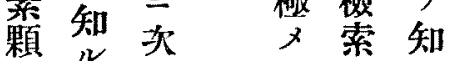
粒先公

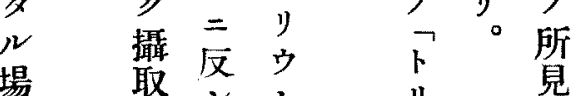
場 合

$=$

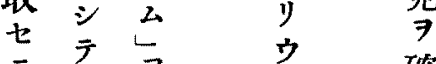
亏痤学確 告灵染公 ザ巽瓷

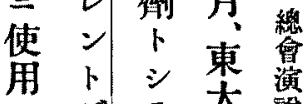

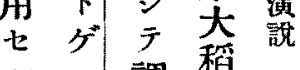
次調榃角 覺製离捅 化界去科 管父烊

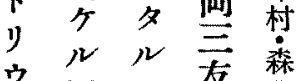

公近焉型 乘酸酸

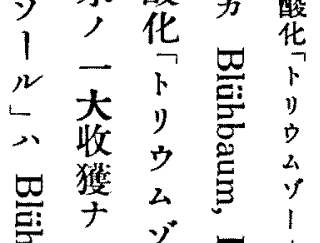

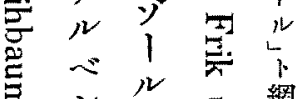

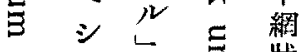
及。马言㽞 飞余用西觉

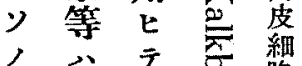

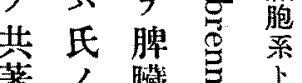

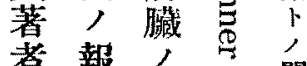

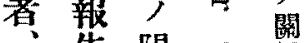
岡告惕 氏接造》㙰 等 ス影 分法

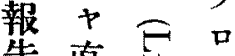
告南家品 掉二娄 少, 总吾 角追試= 佂試成 萻盛》 調手芦 1 
第一表 二酸化「トリウムゾール」注射後脾贜灌流試驗

\begin{tabular}{|c|c|c|c|c|c|c|c|c|c|c|}
\hline \multirow{5}{*}{$\begin{array}{l}\text { 䶝 } \\
\text { 照 } \\
\text { 試 } \\
\text { 驗 }\end{array}$} & \multirow{3}{*}{$\begin{array}{l}\text { 灌 } \\
\text { 流 } \\
\text { 月 } \\
\text { 日 } \\
5 / X\end{array}$} & \multirow{3}{*}{ 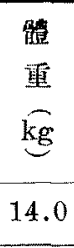 } & \multirow{3}{*}{ 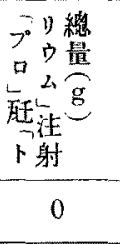 } & \multirow{3}{*}{ 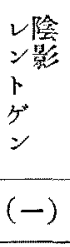 } & \multirow{2}{*}{\multicolumn{2}{|c|}{ 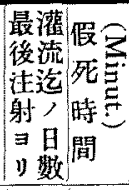 }} & \multirow{3}{*}{\begin{tabular}{|c|}
$\begin{array}{c}\text { 灌 } \\
\text { 流 } \\
\text { 血 } \\
\text { 量 } \\
\mathrm{ccm}\end{array}$ \\
210 \\
2
\end{tabular}} & \multirow{3}{*}{ 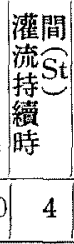 } & \multicolumn{2}{|c|}{ 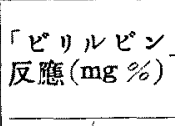 } \\
\hline & & & & & & & & & 前 & 後 \\
\hline & & & & & & 14 & & & $(-)$ & $\begin{array}{l}(+) \\
\text { 痕跡 }\end{array}$ \\
\hline & $21 / X$ & 14.3 & 0 & $(-)$ & & 20 & 200 & $|2.5|$ & $(-)$ & 0.82 \\
\hline & $12 / 8 I$ & 13.2 & 0 & $(-)$ & & 18 & 190 & 3.5 & $(-)$ & 2.07 \\
\hline & $14 / 8 I$ & 16.7 & $0.15 \times 1$ & $(-)$ & 1 & 10 & 220 & 4 & $(-)$ & 0.64 \\
\hline & $7 / X I$ & 11.2 & $0.15 \times 2$ & $(+)$ & 2 & 15 & 105 & 4 & $(-)$ & 0.56 \\
\hline 本 & $2 / \mathrm{XI}$ & 11.7 & $0.15 \times 2$ & $(+)$ & 1 & 17 & 190 & 3.5 & $(-)$ & 2.31 \\
\hline & $19 / 18$ & 12.0 & $0.15 \times 3$ & $(+)$ & 1 & 17 & 215 & 4 & $(-)$ & $\begin{array}{l}(+) \\
\text { 痕跡 }\end{array}$ \\
\hline & $14 / \mathrm{IX}$ & 6.7 & $0.15 \times 4$ & $(H)$ & 2 & 14 & 230 & 4 & $(-)$ & $(-)$ \\
\hline & 30/IX & 12.0 & $0.15 \times 4$ & $(t+)$ & 2 & 13 & 185 & 4 & $(-)$ & $(-)$ \\
\hline 試 & $26 / X$ & 11.3 & $0.15 \times 5$ & $(H)$ & 1 & 20 & 218 & 4 & $(-)$ & $(-)$ \\
\hline & $30 / \mathrm{X}$ & 8.4 & $0.15 \times 6$ & $(H)$ & 2 & 20 & 194 & 4 & $(-)$ & $(-)$ \\
\hline & $10 / X \mathbb{I}$ & 9.6 & $0.15 \times 6$ & $(t+)$ & 14 & 16 & 190 & 4 & $(-)$ & $( \pm)$ \\
\hline 1 踋 & $9 / \mathrm{XI}$ & 13.1 & $0.15 \times 6$ & $(t+)$ & 14 & 12 & 190 & 4 & $(-)$ & $\begin{array}{l}(+) \\
\text { 痕踪 }\end{array}$ \\
\hline & $11 /$ II & 8.7 & $0.15 \times 6$ & $(\mathrm{H})$ & 23 & 20 & 190 & 4 & $(-)$ & $\begin{array}{l}(+) \\
\text { 痕跡 }\end{array}$ \\
\hline & $18 / I$ & 9.7 & $0.15 \times 6$ & $(H)$ & 30 & 7 & 190 & 4 & $(-)$ & 0.3 \\
\hline & $27 / \mathbb{I}$ & 10.9 & $0.15 \times 6$ & $(H)$ & 30 & 12 & 160 & 4 & $(-)$ & 0.54 \\
\hline
\end{tabular}

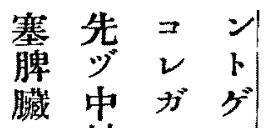

, 村

ビ シ 線

り本就 $=$

劑 ビ

ビ 录シリ

之用㫐方

生 テ成

成填二知

機塞及》

能セボ得

$=N \times N$

就 犬 影 點

キ , 響二

于 脾 7 存

八臟見

可剔占 是

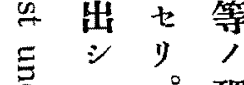

ב $ב$ 理

震 2 由

政 7

灌界

八粪等

影 天 八

響 当本

ナ 少㓧

新学用

去 ビ 用

云

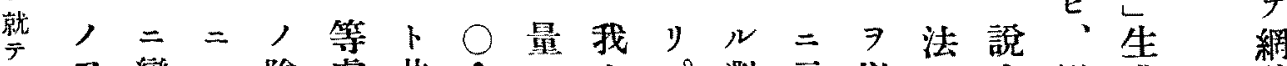

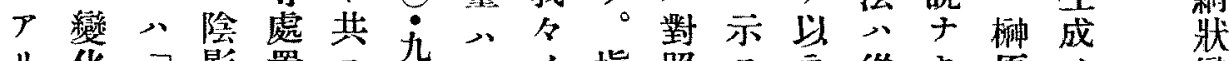

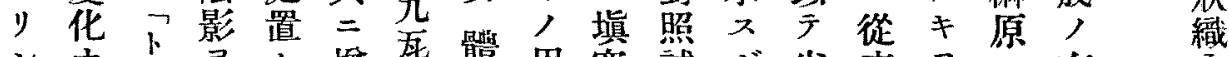

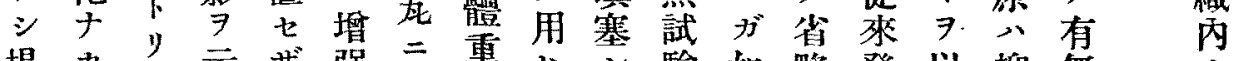

場カウ示ザ强 シ重七主驗如略發以抑無皮

合り

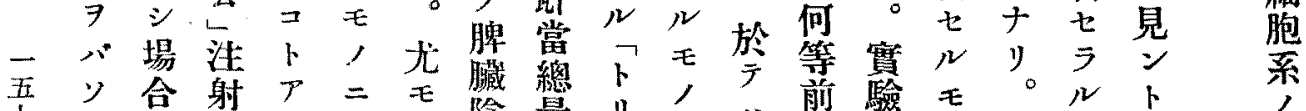

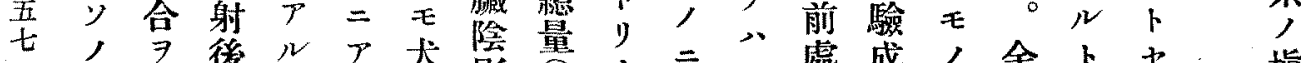

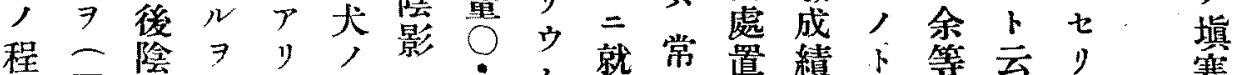

度二影以テ脾

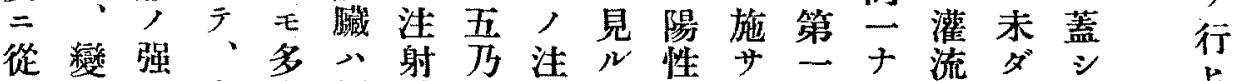

七华サ表少何量至射二ナザ表ル方定填 


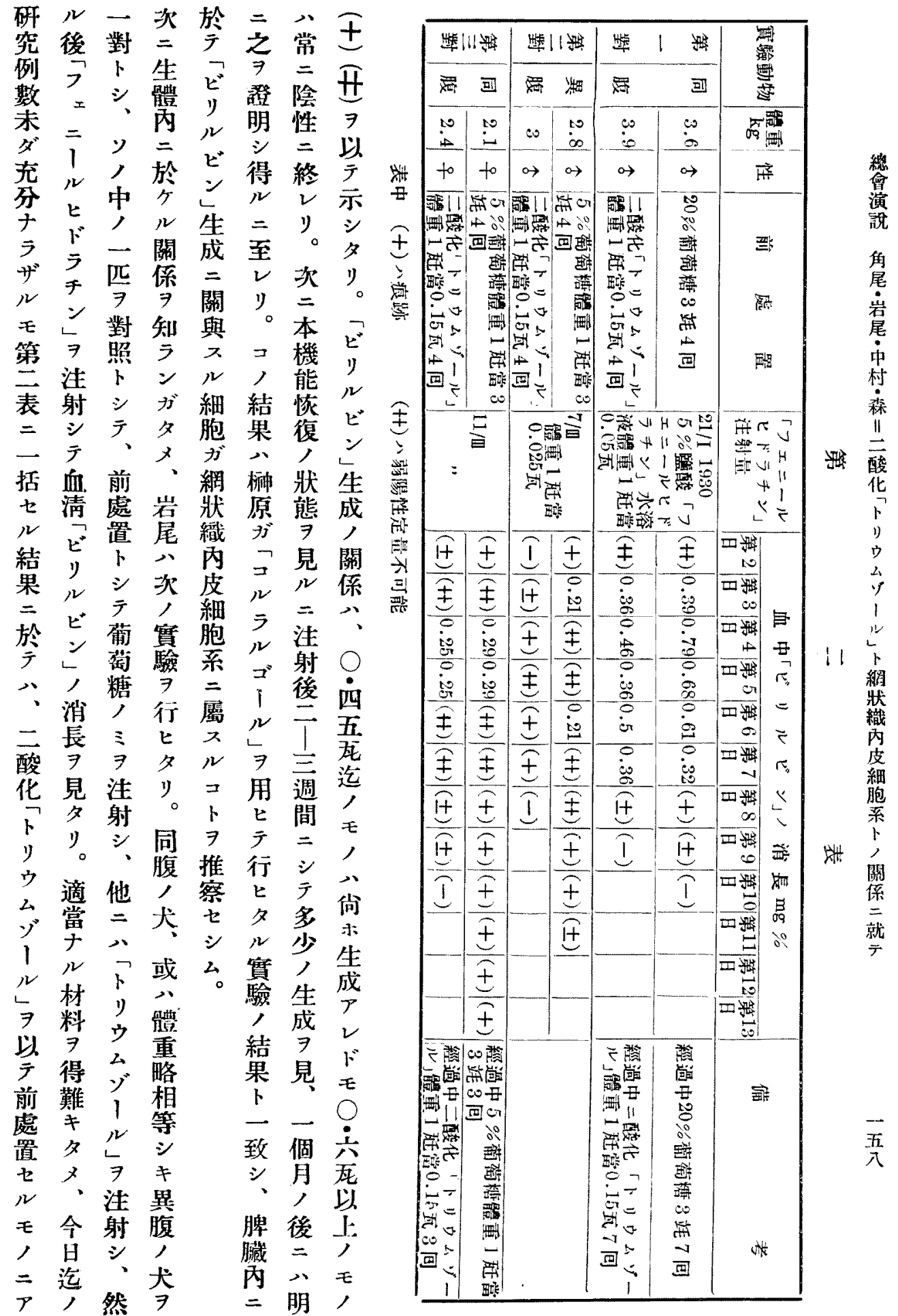




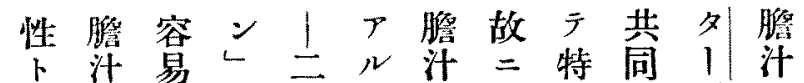
ナ丙 二重 $\overrightarrow{\mathrm{O}}$ 水酸、暴作!酸 シ $\exists$ 定 才り量ク $\%$ 內, 二小著 1 研

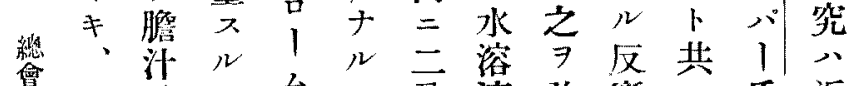

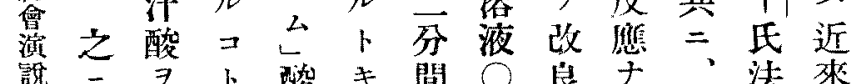
梳三卡酸 $\neq$ 間○良子、法来

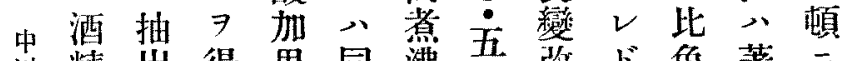
川精出得里同沸韋改ド色著二 藤 $尹$ ス心液 川投ルシ人色ル燐テ、二ク步

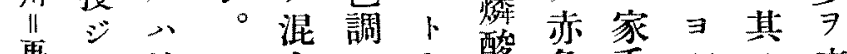

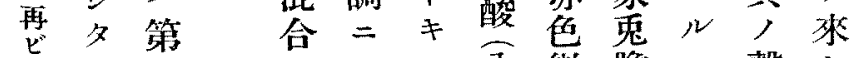
怔 $几$ -

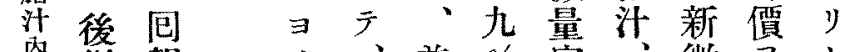
滕微報、美\%定、微 $\exists$ 卜 沙量告而心二量人量高踓 酸公三作王

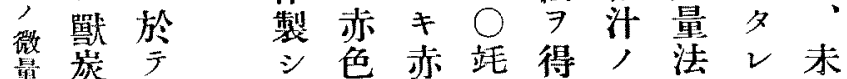

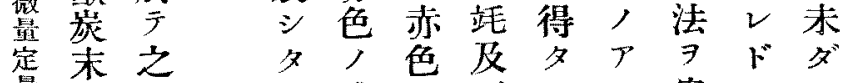

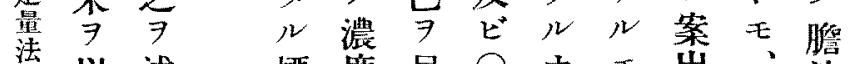
望述標度呈?ナモ出、汁

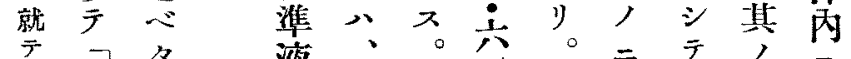
テ

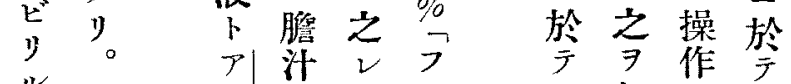
ル師酸赤ル報三 ビチ舀監色フ事告心ラ

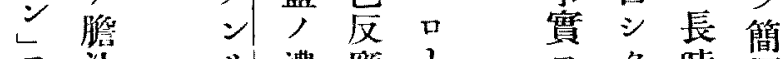

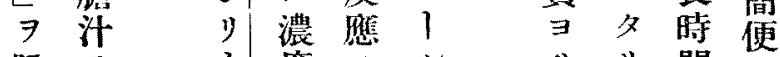
腼 $\exists \quad 1$ 度, 色先占正原酒

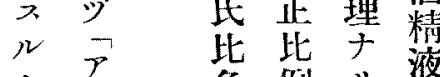

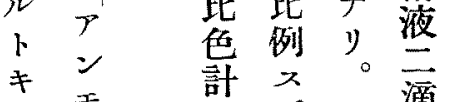
キ 容憵故 シ 加

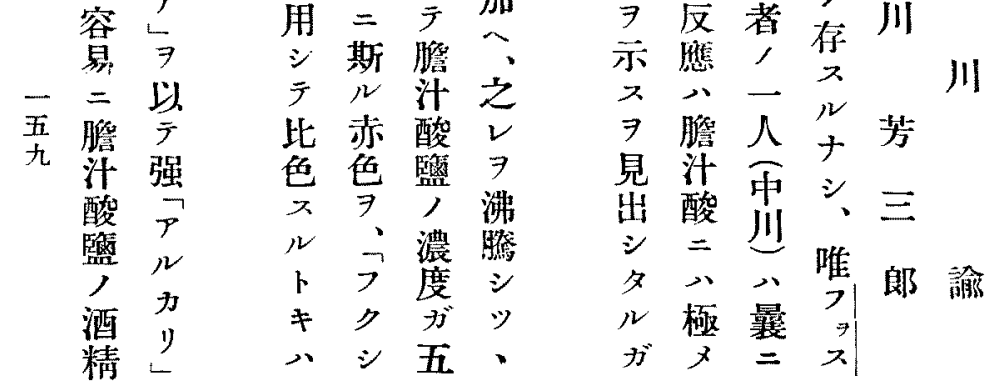

内 y $=\bar{\gamma}$ 於 八 手 モ清 E⿱ y $=\quad \begin{array}{r}N \\ \text { ビ }\end{array}$ 再告 ビ成出 膽卢頖 内忩些

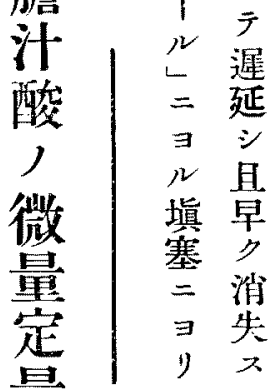
是 于 法多傾

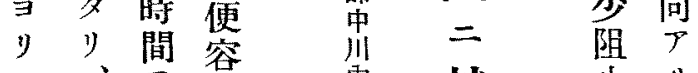

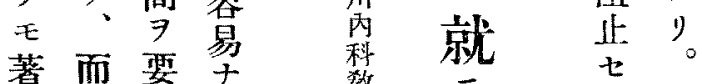

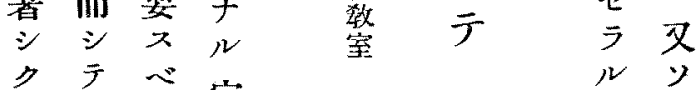
低該シ宣藤中、,

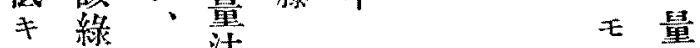
值䇼述法, 量 于常 s $=$ コ少 卜 F $\exists$ シ 知 12 郎 生 


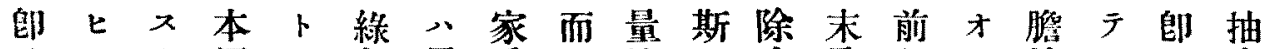
千 ${ }^{\exists}$ 万人一色暴鬼シ法

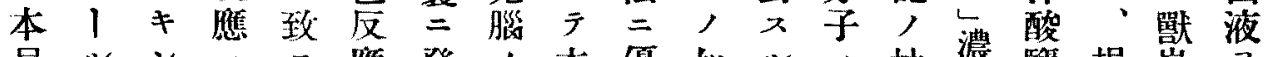

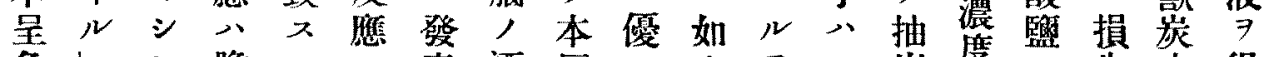
色酸七脆火只表酒反乚为

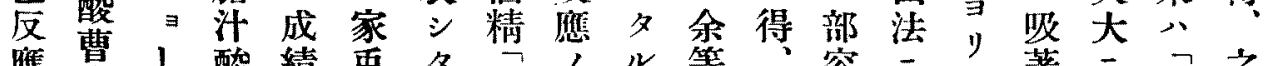

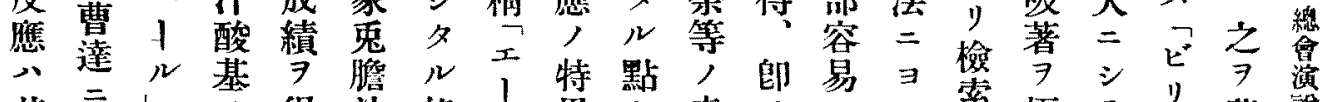

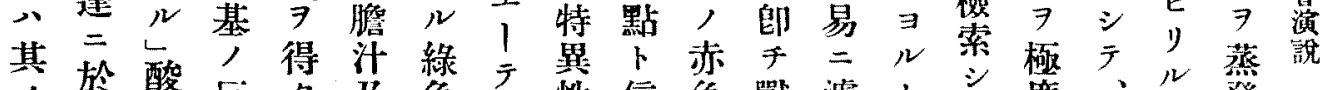

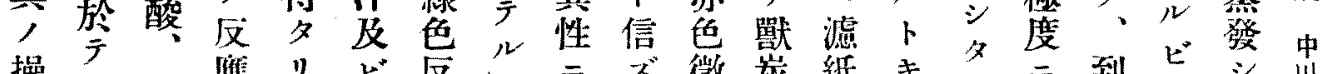

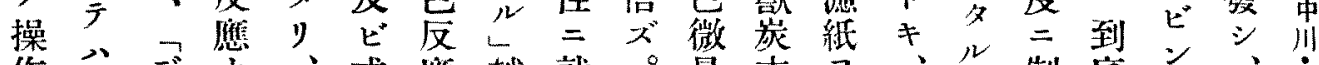
作一デナ、或慰越就 極 $\bar{O}$ 上, 其

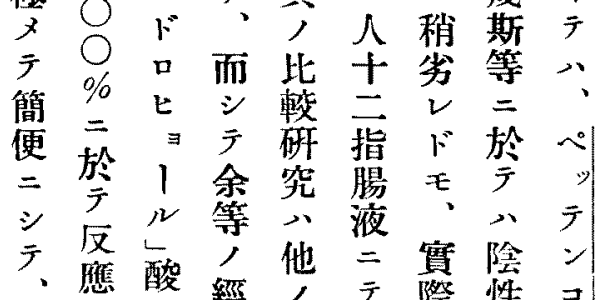
殊 。於驗教

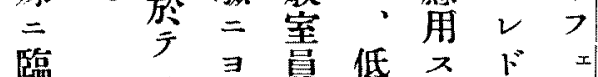

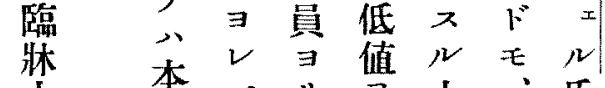

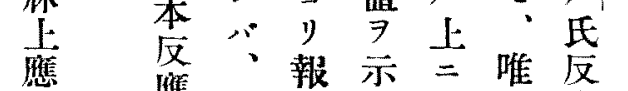

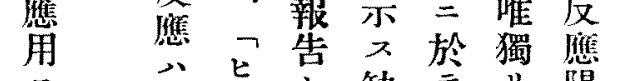

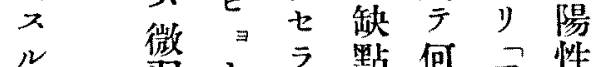

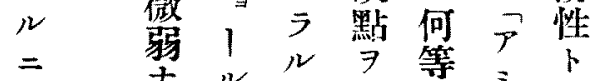
當 サハルバ

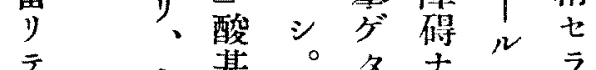

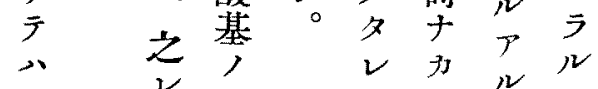
最二反踏、

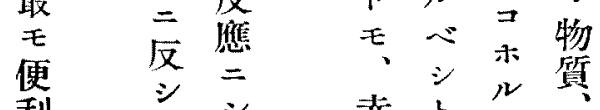
利 シ シ 赤卜必方 ナ、色信 $=$ テ

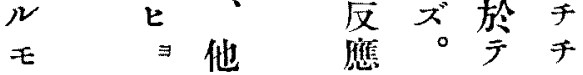

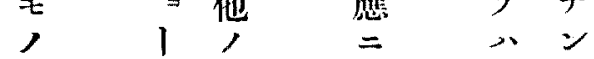

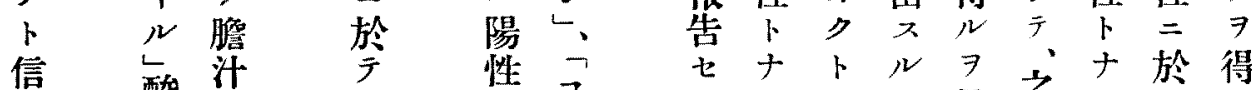

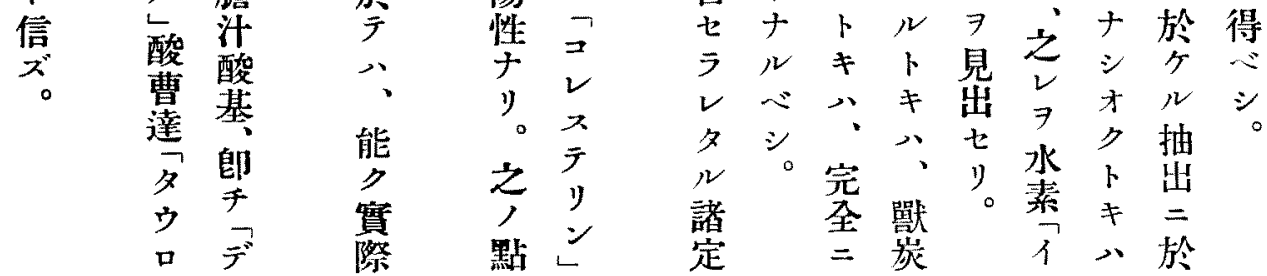




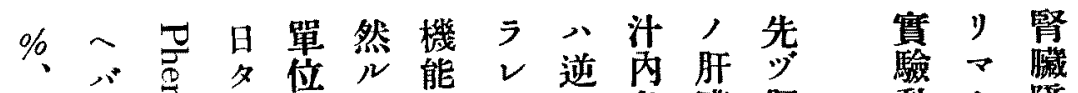

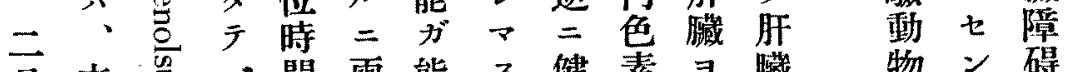

百本总心間雨能

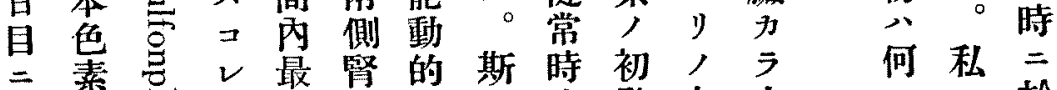

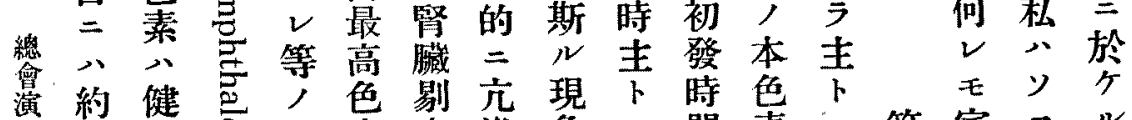

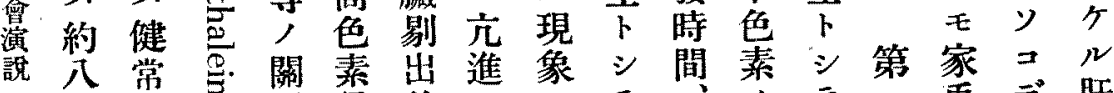

颈 $\bigcirc$ 時 二係量後

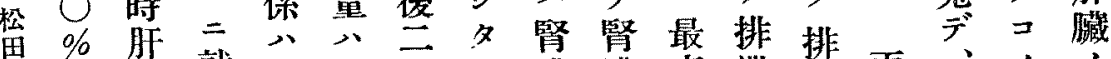

雷排藏就一著十卜蔵藏高泄泄雨、,

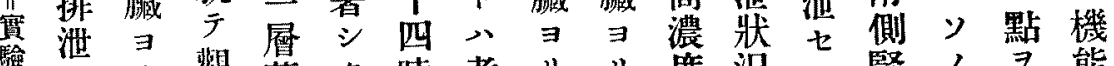

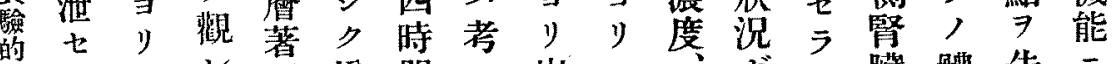

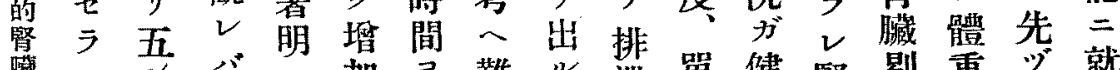

留

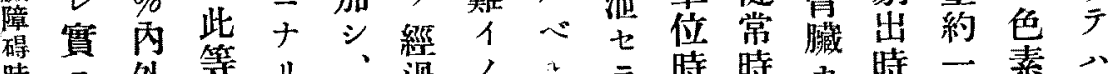

時二外等 y、過,

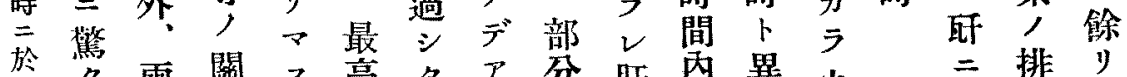

於名雨關 $又$ 高々ア分肝內異少二排り

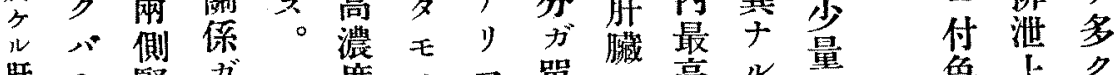

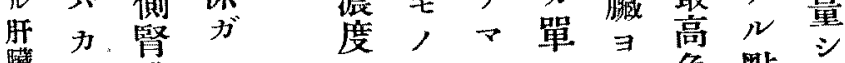

睵り臟 -

急多剔猎達 、。肝 、素分排

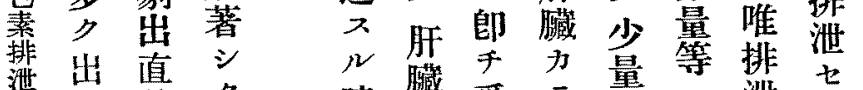

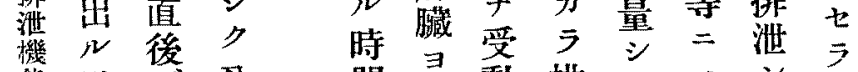

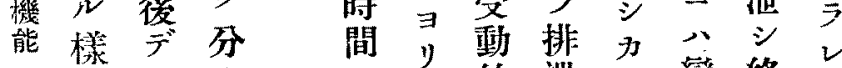

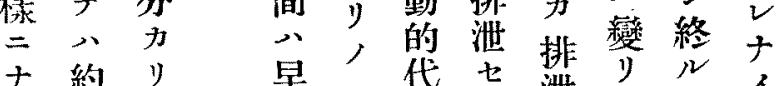

ナ約り 早只償

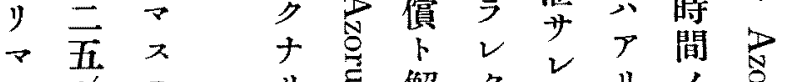

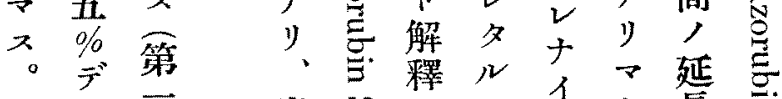

$>$ 圖出 U $x=1$ 七長声

\%圖終, 心過すン导心

夕。少初キ寻合、

モ便 時發モナ 尊第總就

, 宜間時ノ人姜排

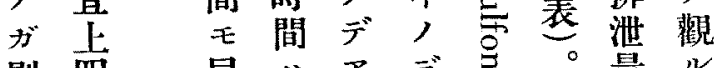

剔酉早ハアア゙导。量ル

出時 ク早りア居 $ォ$

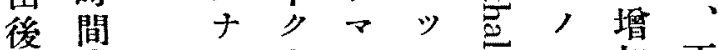

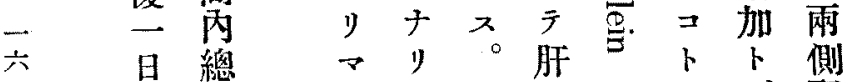

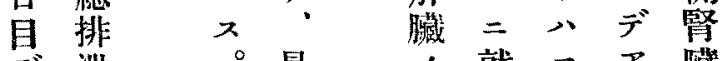

色上多

賓

䛗

的

腎

藏

障

碍

素寻,

時

液 少 研

一 襝 究

践 今

宛落ナ

注 $=$ 亿。

射 $y$

夺結 特

シ 果 經

タ $\Rightarrow$ 過

遐就

告追梏色

デ 泄

○最，就コア藏

光之排

八量剔高色示人ッ剔

約多出濃 素モ色テ、出

兵後度 排認素、直

思 観

已察

$\checkmark \Rightarrow$ 田

중

於

ケ

ル

肝

藏

○言 三泄

$x$

, 武

殆

夫夫 


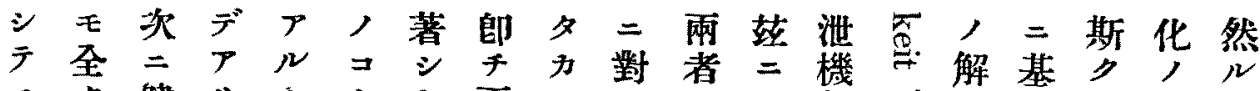
モ夕健り卜トキ雨卜卢く能デ沈尖, 程二 肝出常 $、$ 八差側言 臟ナ時

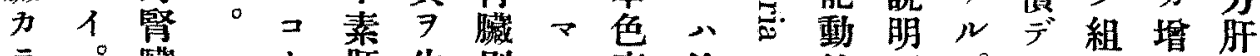

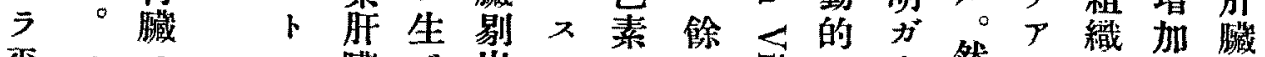

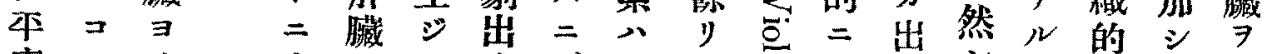

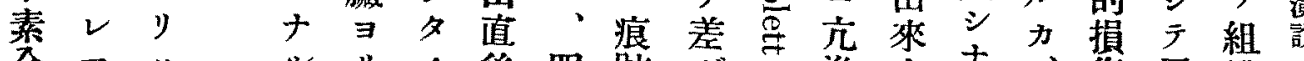
全マハル，後四跡ガ進ナナナ、隽居䅧

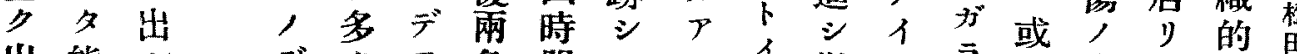

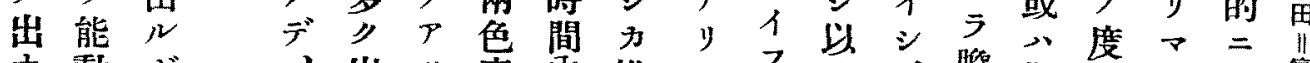

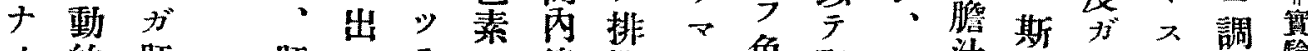

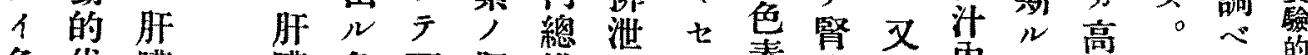

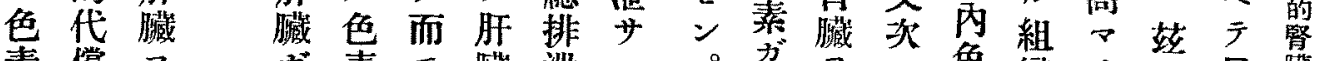

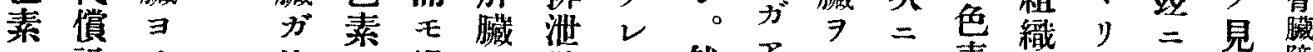

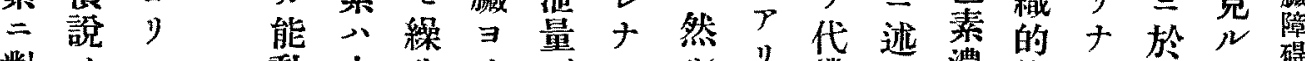

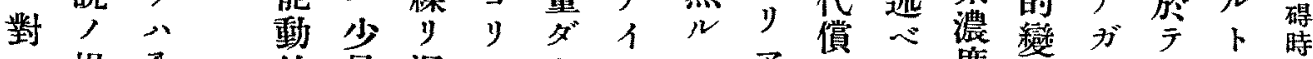
シ 根全的量返, 个, = $>$ 个 テ據

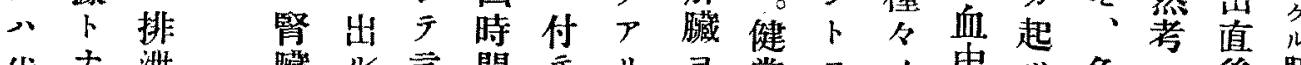

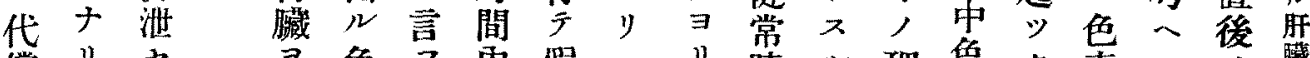

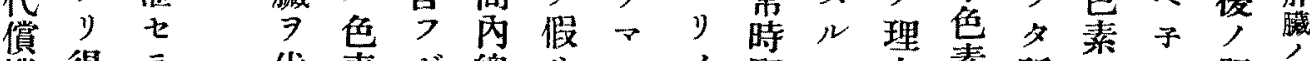

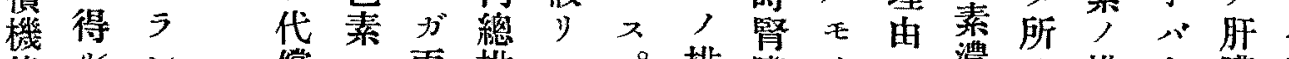
能ルレ償 $ニ$ 兩排

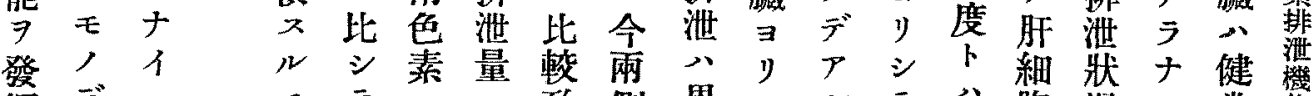

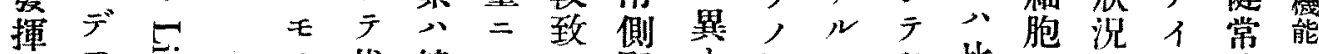

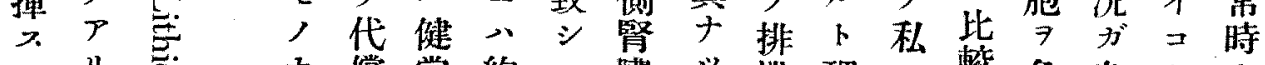

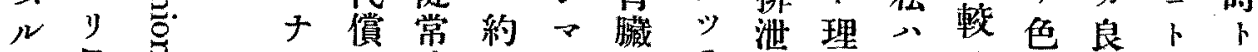

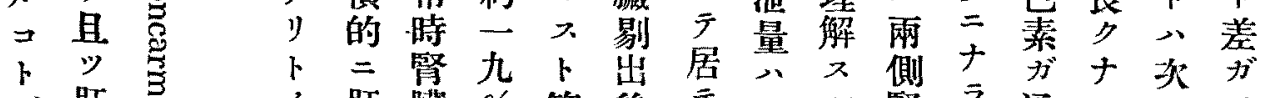

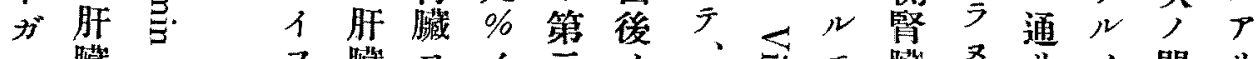

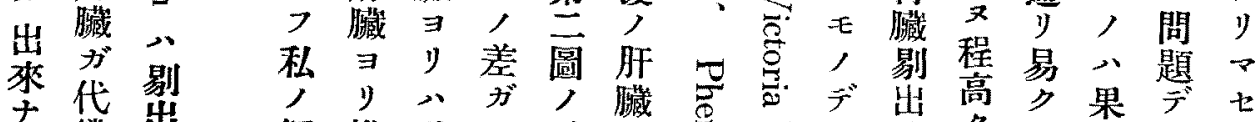

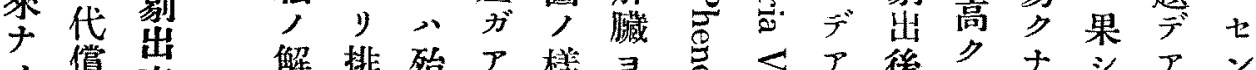

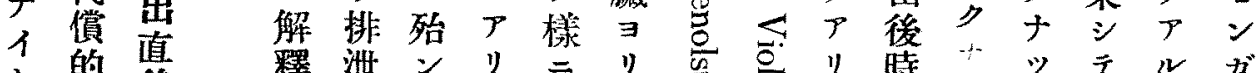

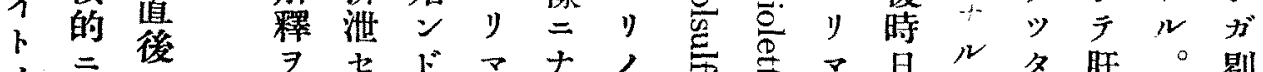

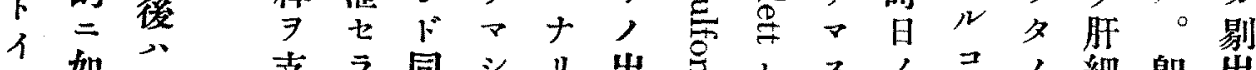

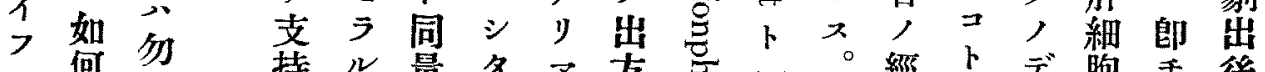

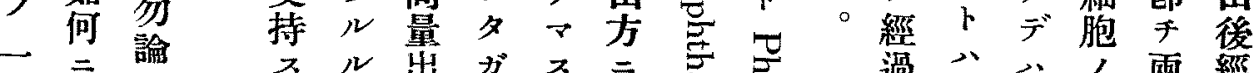
定台一

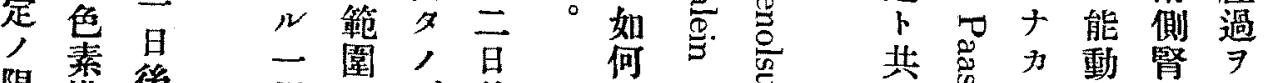
限排 後 根 ガ 定沘二據著 7 機旦

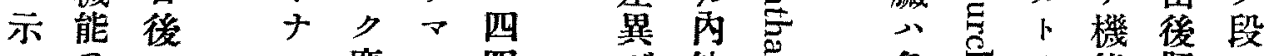

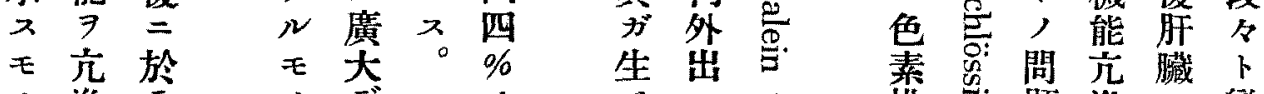
, 進テ, デコ, 
，側卜 剔 导 兩 兩

色筒ナ出导 侧 侧

素歲 ツ時 堅腎

排剔夕卜占藏臟

泄出卜比，剔動

機 $\exists$ 亿較排出輀

總能行

會 $\exists$ 演 $ン$ 泄場結

境代夕明心兩合禁第 償 場 $テ$ 第側 $⺊$ 直 三 照

出 宽機モ盾, 留 驗能認 7 样忽ル臟堅 留 $\exists$ 来二出卜弓臟

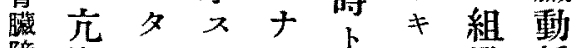
障進, ノリ八 八織静 時シデデー 界一的脈 得 $\gamma r$ 又異層所結

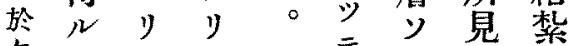
ルガ マ マ 肝、シ 爫, 居損健

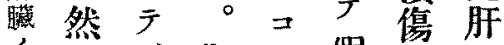
色 、斯卜假光卜

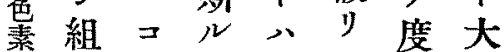
翡織 $v a$ 肝 $=$ ガ $^{*}$ 涂的等

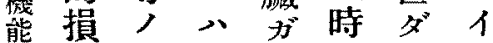
傷 コラ組間 シ 。 ガトク織丙イ然 强 $、$ 的肝,

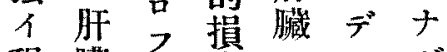

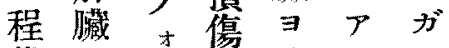

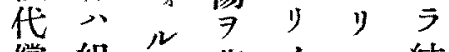
償組公蒙ノ 機織 ム 能的 デタ宁吕 >損豫夕导 此 日 軼傷 メ 吾際後 圍 $\exists$ 朋 $=$ 夏肝 八蒙細。导臟 日 减》胞怘壱 $\exists$ 後

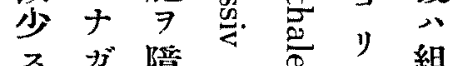

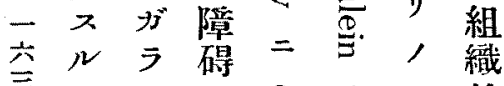
三 $₹ \quad \Sigma \cong, \nabla$ 的 , 少于芌總哥損 ナ良置导排名傷

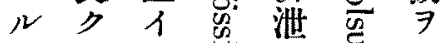
事 㹂
七レモル, 以力監フ田デ 子ル, $ル コ$ 上二蔵り芭

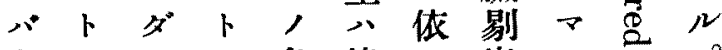
ナイラ フ色總 ツ 出 ス

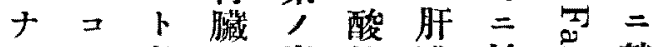
1。考㔀出性臟於怘就 ソラ = 色ミ市? 観 , $、 \exists$ 餘素 $\exists$ 平?

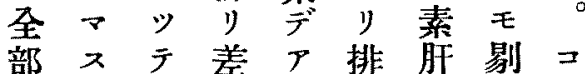

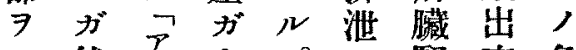

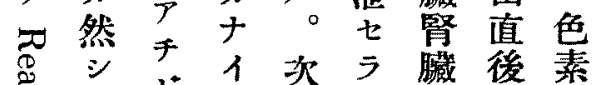
总 亥

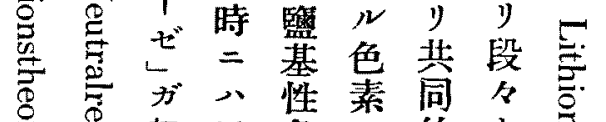
灾起二色 二的卜号

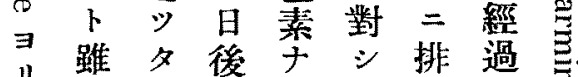
1飞夕, 壬 影剔メ方々

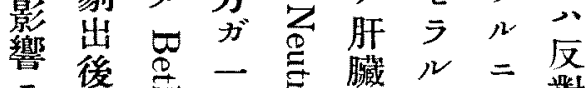

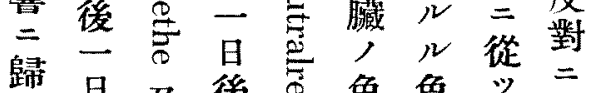
歸白及㣪官色色二

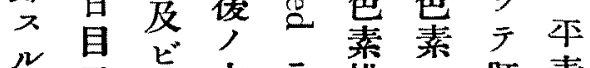
二 三 方 就 排

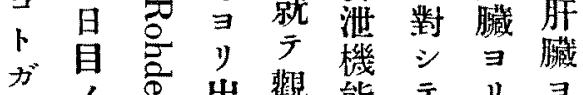
出方, 出漞能

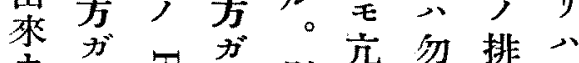

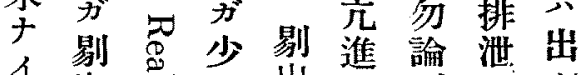
イ 出 至 $シ$ 嵌 矢直恶後 張後总方六卜ル次腎 リノ客栐旦人ガ良臟

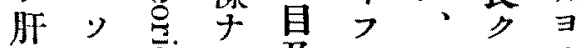
臟 $レ \bar{D}^{\circ}$ 及コ本ナり , $\exists=ト$ ビ 素り

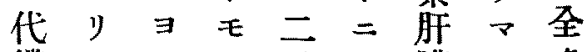

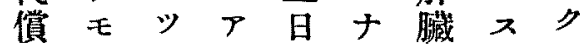
機 $\exists$ テ目ルノノ"出 能》影子ノ $>$ 特然

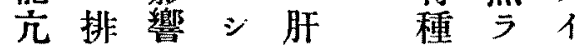
進泄サ夕臟藏至 こ七レ海雨, 歸ラタ斯り臎側デ 


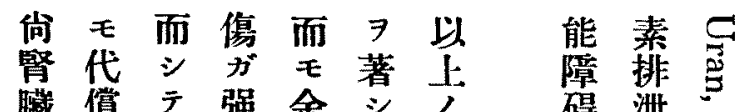

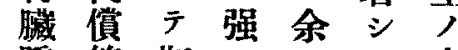

障 範 斯使, 事

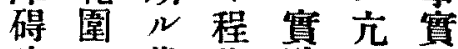

時 $\rightarrow$ 代代 驗進

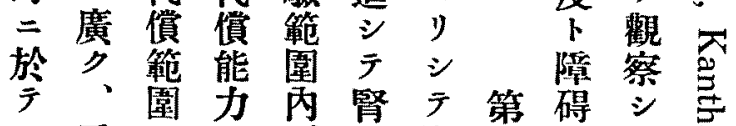

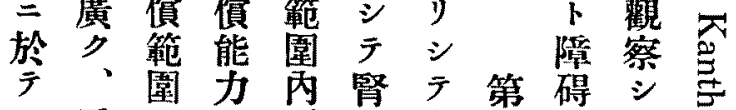

、又二小デ藏腎五後 マ高. 四

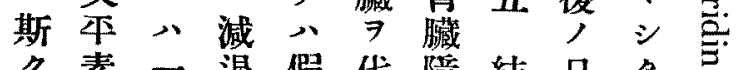

夕素一退假代暚結日 タ

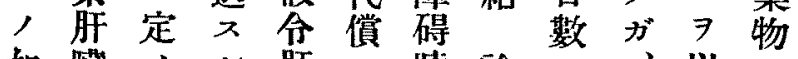

如歲, $⿻$ 肝 $又$ 時諭 $=$ 以

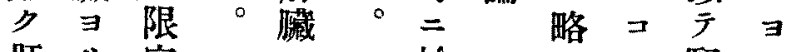

肝y定分於简

臟全 $ア$ 組采祭藏腎

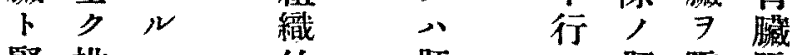

腎排モ的肝方阶障障

臟泄, 損歲

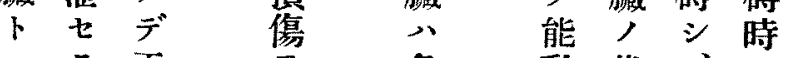

$=$ 本

共 $サ$ 素 蒙 素

色動代:

ナル臟排 モ蓝腎

色帅赤泄色物臟

機素 リ ラ 上 素, 剔

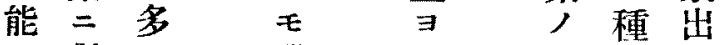

人對夕り排類時

ミ シ 出 能 觀 泄 $=1$

ガテル的機特同

代八色二䨞 能有嵄

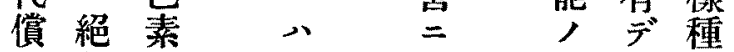

的對二代受亲心多

二 数 償動進ナノ

充腎 性的色

進 臟 テ

不

代少

ガ

，償 量

著要

₹ $\quad=$

十 得 出

j十

ズ、色

訮 云 然 毛

明龺

今 ル 各 素

$=\quad 5$

7 藥 用

知 物

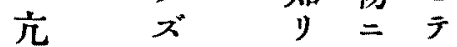

進能佊訮

$\begin{array}{llll}\text { 特 } & \text { 組 胞 } \\ \text { 種 } & \text { 織 } & & \end{array}$

シ $ル$ 臟

ス動

N 的

夕腎及

$=\circ$ 臟 ビ

モ ノ腎

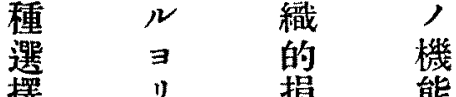

色 臟

素

排 y

泄,

機色

、 局，偏示

スル小等 側

モ殘臟堅

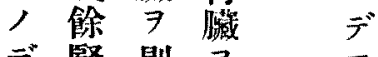

デ腎剔 $\ni$ ア

$\boldsymbol{P}=$ 出剔り

ッ $\exists$ 出

テツ テ シ

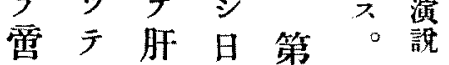

二完縅 7 严松

受全, 追一想

硕三色方俯

的 代素 テ 側 筑

代償排肝堅的

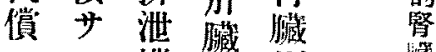

$=レ$ 機及剔险

止 $\checkmark$ 能残出 碍

$\nabla 7$ 稌時時

ブ"然篮於

尚

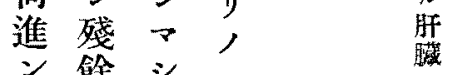

デ婜タ

能 $=\boldsymbol{s}^{*}$

動 完偏

的 全 側

$=$ 二敁

色代藏 哥

素 償 $\Rightarrow$ 异

排七剔五

泄 5 出 导

機 レセ

能

$\Rightarrow$ 迄場排

元, 合 渄

進經

又過 八粯

出從察

$\tau=$ 承

, 於 $\exists$ 或

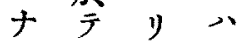

ル 脈 謂 實

$\Rightarrow$ 臟 $>$ 驗

知 $千 v$ 直

就

夕代军二

ノ償 ル更

デ 二嵄 二

$\boldsymbol{\gamma}$ 關 $=$ 残

り與結り 


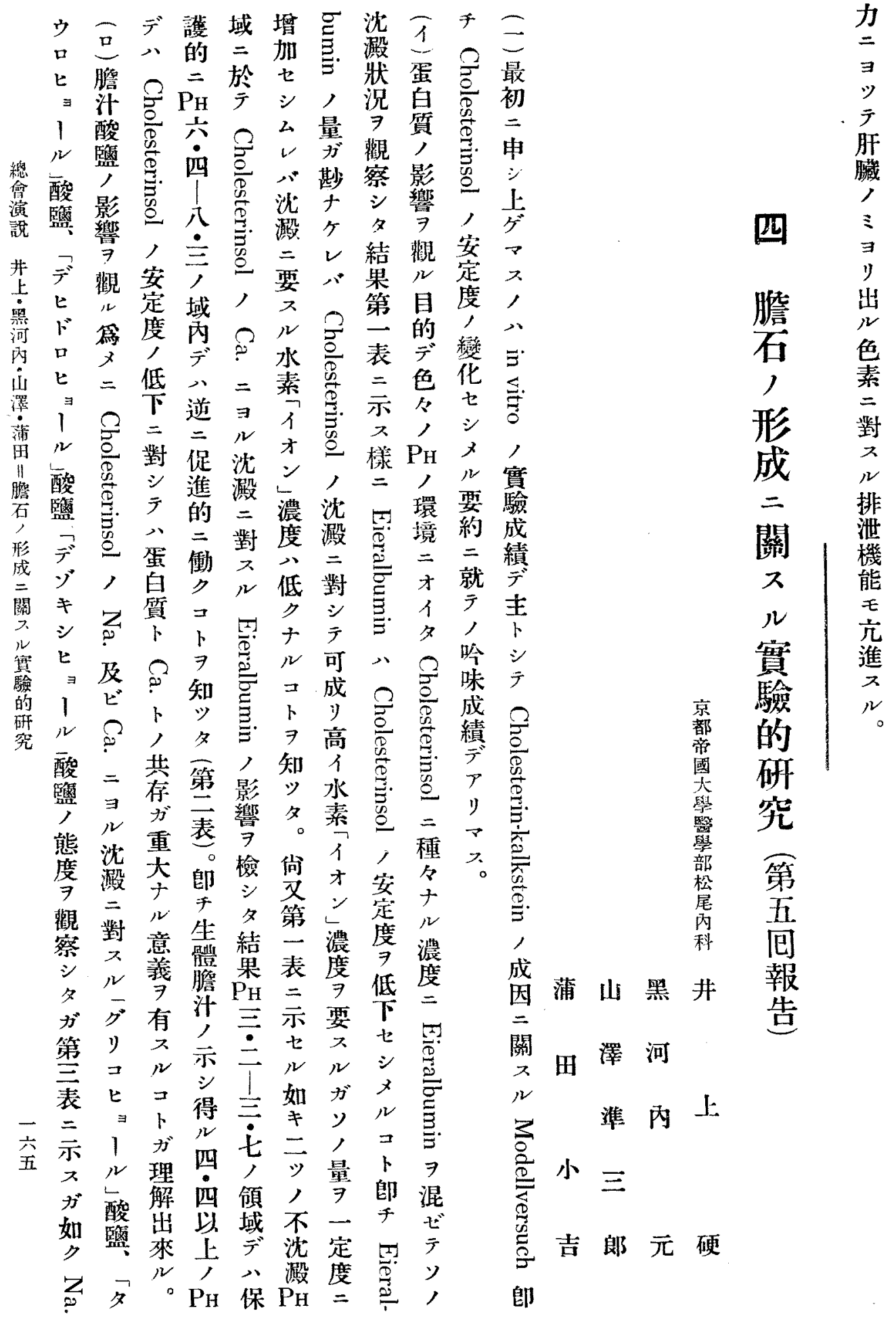




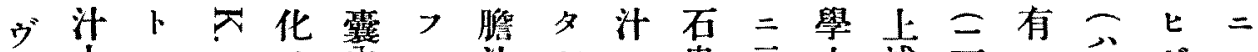

1 中八, 而 $ル$ 汁 $N$ 患示士述三ス已

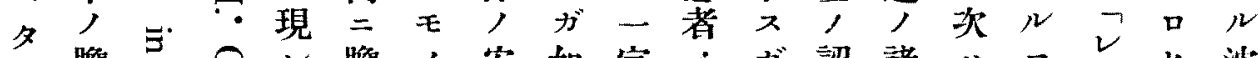

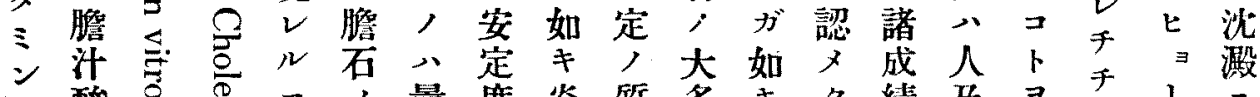

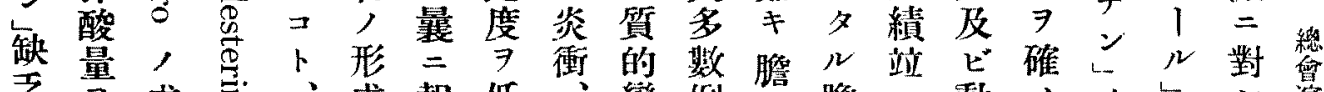

之 成声、成報低、變例石膽二動

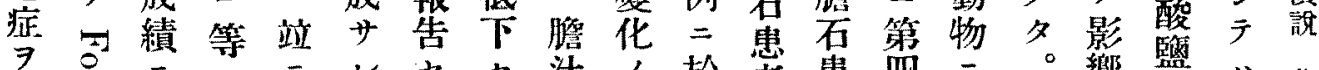

起帛 $=$ 三

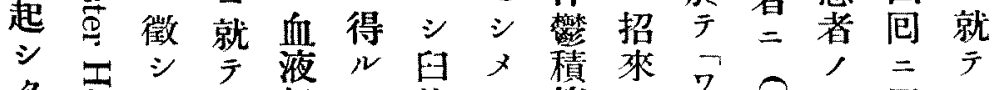

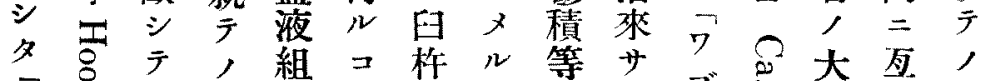

モ 导明檢成卜博要,

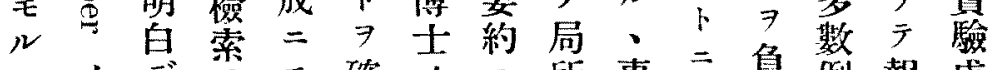

モノ デ 孚 $モ$ 確

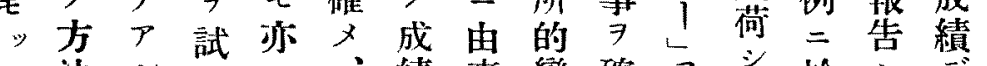

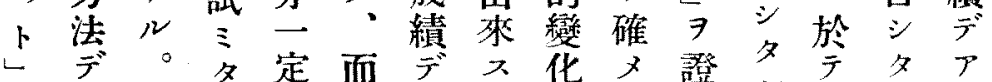

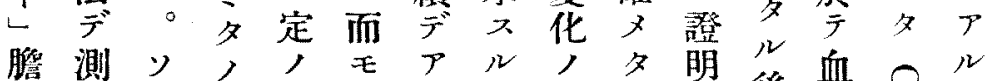

汁定

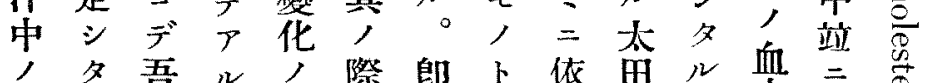

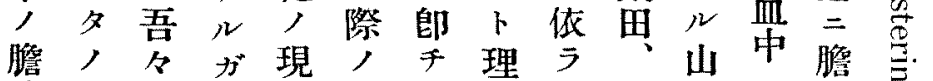

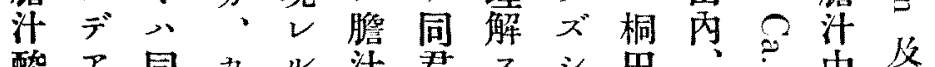

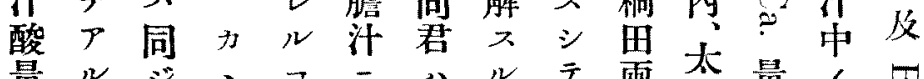

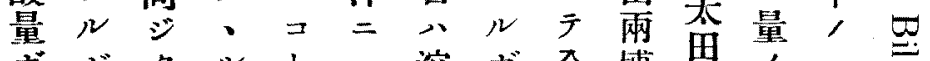

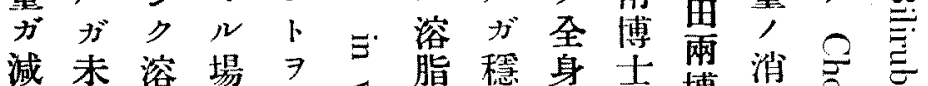

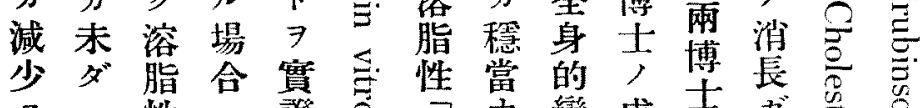

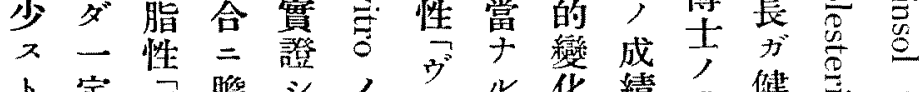

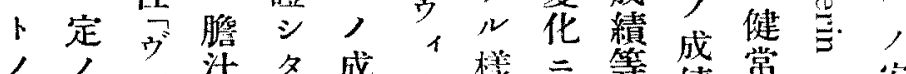

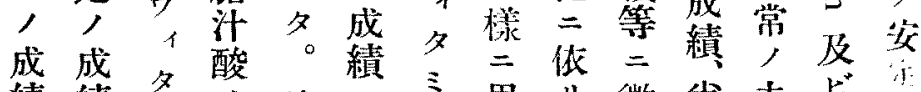

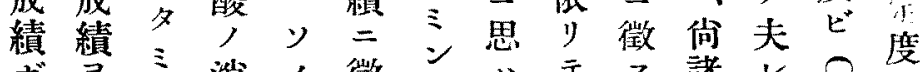

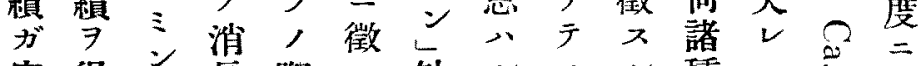

家得

鬼蒛 $\exists$ 同テ方。起二植比量

二 之吟君結食コリ、物べ代

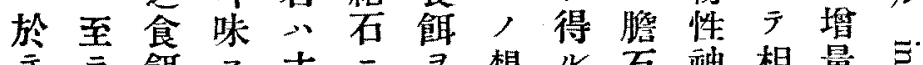

亏 慨入主三马想儿石神相量

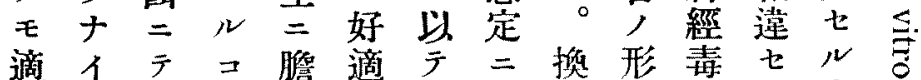

角。飼卜汁飼有言成 $\exists ル$ 事

サ村㕕 ガ, ル㕕力 分投事實實

レ上七必

得氏 $N$ 要

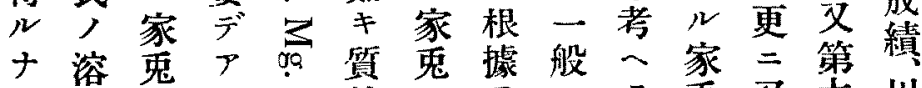

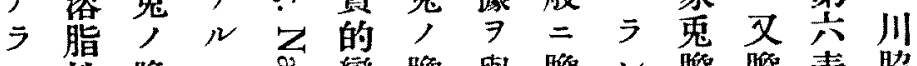

バ性 膽

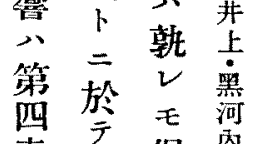

表 輕保

第輕護崖

吾藮焦澤

表 八用薄

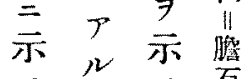

入

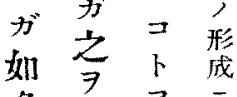

䣲 7 認

酸

監

$\exists$ ב

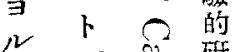

沈茎二究

測积 $\exists$

又

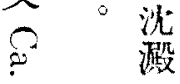

$=\quad$ 對

$\exists \quad$ 的

佂

澱

$=\overline{3}$

對吕

シ $\quad$ 口

₹

定 $\quad 1^{\exists}$ 章

保酸

作監

用 亏゙ 


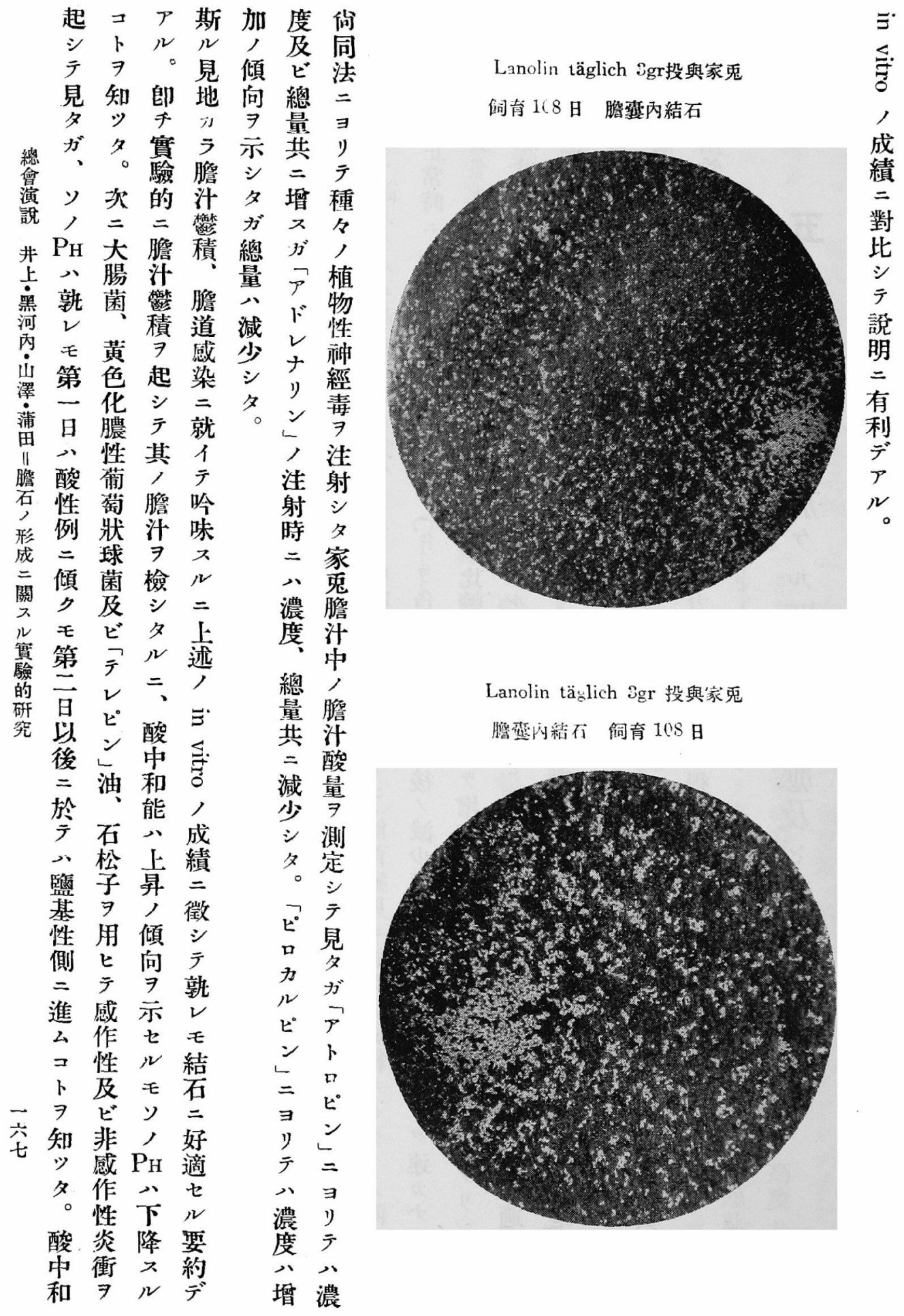




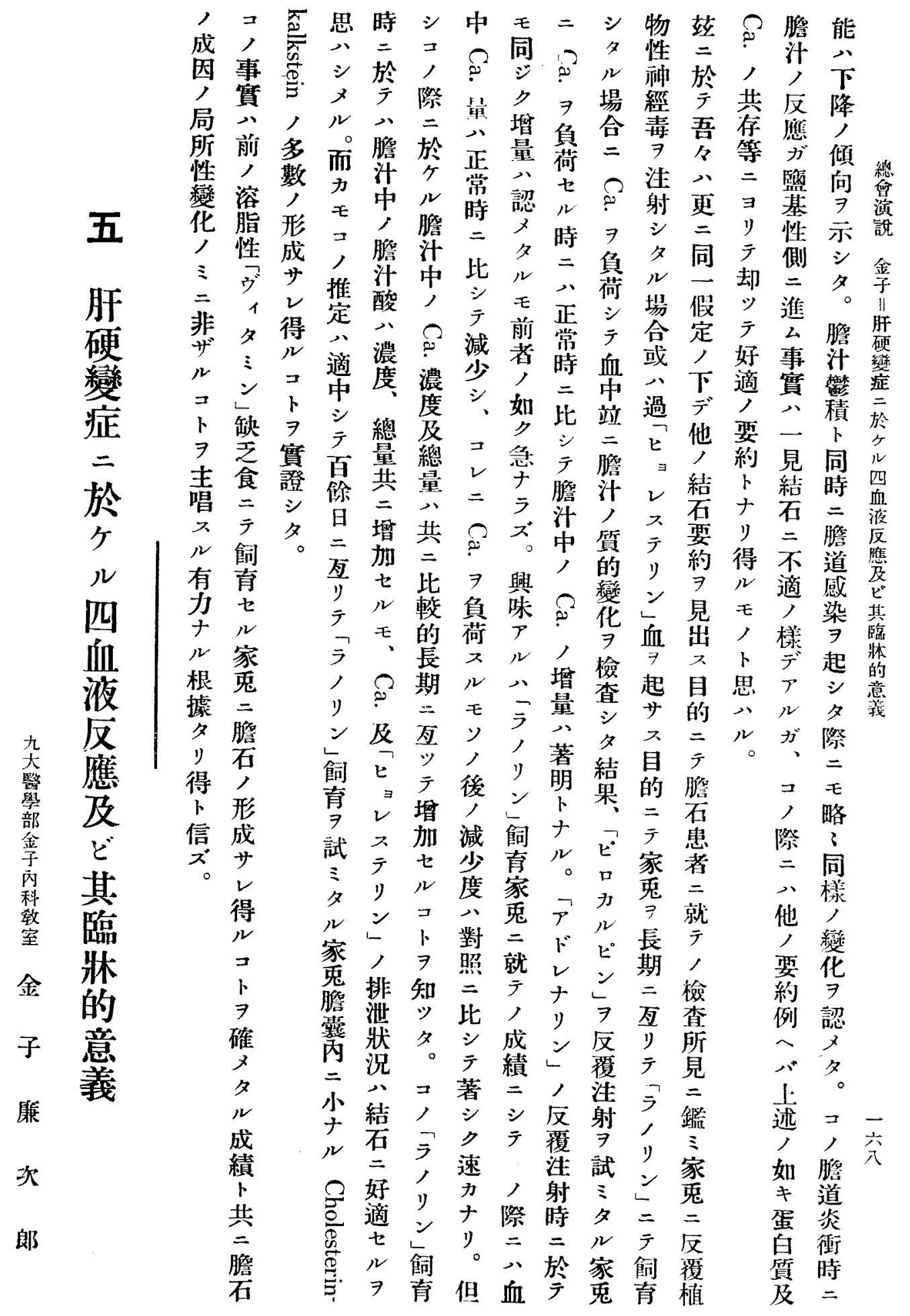



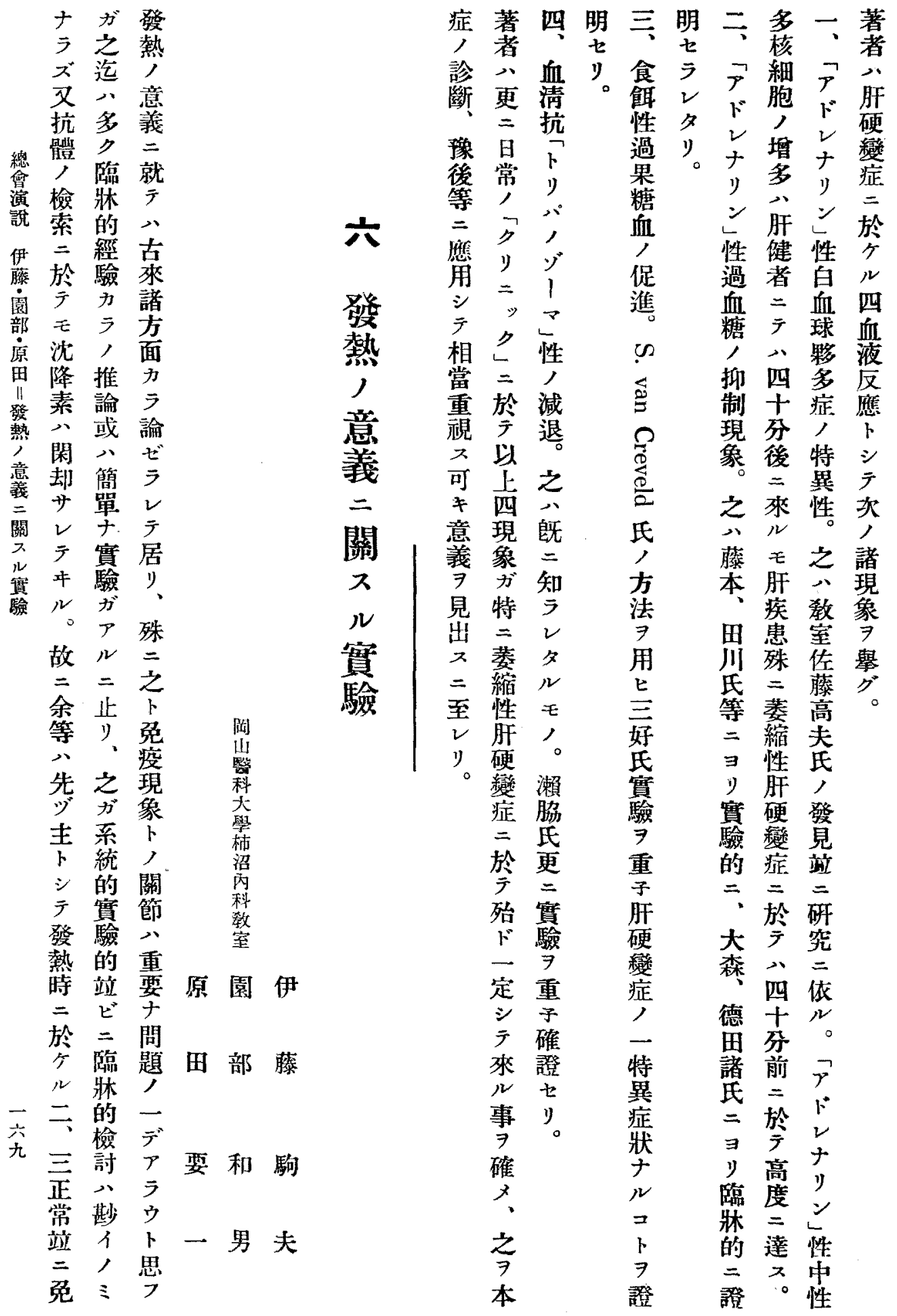
クデ依上次ク向合 $ル=$ 影降, 降次正家一疫

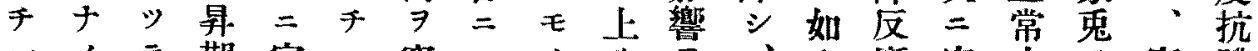
ンイ。テ期家ざ竇

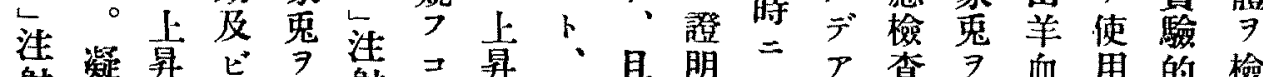

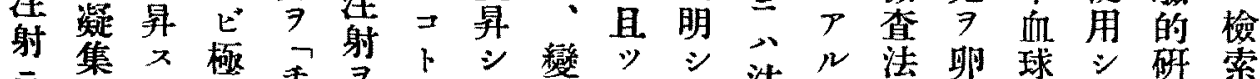

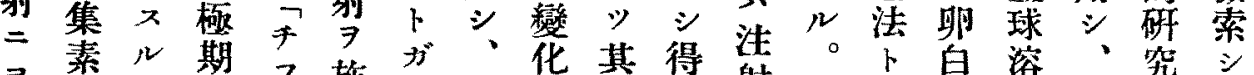
$\exists$ 例

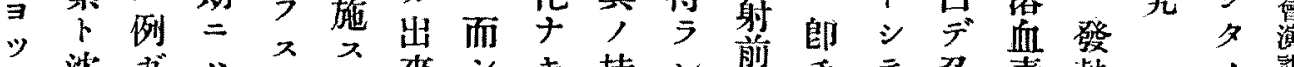
テ沈 $カ ゙$ 、ス ス 來 シ

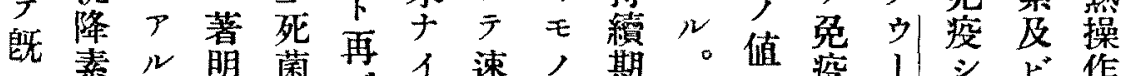

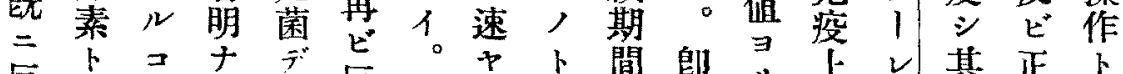

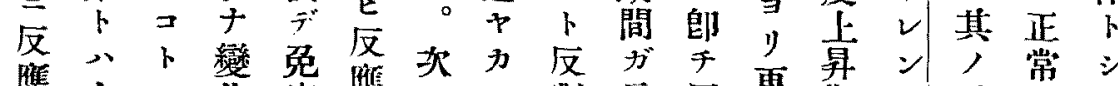

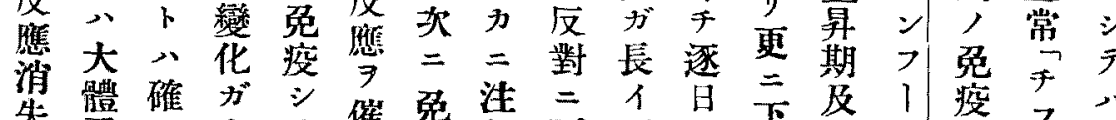

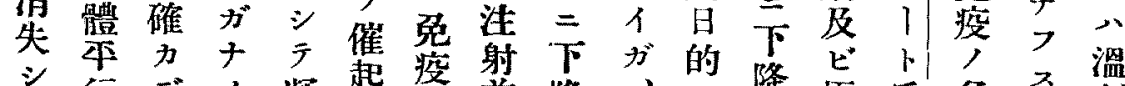

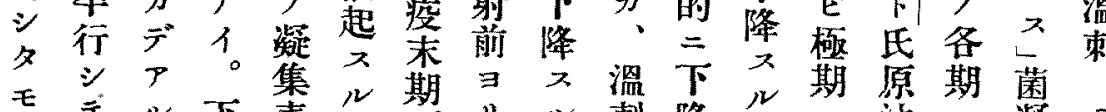

こ 消

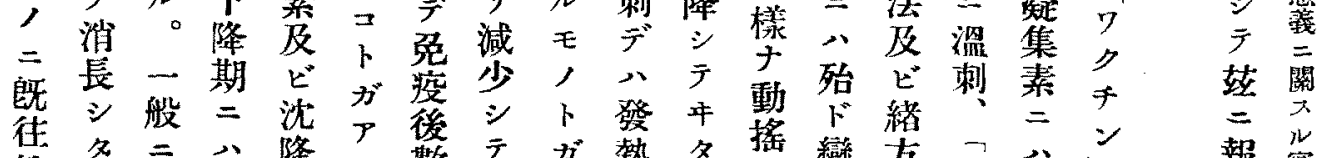

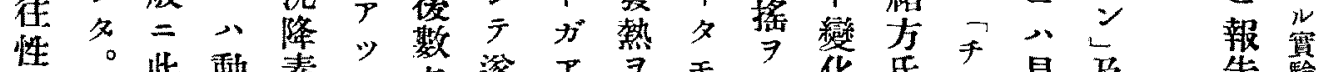

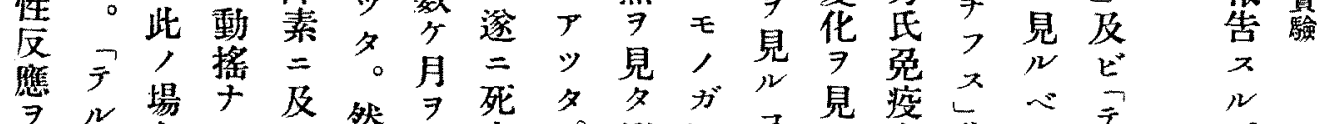

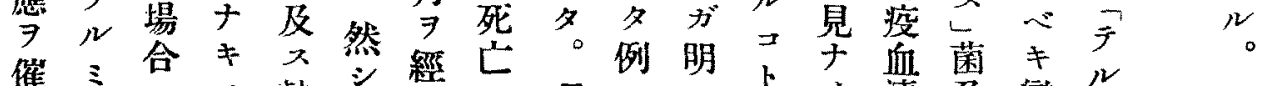

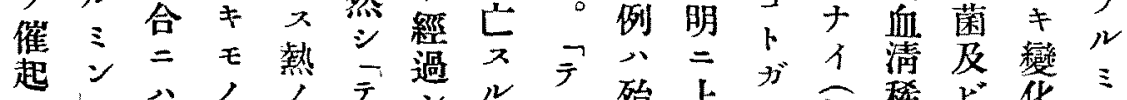

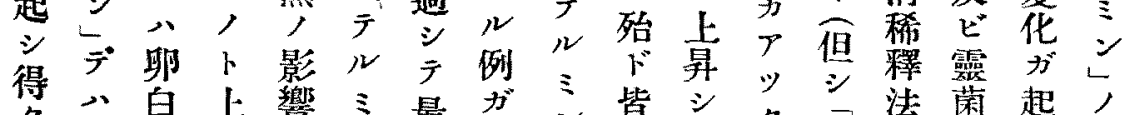

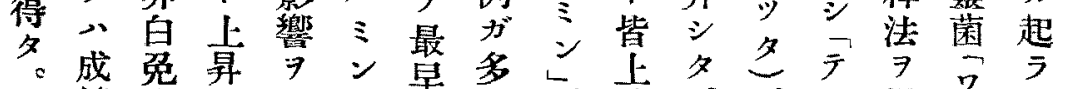
皇

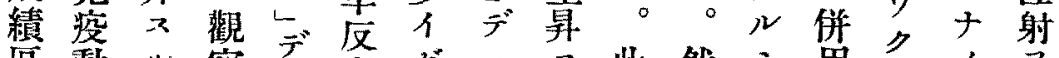

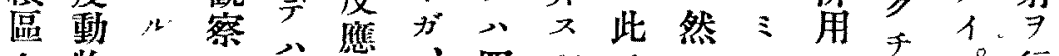

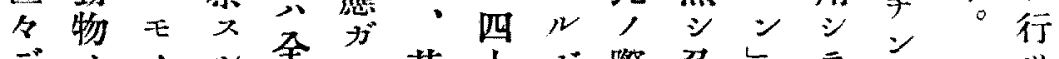

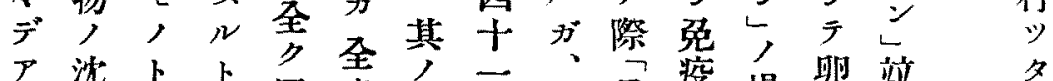

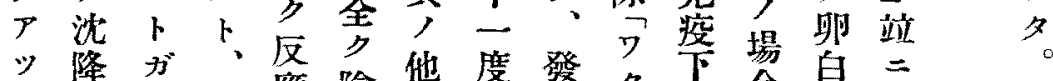

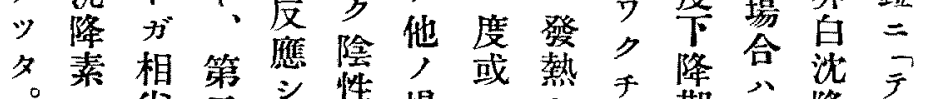

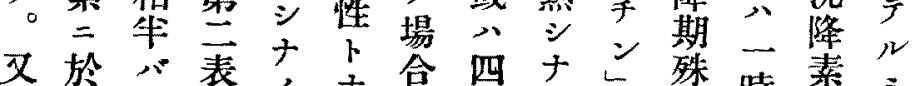
此

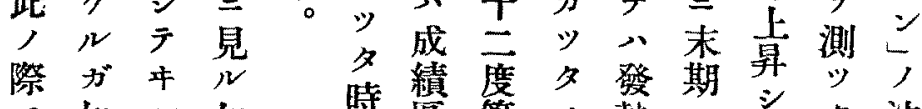
モ如 $⿻$ 如

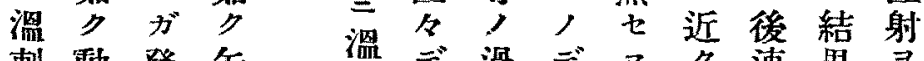

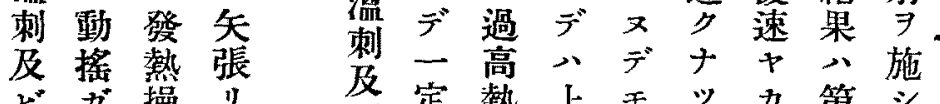

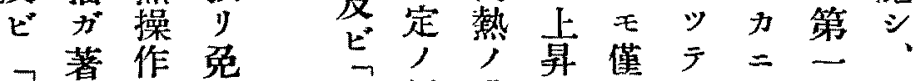

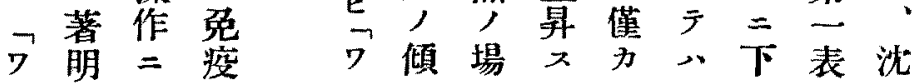




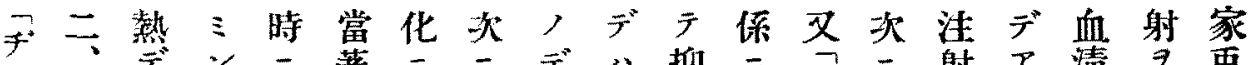

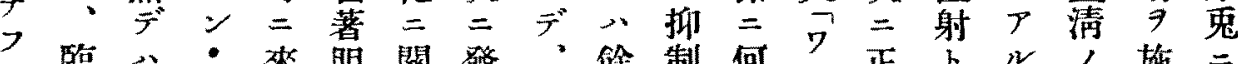

于臨

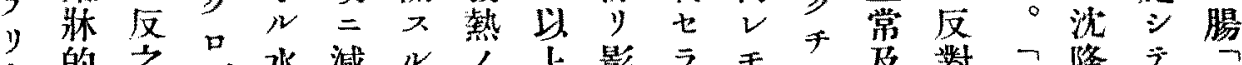

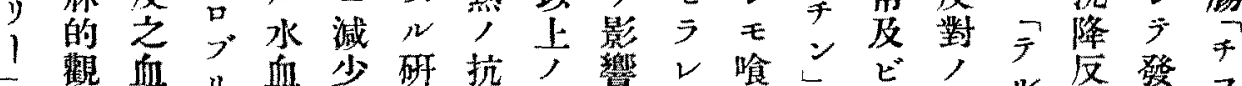

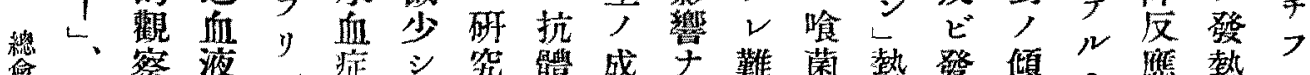

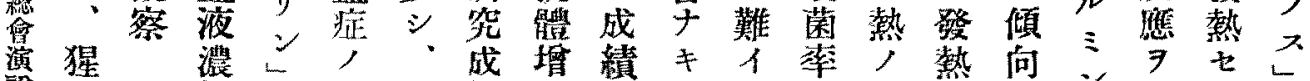

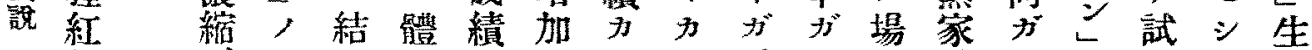

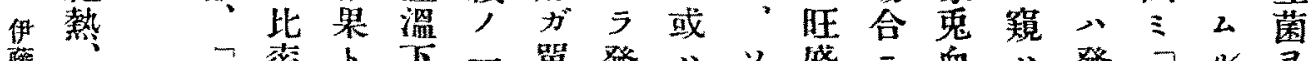

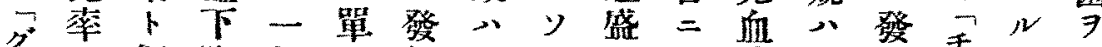

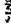

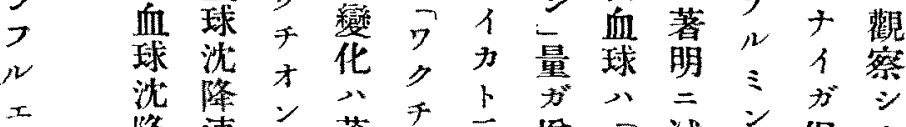

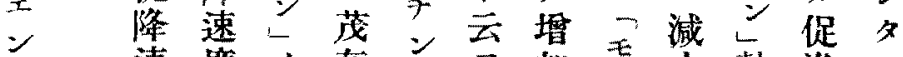

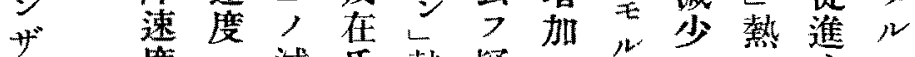

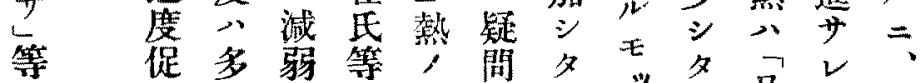

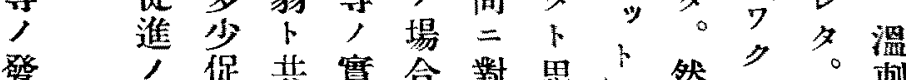

發人促共實合對思然然。刺

熱傾進三䮲

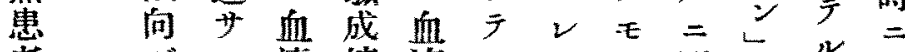

者

$=$

於

于示度致成时

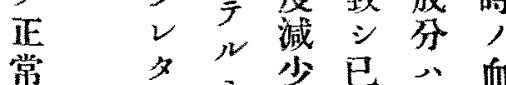

一山

七羊

眮

溶

血

素

及

$カ ゙ レ$ 清績液》N, 單熱 $ル$

認夕粘卜有發。、广殆ミ喰

兮ン洼率

葡ンチ射 ガ

猲等 著

三 三 觶 液

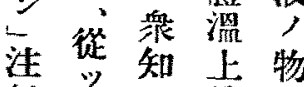

射

$=\stackrel{5}{=}$ 如花

$\exists \curlyvee$ 伴學

$N \sim$ 發七 的

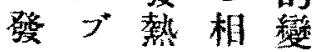

狀光当

球 $y$, 際 多

菌产学促

使注射熱等
用 射 $=\stackrel{r}{r}$
菌 ル

勢

凝

入矮入

ᄀ 즌 集

泩 菌素

射沈及卜

入降

$\nu$ 元 沈

心, 降急

死檢素速

亡掌,

等

早 万生熱

×

一十促 又

定其進速

, $>$ 力

成反 $N=$

績㦄。下

头度又降

得架手

†高于

A $>$ 例

开东

大。菌多

娟即家

$=$ 兔

於發聂此

于熱疫,

八 八血 場

寧紬清 合

口菌 7 溫

溋崩以刺

刺壤 及

及 $\Rightarrow$ 生 ビ

飞促菌

フ進隻名

万文

チル家さ

タノョ ミ無タ。 


\section{家兔, 沈降素)}

\begin{tabular}{|c|c|c|c|c|c|c|c|c|}
\hline খっ」 注 & 射 & & & 「D & D & ¿」 & 注 & \\
\hline 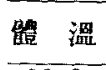 & 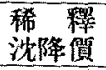 & 只此沈降㵋 & $\begin{array}{l}\text { 家鬼 } \\
\text { 番號 }\end{array}$ & & & 體 溫 & $\begin{array}{l}\text { 稀 䅣 } \\
\text { 沈降貲 }\end{array}$ & 吕纯沈降價 \\
\hline 38.2 & $1: 50$ & $1: \quad 5,000$ & & 最释叒疫後 & 前 & 38.1 & $1: 50$ & 5,000 \\
\hline 39.8 & $1: 100$ & $1: 10,000$ & 13 & 第2 $\mathbf{日}^{\top} \neq$ ᄀ & 2 時 & 40.5 & $1: 100$ & $1: 50,000$ \\
\hline 38.9 & $1: 100$ & 1: $\quad 5,000$ & & $\lambda_{f}$ pro $K$ & 後 6 & 39.4 & 1: 250 & $1: 25,000$ \\
\hline 38.3 & 1: 50 & 1: $\quad 5,000$ & & I c c 诖射 & 218 & 38.3 & 1: 250 & $1: 50,000$ \\
\hline 38.4 & $1: 50$ & $1: 10,000$ & & & 前 & 38.2 & $1: 25$ & 1,000 \\
\hline 40.9 & $1: 100$ & 1 $: 25,000$ & 14 & 第3日门霜 & & 41.1 & 1: 50 & 1: 5,000 \\
\hline 40.1 & $1: 100$ & $11: 10,000$ & & $1 \mathrm{ccc}$ & 後 $\left\{\begin{array}{c}6 \\
6\end{array}\right.$ & 39.4 & $1: 100$ & 1: $\quad 5,000$ \\
\hline 35.2 & 1: 25 & $1: 25,0$ & & & 118 & 38.1 & 1: 250 & 1: 25,000 \\
\hline 38.6 & $1: 250$ & $1: 50,000$ & & & 前 & 38.2 & 1: 500 & $1: 50,000$ \\
\hline 39.9 & $1: 250$ & 1: 50,000 & 15 & 第 8日 鼣」 & 13 & 40.5 & $1: 500$ & 1: 50,000 \\
\hline 59.6 & $1: 250$ & $1: 25,000$ & & $1 \mathrm{coc}$ & 後 6 & 39.3 & 1: 500 & $1: 250,000$ \\
\hline 38.3 & $1: 250$ & 11: 5,000 & & & 118 & 38.4 & $1: 250$ & $1: 250,000$ \\
\hline $\begin{array}{l}38.0 \\
41 .\end{array}$ & $1: 250$ & $1: 25,000$ & & & 前 & 38.2 & 1: 500 & $1: 100,000$ \\
\hline 41.2 & $1: 500$ & $1: 100,60 c( \pm)$ & 16 & 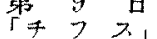 & $a_{0} \rightarrow$ & 39.6 & $1: 1000$ & $1: 100,000$ \\
\hline 40.3 & $1: 500$ & $1: 50,000^{\circ}$ & & (.) J & 後 6 & 38.7 & $1: 1000$ & $1: 100,000$ \\
\hline 37.5 & $1: 100$ & $11: 50,000$ & & & 118 & 38.4 & 1:1000 & $1: 100,000$ \\
\hline 37.8 & $1: 640$ & $1: 50,000$ & & 最終面疫復 & 9 日 & 28.5 & $1: 320$ & $1: 10,000$ \\
\hline 37.5 & $1: 10$ & 250 & & & 44 & 38.2 & 1: 40 & 1,000 \\
\hline 39.4 & $1: 20$ & 500 & 17 & $r \neq-$ & $c^{2}$ 時 & 39.8 & 1: 160 & 2,500 \\
\hline 39.1 & 1: 10 & 500 & & 1 的的 & $\{18$ & 38.3 & 1: 160 & 2,000 \\
\hline 38.4 & 1: 10 & 250 & & 1 C. 红射敒 & 148 & 38.4 & 1: 320 & 2,000 \\
\hline 38.3 & 1: 5 & 250 & & 最終恐疫後 & 7日 & 38.4 & $1: 640$ & $1: 100,000$ \\
\hline 38.6 & $1: 320$ & $1: 50,000$ & & & 126日 & 38.0 & $(-)$ & \\
\hline 38.5 & $(-)$ & 25 & & & 3時 & 41.1 & 1: & 1: \\
\hline 40.1 & $(-)$ & 25 & 18 & $r \neq$ & 6 & 88.0 & & 1: \\
\hline 39.4 & $(-)$ & 25 & & 1 c.c注射後 & 18 & 38.9 & 1: & 1: \\
\hline 38.7 & $(-)$ & 1: & & & 24 & 38.8 & 1: & 1: \\
\hline 38.8 & $(-)$ & 25 & & & 48 & 38.5 & $1: 2.5$ & 1: \\
\hline
\end{tabular}

于 ン」注射家鬼, 沈降素及凝集紫)

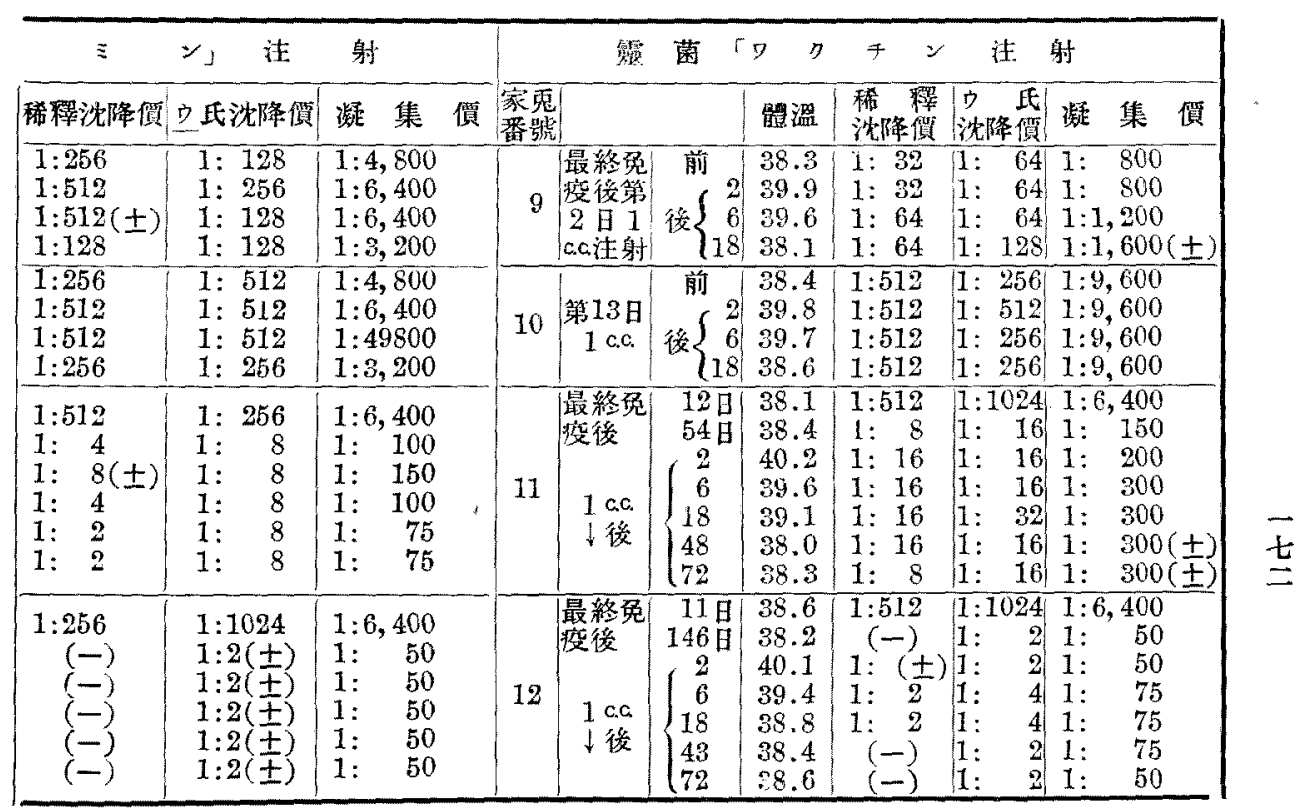


第

表

(卵白质疫

\begin{tabular}{|c|c|c|c|c|c|c|c|c|}
\hline \multicolumn{3}{|c|}{ 溫 } & \multicolumn{3}{|c|}{ 刺 } & \multicolumn{2}{|r|}{$r^{\prime}$} & N \\
\hline $\begin{array}{l}\text { 家者 } \\
\text { 香號 }\end{array}$ & & & 體 溫 & 稀㵋沈降頱 & 立氏沈降傊 & 家黾 & & \\
\hline 1 & $\begin{array}{l}\text { 最終䧺疫後 } \\
\text { 第2 } 2 \text { 日第刺 }\end{array}$ & 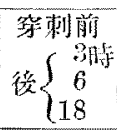 & $\begin{array}{l}38.4 \\
39.6 \\
39.8 \\
98.1\end{array}$ & $\begin{array}{l}1: 50 \\
1: 50 \\
1: 50 \\
1: 100\end{array}$ & $\begin{array}{l}1: 5,000 \\
1: 5,000 \\
1: 10,000( \pm) \\
1: 5,000\end{array}$ & 7 & 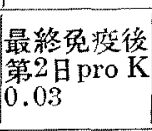 & $\begin{array}{l}\text { 注 射 前 } \\
2 \text { 時 } \\
6 \\
18\end{array}$ \\
\hline 2 & 箖 3 日 & 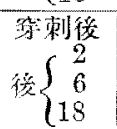 & $\begin{array}{l}38.0 \\
40.2 \\
38.8 \\
88.4\end{array}$ & $\begin{array}{l}1: 100 \\
1: 100 \\
1: 100 \\
1: 250\end{array}$ & $\begin{array}{l}1: 25,000 \\
1: 25,000 \\
1: 25,000 \\
1: 10,000\end{array}$ & 8 & $\begin{array}{c}\text { 第 } 2 \text { 日 } \\
0.04\end{array}$ & $\left\{\begin{array}{l}\text { 前 } \\
2 \\
6 \\
13(+)\end{array}\right.$ \\
\hline 8 & 第 6 日 & 後 $\left\{\begin{array}{r}3 \\
6 \\
18\end{array}\right.$ & $\begin{array}{l}38.2 \\
40.0 \\
89.8 \\
39.4\end{array}$ & $\begin{array}{l}1: 250 \\
1: 250 \\
1: 250 \\
1: 250\end{array}$ & $\begin{array}{l}1: 50,000 \\
1: 50,000 \\
1: 50,000( \pm) \\
1: 25,000\end{array}$ & 9 & $\begin{array}{c}\text { 第7 日 } \\
0.08\end{array}$ & $\left\{\begin{array}{r}\text { 前 } \\
3 \\
6 \\
18\end{array}\right.$ \\
\hline 4 & 第 7 日 & 後 $\left\{\begin{array}{l}2 \\
16 \\
18\end{array}\right.$ & $\begin{array}{l}38.6 \\
39.9 \\
39.7 \\
38.4\end{array}$ & $\begin{array}{l}1: 100 \\
1: 250( \pm) \\
1: 100 \\
1: 100\end{array}$ & $\begin{array}{l}1: 50,000 \\
1: 50,000 \\
1: 50,009 \\
1: 50,000\end{array}$ & 10 & $\begin{array}{c}\text { 第11日 } \\
0.04\end{array}$ & 妓 $\left\{\begin{array}{l}\text { 前 } \\
2 \\
6 \\
10(+)\end{array}\right.$ \\
\hline 5 & 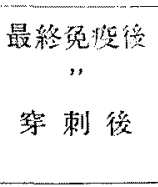 & $\begin{array}{l}\begin{array}{r}9 日 \\
70 日\end{array} \\
\left\{\begin{array}{l}3 \text { 特 } \\
18 \\
48\end{array}\right.\end{array}$ & $\begin{array}{l}38.4 \\
38.7 \\
40.5 \\
38.5 \\
38.7\end{array}$ & $\begin{array}{l}1: 320 \\
1: 10( \pm) \\
1: 20 \\
1: 10 \\
1: \\
5\end{array}$ & $\begin{array}{ll}1: 50,000 \\
1: & 250( \pm) \\
1: & 250 \\
1: & 100 \\
1: & 100\end{array}$ & 11 & $\begin{array}{c}\text { 最終觉疫後 } \\
\text { " } \\
0.03 \text { 注射㢺 }\end{array}$ & $\begin{array}{l}10 日 \\
72 \text { 日 } \\
3 \\
6 \\
18 \\
48\end{array}$ \\
\hline 6 & 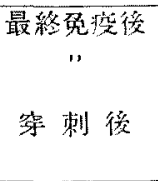 & $\begin{array}{l}8 \text { 日 } \\
115 \text { 日 } \\
\left\{\begin{array}{c}2 \text { 咭 } \\
18 \\
48 \\
72\end{array}\right.\end{array}$ & $\begin{array}{l}38.6 \\
38 . .3 \\
40.1 \\
38.8 \\
38.6 \\
38.7\end{array}$ & $\begin{array}{c}1: 320 \\
(-) \\
1: 5 \\
1: 2.5( \pm) \\
1: 2.5( \pm) \\
(-1)\end{array}$ & $\begin{array}{lr}1: 25,000 \\
1: & 25 \\
1: & 25 \\
1: & 50 \\
1: & 25 \\
1: & 25\end{array}$ & 12 & 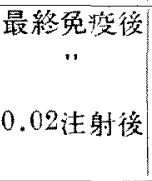 & $\begin{array}{l}10 \text { 日 } \\
138 \text { 日 } \\
\left\{\begin{array}{c}2 \text { 時 } \\
6 \\
18 \\
48\end{array}\right.\end{array}$ \\
\hline
\end{tabular}

第

二 表

(「チフスワク

\begin{tabular}{|c|c|c|c|c|c|c|c|c|c|c|}
\hline \multicolumn{4}{|c|}{ 温 } & \multicolumn{3}{|c|}{ 刺 } & \multicolumn{4}{|c|}{$i \xi$} \\
\hline 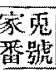 & & & 體溫 & 稀程沈降價 & 立氏沈降價 & 凝 集 償 & $\begin{array}{l}\text { 家爫 } \\
\text { 番號 }\end{array}$ & & & 體溫 \\
\hline 1 & 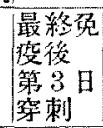 & 姼 $\left\{\begin{array}{r}2 \\
6 \\
18\end{array}\right.$ & $\begin{array}{l}38.4 \\
39.8 \\
38.8 \\
38.5\end{array}$ & $\begin{array}{l}1: 64 \\
1: 64 \\
1: 64 \\
1: 118\end{array}$ & $\begin{array}{ll}1: & 32 \\
1: & 32 \\
1: & 32 \\
1: & 32\end{array}$ & $\begin{array}{l}1: 1,200 \\
1: 1,200 \\
1: 1,200 \\
1: 1,600\end{array}$ & 5 & $\begin{array}{l}\text { pro K } \\
0.02 \\
\text { 注射 }\end{array}$ & $\left\{\begin{array}{r}2 \\
6 \\
18\end{array}\right.$ & $\begin{array}{l}38.7 \\
41.6 \\
38.9 \\
38.2\end{array}$ \\
\hline 2 & 第 9 日 & 後 $\left\{\begin{array}{r}3 \\
6 \\
18\end{array}\right.$ & $\begin{array}{l}38.2 \\
39.9 \\
38.5 \\
38.6\end{array}$ & $\begin{array}{l}1: 512 \\
1: 512 \\
1: 512 \\
1: 512\end{array}$ & $\begin{array}{l}1: 1024( \pm) \\
1: 1024( \pm) \\
1: 1024( \pm) \\
1: 1024( \pm)\end{array}$ & $\begin{array}{l}1: 9,600 \\
1: 9,600 \\
1: 9,600 \\
1: 9,600\end{array}$ & 6 & $\begin{array}{c}\text { 第12日 } \\
0.03\end{array}$ & 後 $\left\{\begin{array}{r}2 \\
6 \\
18\end{array} \mid\right.$ & $\begin{array}{l}38.2 \\
40.4 \\
38.9 \\
37.6\end{array}$ \\
\hline 3 & $\begin{array}{l}\text { 最終挽 } \\
\text { 没後 } \\
\text { 玡剌後 }\end{array}$ & $\begin{array}{r}9 \text { 日 } \\
68 \text { 日 } \\
2 \\
6 \\
18 \\
48 \\
72\end{array}$ & $\begin{array}{l}38.4 \\
38.6 \\
40.7 \\
39.5 \\
38.3 \\
38.6 \\
38.0\end{array}$ & $\begin{array}{rr}1: 256 \\
1: & 8 \\
1: & 16 \\
1: & 16 \\
1: & 16 \\
1: & 8 \\
1: & 4 \\
\end{array}$ & \begin{tabular}{ll|}
$1:$ & 512 \\
$1:$ & 16 \\
$1:$ & 16 \\
$1:$ & 16 \\
$1:$ & 16 \\
$1:$ & 16 \\
$1:$ & 16
\end{tabular} & $\begin{array}{ll}1: 6,400 \\
1: & 100 \\
1: & 150 \\
1: & 200( \pm) \\
1: & 150 \\
1: & 100( \pm) \\
1: & 100( \pm)\end{array}$ & 7 & $\begin{array}{c}\text { 最終免 } \\
\text { 虔後 } \\
0.03 \\
\downarrow \text { 後 }\end{array}$ & $\begin{array}{l}10 日 \\
78 \text { 日 } \\
\qquad \begin{array}{c}3 \\
6 \\
18 \\
48\end{array}\end{array}$ & $\begin{array}{l}38.4 \\
38.7 \\
40.4 \\
39.3 \\
38.6 \\
38.8\end{array}$ \\
\hline 4 & 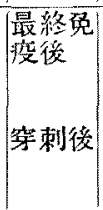 & $\begin{array}{l}\text { 11日 } \\
90 \text { 日 } \\
2 \\
2 \\
6 \\
18 \\
48 \\
72\end{array}$ & $\begin{array}{l}38.8 \\
37.9 \\
40.0 \\
39.2 \\
38.4 \\
38.7 \\
38.1\end{array}$ & $\left|\begin{array}{ll}1: 512 \\
1: & 16 \\
1: & 32 \\
1: & 32 \\
1: & 32 \\
1: & 32( \pm) \\
1: & 16\end{array}\right|$ & $\begin{array}{ll}1: & 256 \\
1: & 32 \\
1: & 32 \\
1: & 64( \pm) \\
1: & 64 \\
1: & 32 \\
1: & 32\end{array}$ & $\begin{array}{ll}1: 9, & 600 \\
1: & 100 \\
1: & 150 \\
1: & 200( \pm) \\
1: & 200 \\
1: & 150 \\
1: & 100\end{array}$ & 8 & $\begin{array}{c}\text { 最終免 } \\
\text { 疫後 } \\
0.02 \\
\downarrow \text { 後 }\end{array}$ & $\begin{array}{l}13 \text { 日 } \\
128 \text { 日 } \\
\left\{\begin{array}{c}2 \\
6 \\
19 \\
48\end{array}\right.\end{array}$ & $\begin{array}{l}37.9 \\
37.7 \\
39.6 \\
39.2 \\
38.3 \\
38.1\end{array}$ \\
\hline
\end{tabular}




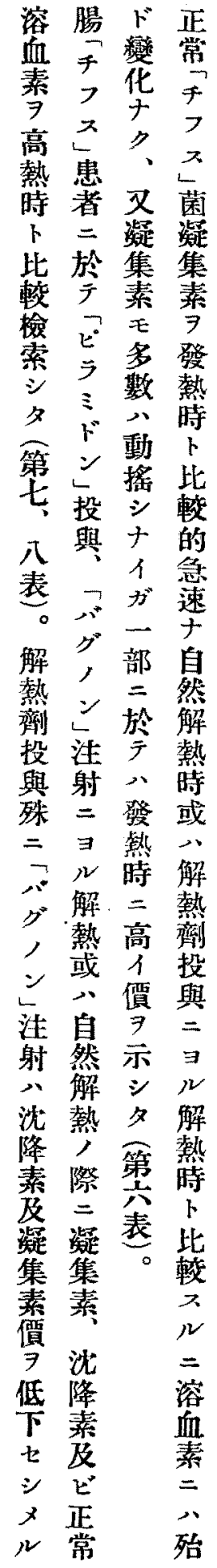

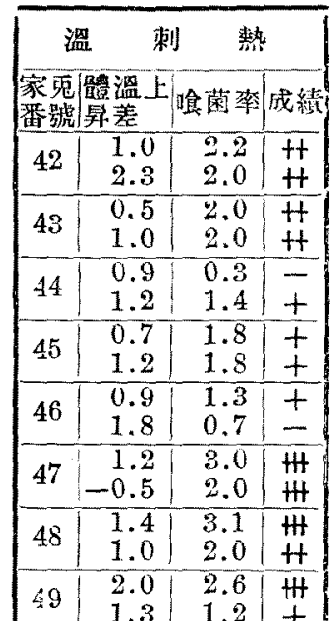

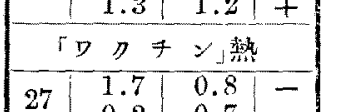

$27 \mid$\begin{tabular}{l|l|l|l}
1.7 & 0.8 & - \\
& 0.2 & 0.7 & - \\
\hline & 1.9 & 7.7 & +
\end{tabular}
\begin{tabular}{l|l|l|l|}
29 & 1.9 & 1.2 & \pm \\
\hline & 0.8 & 1.0 & \pm \\
\hline
\end{tabular} $28{ }^{2} \mid$\begin{tabular}{c|c|c}
1.8 & 2.0 & $H$
\end{tabular}

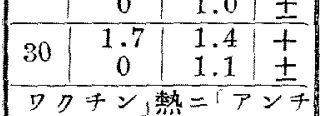
比

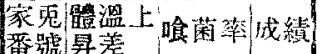

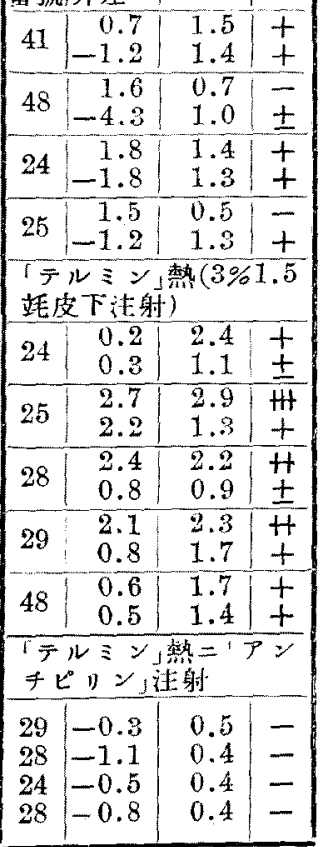

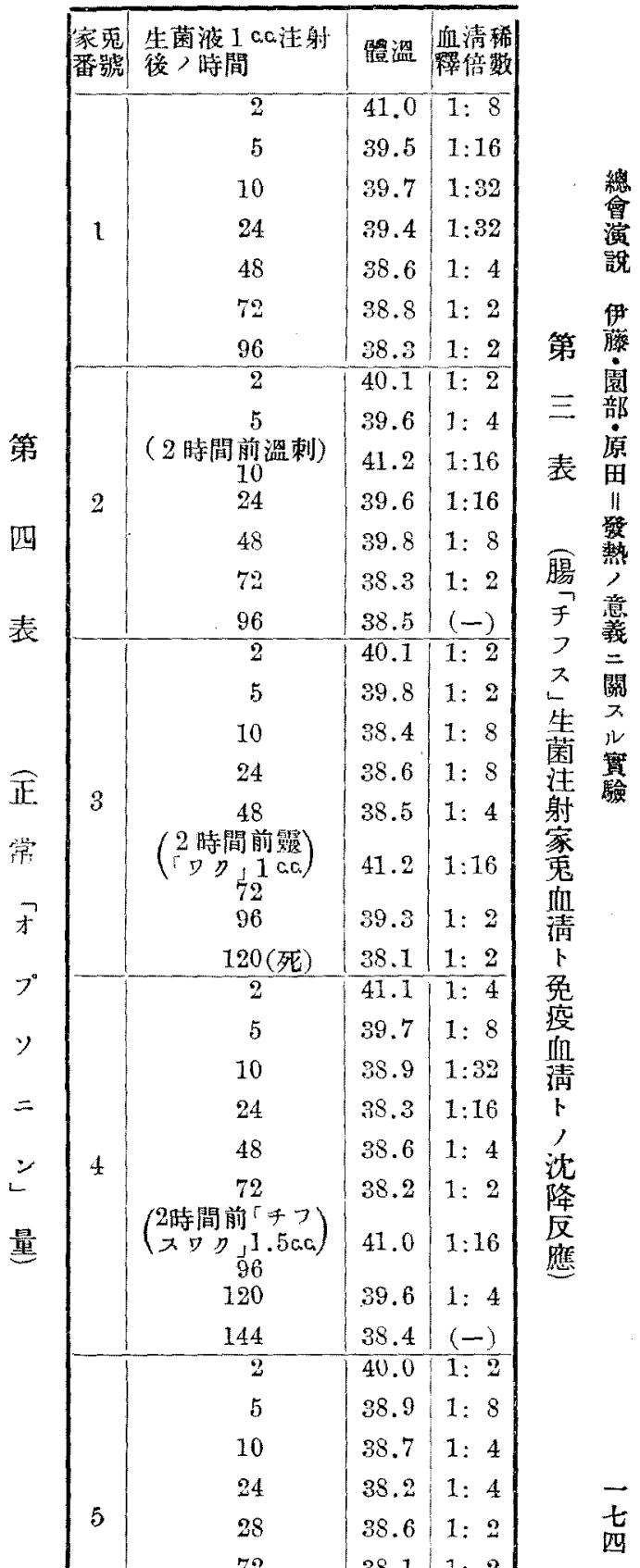


令家鬼 體重 $2150 \mathrm{~g}$. 溫 刺

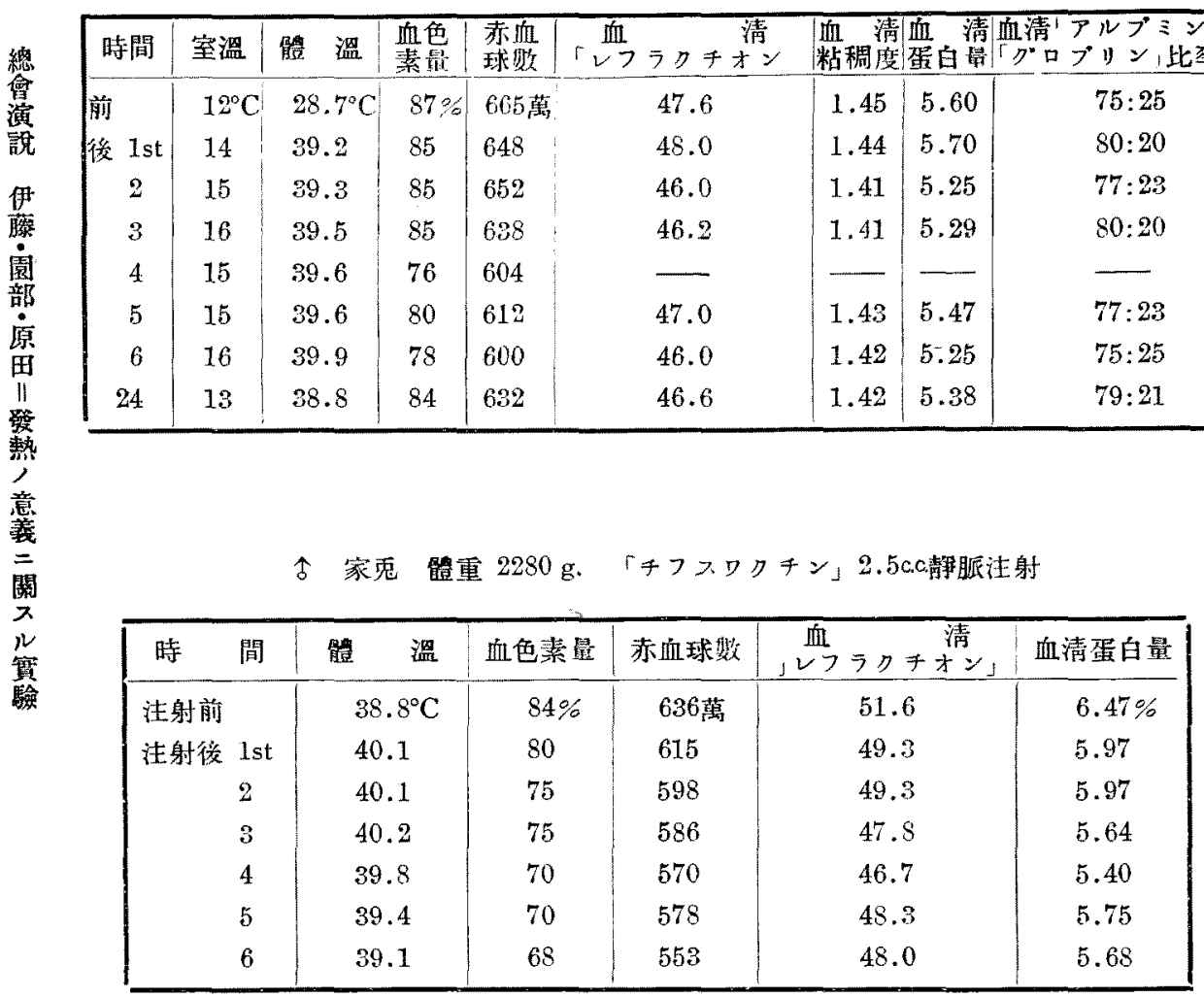

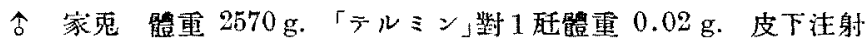

\begin{tabular}{|c|c|c|c|c|c|c|c|}
\hline 時 & 間 & 室 溫 & 顝温 & 血色素量 & 赤血球斯 & 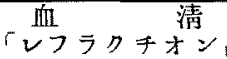 & 血清蛋白量 \\
\hline \multirow{8}{*}{$\begin{array}{l}\text { 注射前 } \\
\text { 注射後 }\end{array}$} & & $15^{\circ} \mathrm{C}$ & $39.0^{\circ} \mathrm{C}$ & $88 \%$ & 668 萬 & 49.0 & $5.90 \%$ \\
\hline & 1st & 16 & 40.6 & 104 & 798 & 54.0 & 6.98 \\
\hline & 2 & 17 & 42.1 & 114 & 850 & 52.3 & 6.62 \\
\hline & 3 & 17 & 41.9 & 107 & 804 & 52.0 & 6.55 \\
\hline & 4 & 16 & 41.4 & 107 & 800 & 51.9 & 6.53 \\
\hline & 5 & 16 & 40.2 & 107 & 808 & 51.7 & 6.49 \\
\hline & 6 & 17 & 39.4 & 107 & 786 & 50.4 & 6.21 \\
\hline & 7 & 17 & 38.8 & 105 & 775 & 49.0 & 5.90 \\
\hline
\end{tabular}


第 六 表 (墢熱患者)正常凝集素及溶血素)

\begin{tabular}{|c|c|c|c|c|c|c|c|c|c|c|}
\hline 番號 & 患者名 & 病 & 名 & 年䤅 & 性 & 日時 & | 鳢溫 $\mid$ & 凝集價 & |溶血價 $\mid$ & 歲 \\
\hline 1 & & 「インフルメ & ンザ」 & 18 & 占 & $\begin{array}{l}6 / \mathrm{NI} \\
8 / \mathrm{VI}\end{array}$ & $\left|\begin{array}{l}38.5 \\
36.0\end{array}\right|$ & $\begin{array}{l}1: 50 \\
1: 50\end{array}$ & $\begin{array}{ll}1: & 40 \\
1: & 40\end{array}$ & \\
\hline 2 & & $"$ & & 21 & 우 & $\begin{array}{l}26 / \mathrm{NI} \\
28 / \mathrm{VI}\end{array}$ & $\begin{array}{l}38.8 \\
37.1 \\
\end{array}$ & $\begin{array}{ll}1: & 50 \\
1: & 25\end{array}$ & $\begin{array}{l}1: 80 \\
1: 80\end{array}$ & 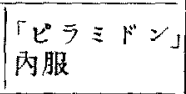 \\
\hline 3 & & 不 & 明 & 22 & $\hat{\delta}$ & $\begin{array}{l}31 / \mathrm{VII} \\
4 / \mathrm{IX}\end{array}$ & $\begin{array}{l}39.3 \\
36.5\end{array}$ & $\begin{array}{l}1: 150 \\
1: 150\end{array}$ & $\begin{array}{ll}1: & 80 \\
1: & 80\end{array}$ & \\
\hline 4 & & 腎 孟 & 焱 & 35 & 우 & \begin{tabular}{l|}
$16 / \mathrm{IX}$ \\
$16 / \mathrm{IX}$
\end{tabular} & $\left|\begin{array}{l}38.5 \\
36.5\end{array}\right|$ & $\begin{array}{l}1: 75 \\
1: 75 \\
\end{array}$ & $\begin{array}{ll}1: & 40 \\
1: & 40\end{array}$ & \\
\hline 5 & & $"$ & & 57 & 우 & $\begin{array}{l}4 / x \\
8 / x \\
\end{array}$ & $\left|\begin{array}{l}38.9 \\
36.2\end{array}\right|$ & $1: 50$ & $\begin{array}{l}1: 20 \\
1: 20\end{array}$ & \\
\hline 6 & & 肺＼cjkstart結 & 核 & 31 & $\uparrow$ & $\begin{array}{l}20 / X \\
21 / X\end{array}$ & $\left|\begin{array}{l}39.2 \\
36.4\end{array}\right|$ & $\begin{array}{ll}1: & 50 \\
1: & 50\end{array}$ & $\begin{array}{l}1: 160 \\
1: 160\end{array}$ & $\mid \begin{array}{l}\ulcorner ヒ ゚ ラ ミ ト ゙ ン \\
\text { 内服 }\end{array}$ \\
\hline 7 & & 箐＼cjkstart皿 & 桨 & 27 & 우 & $\begin{array}{c}13 / \mathrm{XI} \\
7 / \mathrm{XII}\end{array}$ & $\left|\begin{array}{l}39.2 \\
36.7\end{array}\right|$ & $\begin{array}{l}1: 100 \\
1: 100\end{array}$ & 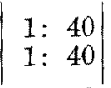 & \\
\hline 8 & & 肺 & 炎 & 52 & 우 & $\begin{array}{l}12 / \mathrm{m} \\
14 / \mathrm{ID}\end{array}$ & $\begin{array}{l}39.7 \\
38.0\end{array}$ & $\begin{array}{l}1: 100 \\
1: 50\end{array}$ & 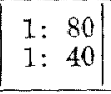 & \\
\hline 9 & & 赤 & 莉 & 25 & + & $\begin{array}{l}22 / X \\
24 / X\end{array}$ & $\left|\begin{array}{l}38.4 \\
36.0\end{array}\right|$ & $\begin{array}{ll}1: & 25 \\
1: & 25\end{array}$ & 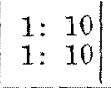 & \\
\hline 10 & & " & & 54 & + & $\begin{array}{l}14 / \mathrm{IX} \\
30 / \mathrm{IX}\end{array}$ & $\begin{array}{l}37.5 \\
36.7\end{array} \mid$ & $\begin{array}{l}1: 150 \\
1: 150\end{array}$ & $\begin{array}{ll}1: & 80 \\
1: & 80\end{array}$ & \\
\hline 11 & & $"$ & & 17 & 후 & $\begin{array}{l}7 / \mathrm{VW} \\
9 / \mathrm{VWI}\end{array}$ & $\left|\begin{array}{l}39.5 \\
26.9\end{array}\right|$ & $\begin{array}{l}1: 200 \\
1: 200\end{array}$ & $\begin{array}{ll}1: & 80 \\
1: & 80\end{array}$ & 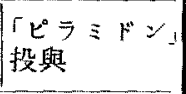 \\
\hline 12 & & 猩＼cjkstart紅 & 熱 & 14 & $\uparrow$ & $\begin{array}{r}21 / \mathrm{XT} \\
5 / \mathrm{XII} \\
\end{array}$ & \begin{tabular}{|l|}
39.0 \\
36.5
\end{tabular} & $\left|\begin{array}{ll}1: & 25 \\
1: & 25(-)\end{array}\right|$ & 1: 10 & \\
\hline 13 & & $"$ & & 17 & 우 & 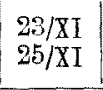 & $\left|\begin{array}{l}37.8 \\
36.7\end{array}\right|$ & $\begin{array}{ll}1: & 50 \\
1: & 50 \\
\end{array}$ & $\begin{array}{ll}1: & 80 \\
1: & 80\end{array}$ & \\
\hline 14 & & $"$ & & 10 & $\hat{\sigma}$ & $\begin{array}{r}3 / \mathrm{XII} \\
15 / \mathrm{XI} \\
\end{array}$ & $\begin{array}{l}39.5 \\
36.3\end{array}$ & $\begin{array}{l}1: 75 \\
1: 25\end{array}$ & $\begin{array}{ll}1: & 40 \\
1: & 40\end{array}$ & \\
\hline 15 & & $"$ & & 7 & 占 & $\begin{array}{c}18 / \mathrm{XII} \\
6 / \mathrm{I}\end{array}$ & $\begin{array}{l}39.8 \\
37.4\end{array}$ & $\begin{array}{l}1: 50 \\
1:\end{array}$ & $\begin{array}{ll}1: & 80 \\
1: & 80\end{array}$ & 血清注射 \\
\hline 16 & & 血 清 & 满 & 26 & $\hat{\delta}$ & $21 /$ XIII & $\begin{array}{l}39.7 \\
36.8 \\
\end{array}$ & $\begin{array}{l}1: 100 \\
1: 50\end{array}$ & $\begin{array}{ll}1: & 80 \\
1: & 80\end{array}$ & \\
\hline 17 & & 「ギフテッ & & 12 & $\hat{\delta}$ & $\begin{array}{l}22 / \mathrm{VII} \\
24 \mid \mathrm{VII}\end{array}$ & $\left|\begin{array}{l}40.0 \\
37.3\end{array}\right|$ & $\begin{array}{l}1: 50 \\
1: \\
50\end{array}$ & $\begin{array}{ll}1: & 10 \\
1: & 10\end{array}$ & 血清注射 \\
\hline
\end{tabular}


第 七 表 (腸「チフス」患者)凝集素及正常溶血菜)

\begin{tabular}{|c|c|c|c|c|c|c|c|c|}
\hline 番號 & 患者名 & 年龄 & 性 & 病日 & 鳢 溫 & 凝集價 & 溶 血 價 & 備 \\
\hline 1 & & 13 & 今ิ & $\begin{array}{l}9 \\
9\end{array}$ & $\begin{array}{l}38.2 \\
35.9\end{array}$ & $\begin{array}{l}\text { 1: } 400 \\
1: 400\end{array}$ & $\begin{array}{l}1: 20 \\
1: 20\end{array}$ & 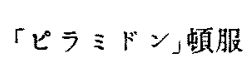 \\
\hline 2 & & 22 & 우 & $\begin{array}{l}12 \\
14\end{array}$ & $\begin{array}{l}40.2 \\
37.8\end{array}$ & $\begin{array}{l}\text { 1: } 600 \\
1: 800\end{array}$ & $\begin{array}{l}1: 20 \\
1: 20\end{array}$ & 「ピラミドン冎服 \\
\hline 3 & & 11 & $\hat{\jmath}$ & $\begin{array}{l}11 \\
12\end{array}$ & $\begin{array}{l}39.8 \\
37.4\end{array}$ & $\begin{array}{l}1: 400 \\
1: 300\end{array}$ & $\begin{array}{l}1: 10(-) \\
1: 10(-)\end{array}$ & 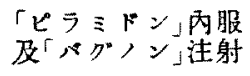 \\
\hline 4 & & 44 & 우 & $\begin{array}{l}18 \\
19\end{array}$ & $\begin{array}{l}39.8 \\
36.5\end{array}$ & $\begin{array}{l}1: 1200 \\
1: 1200\end{array}$ & $\begin{array}{l}1: 160 \\
1: 160\end{array}$ & 「バグノン」注射 \\
\hline 5 & & 42 & $\hat{\delta}$ & $\begin{array}{l}23 \\
24\end{array}$ & $\begin{array}{l}89.1 \\
37.0\end{array}$ & $\begin{array}{l}1: 1600 \\
1: 1600\end{array}$ & $\begin{array}{l}1: 80 \\
1: 80\end{array}$ & 「ビラミドン」內服 \\
\hline 6 & & 18 & $\hat{\delta}$ & $\begin{array}{l}6 \\
7\end{array}$ & $\begin{array}{l}40.4 \\
39.0\end{array}$ & $\begin{array}{l}1: 150 \\
1: 100\end{array}$ & $\begin{array}{l}1: 40 \\
1: 40\end{array}$ & 「ペグノン」注射 \\
\hline 7 & & 44 & $\hat{f}$ & $\begin{array}{l}23 \\
23\end{array}$ & $\begin{array}{l}39.3 \\
36.1\end{array}$ & $\begin{array}{l}1: 800 \\
1: 800\end{array}$ & $\begin{array}{l}1: 20 \\
1: 20\end{array}$ & \\
\hline 8 & & 41 & 우 & $\begin{array}{l}40 \\
41\end{array}$ & $\begin{array}{l}38.5 \\
36.2\end{array}$ & $\begin{array}{l}1: 3200 \\
1: 2400\end{array}$ & $\begin{array}{l}1: 80 \\
1: 40\end{array}$ & 「バグノン」注射 \\
\hline 9 & & 21 & +9 & $\begin{array}{l}36 \\
37\end{array}$ & $\begin{array}{l}39.1 \\
37.0\end{array}$ & $\begin{array}{l}1: 800 \\
1: 800\end{array}$ & $\begin{array}{l}1: 10 \\
1: 10\end{array}$ & 「ピラミドン』内服 \\
\hline 10 & & 20 & 우 & $\begin{array}{l}23 \\
23\end{array}$ & $\begin{array}{l}38.5 \\
37.3\end{array}$ & $\begin{array}{l}1: 1600 \\
1: 1600\end{array}$ & $\begin{array}{l}1: 40 \\
1: 40\end{array}$ & 「ビラミドンム内服 \\
\hline 11 & & 36 & $\hat{\delta}$ & $\begin{array}{l}22 \\
22\end{array}$ & $\begin{array}{l}40.4 \\
36.8\end{array}$ & $\begin{array}{l}1: 1200 \\
1: 1200\end{array}$ & $\begin{array}{l}1: 80 \\
1: 80\end{array}$ & \\
\hline 12 & & 31 & 우 & $\begin{array}{l}46 \\
47\end{array}$ & $\begin{array}{l}40.5 \\
35.1\end{array}$ & $\begin{array}{l}1: 1200 \\
1: 600\end{array}$ & $\begin{array}{l}1: 40 \\
1: 40\end{array}$ & 「ピラミドン」丙服 \\
\hline 13 & & 25 & 오 & $\begin{array}{l}16 \\
18\end{array}$ & $\begin{array}{l}39.0 \\
36.2\end{array}$ & $\begin{array}{l}1: 800 \\
1: 600\end{array}$ & - & \\
\hline 14 & & 25 & 오 & $\begin{array}{l}60 \\
62\end{array}$ & $\begin{array}{l}39.5 \\
37.0\end{array}$ & $\begin{array}{l}1: 400 \\
1: 400\end{array}$ & $\begin{array}{l}1: 20 \\
1: 20\end{array}$ & 「ピラミドン」內服 \\
\hline 15 & & 23 & $\uparrow$ & $\begin{array}{l}18 \\
19\end{array}$ & $\begin{array}{l}40.0 \\
38.5\end{array}$ & $\begin{array}{l}1: 2400 \\
1: 2400\end{array}$ & 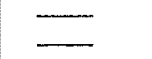 & 晹出血 \\
\hline 16 & & 18 & 우 & $\begin{array}{l}36 \\
36\end{array}$ & $\begin{array}{l}39.8 \\
38.2\end{array}$ & $\begin{array}{l}1: 2400 \\
1: 1600\end{array}$ & $\begin{array}{l}1: 20 \\
1: 20\end{array}$ & 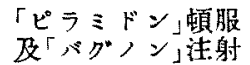 \\
\hline 17 & & 22 & $\hat{\sigma}$ & $\begin{array}{l}20 \\
20\end{array}$ & $\begin{array}{l}38.6 \\
36.3\end{array}$ & $\begin{array}{l}\text { 1: } 800 \\
1: 600\end{array}$ & $\begin{array}{l}1: 40 \\
1: 20\end{array}$ & $"$ \\
\hline
\end{tabular}


第

八

表

（腸「チフス」患者ノ沈降素竝二免度血清卜患者血清トヌ以テスル沈降反憵）

\begin{tabular}{|c|c|c|c|c|c|c|c|c|c|}
\hline 番㩆 & 患省名 & 年龄 & 性 & 病日 & 體溫 & $\begin{array}{l}\text { 稀釋 } \\
\text { 淡降償 }\end{array}$ & $\begin{array}{l}\text { 点氐 } \\
\text { 沈降榎 }\end{array}$ & $\begin{array}{l}\text { 血清稀 } \\
\text { 棏倍教 }\end{array}$ & 储 \\
\hline 1 & & 20 & $\hat{\delta}$ & $\begin{array}{l}32 \\
33\end{array}$ & $\begin{array}{l}40.9 \\
38.3\end{array}$ & $\begin{array}{l}1: 64 \\
1: 64\end{array}$ & $\begin{array}{ll}1: & 4 \\
1: & 4\end{array}$ & = & 「パグノン」证射 \\
\hline 2 & & 22 & q & $\begin{array}{l}12 \\
14\end{array}$ & $\begin{array}{l}40.2 \\
37.8\end{array}$ & $\begin{array}{l}1: 16 \\
1: 16\end{array}$ & $\begin{array}{l}1: 64 \\
1: 64\end{array}$ & 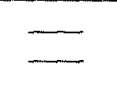 & 「ビラミドン」内服 \\
\hline 3 & & 11 & $\delta$ & $\begin{array}{l}11 \\
12\end{array}$ & $\begin{array}{l}39.8 \\
37.4\end{array}$ & $\begin{array}{l}\text { 1: } 32 \\
1: 16\end{array}$ & $\begin{array}{l}1: 64 \\
1: 64\end{array}$ & E & $\begin{array}{l}\text { 「ピラミジン」內服 } \\
\text { 及「バグ,ン」注射 }\end{array}$ \\
\hline 4 & & 44 & 우 & $\begin{array}{l}18 \\
19\end{array}$ & $\begin{array}{l}39.8 \\
36.5\end{array}$ & $\begin{array}{l}1: 128 \\
1: 128\end{array}$ & $\begin{array}{l}1: 33 \\
1: 32\end{array}$ & $=$ & 「バグノン」洼射 \\
\hline 5 & & 18 & $\hat{\delta}$ & $\begin{array}{l}6 \\
7\end{array}$ & $\begin{array}{l}40.4 \\
39.0\end{array}$ & $\begin{array}{ll}1: & 4 \\
1: & 2\end{array}$ & $\begin{array}{l}1: 16 \\
1: 16\end{array}$ & $=$ & 「バグノン」注射 \\
\hline 6 & & 38 & 우 & $\begin{array}{l}29 \\
29\end{array}$ & $\begin{array}{l}39.7 \\
86.0\end{array}$ & $\begin{array}{l}1: 128 \\
1: 128\end{array}$ & $\begin{array}{l}1: 64 \\
1: 64\end{array}$ & $\begin{array}{l}1: 64 \\
1: 64\end{array}$ & \\
\hline 7 & & 41 & 우 & $\begin{array}{l}40 \\
41\end{array}$ & $\begin{array}{l}38.5 \\
36.2\end{array}$ & $\begin{array}{l}1: 856 \\
1: 128\end{array}$ & $\begin{array}{l}1: 256 \\
1: 256\end{array}$ & $\begin{array}{l}1: 64 \\
1: 32\end{array}$ & 注射 \\
\hline 8 & & 66 & 우 & $\begin{array}{l}13 \\
13\end{array}$ & $\begin{array}{l}39.7 \\
37.5\end{array}$ & $\begin{array}{l}1: 16 \\
1: 16\end{array}$ & $\begin{array}{l}1: 32 \\
1: 33\end{array}$ & $\begin{array}{l}1: 32 \\
1: 32\end{array}$ & 腸出血 \\
\hline 9 & & 21 & $q$ & $\begin{array}{l}36 \\
37\end{array}$ & $\begin{array}{l}39.1 \\
37.0\end{array}$ & $\begin{array}{l}1: 32 \\
1: 32\end{array}$ & $\begin{array}{l}\text { 1: } 64 \\
1: 64\end{array}$ & $\begin{array}{l}1: 16 \\
1: 16\end{array}$ & $\ulcorner ヒ ゚ ラ ミ$ \\
\hline 10 & & 14 & $\hat{\delta}$ & $\begin{array}{l}23 \\
24\end{array}$ & $\begin{array}{l}39.2 \\
37.9\end{array}$ & $\begin{array}{l}1: 256 \\
1: 256\end{array}$ & $\begin{array}{ll}1: & 8 \\
1: & 8\end{array}$ & $\begin{array}{l}1: 64 \\
1: 32\end{array}$ & 「バグ \\
\hline 11 & & 36 & $\hat{\delta}$ & $\begin{array}{l}22 \\
22 \\
\end{array}$ & $\begin{array}{l}40.4 \\
36.8\end{array}$ & $\begin{array}{l}1: 64 \\
1: 64\end{array}$ & $\begin{array}{l}\text { 1: } 64 \\
\text { 1: } 64\end{array}$ & $\begin{array}{l}1: 64 \\
1: 16 \\
\end{array}$ & \\
\hline 12 & & 31 & $q$ & $\begin{array}{l}46 \\
47\end{array}$ & $\begin{array}{l}40.5 \\
35 . \bar{I}\end{array}$ & $\begin{array}{ll}1: & 64 \\
1: & 32\end{array}$ & $\begin{array}{l}1: 128 \\
1: 128\end{array}$ & $\begin{array}{ll}1: & 8 \\
1: & 2\end{array}$ & 丙服 \\
\hline 13 & & 15 & $\hat{\delta}$ & $\begin{array}{l}21 \\
21\end{array}$ & $\begin{array}{l}39.7 \\
37.6\end{array}$ & $\begin{array}{l}1: 128 \\
1: 128\end{array}$ & $\begin{array}{l}1: 256 \\
1: 256\end{array}$ & $\begin{array}{l}1: 128 \\
1: 128\end{array}$ & \\
\hline 14 & & 41 & + & $\begin{array}{r}9 \\
11\end{array}$ & $\begin{array}{l}39.7 \\
38.3\end{array}$ & $\begin{array}{l}1: 16 \\
1: 16\end{array}$ & $\begin{array}{l}1: 64 \\
1: 64\end{array}$ & $\begin{array}{l}1: 126 \\
1: 64\end{array}$ & \\
\hline 15 & & 25 & q & $\begin{array}{l}60 \\
62\end{array}$ & $\begin{array}{l}39.5 \\
37.0\end{array}$ & $\begin{array}{l}1: 16 \\
1: 16\end{array}$ & $\begin{array}{l}1: 32 \\
1: 32\end{array}$ & - & 「ピラミドン」內服 \\
\hline 16 & & 23 & $\hat{\delta}$ & $\begin{array}{l}18 \\
19\end{array}$ & $\begin{array}{l}40.0 \\
38.5\end{array}$ & $\begin{array}{l}1: 64 \\
1: 64 \\
\end{array}$ & $\begin{array}{l}1: 256 \\
1: 256 \\
\end{array}$ & $\begin{array}{l}1: 64 \\
1: 64 \\
\end{array}$ & 晹出血 \\
\hline 17 & & 18 & + & $\begin{array}{l}36 \\
36\end{array}$ & $\begin{array}{l}39.8 \\
38.2\end{array}$ & $\begin{array}{l}\text { 1: } 64 \\
1: 32\end{array}$ & $\begin{array}{l}1: 32 \\
1: 32\end{array}$ & $\begin{array}{l}1: 64 \\
1: 32\end{array}$ & 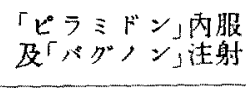 \\
\hline 18 & & 22 & $\hat{\jmath}$ & $\begin{array}{l}20 \\
20\end{array}$ & $\begin{array}{l}38.6 \\
36.3\end{array}$ & $\begin{array}{l}1: 16 \\
1: \quad 8\end{array}$ & $\begin{array}{ll}1: & 1 \\
1: & 1\end{array}$ & $\begin{array}{l}1: 128 \\
1: 128\end{array}$ & 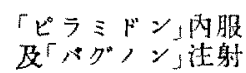 \\
\hline
\end{tabular}




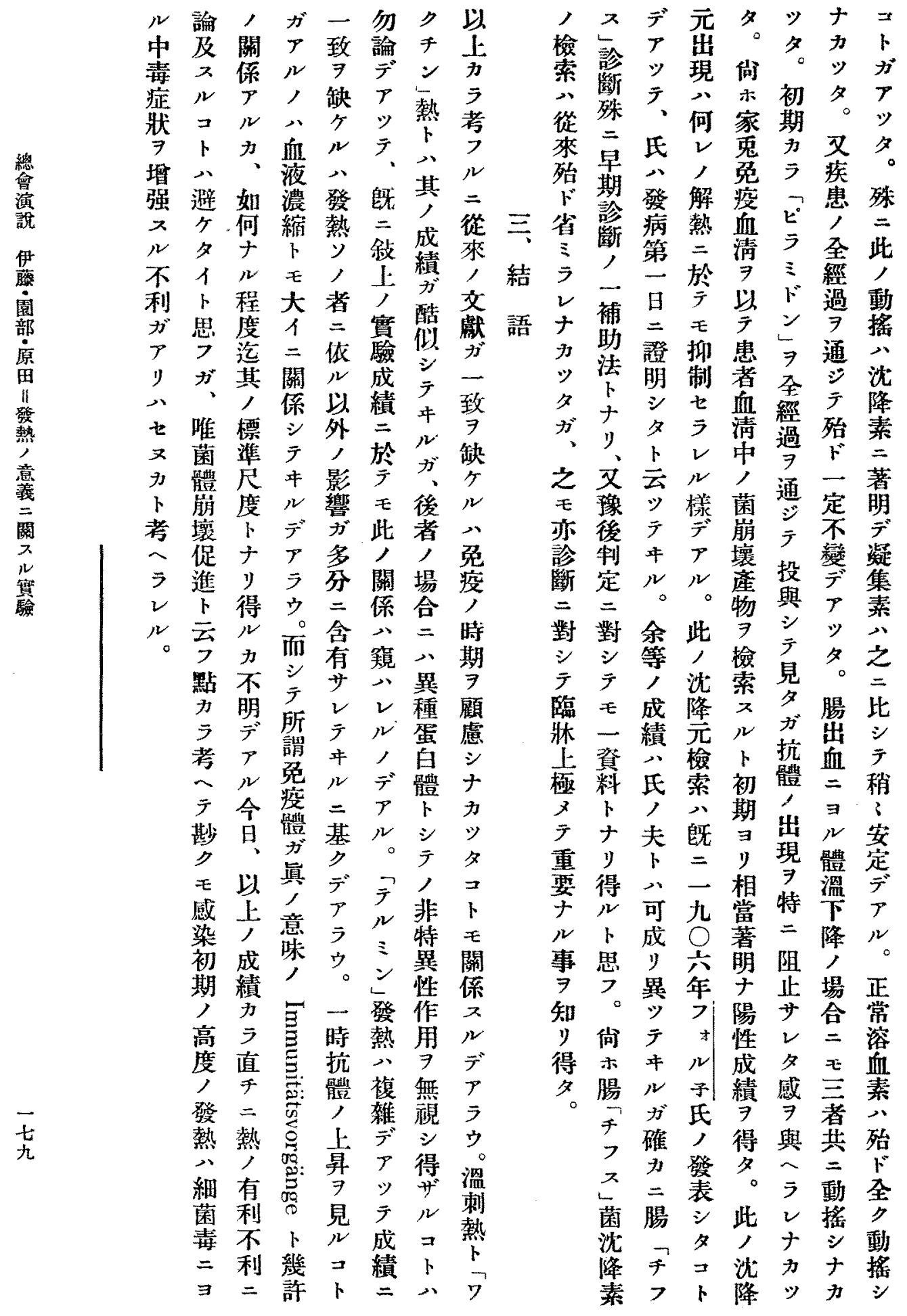


モ時五一體，公依溫年シ，見ス

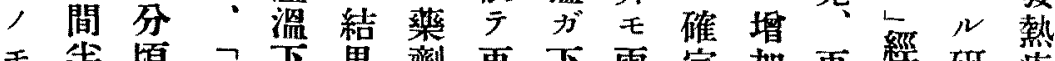
モ半頃 ア下果弱更下雨定加更編研疾 ᄀ多之降 7 自三降方的人三過究患

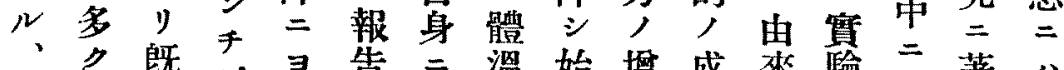

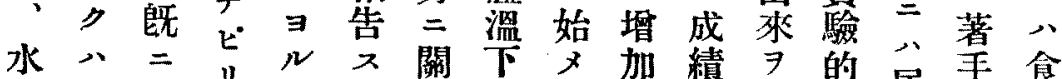

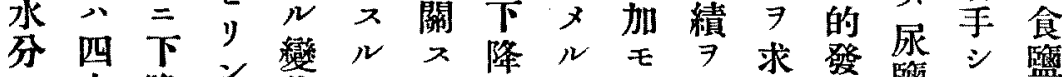

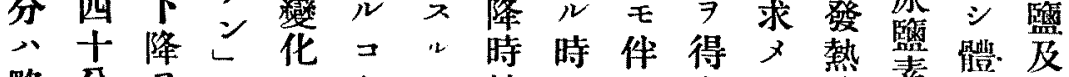
略分 $\Rightarrow$ 卜 之䔛始 $ァ=リ 二$ 時ナカ卜三排上分

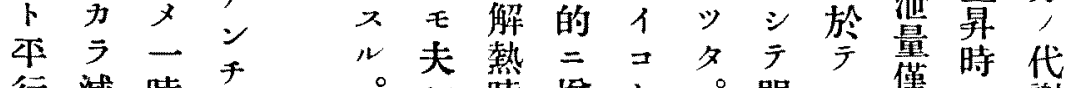
行減時 ス 少間ビ

ガ始最 こ

又邓低 僬體二 當 当溫 $\overrightarrow{\text { 乃 }}$ 減節至

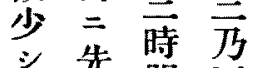
體先間至

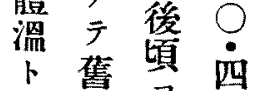
平態寻死 行㐫復焉 王上舊政 ，增始家 $モ>ス$ 體 $ア ル カ ゙$ 溫 毛血 $尹$ デ葆

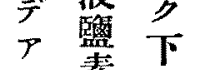

ル素降

ガ、早 シ 此 $\neq>$ 減芰得 少吾气 來㢑 ジ 亏 投 ナ 八與 1-

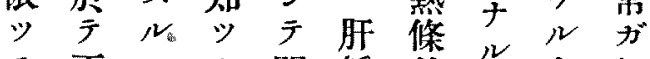
于 兩 $コ$ 夕開静 件極血起 起者卜、腹脈, 極液心 , 7 又 $=$ 如期丙二 體變認加 $\exists$ 下何二監卜 溫化 溫

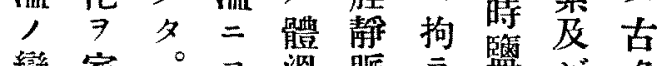

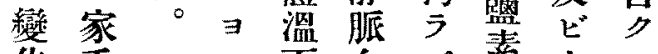

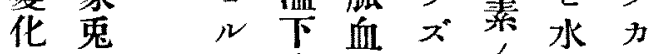
$\exists \exists$ 體降三體三分亏 圭用溫分就温荠, 知

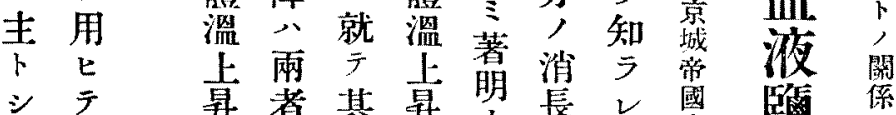

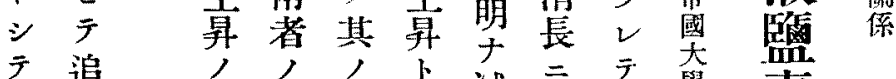

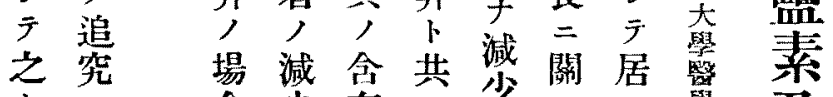

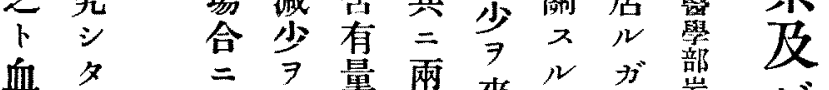

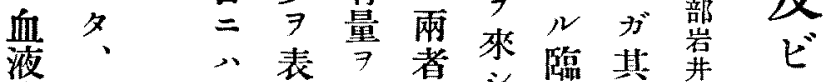

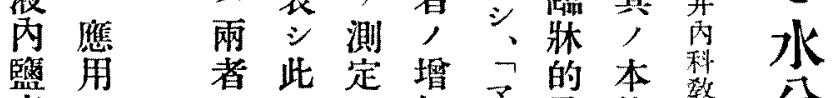

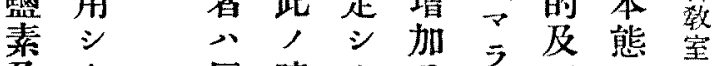

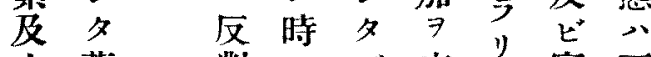

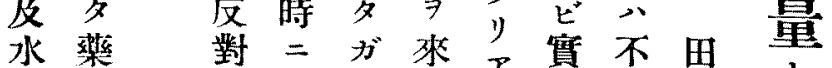
分利 $=八$. ，八減既三コ熟的

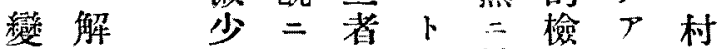

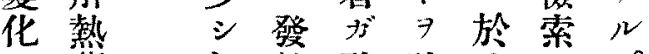
$\exists$ 䒚加熱㱠確今君。

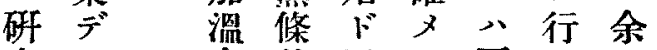

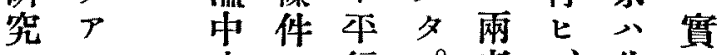
分 江步公行。者:先 夕が=體三而，腸三

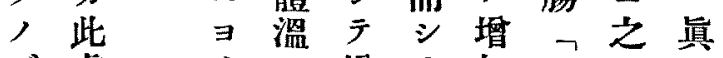
デ 處 y, 增示加于三 此二體上減此 $7>$ 關 


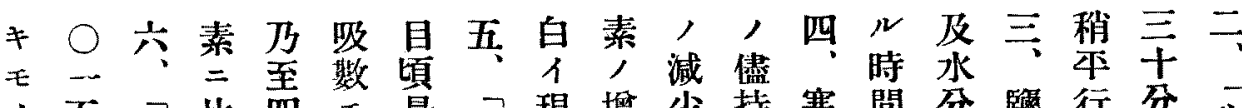

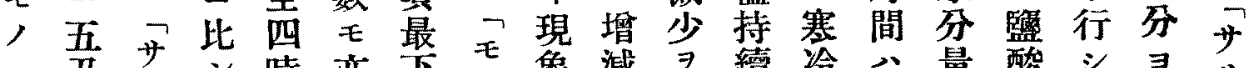
三丨乃至 者者

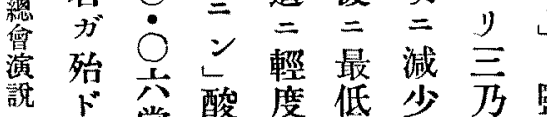

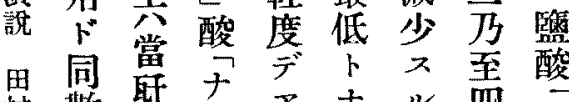

村数 氐ナ゙ト

解位、、y

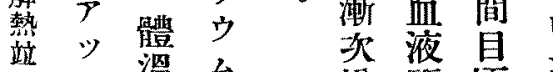

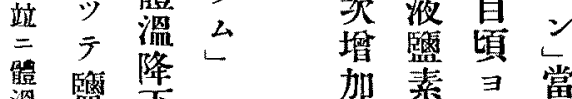

盜監青加素寻當

降素分

血沓著

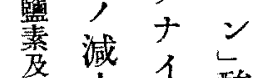

范少、酸

水 7 輕

盆来度要

, 夕下

關モ降ウ

係, 年么

時 赤始

目行亲至

デセ 時官

多遴以 二

ク三上瓦

八集經 》

今公復

數

舊テシ 二

他, 溫

文 字 三

ナ時復 十

$\rightarrow$ 及

不對劣

變 镥著

又度

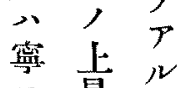

算樣

加ナ三本 $三$ 家下

、生 後

水苛:

妿至・著

八三手明

監 時論 ナ

素間 此 體

卜目, 溫

略頃 時 降

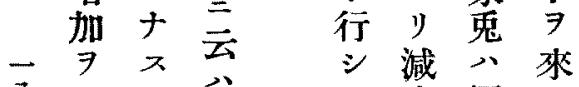

分示䚾

シ, 壬減 7 平モ

又及居少始静，

此 ビ居 ス采

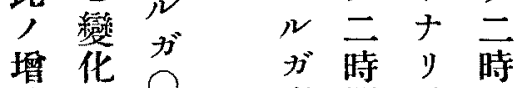

減ナ?

監 間 呼 間

行漸王泠尕力

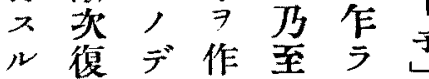

$カ^{*}$ 舊 寒 用 三體

明シ冷七時溫當少市

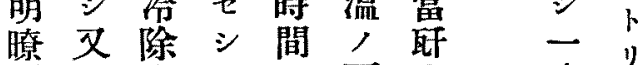

デ 心去メ下○時り

ナ更後ル 間降宁 間

イ、輕 時家

加度間兔時例虔尔

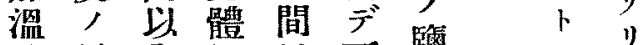

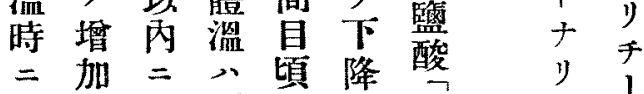

踖 $\exists$ 常下分時 $\neq$

溫示態降最一=

卜 $シ=$ 低時 1

兩寒復ルデ減子

者椧 シ モ $P$ 少

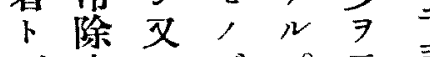

ガ去 $テ ゙ \circ$ 示

他後夫䯏

, 再 v 溫

條 ビ 以

件二上此

$=$ 時 =

$\exists$ 的上時

減昇一

體 少 ᄀ時

温 $\ni ル$ 間

上 示 而

昇洞，至

時 後デ—

卜復 血 時

八鹤液 間

反不監年

對 ル素後

$=モ \gg=$

十, 寒

ルデ椧最

，文，低

卜水初二

共分期達

二小輕 シ

面監度其
ガ體 シ ム

他溫水

例集分當

デ 盬

シ 度 略 互

广 $>$ 同

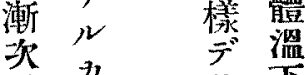

䝰赤共下

加父 二降

示却體

ス、テ 宁 デ

而年降厂

₹ 時 $\rightarrow j$

减沓間 監

少 罶

ス素

的素
入復䇺

却铔素立 


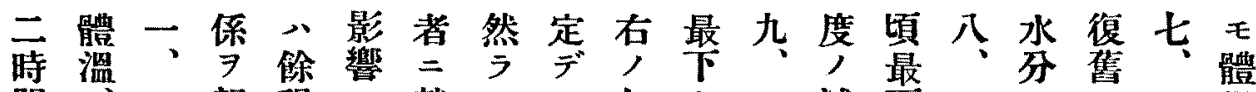

間、ワ報程

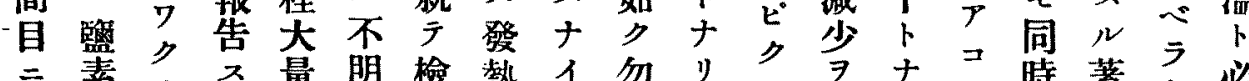

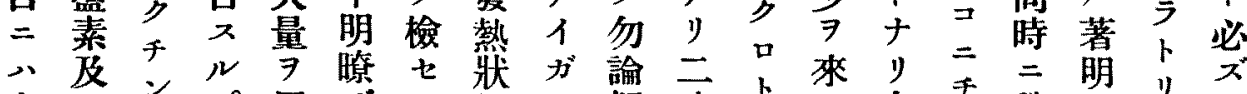

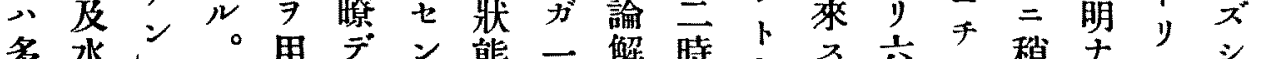

多水こ。用デン態一解時キス六チ稍ナンシ

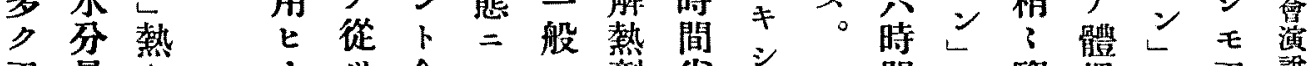

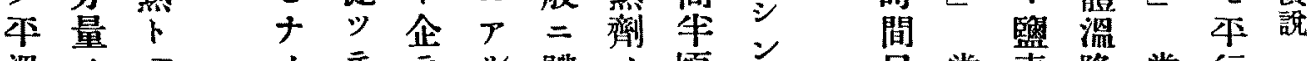

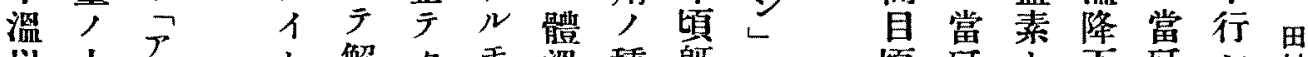

類二當歪 $\bigcirc$ 同 $\Rightarrow \bigcirc$ ナ

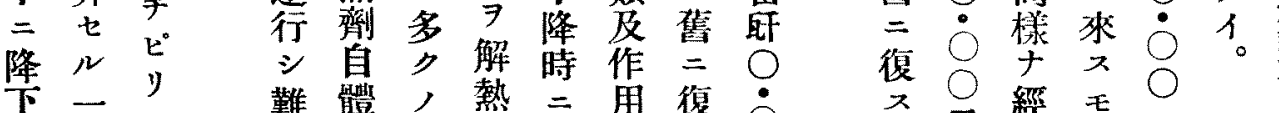

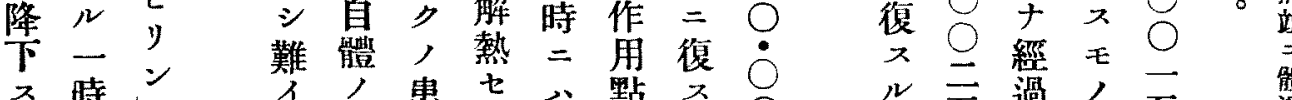

ス 時こ

モ 後一萣溫者

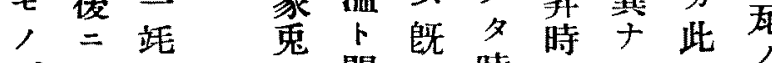

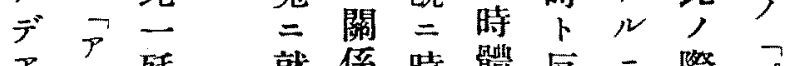

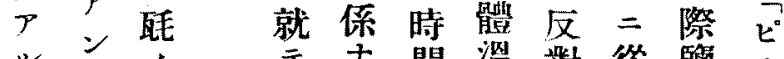

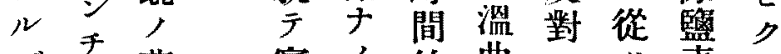

ガ 菌惯余的曲三ツ素口

鹽

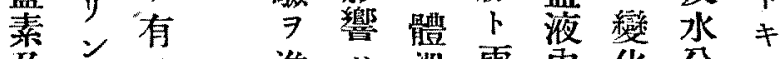

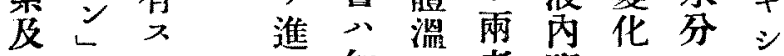

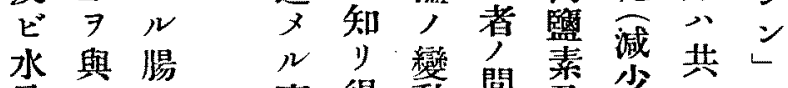

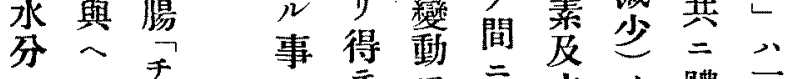

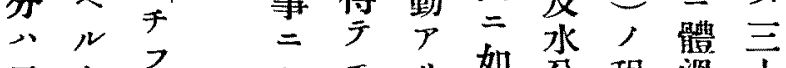

二 1 为 $モ$ 㚾分程溫市

時既元夕當又何, 度降分

間 = 、面解ナ減三下

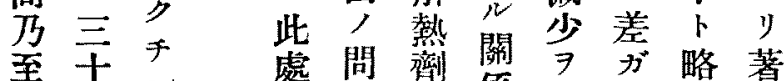

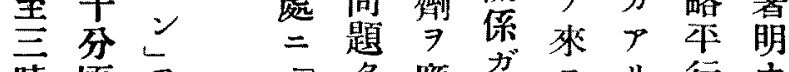

時顷 $\rightarrow$ 多應

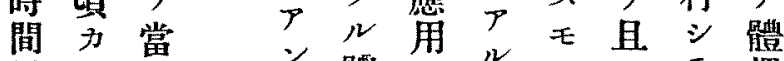

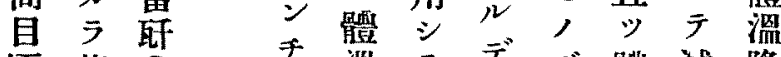

頃著○チ溫テデデ體減降

迄奛酉比,

增子四變普ラルトト

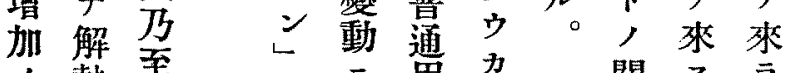

, 熱至 二 =通カ、關ス

狀笋? ヨョ量之係之シ

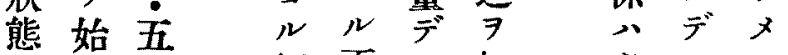

二又踝解雨 心初

ル 泩

熱者之メ

必 $ア-$

ッ 射

管, = 發

ズル 時

テ, 政

次 デテ

, 消 $\exists$ 熱

シ。間

關 長 $ル$ 患

モ 牛

-

監

素 $ッ$ 素へ

隇コテ只う

少二減三卜

八チ・少時り

輕ンス間ン

度し几。目し

テ著冠一

乃奛二時

至ナ最間

此低目

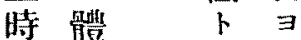

間溫ナり

自下》始

垻降四?

$=\Rightarrow$ 乃

認來 至主

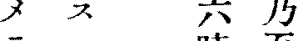

5 モ 時至

ᄂ, 間 四

ルデ 目時

- 三而間

水干茫 デ

分分笪最

監り舊卜

等始画

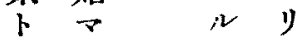

略り減六

同三少時

栐時 $\quad$ 間

= 間 示目

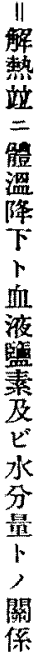

輕目 シ 頃 


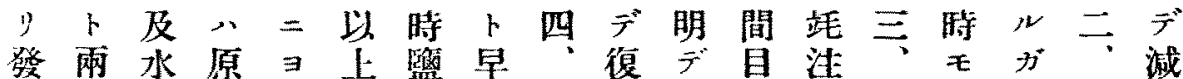

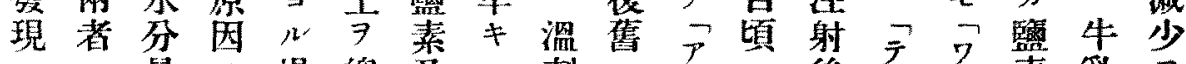
八量, 場總及心刺

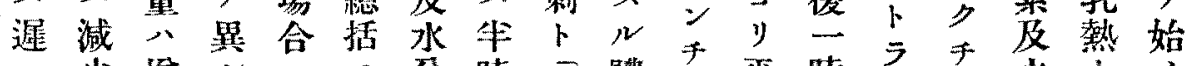

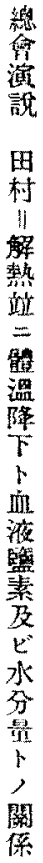

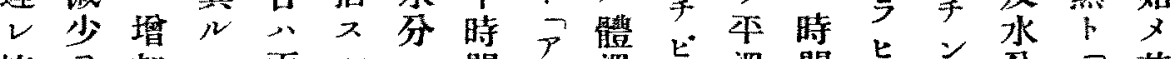

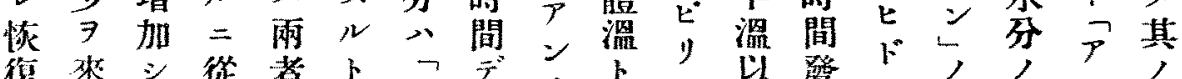
復來 シ從者卜,

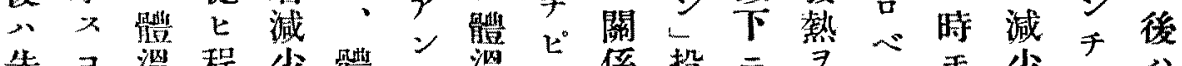
先 ッ 、降, $x^{\circ}$ 上

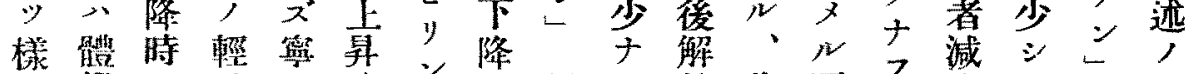
デ 㴘 = 重口時こ

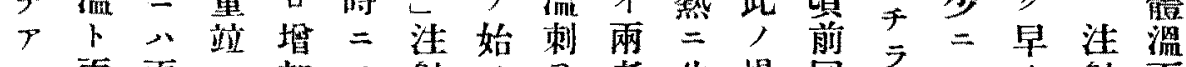

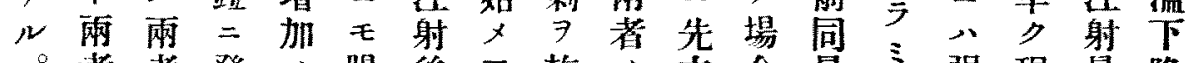
者者發, 腸後二施人立合量乏强現量降 ト ガ現傾

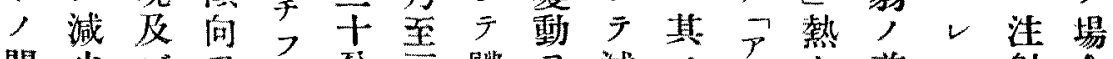
間少

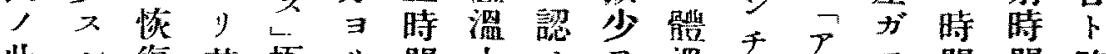
此 $ル$ 復其極り問上ヌ $上$ 温

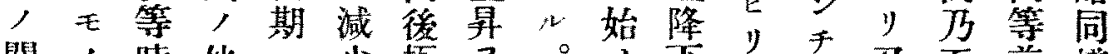
關, 時他二少極 $尹$ ○ $又$ 下

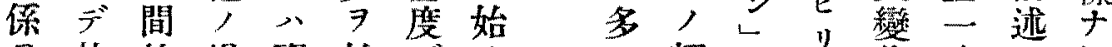

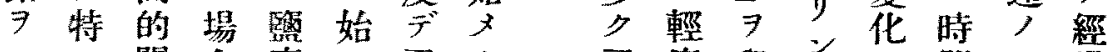
$\exists=$ 關合素邓巫名 三度與

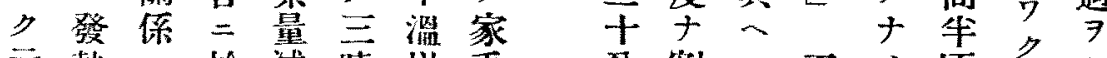

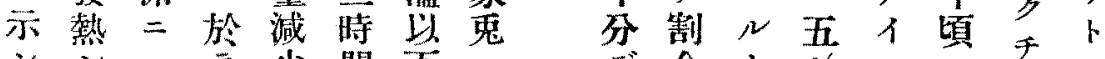
シ シ $シ$ 少間下

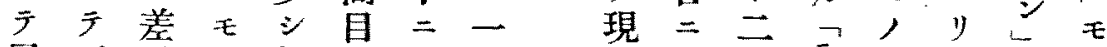

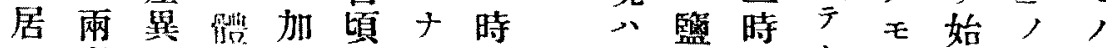
者 八溫㴘復り間レ素間 、增 $\succ 上$ 時舊五後二及目 倘加

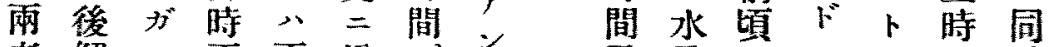

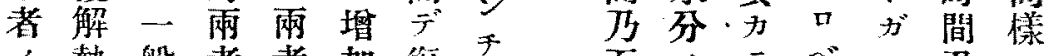
人熱般者者加復 ピ至, ラべア乃二

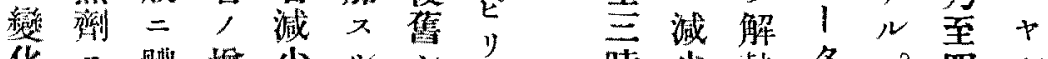
化二體篔少ルシ時少熱夕。四心

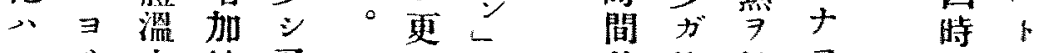
一, 上证又三

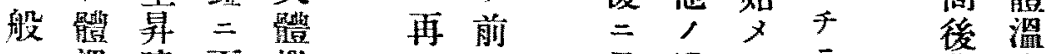
二溫時下溫 ビト最場二ラ 舊曲 八 $\exists$ 二降下同下合時ミ三線 䐬下 蘊降血雨時

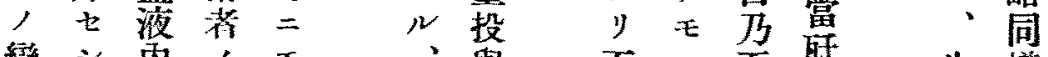

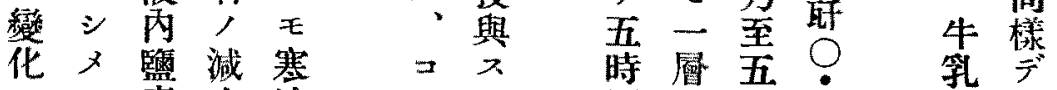

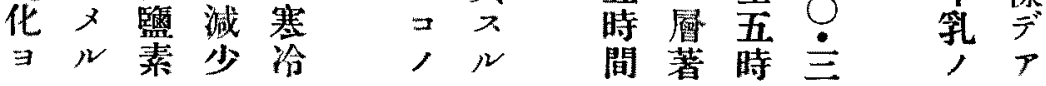




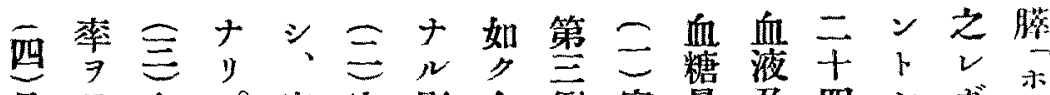
是見犬。家家影血屍家量及四 シ 湆示

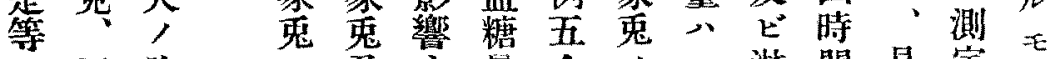

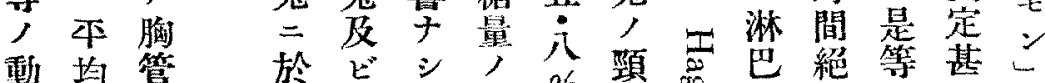

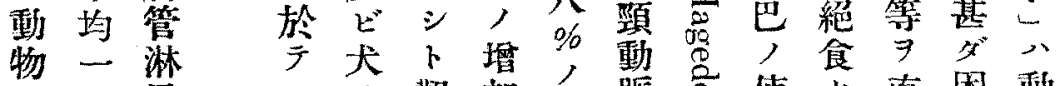

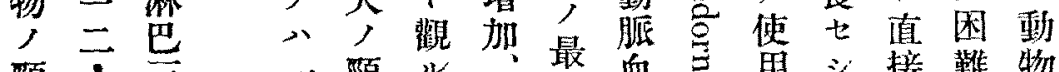

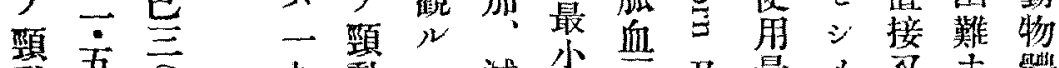

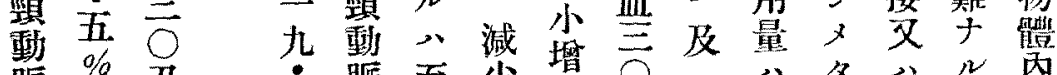

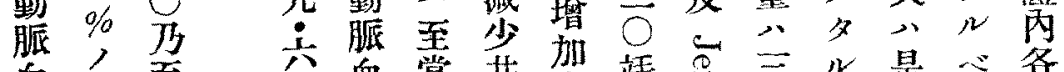

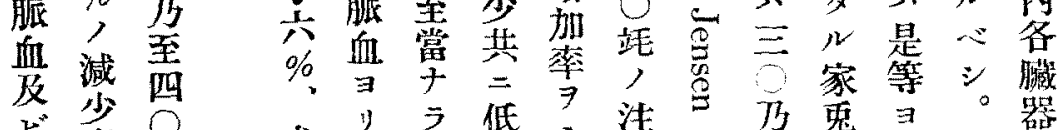

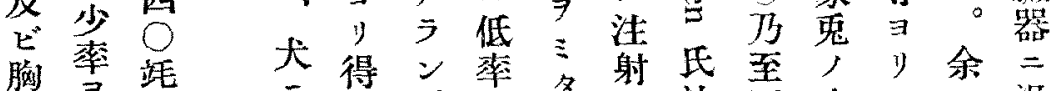

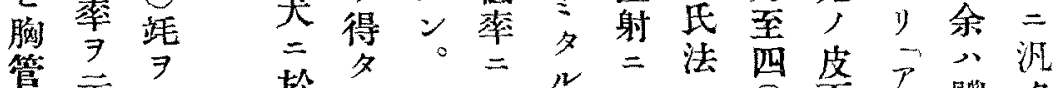
淋示直笑为洌

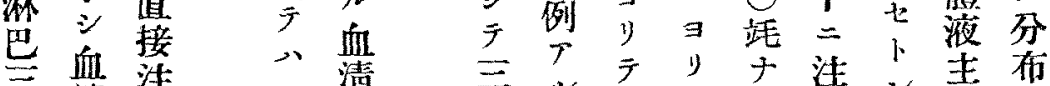

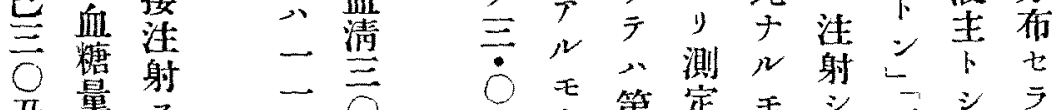
艿量

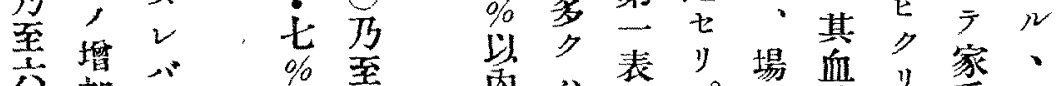

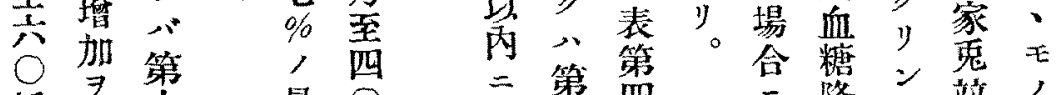

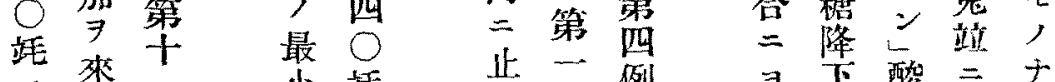

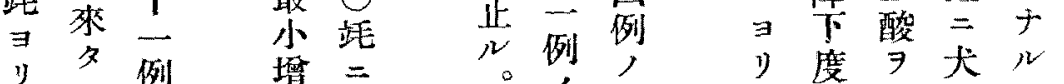

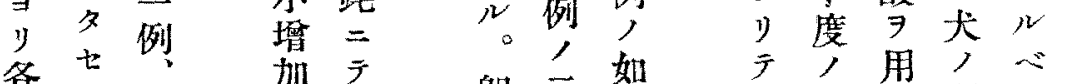

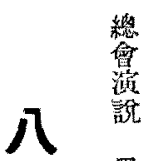
各例第萃

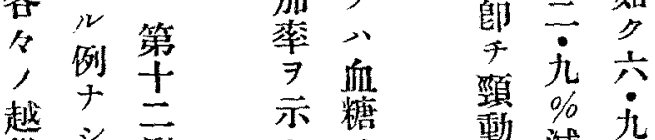

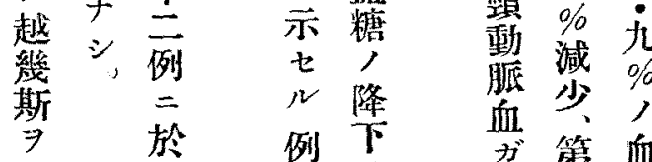

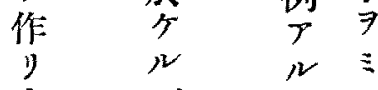

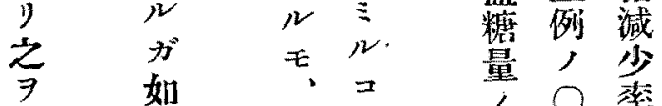

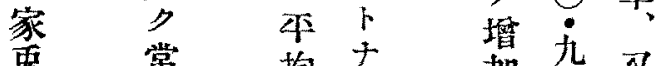

兔常均学妿杂无

皮 - 、減最第

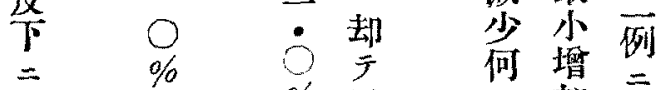

洼 以 \% 增 2 加

射占最架對率分

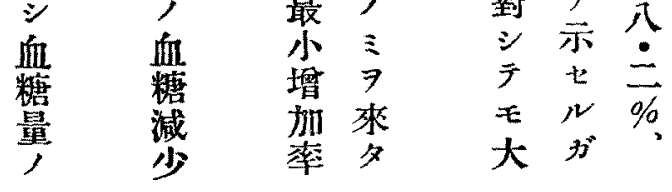

公分用頸 シ 六小心動 斗微脈踓悉

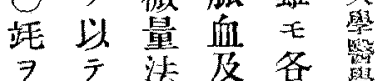

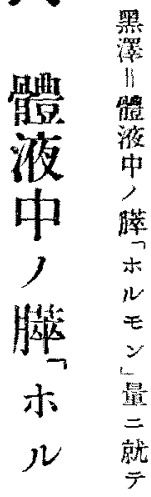
モ 偖 二 就 テ 用䑏 $\exists$ 七名部 七水以脸其態 夕示管含窉 り。モ作淋有刑 亡 量越, 異

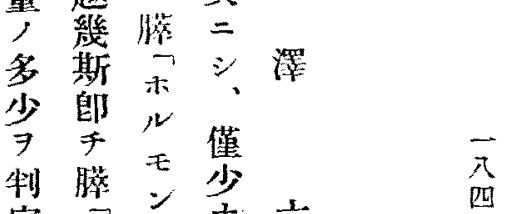

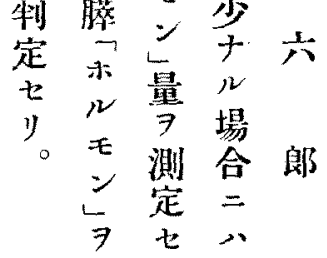




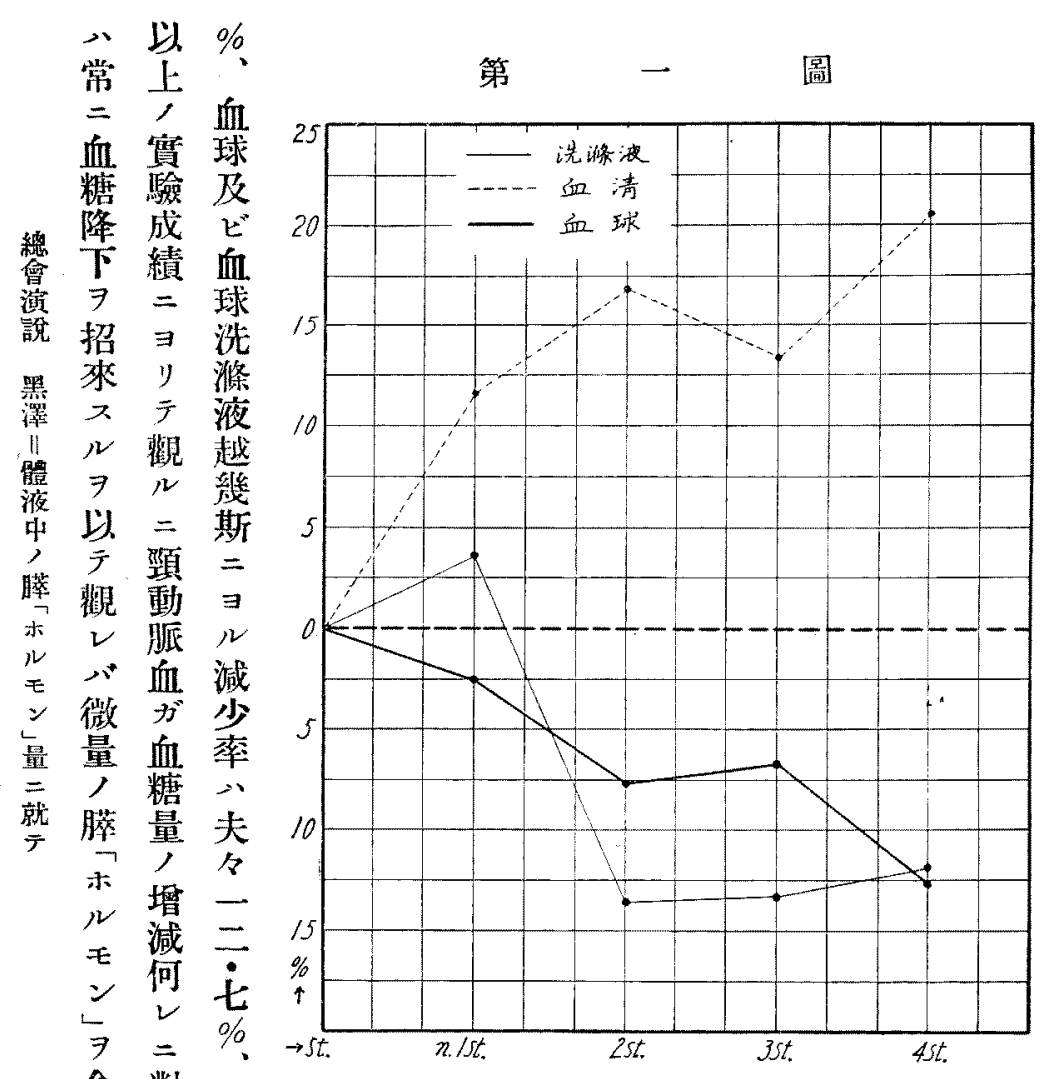

五斯 畿增

家 $\exists=7$

兔 リ 天 貺

灭 二察

鴙常

, $\frac{\text { W }}{=}=$

获

静

脈\%

血 乃 畿

及 至 \% 斯

ビ全、二

潆二犬於

$\because \div$,

无血

指 \% 液 血

垣, 越 糖

㗈減幾量

胍少斯,

脈萃二增

血 $\ni$ 加

- 示 一 7

○七 $\dot{t}$ 來

乃

王第

含 對

厶 $シ$ 一球 球

二 四第沅洗血琵 7 、兵其於二

卜E五圆滌滥清者的採刃膵率亏血

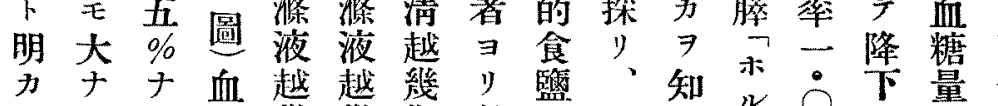

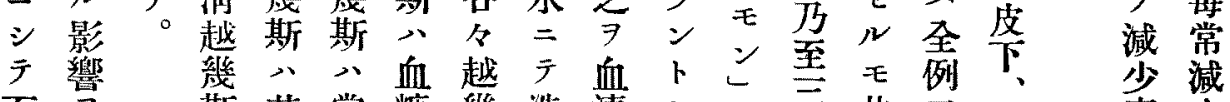

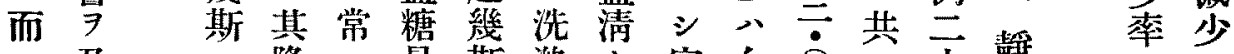

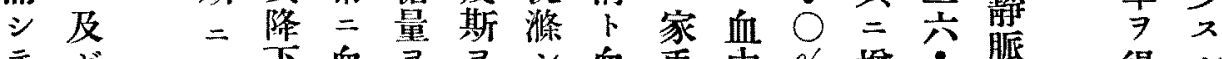

テボ

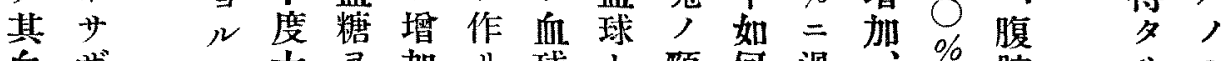

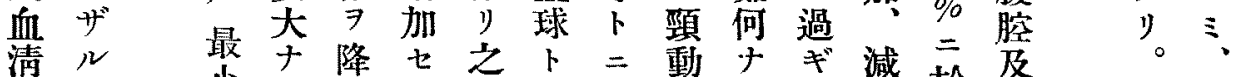

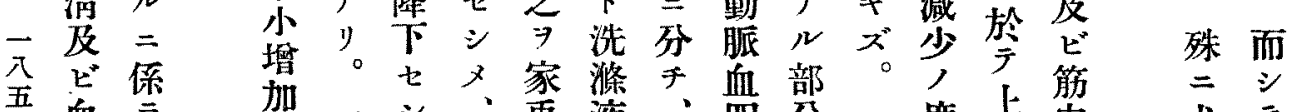

血亏 率二

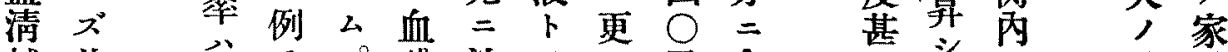

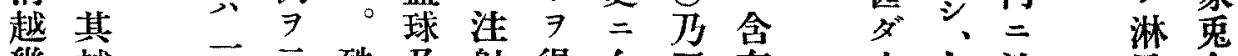

幾越二示殊及射得血至有少七注岜血

斯幾茷七

八斯 七 
時

第

$=$

周

N 甚

モ ダ

後

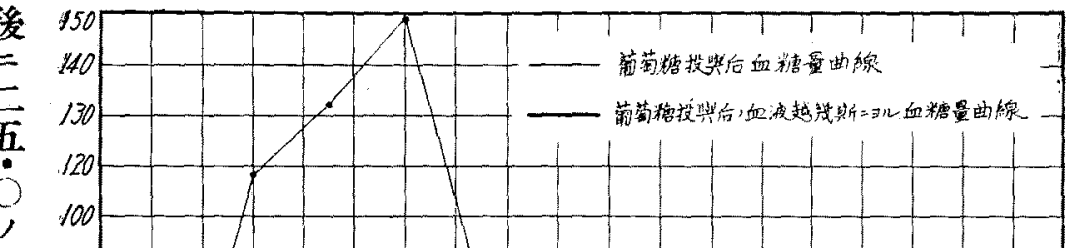

增

加

90

率

f

t)

t

時

間

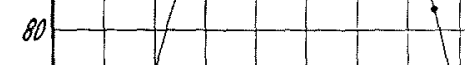

70

60

政

放

恝

投

與

前

血

糖

量

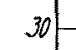

$20-$

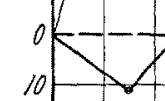

20

${ }_{40}^{30}$

$\hat{\hat{\hat{t}}}$

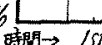

yレ後

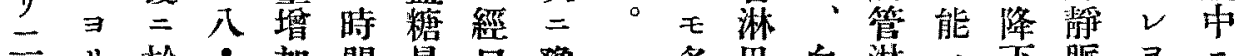

二y於方加間量口像多巴血淋入下脈 $7=$

$\doteq$ 後

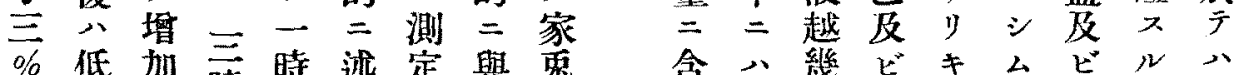

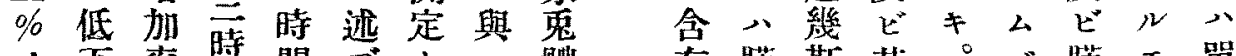

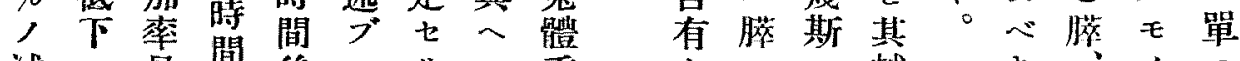

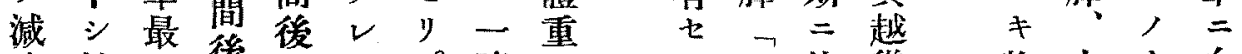

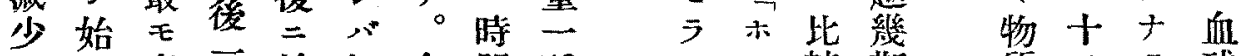

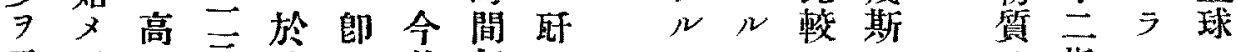

示无夕三手其每

シ時一五糖增二對 $=ン$ 其常明腸。附

間四四四投加十シレ作三召静著

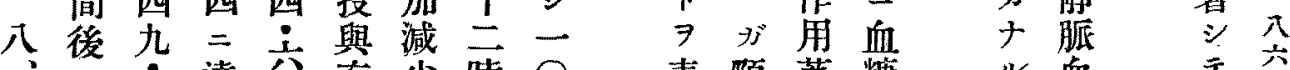

二 達公直少時 $\bigcirc$ 表頸著糖 $ル$ 血

九兲

十四示、時 $\exists,=$, 又脤

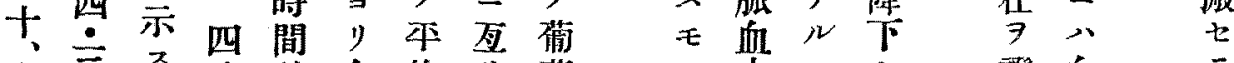

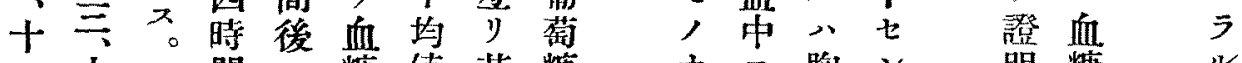

二六 $=$ 間 糖值其糖 
第一表 一冝 液 淋 巴

\begin{tabular}{|c|c|c|c|c|c|c|c|c|c|c|}
\hline \multirow{3}{*}{$\begin{array}{l}\text { 番 } \\
\text { 號 }\end{array}$} & \multirow{3}{*}{$\begin{array}{l}\text { 家鬼 } \\
\text { 體壷 } \\
\text { (瓦) }\end{array}$} & \multirow{3}{*}{ 注射材料 } & \multirow{3}{*}{$\begin{array}{l}\text { 诘 } \\
\text { 射 } \\
\text { 量 } \\
\text { (犝) }\end{array}$} & \multicolumn{2}{|r|}{ 血 } & \multirow[t]{2}{*}{ 糖 } & \multirow{2}{*}{$\begin{array}{c}\text { 量 } \\
\text { 射 } \\
\end{array}$} & \multicolumn{2}{|l|}{$\%$} & \multirow{3}{*}{$\begin{array}{l}\text { 增加減少 } \\
\text { 率\% }\end{array}$} \\
\hline & & & & \multirow{2}{*}{ 注射前 } & 注 & & & \multicolumn{2}{|c|}{ 後 } & \\
\hline & & & & & 一時間 & 二時間 & 三時間 & 四時間 & 五時間 & \\
\hline$I$ & 1540 & $\begin{array}{l}\text { 家鬼頱動 } \\
\text { 脤血 }\end{array}$ & 30 & 0.104 & 0.110 & 0.101 & 0.110 & 0.118 & 0.119 & (-) 2.9 \\
\hline II & 1510 & ", & 80 & 0.109 & 0.144 & 0.118 & 0.137 & 0.138 & 0.148 & $(+) 8.2$ \\
\hline III & 1510 & ", & 30 & 0.102 & 0.118 & 0.136 & 0.108 & 0.120 & 0.124 & (t) 5.8 \\
\hline IV & 1440 & " & 30 & 0.116 & 0.108 & 0.122 & 0.131 & 0.142 & 0.149 & $(-) 6.9$ \\
\hline$\nabla$ & 2000 & " & 30 & 0.108 & 0.109 & 0.113 & 0.119 & 0.120 & 0.122 & $(+) 0.9$ \\
\hline VI & 1420 & 家雸血清 & 30 & 0.112 & 0.135 & 0.189 & 0.160 & 0.163 & 0.160 & $(+) 19.6$ \\
\hline VII & 2000 & ", & 35 & 0.109 & 0.112 & 0.132 & 0.126 & 0.125 & 0.128 & (+) 2.7 \\
\hline $\mathrm{Vm}$ & 1730 & 犬血 清 & 30 & 0.109 & 0.121 & 0.112 & 0.114 & 0.111 & 0.126 & (+) 2.7 \\
\hline IX & 1400 & , & 30 & 0.088 & 0.106 & 0.098 & 0.096 & 0.095 & 0.094 & (t) 6.9 \\
\hline$X$ & 1650 & & 40 & 0.069 & 0.077 & 0.105 & 0.103 & 0.110 & 0.112 & $(+) 11.7$ \\
\hline$X I$ & 1400 & 夿胸管淋 & 30 & 0.114 & 0.097 & 0.109 & 0.118 & 0.122 & 0.118 & $(-) 14.9$ \\
\hline XII & 1200 & , , & 40 & 0.109 & 0.099 & 0.103 & 0.108 & 0.118 & 0.113 & $(-) 10.1$ \\
\hline
\end{tabular}

第 二 表 血液. 淋巴越幾斯

\begin{tabular}{|c|c|c|c|c|c|c|c|c|c|c|c|}
\hline \multirow{3}{*}{$\begin{array}{l}\text { 番 } \\
\text { 號 }\end{array}$} & \multirow{3}{*}{$\begin{array}{l}\text { 家鬼 } \\
\text { 體重 } \\
\text { (五) }\end{array}$} & \multirow{3}{*}{ 木 } & \multirow{3}{*}{ 料 } & \multirow{3}{*}{ 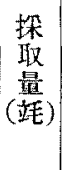 } & \multicolumn{2}{|r|}{ 血. } & \multirow[t]{2}{*}{ 糖 } & \multirow{2}{*}{$\frac{\text { 量 }}{\text { 射 }}$} & \multicolumn{2}{|l|}{$\%$} & \multirow{3}{*}{$\begin{array}{l}\text { 顈加減少 } \\
\text { 复 }\end{array}$} \\
\hline & & & & & \multirow{2}{*}{ 注射前 } & 注 & & & \multicolumn{2}{|c|}{ 後 } & \\
\hline & & & & & & 一時間 & 二時間 & 三時間 & 四時間 & 五時間 & \\
\hline I & 1450 & & 鬼血液 & 30 & 0.102 & 0.112 & 0.102 & 0.100 & 0.102 & 0.102 & (-) 2.0 \\
\hline II & 1712 & & , & 80 & 0.103 & 0.095 & 0.108 & 0.104 & 0.106 & 0.107 & $(-) 8.0$ \\
\hline III & 2100 & & ", & 40 & 0.102 & 0.097 & 0.099 & 0.106 & 0.092 & 0.097 & (-) 9.8 \\
\hline IV & 1420 & & 血 液 & 60 & 0.121 & 0.119 & 0.119 & 0.121 & 0.120 & 0.125 & (-) 1.7 \\
\hline$\nabla$ & 1200 & & " & 60 & 0.122 & 0.116 & 0.114 & 0.118 & 0.113 & 0.113 & $(-) 8.2$ \\
\hline VI & 2050 & & " & 40 & 0.108 & 0.102 & 0.098 & 0.111 & 0.098 & 0.098 & $(-) 9.2$ \\
\hline VII & 1710 & & 淋 巴 & 40 & 0.124 & 0.122 & 0.108 & 0.108 & 0.100 & 0.103 & $(-) 12.9$ \\
\hline VIl & 1820 & & $"$ & 40 & 0.113 & 0.106 & 0.100 & 0.120 & 0.120 & 0.115 & $(-) 11.5$ \\
\hline IX & 2200 & & ", & 40 & 0.103 & 0.104 & 0.093 & 0.095 & 0.101 & 0.101 & (-) 9.7 \\
\hline $\mathrm{X}$ & 2000 & & , & 40 & 0.113 & 0.113 & 0.104 & 0.110 & 0.110 & 0.118 & (-) 8.0 \\
\hline
\end{tabular}

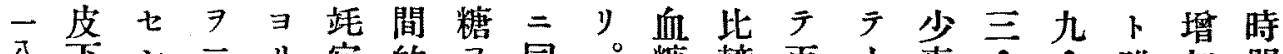

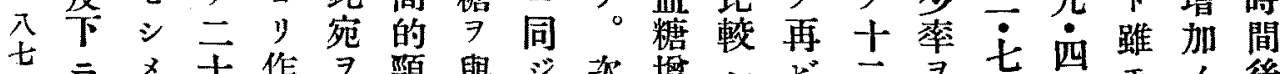
钼與 シ 次增 $シ$ ビ

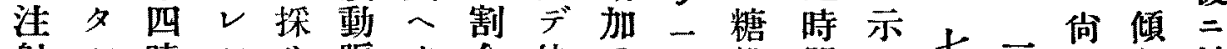

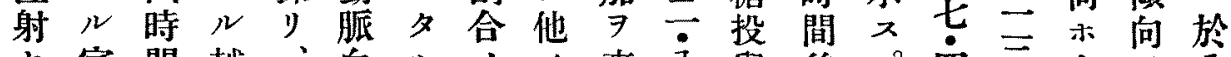

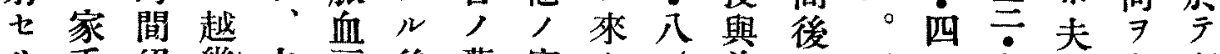
り兔絕幾之恶後葡家夕\%前而, 九各有漸

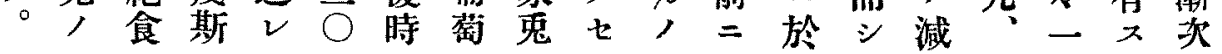


脂第 詳 余

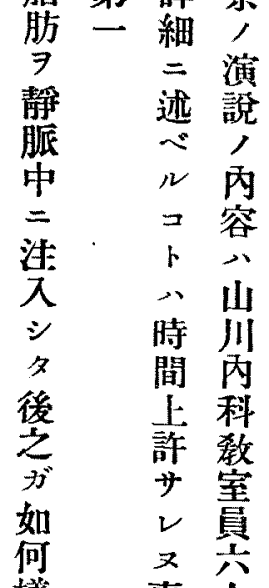

樣事人

$=r$,

新思各

陳>别

代故,

謝只研

二 $\quad$ 究

利中

用

省
2

簡 演 小堀五

師咕 題

チ、二制野田味

1 明, 崎誠朝

㴯点合悌之一

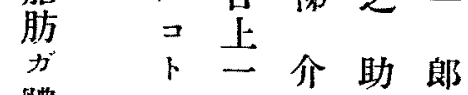

體=ッ界

丙 $x=$

デ直皇

接

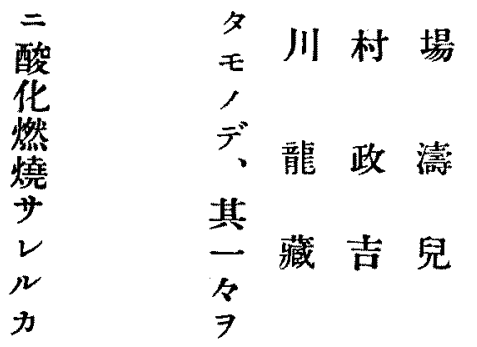

》郎師 7 增 $八=7$ 勿

䑏于千却加一探來論

东比平亦一血夕同

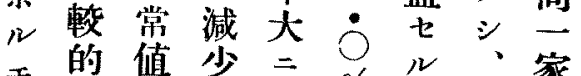

自值少 $三 \%$ 家

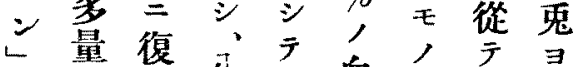

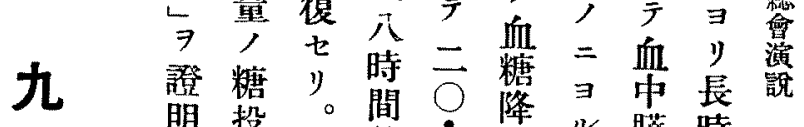

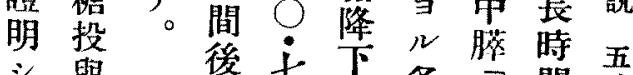

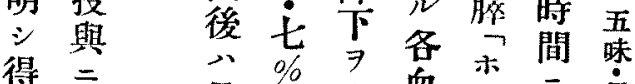

脂 得 $=$ 八 $\%$ 本血杰留

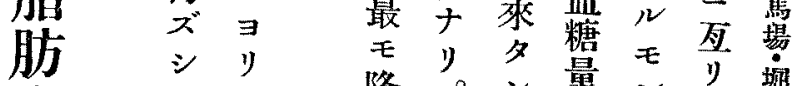

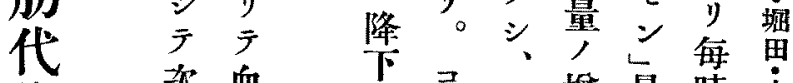

㴬次血, 二增量時禾

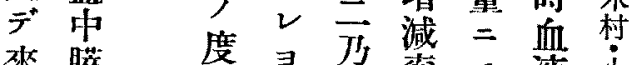

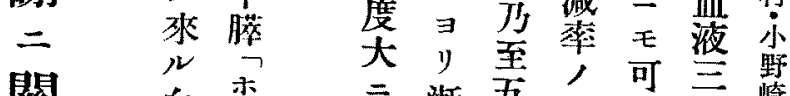

關
ス
ル
察
驗

血杰 三漸吾平成

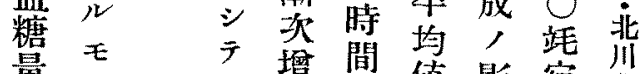

量亡 天增間值影宛川

減

少量 一秦入上变探肍

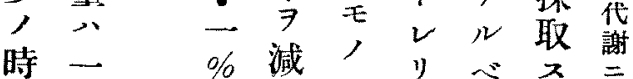

期 時

二血至六血第 $\exists コ$ 等

於糖公。時糖等慮卜筫

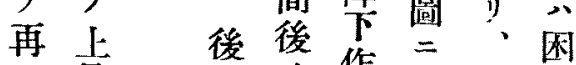

ビ昇漣系角表每難

證卜次飞, 用小度二

明共降, 心多筫 シ

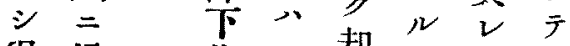

得增 作三却 $カ ゙$ 具

于加用

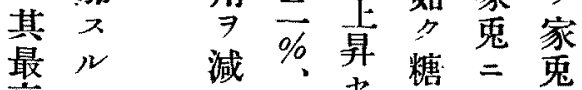

高モ。涪七 投糖,

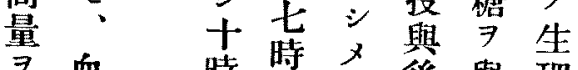

衁 時椨 又後與理

示糖 間間四後興的

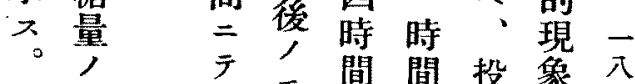

最 $\bigcirc$, 留閣投興

高 \%八, 血後著

位

前ナ七, 越一キ

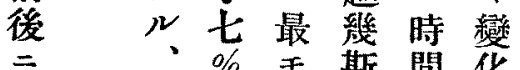




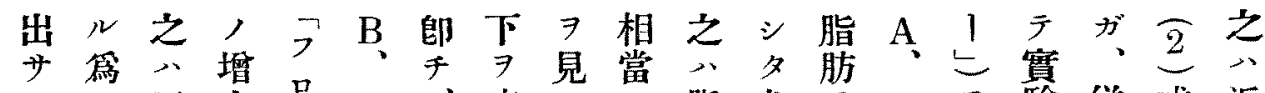

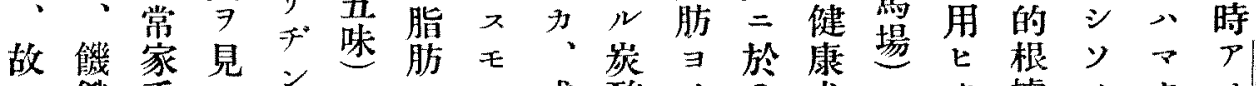

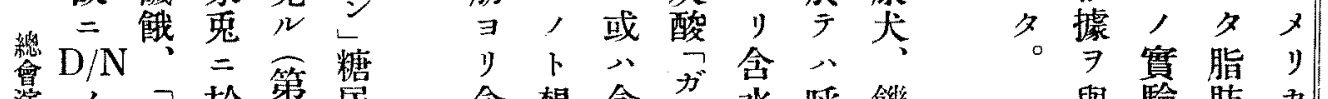

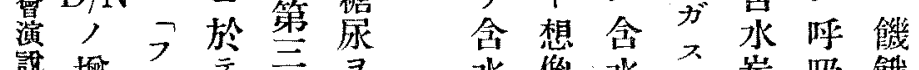

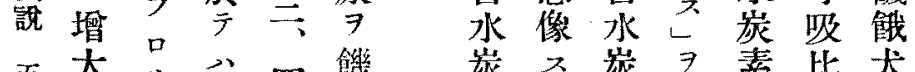
五大y 眛卡體四餓素少素生 $尹$, 覀ナン内五家事新方生著注

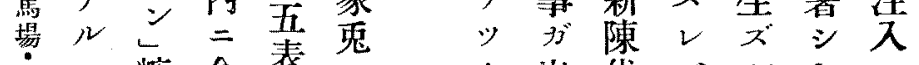
堀モ糖含表二出代心゙ルキ 田, 尿水略起り來謝呼

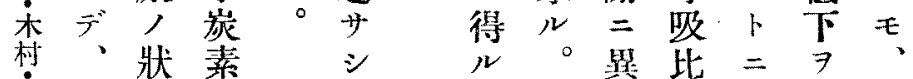
手脂態; 子一常二依桃》

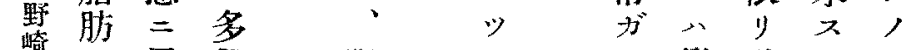

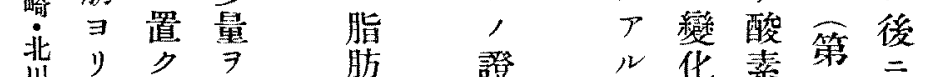

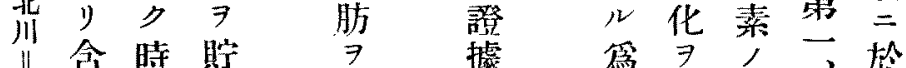

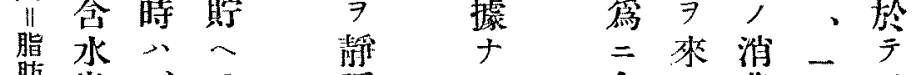

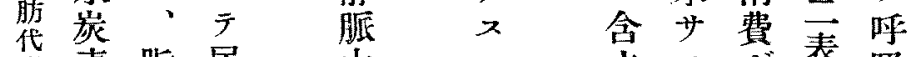
謝素脂居 中

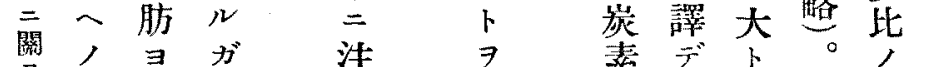

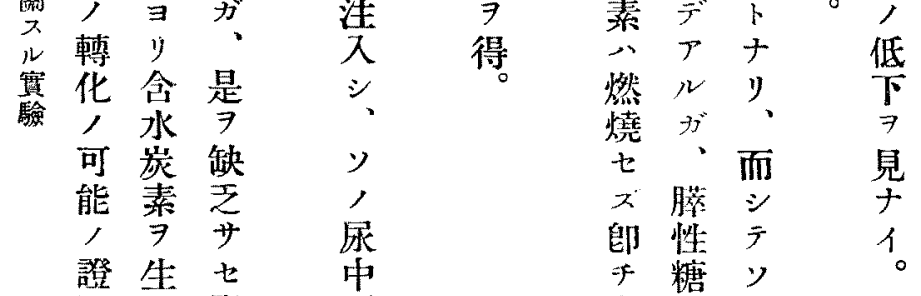

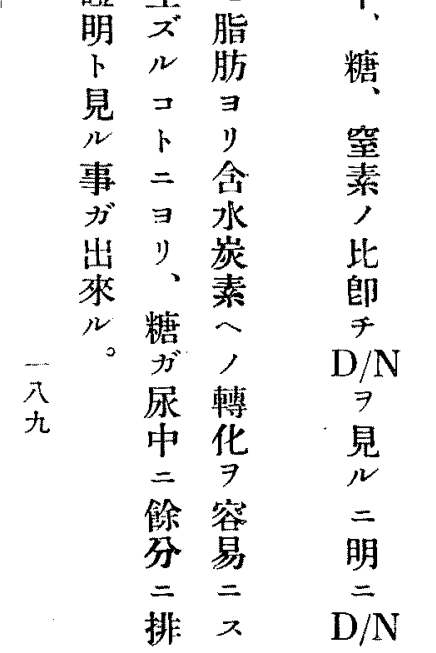

炭展，只

酸卡生櫒 $\rightarrow 5$ 成 性

ス

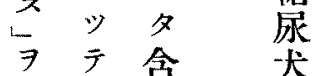

造, 沓

ナ, 䓯 素

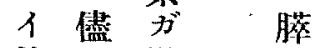

故 尿 燃臟

二中燒 7

呼 = 致大

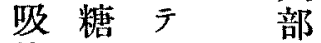

比, = 分

低热 $=$ 摘

與 驗肪 力

ح的 $力$,

得 根 $ラ ル$

夕據含

》 八水行。

卜案炭,

信外素教

ズ薄三室

弱轉 デ

成于化 熱

績 モ 量

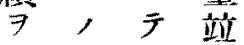

得 デ 然 =

夕呼

デル後骂

此余华罳

二等 燃等

發 心燒

表此 入 昌

不, 㖞

後力

コ説”居

卜含之吕

不永篌說

公炭筑

几素來末

脂軲”學

肪华學界

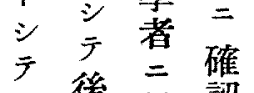

八後信 認

總酸ゼセ

亏燃

脂燒 と多

乳爻居譯

化說 $ル$ デ

液說所

$\underline{7}=$ デナ

$p$ 就 $>$ 。 


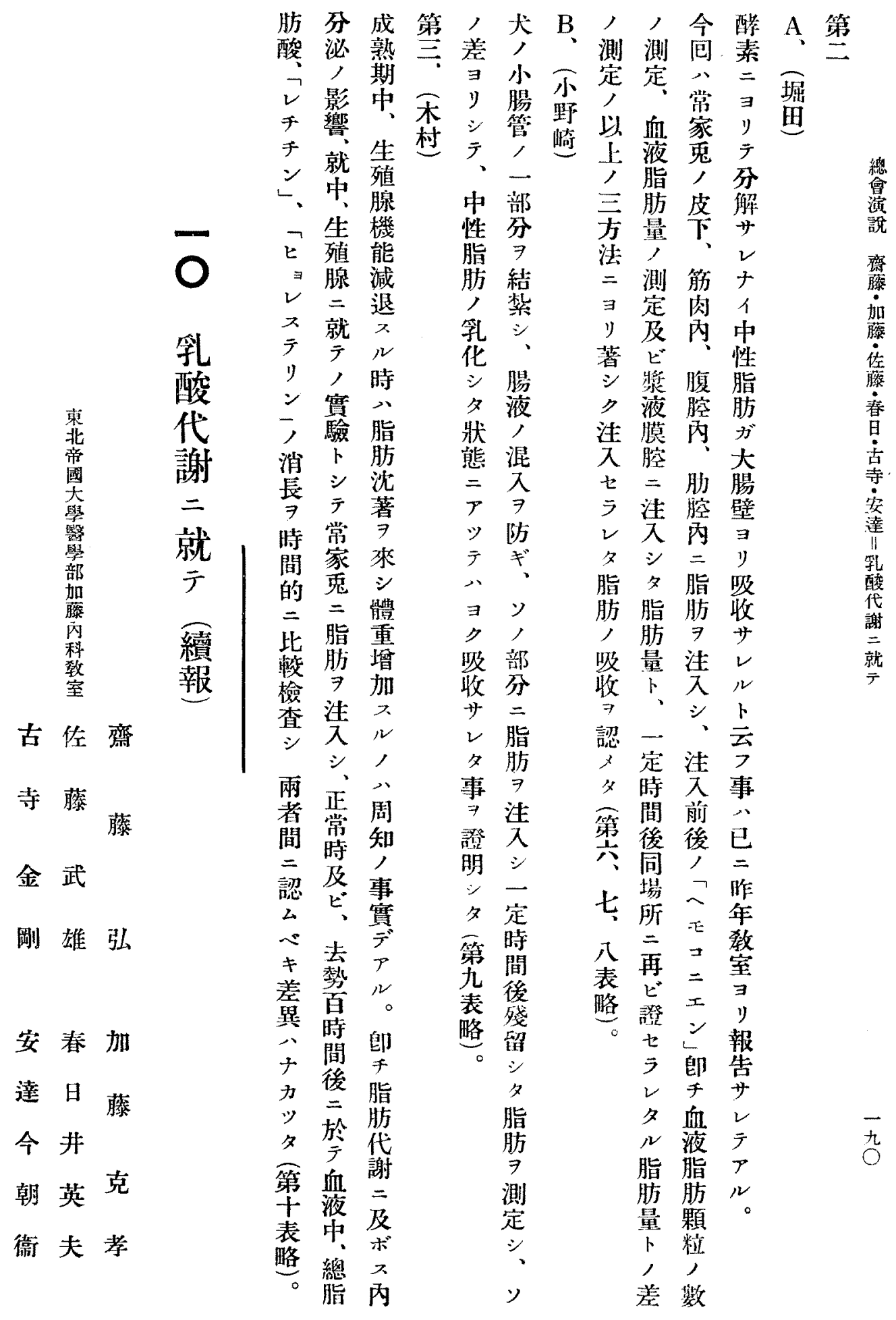


シ 健比酸縮 コ循次州遲漸前日健 コ二先 $\exists$ 余

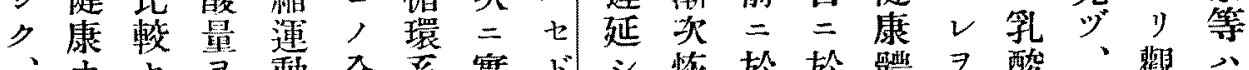

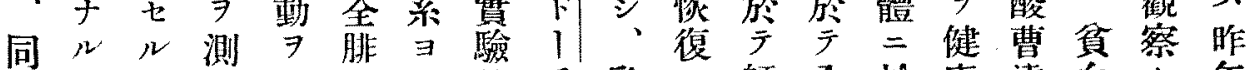
時筋二定行晹 y的氏乳二既全於康澾血七年

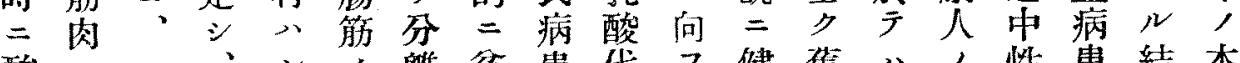
總酸二、シ，離貧忠代〉健舊、，性患結本 演素於同メミス血者謝モ康值〉ソ溶者果總

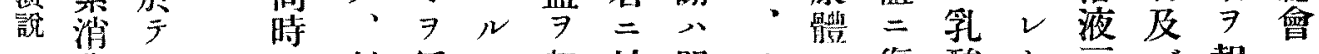

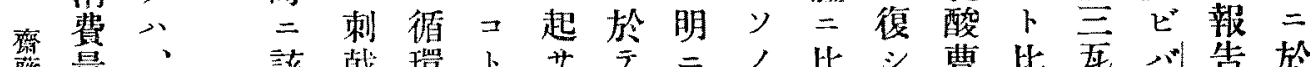

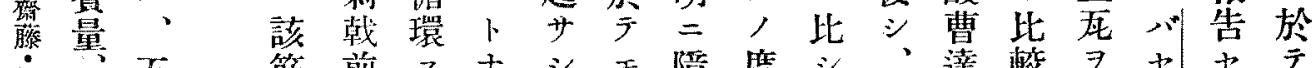

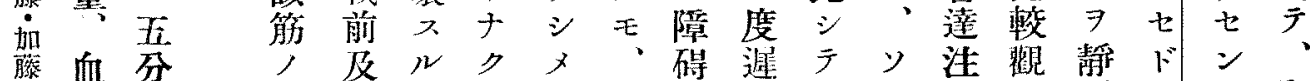

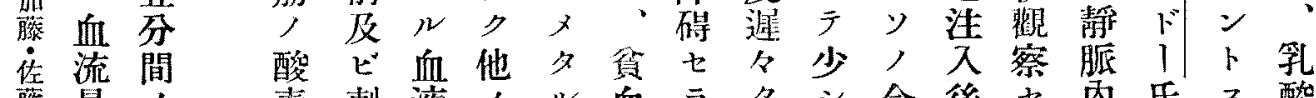

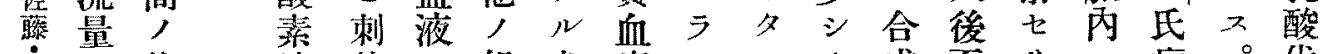
春王收消战二組犬病ルル少成五》二病。代 著維費，就織，患 $ル E$ 高機分“注患謝

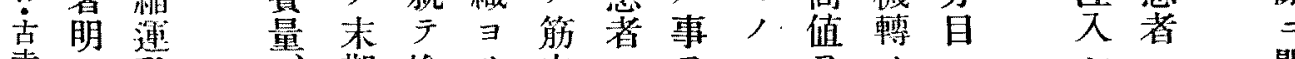
寺二動 安增 = 達 加 $\exists$ 乳 シ y

鐜

$$
\text { 浬 }
$$

謝糖 血

テ 減 酸

少 量

入 入

而赩血二施

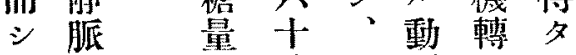

于血，分坐胍 $7 y$

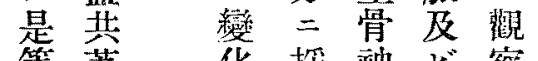

等著 化採相 ビ察

, 明 $\Rightarrow$ 血 經之 $之$

變 モ モ シ

化增合、五り卜

八加七該分出

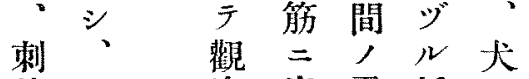

战 $\Rightarrow$ 察出電静,

中 $r$ 入氣脈一

一正 $=、 x$ 刺 $\Rightarrow$ 側

九後静健ル战唯,

至脈 康 動 7 一腓

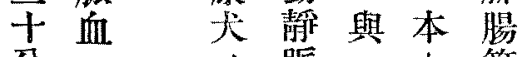

务二；脈人觔

万於 ソ血筋ナ

至テレノノシ 一

亲㒽学收テ般 $\forall=$

注尔

入

前乳究

及 酸

七’

注 酸

十洼心著

分 入 = 明

二 後

入 化

後 合

至茾貧 增

分 血 加

七回病

来 = 患

名於荐モ

舊

值 》於 y

二健

復康 、後

七䯈、速

x゙同向

。䈋 液 酸

師装乳化

于 明 酸 合

学二量成

酸堆 八七

名加 孚

化 シ 酸 レ

合、曹厅

成ソ達十

機, 洼五

輔後入芴
五成

忍 機

-1. 7

五 籍

页

站

二卜 後

$\equiv$ 就

分 串

二者

探早

血 朝

空

、腹

酸絕種

量 䯏

7 安

測 郝

定
其

引

程

キ

又

乳

酸

㪕

.

所

y

シ

代

广

N

左 


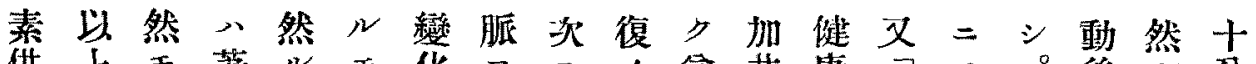

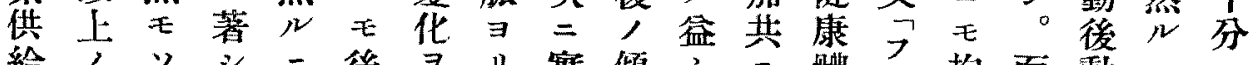

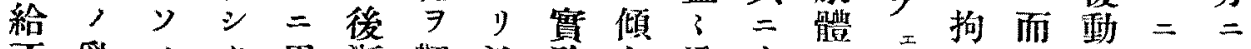

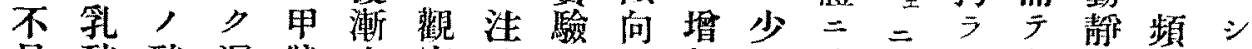
足酸酸逮狀次察入的 $\exists$ 加于比 ス 化延腺下

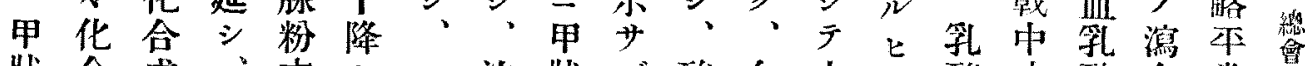

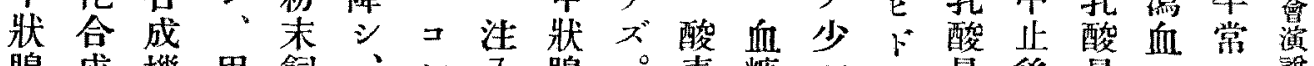

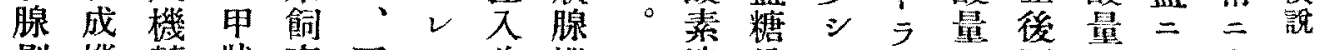
剔機轉狀育三 $\exists$ 前機消量ク乎, 公妇復 出轉八腺家干健及能费, 高ン恢干共心又 , , 明剔兔分康ビ障量減值乞復分二慢几 場障二出二不家泩碍 合碍避家於至兔 7 二八延鬼竎空, 後起 於種不二小五五

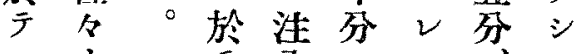
八+ 一 般原泩䓊亏堹五儿 物因入分略七分家 質 $=$ 後自正 代 $\exists$ 五三常二三= 謝 $⿻$ 分於值・市就 障决目名二健分 碍貧 $=儿$ 復康站 二血於乳严家三, ヨ及尔酸、鬼六乳 ヒビ量酸二十酸 組甲乳, 素於分名

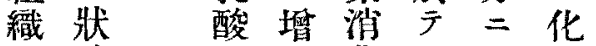
人腺量加費 八股合 酸機, 八量、動成 素能齄健, 注脈狀

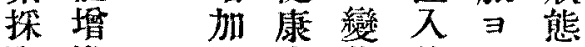
取進小家化後y 能三健鬼王五探極 力於康, 亦分血 年家y然二 減、鬼

退学分寻。孚

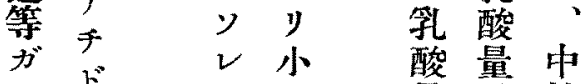

○年量及性

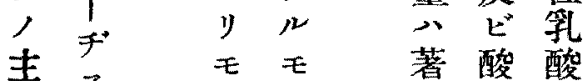

毒天著气蕫酸酸

$\exists=$ 明 $=$ 消薘

ナ $3 \quad$, 型費

ス $心$ 恔加量耳

モ酸示復不静

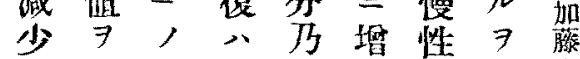
血毛示連燕至加筫認佳 流亦 $シ$ 維 量少'注ク十ル皆及春 公刺射避分モ二り旦 徐シ载 $=$ 延二、於。克

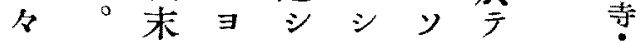

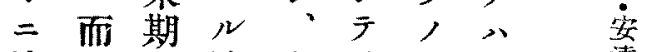
恢亏三溶血酸度、達 復刺於血糖素健乳乳 二战ヶ性量沙康酸酥 向中心颁, 費篂化 ᄀ止動血恢量二公 謝 氐後教犬復及比動就 康干血於亦血于脈 體分乳于著流僅血 二、酸入量微基 比六量、夕只二健

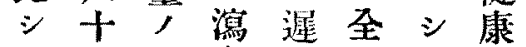
于分堦血延名学體 著二加犬又甭: = 至・至。二酸比

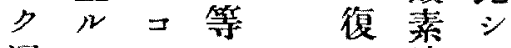
遲モレシ ス消 延血二ク心費少 液件、品量 、乳〉血或量” 減酸酸液 $心$ 血高 少量素乳却流值 七八消酸广量寻 何費量嚄, 示 血等量公值堵 糖 恢 刺 量復血戜り毛筋 , 流前減極, 何傾量二少多收 等向，於石方縮 恢大增示少運 
酸保量 7 發四次，酸至量然化加 $=$ 前血灭，

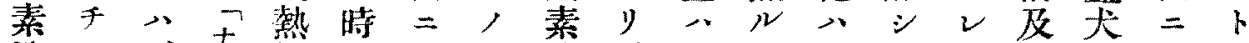

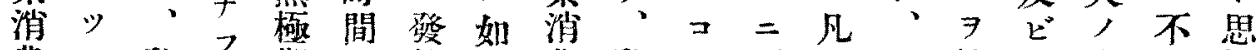

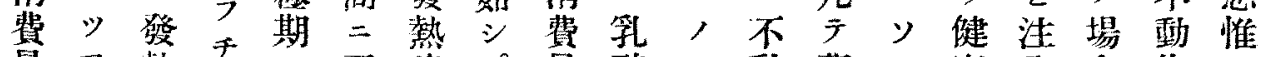
量つ熱テ，互時。量酸、動舊，康入合作七 愈發 $=$ 期 ミ 始血於

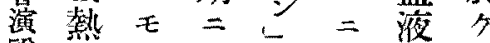

説㰁拘僬泩增乳儿 期 5 射加酸笔 滕 =ズルニセ量 酸 如達”直 $\exists$ 多代 藤七大㣪り乳ビ謝 焦江體三發酸血， 藤直蓄熱心糖狀 春後時奛七大量態

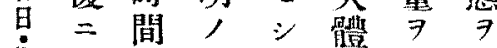
克著後上风㥀测知 寺学算、昇、時定 安夕酸 $\Rightarrow$ 腓間七ン

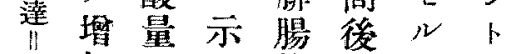

乳加

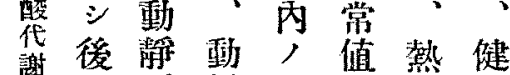

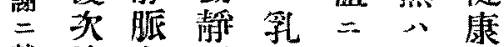
就第血脈酸復極家 二共血酸 省期兔 $T=$ 乳化、 $=$

降正酸合血達 溫 シ常量成糖 シ 制 $=$ 機 モ

四復差軧發 $\exists$ 施

時 シ $\rightarrow 7$ 熱り

間、相䫏初殆發

後動接少期 ゙゙熱

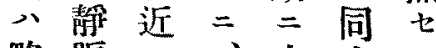
略脈 シ、士上吉 正血、該昇景 常学》筋 $又$ 度

值酸, 二

二量後出モ示”

復人䒈入後方最

天㾏㴓入漸 ツ高

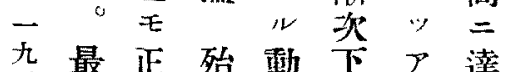

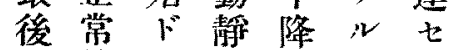

二优同脈 $x=N$

健 =上血 ${ }^{\circ}=E$ 直

承復星血隶拘㣪

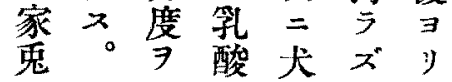
八

\section{絶 齿} 、作 二度犬後, 性 又脈妫分”緬

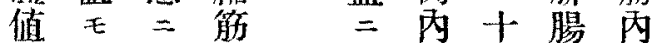
$=$ 略 $\bar{\gamma}=$ 於了瀷於 泩 加 テ $\therefore$ 入 健 前

鹿, 後乳 犬值 漸 酸 , 二 次 曹 ソ 復恔澾 以及復注 $\exists \circ=\frac{1}{=}$ y 向 前

E

著

明 吉孚

大 分酸

子後䥣

儿 = 愎

モ、於嗸

泩 始 血

入 $邓$

徯 少

, 塪 E

戀胍動

化 血 胧

$\therefore$ 究 血

健

康

犬

$=$

於

次

次

酸

大 ${ }^{7}$ 注

差嘿後

广

$\neq$

E
於二五能二

于於分，於

甚多、ミケ

叫 三 7 ル

》變十循乳 化分環 酸

同卜站 $九$ 酸

時 比 $=ル$ 化 二較六血合 酸七十夜成 素 消二二就轉 費、動 テ 量 健敖檢 窥 康 脈 測

血. 犬血 シ 流二 7 得 量於探必 モ文取ヤ 共 、シ 少 二泩笔二, 增入酸處 加後量置 ス五、 分酸文 、シ 消性切 注 テ 費 乳逧 入乳量酸㣪 ガ方後酸曹約 動 大 脈 $=$ IIII :

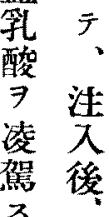
ル军 二 酸

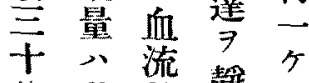

分動量静原公

至敖胍變丙

血化二過

八共共泩迥

如著觀入 ル

上明察 シ 後

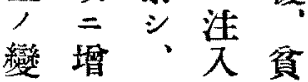
モ 二素性腱 
テ丙余遇 蛋韭

前靘

期 脈 全的

卜內實大策

同二驗

注 期

万 日

窒 シ九實

素次白驗

ナ豆昙方

キ日 期

㮡 $=$

湌於分

液 亏 類

$\exists$ 該

注 策 前

入 養期

シ 液二

$y=>$

, 加 含

體 > 水

溫少

二 素

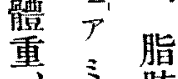

属, 肪

中 酸 覧

, 混 類

合 $\exists$

三液!

'犬

酸, 檾

及 血 養

ビ 清 液

尿及 $\Rightarrow$

屎 ビ水

中 全 7

, 血 興

總 7 -

窒以ザ

素

量 シ、䭇

次餓

檢 後 犬

期 二

生 二 腹

體 於腔
量養

泩 下

入

八

窒,

素蛋

白

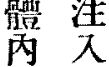

㴚然 “

溜 未

r 代

y 動

, 物

燃 實

燒 驗

' '

能 稚

$\Rightarrow \quad$

弪

ク 時

者代

$\gamma$
$\nu$
$\gamma$

E y

色

㿋從

學 來

上買

ア 種

ᄀ清 津 黑

今 卵

丰白

江川

1 力

其

他ン一利

困一。

難植鉴雄

二物

逢 性
織於極 $心 ル=$

二 ケ 更毛、炭

, n $\bar{y}$ 二 酸 酸

醉如僅著三素死

素”少明十吸斯

供對 $7=$ 分 7

給照り燳徯時吸

不 $=$ 。加 $=$ 入满

足比血学於於七梳

一 $\quad=$ 液後示方

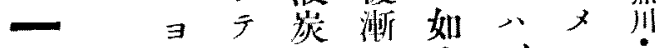

2 嚾酸次上“津

非王少量恢, 乳界

非, 与公復篗酸中非

絯卜”岸二化曹性程

和思。酸问 八達乳口

口惟コ死 7 略注酸的

的七，斯七嚄入曹榡

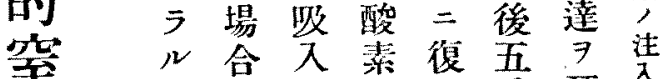

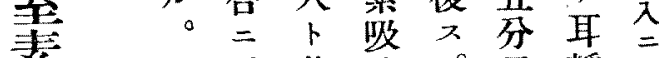

於共入。目静就

兵 時然 = 脈

$N$ 增 $=N$ 乳内

乳加比二酸二

酸 シ シ 炭量 泩

酸、广酸公入

化乳著死最シ。

合酸 シ 斯高

成曹》紧二y

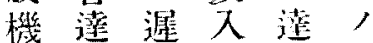

轉注延時 シ 酸

, 入又

嗯二。於酸合

碍 $\exists$ 酸 天菜成

モり㮃 八消 機

主天消、費棘

占留乳量

称量酸モ純

于增公曹 马酸

予加注達

千不入注二吸

$N=$ 入伴 入

I モ $\exists$ 後

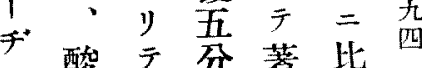

又酸素增首萌較

二 消 加 $=$ = 觀

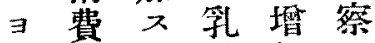

$ル$ 量 $ル$ 酸加七

組 =モ量スル 


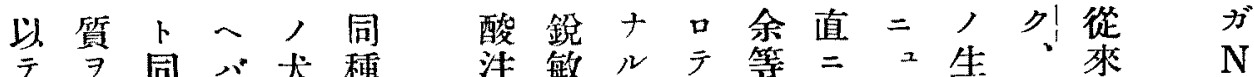

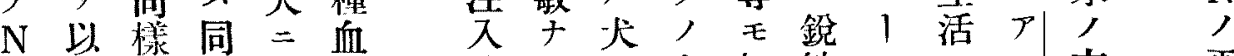
, 三 二種於清時 $⿻$, 1 初敏レニン文本

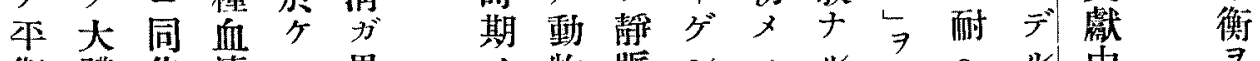

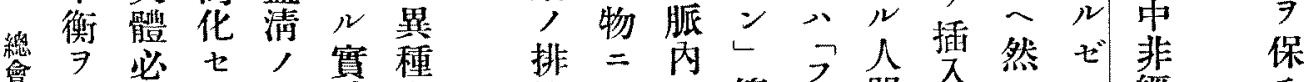

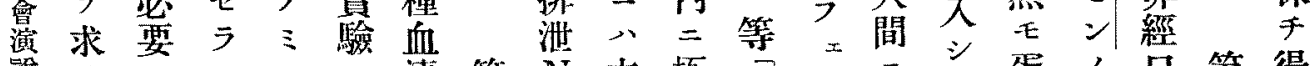

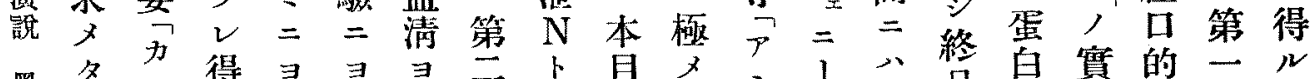
黙 津事り

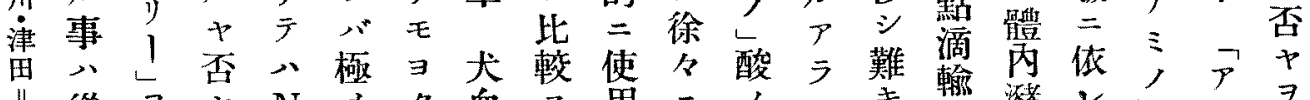

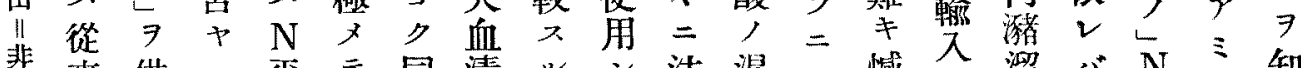

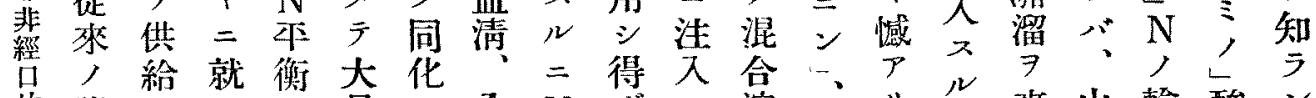

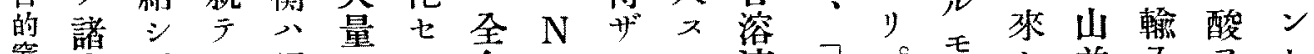
等䨘、 、保,

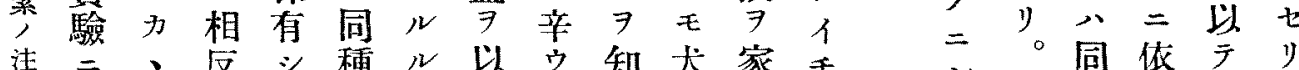

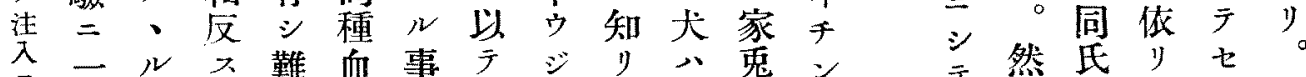
就步狀

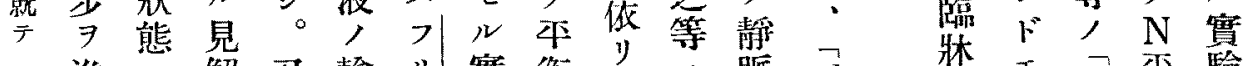

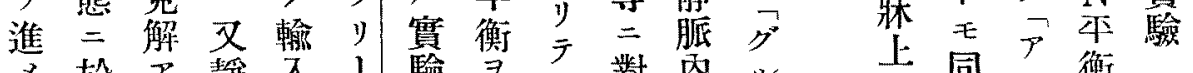

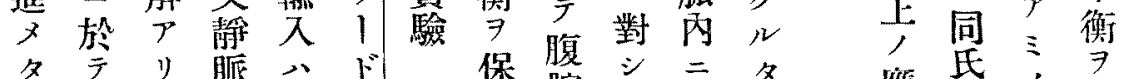

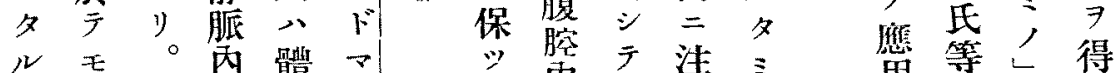

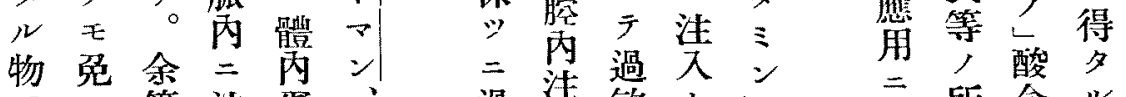

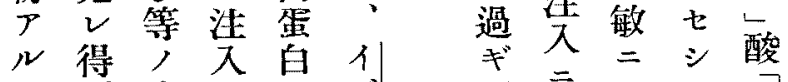
事 ザ實

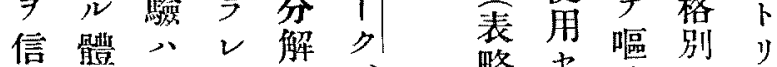

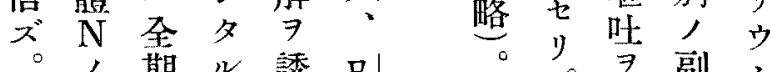
損㫷 失通白百等 $\exists$ 济出 含 テ 腸 $カ ゙$ 等 葙葡管如, 物萄实名指 質糖》又摘 一 注脂紧名艻 无涑脂奖》。所 等 $\bar{n}$ 品 э) $<y, 2$

y) 無名 $x$

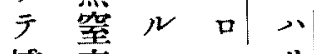
補素, =

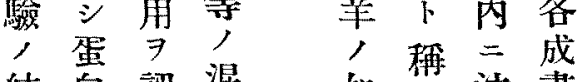

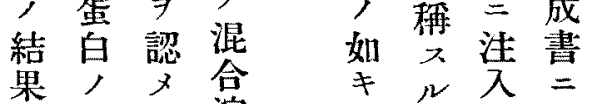
分ザ察鈍、方引 犬解》液感频告用

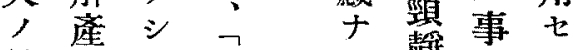

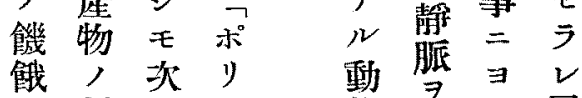
$\mathrm{N}$ 静二夕物切”居

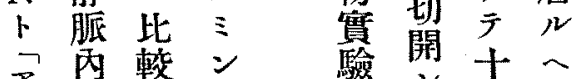

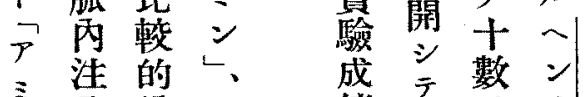

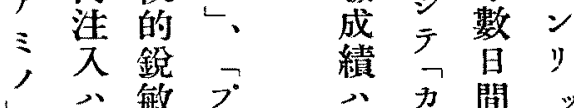
七物上従 
更余肪 $ア$ 二私快夕又ガ然乃余

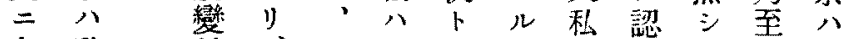

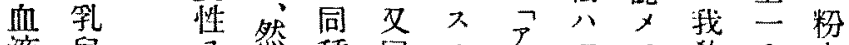

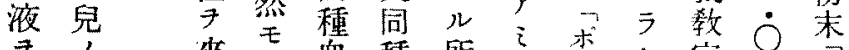

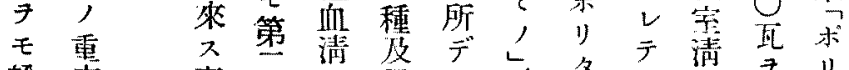

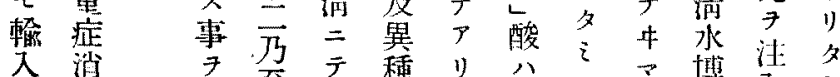

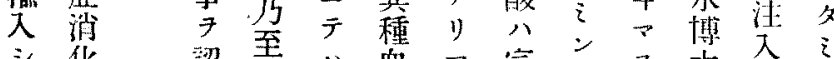

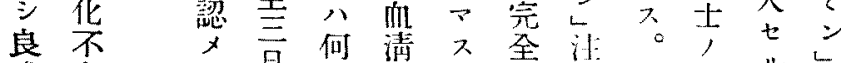

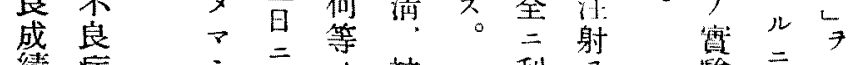

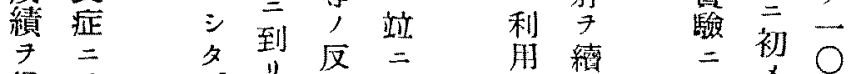

得 於

タ テ

1) 猃

之看

對 法

ス 緢

實行

驗

的

根文

摅場

㫮

川 生

等 理

, 的

舆 食

䟚

几萳

實 菊

驗 糖

寻脂

テ 笔

舆 化

亏

レヤ東

夕,

ル

㕝

ブ

卜腹 繁

共 脫

$=$ 内

將 $=$

來 注 造

此 天
1)。應 卵

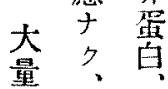

蛋中珔

采归

中台”

排可

泄攀

ラ化植

儿 $\neq$ 性

事翼曋

認種开

ル文

外蛋㪇

組 白 等

織 溶

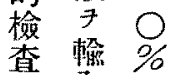

行七溶

ᄂ 時 7 、

督八家

藏薄

稩注背舀

管 時 内

二 相

著當輸

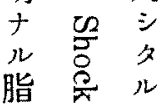

タ监 ナ

的液一
用㜊

学比

ル ハ呼溶

儿後

韭 㓢

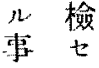

$\Rightarrow$ u

䜀 組

× 織

子栖

夕

此於

基 訮

$\underset{7}{\text { 面 藏 }}$

異 膊

三 脂
三 脂

父脂

研 變

究

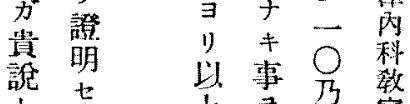

略 $三$ 上皇室

略沓尿塄志足

其故氺方员

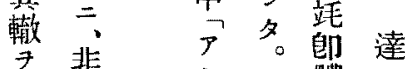

一韭經體

$=$ 口筑重哲

三的酸酷

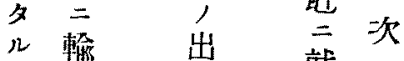

7 型就

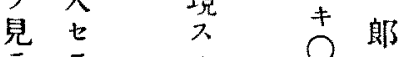

テ

放 2
酸 柗 要 次

混蛋之二

合百、表

物 類 日 示

， 7 下

腹使, ル

腔用所 $\sharp ゙$ 總

内七儖如演

追注ン林名预

入 $卜$ 能啙

加 $\rtimes^{\prime}$ 入 非重 川

最儿經人津

見試口恕田

込三的激韭

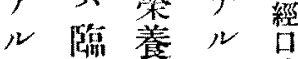

方牀二減的

法的於少篓

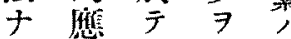

y用 $N$ 阻 法

$卜=$, 此

思 > 本

向 衡 $\mathrm{N}$ テ

相 保 體

當ッ內

器夕湴

车 溜

距 $=7$

嚾、明

$=$ 同白

$>$ 種 $=$

血 $シ$

ガ 液 得

如人

夕注り

動 入埊

試最 略

驗 安

, 全

結 二

果 シ

$=$ テ

於基宍

$\therefore$ 他

$\neg=$

些

ᄂ 照 


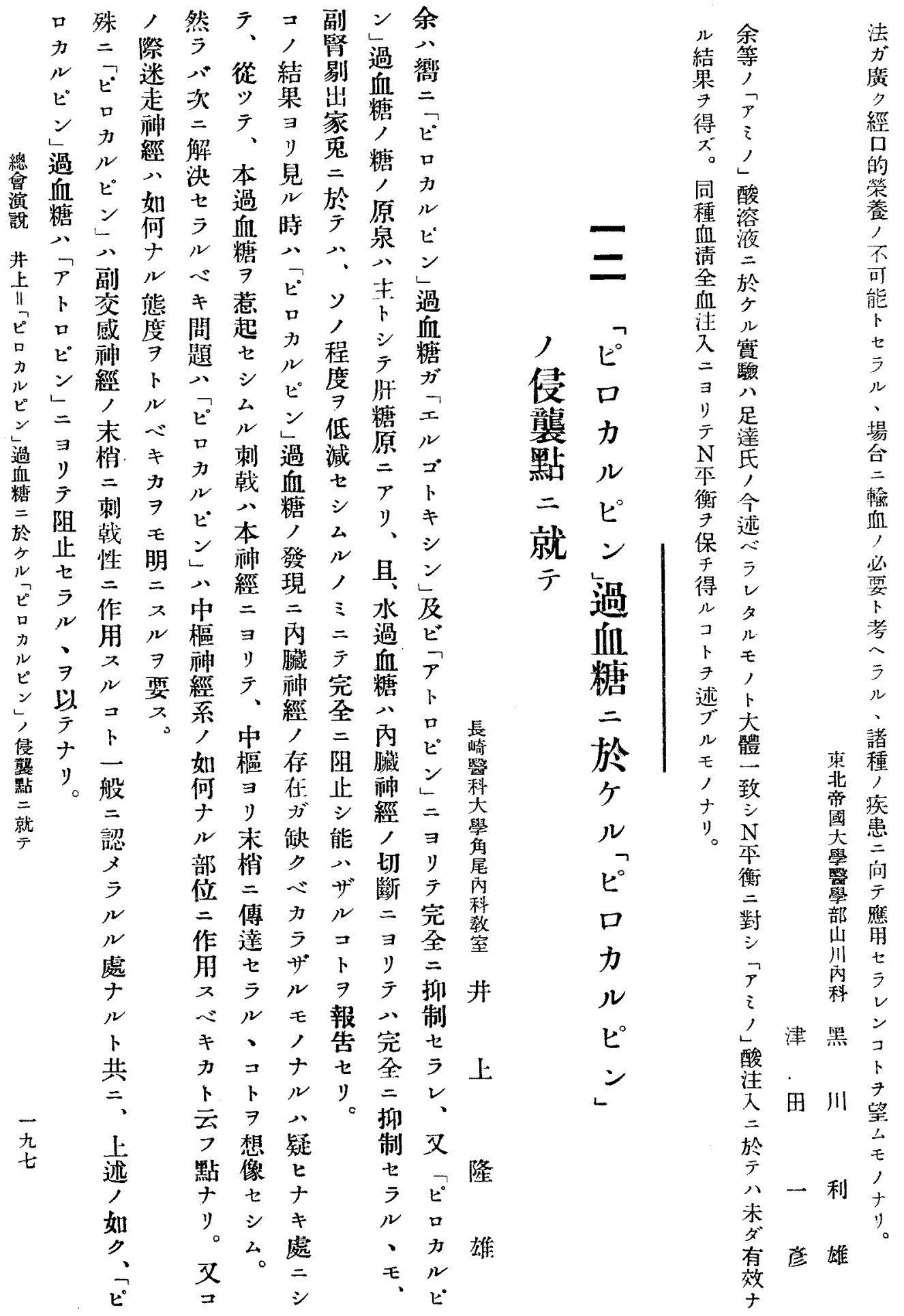


次 $ル=$ 去五二然 ᄀ等實端 $E$ 刺四二中 $\bar{T}$ 是

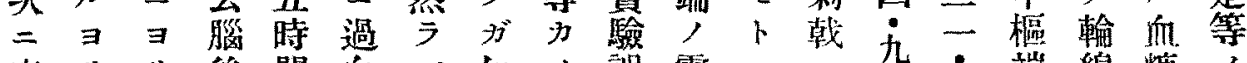

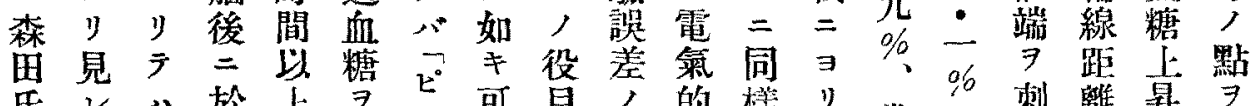
氏

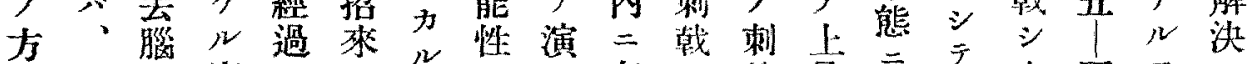

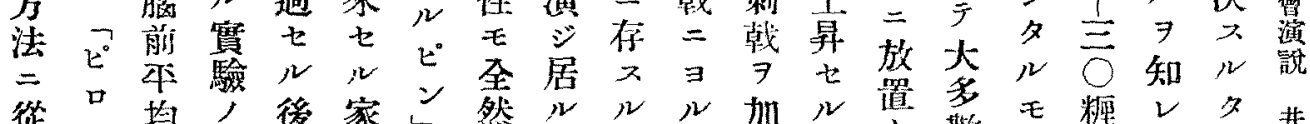

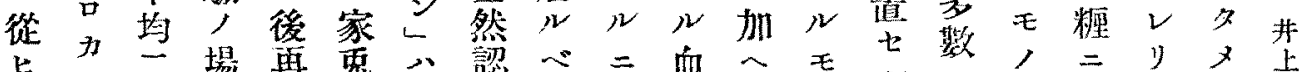

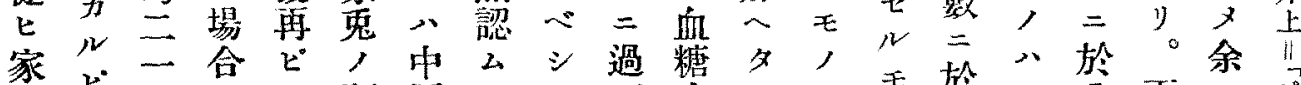

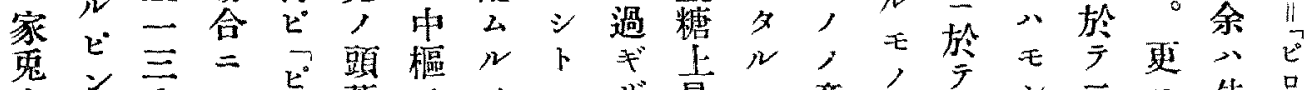

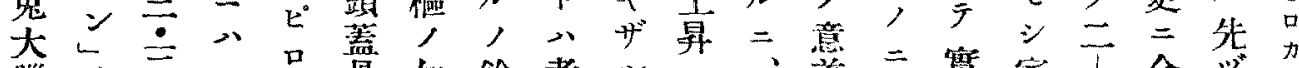

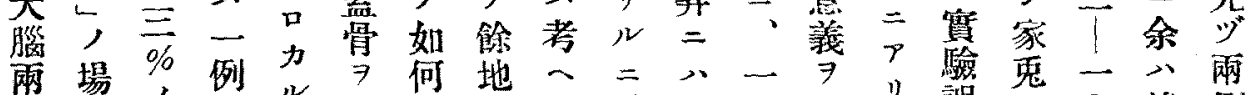
兩場 $\%$ 例 $⿻ \Rightarrow$ 何地一二

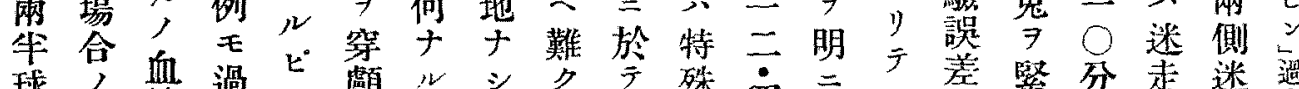
球成糖過

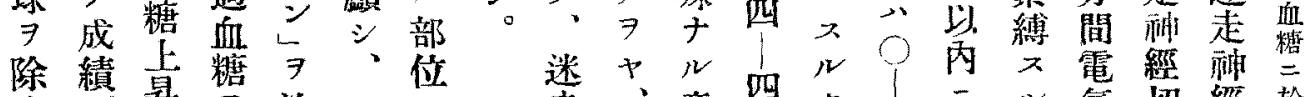

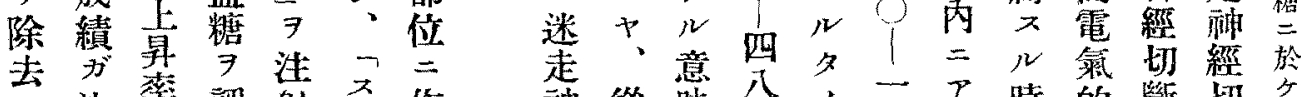
決萃認射

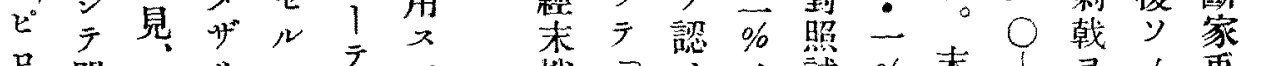
口單去

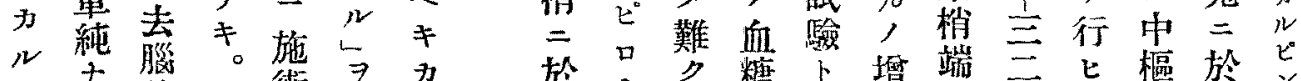

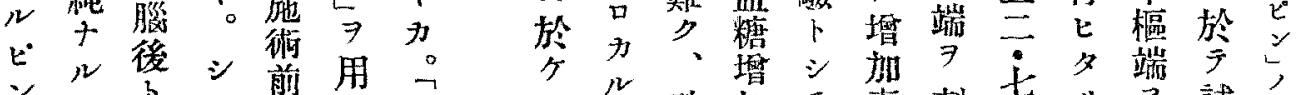

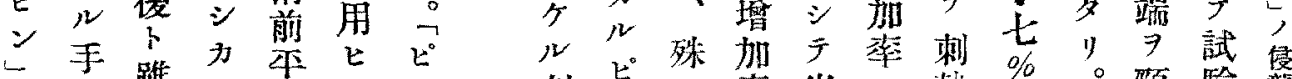

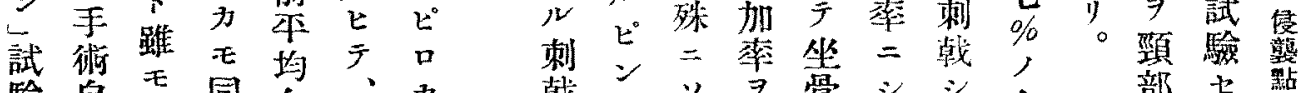
驗自尚同血・カ韩 $>$ 結

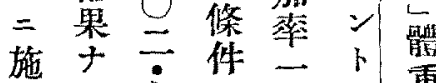
術y七, 六訓重 前 $r \%$ 兵 $\%$ 本心郎占寺去當 血人著於\%部㒸 糖難奛 $\overline{7}$ 估 $\dot{\bigcirc}$ 增

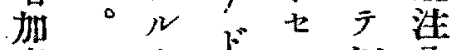
萃 血 $r N$ 切 三 糖ナニ斷 交真背拘行 咅罗注令一著

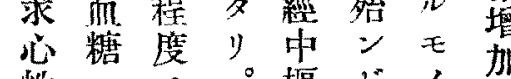

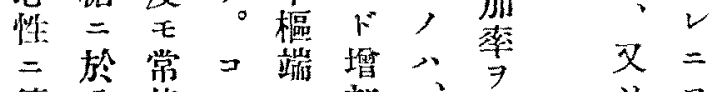
傳点態 $レ=$ 加、示y 趡迷 $=$ 二十掔示系

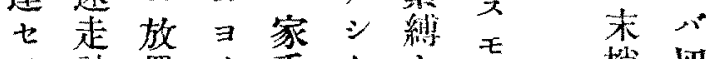
亏就置y鬼卜七自梢切

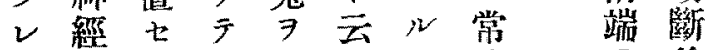

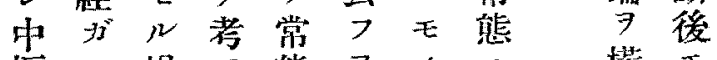
榀y場子態 $\exists$, 三 横王 $\Rightarrow$, 会 $v \triangleq$ 得 $=$ 放隔传一

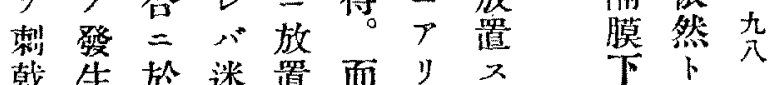

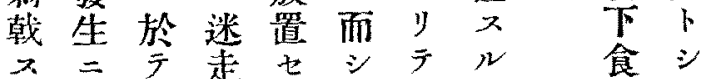

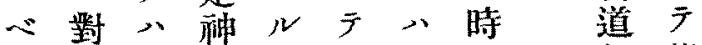
シ 多經條中门只部著

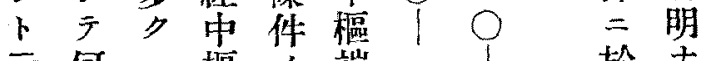
云何 》樞, 端一个於子 


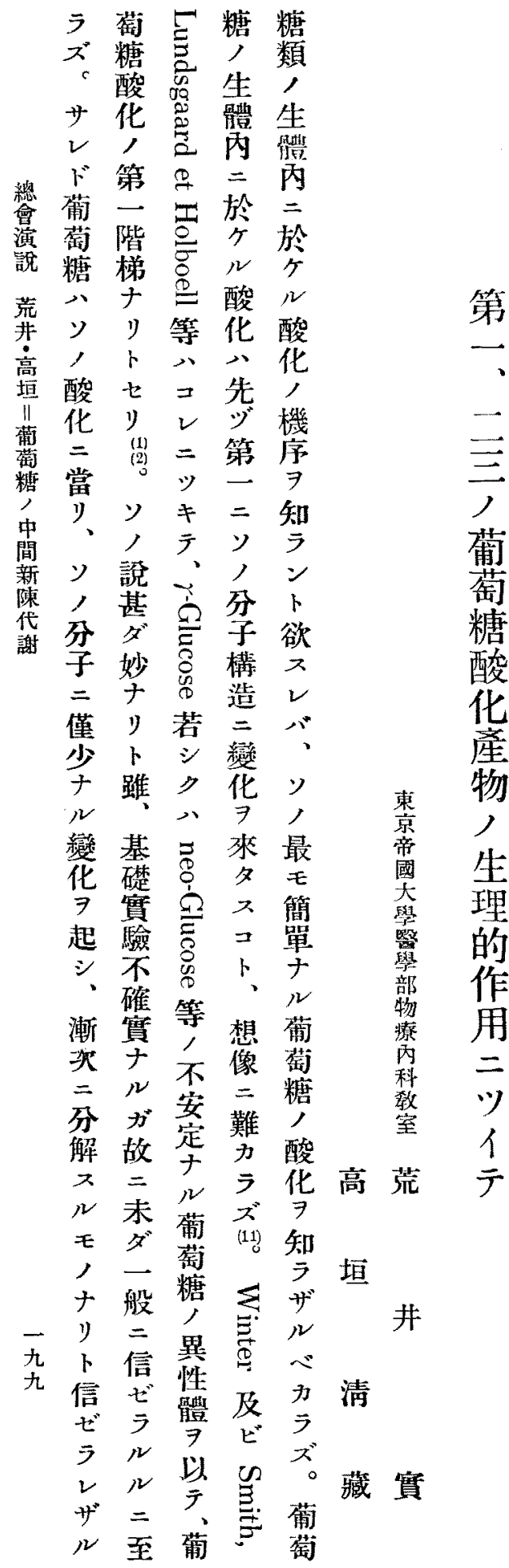

モ $卜$ 迷唯

, 口走 $=$ 考 $v$ 術

卜ヒ秒、 $ニ=$ 後

推ン經 ニザ $コ$ 平

定气

七二切示心テ二

ン恰桓考力見三

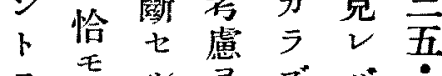

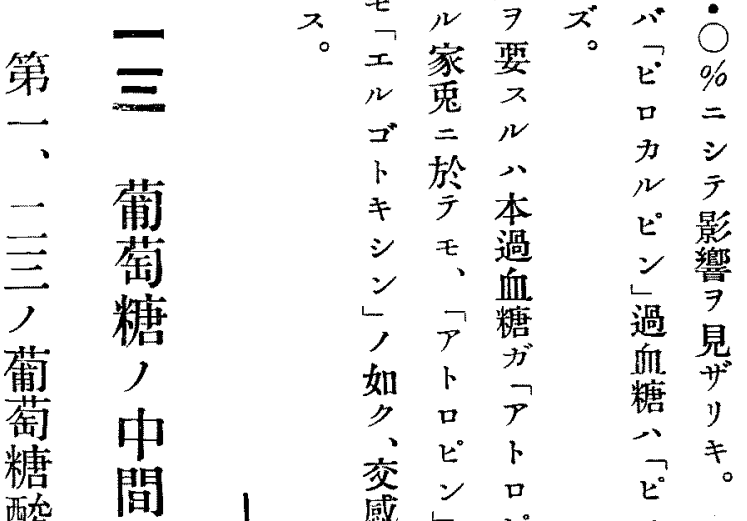

酸成感

神 ガ ブ

經 ヒこ ル

中 \begin{tabular}{lll} 
& $=$ \\
\hline &
\end{tabular}

存架寻 ン

ス

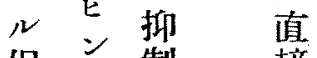

促

進過七間

神 血 5 腦

經糖バ 省

對 抑 點戴

シ 制ナス

テ シ y

麻 得。

㾇公余社

的事 $=$

實 7 帅

作 $=$, 》

用 基 點

シ ジ $尹$ 招

得 キ 境來

痭七

能 恐 $セ$ ラ

力 $5=N$

存名、

沗号 


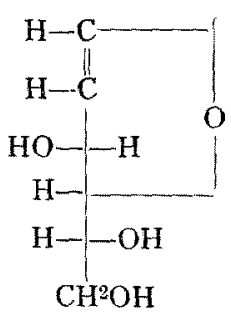

Glucal

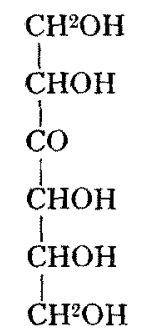

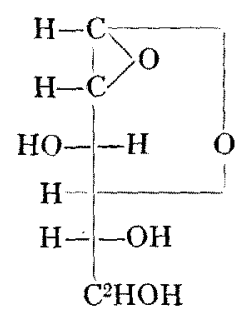

$\alpha-$ Glucosan

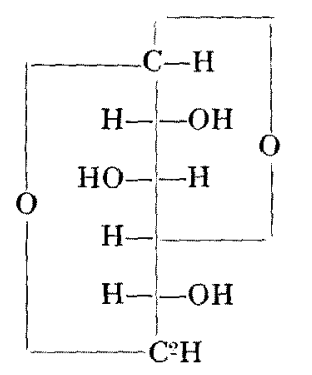

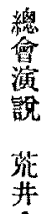

Laevoglucosan

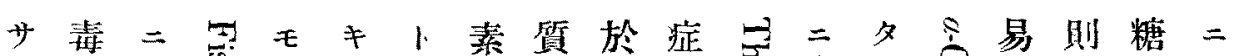

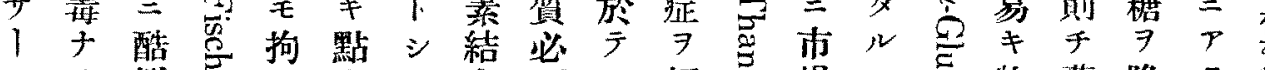

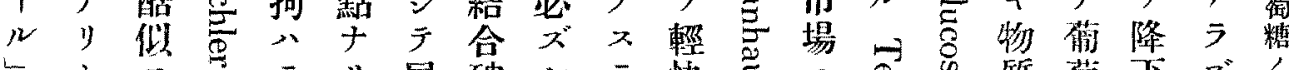

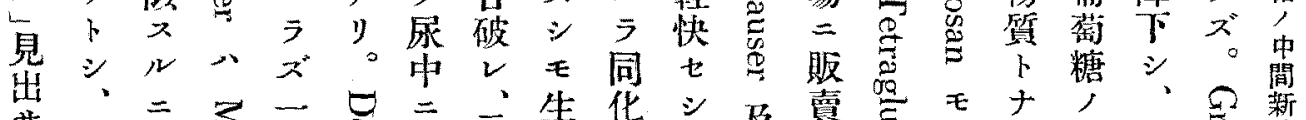

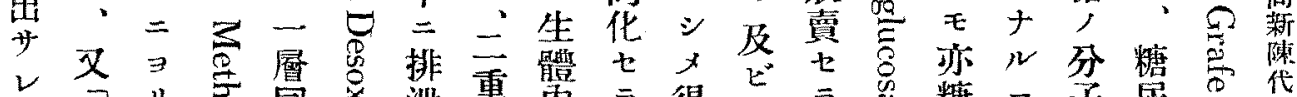

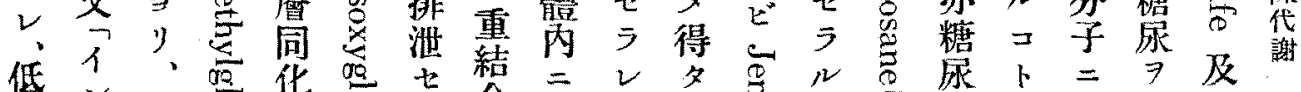

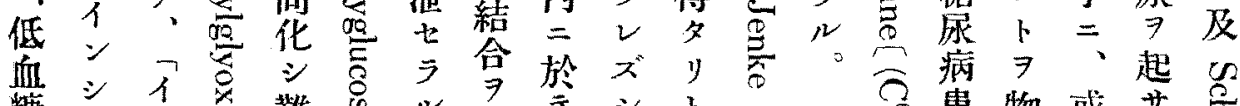

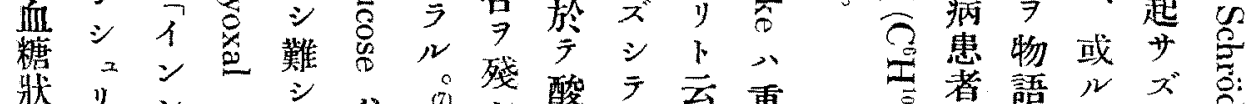

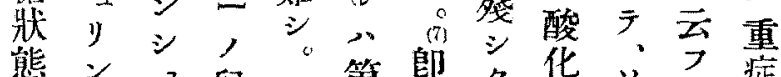

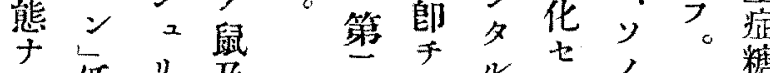
ル低り芜 血

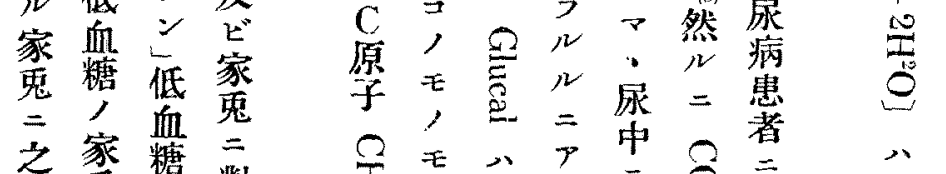
槐分對 泩, 疗

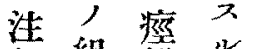
射組變中 ๖花 毒 瘵血 㘘 液

$\exists=N 、$

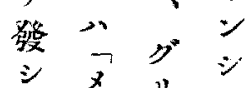

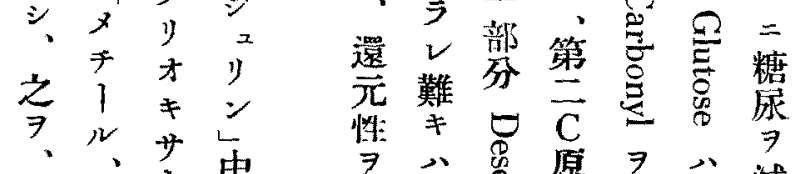

摘 出り年,

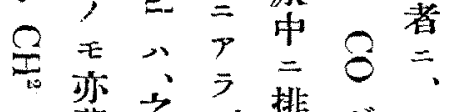

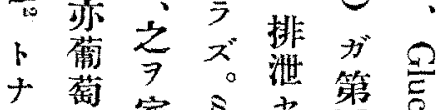

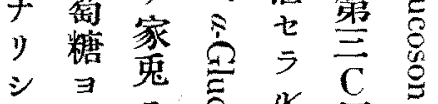
$z \quad=8 \%$ 原 $\Rightarrow$

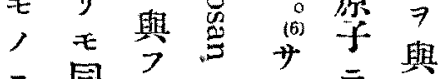

$=$ 同

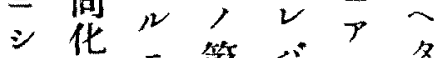

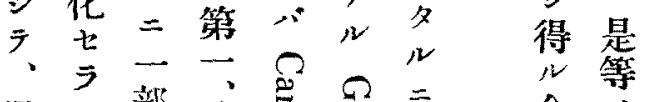

风七

糖ラ

含, 䧟り齐 患卜 心復 糖 者拜”七尿 , 七葡 シ 病 攝 ラ萄么 患 取 レ 糖ル者 シ $\exists 7=$ 永失 尖 素糖同 此 七 卜

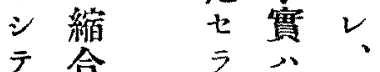

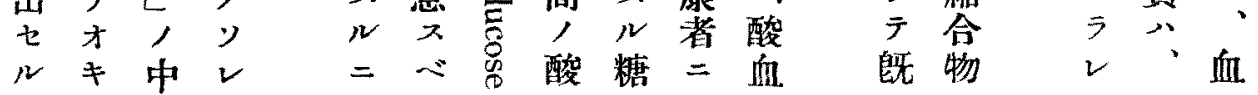



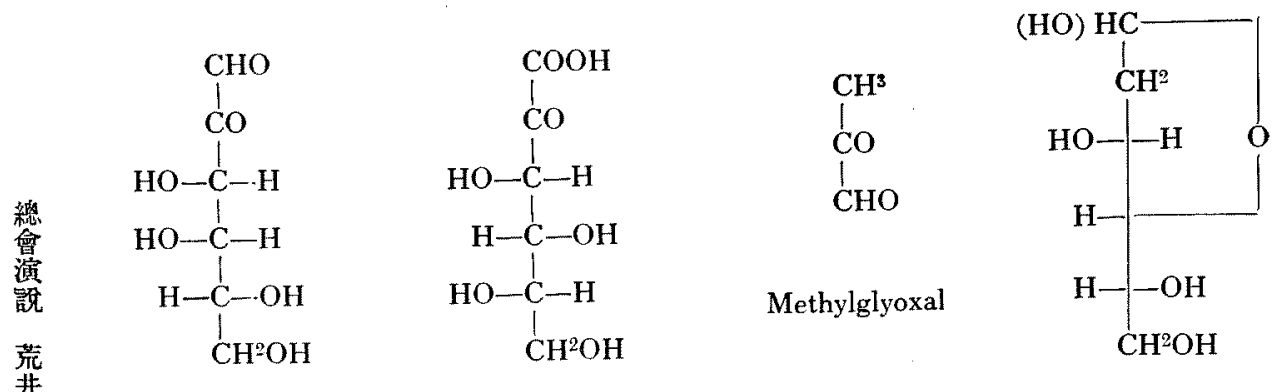

Galactoson

a-Keto-d-glucon 酸

Desoxyglucose

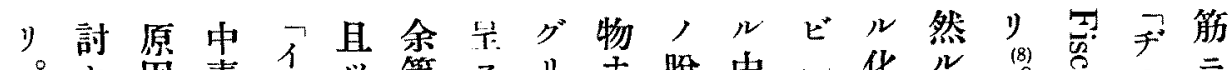

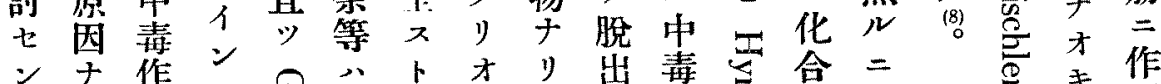

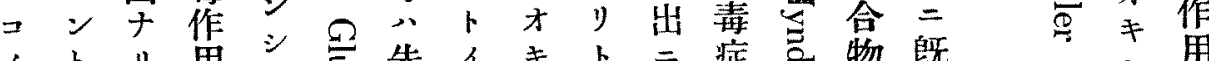

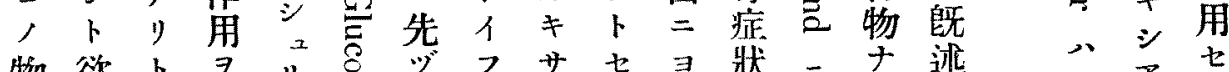

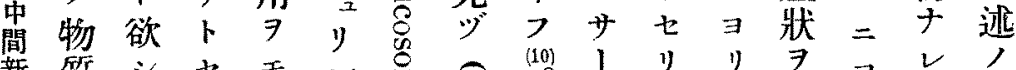
質 $=、 N$ 增 恋更說强中毒中怘

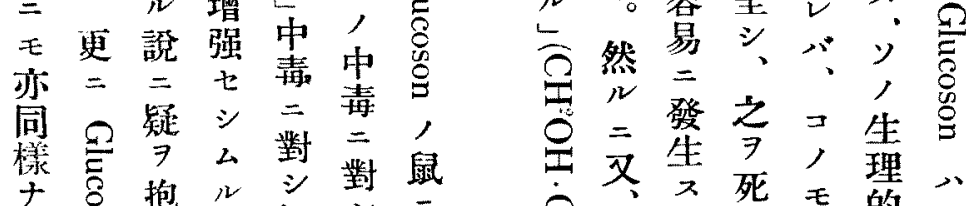

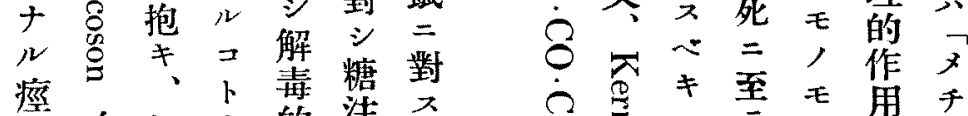

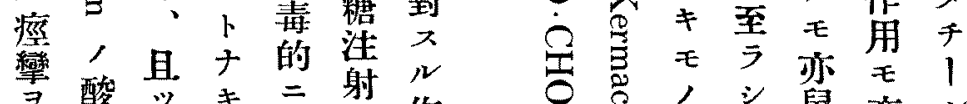

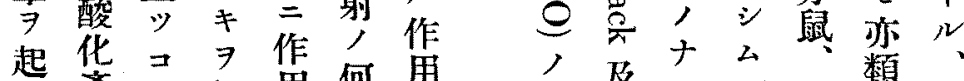
又産 $v$ 知用何用

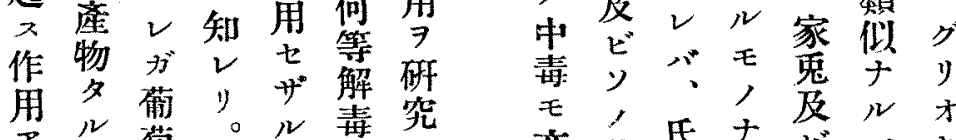
厂萄故儿毒究

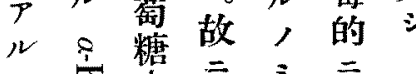
空紧二三云

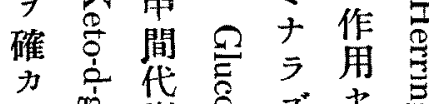

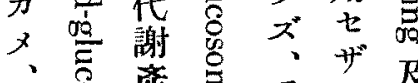

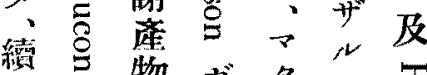

テ酸

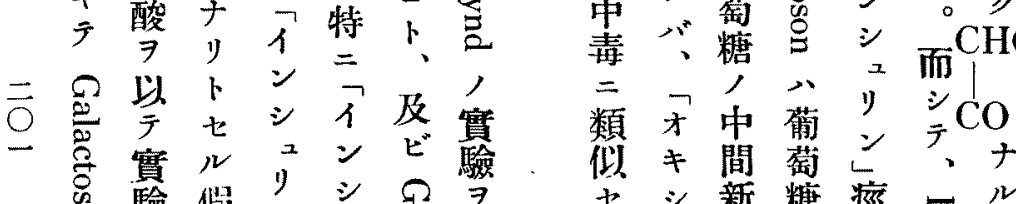
栄驗假り シ

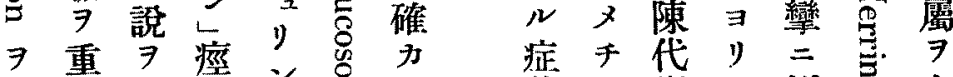

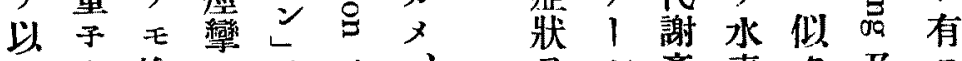
今夕檢, , 、

フ キ 1 ソ M 7 グ同ソ り時 才 商 泩 奮 サ射 性 $1>7$ ル

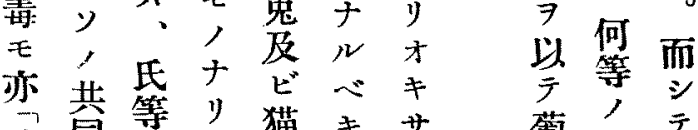
1 同等 独猫

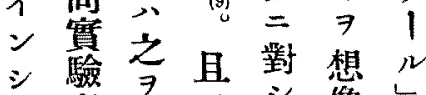

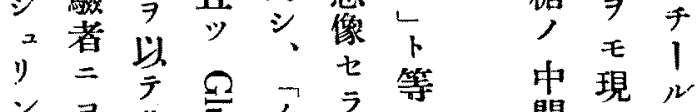

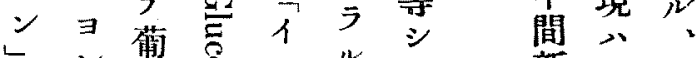

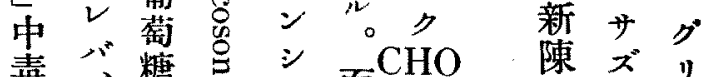

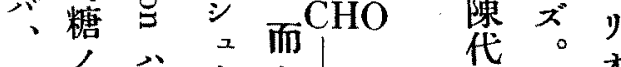
謝 是 產等 当 物 1 ナ事 ル り實 ᄂ 卜 $\exists$ 及 七り ビ 


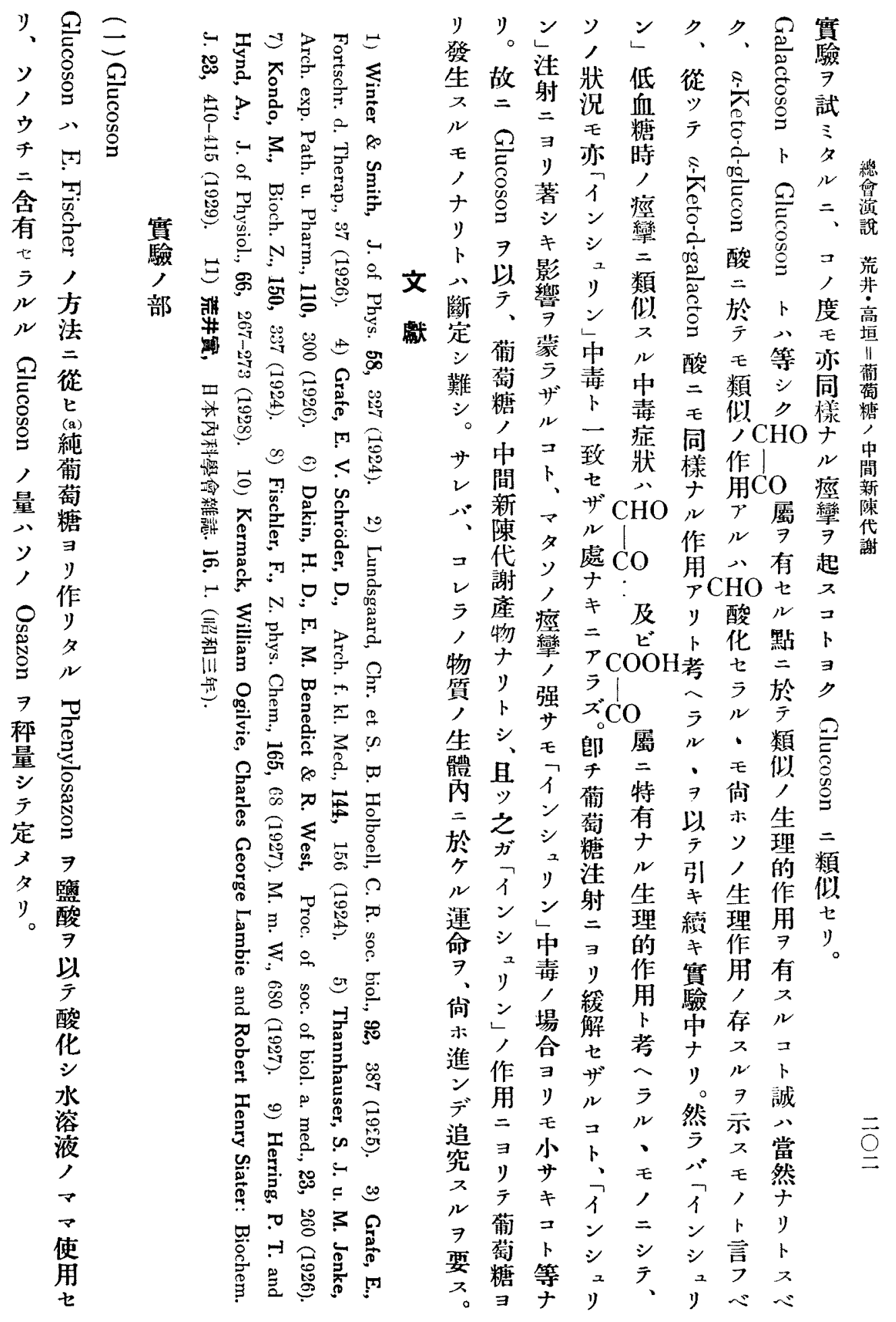




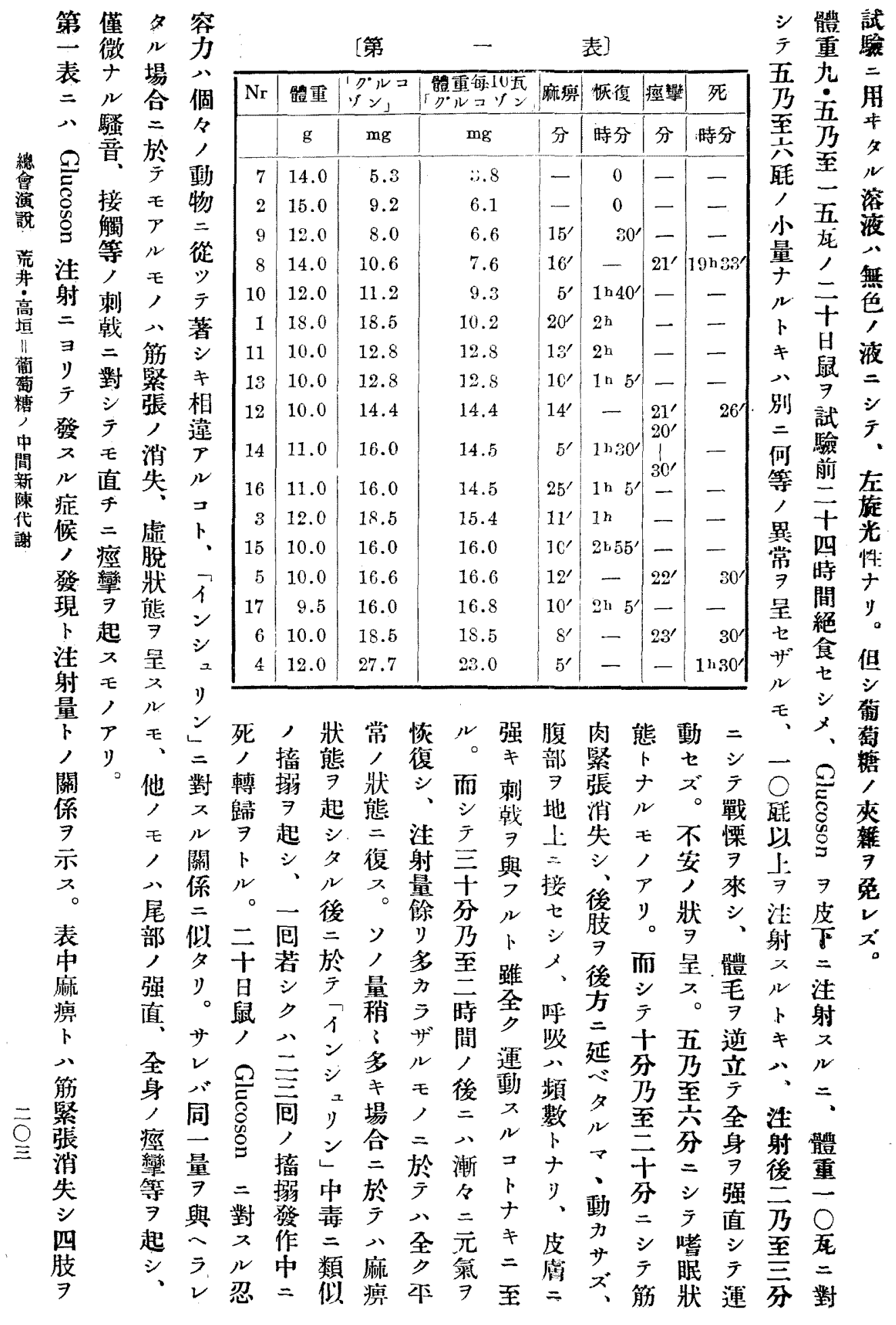


第

表了

\begin{tabular}{|c|c|c|c|c|c|c|c|}
\hline 䯠重 & 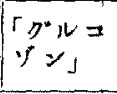 & 葡 萄 糖 & 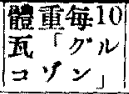 & 麻境 & 痙籽 & 快復 & 死 \\
\hline $\mathrm{g}$ & $\mathrm{mg}$ & 時 & $\mathrm{mg}$ & 時分 & 特分 & 時分 & 特分 \\
\hline 14.0 & 10.6 & 後 $12^{\prime} 0.1$ & 7.5 & 214 & - & - & $2 \mathrm{~h} 24^{\prime}$ \\
\hline 14.0 & 11.2 & 0.05 & 8.0 & 20 & - & - & $1 \mathrm{~h} 25 \mathrm{f}$ \\
\hline 14.0 & 12.8 & 前 $18^{\prime} 0.2$ & 9.1 & $55^{\prime}$ & - & $1 \mathrm{~b} 30^{\prime}$ & - \\
\hline 16.5 & 18.5 & 前 $5^{\prime} 0.1$ & 11.2 & - & - & 0 & - \\
\hline 9.5 & 11.2 & 前 $37^{\prime} 0.2$ & 11.8 & - & - & 0 & - \\
\hline 15.0 & 18.5 & 後 $20^{\prime} 0.1$ & 12.3 & $23^{\prime}$ & - & - & $1 \mathrm{~h} 40^{\prime}$ \\
\hline 14.0 & 19.2 & 前 $20^{\prime} 0.2$ & 13.7 & 501 & - & $2 \mathrm{~b} 50$ & - \\
\hline 11.5 & 16.0 & 前 $60^{\prime} 0.2$ & 13.9 & 28 & - & - & 1 th 281 \\
\hline 11.0 & 16.0 & 前 $60^{\prime} 0.2$ & 14.5 & $30^{\prime}$ & 1139 & - & $1^{\text {b } 42}$ \\
\hline 7.5 & 11.2 & 前 $60^{\prime} 0.2$ & 14.9 & $20^{\prime}$ & 43 & - & $1 \mathrm{~h} 45$ - \\
\hline 12.0 & 18.5 & 後 $10^{\prime} 0.1$ & 15.8 & 181 & - & - & $?$ \\
\hline 12.0 & 18.5 & 0.1 & 15.8 & - & - & 0 & - \\
\hline 11.0 & 18.5 & 啳 $10^{\prime} 0.1$ & 16.8 & $17^{\prime}$ & - & $2 \times 45^{\prime}$ & - \\
\hline 13.0 & 25.0 & 0.1 & 19.2 & $1 \times 23^{\prime}$ & - & - & $2^{\mathrm{h}} 5 \bar{s}^{\prime}$ \\
\hline
\end{tabular}

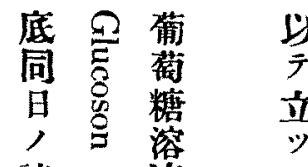

談中液

二 毒 9 神

$P$ 症 $\Omega$ 能

亏牀志 會

용 8 境

幾落范腹茫

分注总部并

楥射中地意

七同毒上葡

: 若

$\exists$ 若公

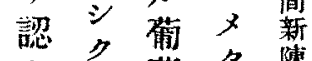

厶八䓒夕陳

レ之糖少謢

下之,

E 作 $\neq$

先角 7

考立示

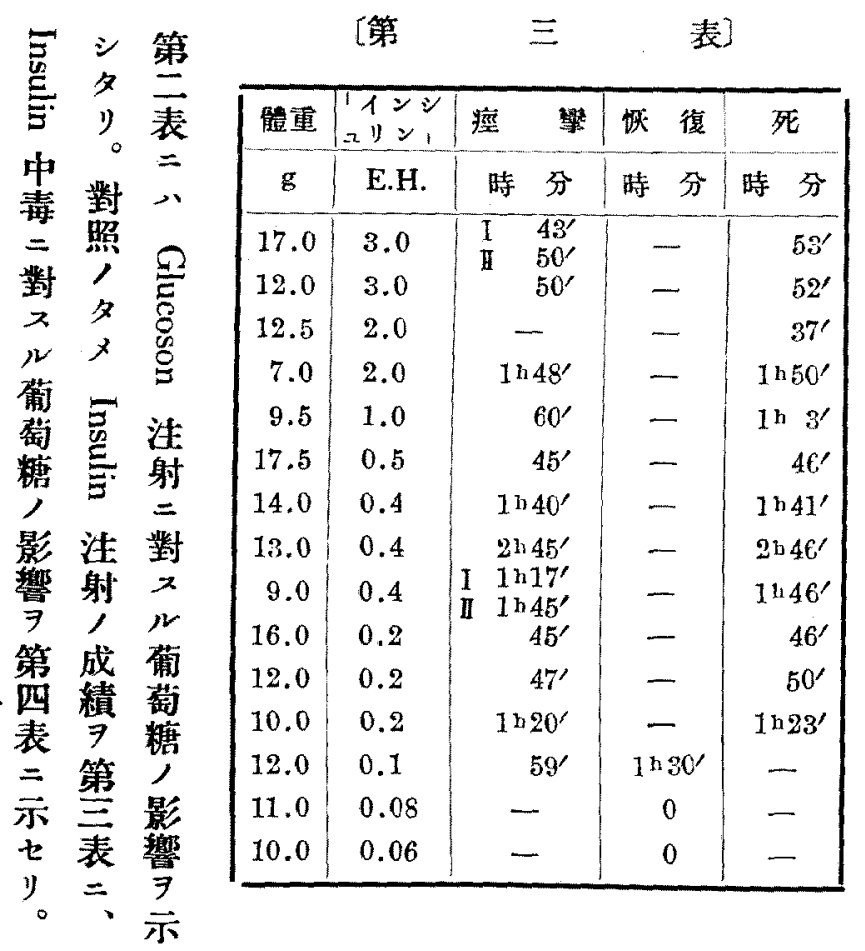

7 。

莺慗

中 時

毒 =

= 皮

對卢

x $=$

儿泩

葡 射

蔼

糖 夕

, N

效場

果 合

$=$

比於

較

品

,

卜 試

₹ 驗

八鼠

到 


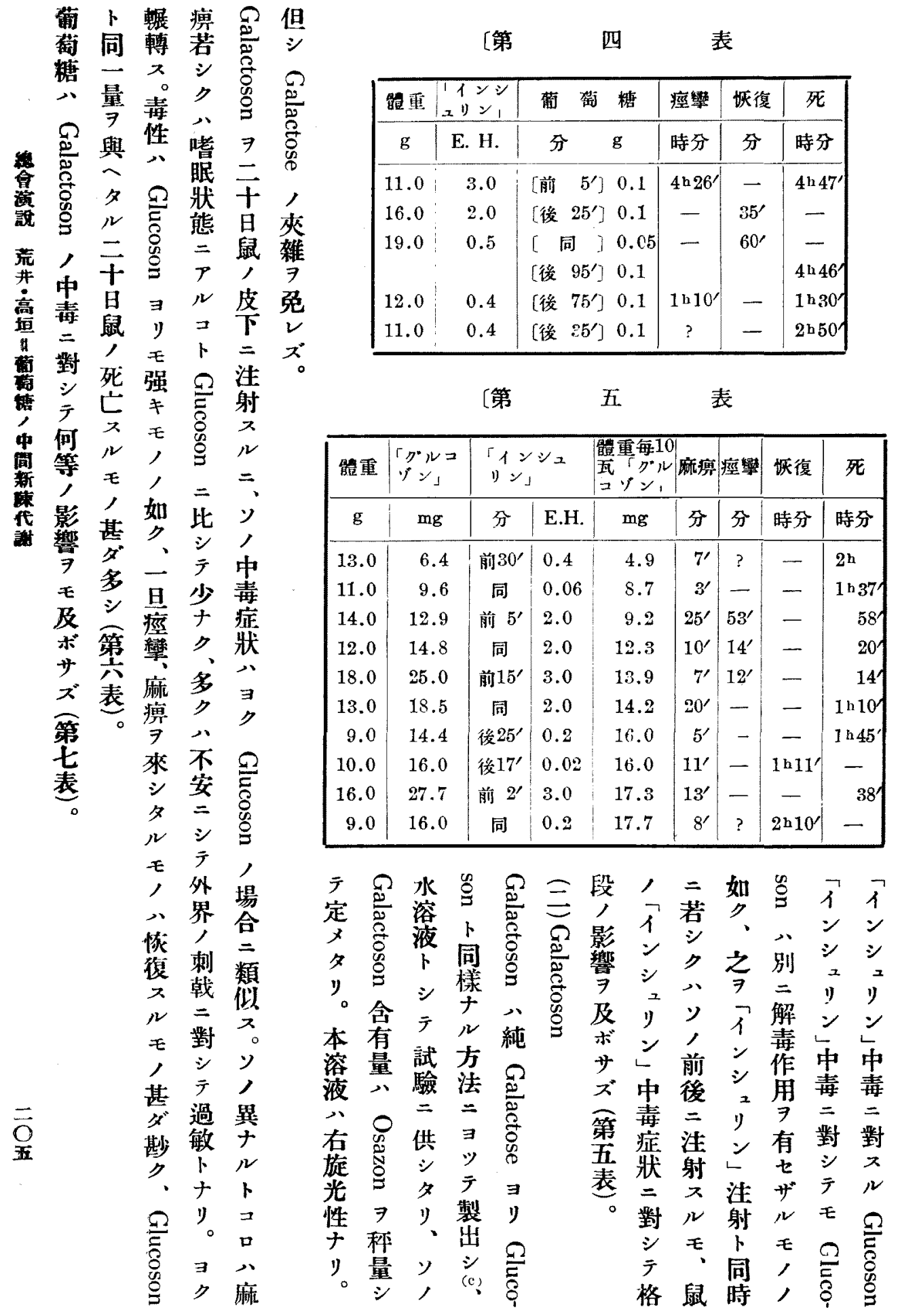




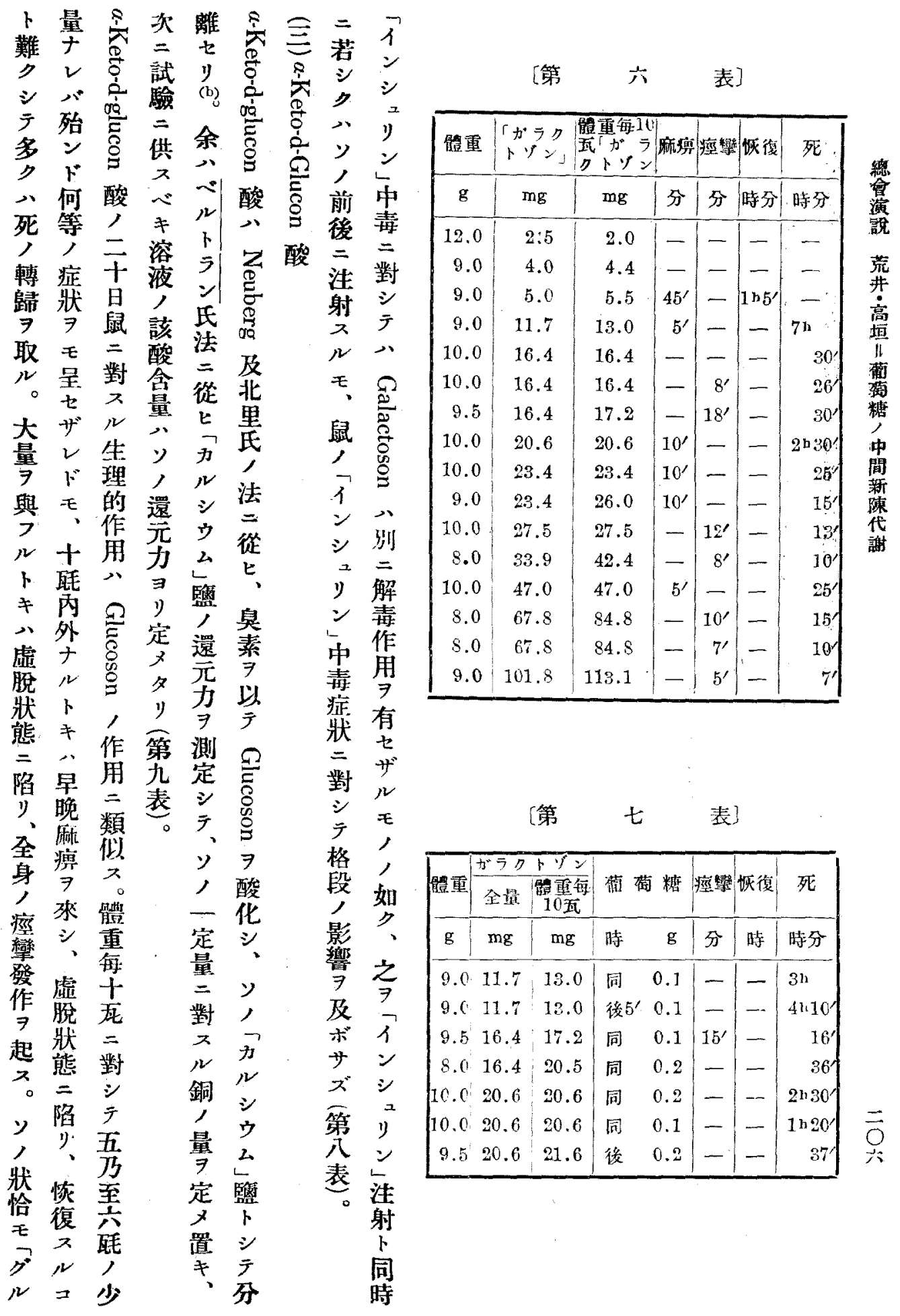




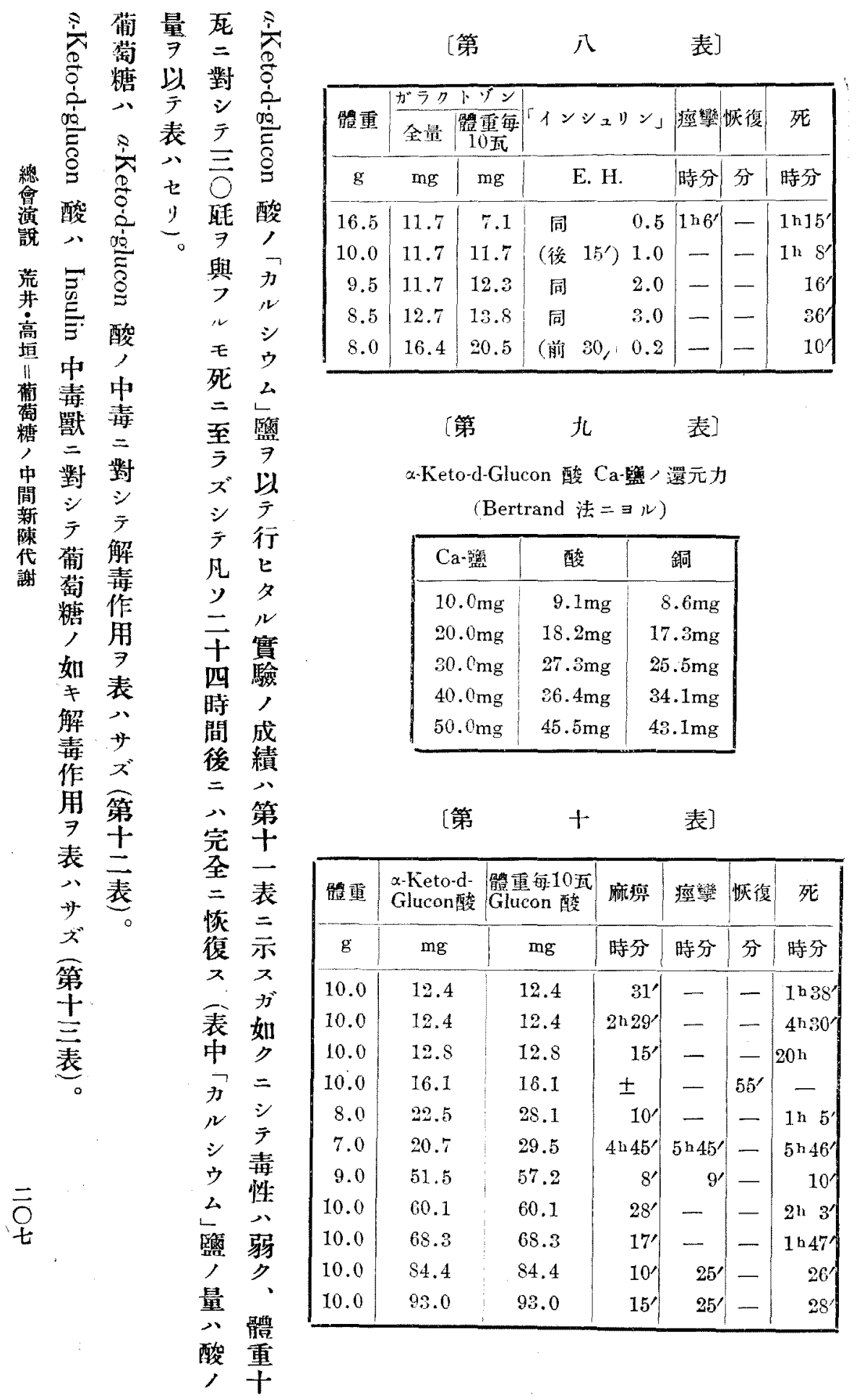

肢

ノゾ

揞

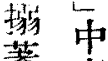

著毒

明

二 類

声侧

全

身 5

飛

躍 發

又 作

, ,

召 持

如 續

₹

二 短

卜

$+\Rightarrow$

シ

○

第 概

+ 子

表一

$=$ 分

八 時

注

射充

量 名

下

中。

毒 然

症

狀

發

現 亏

, x

時 發

期 作

1,

，狀

關 態

係

7 四

示肢

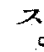




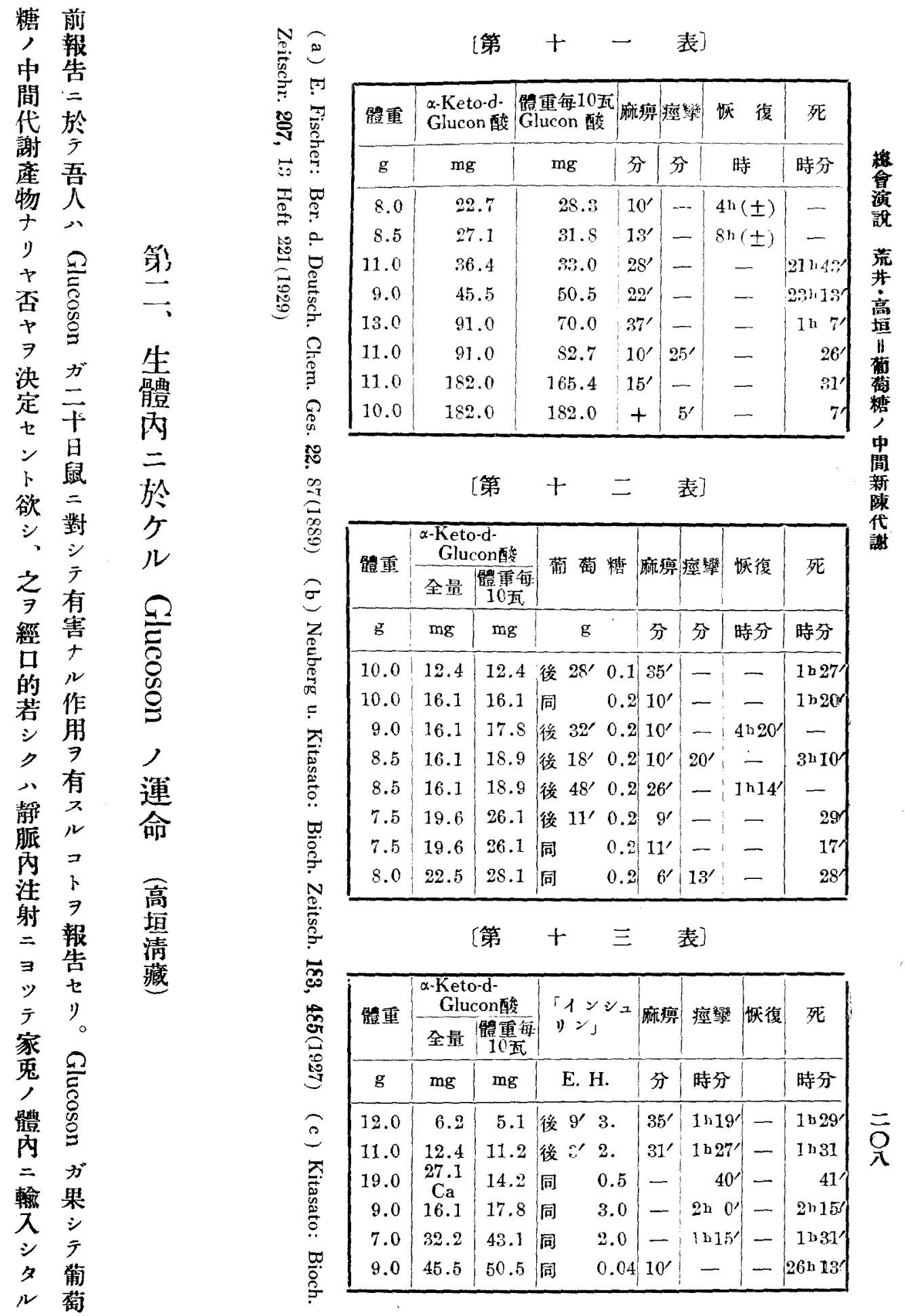


候百。試三

呈一中前静

问毒三脈

2 乃症十内

總 $=$ 至狀四泩

會卜兰, 時 射

演宁發間試

訊ク，現以。驗

荒 ヨ 泩 7 声

高食 $\exists$ 防食

坦”物行

菊 $\ni>ル$

菊葡攝二、タメ

糖取・ 又夕

泩 $=$ 射

蕳示射、家

整常一, 二

代少 上量排

如云

態間回行

度

取 亏 二 正

五五 常

七?

页 $\doteq=$

間 五

嘠 卜 確

慄ナメ

$\exists$ シ

來

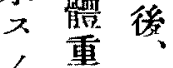

三 每: 靜

$=$ 成而

テ $0=$

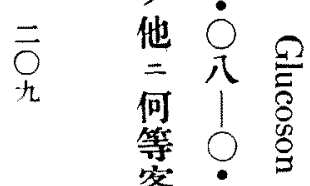

客觀六

症无射

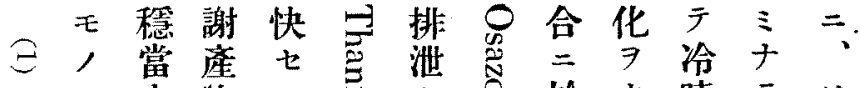

Z = +物 シ 壱七方於り時 ラン

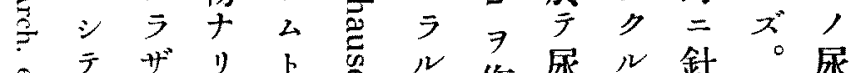

马テザり 占要ル作尿ル針。尿

劣，，，狀其中

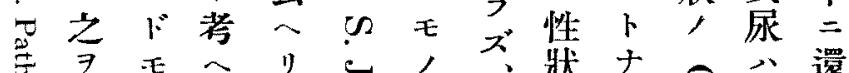

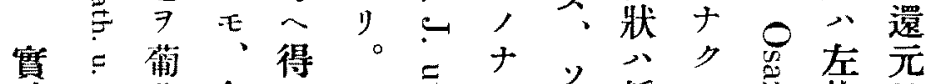

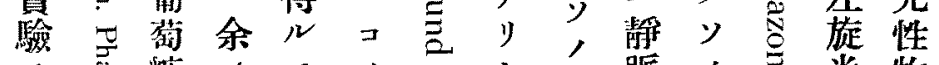

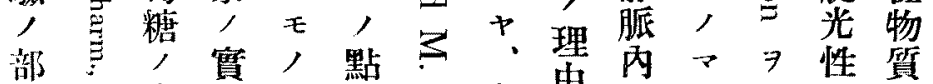

吉中驗 $ナ 、$ 點

間 陳績然 $>$ 八 豆場 $=$ 且七 代 $\rightrightarrows$ ル

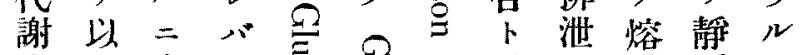

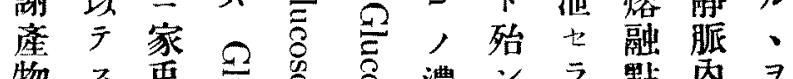

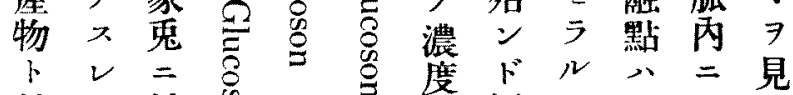

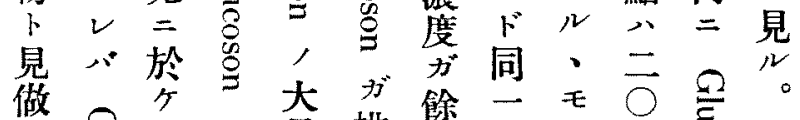

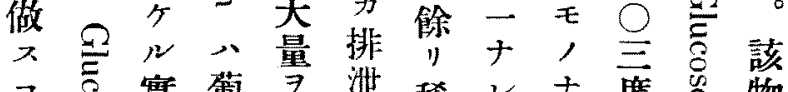
能气, 糖尿亏溥下留 八, 結寻病 ズ健果り患・ = 可 $、$ 與萄

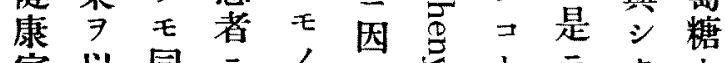
家以同 = , 思导 兔方化與卜カ层

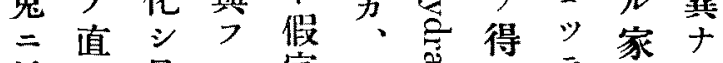
於二易 2 定宕芯令广兔り、 今糖キ化 糖 ン シ

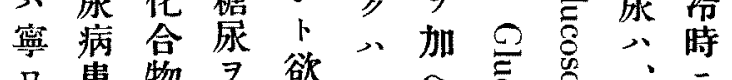

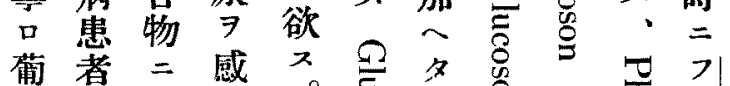

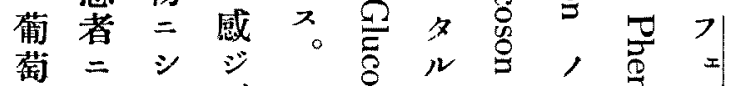

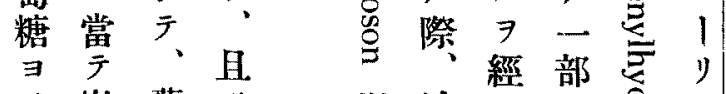
り嵌 葡

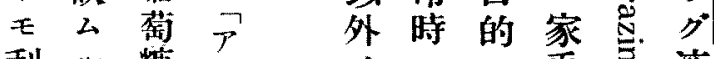
利 用糖七ア 七ト 中 ラ $、$ 間 元新症物後夕於二 難 $\exists$ 陳 $\exists$ 啠 キリ代輕学毛場變 $\%$, 


\begin{tabular}{|c|c|c|c|c|c|c|c|c|c|c|c|c|}
\hline 日 附 & $\mathrm{Nr}$. & 體重 & $i M^{*} ル=y$ & 2 & 每: 1啁 & 同 & 水 & 色 & Nyl & Feh] & $\begin{array}{l}\text { Bert- } \\
\text { rand }\end{array}$ & 排哔量 \\
\hline & & $\mathrm{kg}$. & $g$ & $\mathrm{ccm}$ & $\mathrm{g}$ & 時 & $\mathrm{ccm}$ & & & & Cu.mg & \\
\hline $25 / 1 X$ & Nr. 1 & 1.700 & 0.217 & 5 & 0.127 & $15 \mathrm{~h}$ & 65 & 墨禩 & + & + & 33.1 & $18.8 \%$ \\
\hline $4 / X$ & Nr. 2 & 2.050 & $\begin{array}{r}0.320 \\
\left(\text { 後 } 45^{\prime}\right) 0.320 \\
\left.\text { (後 } 90^{\prime}\right) 0.320\end{array}$ & $\begin{array}{l}2 \\
2 \\
2\end{array}$ & $\begin{array}{l}0.156 \\
0.156 \\
0.156\end{array}$ & $40^{\prime}$ & 10 & 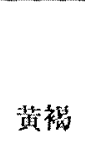 & $H$ & tt & $?$ & $?$ \\
\hline $9 / X$ & Nr. 2 & 1.904 & $\begin{array}{r}0.160 \\
\text { (徣 } 1 \mathrm{~b}) 0.160 \\
\left.\text { (淩 } 2^{\mathrm{h}}\right) 0.160\end{array}$ & $\begin{array}{l}1 \\
1 \\
1\end{array}$ & $\begin{array}{l}0 . \csc \\
0 . \csc \\
0 . \csc \end{array}$ & $80^{\prime}$ & 8 & 熼色 & $H$ & + & $?$ & $?$ \\
\hline $7 / \mathrm{X}$ & Nr. 3 & 2.130 & $\begin{array}{r}0.320 \\
\left.\text { (援 } 40^{\prime}\right) 0.320 \\
\left.\text { (接 } 80^{\prime}\right) 0.320\end{array}$ & $\begin{array}{l}2 \\
2 \\
2\end{array}$ & $\left|\begin{array}{l}0.150 \\
0.150 \\
0.150\end{array}\right|$ & $40^{\prime}$ & 21 & 褐色 & Ht & t+ & 192.7 & $24.2 \%$ \\
\hline
\end{tabular}

\begin{tabular}{|c|c|c|c|c|c|c|c|c|c|c|c|c|c|}
\hline 日附 & $\mathrm{Nr}$ & 體重 & $\left(D^{*}\right.$ & $v=v$ & YI & & 每 1 残 & 尿 & & 色 & $\mid \begin{array}{l}\text { デーラン } \\
\text { デル }\end{array}$ & $\left|\begin{array}{l}7 x-11 \\
y y^{2}\end{array}\right|$ & 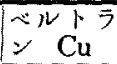 \\
\hline & & $\mathrm{kg}$. & 時 & 寺 & $\mathrm{g}$ & $\mathrm{ccm}$ & $\mathrm{g}$ & 時 $c$ & $\mathrm{ccm}$ & & & & $\mathrm{mg}$ \\
\hline $\begin{array}{r}9 / X \\
10 / X \\
11 / X\end{array}$ & $\mathrm{Nr}$ & 1.7 & $\begin{array}{l}4.40^{\prime} \\
5.0^{\prime} \\
9.0^{\prime} \\
4.0^{\prime}\end{array}$ & $\begin{array}{l}\text { p.m. } \\
\text { p.m. } \\
\text { p.m. } \\
\text { p. m. }\end{array}$ & $\begin{array}{l}1.6 \\
1.6 \\
2.0 \\
2.0\end{array}$ & $\begin{array}{l}40 \\
40 \\
50 \\
50\end{array}$ & $\begin{array}{l}0.941 \\
0.941 \\
1.176 \\
1.176\end{array}$ & $\left|\begin{array}{c}16 \mathrm{~h} \\
15 \mathrm{~h} \\
6 \mathrm{~h} \\
16 \mathrm{~h}\end{array}\right|$ & $\begin{array}{r}94 \\
160 \\
65 \\
140\end{array}$ & 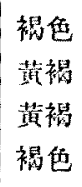 & $\begin{array}{l}+ \\
+ \\
H \\
H\end{array}$ & $\begin{array}{r}+ \\
+ \\
+ \\
+\end{array}$ & $\begin{array}{r}68 \\
72 \\
263 \\
587\end{array}$ \\
\hline $2^{\prime} X$ & $\mathrm{Nr} 5$ & 1.2 & $2.40^{\prime}$ & p. & 2.0 & 50 & $1.66 \theta$ & $6 \mathrm{~b}$ & 65 & 蓝褐 & tt & $H$ & 92 \\
\hline
\end{tabular}

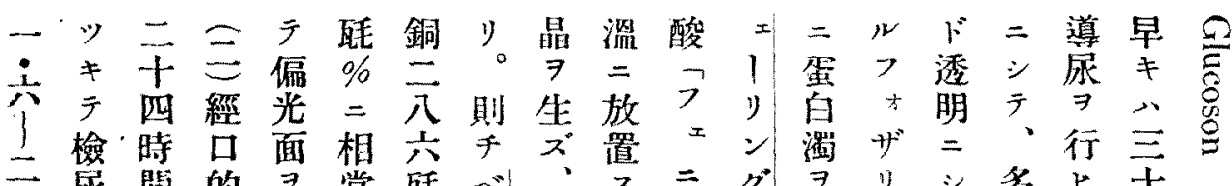

一疗間的 $\Rightarrow$ 當䀲

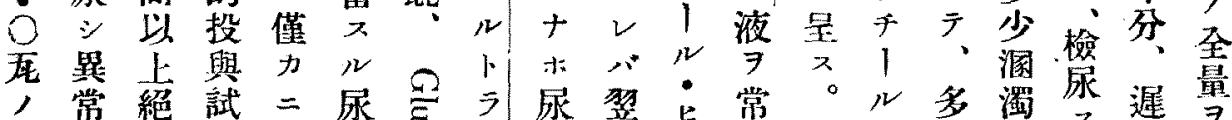

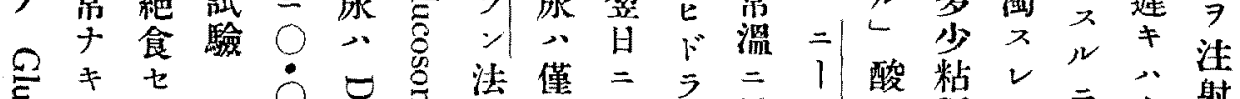

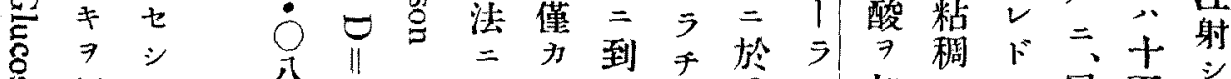

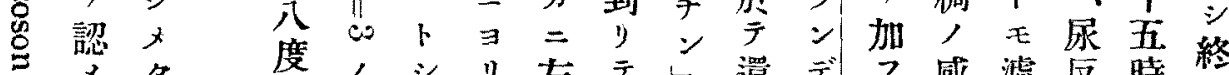

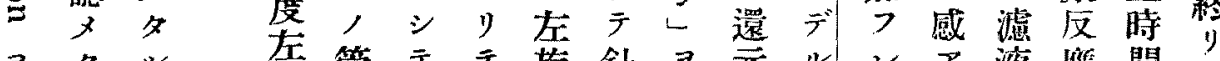

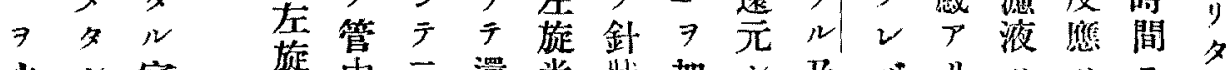

水 $儿$ 家旋中三還光彇加

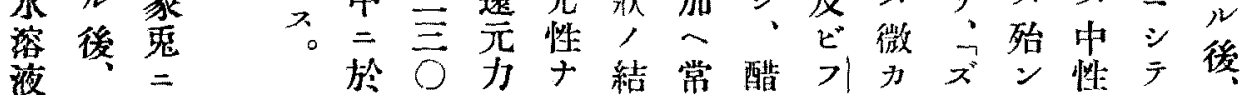




\begin{tabular}{|c|c|c|c|c|}
\hline \multicolumn{5}{|c|}{ 稿口的投與 卜 㨫粕 } \\
\hline \multicolumn{2}{|c|}{ 家鬼 $\mathrm{Nr} .7$} & $24 / x$ & $30 / \mathrm{X}$ & $4 / \mathrm{XI}$ \\
\hline \multicolumn{2}{|c|}{ 呺重重 g. } & 1820 & 1800 & 1700 \\
\hline \multicolumn{2}{|c|}{ Glucoson } & \multirow[b]{2}{*}{$\begin{array}{c}40 \mathrm{ccm} \\
20 \mathrm{~g} .\end{array}$} & $\begin{array}{c}5 \mathrm{cccm} \\
1.1 \mathrm{~g} .\end{array}$ & \multirow[t]{2}{*}{$\begin{array}{c}50 \mathrm{ccm} \\
1.1 \mathrm{~g}\end{array}$} \\
\hline & 萄 糖 & & & \\
\hline \multirow{9}{*}{ 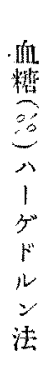 } & 空腹時 & 0.108 & 0.101 & 0.100 \\
\hline & $30^{\prime}$ & 0.144 & 0.143 & 0.142 \\
\hline & 試 $1^{h}$ & 0.214 & 0.161 & 0.129 \\
\hline & 驗 $2^{\mathrm{h}}$ & 0.182 & 0.140 & 0.164 \\
\hline & 液 3 h & 0.146 & 0.194 & 0.207 \\
\hline & 投 $4 \mathrm{~h}$ & 0.120 & 0.206 & 0.830 \\
\hline & 與 $5 \mathrm{~h}$ & 0.107 & 0.144 & 0.136 \\
\hline & 後 6 I & 0.090 & 0.136 & 0.106 \\
\hline & $7 \mathrm{~h}$ & 0.108 & 0.119 & 0.095 \\
\hline \multicolumn{2}{|c|}{ 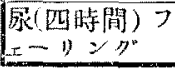 } & + & H & H \\
\hline
\end{tabular}

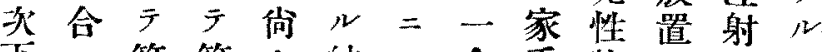

下第第柰結 $\exists$ 冤物

降於兵四經果\%互第買夕場合

シ $テ$ 時時口

、間間的得胃'號。場占尿

第第目目二多內 $\cong \bumpeq$ 合等

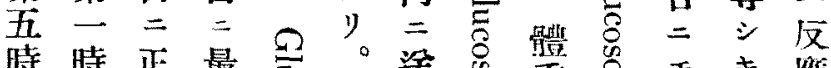

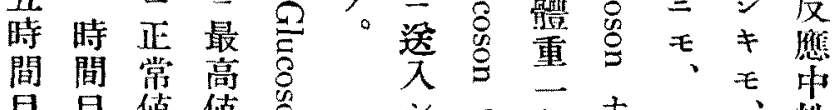

目目值值总 シ $尹$ 七十 -

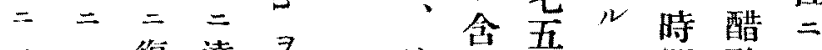

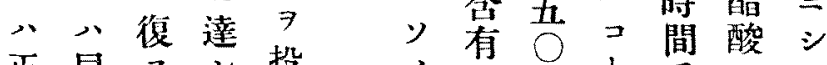

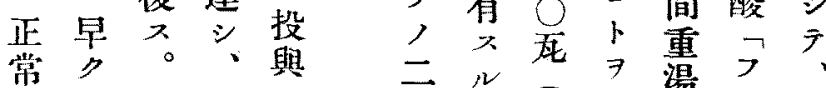

值王蒲y シ

二最萄レ为

復高糖 $\exists$ 少

又值 $\Rightarrow$ y家

○達口經又,

二 吾落品再 血

二8 $=$ 的再 血

、投濑

投

與 $v \dot{*}=$ 次

$=\exists$ \下

因、儿降昇

\%漸場 シ シ
二元瓦

㞣 0 雄證煎 = 微

尿, 站不去儿二

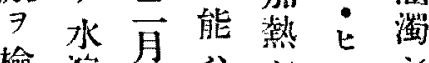

查液旨ズ。

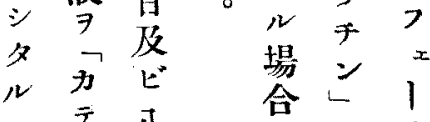

$=\overline{1}$ 八

同 白

等各各
モ 添

結架橸
檢溶去心梁
光力

$\alpha$

$\mathrm{D}=-2$

277

287

$-0.32$

$-0.34^{\circ}-0.22^{\circ}$ 
關然梅年素用以連其其過演 係

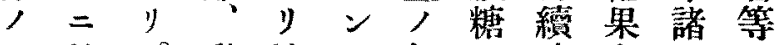
三該。耐糖卜如三時血種, $\exists$ 試以糖尿試 $₹$ 重間糖方一 以驗上能病三實負站調法人 于 = 茢試, 夕驗荷三節三澤 八於舆驗診り的試終機 $\exists$ 思

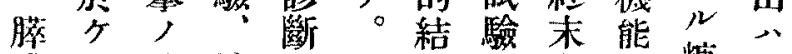

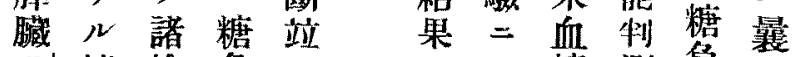

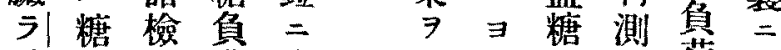
氏負試荷豫得 島荷方試後名慰法試兔 機後法驗判帅等乃驗 能, 中等定二 人血糖其= $=$ ブ見標行

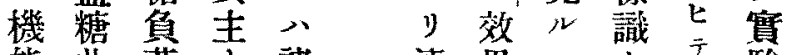
能曲荷子諸連果、ト文驗 籁線試 ル種續, 該 $三$ 觀的

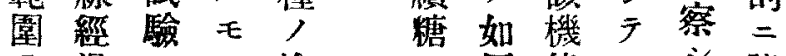
$\exists$ 過 只, 檢何能 、 明量最大香重二制、夕種 確最モり。吕椐ア测初結方 知血重以陚至試事參血果㳙

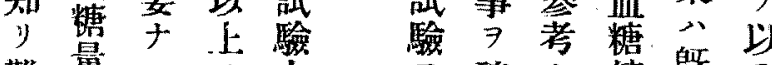
難量儿, 方確卜值既示 キ高位外法臨メ十公血 場高置先学呀タ儿其本糖

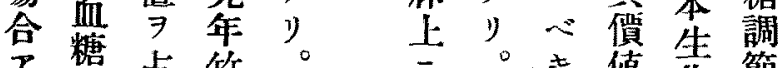
7 持占竹。云值花節 》。䊧么田例應標少學機 時 12 公用諳》、會能

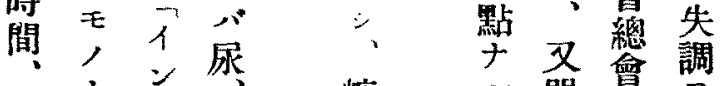
終ナジ糖学單會、

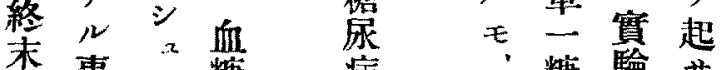

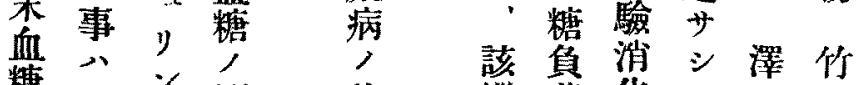
糖二ざ测部機荷华 等般二定斷能試器 $=\exists$ 端制驗病該 站認 $心$ 全 $=$ 測 = 學 機 二x血身豫上 $\exists$ 會能真 血亏糖牀後最心等失 糖 ル反態 卜、位

尿處試合 傥糖堆時

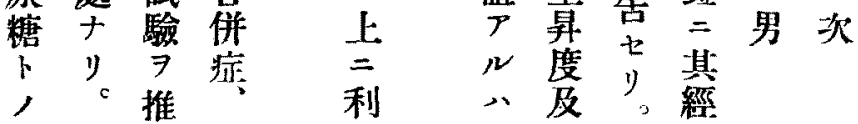

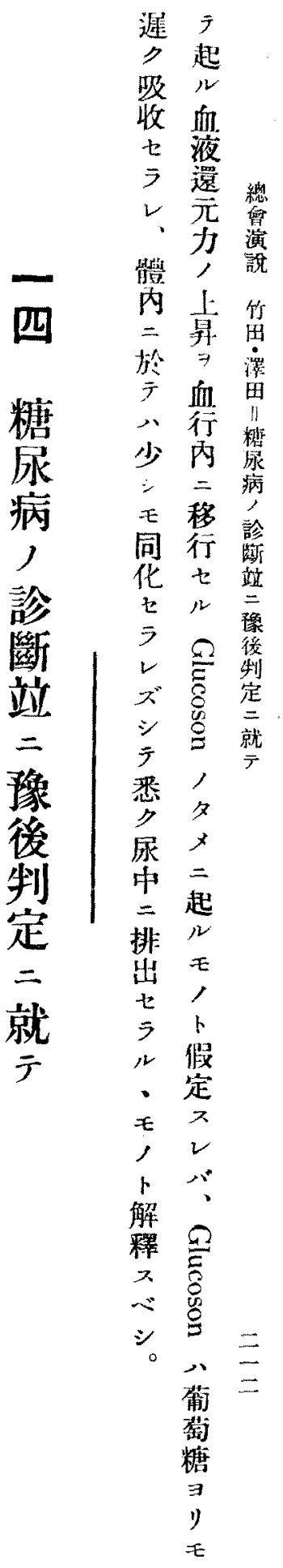




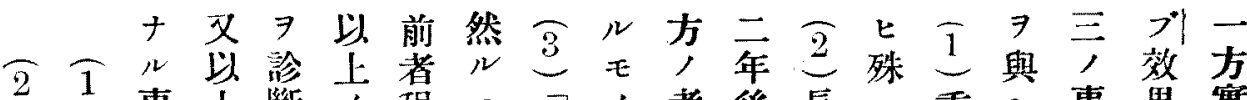

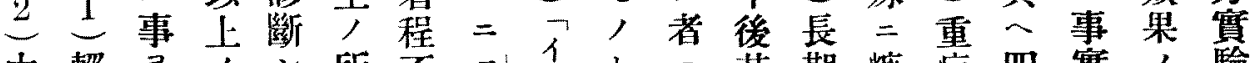
中輕 $\Rightarrow$, 多所不外占卜三其期糖症四實 等 提結 殊見良氏血思于血間負糖時 7 如的

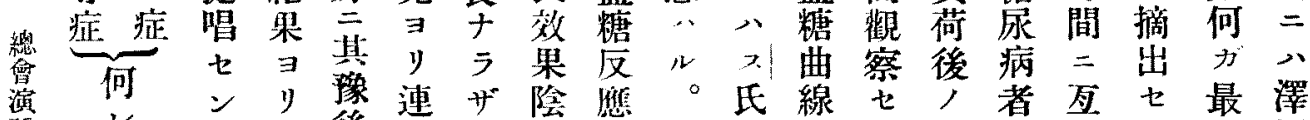
院

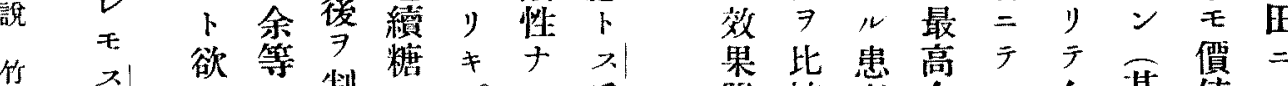
思弪点制糖

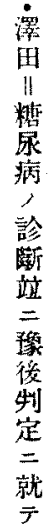

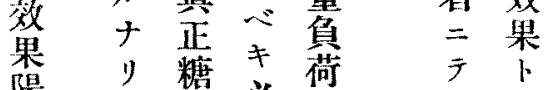

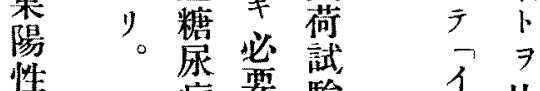
性病要驗代比

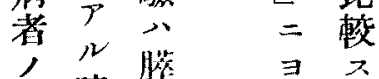

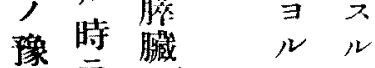

後

$\exists \longrightarrow$ 氏

制 1 島

ゼ血ノ應 氏

蹁糖能践常果

二範 $\quad$ 著

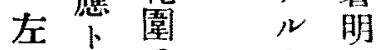

如共此者陰

₹該較

夫方 的

リ

々 法 明

分破該二

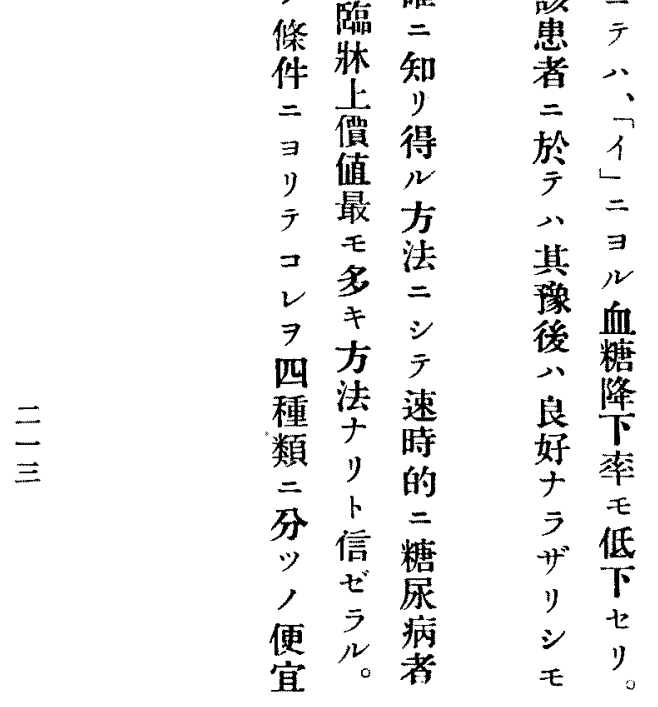

ルナ性曲门立

楾 フ

者り經效糖

$=$ 過果負

於二开荷

二上，

八其 F性 驗

其前同 $+=$

病年樣り於

勢，卡。年

進 血 思

行糖分

性 曲 $v$

N

糖

N 两線

驗 ル 諸

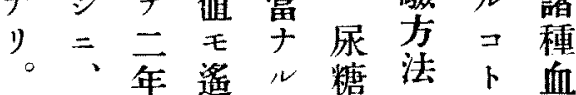

即其前二万尹办 7 糖

此增 二低不測 早證調

結惡行下站定朝七節

氏 外, 不其

空 5 機

方糖二饭

時々失

$=v$ 調

葡 心

萄際

糖 今 其

五 此 機

方能

瓦法判

水 臨 方

三林 法

五 上

$0= \pm$

靖 然

㧫用

取 連

七 得 續

多糖

二所重

尹差者經

示違 $=$ 過

爻無就良

時見負

間中荷

後 $\exists$ 試

㣚り驗

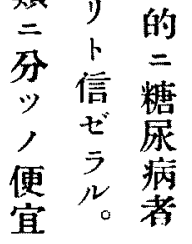

場力

合り再

好

量 興 二

, 味 $\exists$

葡学心

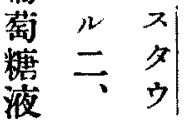


十神糖切系神幾注見模糖

》經 及斷緊經分意 $工$ 排排

系糖七張麻力シ夕出出

子排ラ減淠切テル閾間

與出

偣閾タノタ七驗川モ植

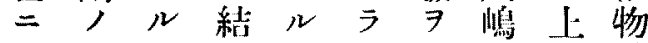

$\exists$ 上七果こレ反及昇神

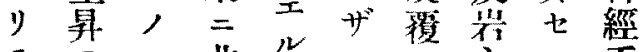

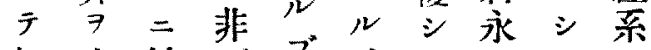

起桃於ズ ゴ神夕齐么゙,

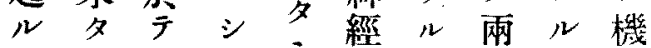

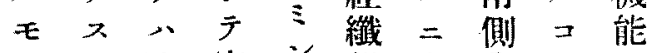

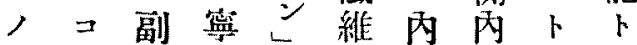

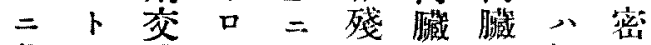

非ナ感ソ $ヨ$ 存神市斟切

メ゙シ神ノりセ經經二ナ

シ。經 興 ラリ, 切報關

テ = 刺鹪抑卜切断告保

$コ レ$ 韩 二 制 思斷 娞

, = 辈 $\exists$ 八完三八有

際ヨ多

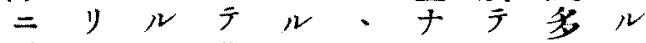

於于营、二”一, 二

ケ見它起 コ例 シ過貫卜

少七七ト二五性驗殊

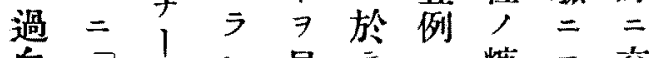

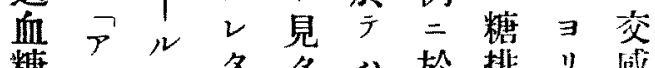

糖七七名 一於排り感

$卜 \mp \exists N y$ 手出確相

同

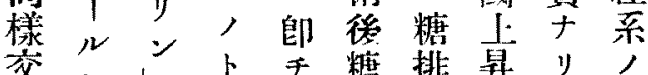

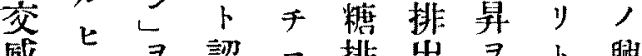

感 $\exists \Rightarrow$ 認 $\exists$ 排出 7 卜 與

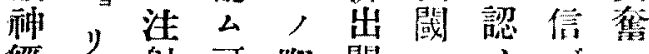

殌 ๖射可際閾

中 $匚 x \neq=$, 毫多“糖

榀 $=ル ナ$ 於上无只同

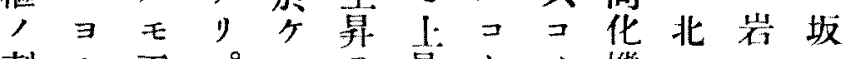

刺 $ル$ 正。ル＼cjkstart昇卜人機

戟糖常又糖桃七十所能

二排犬雨排タズり見 7 阙永口

$\exists$ 出二側出 $シ$ ・

閾於内間・手

モ, ケ臟上马術、致也

ノ上儿神昇, 不久七シ正芳康

重 $\frac{3}{3}$

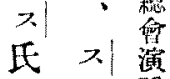

一 效 氏 說

五 果数坂

五㓌果品

糖售芯

排 血

出糖

間后痼简

閶 低 煻

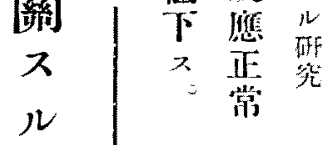

研

究

奖
嵊
离
程

我 經 $\because 1$.

認 八如 ガ交輣全後ハル

厶副》完威

可萃、全神交新永如共

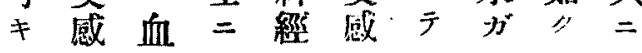


） 乃一次著度七出不記奮 小糖

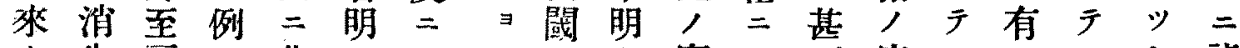

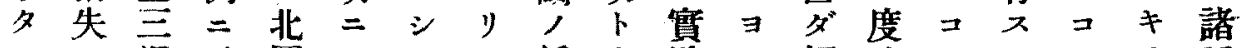
スシ週於岡コテン低ナ驗ル輕略レルレテ種

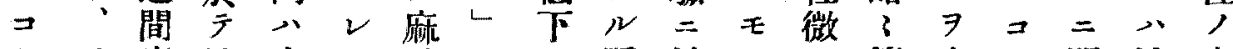

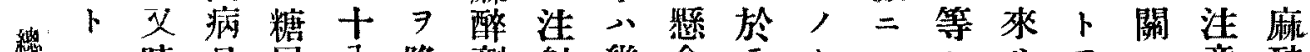

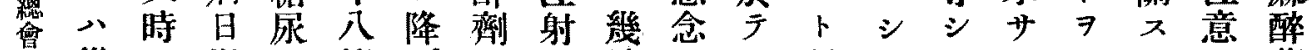
得從々

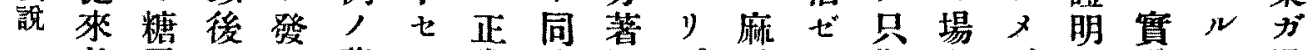
坂考尿二見黄シ常時明。醉 ラ斯合、シ驗モ過

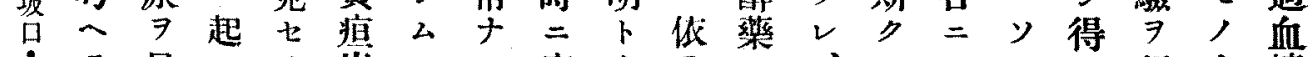

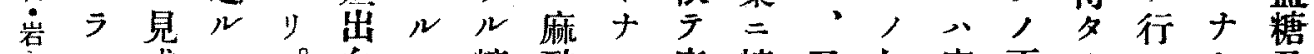
永々或モ。血コ糖醉と魔糖又如麻雨》。车及 北夕八人但性卜排劑、醉排㚆 $キ$ 醉者。タガビ

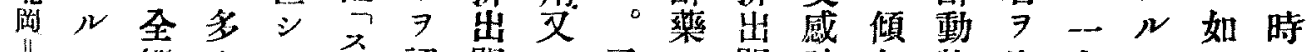

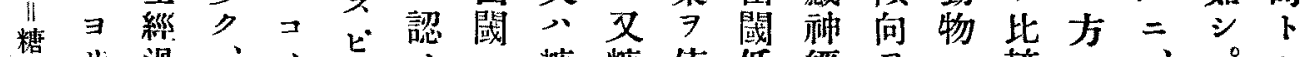

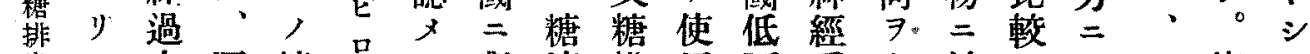
出 $モ$ 中三糖人夕對夜排角下系有於入八コ依云 䈅多只南

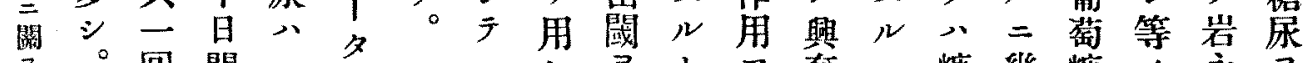
又。问間一名

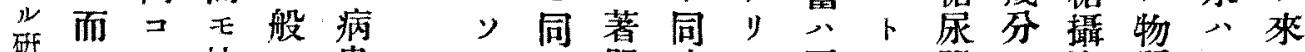

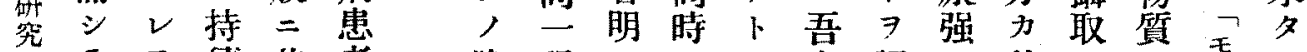

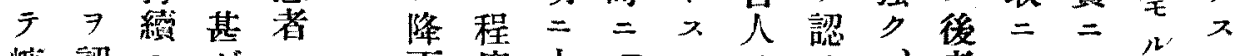

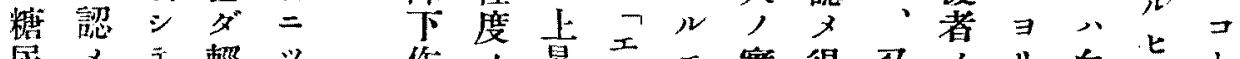
尿

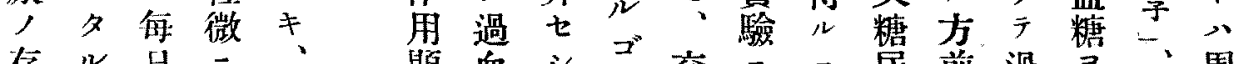

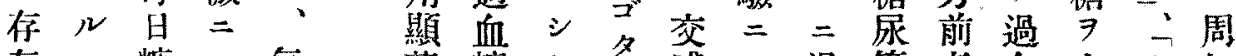
在二糖シ锤著糖么今感 $\exists$ 過等者血上》知

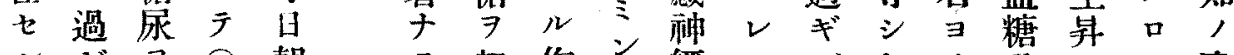

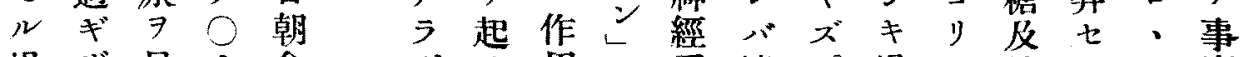
場ザ見字食ザサ用 $¥$ 系糖。場モ糖シ フ賈

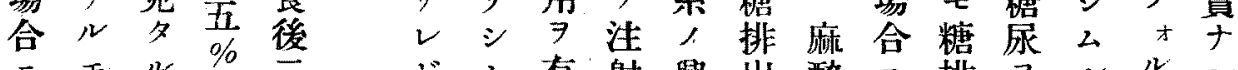
モ 2 以二厶有射興出醉二排 $\Rightarrow N ル V$

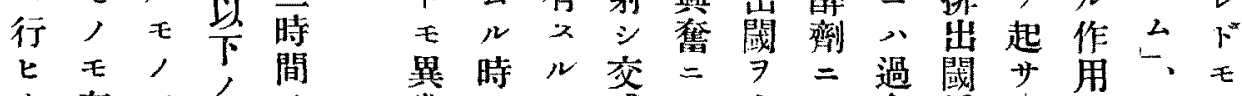
名存 血. 糖 兔毛多以

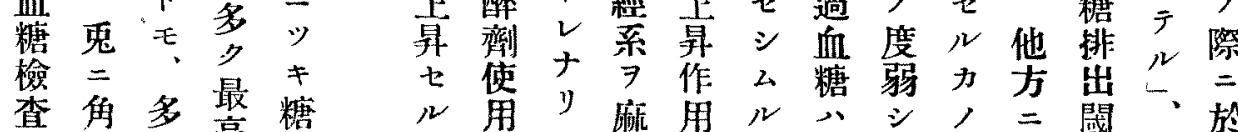

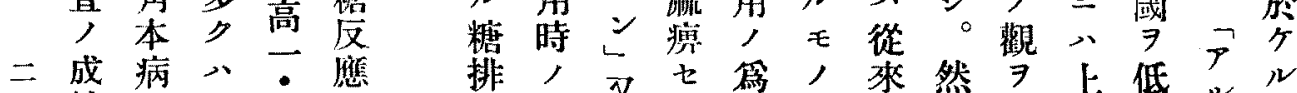
五績 五䈠 㭆 $\%$ 檢閾糖 $\exists$ 過至ナ $ン$ 尿

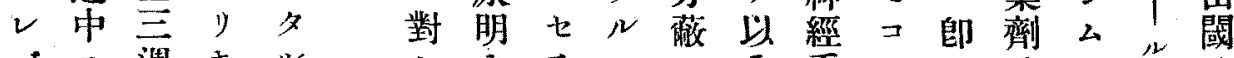

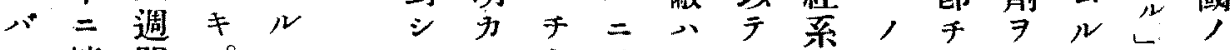
二糖間 ${ }^{\circ}=$ 示 $=1$ 糖 $レ$, 美過使作 $\Rightarrow$ 關 ' 尿二二十 $、$ 高 $N$ 排 


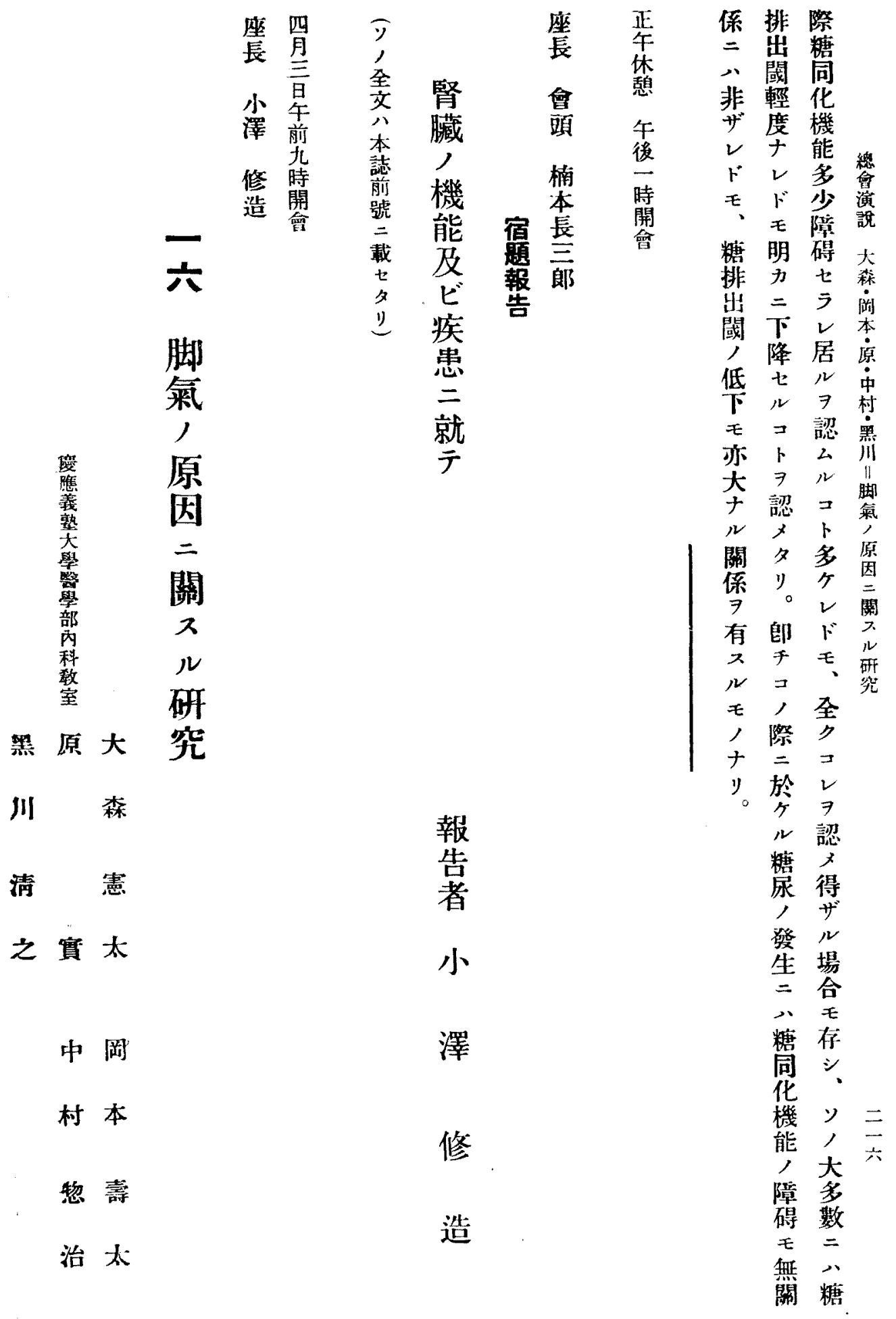


米り卜第昭經ス酒蕰精心試年キ著氣最 工。能向和号心精无白自驗暮脚方, 近

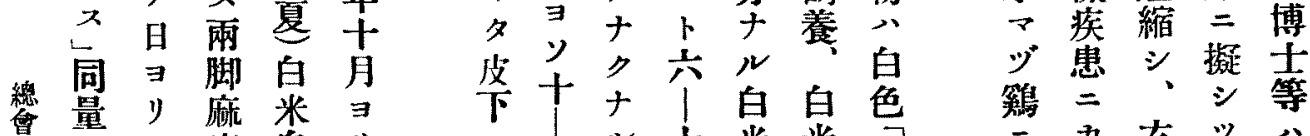
演 瘰自り

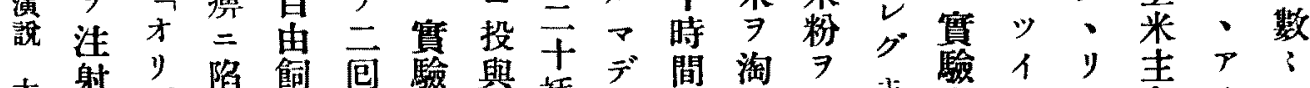

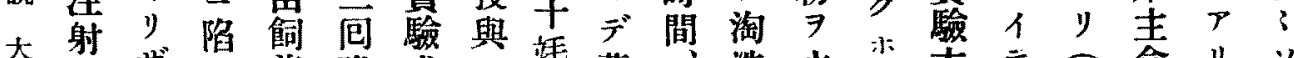

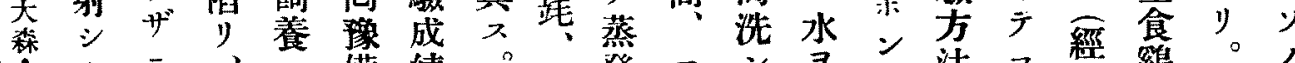

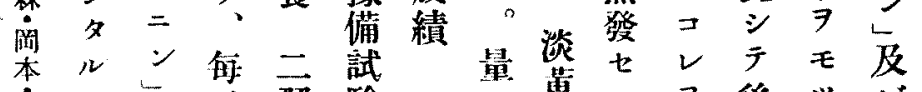

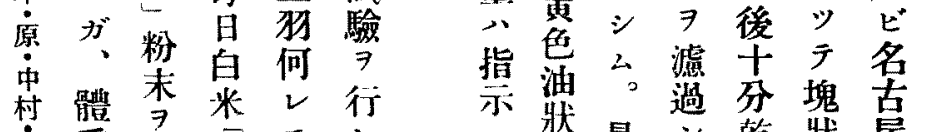
墨重與工王飞

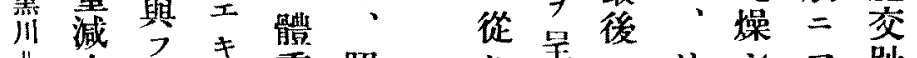

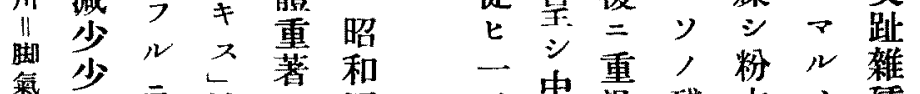
原”何洼汽四早性湯殘末 未種

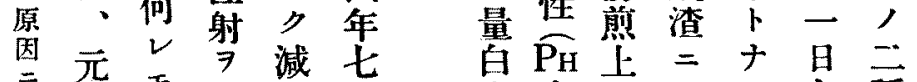
關氮麻行少肙来亲三サシ

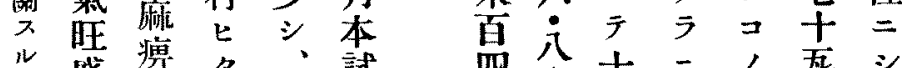
研盛廙夕、試四公十二, 死

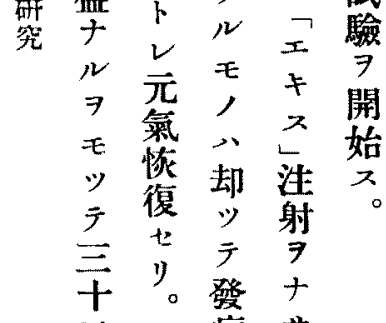

$$
\begin{aligned}
& \text { 百同病 サ } \\
& \text { 日時遲 び } \\
& \text { 音 } \\
& \text { 于蓄主, } \\
& \text { 實息夲索 }
\end{aligned}
$$

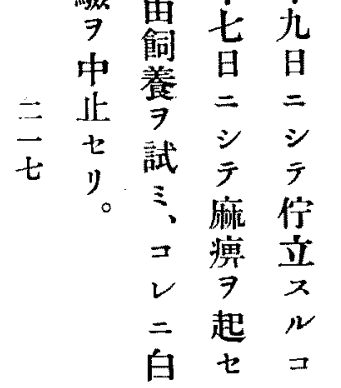
士七分純粉, 死七酒酒未制體 $=\bigcirc$ 精 精一 二 重 相 $7 \Rightarrow$ 助 與一 當り蒸加

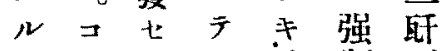
分 $v$ 三 振 純制 量二 2 盪酒飼飼 ナ少ルシ精養養 り許 コ・元, 法 水卢, 主 主 水门雨音法泉 加 振白液年少 䁑白波。 嘼类集温酒水 テ酒集

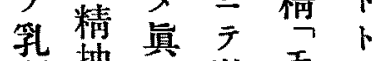
劑出空激 $キ モ$ ナス䭙クス興 2 签鴙不研 $\exists$ 的才产究 陚”赶發 シ起毛コ表 得希㦈オテ 人患》白 事モ㭧ザ米 實 $\vee \quad \neq$ 酒 夺コム シ 精 草 $ン コ 一$ 出 報寻占皮 七吕尔キ 义的。又 $卜$ 而入七。 ス與 シ 經 氏 尖的; $+\quad=1$ キ家投 脚兔興工 氣王入儿

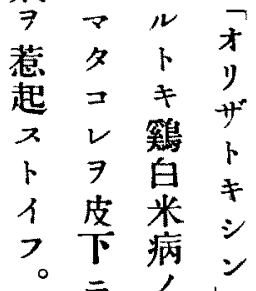
余注 羅 7 等 射 患 八入日 日 一ル數 テ 昨 ト $\rightrightarrows$ 脚 
荡急第最米第五第

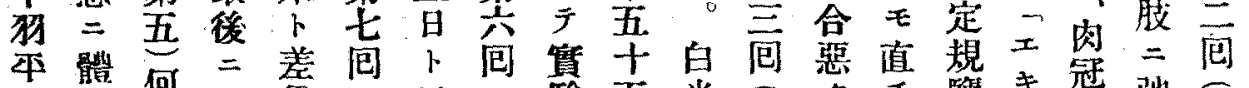

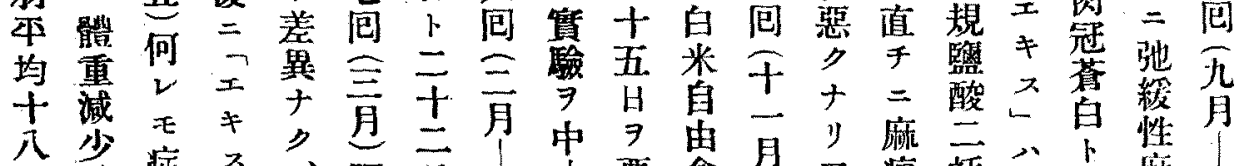

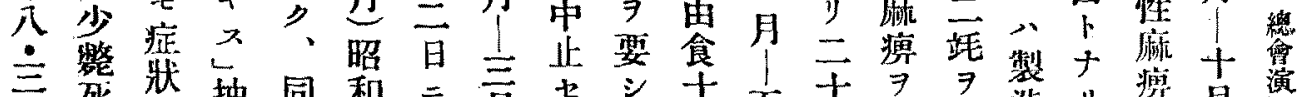

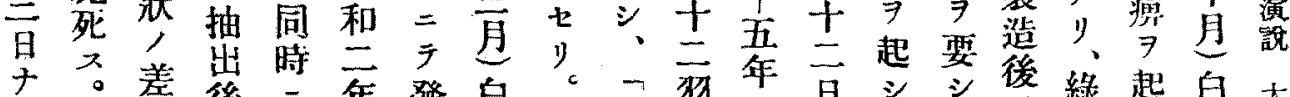

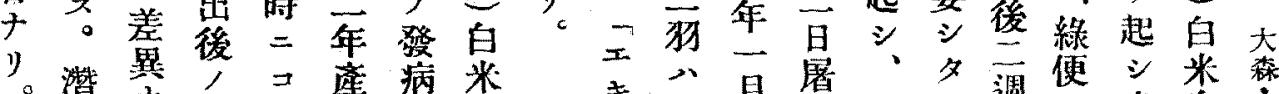

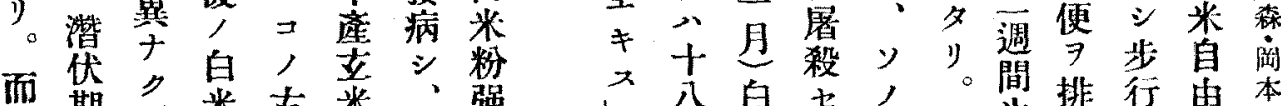

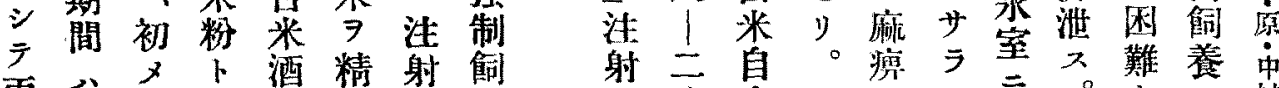

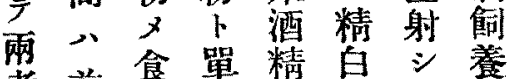
者前食單精白方養

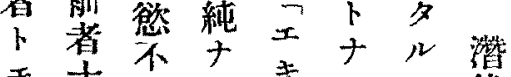

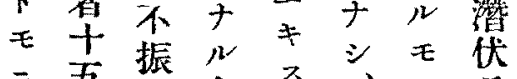
五現白之文，日 豫日心米 $\exists=\cdots$ 數 ᄀ上粉泩，士短 才草草射古五維 吉緑, 㴡白 サ文色比夕米卜州

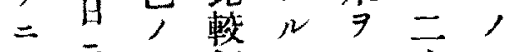
ン 三便飼モモ十 $モ$ 粉 $\exists$ 養,

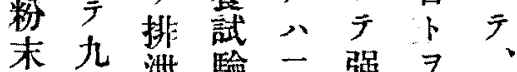

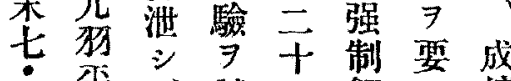

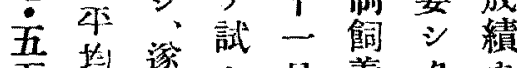

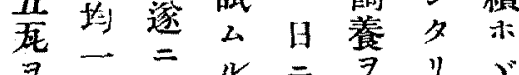

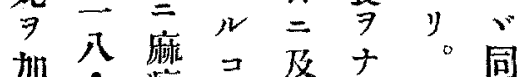

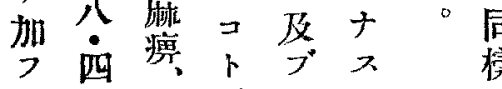

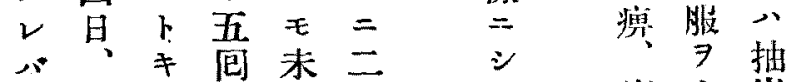

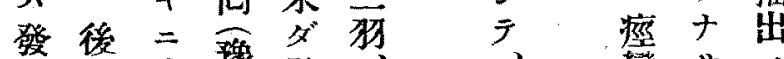

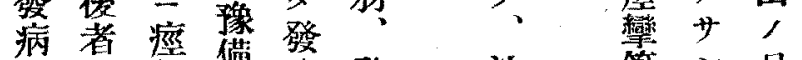

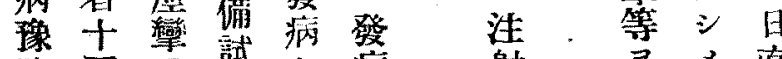

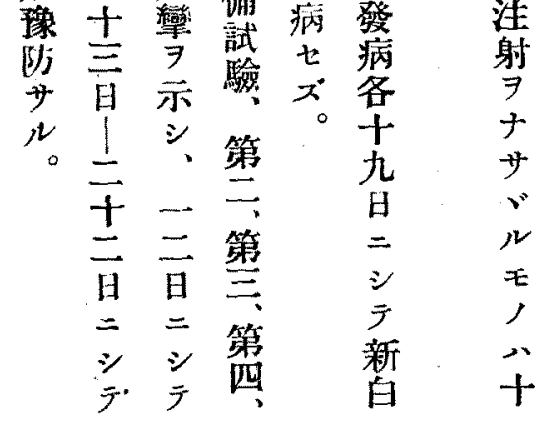
想認名便 サ $\mu$ 角 能 , 又

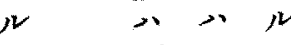
毛公示

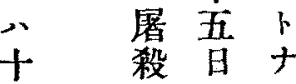
”三貯二卢十㷊

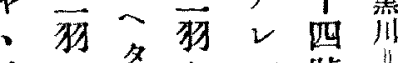
$\exists$ 直

夕 =

海第

毛發亩

苪疼騊

焉成

五 維

寺之鑑

日皇

王米

芦手亲

王출

麻两 즌

演服,

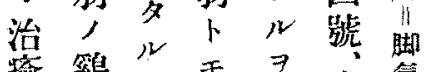

癒籍毛表录十策

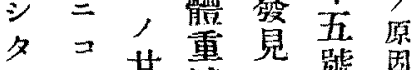

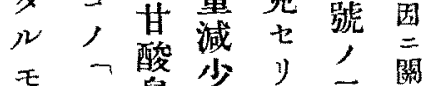

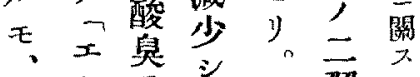

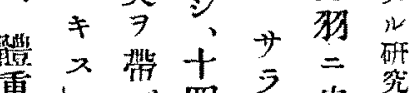

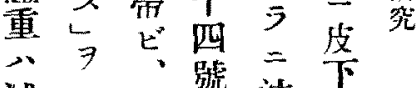

減可酸躆清洼

少回性七射射

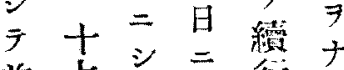

前究三行行

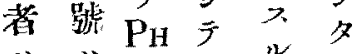

+全五死

公意方要厥

昌十一+瘐二

社五甚三

天號○號三時

死“跬”夕間

它车 九 “後

量中日五雨二

後注和二日側齐

学射不屡二㷠入

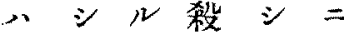

再名二七注

右必主食射

足唯分 篗 側 

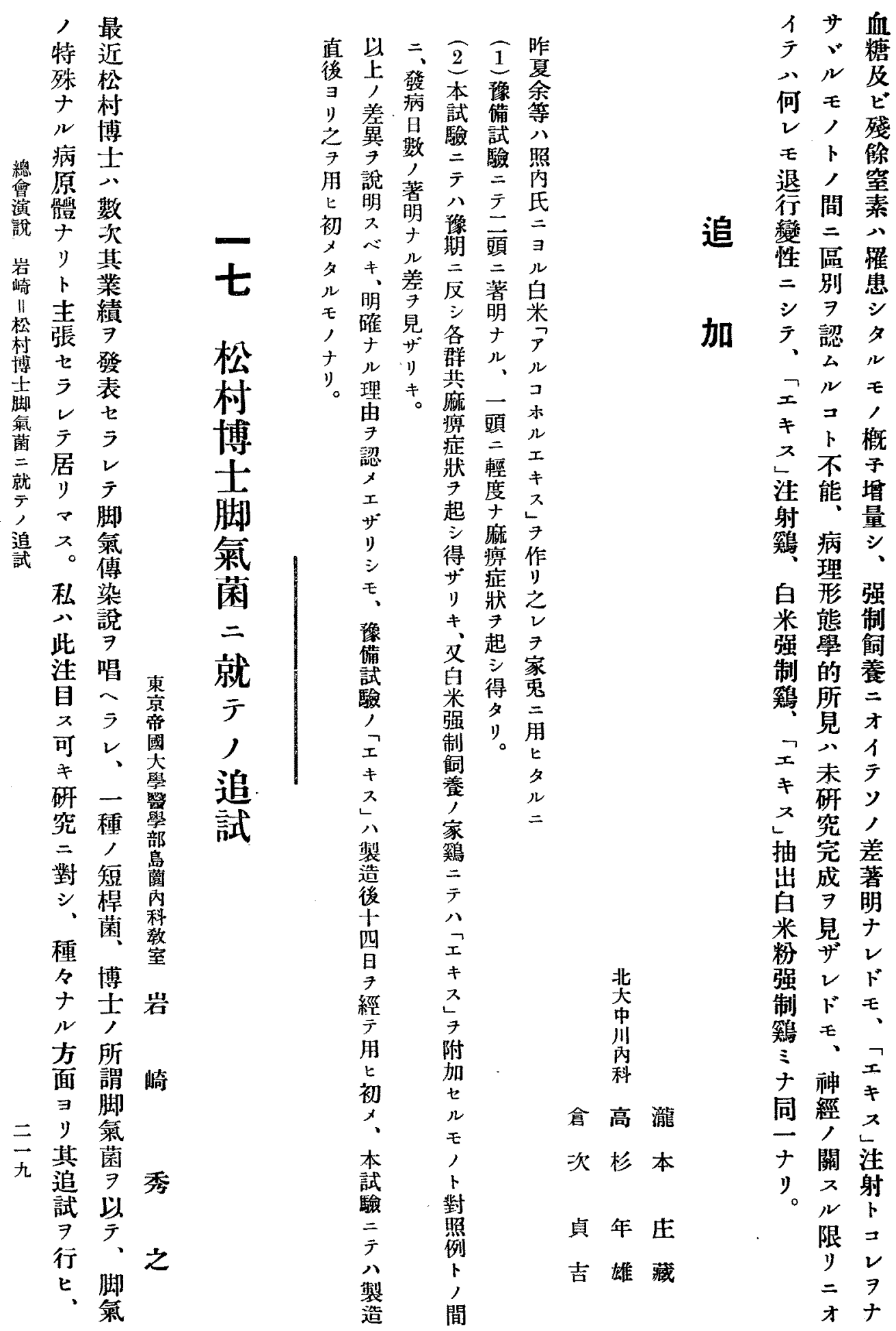
第一表 脚氮患者血清，脚氣菌凝集反㗹

\begin{tabular}{|c|c|c|c|c|c|c|c|c|c|c|c|c|c|c|}
\hline \multicolumn{2}{|c|}{ 脚氣菌排淮度 } & $\begin{array}{l}\mathrm{A} \\
+ \\
\end{array}$ & - & $\begin{array}{l}\mathrm{A} \\
\mathrm{M}\end{array}$ & - & - & $\begin{array}{r}\mathrm{B} \\
+ \\
\end{array}$ & $\begin{array}{l}\text { A } \\
\text { H }\end{array}$ & $\begin{array}{r}\mathrm{B} \\
\mathrm{H} \\
\end{array}$ & $\begin{array}{l}\mathrm{A} \\
+\end{array}$ & $\begin{array}{l}A \\
+\end{array}$ & - & $\begin{array}{l}\mathrm{A} \\
\mathrm{H}\end{array}$ & $\begin{array}{l}B \\
+ \\
\end{array}$ \\
\hline \multicolumn{2}{|c|}{ 脚氣菌 $\mathrm{A}$ 型 } & 200 & 50 & 400 & 100 & 400 & 200 & 300 & 400 & 50 & 200 & 50 & 300 & 400 \\
\hline \multicolumn{2}{|c|}{ 脚氣菌 B 型 } & 200 & 50 & 400 & 100 & 300 & 300 & 100 & 200 & 50 & 300 & 100 & 400 & 300 \\
\hline \multirow{4}{*}{$\begin{array}{l}\text { B. coli } \\
\text { communior }\end{array}$} & $\mathrm{KIa}$ & & 100 & & 200 & & & 300 & & & & & & 400 \\
\hline & $\mathrm{Ib}$ & 200 & 200 & & & & 300 & & & & & & 200 & \\
\hline & MII & & 50 & 100 & & & 100 & & 100 & 50 & 300 & 200 & & \\
\hline & G15 & & & 300 & & 300 & & 400 & & 100 & & & & 200 \\
\hline \multicolumn{2}{|c|}{ B. coli commune } & 50 & & 100 & & & 50 & & & & 100 & & & 50 \\
\hline \multicolumn{2}{|c|}{ B. acidi lactiti } & & & 100 & 50 & & & & & & & & & 50 \\
\hline \multicolumn{2}{|c|}{ B. lactis aerogenes } & 400 & 300 & 300 & 200 & & & & 400 & & 100 & 200 & & 300 \\
\hline
\end{tabular}

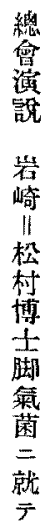

第二表 脚氣，䥺往症無未健康者及他疾患者血清，脚氣菌凝集反憵

\begin{tabular}{|c|c|c|c|c|c|c|c|c|c|c|c|c|c|c|}
\hline \multicolumn{2}{|c|}{ 脚策菌排淮度 } & $\begin{array}{r}B \\
+ \\
\end{array}$ & - & - & - & - & $\begin{array}{l}\mathrm{A} \\
\mathrm{H}\end{array}$ & - & - & - & - & - & - & - \\
\hline \multicolumn{2}{|c|}{ 脚氣菌 $\mathrm{A}$ 型 } & 300 & 200 & 200 & - & 100 & 400 & 200 & 100 & 200 & 300 & 50 & 100 & 200 \\
\hline \multicolumn{2}{|c|}{ 脚 氣菌 B 型 } & 400 & 200 & 100 & - & 50 & 300 & 200 & 100 & 200 & 100 & - & 50 & 300 \\
\hline \multirow{4}{*}{$\begin{array}{l}\text { B. coli } \\
\text { communior }\end{array}$} & KIa & & & & & & & & 50 & & 200 & & & \\
\hline & Ib & 200 & & 100 & 50 & & & & & & & & & \\
\hline & MII & & & & 50 & & 400 & & & & & & 50 & 300 \\
\hline & G15 & & & & - & 50 & 200 & 300 & & & & & & \\
\hline \multicolumn{2}{|c|}{ B. coli commune } & 50 & & & & 50 & 50 & & & 50 & & & & \\
\hline \multicolumn{2}{|c|}{ B. acidi lactiti } & 50 & & & & & & & & & 50 & & & 50 \\
\hline \multicolumn{2}{|c|}{ B. lactis aerogenes } & & 100 & & & 50 & 300 & & & & 300 & 50 & & \\
\hline
\end{tabular}

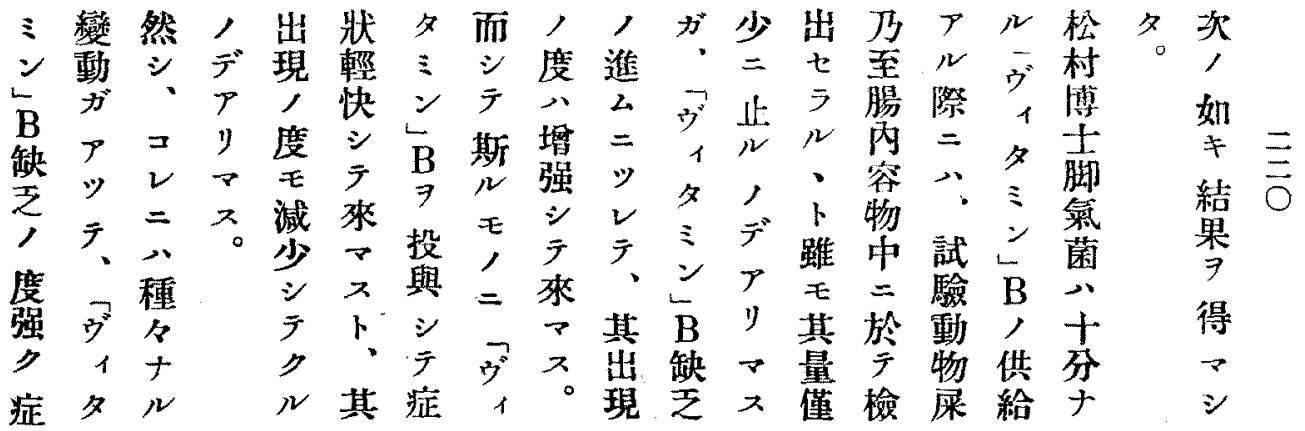


郎據發更ル脚型菌傾即 $、$ 次二 $ン$ 物殊

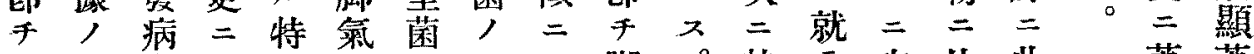

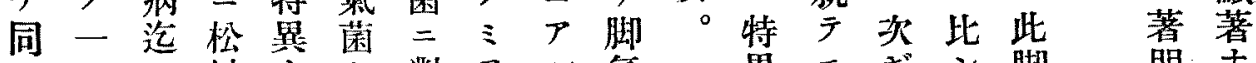

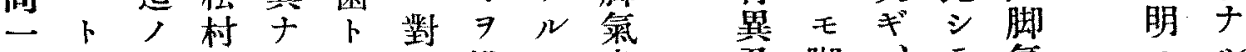
條ナ日博次, 又排刃患

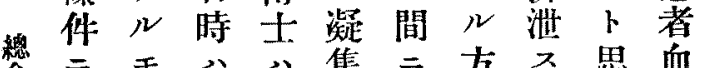
會於モ心集二方复思血

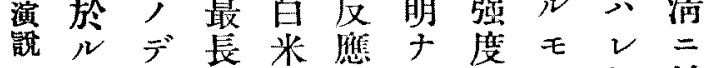

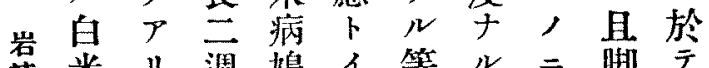
琦米り週䲴 1 等 $ル=$ 脚 模食 $、$ 間 $三$ 差場於氮

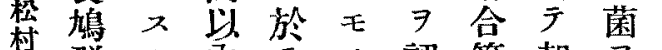
博群力丙示, 認等却 $\exists$ 脚

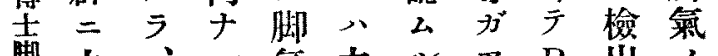

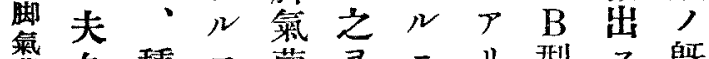

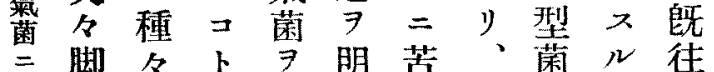
就氮ナ $\overline{\bar{\gamma}}$ 菌 $ル$ 主口確 $カ ゙=$ 對著無 追 A 方張的登如八ス明 $\neq$ 試型法セ二スキ脚ルナ健

B 以 以與事, 菌集モ者

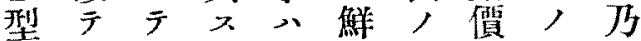
反居ル出》ミ峌

可覆り時來無 ゙゙方於他 范 严 总之。所, デ他り、稍者 羷事濳アリ腸又明清

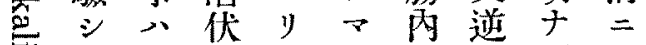
品 夕脚期 $\checkmark=$ 菌三凝比 , 氛筑 デ菌著。、對型反其 曰ア , 明特 , y 病 $=N, \exists$ 氣 查原短脚凝三呈菌 $z$ 性縮 氣集檢 $x=$ 息原出 $N$ 對 要制 $シ$ 者㮣七モ

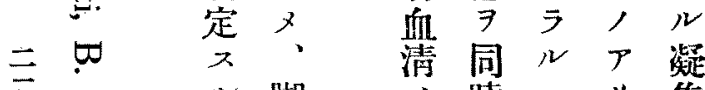
三告脚分時、y集

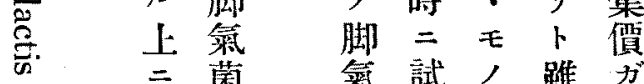

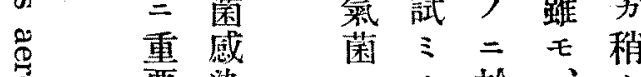
害 要染 $=$ 於 † 寻對時 F A 高

根り 入
恳脚、于氮 疫氣白多菌 反菌鼠1, 應 $\exists$, 出 阝 證家 デ現 シ 明兔 $P$ 永 テ シ 、 y 試 , 得猫 $\checkmark$ 驗 人 $于=$ 動 血1於 $カ ゙$ 物 清場亏、, 二合 、鳩異

$\exists \rightarrow ゙$ 、ガ

多定 氣, 菂 $1 \%$

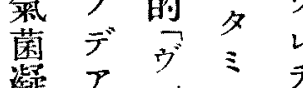
㵶

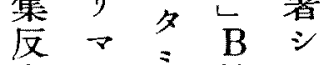
應スミ缺手 デ。さ兄異 $\Upsilon$ B 症同

y 缺 $=Y$

$\rightarrow$ 芝䊒り

入 症 $\mu$

$\nexists j \quad \exists$ 時 鳩

成起屎於

績 七中方

少本八

第

表

站

$=$

第

㤗

$=$

示

장

如

デ

デ

y
例菌健 二增常 於 加時 F 7 既 モ 見二

其少本

屎事菌 又多 7

八名證

腸、明

丙人

容胞

物挡 , 症卜 何 公他
其 若 $心=$

$=N$

證モ

明,

七 $=$ 万於 ル

、

†終

ウ 始

二 全

\%菌 夕, モ 證 ，明 $=$ 出 於 來 テナ モ 1 少 米了 檢 出又 , 電 都加 度 シ 著 テ 居 亿 變毛 動

, 存 又 輕 $\sim$ 微 E) , 度 $\pi^{\prime \prime}=$ 寡 ） ナ 人) デ 䙵 $P>$ 


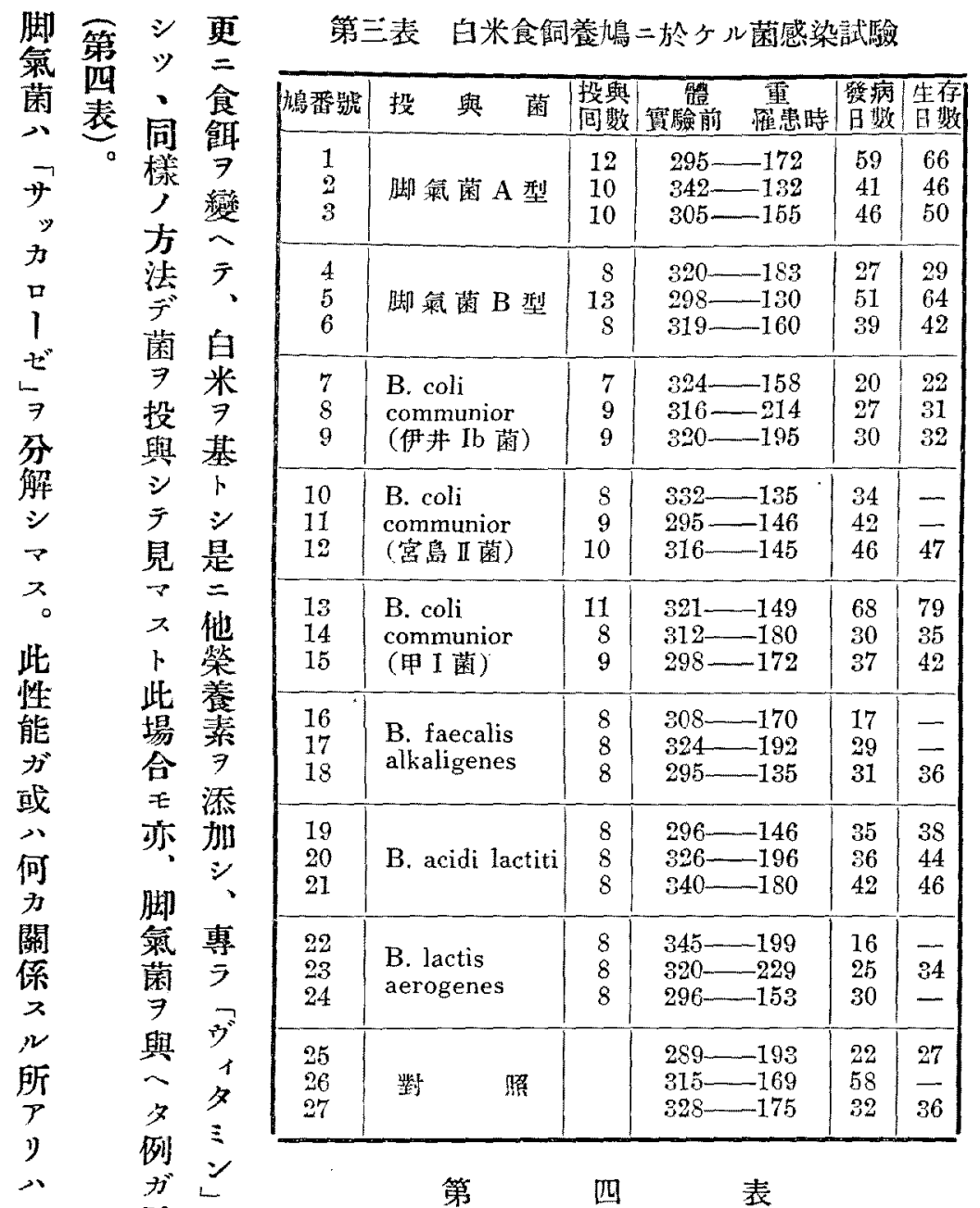

夕致 站

デー 脚

$\gamma$ シ 莪

y夕患

小者

又y屎

ガシ 中

、方, 訊

其白 $\rightarrow$ 岩

結米

果食公松

八二厶㭠

脚移 文博

筬少吉

菌卜1脚

二同少莱

$\exists$ 時大 $=$

$N=$ 腸 就

投㯰

来興簇追

病 $シ$ 芦試

踓 始

患 メ A

促、型

進 其

作量王

用及 B

、 ビ 型

$\Rightarrow$ 間 デ

2 隔

$\Rightarrow 7$ 無

認種

公各正

「多タミン」B缺之食飼養九島二於ケル菌感染試羷

$N=1$

ナ 早 $\mathrm{B}$

1 篗 三

力、患

使采龊

\begin{tabular}{|c|c|c|c|c|c|}
\hline 㑑香號 & 投 與 菌 & 投與 & 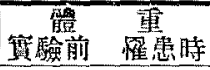 & 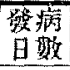 & 生存 \\
\hline $\begin{array}{l}101 \\
102\end{array}$ & 脚氣菌 $\mathrm{A}$ 型 & $\begin{array}{r}10 \\
9\end{array}$ & $\begin{array}{l}308-155 \\
312-175\end{array}$ & $\begin{array}{l}27 \\
21\end{array}$ & $\begin{array}{l}27 \\
25\end{array}$ \\
\hline $\begin{array}{l}103 \\
104\end{array}$ & 脚氣菌 $\mathrm{B}$ 型 & $\begin{array}{r}9 \\
10\end{array}$ & $\begin{array}{l}328-143 \\
805-139\end{array}$ & $\begin{array}{l}24 \\
42\end{array}$ & $\begin{array}{l}28 \\
45\end{array}$ \\
\hline $\begin{array}{l}105 \\
106\end{array}$ & $\begin{array}{l}\text { B. lactis } \\
\text { aerogenes }\end{array}$ & $\begin{array}{l}9 \\
9\end{array}$ & $\begin{array}{l}372-143 \\
303-131\end{array}$ & $\begin{array}{l}26 \\
25\end{array}$ & $\begin{array}{l}30 \\
27\end{array}$ \\
\hline $\begin{array}{l}107 \\
108 \\
109 \\
110 \\
111 \\
112\end{array}$ & 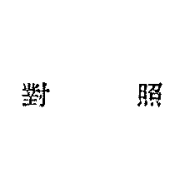 & & $\begin{array}{l}352-143 \\
302-142 \\
315-146 \\
312-100 \\
296-159 \\
342-148\end{array}$ & $\begin{array}{l}21 \\
20 \\
36 \\
28 \\
29 \\
23\end{array}$ & $\begin{array}{l}22 \\
34 \\
40 \\
38 \\
34 \\
27\end{array}$ \\
\hline
\end{tabular}

事換 三

$\exists$ 分種

得 相

$\checkmark$ 反以

七復 声

\%

广 12

白 フ 食

米事 解

$=\quad>\quad \Rightarrow$

二 見 以

○ 5 \%

$\%$ ᄂ 鳩

$>>7$

割七飼

= ン 䓹

ン

デ 企種

シ 經

多藏

$\equiv$ 口

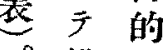

。投 $=$

其投 


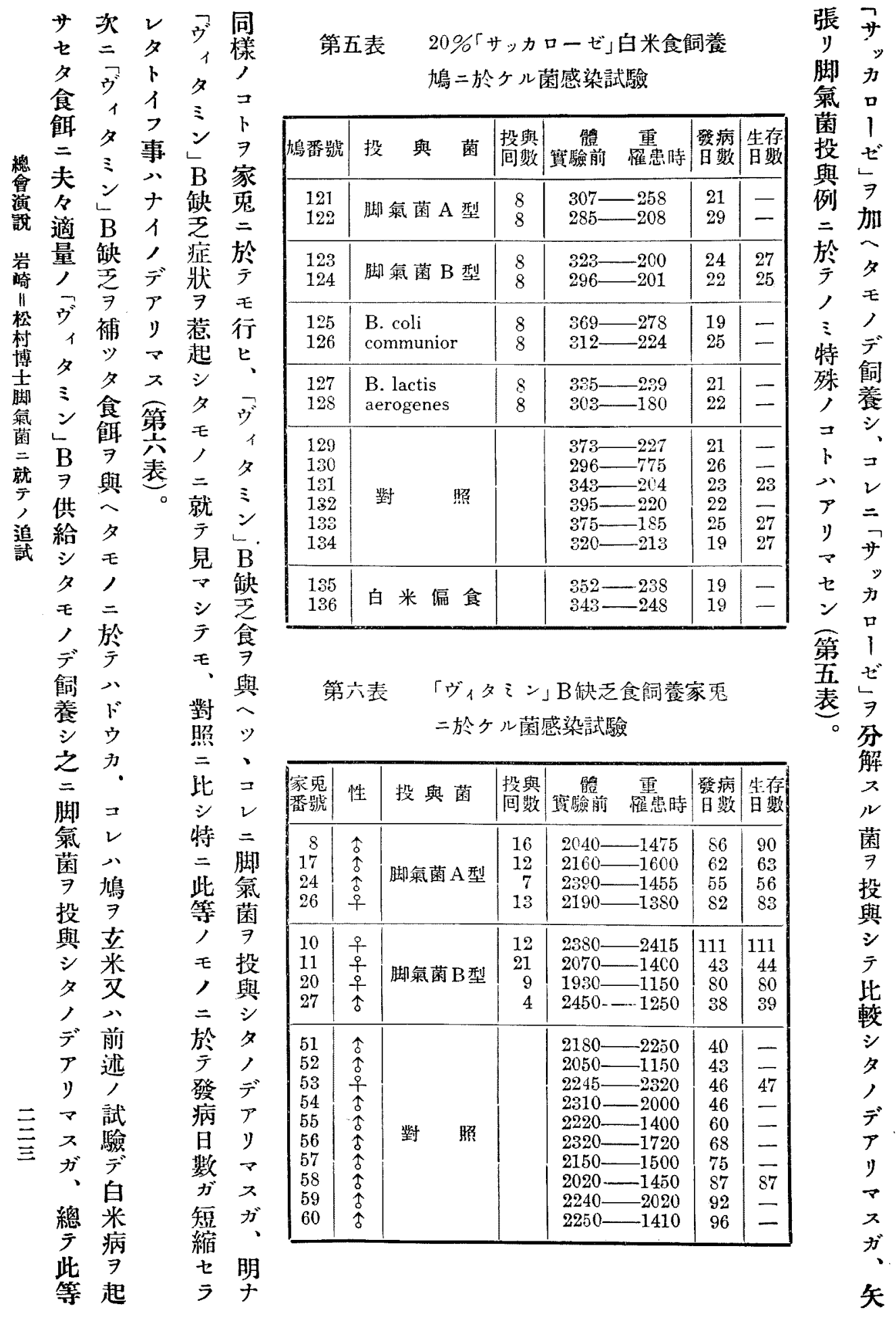




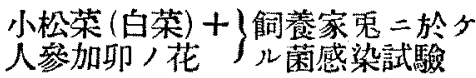

\begin{tabular}{|c|c|c|c|c|c|}
\hline 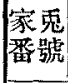 & 性 & 投與萄 & 投與 & 寒驗 & 歸 \\
\hline \begin{tabular}{r|}
1 \\
2 \\
3 \\
13 \\
14
\end{tabular} & 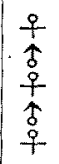 & $\begin{array}{l}\text { A琺㴋菌 } \\
\mathrm{A} \text { 型 }\end{array}$ & \begin{tabular}{r|}
3 \\
22 \\
3 \\
22 \\
22
\end{tabular} & $\begin{array}{l}1965-1860 \\
2175-2695 \\
2110-1915 \\
1795-2405 \\
2870-2650\end{array}$ & $\begin{array}{l}\text { 5日目死亡 } \\
\text { 200日見健 } \\
6 \text { 日目死亡 } \\
200 \text { 日目健 } \\
200 \text { 日自煡 }\end{array}$ \\
\hline $\begin{array}{r}4 \\
5 \\
6 \\
15 \\
22 \\
25 \\
28 \\
51 \\
53 \\
53 \\
54 \\
55 \\
56\end{array}$ & 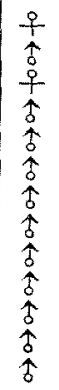 & 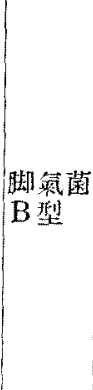 & \begin{tabular}{r|}
3 \\
25 \\
25 \\
12 \\
2 \\
4 \\
3 \\
15 \\
14 \\
7 \\
15 \\
15 \\
15
\end{tabular} & $\begin{array}{r}2130-1920 \\
2000-2350 \\
1910-2400 \\
2065-1450 \\
2110-1830 \\
2400-2450 \\
2200-2105 \\
23400-2502 \\
2260-1785 \\
2340-1955 \\
2610-2470 \\
2360-2370 \\
1970-2060\end{array}$ & 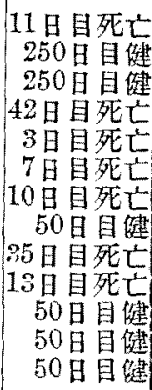 \\
\hline
\end{tabular}

又又王以，脚王コＰ= $ル$ 菌症上デ禾無レり於

$\nexists^{*}$ 感

如染宝以》

キ 試脚 ッ $\rightarrow$ 與䭒家管脚

事驗㴋テスヘ

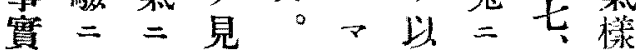

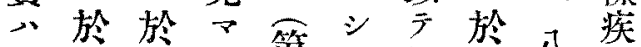

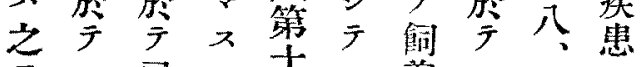

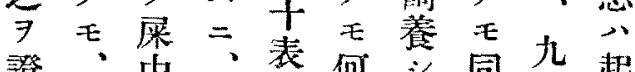

證、中表何方同表起

明特二脚等 夕一表名

シ 異多或 脚ルデ。 ズ

得ナク菌归无

$ナ N$ 出 $、$ 樣, 少

1病現鳥症 $=-7$

, 原又白狀短

デ䯈心 米分手テ

ア

マ 亏 凝 ヴ

第 集

テ、二反

以的 義

上 = 於

当作 天 B

事用 $乇$ 缺
試

臨

動

物

萎?

起 $シ$

七 テ す

シ

得 区 三

$v=\mathrm{B}$

ナレ,

$1=$ 缺

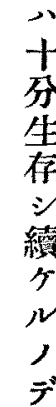

亏覆 レ
第

七

表

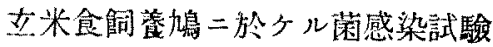

\begin{tabular}{|c|c|c|c|}
\hline 焬番暍 & 投與菌 & 投與 & 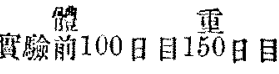 \\
\hline 151 & \multirow{3}{*}{$\begin{array}{l}\text { 脚桃菌 } \\
\mathrm{A} \text { 型 }\end{array}$} & 27 & $305-295-306$ \\
\hline 152 & & 27 & $308-287-301$ \\
\hline 153 & & 27 & $300-306-305$ \\
\hline 154 & \multirow{3}{*}{$\begin{array}{l}\text { 脚㟈橧 } \\
B \text { 型 }\end{array}$} & 27 & $310-289-309$ \\
\hline 155 & & 27 & $305-320-302$ \\
\hline 156 & & 27 & $310-305-385$ \\
\hline
\end{tabular}

第

公

韭

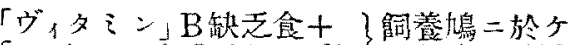

「エビオスっ0.5工 Pro diel儿菌感染試驗

\begin{tabular}{|c|c|c|c|}
\hline 晹番號 & 投與菌 & 投與 & 實驗體 50 日目 100 日目 \\
\hline 161 & \multirow{2}{*}{$\begin{array}{l}\text { 脚氯苗 } \\
\text { A型 }\end{array}$} & 19 & $318-315-314$ \\
\hline 162 & & 19 & $295-282-286$ \\
\hline 83 & \multirow{2}{*}{ 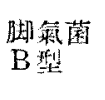 } & 19 & $925-317-310$ \\
\hline 194 & & 19 & $290-286-295$ \\
\hline 165 & \multirow{2}{*}{ 歯 照 } & & $885-281-290$ \\
\hline 166 & & & $328-319-320$ \\
\hline
\end{tabular}

第儿表 $4 \%$ 「土ビオ入古米食跼

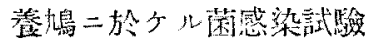

\begin{tabular}{|c|c|c|c|}
\hline 䲨番號 & 投與菌 & 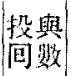 & 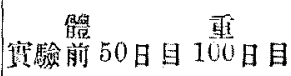 \\
\hline 171 & \multirow{2}{*}{$\begin{array}{l}\text { 脚氮菌 } \\
\mathrm{A} \text { 型 }\end{array}$} & 19 & $285-296-291$ \\
\hline 172 & & 19 & $296--302-294$ \\
\hline 173 & \multirow{2}{*}{$\begin{array}{l}\text { 脚籍菌 } \\
\mathrm{B} \text { 型 }\end{array}$} & 19 & $282-315-318$ \\
\hline 174 & & 19 & $305-300-315$ \\
\hline 175 & \multirow{2}{*}{ 對 㺟 } & & $278-302-268$ \\
\hline 176 & & & $312-326-321$ \\
\hline
\end{tabular}




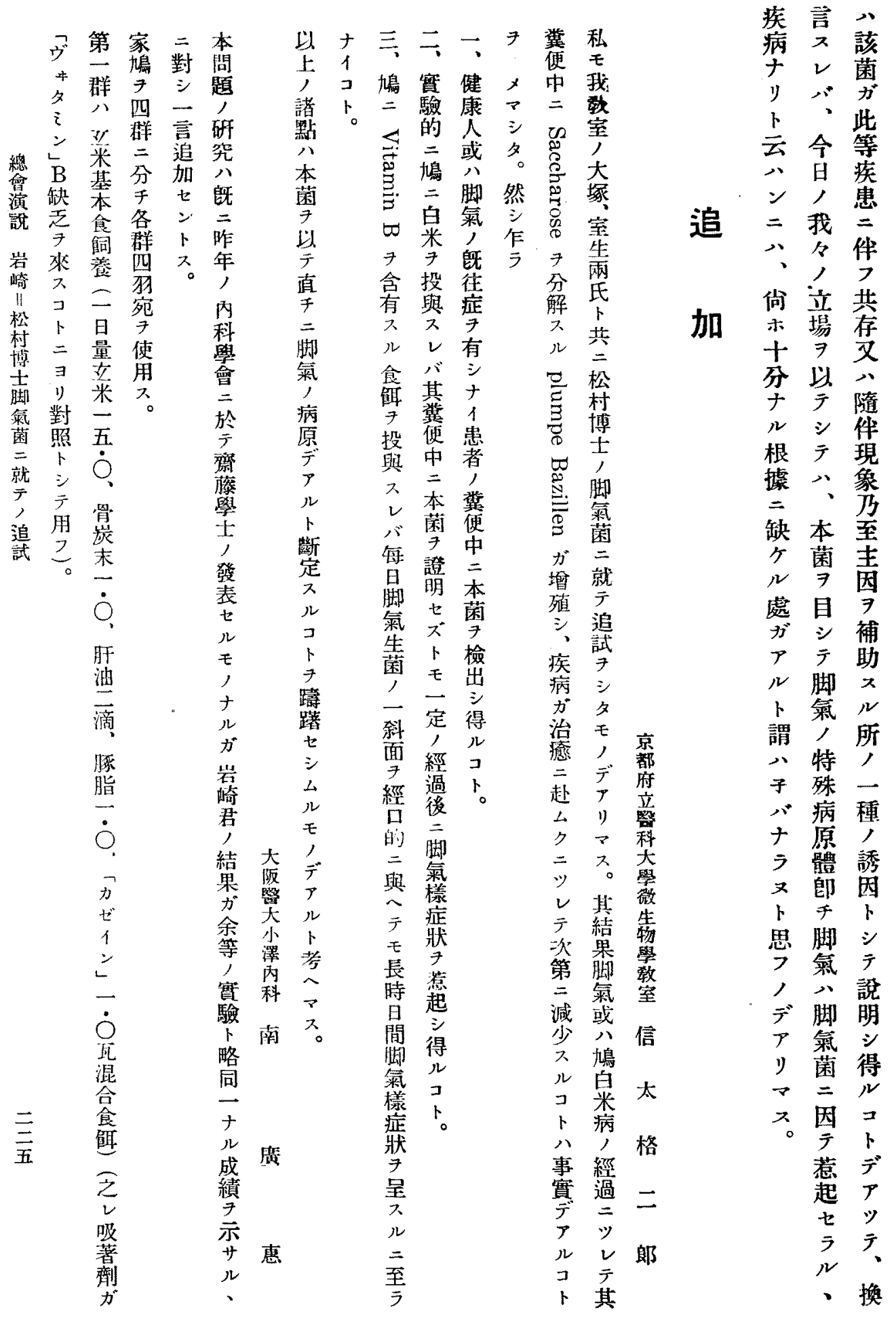




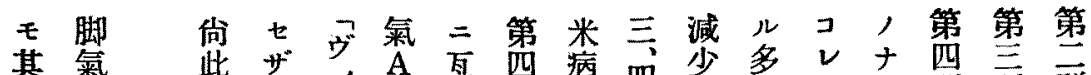
其氣 此 立上盛 $i$ 投興示 $\exists==$ 績 2 與入干 見白於寻, 当儿四整八一證第粉秱粉

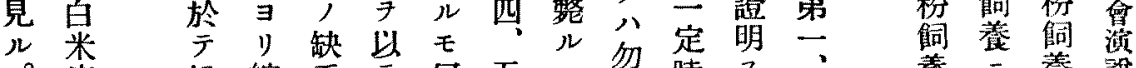

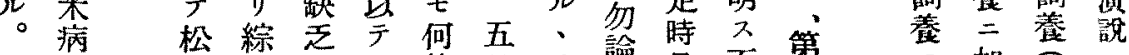
而動 村合 $\begin{gathered}\text { 等 } \\ \text { 日 }\end{gathered}$

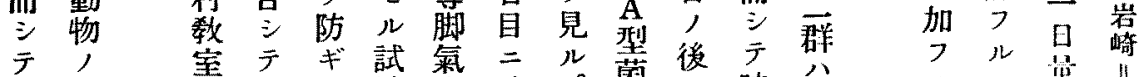

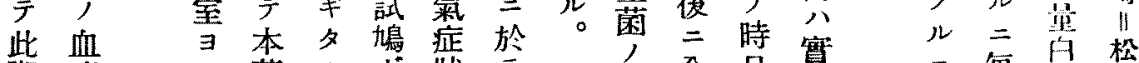

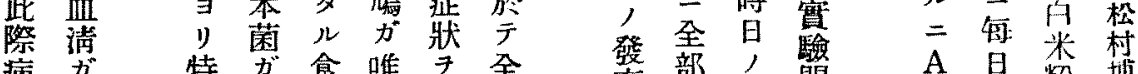

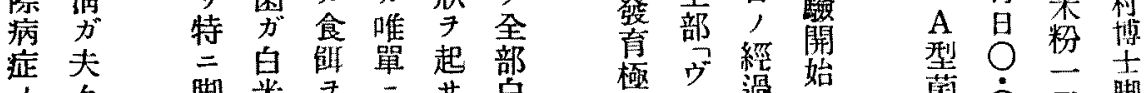

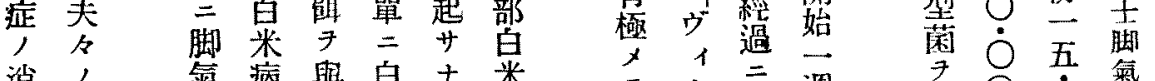

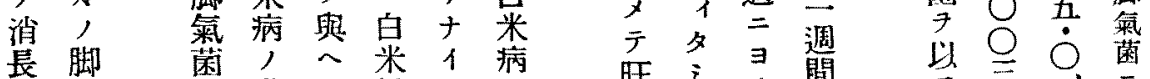

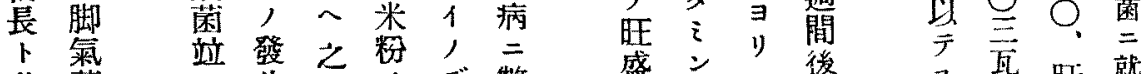

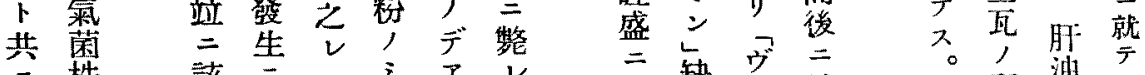

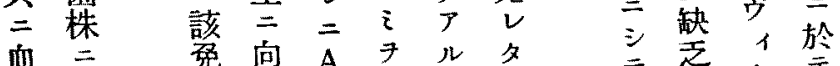

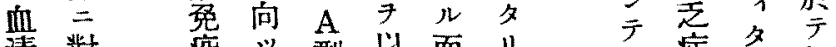

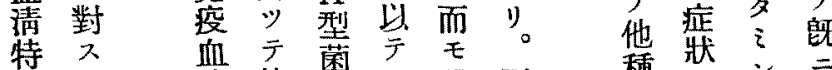

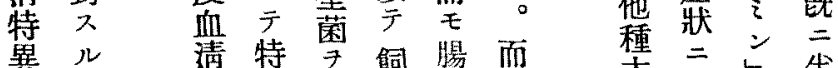
反反, 種加養内丙奛当上, 牛

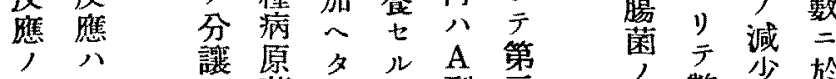

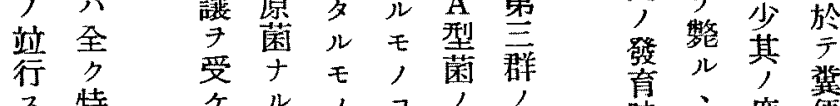
ス特多儿, 㤦,

儿異 夕價艻り当如 八的 儿值長モ 基立

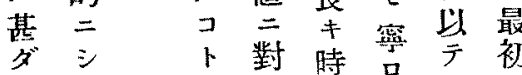

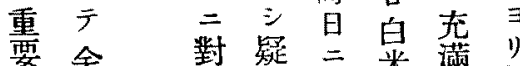

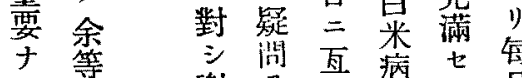

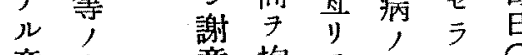

意䆵 意抱テ發 䉝 磁

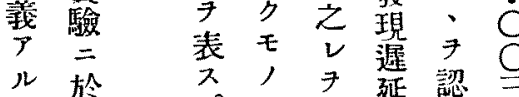

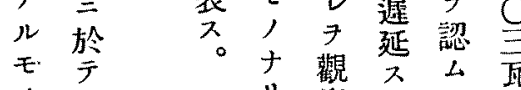

モ松り。察儿即升

ז

入事 千 A

モ實自型

他

何第 粉 $尹$

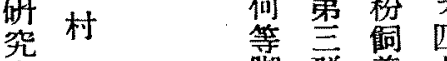

者

脚群盖十

啹

氧, 二八

告

症 結 加

二 肃

狀 果 ᄀ間

於

惹 如

時子度便

共自增

少。加 $\bar{A}$

堿型

少儿菌

入 徥勇

丹 血

見 テ清

ル 同二

而

菌

如所 油 思

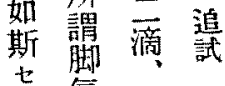

儿氮菌

各 A 脂

群型

每: 7 。

週添 万

回 加 ゼ

宛它

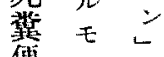

便, 一

檢 $三 \dot{0}$

查示酉

马 本 混

行惯 合

其

) , 年

シ 出凝中役

第琴集

そ集年穴

第多心゙ル演

群 夕キ菌光

反 所

十對 謂

種, 亲

八二脚類ナ

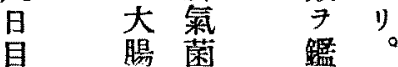

二 菌云別

$\begin{array}{lll}\text { 全 } & \text { 相 } \\ \text { 部学 } & \text { 在 } & \text { 當 }\end{array}$ 


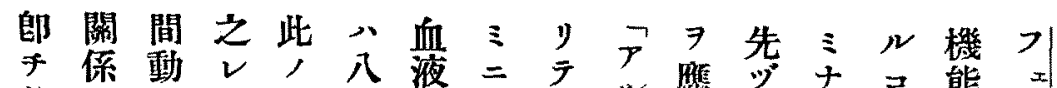

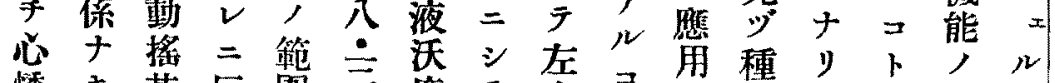

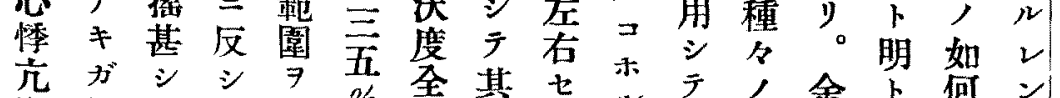

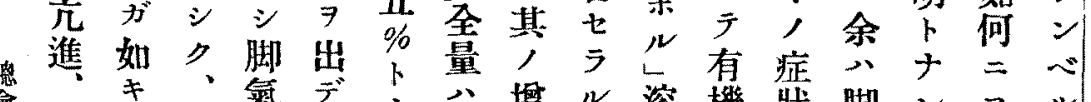

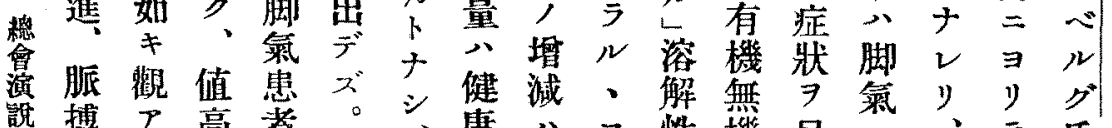

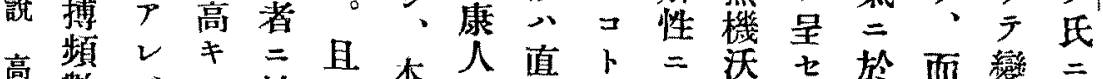

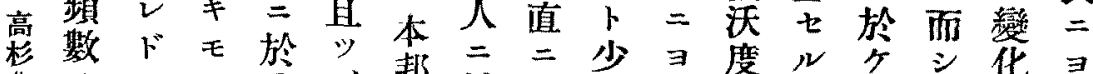

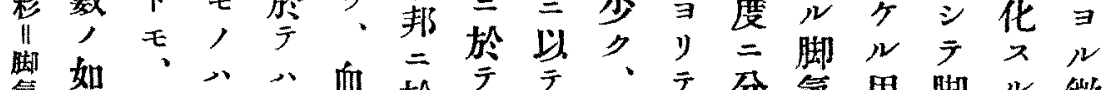

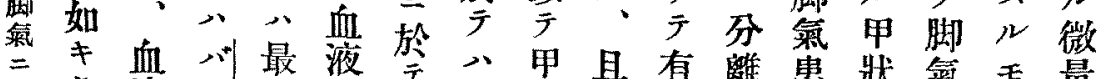

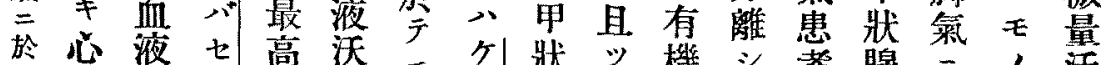
々臟沃

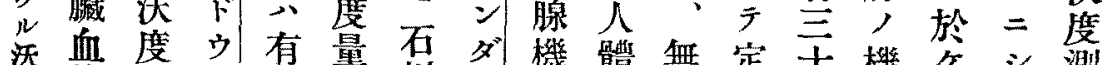
度管量氏機, 川機骾無定士機方 代症下病沃約氏 㒄狀同二度兵二帅卜

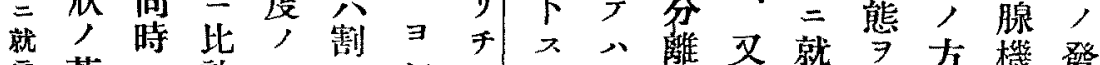

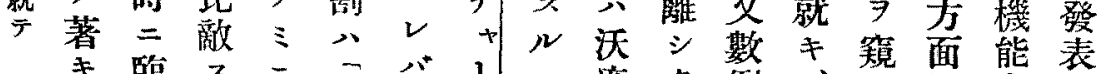

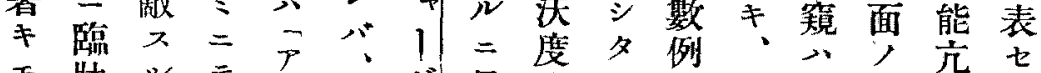

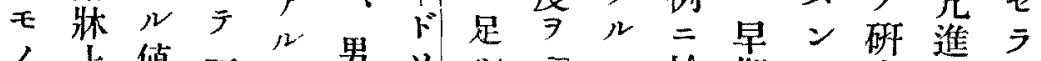

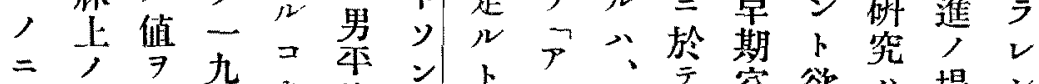

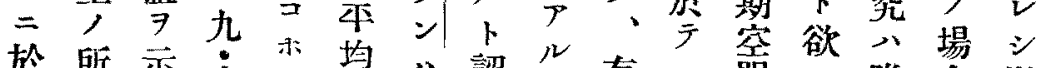

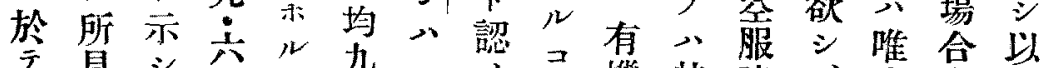

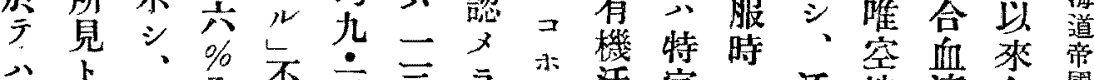

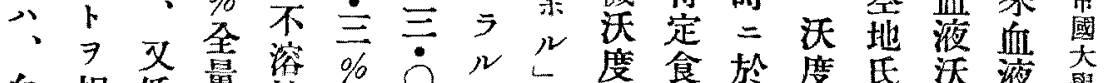
血相低量性\%、○年度食於度氏沃液學 液比 $\neq \equiv$ 沃女\%故溶前, 12 謝沃量正學

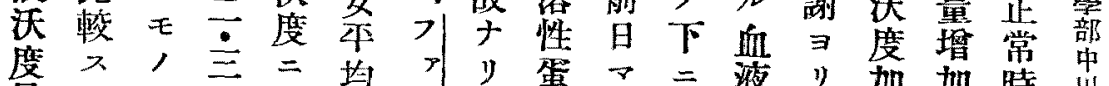

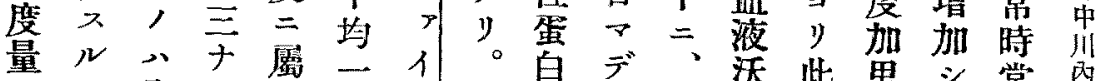
量

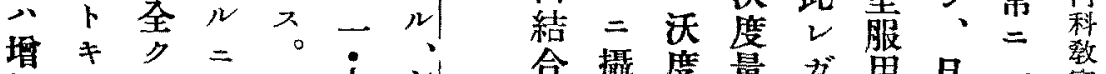
加 シ、或常

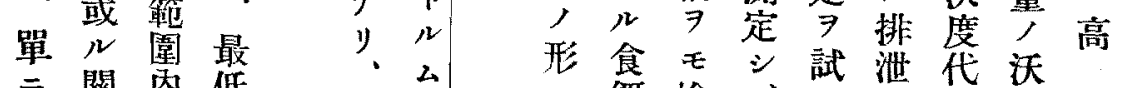

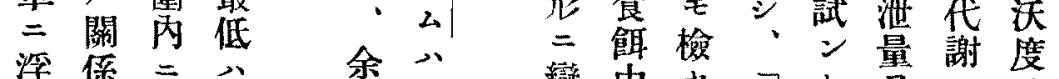

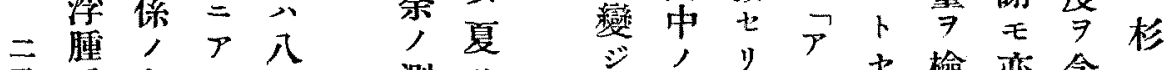

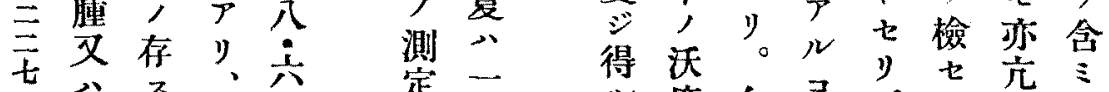

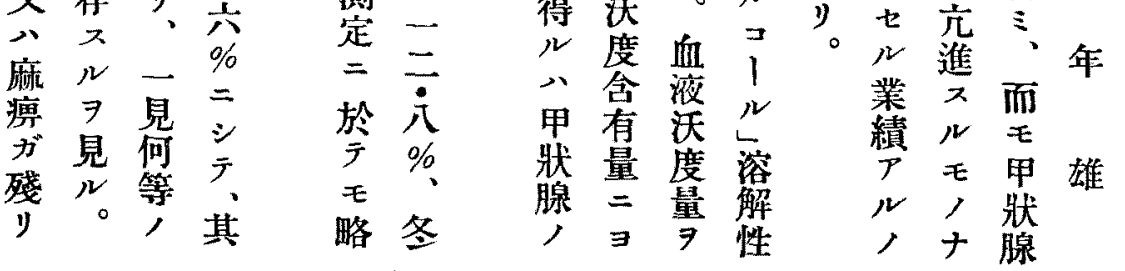


或き譇皇私

失二牀病脚

調子人及釆

年發

之等現白於

7 組 亦分

促䋨集年

進呼延夕狀

入 吸 $三$ 名腺

儿抑、之機

モ 制 - L 能

, 物 般 $\mathrm{B}$,

考質 輕単菹

投度症三

ル與

，ス儿於意

デルドテス

ア時モ 沃儿

リ八、度者

マ著是范デ

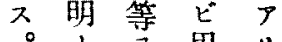

$+\Rightarrow$ 甲

儿大狀?

罹量腺 シ

患投物テ

促舆質先

進次適年

見バ㗬之

事 却 量

亭

リ罹與

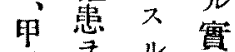

狀促時

腺進 促

機 入 對 致

能事照方篗

持證比名

本奛三方

鿊 シ 倍玆

抑方至追

制方王迎

方於倍致金

其严長

異酸闍䄪郎

穴舆存

進酸三鳩
军 $=$ 一深代 $=$ 脚尔 7 又 7

二 テ 般 $\neq$ 謝 於氮衡超沃

於り確二關高亏

テテメラ係ク 八基保

モ證 ラ

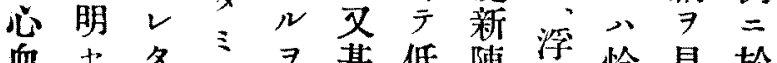

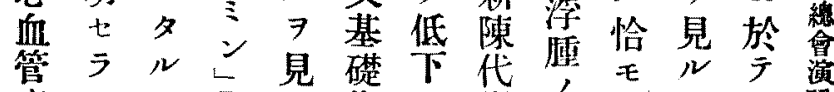

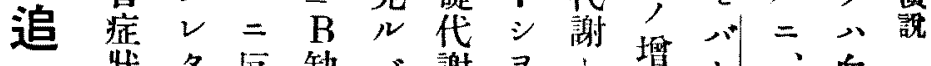

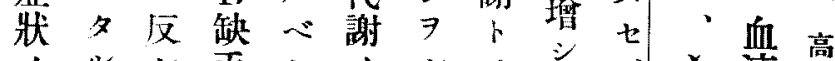

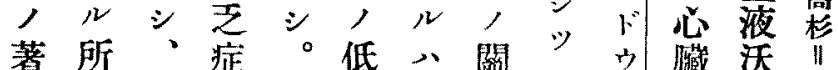

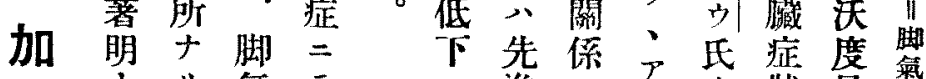
ナリ氮テ シ進二病狀量篓 N 97 屍八諸就例二,

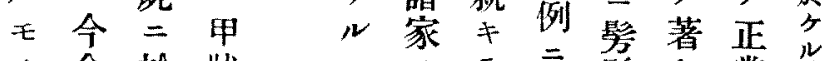
, 余於狀, 天云琵毛常炎

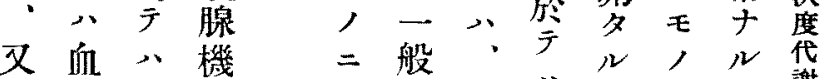

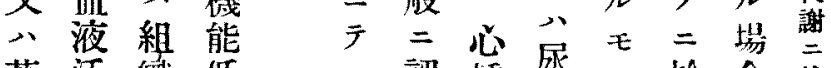
著沃織低 $，$ 認揫量, 於合就

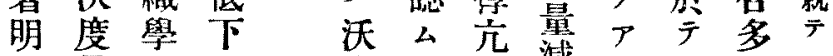

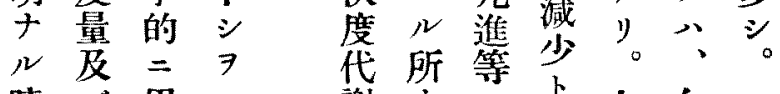

時 二度腺つ髚ガ省二沃二沃

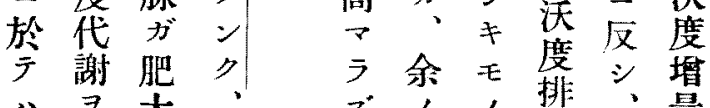

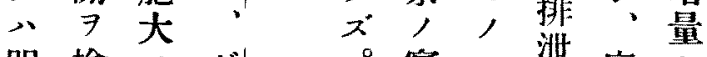
明檢 $x$ ド| 筫二泄麻

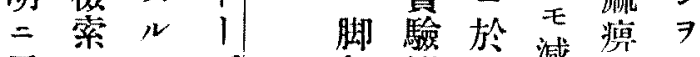

甲 $シ コ ク ゙$ 氣例 テ減 狀テトラ 腺甲 7 ス 於於多 譏狀り、テテ少體声二 能腺

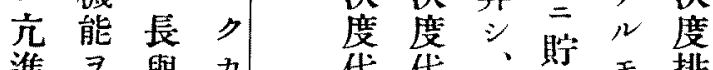
進 7 與 力 代代、留モ排

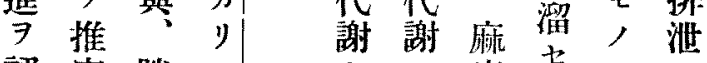

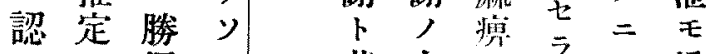

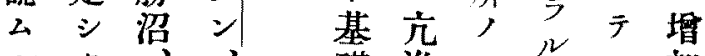
ル夕、礎進、 $、$ 小加

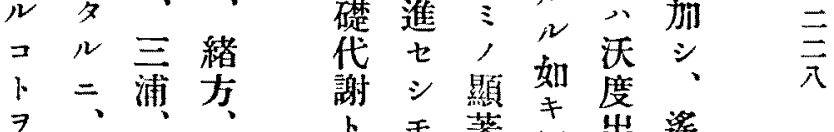
得同堀过, 夕溙澤等 間 $心$ 向納二 り $=$ 楛 $=$ 基 $E$ Y 全取 脚 氏 裂礎, リ。多量 
著酸儿般庤少 $尹$ 代公，老檢表研老 症 $モ=$ 間數缺, 過 コ人查卜究人

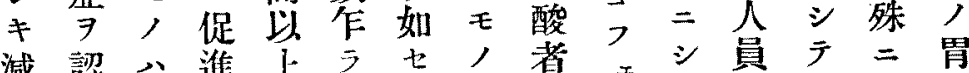

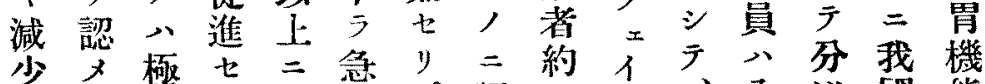

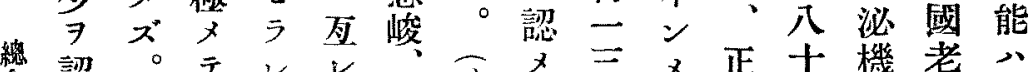
蔩認

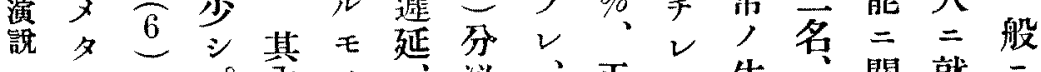
尼”。”丙，泌:正之生中關就三

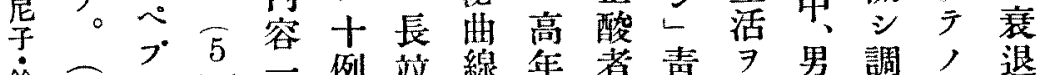

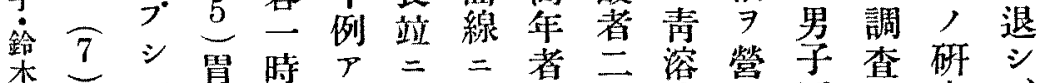

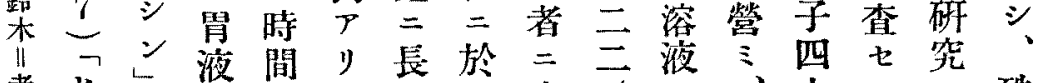

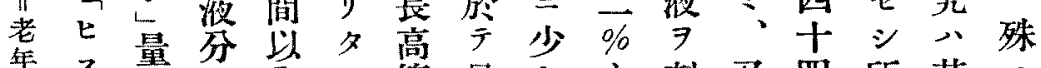
者不量泌立り等最手ナ刺又四所其二

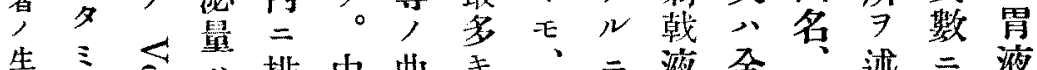

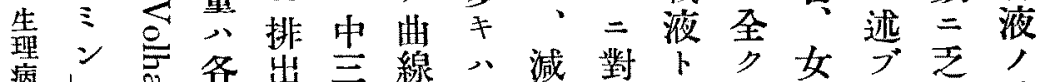

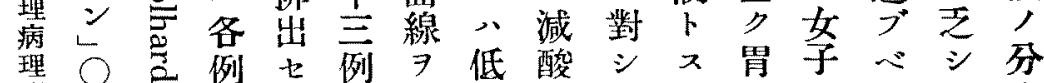

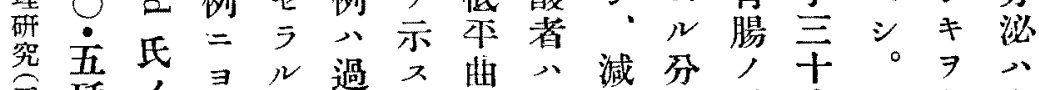

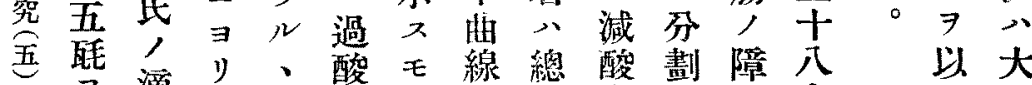

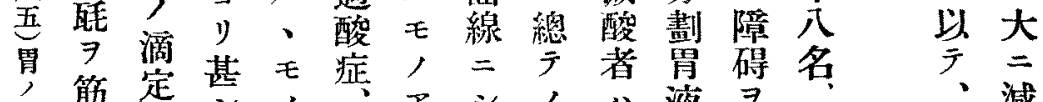
機筋定 能丙法力大四》三年六檢訴就吾弱 检内異多例。全龄五查人上只七 查二ヨ寻数入減體三\%法ザモ 洼 射正モシ常著亲等多依モ團

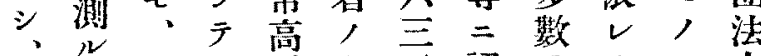

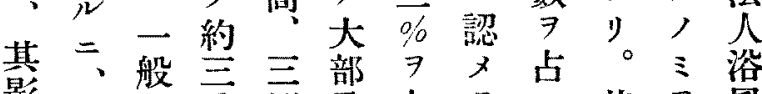
影大=分例分占今台其雨 響㻕五, 八学, 2 。成選曾 檢酸○云減低、。倘績心゙二

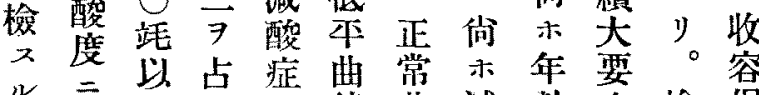
二茫上叉線曲減路资檢保 行分反”丑線酸的，查讙 a 谷泌乍示者關如, 總無量之百节示入係シ。方” 三酸酸 ヨ時胃。モ分過分分ア

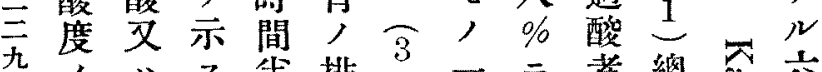

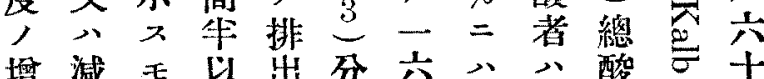
加酸, 上機泌\%遊主酸巨葴

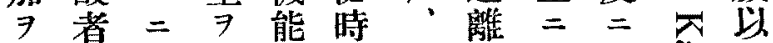

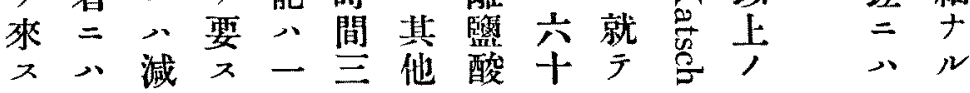

數 事

來 既

行 $=$

先

黄

老說

生 号

理㫹鈴尼查

理 12 
夕先分 $\exists$ 減胃

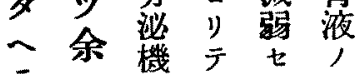

テ、公轉惹三分 人, 起么泌

レ體 考サ。二

$1=$ 察 $v$ 關

ᄀ於 多吕主

ᄀ全體分

ス葡熋泌不

氏萄動二八ン

法糖物八單 シ

二㳸 就等分

$\exists$ 皮等 分

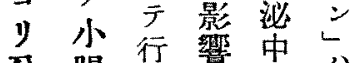

分腸行箱樞寒

劃内夕ア管

的 $=$, 夕興 血

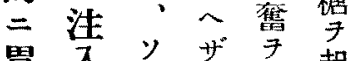

胃入ソ ザ弆起

落シ、結八步

採血整年

取糖\%實台的

シ $尹$ 驗 $儿$ =

テ、上報俏結分

過七告器分沙

血 シ ン學 乷, 相

糖メ、卜會抑刺

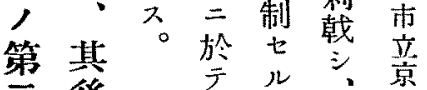

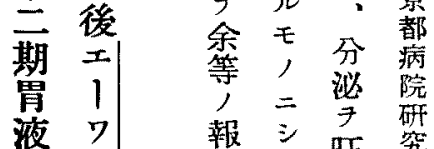

䇗

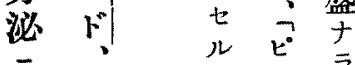

二 所告亏松

及杜尔力シ

ボ

芣斌其

譬 驗後贞 反

追食

究 八

七お去糖

り。草 余分永

$\exists$ 胃 液
リ $=\boldsymbol{\exists}$ 三間 $\exists$ 木

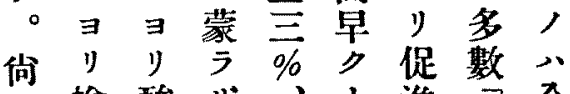

末检酸ザ、ナ進圭

色七度儿不儿七不例

素

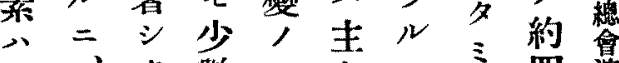

同、多数モ下、文四演

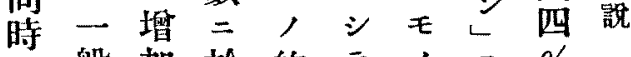

二般加於約 天'、二\%、松

尿二又天五滅、反沙

中急如延五 酸戀照忍胃

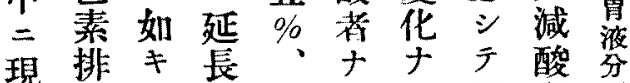

胃現排キ長年示酸分

八出症七約りキ胃者汹

$v$ 機例 $j$ - $є$ 液 $=$ 機

分、能 $=v=0$, 分

泌二著

機 三クブ促却夜占高三

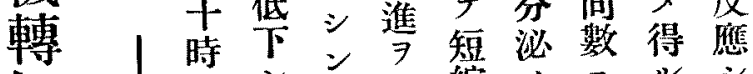

知

見 其而增多尔長

補 洺是加

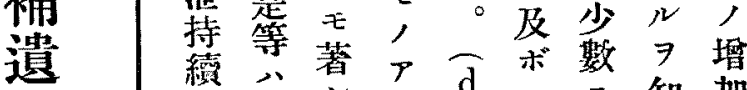

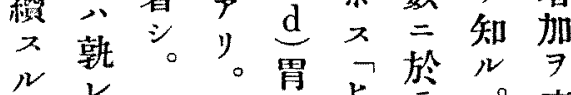

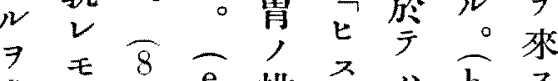

常減 $\stackrel{8}{\mathrm{e}}$ 排各,

卜酸最亏出名却最モ

ス酸後ぺ機ミ省临ノ

三胃 シ 能レ, 脠酸其

テ、色亡大影芯蓄

即素泌数響モ達\%

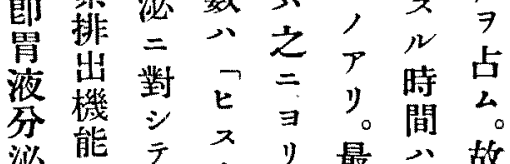

泌能テ ス 早 最故

機能 、

卜苞:

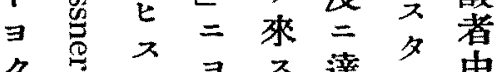

新, 妇達三中

行方ミ影, 毛之=

七法レ゙蒥約時二倘 

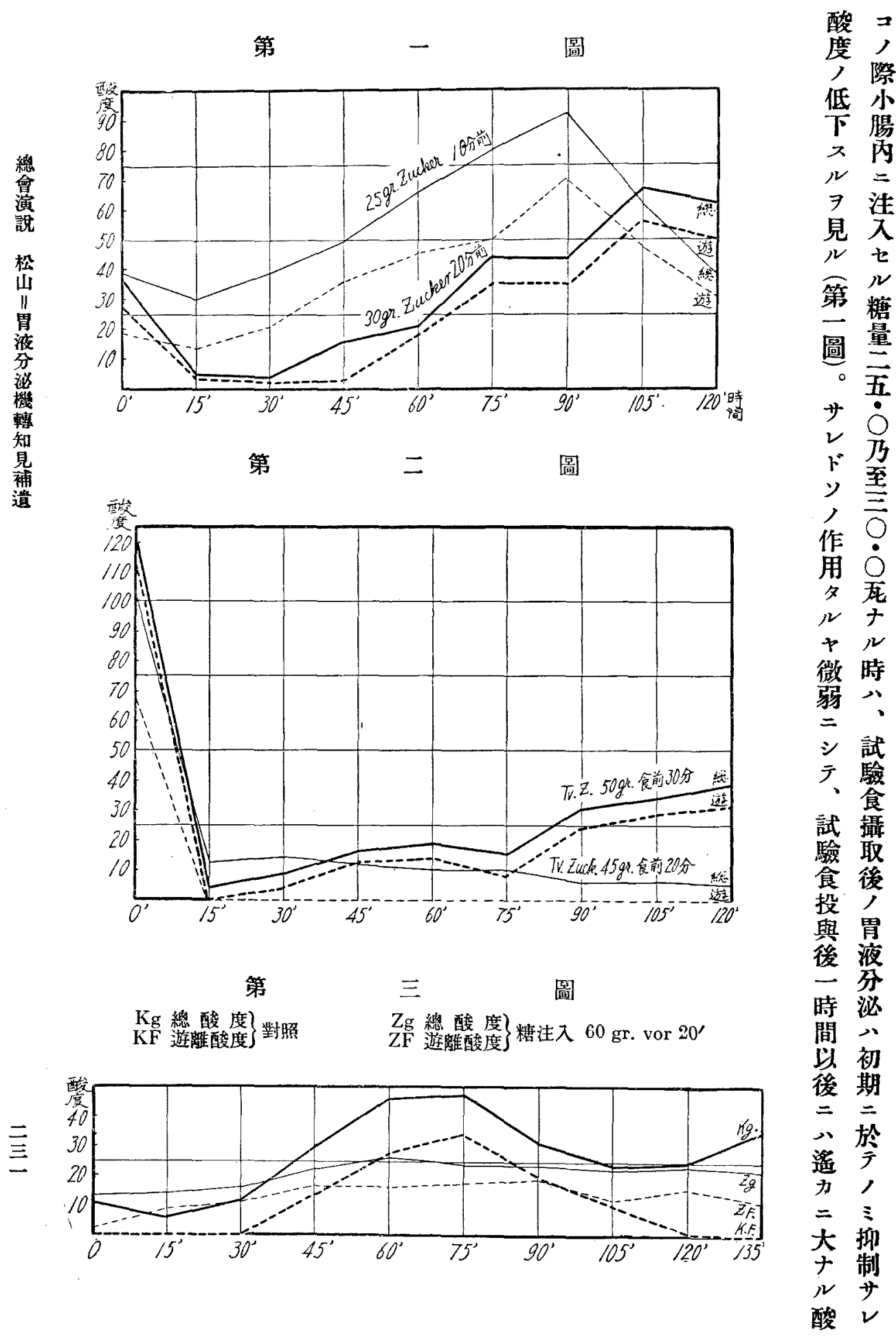
入 難

入 $\neq$

N 7

$=$ 見

r

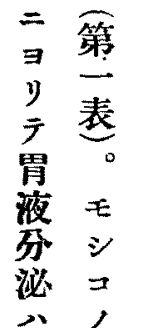

起 際

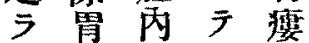

ザ膑 ガ 斾

乙丙無經有物求 $N$ 抑, 夕三如

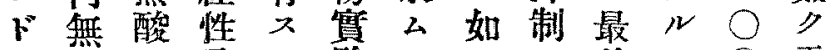

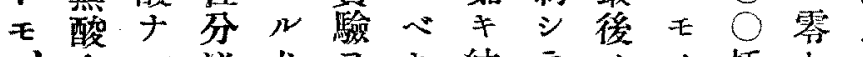

$\dot{\neg}, \mu$ 泌 犬

$\overrightarrow{\mathrm{E}} \mathrm{g}$

スザ時機

夕人牛軗用合国

三心学除

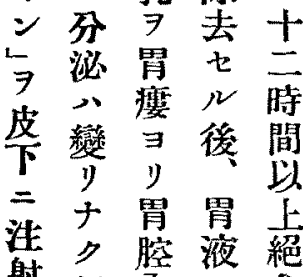

射行等, 食

又心二化七

バ 泩 學 シ

胃第入的メ

第入第元

蒋 至泌

“表飞機 後

多。胃囀算

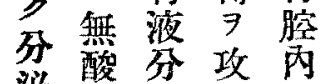

泌酸永究

年場心七洗

合起皆。涤

ガ

故牛必, 麻

二乳刃結醉

第势起果二

第洼胃

第

四

[a
時 度

$=$

八達

遊

陮

監 然

酸 ル

$\exists=$ 演

全泩 境

多松

證 糖 山

明 量

七四

ザ五.

胃

㳖

分

機

僌

知

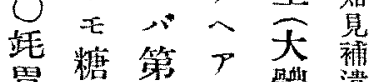

胃注气體 遗

內期 $=$ 䚟

原果分三要用含

$\Rightarrow$ 貫 $九$ 糖

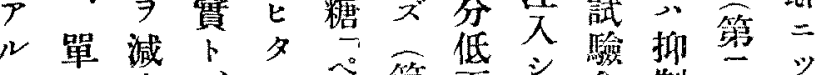

二 二少、次第下食制二ッ

ア血入昨ニブ至七試攝サ圖キ

ラ糖

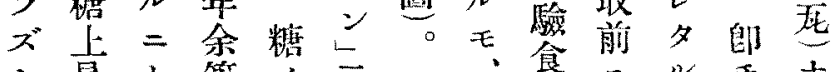

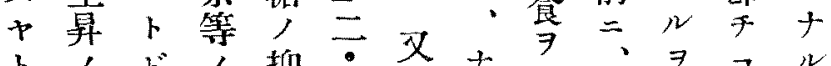

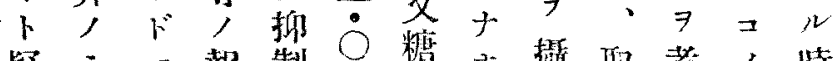

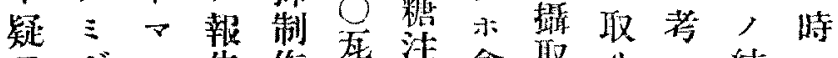

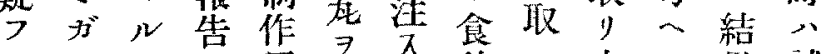

二ソト七用 $\exists$ 入後七去シ果試

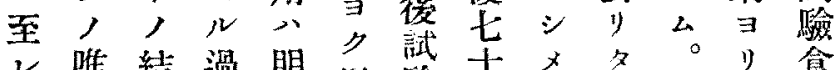

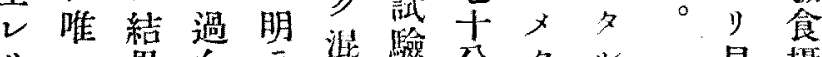

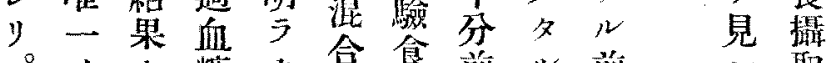

。'十糖力合食前ル前取

コ抑 $コ$ 八

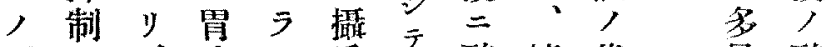

原的、液 ズ氐酸糖代量酸

因原余分第兰度泩用, 度

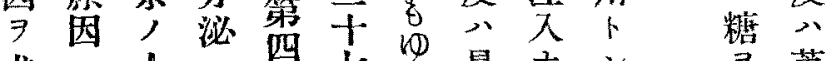

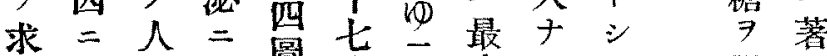

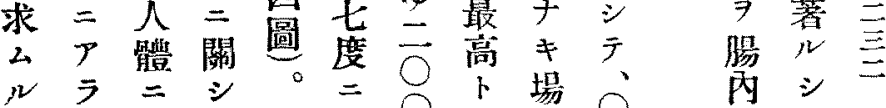

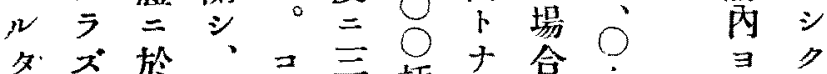

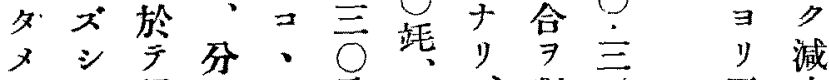

二广得泌二分・對\% 四少

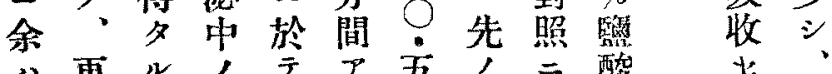


第三表 V四 犬

磨睟㖟牛乳注入及「七スタ ンン注射

\begin{tabular}{|c|c|c|c|c|}
\hline 時＼cjkstart間 & 液 量 & 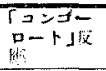 & $\begin{array}{l}\text { 推被 } \\
\text { 酸度 }\end{array}$ & 總酸度 \\
\hline $0^{\prime}-15^{\prime}$ & $0.2 \mathrm{ccm}$ & $(-)$ & 0 & 6.0 \\
\hline $\begin{array}{l}15^{\prime}-30^{\prime} \\
30^{\prime}-35^{\prime}\end{array}$ & \multicolumn{4}{|c|}{ 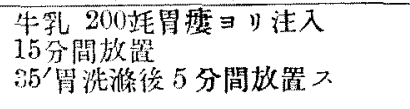 } \\
\hline $35^{\prime}-50^{\prime}$ & $2.0 \mathrm{ccm}$ & $(-)$ & 0 & 6.0 \\
\hline $50^{\prime}-65^{\prime}$ & 0.5 & $(-)$ & 0 & 4.0 \\
\hline$-80^{\prime}$ & 0.2 & $(-)$ & 0 & 5.0 \\
\hline$-95^{\prime}$ & 0.15 & $(-)$ & 0 & 6.6 \\
\hline$-110^{\prime}$ & 0.1 & $(-)$ & 0 & 10.0 \\
\hline$-125^{\prime}$ & 0.15 & $(-)$ & 0 & 13.3 \\
\hline $125^{\prime}$ & \multicolumn{4}{|c|}{$\begin{array}{l}0.1 \% \text { Histamin. hydrochl. } \\
5.0 \text { c.c 皮下注射 }\end{array}$} \\
\hline $125^{\prime}-140^{\prime}$ & 0.4 & $(-)$ & 0 & 17.5 \\
\hline$-155^{\prime}$ & 1.4 & $(+)$ & 34.0 & 42.0 \\
\hline$-170^{\prime}$ & 2.7 & $(+)$ & 91.0 & 115.0 \\
\hline$-185^{\prime}$ & 16.8 & $(+)$ & 117.0 & 132.0 \\
\hline$-200^{\prime}$ & 9.5 & $(t)$ & 129.0 & 146.0 \\
\hline$-215^{\prime}$ & 6.6 & $(+)$ & 114.0 & 121.0 \\
\hline
\end{tabular}

第四表 a VIII犬

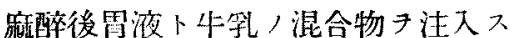

\begin{tabular}{|c|c|c|c|c|}
\hline 時＼cjkstart間 & 液 量 & 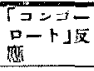 & 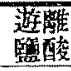 & 總酸度 \\
\hline $0^{\prime}-15^{\prime}$ & $0.8 \mathrm{ccm}$ & $(-)$ & 0 & 23.0 \\
\hline $\begin{array}{l}15^{\prime}-30^{\prime} \\
30^{\prime}-35^{\prime}\end{array}$ & \multicolumn{4}{|c|}{ 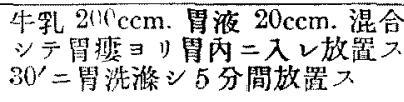 } \\
\hline $35^{\prime}-50^{\prime}$ & $6.1 \mathrm{ccm}$ & $(-)$ & 0 & 9.0 \\
\hline$-65^{\prime}$ & 4.0 & $(+)$ & 15.4 & 26.0 \\
\hline$-80^{\prime}$ & 3.0 & $(+)$ & 22.0 & 34.0 \\
\hline$-95^{\prime}$ & 1.1 & $(+)$ & 14.0 & 54.0 \\
\hline$-110^{\prime}$ & 1.3 & $(+)$ & 19.0 & 60.0 \\
\hline$-125^{\prime}$ & 0.9 & $(+)$ & 10.0 & 52.0 \\
\hline$-140^{\prime}$ & 0.8 & $(+)$ & 10.0 & 53.3 \\
\hline$-155^{\prime}$ & 0.8 & $(-)$ & 0 & 36.6 \\
\hline$-170^{\prime}$ & 0.3 & $(-)$ & 0 & 23.3 \\
\hline$-185^{\prime}$ & 0.2 & $(-)$ & 0 & 25.0 \\
\hline
\end{tabular}

胃液 遊離篦酸 86.0
第一表 V 犬 磨醉後牛乳注入

\begin{tabular}{|c|c|c|c|c|}
\hline 時＼cjkstart間 & 液 量 & 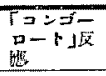 & 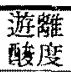 & 總酸度 \\
\hline $0^{\prime}-15^{\prime}$ & $0.8 \mathrm{ccm}$ & $(-)$ & 0 & 1.0 \\
\hline $15^{\prime}-30^{\prime}$ & 0.8 & $(-)$ & 0 & 1.5 \\
\hline $\begin{array}{l}30^{\prime}-45^{\prime} \\
45^{\prime}-50^{\prime}\end{array}$ & \multicolumn{4}{|c|}{ 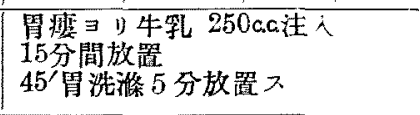 } \\
\hline $50^{\prime}-65^{\prime}$ & $0.45 \mathrm{ccm}$ & $(-)$ & 0 & 16.0 \\
\hline$-80^{\circ}$ & 0.12 & $(-)$ & 0 & 25.0 \\
\hline$-95^{\prime}$ & 0.45 & $(-)$ & 0 & 15.7 \\
\hline$-110^{\prime}$ & 0.5 & $(-)$ & 0 & 20.0 \\
\hline$-125^{\prime}$ & 0.3 & $(-)$ & 0 & 10.0 \\
\hline$-140^{\prime}$ & 0.1 & $(-)$ & 0 & 25.0 \\
\hline$-155^{\prime}$ & 0.2 & $(-)$ & 0 & 25.0 \\
\hline$-170^{\prime}$ & 0.3 & $(-)$ & 0 & 23.0 \\
\hline$-185^{\prime}$ & 0.1 & $(-)$ & 0 & 20.0 \\
\hline$-200^{\prime}$ & 0.1 & $(-)$ & 0 & 20.0 \\
\hline$-215^{\prime}$ & 0.05 & $(-)$ & 0 & 10.0 \\
\hline$-230^{\prime}$ & $0 . C 5$ & $(-)$ & 0 & 10.0 \\
\hline
\end{tabular}

第二表 VII 犬 廂醉後牛乳注入

\begin{tabular}{|c|c|c|c|c|}
\hline 時閐 & 液 量 & 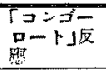 & 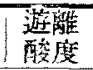 & 總酸度 \\
\hline $0^{\prime}-15^{\prime}$ & $6.4 \mathrm{ccm}$ & $(+)$ & 27.5 & 45.0 \\
\hline $\begin{array}{l}15^{\prime}-30^{\prime} \\
30^{\prime}-35^{\prime}\end{array}$ & \multicolumn{4}{|c|}{ 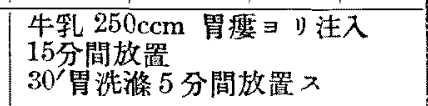 } \\
\hline $85^{\prime}-50^{\prime}$ & $12.8 \mathrm{ccm}$ & $(+)$ & 33.0 & 55.0 \\
\hline$-65^{\prime}$ & 17.3 & $(+)$ & 45.0 & 68.5 \\
\hline$-80^{\prime}$ & 4.8 & $(+)$ & 72.0 & 99.5 \\
\hline$-95^{\prime}$ & 3.8 & $(+)$ & 88.3 & 106.6 \\
\hline$-110^{\prime}$ & 2.7 & $(+)$ & 97.5 & 127.5 \\
\hline$-125^{\prime}$ & 3.2 & $(+)$ & 105.5 & 113.5 \\
\hline$-140^{\prime}$ & 5.0 & $(+)$ & 93.5 & 110.0 \\
\hline$-155^{\prime}$ & 3.0 & $(+)$ & 98.0 & 116.0 \\
\hline$-170^{\prime}$ & 2.0 & $(+)$ & 58.0 & 69.0 \\
\hline$-185^{\prime}$ & 1.5 & $(+)$ & 58.2 & 80.0 \\
\hline$-200^{\prime}$ & 2.0 & $(+)$ & 57.0 & 72.0 \\
\hline$-215^{\prime}$ & 1.0 & $(+)$ & 57.0 & 83.0 \\
\hline
\end{tabular}


第六表 XI 犬. 㮐醉後. 牛学及非働性 照液, 混合物 7 胃瘦ヨリ注入ス

\begin{tabular}{|c|c|c|c|c|}
\hline 間 & 液 量 & 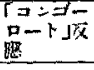 & $\begin{array}{l}\text { 遊踓 } \\
\text { 酸度 }\end{array}$ & 總酸度 \\
\hline $0^{\prime}-15^{\prime}$ & $0.5 \mathrm{ccm}$ & $(-)$ & 0 & 4.0 \\
\hline $\begin{array}{l}15^{\prime}-30^{\prime} \\
30^{\prime}-35^{\prime}\end{array}$ & \multicolumn{4}{|c|}{ 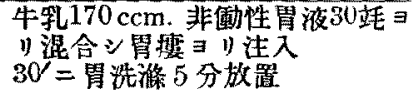 } \\
\hline $35^{\prime}-50^{\prime}$ & $3.2 \mathrm{ccm}$ & $(-)$ & 0 & 26.0 \\
\hline$-65^{\prime}$ & 1.6 & $(t)$ & 27.0 & 54.0 \\
\hline$-80^{\prime}$ & 1.8 & $(t)$ & 37.0 & 79.0 \\
\hline$-95^{\prime}$ & 4.8 & $(+)$ & 59.0 & 91.0 \\
\hline$-110^{\prime}$ & 4.2 & $(t)$ & 62.0 & 98.0 \\
\hline$-125^{\prime}$ & 1.3 & $(+)$ & 35.0 & 80.0 \\
\hline$-140^{\prime}$ & 1.0 & $(t)$ & 47.0 & 83.0 \\
\hline$-155^{\prime}$ & 0.6 & $(+)$ & 43.0 & 63.0 \\
\hline$-170^{\prime}$ & 1.2 & $(+)$ & 47.0 & 80.0 \\
\hline$-185^{\prime}$ & 0.4 & $(t)$ & 35.0 & 60.0 \\
\hline$-200^{\prime}$ & 2.5 & $(t)$ & 44.0 & 83.0 \\
\hline$-215^{\prime}$ & 1.4 & $(+)$ & 41.0 & 70.0 \\
\hline
\end{tabular}

第七表 8 目 犬。麻醉後監酸及牛 稞胃內二注入入

\begin{tabular}{|c|c|c|c|c|}
\hline 時間 & 液 量 & $\begin{array}{l}5=-7 \bar{x} \\
a-15 \sqrt{x}\end{array}$ & $\begin{array}{l}\text { 避離 } \\
\text { 旺酸 }\end{array}$ & 總酸的 \\
\hline $0^{\prime}-15^{\prime}$ & 痕 跡 & $(-)$ & 0 & \\
\hline $\begin{array}{l}15^{\prime}-30^{\prime} \\
30^{\prime}-35^{\prime}\end{array}$ & \multicolumn{4}{|c|}{ 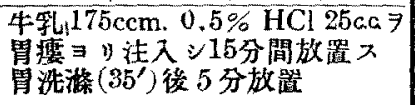 } \\
\hline $35^{\prime}-50^{\prime}$ & $7.1 \mathrm{ccm}$ & $(t)$ & 89.0 & 102.0 \\
\hline$-65^{\prime}$ & 2.8 & $(t)$ & 107.5 & 119.0 \\
\hline$-80^{\circ}$ & 3.2 & $(+)$ & 117.0 & 123.0 \\
\hline$-95^{\prime}$ & 7.5 & $(+)$ & 116.5 & 120.0 \\
\hline$-110^{\circ}$ & 2.1 & $(+)$ & 95.0 & 107.0 \\
\hline$-125^{\prime}$ & 1.5 & $(+)$ & 69.0 & 83.0 \\
\hline$-149^{\prime}$ & 1.2 & $(+)$ & 51.0 & 83.0 \\
\hline$-155^{\prime}$ & 1.2 & $(+)$ & 40.0 & 57.0 \\
\hline$-170^{\prime}$ & 1.0 & $(+)$ & 29.0 & 49.0 \\
\hline$-185^{\prime}$ & 1.0 & $(t)$ & 30.0 & 45.0 \\
\hline$-200^{\prime}$ & 1.3 & $(t)$ & 25.0 & 41.0 \\
\hline$-215^{\prime}$ & 1.3 & $(+)$ & 36.0 & 48.0 \\
\hline
\end{tabular}

第 四 表b IX 犬 魔醉後牛乳，牛乳及胃液子注入入

\begin{tabular}{|c|c|c|c|c|}
\hline 間 & 液 量 & $\begin{array}{l}3 \times 9 \bar{x} \\
0-1 \sqrt{x}\end{array}$ & 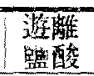 & 總酸度 \\
\hline $0^{\prime}-15^{\prime}$ & $2.2 \mathrm{ccm}$ & $(+)$ & 87.0 & 97.0 \\
\hline $\begin{array}{l}15^{\prime}-30^{\prime} \\
30^{\prime}-35^{\prime}\end{array}$ & \multicolumn{4}{|c|}{ 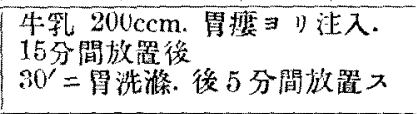 } \\
\hline $\begin{array}{r}35^{\prime}-50^{\prime} \\
=69^{\prime} \\
-80^{\prime} \\
=95^{\prime} \\
-110^{\prime}\end{array}$ & $\begin{array}{l}5.2 \\
2.5 \\
2.8 \\
0.4 \\
0.1\end{array}$ & $\begin{array}{l}(-) \\
(+) \\
+ \\
+\end{array}$ & $\begin{array}{c}0 \\
10.0 \\
19.0 \\
12.5 \\
0\end{array}$ & $\begin{array}{l}20.5 \\
30.0 \\
52.0 \\
52.0 \\
30.0\end{array}$ \\
\hline $\begin{array}{l}110^{\prime}-125^{\prime} \\
125^{\prime}-130^{\prime}\end{array}$ & \multicolumn{4}{|c|}{ 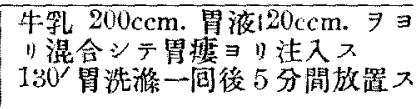 } \\
\hline $\begin{array}{r}130^{\prime}-145^{\prime} \\
-160^{\prime} \\
-175^{\prime} \\
-190^{\prime} \\
-205^{\prime} \\
-220^{\prime} \\
-235^{\prime} \\
-250^{\prime}\end{array}$ & $\begin{array}{c}7.7 \mathrm{ccm} \\
15.5 \\
8.2 \\
9.0 \\
5.4 \\
1.7 \\
4.0 \\
5.0\end{array}$ & $\begin{array}{l}(+) \\
(+) \\
(+) \\
(+) \\
+(+) \\
(+) \\
(+)\end{array}$ & $\begin{array}{r}66.0 \\
94.5 \\
117.5 \\
133.0 \\
129.0 \\
104.5 \\
104.0 \\
110.0\end{array}$ & $\begin{array}{r}77.5 \\
102.5 \\
129.0 \\
142.0 \\
136.5 \\
111.0 \\
115.0 \\
118.0\end{array}$ \\
\hline
\end{tabular}

胃液 F. HCl. 66.0

第五表 XI 犬. 㢕障後. 中和七儿胃 液卜牛乳，混合物斗注入入

\begin{tabular}{|c|c|c|c|c|}
\hline 時間 & 液 量 & 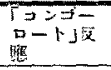 & 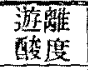 & 總酸度 \\
\hline $0^{\prime}-15^{\prime}$ & $0.5 \mathrm{ccm}$ & $(-)$ & 0 & 28.0 \\
\hline $\begin{array}{l}15^{\prime}-30^{\prime} \\
30^{\prime}-35^{\prime}\end{array}$ & 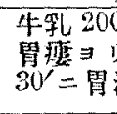 & 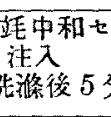 & 心霄液 & 55䇈 \\
\hline $\begin{array}{r}35^{\prime}-50^{\prime} \\
-65^{\prime} \\
-80^{\prime} \\
-\quad 95^{\prime} \\
-110^{\prime} \\
-125^{\prime} \\
-140^{\prime} \\
-155^{\prime} \\
-170^{\prime} \\
-185^{\prime} \\
-200^{\prime} \\
-215^{\prime} \\
-230^{\prime}\end{array}$ & $\begin{array}{l}1.3 \mathrm{ccm} \\
1.0 \\
0.1 \\
0.2 \\
0.3 \\
0.2 \\
0.2 \\
0.1 \\
0.6 \\
0.2 \\
0.6 \\
0.5 \\
0.5\end{array}$ & $\begin{array}{l}(-) \\
(-) \\
(-) \\
(-) \\
(-) \\
(-) \\
(-) \\
(-) \\
-) \\
-)\end{array}$ & $\begin{array}{l}0 \\
0 \\
0 \\
0 \\
0 \\
0 \\
0 \\
0 \\
0 \\
0 \\
0 \\
0 \\
0\end{array}$ & \begin{tabular}{|r|}
5.0 \\
7.0 \\
10.0 \\
5.0 \\
5.0 \\
2.5 \\
2.5 \\
10.0 \\
3.0 \\
15.0 \\
13.3 \\
12.0 \\
11.2
\end{tabular} \\
\hline
\end{tabular}




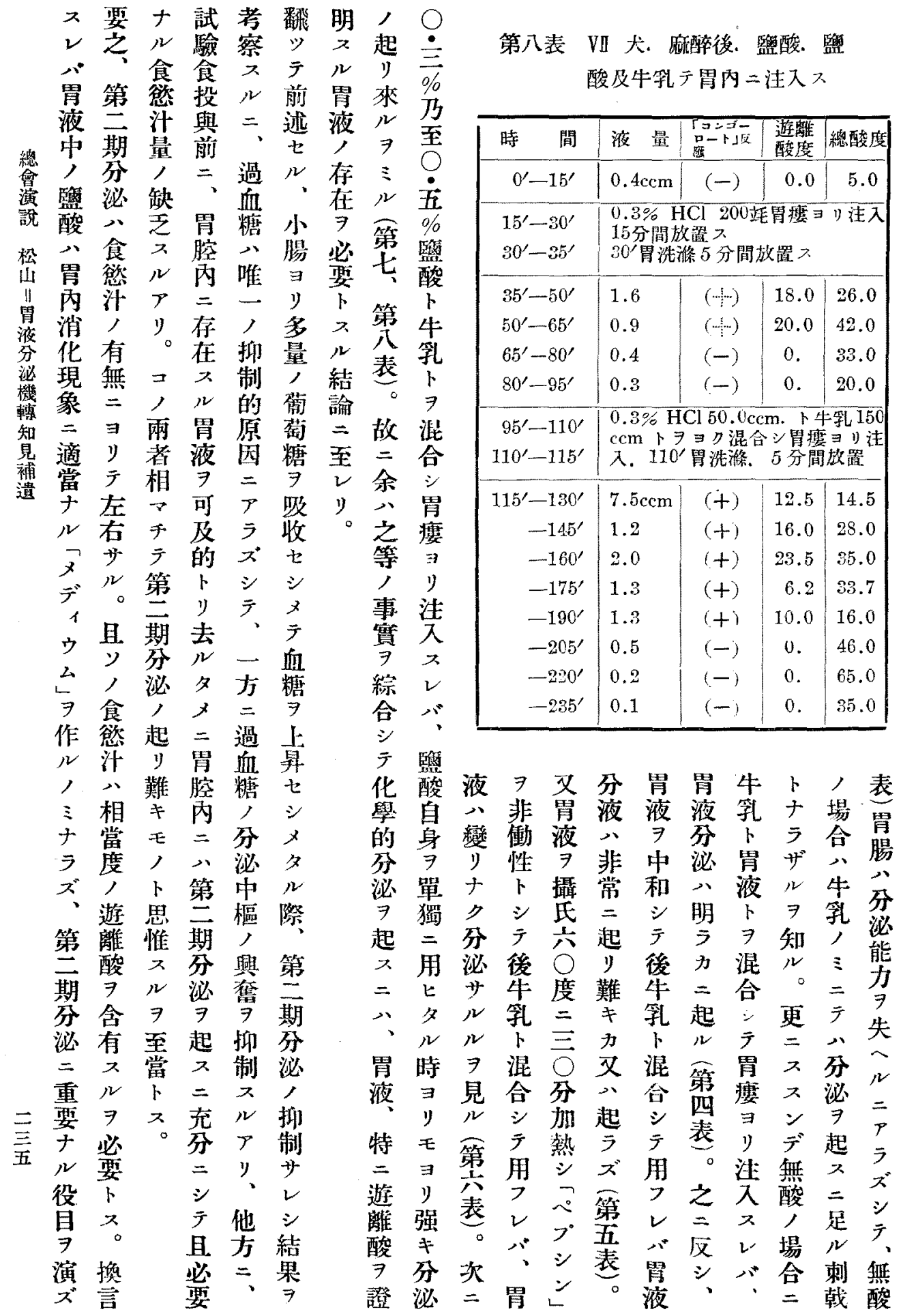




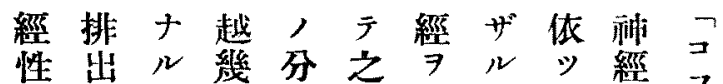

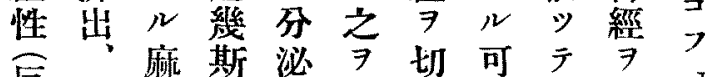

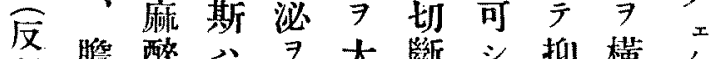
射䑏醉

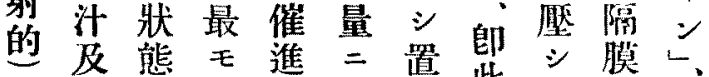
膽荟態有進立置此得直 囊液 $P$ 效 $上$ 三 等名上酒 丙,

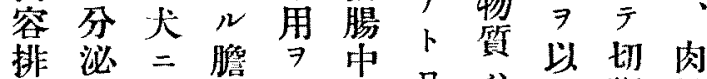
出起胃霓有二品余断越 磨り、丙

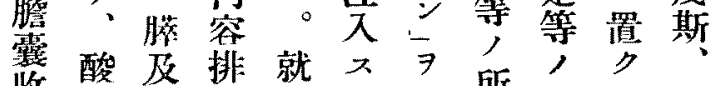
收度總出中心用所物モつ 縮高殓劑㩆時工謂啠胃心 機き管, 著一心䯣心液心

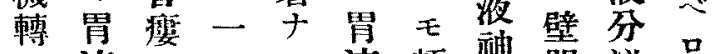
$=$ 液 $\Rightarrow \% ル$ 液 頗 對, 構ナ事分䅔望 分成 $几$ 實泌强性樞孛 體泌 $シ コ 八 二$ 盛刺二進等 液 $尹$ 置卜頗 川小素モス 性見 $キ$ 馀儿素刺ハ静 機ル菠發濃少胃年韩作脈

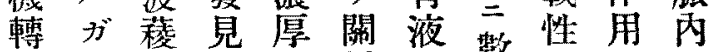
二故草 $シ+$ 係分數 $=\cdots=$

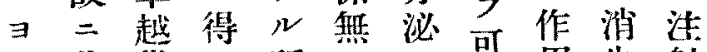

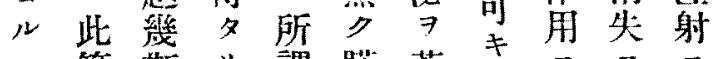
モ等斯り謂䑏惹丰 ス

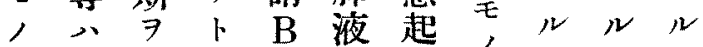
上神塪信脆及塄及モ二時 認經脈ズ汁脆ル居, 至八

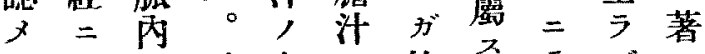
ラ八又又多, 故ス。元 上關六量分二波分、夕

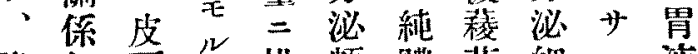
膽無下排頗體草細 $v$ 㳸塚倉荫 囊 $キ=ヒ$ 出ル液越胞ド分

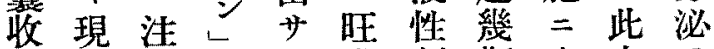
縮爱入及ル盛刺斯直艺 $尹$ 原持田

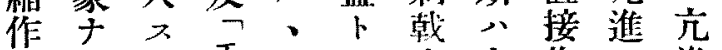
用ルル王コナ素之作心進

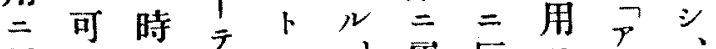

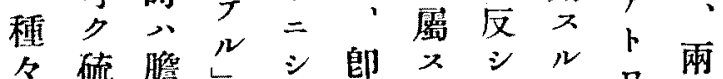

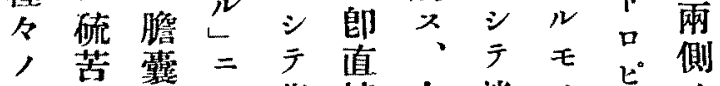
機等苪亏菠接人迷, ピ, 雄一郎 轉 容完薐此三走二に迷 椠神, 基草等於耐非二走

俊 寬三

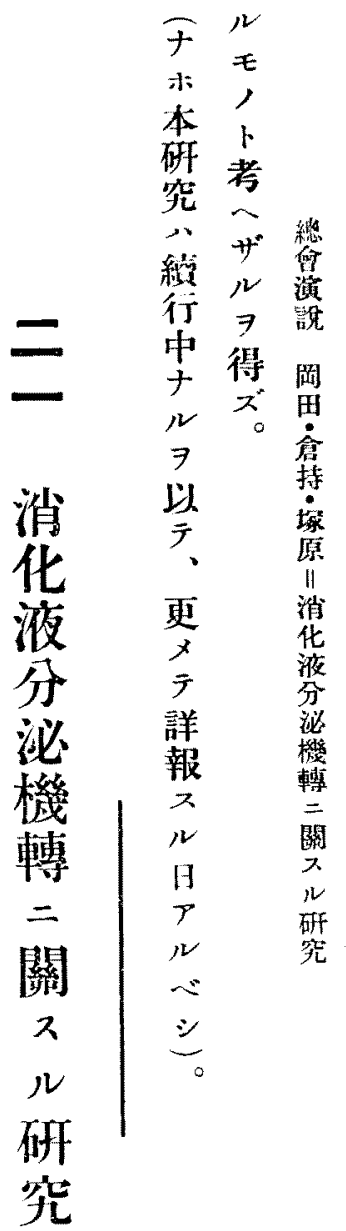

續

報 


\section{第 三 表 \\ 十二號犬 우 11.0 酕}

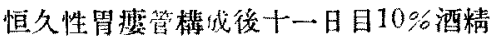
100 竜静胍內注射

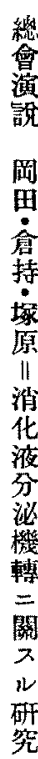

\begin{tabular}{|c|c|c|c|}
\hline \multirow{2}{*}{ 時 間 } & \multicolumn{2}{|l|}{ 胃 } & 液 \\
\hline & 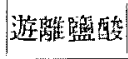 & 總酸度 & 液地 \\
\hline \multicolumn{2}{|c|}{ 泟 } & \multicolumn{2}{|c|}{ 前 } \\
\hline $\begin{array}{l}15^{\prime} \\
30^{\prime} \\
45^{\prime} \\
1 \mathrm{~h}\end{array}$ & $\begin{array}{r}21 \\
20 \\
14 \\
8\end{array}$ & $\begin{array}{l}28 \\
38 \\
22 \\
18\end{array}$ & $\begin{array}{l}2.0 \\
1.5 \\
1.0 \\
1.2\end{array}$ \\
\hline \multicolumn{2}{|c|}{ 注 } & \multicolumn{2}{|c|}{ 该 } \\
\hline $\begin{array}{r}15^{\prime} \\
30^{\prime} \\
45^{\prime} \\
1 \mathrm{~h} \\
1 \mathrm{~h} 15^{\prime} \\
1 \mathrm{~h} 30^{\prime}\end{array}$ & $\begin{array}{l}18 \\
25 \\
46 \\
47 \\
34 \\
20\end{array}$ & $\begin{array}{l}22 \\
31 \\
52 \\
54 \\
40 \\
29\end{array}$ & $\begin{array}{l}2.0 \\
4.5 \\
8.8 \\
5.3 \\
2.0 \\
2.0\end{array}$ \\
\hline
\end{tabular}

第

四

表

十四號犬 우

雨㑬迷走新經切断该十四日恒久性胃瘦

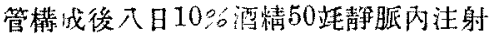

\begin{tabular}{|c|c|c|c|}
\hline \multirow{2}{*}{ 時 間 } & \multicolumn{2}{|l|}{ 胃 } & 液 \\
\hline & 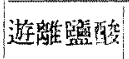 & 總酸度 & 液 $^{\frac{\text { 量 }}{12}}$ \\
\hline \multicolumn{2}{|c|}{ 注 } & \multicolumn{2}{|c|}{ 前 } \\
\hline $15^{\prime}$ & 14 & 30 & 4.0 \\
\hline $80^{\prime}$ & 20 & 34 & 8.0 \\
\hline $45^{\prime}$ & 20 & 34 & 2.0 \\
\hline $1 \mathrm{~h}$ & 14 & 32 & 0.8 \\
\hline \multicolumn{2}{|c|}{ 就 } & \multicolumn{2}{|c|}{ 後 } \\
\hline $15^{\prime}$ & 28 & 46 & 1.5 \\
\hline $30^{\prime}$ & 66 & 77 & 7.2 \\
\hline $45^{\prime}$ & 88 & 95 & 8.3 \\
\hline $1 \mathrm{~h}$ & 79 & $9 \pi$ & 4.3 \\
\hline $1 h 15^{\prime}$ & 81 & 96 & 4.0 \\
\hline 1heo' & 89 & 100 & 2.7 \\
\hline $1 \mathrm{~h} 45^{\prime}$ & 52 & 71 & 5.0 \\
\hline $2 \mathrm{~h}$ & 46 & 66 & 4.0 \\
\hline $2 \mathrm{~h} 15^{\prime}$ & 51 & 68 & 2.0 \\
\hline $2 \mathrm{~h} 30^{\prime}$ & 50 & 67 & 2.0 \\
\hline
\end{tabular}

$$
\text { 第 一 表 }
$$

四號犬 + 15.0 玨

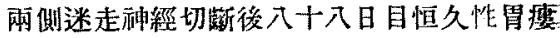
管構成後六十三日目「ュフェイン」0.2瓦

（1\%水溶液卜シ)静棴丙注射

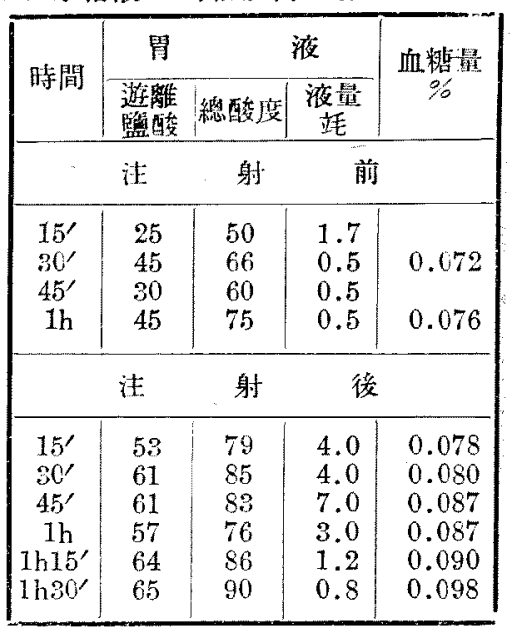

第 二 表

四䓵犬 点

雨側迷走种䌦切断淩九十一日目恒久性胃瘦 管構成徣六十六日目「コフェイン」0.2瓦(1 \%水溶液卜シ) 静脈內注射其，前後 $15^{\prime}=$ 「アトロピン」皮下注射

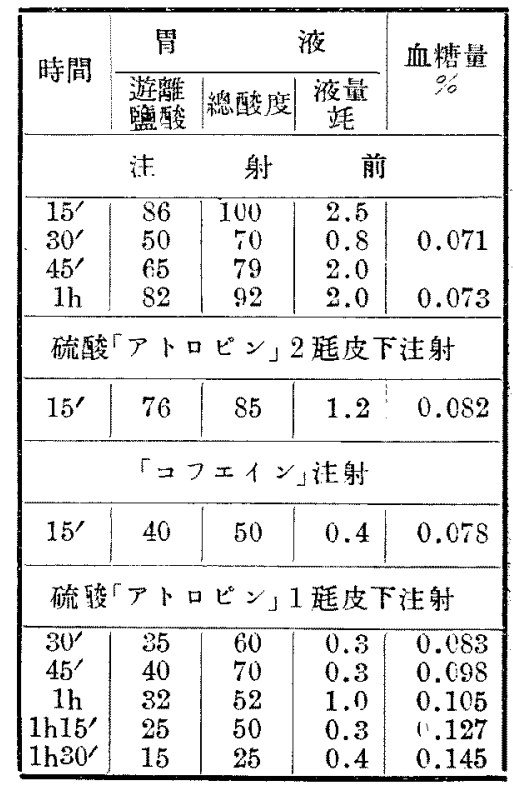

備考 : 瞳孔八極度二散大シ「アトロピン」ニ ヨル著シキ嬹隼狀態习呈ス 
第 七 表 十四號大 + +

雨例迷走神經切断後二十七日目恒久性胃覀 管棈成後二十一日目 $5 \%$ ○ービ, , 七氏肉越 幽斯50理静胍內注射》, 前 $15^{\prime}$ 及同時硫酸 「アトロピン」各2磁皮下注射

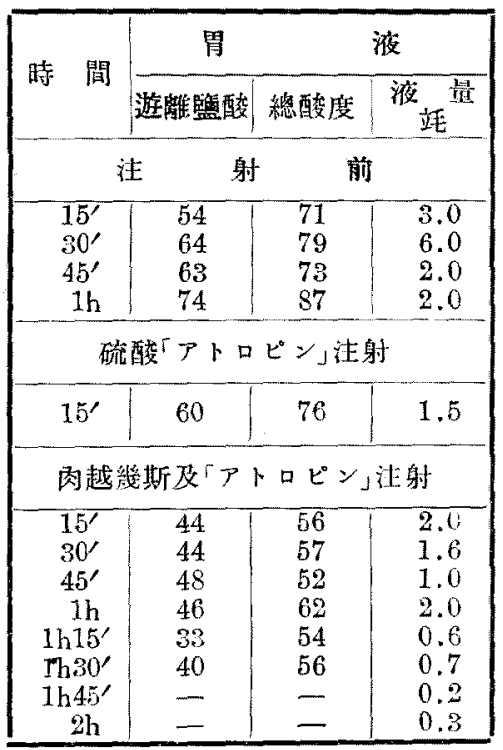

喵考: 肉越幾斯八凡厂 $0.5 \%$ 食留水二溶 解又

第

八表

十四號犬 +

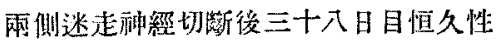

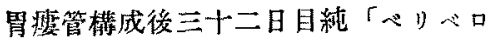

ール」0.5酉 750 犝生理食辟水二溶解》

静脈丙注射

\begin{tabular}{|c|c|c|c|}
\hline \multirow{2}{*}{ 時 閒 } & \multicolumn{2}{|l|}{ 䏴 } & 液 \\
\hline & 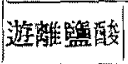 & 總酸度 & 液毕 \\
\hline \multicolumn{2}{|c|}{ 注 } & \multicolumn{2}{|c|}{ 前 } \\
\hline $35^{\prime}$ & 18 & 30 & 1.5 \\
\hline $30^{\prime}$ & 18 & 31 & 1.5 \\
\hline $45^{\prime}$ & 16 & 28 & 0.5 \\
\hline $1 \mathrm{~h}$ & 18 & 30 & 0.5 \\
\hline \multicolumn{2}{|c|}{ 注 } & \multicolumn{2}{|c|}{ 後 } \\
\hline $15^{\prime}$ & 13 & 22 & 2.5 \\
\hline $30^{\prime}$ & 76 & 84 & 27.5 \\
\hline $45^{\prime}$ & 87 & 93 & 6.5 \\
\hline th & 73 & 81 & 5.1 \\
\hline 1 h15 & 66 & 76 & 1.0 \\
\hline Ih $30^{\prime}$ & 64 & 74 & 2.8 \\
\hline
\end{tabular}

第 五表

十四號犬 + +

雨側迷走科經切榐後三十六日目惟久性

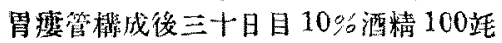

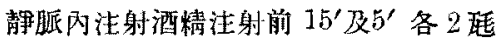
婉硫酸「アトロピン」ノ皮下注射习行つ

\begin{tabular}{|c|c|c|c|}
\hline \multirow{2}{*}{ 時 間 } & \multicolumn{2}{|l|}{ 䏣 } & 淮 \\
\hline & 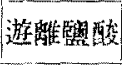 & 緭酸度 & ${ }^{\text {液 }}$ \\
\hline \multicolumn{2}{|c|}{ 注 } & \multicolumn{2}{|c|}{ 前 } \\
\hline $\begin{array}{l}15^{\prime} \\
30^{\prime} \\
45^{\prime} \\
1 \mathrm{~h}\end{array}$ & $\begin{array}{l}38 \\
42 \\
36 \\
32 \\
\end{array}$ & $\begin{array}{l}52 \\
54 \\
48 \\
50 \\
\end{array}$ & $\begin{array}{l}4.5 \\
4.5 \\
1.5 \\
2.5\end{array}$ \\
\hline \multicolumn{4}{|c|}{ 硫酸「アトロビン」洁射 } \\
\hline $15^{\prime}$ & 28 & 40 & 1.4 \\
\hline \multicolumn{4}{|c|}{ 硫酸「アトロピン」注射 } \\
\hline \multicolumn{2}{|c|}{ 酒 } & \multicolumn{2}{|r|}{ 射 } \\
\hline $\begin{array}{r}15^{\prime} \\
30^{\prime} \\
45^{\prime} \\
1 \mathrm{~h} \\
1 \mathrm{~h} 15^{\prime} \\
1 \mathrm{~h} 30^{\prime}\end{array}$ & $\begin{array}{l}26 \\
30 \\
86 \\
32 \\
42 \\
42\end{array}$ & $\begin{array}{l}44 \\
48 \\
48 \\
52 \\
54 \\
50\end{array}$ & $\begin{array}{l}0.5 \\
1.0 \\
1.1 \\
1.0 \\
2.0 \\
1.3\end{array}$ \\
\hline
\end{tabular}

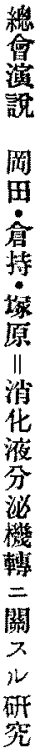

備考：以上，賽驗二於テ酒精八凡 食籃水二テ稀釋ス

$$
\begin{aligned}
& \text { 第亲表 } \\
& \text { 十四號犬 우 } 12.0 \text { 酥 }
\end{aligned}
$$

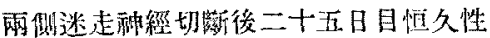

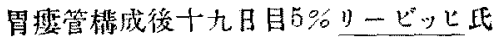

\begin{tabular}{|c|c|c|c|}
\hline \multirow{2}{*}{ 時 䦓 } & \multicolumn{2}{|c|}{ 唯 } & 液 \\
\hline & \multicolumn{2}{|c|}{ 遊離留晸酸 總酸度 } & 淮量 \\
\hline \multicolumn{2}{|c|}{ 证 } & \multicolumn{2}{|c|}{ 前 } \\
\hline $15^{\prime}$ & 24 & 32 & 3.8 \\
\hline $30^{\prime}$ & is & 28 & 1.8 \\
\hline $45^{\prime}$ & 12 & 24 & 1.5 \\
\hline Ih & 8 & 22 & 1.0 \\
\hline & & & \\
\hline $15^{\prime}$ & 12 & 18 & 4.5 \\
\hline $\begin{array}{l}30^{\prime} \\
45^{\prime}\end{array}$ & 24 & 35 & 7.3 \\
\hline $\begin{array}{l}45^{\circ} \\
1 \mathrm{~h}\end{array}$ & $\begin{array}{l}42 \\
35\end{array}$ & $\begin{array}{l}53 \\
44\end{array}$ & $\begin{array}{l}0.0 \\
4.0\end{array}$ \\
\hline 1h $15^{\prime}$ & 36 & 44 & 0.9 \\
\hline $1 \mathrm{~h} 30^{\prime}$ & 29 & 39 & 0.9 \\
\hline $1 \mathrm{~h} 45^{\prime}$ & 18 & 32 & 1.0 \\
\hline $2 \mathrm{~h}$ & 8 & 28 & 1.0 \\
\hline
\end{tabular}

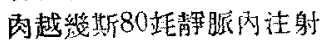




$$
\begin{aligned}
& \text { 第十一表 } \\
& \text { 十一號犬 우 }
\end{aligned}
$$

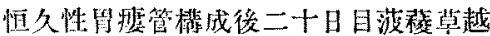
譏斯10.1 跬皮下让射 $15^{\prime}$ 後硫酸「アト口

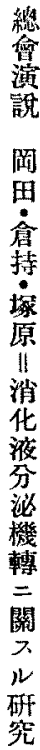

\begin{tabular}{|c|c|c|c|}
\hline \multirow{2}{*}{ 時 間 } & \multicolumn{2}{|l|}{ 周 } & 液 \\
\hline & 遊襍留䈏酸 & 總酸度 & 浓踥 \\
\hline \multicolumn{2}{|c|}{ 注: } & \multicolumn{2}{|c|}{ 前 } \\
\hline $15^{\prime}$ & 107 & 114 & 7.5 \\
\hline $30^{\prime}$ & 115 & 119 & 6.5 \\
\hline $45^{\prime}$ & 103 & 109 & 6.1 \\
\hline $1 \mathrm{~h}$ & 98 & 104 & 5.6 \\
\hline \multicolumn{2}{|c|}{ 声 } & \multicolumn{2}{|c|}{ 後 } \\
\hline $15^{\prime}$ & 102 & 107 & 13.0 \\
\hline $30^{\prime}$ & 122 & 126 & 85.7 \\
\hline $45^{\prime}$ & 140 & 144 & 28.7 \\
\hline Ih & 134 & 138 & 23.7 \\
\hline $1 \mathrm{~h} 15^{\prime}$ & 144 & 148 & 21.1 \\
\hline $1 \mathrm{~h}^{\circ} \mathrm{o}^{\prime}$ & 144 & 148 & 15.2 \\
\hline $1 \mathrm{~h} 45^{\prime}$ & 113 & 120 & 11.0 \\
\hline $2 \mathrm{~h}$ & 119 & 126 & 7.3 \\
\hline $2 \mathrm{~h} 15^{\prime}$ & 140 & 144 & 9.2 \\
\hline $2 \mathrm{~h} 30^{\prime}$ & 132 & 137 & 4.5 \\
\hline
\end{tabular}

ピン」2.0矮皮下洁射

第十二表

十四號大 우 12.0 玨

雨侧迷走神䌡切断後十二日目恒久性胃

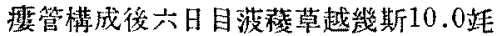
皮下注射

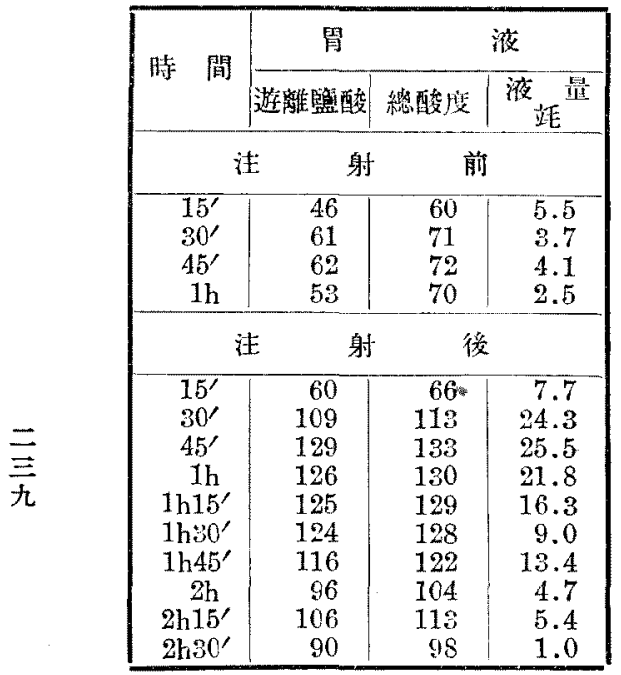

第

九

表

十四號大 우

兩側迷走㼛經切断後四十日目恒久性胃 瘦管棈成後三十四日目純「ぶリべロー ル, 0.5 瓦 750 埕生理食籃水二溶解青静 腿丙洼射り，前 $15^{\prime}$ 及同時二各2.5 珽

\begin{tabular}{|c|c|c|c|}
\hline \multirow{2}{*}{ 洔 閒 } & \multicolumn{2}{|l|}{ 胃 } & 液 \\
\hline & 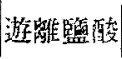 & 總酸度 & 液竨 $^{\text {量 }}$ \\
\hline \multicolumn{2}{|c|}{ 注 } & \multicolumn{2}{|c|}{ 前 } \\
\hline $15^{\prime}$ & 84 & 96 & 3.0 \\
\hline $30^{\prime}$ & 78 & 94 & 1.0 \\
\hline $45^{\prime}$ & 72 & 92 & 0.7 \\
\hline $1 \mathrm{~h}$ & 72 & 92 & 0.5 \\
\hline \multicolumn{4}{|c|}{ 硫酸「アトロピン」注射 } \\
\hline $15^{\prime}$ & 70 & 92 & 1.0 \\
\hline \multicolumn{4}{|c|}{$\begin{array}{l}\text { 『゙リベロール」及硫酸アト } \\
\text { ロビン、注射 }\end{array}$} \\
\hline $15^{\prime}$ & 55 & 70 & 0.3 \\
\hline $30^{\prime}$ & 72 & 90 & 0.5 \\
\hline $45^{\prime}$ & 48 & 64 & 1.0 \\
\hline $1 \mathrm{~h}$ & 42 . & 69 & 1.0 \\
\hline
\end{tabular}
妴, 硫酸「アトロピン」皮下注射

$$
\begin{aligned}
& \text { 第 十 表 } \\
& \text { 十一號犬우 } 18.0 \text { 䣶 }
\end{aligned}
$$

恒久性胃瘦管㩐成後二十二日目波薐草

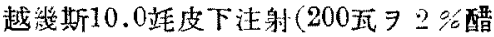
酸液 200 站 $=テ$ 水浴二テ四時間热沸

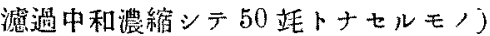

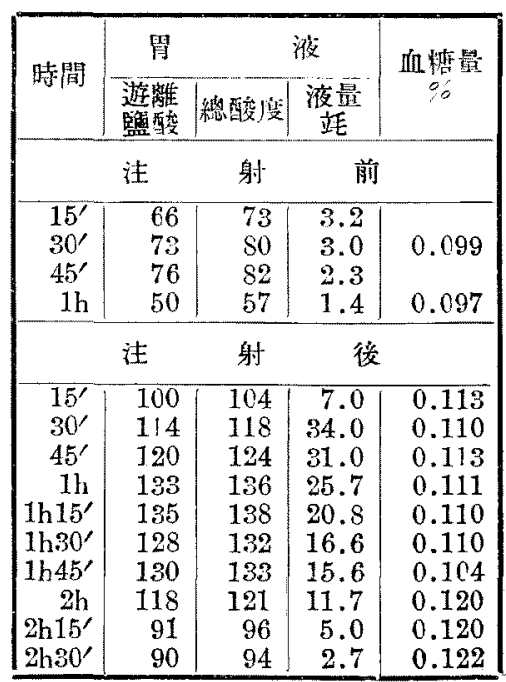


第 1 四表 十六易犬 \& 7.8 酥

「モルヒン」及「メーテル」硒醉下二胃，

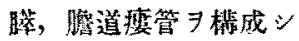

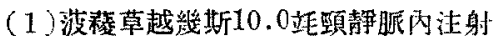

(I) 30 後同上20.0靖注射

(3) 更 $=15^{\prime}$ 後同上15.0靖皮下注射

(甲)膵 液

\begin{tabular}{|c|c|c|c|c|}
\hline & & 䣮 & 素 濃 & 度 \\
\hline 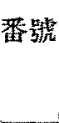 & 㖡是 & 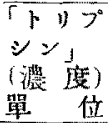 & 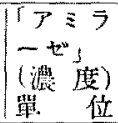 & 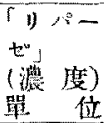 \\
\hline 1 & 0.9 & 2000 & 4112 & 252 \\
\hline 2 & 0.5 & 2000 & 4112 & 252 \\
\hline 3 & 0.2 & 2000 & 4112 & 174 \\
\hline
\end{tabular}

(乙) 管 汁

\begin{tabular}{|c|c|c|c|}
\hline 瓃䠰 & $\begin{array}{c}\text { 液㫜 } \\
\text { 㘪 }\end{array}$ & 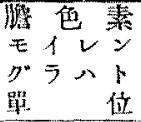 & 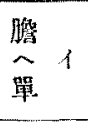 \\
\hline 1 & 5.8 & 880 & 70 \\
\hline $\begin{array}{l}2 \\
3\end{array}$ & $\begin{array}{l}4.1 \\
1.3\end{array}$ & $\begin{array}{l}480 \\
480\end{array}$ & 5800 \\
\hline
\end{tabular}

（丙）胃液：少量，遊離镒酸二富么液 7 得

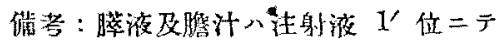
明二出デ來ル二国及三回，徍射 入前司，证射二ヨ心分淡，全》

正ミタル後二行つ

$$
\text { 第十五 表 }
$$

第 $+\neq$ 表

十四號太 斗

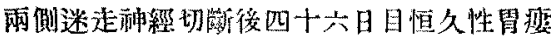

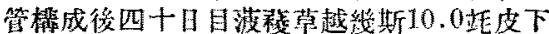
洼射ソ，前 $15^{\prime}=$ 硫酸「アトロビン, 4 配 $5^{\prime}$ 前二 2 婳皮下注制

\begin{tabular}{|c|c|c|c|}
\hline \multirow{2}{*}{ 時 間 } & \multirow[t]{2}{*}{ 盟 } & \multicolumn{2}{|c|}{ 液 } \\
\hline & & 總酸度 & 液 \\
\hline \multicolumn{2}{|c|}{ 清 } & \multicolumn{2}{|c|}{ 前 } \\
\hline $15^{\prime}$ & 68 & 96 & 1.8 \\
\hline $30^{\prime}$ & 80 & 100 & 3.7 \\
\hline $45^{\prime}$ & 84 & 104 & 2.3 \\
\hline $1 \mathrm{~h}$ & 86 & 102 & 2.8 \\
\hline \multicolumn{4}{|c|}{ ラアトロビン注射 } \\
\hline $15^{\prime}$ & 80 & 100 & 1.5 \\
\hline \multicolumn{4}{|c|}{ 「アトロピン」洼射 } \\
\hline \multicolumn{4}{|c|}{ 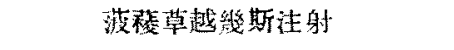 } \\
\hline $15^{\prime}$ & 98 & 110 & 12.8 \\
\hline $30^{\prime}$ & 112 & 120 & 37.8 \\
\hline $45^{\prime}$ & 116 & 124 & 31.8 \\
\hline Th & 112 & 124 & 35.6 \\
\hline
\end{tabular}

借考:『アトロピン」ニヨり瞳孔極度二散大

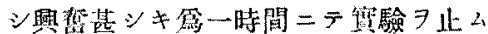

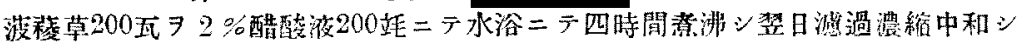

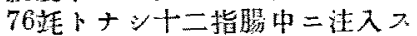

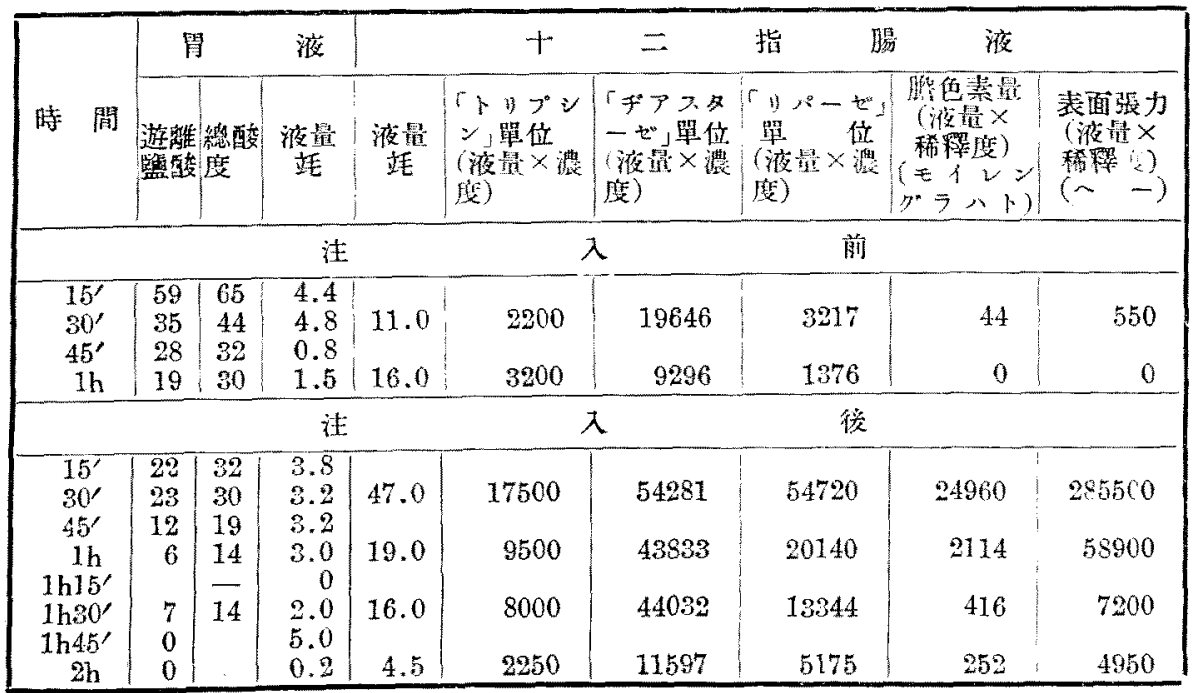

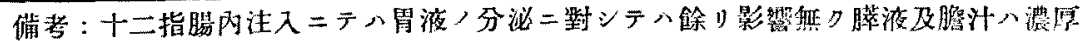
ニシテ多最二出产 
第十八表

十一號 大 + 15.0 硅

恒久性胃度管涉成後十

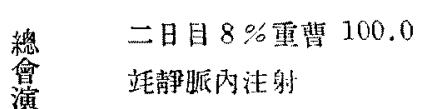

諰

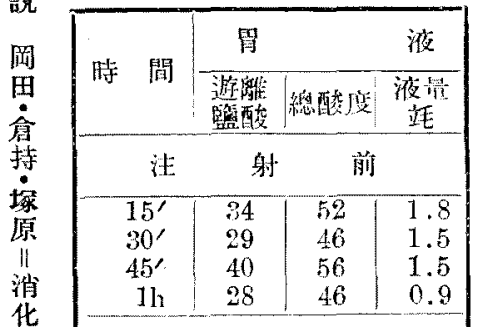

注 射 兴

\begin{tabular}{|r|r|r|r|}
\hline $15^{\prime}$ & 36 & 54 & 0.8 \\
$30^{\prime}$ & 6 & 24 & 0.5 \\
$45^{\prime}$ & 26 & 42 & 1.2 \\
$1 \mathrm{~h}$ & 9 & 27 & 1.0 \\
$1 \mathrm{~h} 15^{\prime}$ & 10 & 26 & 1.1 \\
$1 \mathrm{~h} 30^{\prime}$ & 22 & 36 & 0.5 \\
$1 \mathrm{~h} 45^{\prime}$ & 24 & 40 & 1.5 \\
$2 \mathrm{~h}$ & 12 & 30 & 2.0 \\
\hline
\end{tabular}

第十七表

十五號犬 우 15.0 玨

愐久性舅瘦管棈成媵二十一

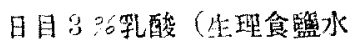

二溶解 1100 .0站静脈肉洼身

\begin{tabular}{|c|c|c|c|}
\hline \multirow{2}{*}{ 洔 間 } & \multicolumn{2}{|l|}{ 䏣 } & \multirow{2}{*}{$\begin{array}{c}\text { 液 } \\
\text { 液㨁 } \\
\text { 樵 }\end{array}$} \\
\hline & 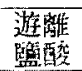 & 称酸度 & \\
\hline 洁 & 射 & 前 & \\
\hline $\begin{array}{c}15^{\prime} \\
80^{\prime} \\
45^{\prime} \\
1 \mathrm{~h}\end{array}$ & $\begin{array}{l}98 \\
89 \\
70 \\
68 \\
\end{array}$ & $\begin{array}{r}100 \\
90 \\
76 \\
74 \\
\end{array}$ & $\begin{array}{l}1.8 \\
1.8 \\
4.5 \\
2.2 \\
\end{array}$ \\
\hline 注 & 身 & 徽 & \\
\hline $\begin{array}{c}15^{\prime} \\
30^{\prime} \\
45^{\prime} \\
1 \mathrm{~h} \\
1 \mathrm{~h} 15^{\prime} \\
1 \mathrm{~h} 80^{\prime} \\
1 \mathrm{~h} 45^{\prime} \\
2 \mathrm{~h}\end{array}$ & $\begin{array}{r}68 \\
70 \\
96 \\
90 \\
72 \\
103 \\
88 \\
94 \\
\end{array}$ & $\begin{array}{r}72 \\
76 \\
98 \\
92 \\
74 \\
106 \\
93 \\
98 \\
\end{array}$ & $\begin{array}{l}0.8 \\
4.9 \\
8.0 \\
6.5 \\
7.8 \\
7.8 \\
7.6 \\
6.5 \\
\end{array}$ \\
\hline
\end{tabular}

第十亲表

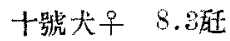

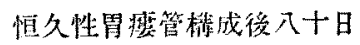
目 $5 \%$ 陪性磷酸曹㵆 100.0 䠧青争脈內注射

\begin{tabular}{|c|c|c|c|}
\hline \multirow{2}{*}{ 時 閐 } & 胃 & & 液 \\
\hline & 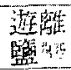 & 樬酸度 & $\begin{array}{c}\text { 液量 } \\
\text { 竓 }\end{array}$ \\
\hline 注 & 射 & \multicolumn{2}{|l|}{ 前 } \\
\hline $15^{\prime}$ & 42 & 68 & 2.5 \\
\hline $30^{\prime}$ & 68 & 86 & 1.5 \\
\hline $45^{\prime}$ & 35 & 56 & 4.0 \\
\hline $1 \mathrm{~h}$ & 24 & 36 & .0 \\
\hline 注 & \multicolumn{3}{|c|}{ 射後 } \\
\hline $15^{\prime}$ & 19 & 86 & 4.0 \\
\hline $30^{\prime}$ & 64 & 74 & 5.8 \\
\hline $45^{\prime}$ & 64 & 80 & 3.0 \\
\hline $1 \mathrm{~h}$ & 69 & 83 & 3.5 \\
\hline 1h15' & 63 & 76 & 3.0 \\
\hline Ihso' & 62 & 80 & 2.2 \\
\hline $1 \mathrm{~h} 45^{\prime}$ & 48 & 66 & 2.8 \\
\hline $2 \mathrm{~h}$ & 48 & 60 & 3.0 \\
\hline
\end{tabular}

第十北表

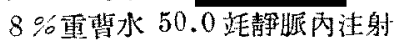

\begin{tabular}{|c|c|c|c|c|c|c|c|c|c|}
\hline \multirow[b]{2}{*}{ 時 間 } & \multicolumn{2}{|c|}{ 䏣 } & 液 & \multicolumn{2}{|r|}{+} & $=$ & 腸 & 液 & \\
\hline & \multicolumn{2}{|c|}{ 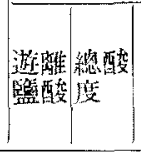 } & $\begin{array}{l}\text { 液量 } \\
\text { 犝 }\end{array}$ & \multirow[t]{2}{*}{$\begin{array}{l}\text { 淮最 } \\
\text { 站 }\end{array}$} & \multirow[t]{2}{*}{ 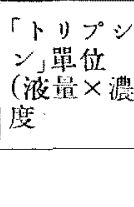 } & \multirow[t]{2}{*}{ 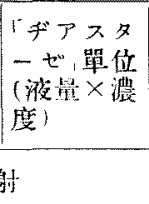 } & 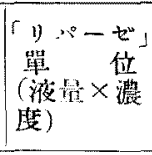 & \multirow[t]{2}{*}{ 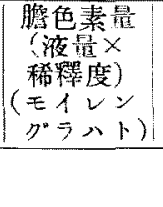 } & \multirow[t]{2}{*}{ 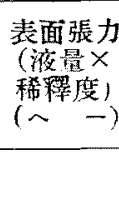 } \\
\hline \multicolumn{4}{|c|}{ 注 } & & & & 前 & & \\
\hline $\begin{array}{l}15^{\prime} \\
30^{\prime} \\
45^{\prime} \\
1 \mathrm{~h}\end{array}$ & $\begin{array}{r}8 \\
10 \\
25 \\
89\end{array}$ & $\begin{array}{l}16 \\
18 \\
29 \\
44\end{array}$ & $\begin{array}{r}11.0 \\
12.0 \\
8.8 \\
10.8\end{array}$ & $\begin{array}{r}26.0 \\
3.4\end{array}$ & $\begin{array}{r}32500 \\
1700\end{array}$ & $\begin{array}{r}84448 \\
9588\end{array}$ & $\begin{array}{r}14976 \\
966\end{array}$ & $\begin{array}{r}4836 \\
95\end{array}$ & $\begin{array}{r}195000 \\
8160\end{array}$ \\
\hline \multicolumn{6}{|c|}{ 洤 } & 射 & 後 & & \\
\hline $\begin{array}{r}15^{\prime} \\
30^{\prime} \\
45^{\prime} \\
1 \mathrm{~h} \\
1 \mathrm{~h} 15^{\prime} \\
1 \mathrm{~h} 30^{\prime} \\
\text { 1h4 } 45^{\prime} \\
2 \mathrm{~h}\end{array}$ & $\begin{array}{l}48 \\
55 \\
82 \\
58 \\
46 \\
68 \\
70 \\
94\end{array}$ & $\mid \begin{array}{r}54 \\
62 \\
84 \\
63 \\
55 \\
74 \\
74 \\
100\end{array}$ & $\begin{array}{r}2.0 \\
7.5 \\
3.8 \\
4.0 \\
8.0 \\
14.8 \\
15.3 \\
12.5\end{array}$ & $\begin{array}{l}17.5 \\
22.0 \\
17.5 \\
32.5\end{array}$ & $\begin{array}{l}21875 \\
27500 \\
14000 \\
40625\end{array}$ & $\begin{array}{l}59068 \\
69960 \\
55650 \\
97240\end{array}$ & $\begin{array}{r}19950 \\
15642 \\
25550 \\
119275\end{array}$ & $\begin{array}{l}2660 \\
4620 \\
1995 \\
2275\end{array}$ & $\begin{array}{l}192500 \\
819000 \\
154000 \\
188500\end{array}$ \\
\hline
\end{tabular}

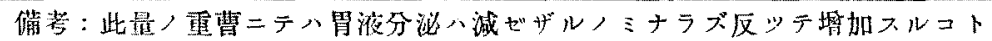
$ア$ 膵液及脆汁八增加スルコト多シ 


$$
\begin{aligned}
& \text { 第二十二表 } \\
& \text { 十三㔠大 + }+14 \text {. 䂠 }
\end{aligned}
$$

雨例迷走种經切断得二十四日目恒久性

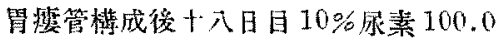

\begin{tabular}{|c|c|c|c|}
\hline \multirow{2}{*}{ 時 間 } & 舅 & \multicolumn{2}{|c|}{ 液 } \\
\hline & 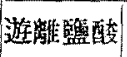 & 稳酰度 & 液踥 \\
\hline \multicolumn{2}{|c|}{ 洼 } & \multicolumn{2}{|c|}{ 前 } \\
\hline $15^{\prime}$ & 66 & 86 & 1.5 \\
\hline $30^{\prime}$ & 42 & 57 & 0.4 \\
\hline $45^{\prime}$ & 45 & 60 & 0.7 \\
\hline Ih & 54 & 74 & 0.8 \\
\hline \multicolumn{2}{|c|}{ 注 } & \multicolumn{2}{|c|}{ 後 } \\
\hline $15^{\prime}$ & 46 & 64 & 1.0 \\
\hline $30^{\prime}$ & 40 & 54 & 0.9 \\
\hline $45^{\prime}$ & 42 & 60 & 0.7 \\
\hline Ih & 42 & 57 & 0.4 \\
\hline $1 \mathrm{~h} 15^{\prime}$ & 32 & 48 & 0.3 \\
\hline $1 \mathrm{~h} 30^{\prime}$ & 39 & 51 & 0.3 \\
\hline $\operatorname{lh} 45^{\prime}$ & 35 & 50 & 0.2 \\
\hline $\mathrm{gh}$ & 32 & 46 & 0.4 \\
\hline
\end{tabular}
站静脈內注射

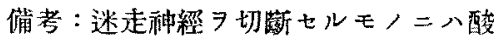
度及液量，啫加 7 來サズ

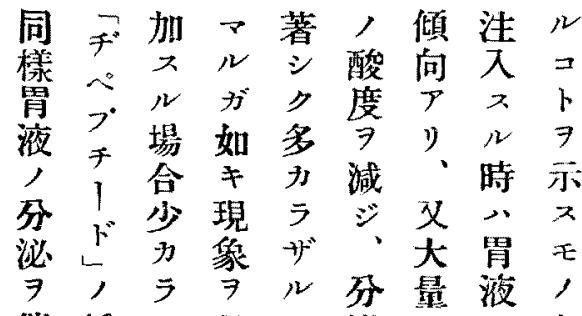
催埆 2 呈 淮脈。減量澞酸信 入内

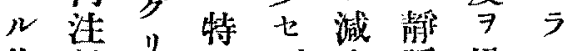
作射于二ザ少榩增心 用 $、$ 膵

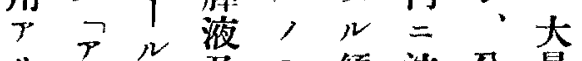
り、ア゙タミ傾注分量 , , 磿ナ向入泌,

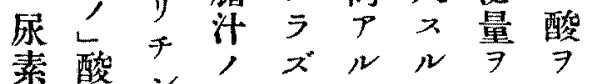

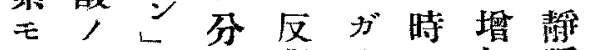
靘法, 泌對洼 $心$ 加脈 脈 射如 $\Rightarrow$ 二 入胃入内 内 $⺊ \neq$ 䝬高量液 $ル=$
第 二十 表

十五能犬 +15.0 死

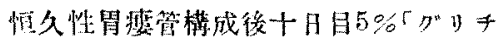

\begin{tabular}{|c|c|c|c|}
\hline \multirow{2}{*}{ 時 間 } & \multicolumn{2}{|l|}{ 胃 } & 渡 \\
\hline & 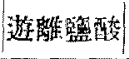 & 總酸度 & 渡地 \\
\hline \multicolumn{2}{|c|}{ 涞 } & \multicolumn{2}{|c|}{ 前 } \\
\hline $\begin{array}{c}15^{\prime} \\
30^{\prime} \\
45^{\prime} \\
1 \mathrm{~h} \\
\end{array}$ & $\begin{array}{r}54 \\
73 \\
86 \\
104 \\
\end{array}$ & $\begin{array}{r}62 \\
80 \\
91 \\
112\end{array}$ & $\begin{array}{l}6.0 \\
6.3 \\
7.2 \\
8.5 \\
\end{array}$ \\
\hline \multicolumn{2}{|c|}{ 津 } & \multicolumn{2}{|c|}{ 後 } \\
\hline $\begin{array}{c}15^{\prime} \\
30^{\prime} \\
45^{\prime} \\
1 \mathrm{~h} \\
1 \mathrm{~h} 15^{\prime} \\
1 \mathrm{~h} 30^{\prime} \\
1 \mathrm{~h} 45^{\prime} \\
2 \mathrm{~h}\end{array}$ & $\begin{array}{l}110 \\
130 \\
128 \\
124 \\
130 \\
116 \\
108 \\
117\end{array}$ & $\begin{array}{l}118 \\
134 \\
138 \\
129 \\
133 \\
120 \\
112 \\
120\end{array}$ & $\begin{array}{r}10.0 \\
22.5 \\
5.2 \\
13.0 \\
30.0 \\
23.5 \\
11.5 \\
10.5\end{array}$ \\
\hline
\end{tabular}
ールグロチン」100.0竓静服队注射

第二十一表

十二战夫㝵 11.75 硅

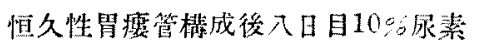

\begin{tabular}{|c|c|c|c|}
\hline \multirow{2}{*}{ 時 間 } & \multicolumn{2}{|l|}{ 胃 } & 漼 \\
\hline & 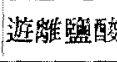 & 總酸度 & 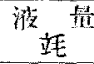 \\
\hline \multicolumn{2}{|c|}{ 诖 } & \multicolumn{2}{|c|}{ 前 } \\
\hline $15^{\prime}$ & 42 & 60 & 2.5 \\
\hline $30^{\prime}$ & 51 & :6 & 2.0 \\
\hline $45^{\prime}$ & 68 & 88 & 1.5 \\
\hline $1 \mathrm{~h}$ & 50 & 70 & 1.7 \\
\hline \multicolumn{2}{|c|}{ 注 } & \multicolumn{2}{|c|}{ 後 } \\
\hline $15^{\prime}$ & 40 & 56 & 2.3 \\
\hline $30^{\prime}$ & 79 & 90 & 6.6 \\
\hline $45^{\prime}$ & 72 & 85 & 5.4 \\
\hline 1h & 60 & 72 & 3.5 \\
\hline $1 \mathrm{~h} 15^{\prime}$ & 36 & 54 & 2.2 \\
\hline Ih $30^{\prime}$ & 20 & 36 & 0.8 \\
\hline $1 \mathrm{~h} 45^{\prime}$ & 24 & 36 & 0.4 \\
\hline $2 \mathrm{~h}$ & 20 & 32 & 2.0 \\
\hline
\end{tabular}
100.0 埕静脈內洁射

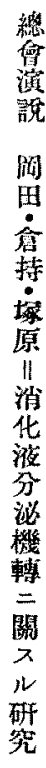




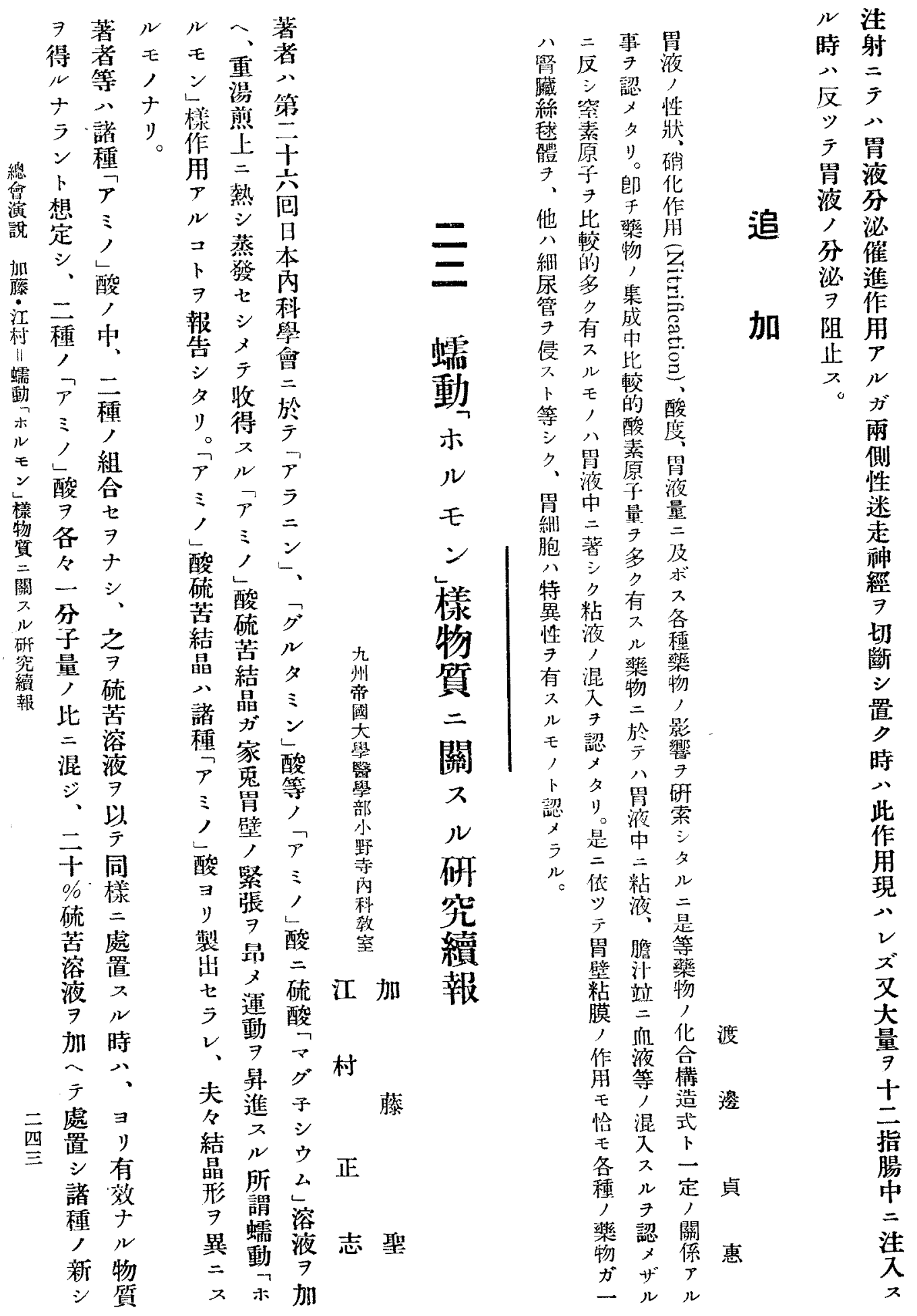


者ズ胃酸豚人注り暴苦對ニ

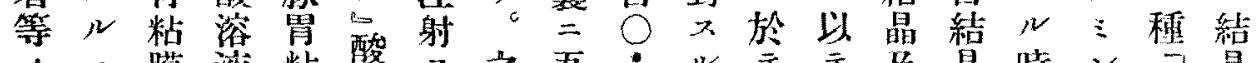

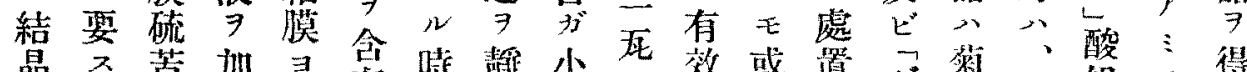

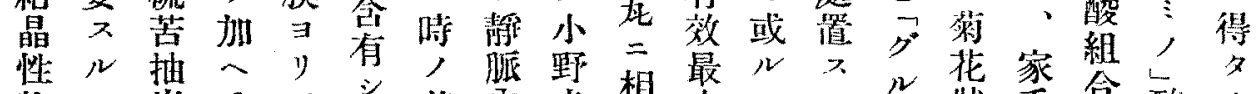
物 7 出于二硫其內寺想少

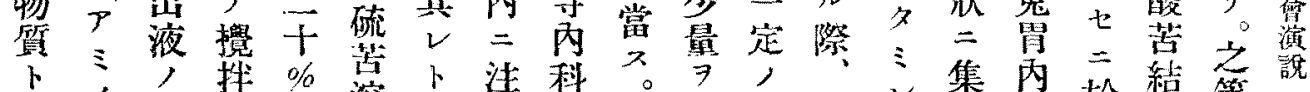

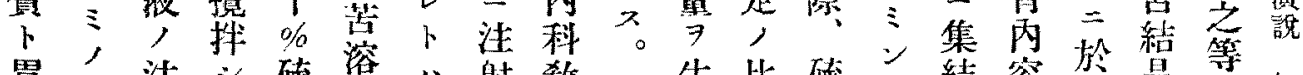
胃 粘酸射、苦液非 $九$ 室

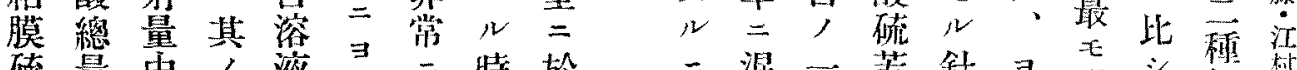

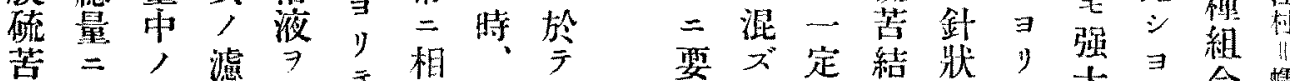

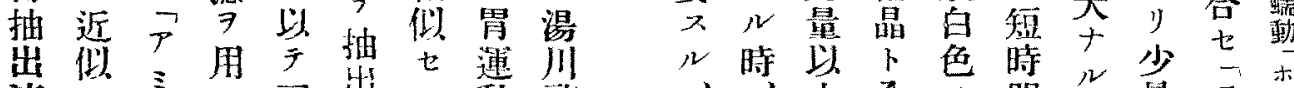

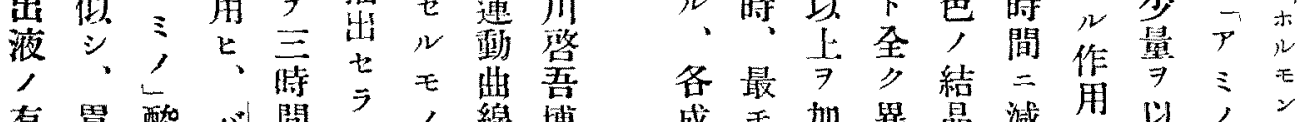
有胃酸心間, 为線博成飞加異晶減角以;

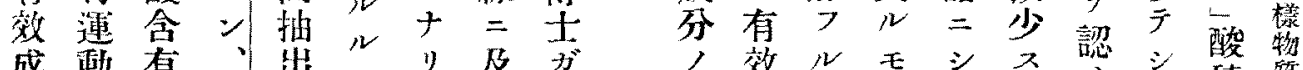
盛曹量 卜線

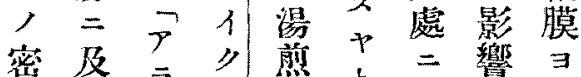

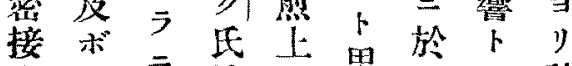
子 ス 法三思惟宇硫 關出 僠液 物作夕分加渵 $=11$ 以 語用今間熱,

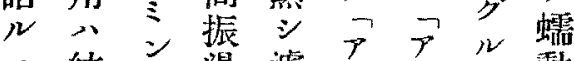

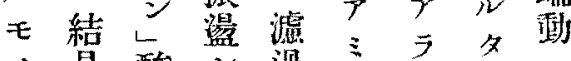
人晶酸シ過, 二ミミ ナ性硫浚 ラ物苦生事酸 レ、酸 モ ト,晶ル数有引硫ン 墨作性看问量心苦し 漖用物斯 $\Rightarrow$ 多結栐 入 二質 $\exists$ 更 测 相, 测三定三性質 似. 有定三七乞物 7 七效シ度り酸質抽 最及\%。等 $尹$ 出 事少り三新, 静七

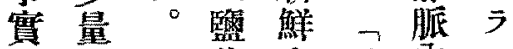
八 化 $ナ ア 內 内$ 著生醋 ルミ二タ

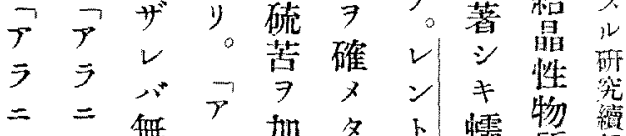
シ $匚$ 無

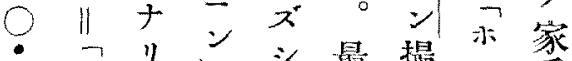
○グリったシ最撮ル鬼 ○皮製有影毛县 香

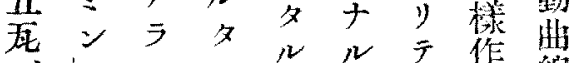

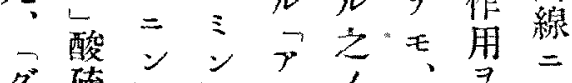

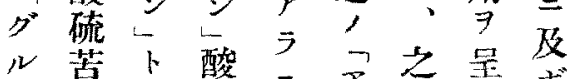

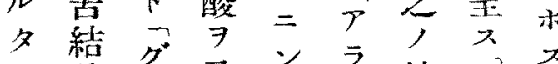
シ晶儿悡レニ結就影

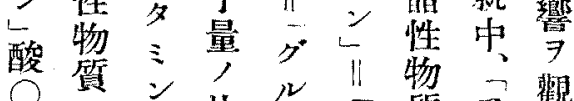
○)

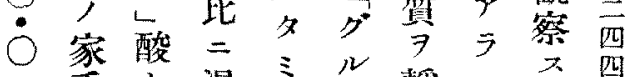
二兔卜混 ミ尛

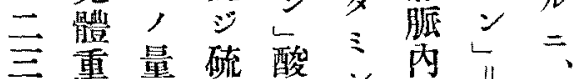
至重量硫期 硫 


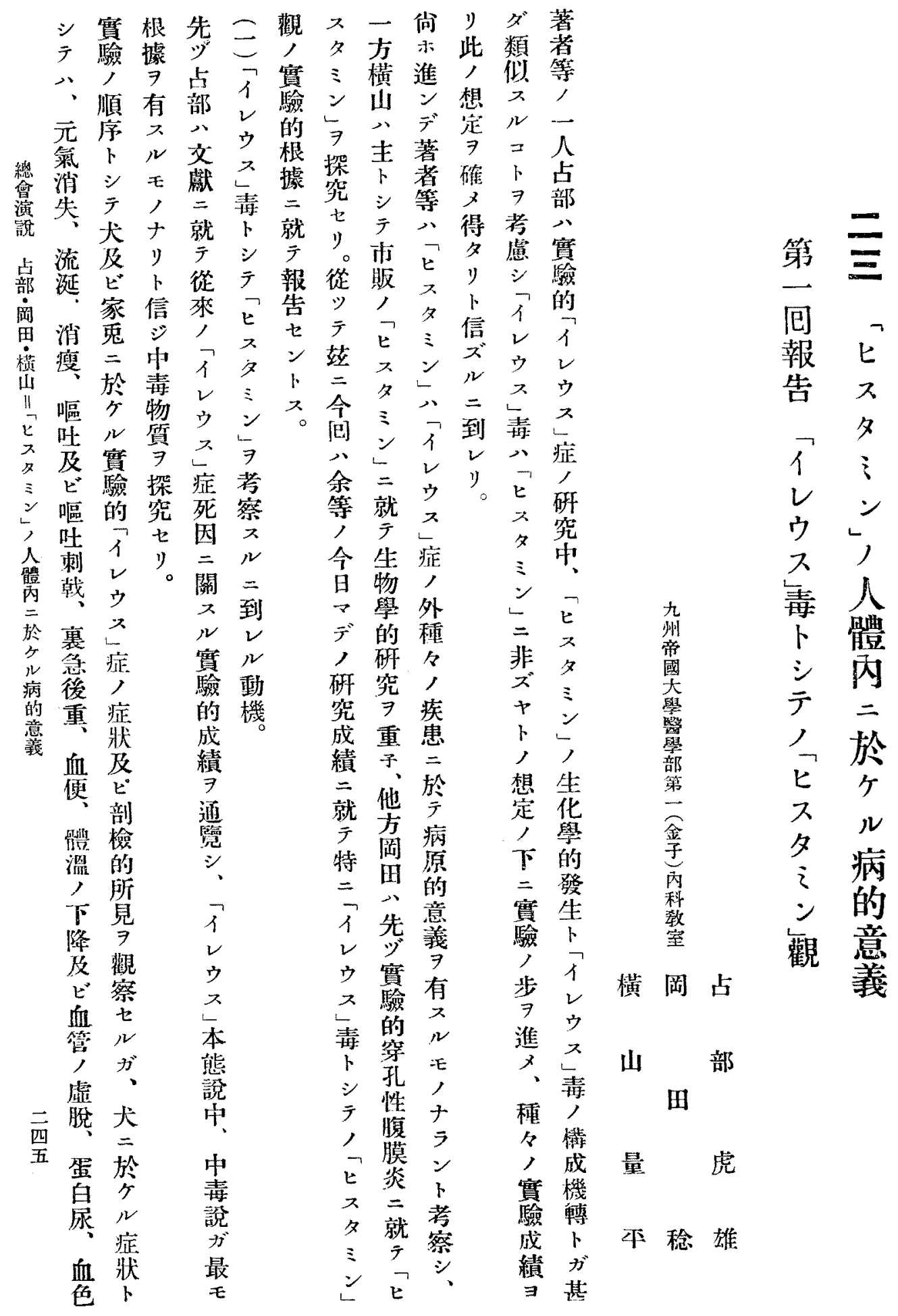


容菌死 5 延而等 7 内著儌多次二剖, 素

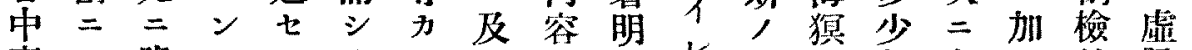

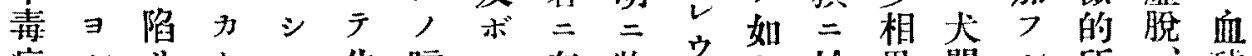

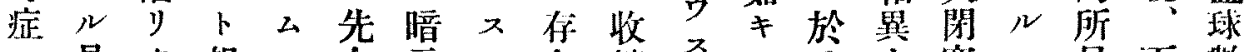

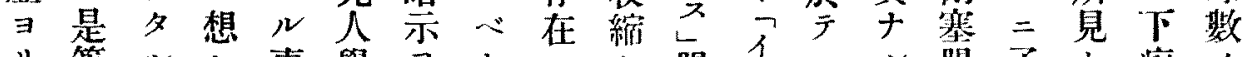

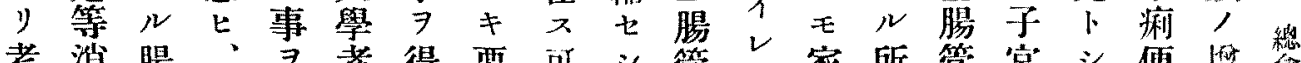

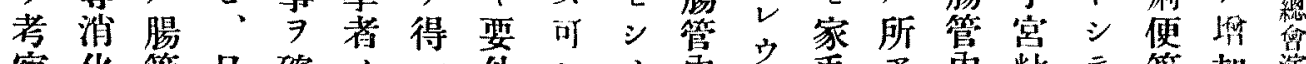

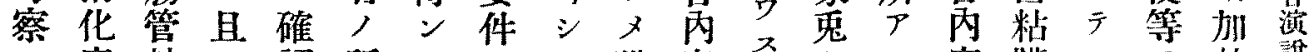
入產粘ツ認所卜卜卜猫容 $ル$ 物膜 $シ$ 論想七想血 $r$, 中先得, 第亏像壓平物同犬蒐出兩出中部

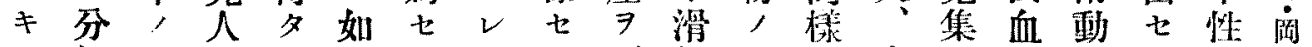

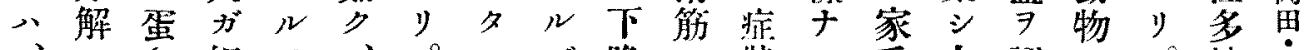

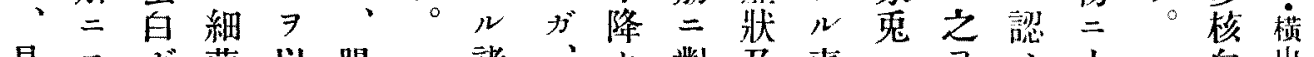

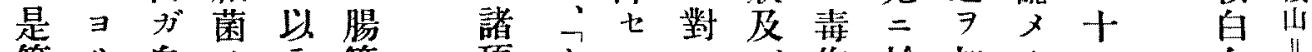
等り自，管項イシ シ ビ作於加タ今 家著、宮

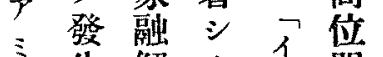
之生解夕亿閉 它辞不当塞

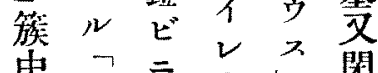

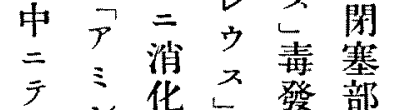
モレ゙货得等腸 $\vec{ヒ}$ 簇 ビ管機管 ス 細内蹧 壁

夕非菌 二 二損 ミ导性於 粘集 二カ白櫭膜 ガ、分殖, 死

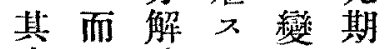
表モ醉儿化寻 役不素事站早

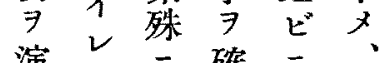

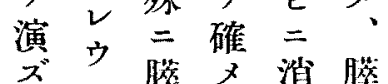
元液夕花液

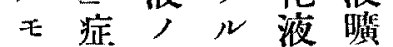
, 泣消 7 等 置 ナビ化以 $=\boldsymbol{H}^{\circ}$

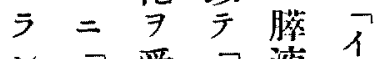
分不受夜夜的 卜レケ、存ウ

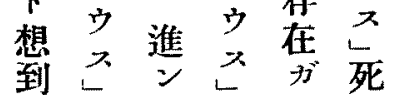
七腸 ゙毒必期 》管 心 要 $尹$ 。呙細壤古痋

$=レ ム$ 特剖用テ熱り。指

就少殊檢

于 又 $=$, 的見實隇

考毒占作乺出驗菌 察浆 $尹$ 用見七的

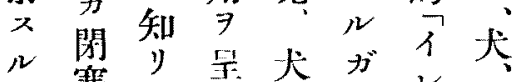
時塞得六家海ウ家 之管 り容從二海云聇猽 虫 レ發從ザイ特方泩 ウ生來少学塄射

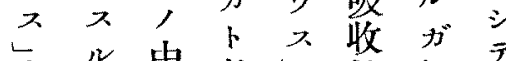

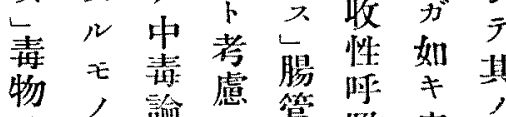

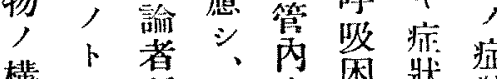

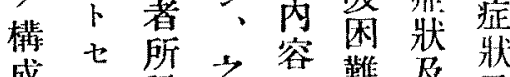

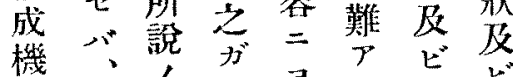

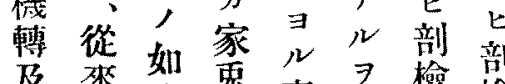

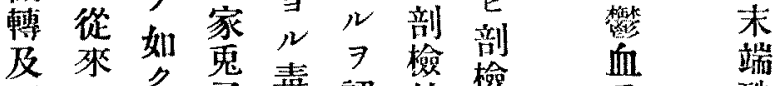

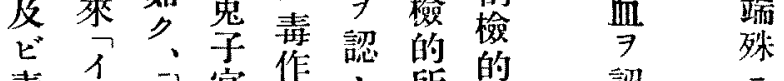

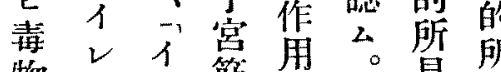
物々筋等。見見 本

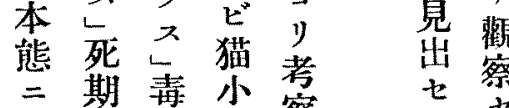
就期 毒小蔡尔每

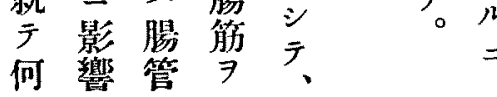

血球 細 胞 肺今 小加留 腸等 骷 粘 $\quad \exists=$ 膜舉於 充家 病 血 兔 的 芝

出 $\rightarrow$

血牛

肝醉 脾態 粲四

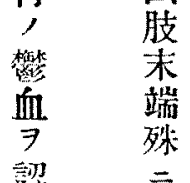
認 燢 家冾 却 j 的 = 之 血 
スルビ，四ス

症場剖 三合檢

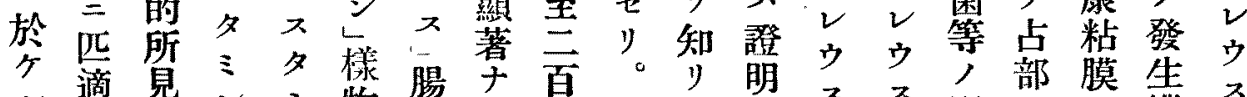

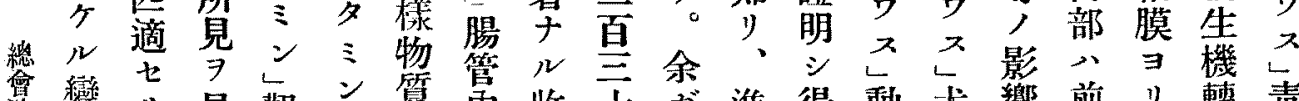

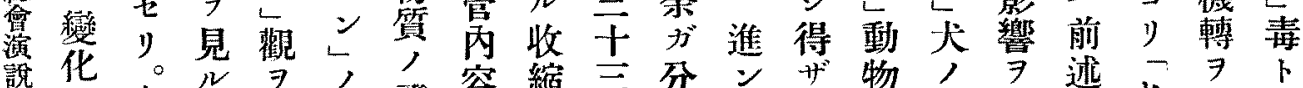

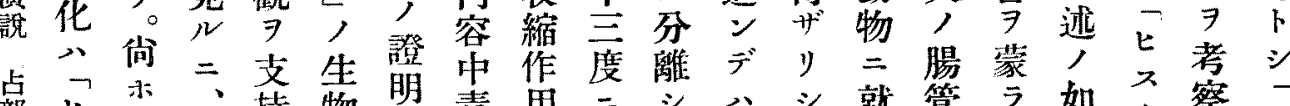

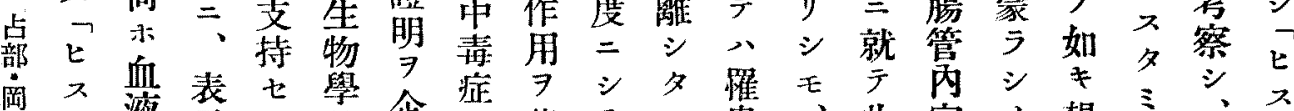
田萑示 $ン$ 的企, 惹

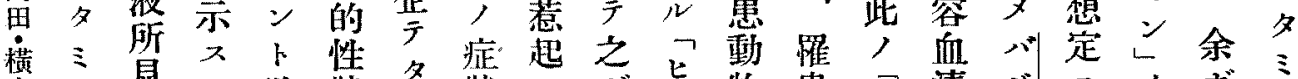

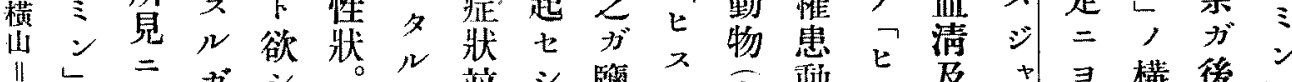

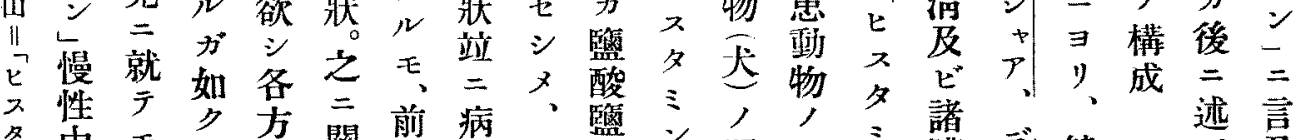

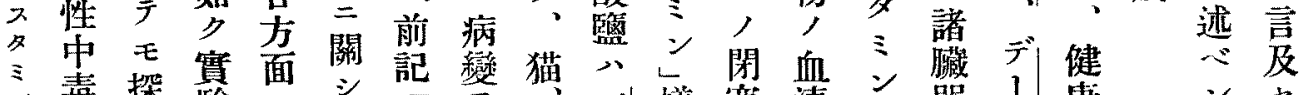
シ毒掏蹇 , 時究的就 人 體見ハ 内

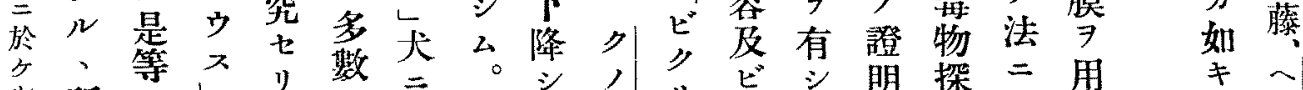
所入尗。”

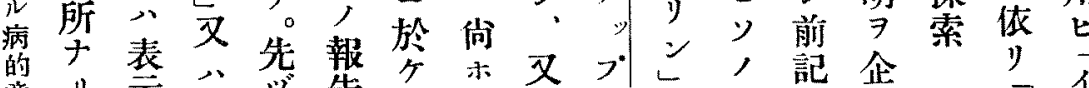
頀り。示

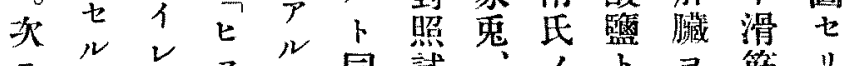

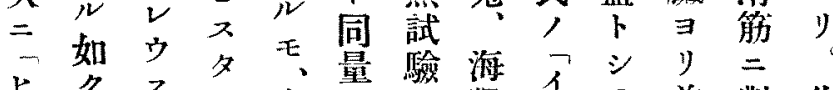

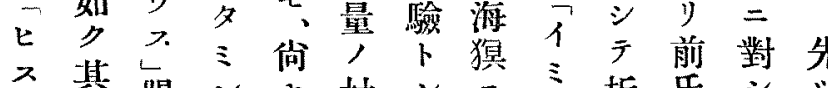

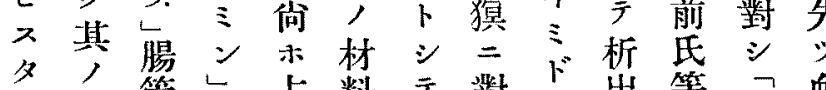

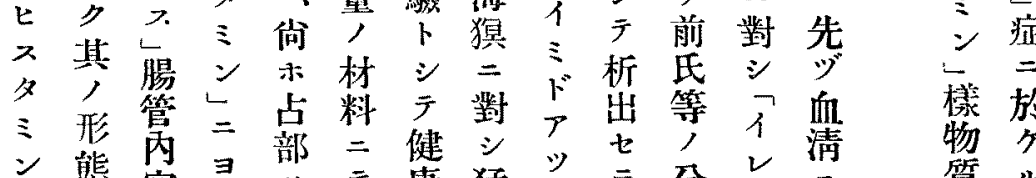

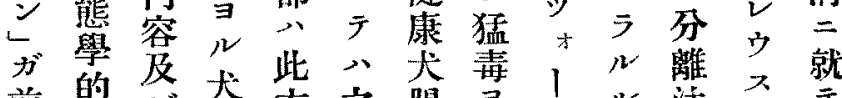
前的芯妿之腸䒜小心法不就

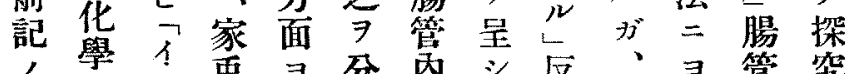

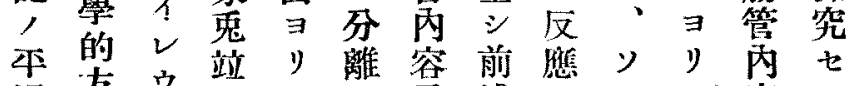

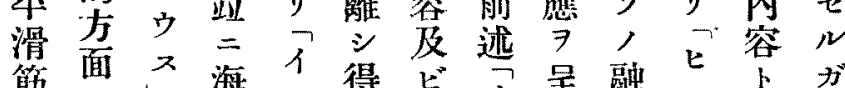
西筋面不海

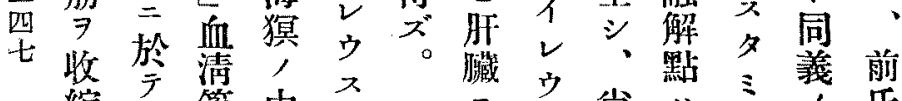

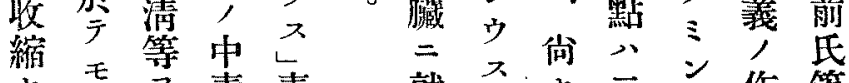

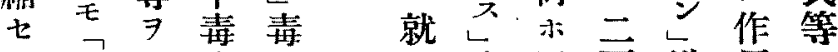
シ 亿泩症卜症本面樣用、人 メ $v$ 射牀 シ 更滑兰物 7 法 猫ウ七及它ビ筋市質有

質

毒

證 物

明 發

七生

$y$ 。機

俥等

$=$

模

做

广

$\sum_{\rightarrow j}$ $\begin{array}{cc}7 & - \\ \text { 實 } & ル \\ \text { 驗 } & 8 \\ \text { 的 } & \searrow\end{array}$

根

據 ゼ 有 入 $ト$ $=ク ゙$ 菲 非 向 ザ イ N 十 氏 り。等 2 F E 述 如 


\begin{tabular}{|c|c|c|}
\hline 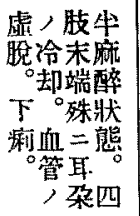 & 状 & $\begin{array}{l}1 \\
v\end{array}$ \\
\hline 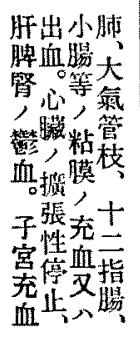 & $\begin{array}{l}\text { 剖 } \\
\text { 檢 } \\
\text { 的 } \\
\text { 所 } \\
\text { 晃 }\end{array}$ & $\begin{array}{l}\text { ウ } \\
\text { 즌 }\end{array}$ \\
\hline 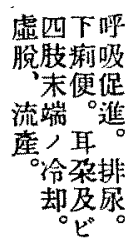 & 痁 & $\begin{array}{l}7 \\
1 \\
v \\
2 \\
2\end{array}$ \\
\hline 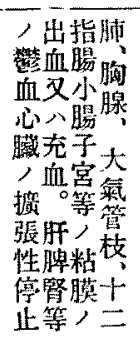 & $\begin{array}{l}\text { 剖 } \\
\text { 檢 } \\
\text { 的 } \\
\text { 所 } \\
\text { 見 }\end{array}$ & $\begin{array}{l}\text { 管 } \\
\text { 容 } \\
\text { 中 } \\
\text { 瑇 } \\
\text { 症 }\end{array}$ \\
\hline 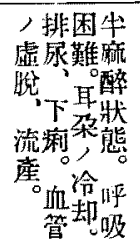 & 症 & $\begin{array}{l}\tau \\
x \\
z\end{array}$ \\
\hline 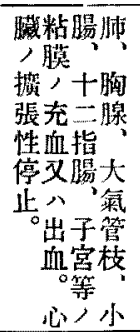 & $\begin{array}{l}\text { 剖 } \\
\text { 检 } \\
\text { 的 } \\
\text { 所 } \\
\text { 見 }\end{array}$ & $\begin{array}{l}\Sigma \\
2 \\
\text { ¿ } \\
\text { 中 } \\
\text { 毒 } \\
\text { 症 }\end{array}$ \\
\hline
\end{tabular}

\begin{tabular}{|c|c|c|}
\hline 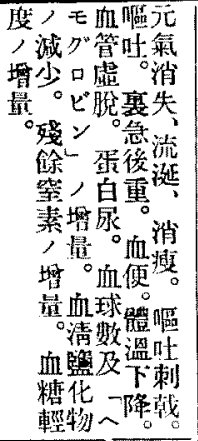 & 狀 & $v$ \\
\hline 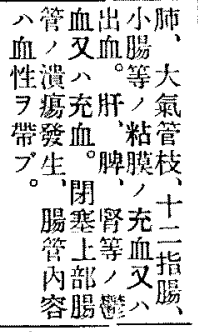 & $\begin{array}{l}\text { 剖 } \\
\text { 檢 } \\
\text { 的 } \\
\text { 所 } \\
\text { 晃 }\end{array}$ & 2. \\
\hline 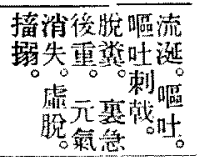 & 狀 & $\begin{array}{l}\overrightarrow{1} \\
2 \\
0 \\
2 \\
2\end{array}$ \\
\hline 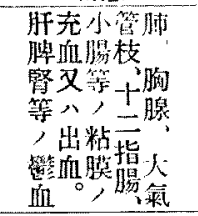 & $\begin{array}{l}\text { 剖 } \\
\text { 檢 } \\
\text { 的 } \\
\text { 所 } \\
\text { 見 }\end{array}$ & 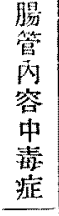 \\
\hline 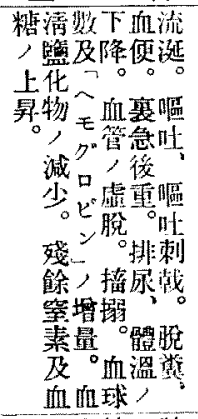 & 症 & 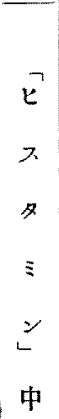 \\
\hline 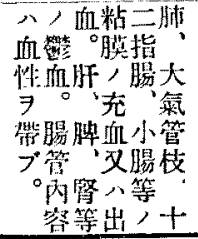 & $\begin{array}{l}\text { 剖 } \\
\text { 檢 } \\
\text { 的 } \\
\text { 所 } \\
\text { 見 }\end{array}$ & 症 \\
\hline
\end{tabular}

其

家

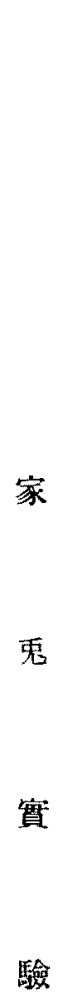

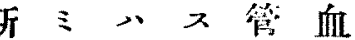

犬

クン痽症内塹

實

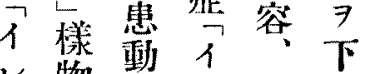

ウ物物

ス 腸 ウ臟 七

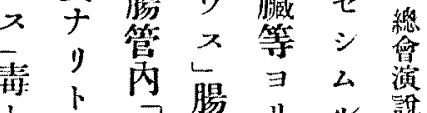

卜考二腸りル鿁

学蔡 不管

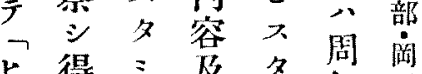

七得三及矢昌

スルンビミ知苗

タモ發血 レ 事 耑

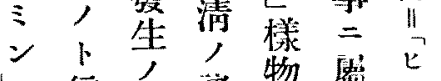

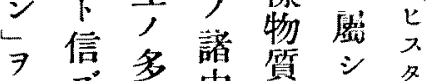

考 希赛中筫

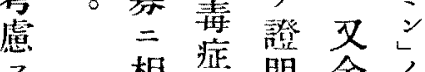

ニ 當殆 シ 等

至ルドと確

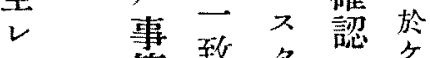

等 x

驗 $\exists \quad \exists$ 三 得病

以. リ事亡 多的

テ、・事多中意

更什篮毒所

淮 レ

進页且其斯

デ 毒其多多

余 국,

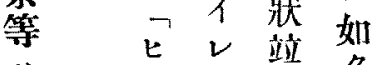

類 学光二實

似、 想

症 $三$ 死檢 的

牀㫐期所公

$\Rightarrow \quad \rightarrow 5=$ 所

有少影見

ル

祭壬及产病

孔フボー，

性七

㙏 ス要レ基

膜名件少腸 


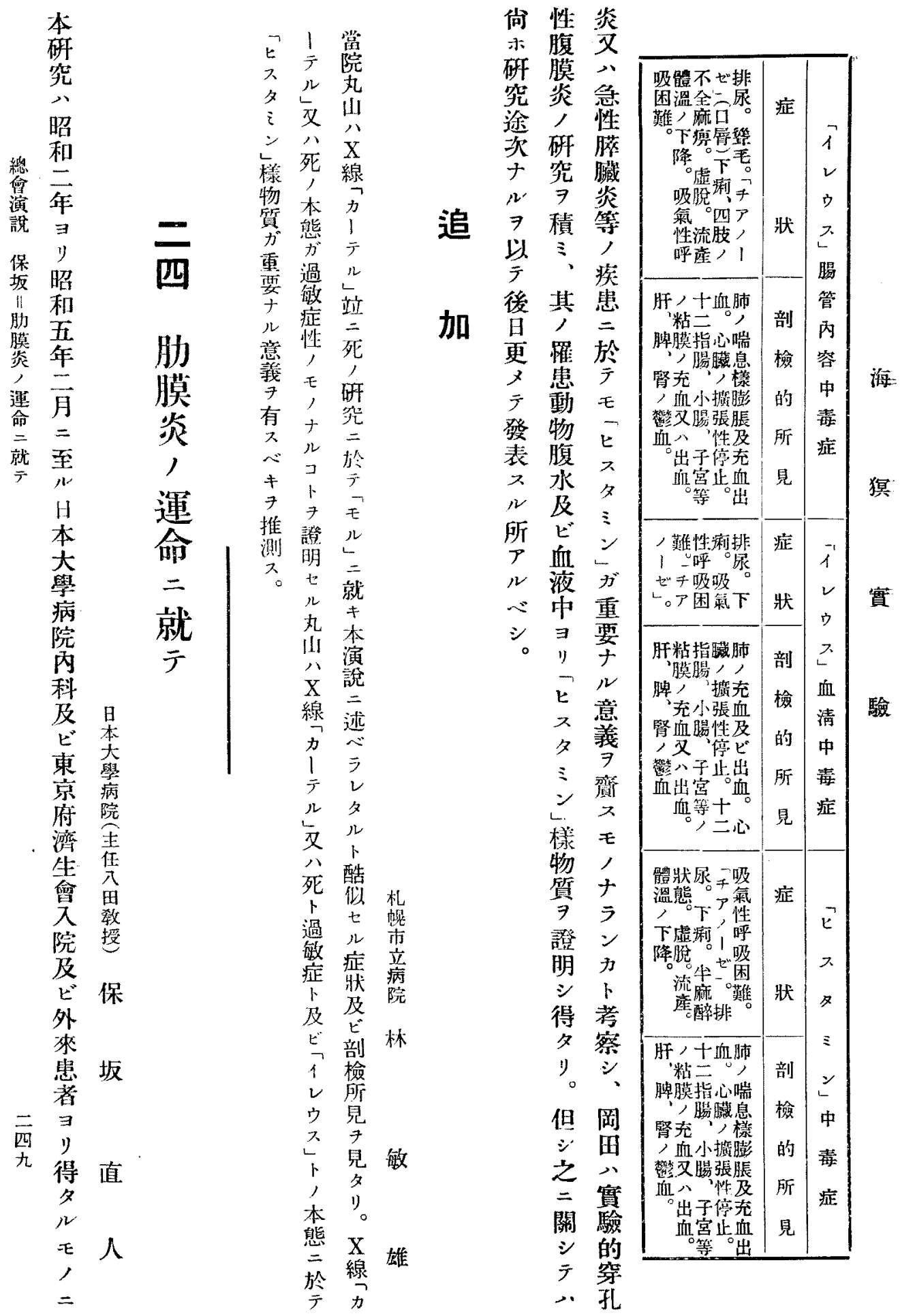


第 一 表 肋膜炎䍜患側ニヨル分類表

脂

\begin{tabular}{|c|c|c|c|c|c|c|}
\hline & \multicolumn{3}{|c|}{ 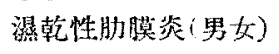 } & \multicolumn{3}{|c|}{ 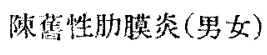 } \\
\hline 椎 隐 側 & 有 & 左 & 丽側 & 右 & $t_{x}$ & 雨侧 \\
\hline 恝 患 㡅 & 1980 & 760 & 660 & 1670 & 600 & 130 \\
\hline \begin{tabular}{l|l} 
金膜 \\
熦
\end{tabular} & 34.1 & 13.0 & 11.3 & 28.9 & 10.3 & 2.2 \\
\hline 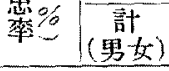 & 58.2 & 22.4 & 19.4 & 69.2 & 25.0 & 5.8 \\
\hline 棓 & \multicolumn{3}{|c|}{$3400(58.6 \% 6)$} & \multicolumn{3}{|c|}{$2400(41.4 \%)$} \\
\hline
\end{tabular}

\begin{tabular}{|c|c|c|c|c|c|c|c|c|c|c|c|c|}
\hline 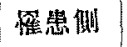 & 在 & tr & 相㒋 & 有 & 庄 & 雨侧 & 有 & $\mathrm{r}$ & 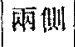 & 有 & t & 倆側 \\
\hline 椎患数 & 610 & 270 & 250 & 610 & 360 & 70 & 1370 & 490 & 410 & 1060 & 240 & 60 \\
\hline 倠 全䑏 & 10.5 & 4.6 & 4.2 & 10.5 & 6.2 & 1.2 & 23.6 & 8.4 & 7.0 & 18.2 & 4.1 & 1.0 \\
\hline $\begin{array}{l}\text { 男 } \\
\text { 女 }\end{array}$ & 54.0 & 24.0 & 22.0 & 58.7 & 34.6 & 6.7 & 60.3 & 21.6 & 10.6 & 82.3 & 17.7 & 4.4 \\
\hline 小 計 & \multicolumn{3}{|c|}{$1130(52.1 \%)$} & \multicolumn{3}{|c|}{$1040(47.9 \%)$} & \multicolumn{3}{|c|}{$2270(62.5 \%)$} & \multicolumn{3}{|c|}{$1360(3) .5 \%$} \\
\hline 合 苦 & \multicolumn{6}{|c|}{$2170(37.4 \%)$} & \multicolumn{6}{|c|}{$3630(62.6 \%)$} \\
\hline 男女敦 & \multicolumn{12}{|c|}{5800} \\
\hline
\end{tabular}

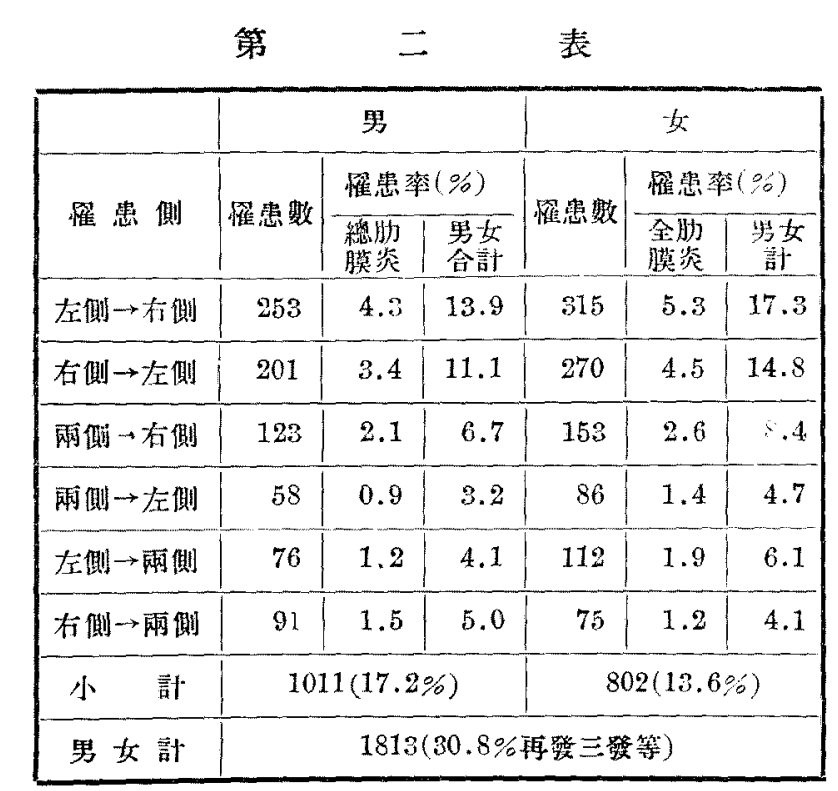

肋 ガ, シ

膜消中广

炎長五著

э7八者

多知七八

* 5 二

テン男九

之卜男㫐

蓝

7 二 兵境

洷 ル二七保

出飞卡男坂

性，分—湖

及ナ 影 二

性

更

陳

院

唖

モ

,

$\Rightarrow$

$x$

加

算

:

F

記

进

te

y

ト

>

而

シ

广

陳

譬

性

肠

膜

笑

r

ㄱ

白 己 


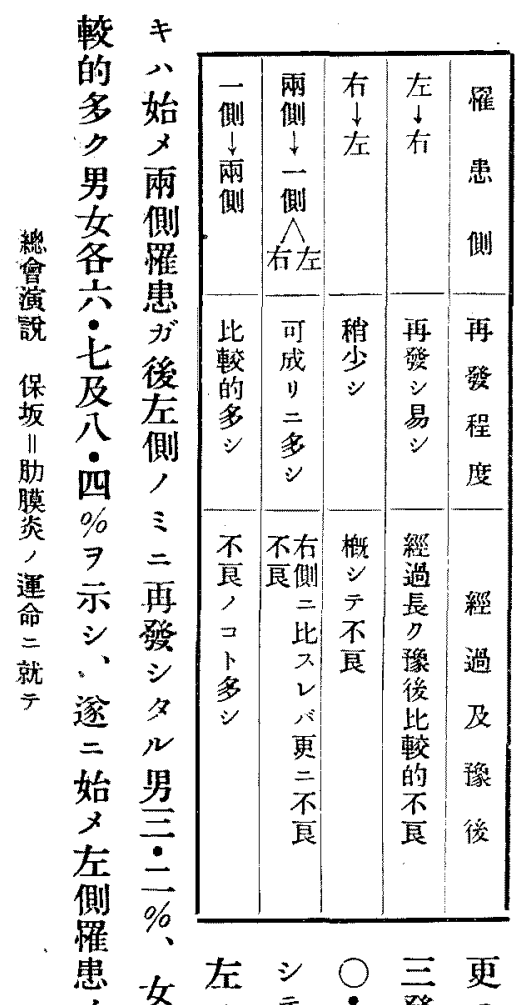

患文左

毛西夜女公登之

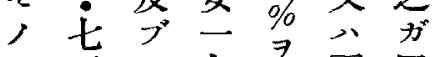

ガ \% 七寻·再羅

後ナ, 兰示患患

兩 ’、男\%其七嘍

側、男\%其 三及

二然女男左毛枈

桃次男左，率

ル

モ 一

, 一无匀示

、, - \% 右一天

男右正二側三

四側及

二西西最三第

二覆穴最毛王

五茎想\%多，全

空名・男脅見

- $⿻$ y次女膜

$\%$ モ

二, 其右數數 》

，最 $\exists=$, 再

天比少り對三發
千右譄罹モ經女五八棵先覺

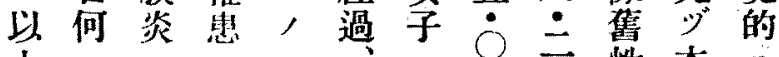
上 力惟始比豫男及、䏚症肳 表十患入

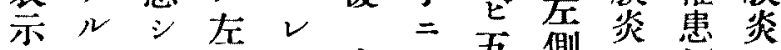
不夕側 $\therefore$ 今比五側二側, レキル經之方三有 7 經

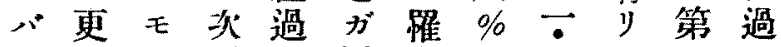
大三， デ羅患ナ四 テ略他 ガ石豫 患数り \% モ 表 知 次, 後側後側多。及永二 , $==-\quad=$ ビ同見ル 如側一來極 $\exists$ 約兩樣卡卜 シ 側

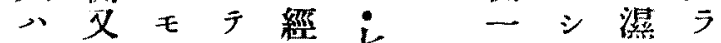
後一, 佳過七九テ乾ザ 兩雨叮良及對酉右性

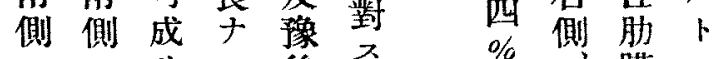

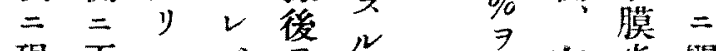
現再二ド 7 - 示左炎

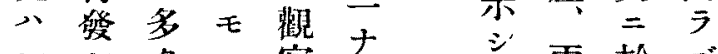
タ タ 之一般察り。後雨於 ル ${ }_{-j}=$ ン 者, 小覺

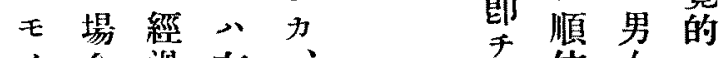
, 合過左、陳位女二

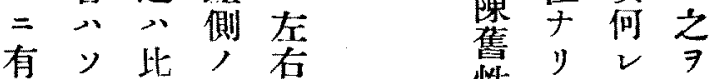
), 輘 ミ 何 于像的, v 八後長埸力

○及合一

人經豫一側 經過㣪右， 過 分側 三 及不微罪, 豫良 虫眻 後二テ二患 八傾不此 = 極良方於 メ、十テ 㕅り經 不之、過其 良始次長兩 ナメデキ 側 リノ最如同 卜病初”時 不僛雨 = 、 $j^{*}$ 側 兩 來 師左胡側
膜而問明 炎 シ 有 り唯最ノ 八率夕以 右見左 左見左 兩 = 之

側 前 二

夫者 次

空二正

九於 兩

二 最

$\%$ 石側

二 五
性。 7 幛 二之右 于患 


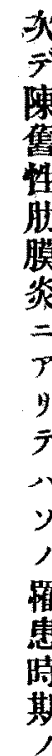

明

確

ナ

5

サ

N

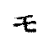

,

及

ビ

初

診

時

年

嚙

$=$

$\exists$

)

5

定

七

$\forall$

2

ド

モ

䏍

且

$\stackrel{\text { ” }}{=}$
第 三 表

\begin{tabular}{|c|c|c|c|c|c|c|}
\hline & \multicolumn{3}{|c|}{ 男 } & \multicolumn{3}{|c|}{ 女 } \\
\hline 榷点例 & 右 & 左 & 兩㑡 & 右 & 左 & 雨側 \\
\hline 雑患数 & 38 & 18 & 0 & 84 & 34 & 4 \\
\hline 惟，全患 & 21.3 & 10.1 & 0 & 47.1 & 19.1 & 2.2 \\
\hline 崇\% 男女 & 67.8 & $|32.2|$ & 0 & 68.9 & 27.9 & 3.2 \\
\hline 小 計 & & $(31.5 \%$ & & & $2(68$. & $4 \%)$ \\
\hline 憱 & & & 17 & & & \\
\hline
\end{tabular}

次儿顫候發以》 デ如强厂 上， 左”クル疼蔯右 側男又二痛舊 側 男五、性 = 二六呼于唍肠始 入、吸飞嗽膜 二 女時患竾夕演 二元胸者喀中心鿁 - 三産茨患モ保 一 三連全者, 圾 $\%$ 例動 少該, = 11 、 7 , 不 部 自 比 女得制知, 覺 女限, 费症 2 ,

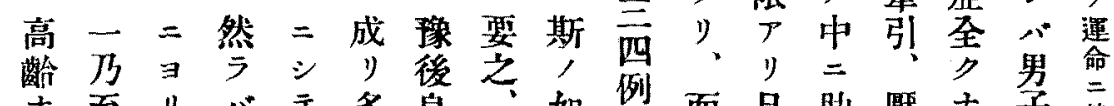

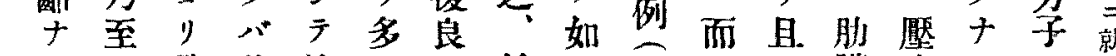
,$ル$ 二 稍肪恰

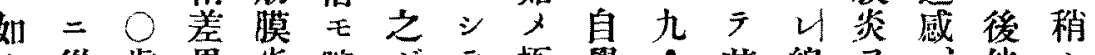

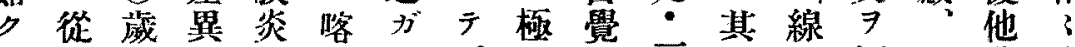

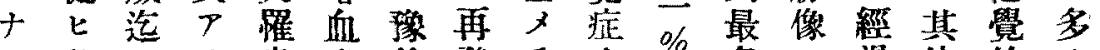
レ急, リ患患後發厅ナ\%多二過他的夕

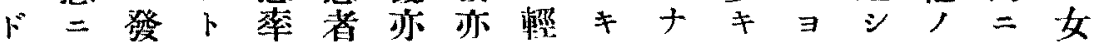

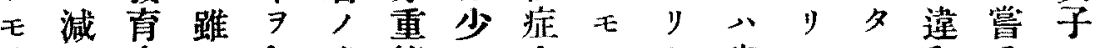

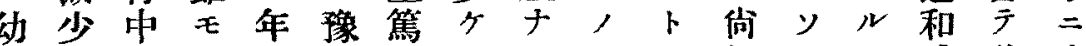
年 $シ$ 三路後 $=$ 七於三别比 於一 $万$ 乃

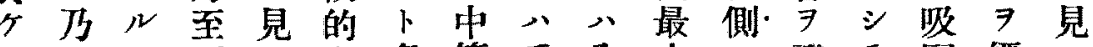
系モ三次良多等重全少二䜅厅困經

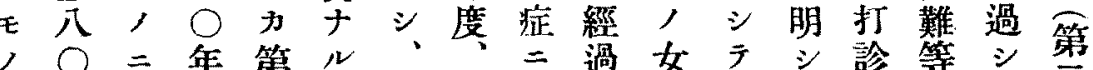

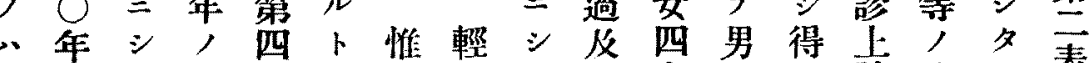

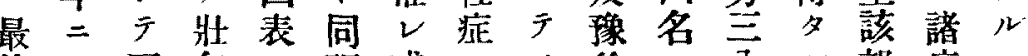
佳、三年三理或 $=$ 後公公部症二

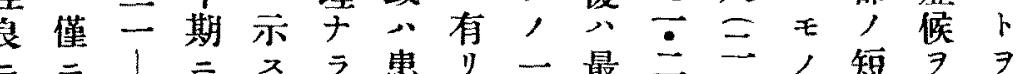

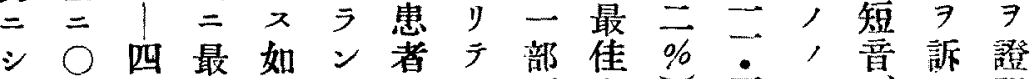
テ 六 $\bigcirc$ 多少力

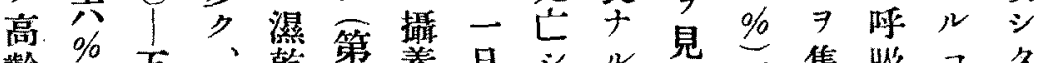

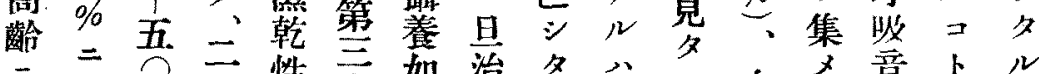

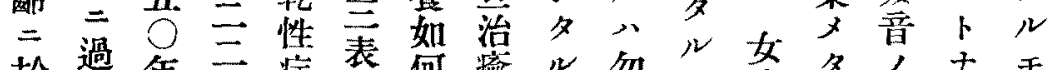

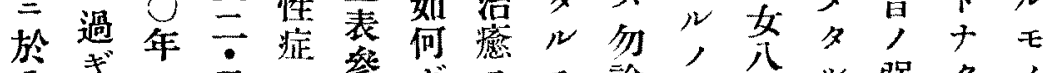

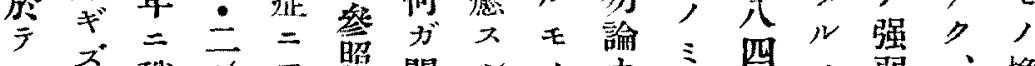
關

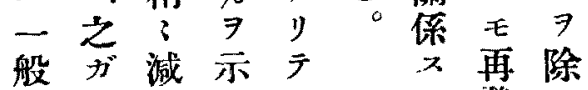

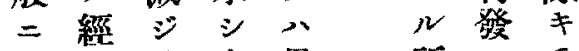
不過其次男所心 良及後デ女大可以
七

-. 表擎 斯

\% 見 振徵 熱 $\overrightarrow{\%}=$ 音我 


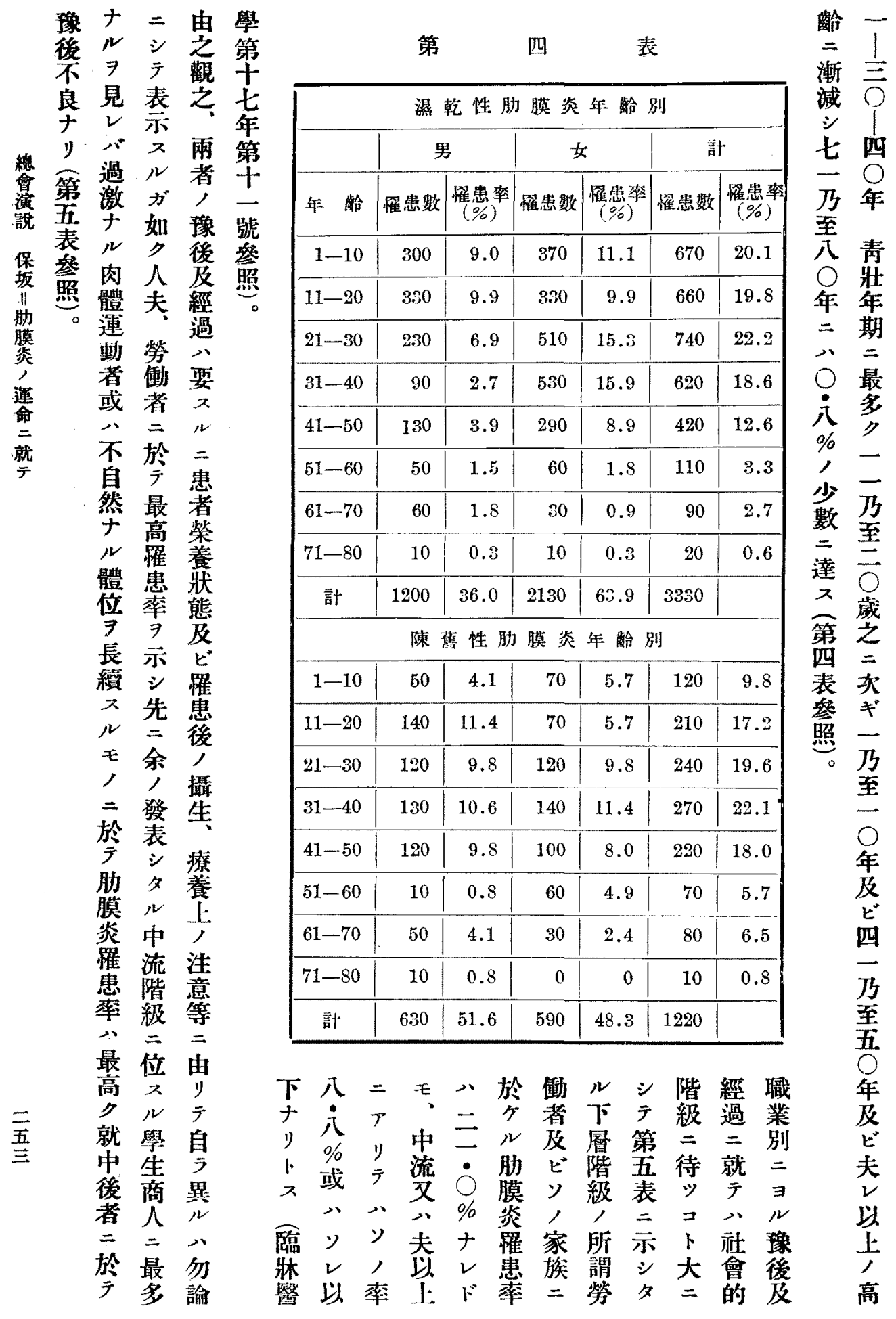


第 五 表 城業別ニヨル經過及潒後

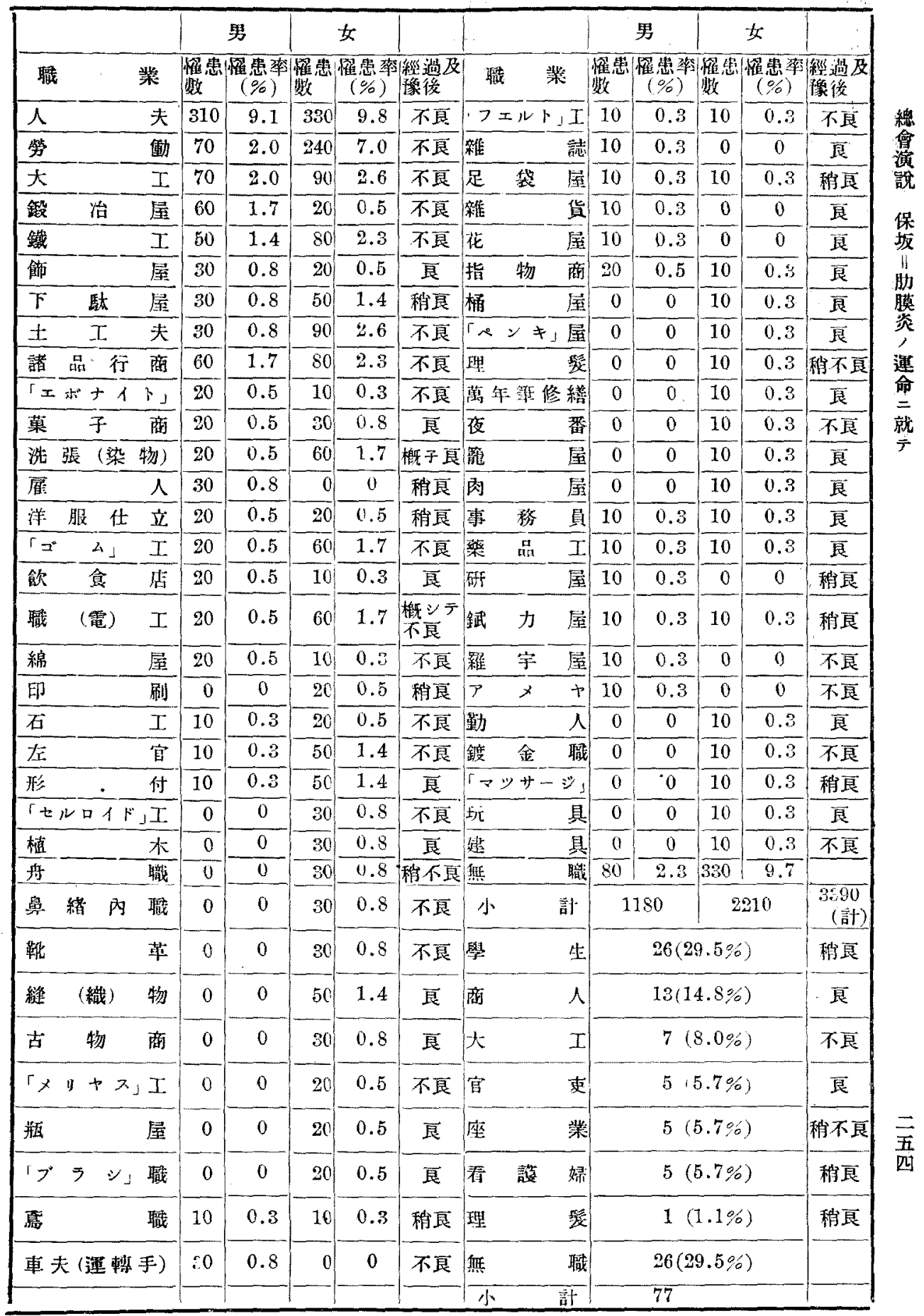


テ要十本結膜核誘膜 斯之り姜果炎性發炎 ル胢。为 $\rightarrow$ 腹

場膜 ソ報腹膜心併

合炎

万人

, 告膜炎

何七罪之ト

經 併

レン患二明 テ

解 $\rightarrow$

城

肋

稓采 1

運齐

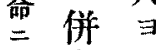

就 發

症 文

連

命 ラ゙

$=$,

一 冬

致 期

又 $=$

最

モ多

如九

偶

併古

發,

症 秋

ナ 期

$\neq$ 之

場 二

合 次

二

广 春

リ 夏

三 $=$ 职

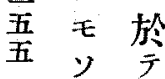

, 少

經 シ

過

橓 シ

モ上二次ナ來

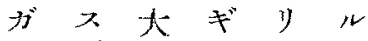

必。十戴'王

ス次管而,

閵枝シ力

モ係加

膜

炎

$\exists$ 答表卜

有 兒 示

閶

䇣

ル

モ

,

ト

'

又尓何

岗 2 V

$ヤ$ 腸 $\rightarrow j \quad \exists$

八障 如 問

議碍 》

論、何 ズ

多心亡唯

₹ 臟夕狹

所病 $儿$ 義

謂

$=$ 等 7

第

公表

テ六品

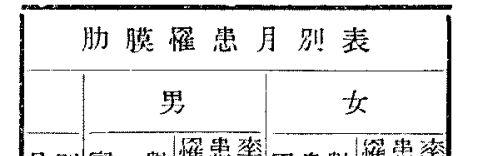

七七時

, 月 期

睢之二

患 二

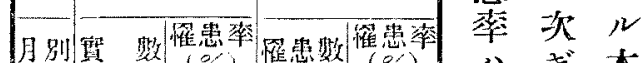

\begin{tabular}{|c|c|c|c|c|}
\hline . & If & $(\%)$ & & $(05)$ \\
\hline I & 224 & 4.3 & 392 & 7.5 \\
\hline
\end{tabular}

八ギ本

夏十症

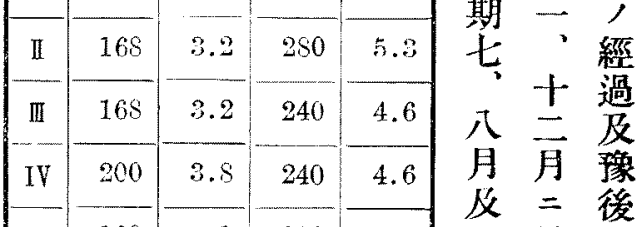

\begin{tabular}{|c|c|c|c|c|}
\hline$V$ & 160 & 3.1 & 200 & 8.8 \\
\hline 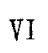 & 120 & 2.3 & 248 & 4.7 \\
\hline
\end{tabular}

\begin{tabular}{|c|c|c|c|c|}
\hline VII & 192 & 3.6 & 400 & 7.7 \\
\hline VII & 224 & 4.3 & 416 & 7.9 \\
\hline IX & 120 & 2.3 & 216 & 4.1 \\
\hline X & 160 & 3.1 & 240 & 4.6 \\
\hline XI & 64 & 1.2 & 192 & 3.6 \\
\hline XII & 228 & 2.4 & 216 & 4.1 \\
\hline 計 & $2028(28.2 \%)$ & $3280(61.8 \% 6)$ \\
\hline
\end{tabular}

尌、祭

月 後

二者二

最二男

多於文

ク $\overrightarrow{7}=$

秦一缽

シ 不 䧼

順問 絬

余位り核

正, 及

此り僧氮

兩月稍

期早

關 $卜$ 發 管

隨係 症枝

$=$ 中 加

就而肺答

テシ結 兒

小广核

决

特此公脯果三命症

洎二主等 $\bar{x}$ 大件り，

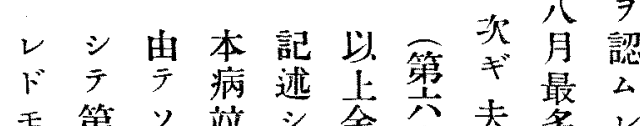

二 黑

八 7

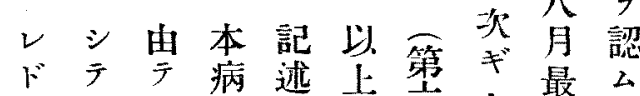

重注位二肋如大七, 羁

夫多

十意 $\ni コ$ 膜 クルテ多患

表等多

)

u

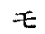

不占り炎大影来》苾

7

觀 ベ

以

察 $\neq$ 五

$\bar{\gamma}$

略 留

小年

經 $+€$

過 - 前

及 若

敄 + =

徭 二

$\therefore \overrightarrow{\text { 月 }}$

夏最 テ

期 少

, $\bigcirc$ 之伴十及種疾過

佳 シ 一

下左 $\%$ 开 種 ボ疾患及

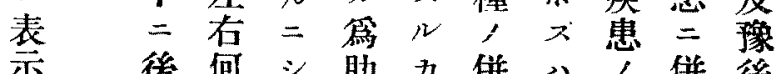

峎・月

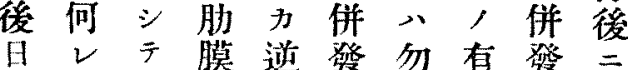

二要及

示

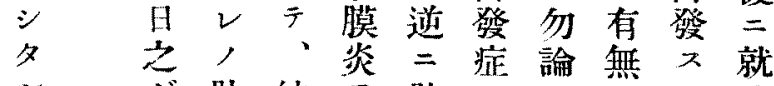

冬之八

期 男 月

最女最

琵 7 多

溥 名 
滲儿肋 $シ 5$ 数關肋

出 7 膜 2 異 5 膜

液見炎而夕常

$\exists ス ゙, * n=$ 脈 經

》。血亏如シ搏過

見液之引》數中

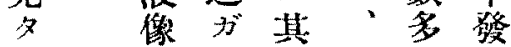

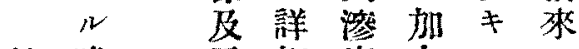

結豫尿細出之モ天

後性二液呼

論 垃

綎

經

逼

ナ

經記、

F 過述 $>$ 如後脈

E = 久

此就几終場良

, テ 所》合ナ微

渗 $\quad \longrightarrow Y==$ ! 繁

出余的於、或

液 八心文此

基. 先 $シ$ 一最關

他二。時不係熱

二䏫輕良八二

關結“熱子恢

シ 核 或 y復

于,$\quad 卜$ 期呼

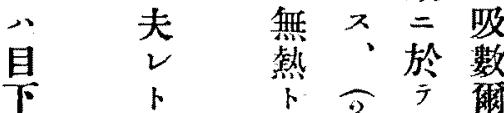

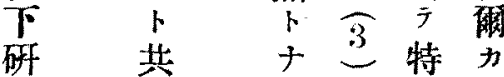

究 $=$ 熱 $=$ "

中 砶 以 型然多

+

ル

$\exists$

以

承

次

问

$=$ 膜

待焱般, 又牀

外

$=$ 肠 $卜$ F

$\therefore$ 膜 $x$.

肺羅 '而

結 患 $\overline{2}$ モ

核 2

\begin{tabular}{|c|c|c|c|c|}
\hline \multicolumn{2}{|r|}{ 第 } & \multicolumn{2}{|l|}{$t$} & 表 \\
\hline \multicolumn{5}{|c|}{ 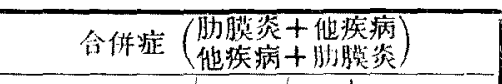 } \\
\hline 病 & 名 & 賽数 & $\%$ & 櫂過及潗後 \\
\hline 肺 & 維 核 & 2940 & 50 & $\begin{array}{l}\text { 般三不京 } \\
\text { 再發最多 }\end{array}$ \\
\hline & 性腹脱苂 & 588 & 10 & 鸼ンテ不良 \\
\hline & 枝加答兒 & 471 & 8 & 艮 \\
\hline
\end{tabular}

致 後

X $八$

2 上

$€$ 述

二 如

非

冬 湜

期 鿁

䍜 保

热 坂

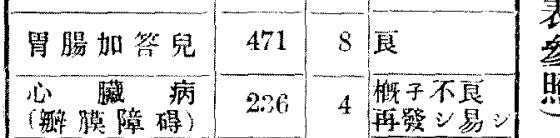

助

E 膜

, 焱

$=$

不

良照

$=$ 就

シ

テ

夏

春

期

最

良

\begin{tabular}{|c|c|c|}
\hline 肺阿結核 & 59 & 1 䅌不良 \\
\hline
\end{tabular}

)

此

頚腺腫服

舅癌

(胃下活症)

貫酸(分泌) 過

1 不良 多症

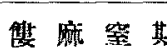

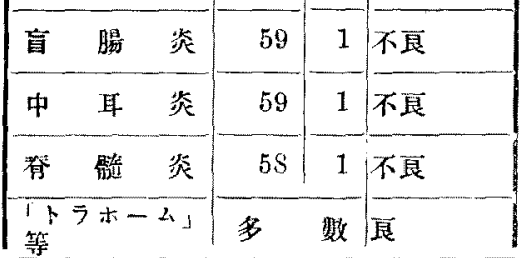

，熱 呼般

一型吸症 シ良般

モ 特 略關恢輕

同 係復減

樣 八時 シ

r $\quad$

+ 兓, 夕

點

$N=$ 脈 $N$

如知搏二

于 $=r$ 併 $干$ 豫

》川大發心後心

併

症

r

多

少

胁

膜

本

病

桃

承

時 吾

卜男子痛

云子り其二男症

必

ᄀ 二 卜他就女, ス

７於踓二王何 經

得 $\bar{x}$ 待 $、 义$ 過

$\dot{y}$

E

心不一ッ上二或 


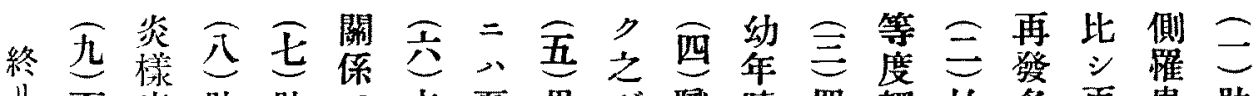

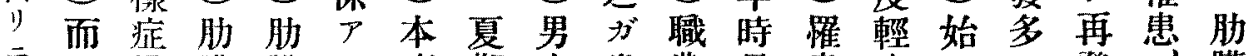

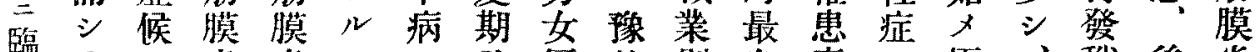
政 二 = 炎炎八, 及何後別良萃二極、稍後炎

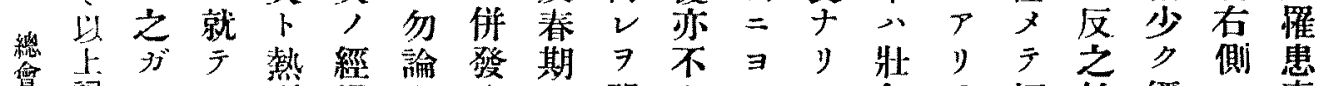

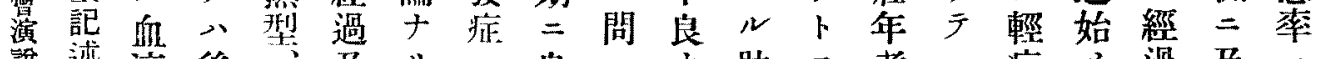

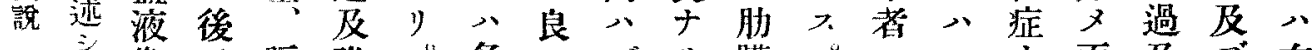
圾范記搏後

助詳尿述及分

啾緗性

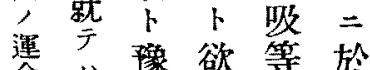

俞後㣪、下砍

$$
\text { 就 }
$$$$
\text { 就 }
$$

再 及

報 過

告 就

兮滲不

所入出良

特液 子

心 二 性

心著狀き

港奛,

ナ少,

見 如

關多 シ

保

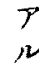

$\exists$

知

亏

זั

吾

像

後

及

ビ

㐐
$=$ テ 期

最冬七

多 期

$\Rightarrow$ 八

秋最月

期 惡 及

之 $シ$

次

ギ

春 月

夏

最

少

:

而

*

广

\%

,

經

過

及

豫

後

是最然

是少少年

娠

時

來

s

助

膜
併等

發

症

，經 勞

良過二

否寻

$$
=
$$

密

接

F

ル

位

$=$

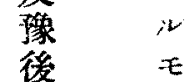

- '

般
唯

患

八

等

動

及

學

生

如

滆

過

N

肉

解

運

動

或

不

鼻

晋
最旦 $ル$ 側豫

多治力十後, 左 癒或 $几$ 八 幼天八 年 2 重後亏 側 之毛症他不經, 二再二, 良過順 次發 $シ$ 一 長二 ギ 八テ 側リクシ 高可一二 “解 天 蒢成部再又後兩 最y死 發始比 側 少多亡入入較最 シ シ 經 ソ夕場 側不 過, $儿$ 合瞧良而 及鳇モ心患且 豫後, 可, 後亦 $\exists$ 成 $モ$ 再左 八重除り, 發側 概 篤 子ナ心多後易膜 羅儿之夕雨 患 コ $\rightarrow$ 豫 側 、 率卜豫後二反右 二多後最罹之侧 一言不患右八 致。佳良天側 三 又良生当,

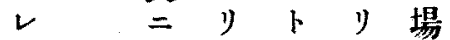
ド シ

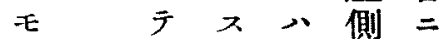

老再。潒二比 年發後至 期 亦及䌊 二 少經 モ過 不年, 唇 良年不 $=$ 良前始 シ E $E$ 者 广 中 $=$ 左 
之一 $\mathrm{CO}_{2}$ 本斯知, デ被圖檢ビ吸㱦呼 ヨ 定\%裝濃儿。如更檢，查顯作八吸

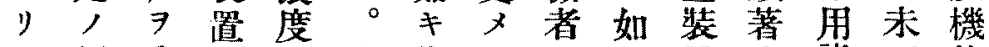
圖傾乘, ’此曲テ学置子諸名能 圖斜 $ス ゙$ 容時實線酸空シ 八, 因充, 三 $\exists 2$ 積間羷 $\exists$ 素腹・デ事子分炭 示示心的, 示 $尹$ 時同卜項, 大酸

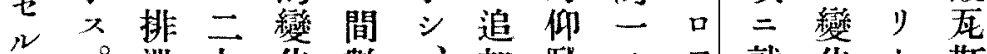
式。泄杂化數、加医，，就化上斯

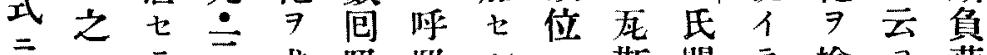

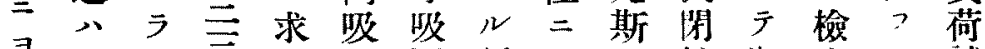

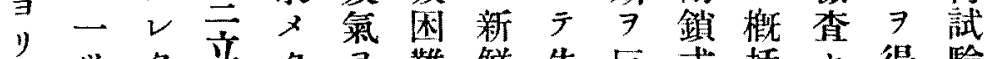

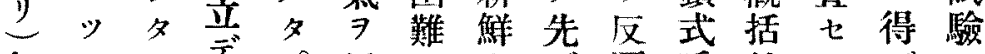
每 ハ

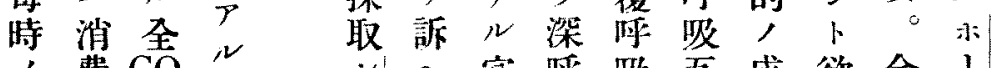
, 費 $\mathrm{CO}_{2}{ }^{2}$ 。 酸七量度和夕襍吸七斯績シ等グ 素亏寒實 消 $v$ 得驗 費 タ心 中 量 酸 ク 尹 素 算量從 出下 5 得排之至

乍 然上分, 呼炭 $\mathrm{CO}_{2}$ 彎 吸酸排 豊鬼泄 補 分量 7 正 傾算 斜, 㼛 呼差 次時

紧 $\exists \geq$ ? 速”下容 迫 方㿼 侍生出 7 , ズ 来 知 呼次少 吸, 呼之 , デ吸 こ 變〉曲其 化 ル 線 時

1 時

$\nu=$ 裝行 $\gg$ 謝述本可 $\varkappa^{\circ}$ デ實置 、!装心實及 1 1 驗内 $シ$ 呼置 y $\exists=$ ×吸, 氏止哚肺蓮炭始便 1 裝 置 $之$ 量 $\Rightarrow$ 吸夕ル始 三。马曲 收, 方メ ヨ此㕰線 角 デ法實 り曲吸 $尹$ E

炭線七畫 酸 $\Rightarrow$ シ 751 整分 斯析 24 云

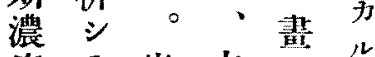

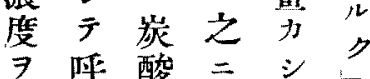

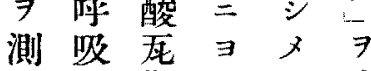
定容斯 \%夕除 量蓄厅。去 之每筫氮 当分共 リ, 三望 實呼呼氣 驗吸吸 二故八, 經 数 > 過及漸 區 中 ビ 次别 , 換克 的 炭 氣進得 酸量 死 $\Rightarrow$ 圖次 實多 尠 驗 鞉 ナ 例, 》 八健 ナ 未康 名者 多及 ク ビ ド $ナ$ 㭧 $モ$ 山小 亿者廣 而,$\quad$ 只

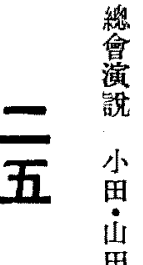
岸 酸 酸 正斯 斯 吸 入挐

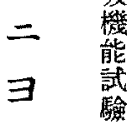
ル 呼 吸 機 能 試 驗 デ就儖田田 $>1$ 呀 ルテ諸

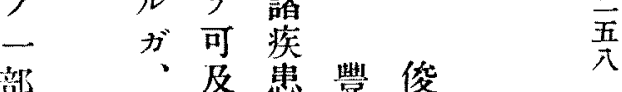
部、及患豐俊 吾 $\Rightarrow$ 實的 $=$ 驗多於 方 數尔 治 郎 法, 几 及呼經 
†康シ全呼者ビ實八刀炭氮的人之氮淢 以

七者テ㾤吸デ高驗全低酸胸小工二腫萿士\%

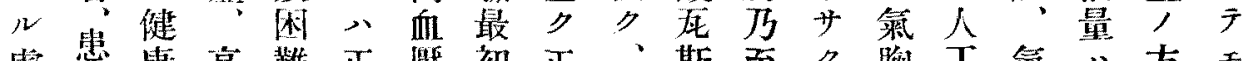

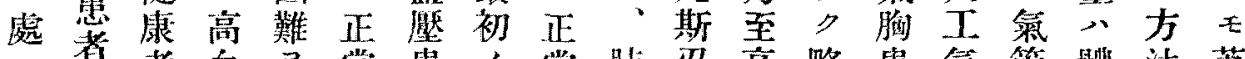

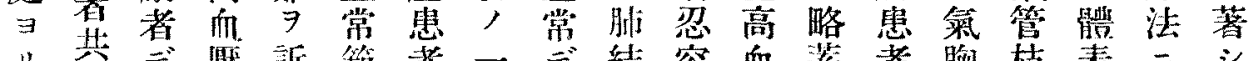

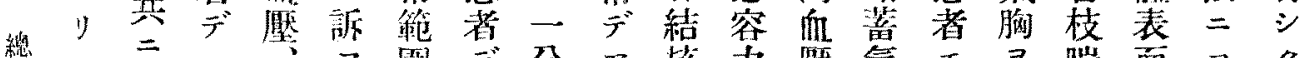

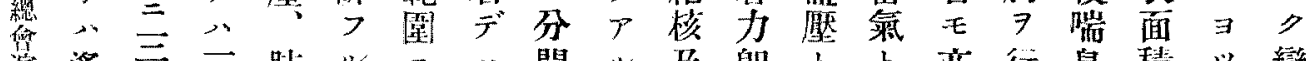

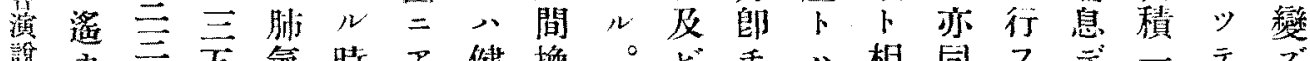

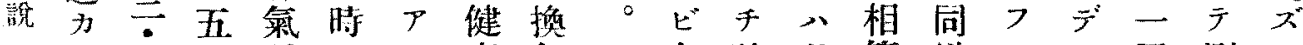

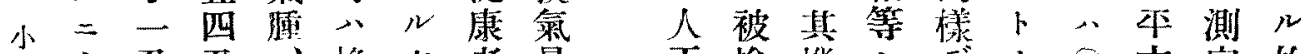

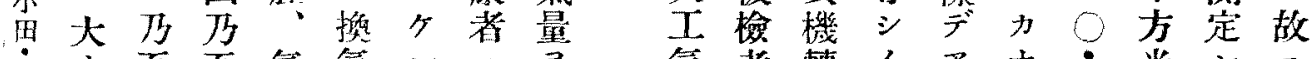

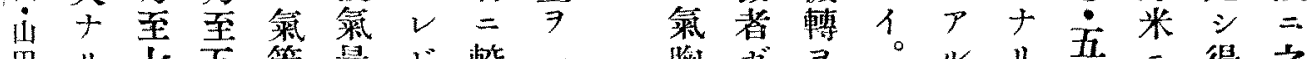

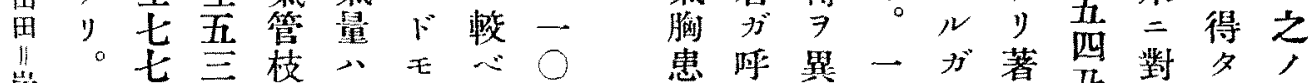

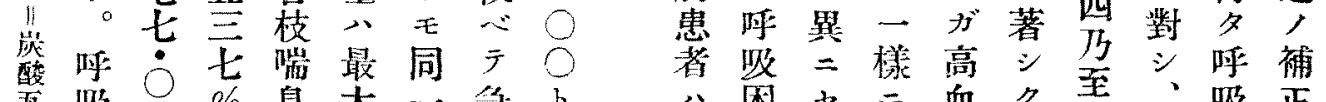

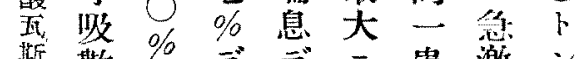
斯数 デ デ デ二患激シ

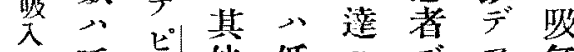

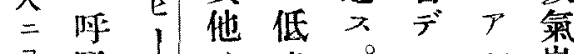

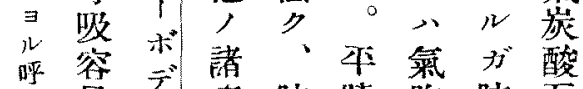
吸量

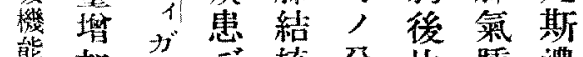

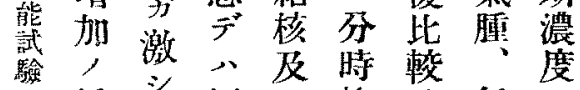
低学何芯換的氮， キ浦上人氮急管增 七運毛工童激校加

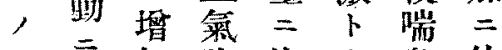

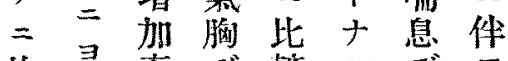

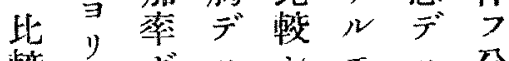

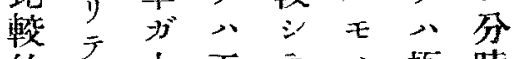

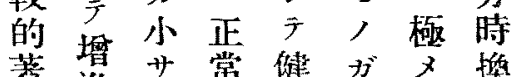

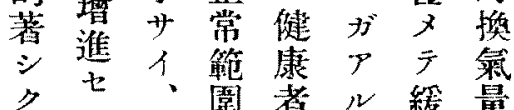

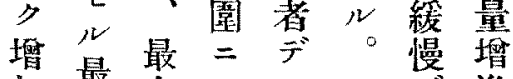

加最大羿学進

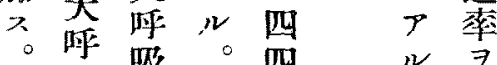

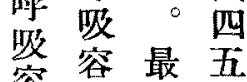

富富最吾盟柴

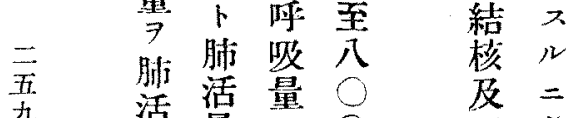

活塏墨口态

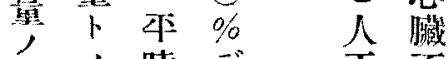

1 比時怘志不

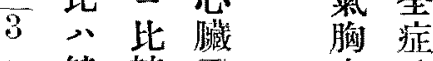

卜健輠不

患及

八困七三血夕至、吸正

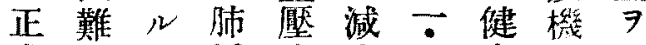

常 $尹$ ? 活症少 康能必

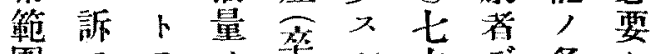

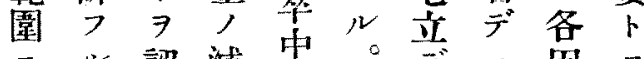

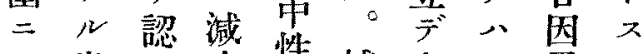

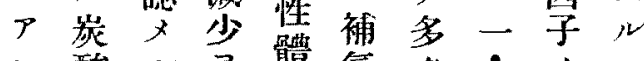

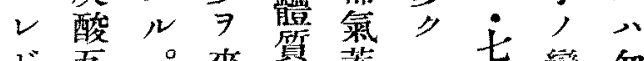

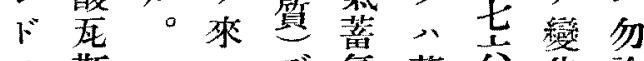

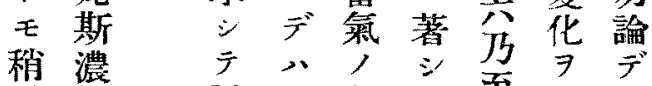

低度居菩割》室概?

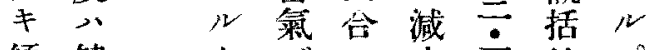

傾健》架少少的

向康々甚健学二

者著多康广立述

示二モ小涺居空心

天比・变光本心

之較䐆”、載暧均

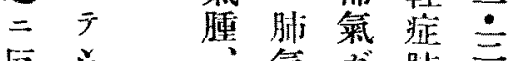

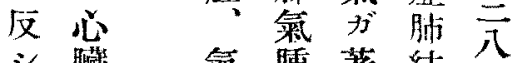

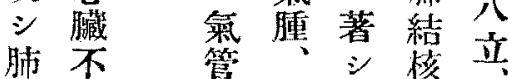

氣全枝氮”患心

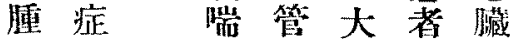

及息枝デず不

飞゙ 飞公喘心 モ全

攻高息銦稍症

管血䏼デ不減

枝檿不入全少高

喘患全補丵学

息者症戴脑后

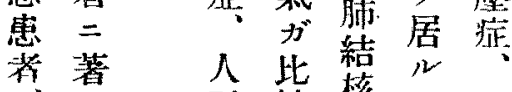

デ

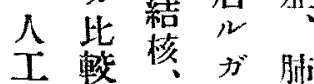


小小不

モ ガ 咸

亦值蒸

疑 二 泄

問物引

質里

1。代 总.

印, 学

千 大

余小

글.

是亦等 总

, 指

關 針 溫

係 十調

7 笛

䦩 $ヤ$

明否營

ᄌ+営

心゙ 二 㹂

發 就外

熟 沓

議 排

浮 論 沘

腄多現

”、象出

物十 妶

筫本次

代機 事

謝能事學

買 $\boldsymbol{J}^{*}$ 沼

常第当离

等 譇義高管

種的以

, , 來 進

病 水之

的 分

牀，調 疑 藤

態節 7

二作人

就用十

テ $\Rightarrow \neq$. 值

, 有毛

不州作

威ヤ

蒸否大
心血余殊余正示不上就每

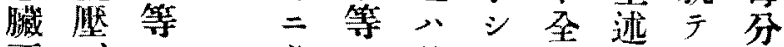

不”, 心 心後夕症,

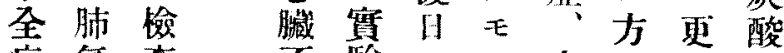

症氣査不歌, , 高法二在

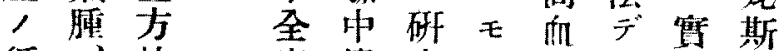

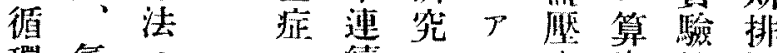

環 氣 $=\quad$ 彎 $=ル$ 症出例泄演

機 管 $\exists$ 結此的·讓、及

能枝り䊝二ル然ビタ重”

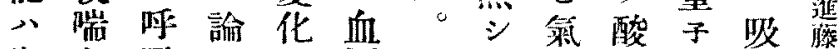

炭息欧

酸患機著及此忠消儿炭 不

死者能 シ ビ 等者費後酸䈋

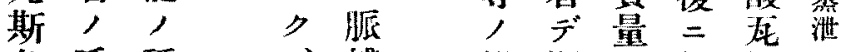

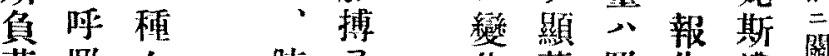

荷吸々肺 $尹$ 化著吸告濃

二機+氣测

對能 埂定何增炭心, 臨

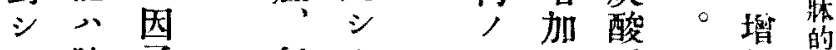

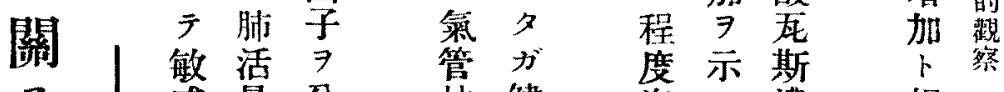

ス 感量分枝健汽七濃相

デ及析揣康邽ル度庈

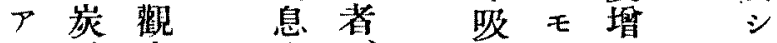

臨

ル 酸 察

○死

斯 ル

但 $=$

渮 ト

鹳

$=j$

岿 出

大 本

N

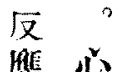

$=$ 臟

於不

公

各症

相肺

篹 結

核

態人

度 杗

取 䐳

䯩
患串位，加

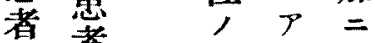

八 严

健 的

康碞

熯

相

堂 近

ナ付

イ

共

$=$

著

兵

増

加

亦

タ
7
變り件

化、 7

二又呼

化 反 吸

少充

モ 健 進

, 康 =

デ者不

又拘

2 小条

力肺 夕

一結 八

力 患

二暮キ

断 = 綵

定 減 化

シ 少

難セケ

ク心

、奇

之現

广

慚

次

減

少

7

而

シ

テ

健

康

者

各

薮

病

倜 三

閐

ガ象心
相

違
遮核著 
第

姓名 莕 38 蔵

\begin{tabular}{|c|c|c|c|c|c|c|c|c|c|c|}
\hline \multirow{2}{*}{ 月 } & \multirow{2}{*}{$\begin{array}{c}\text { (A) } \\
\text { 䯏醒 } \\
\mathrm{g}\end{array}$} & \multirow{2}{*}{ 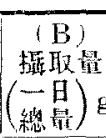 } & \multicolumn{2}{|c|}{ (C)排出㨁 } & \multirow{2}{*}{ (D) } & \multirow{2}{*}{$\begin{array}{l}(\mathrm{E}) \\
\mathrm{A}) \\
\text { 日差 }\end{array}$} & \multirow{2}{*}{$(F)$} & \multicolumn{2}{|c|}{ 氣象(正午) } & \multirow{2}{*}{ 䚚 } \\
\hline & & & 尿重量 & 突重请 & & & & 溫溲 & $\mid$ 䇫度 & \\
\hline $21 / V 11929$ & 54000 & 2695 & 670 & 150 & 1875 & & & & & \\
\hline $22 /$ & 54270 & 1650 & 972 & - & 678 & +270 & 1605 & $26^{\circ} \mathrm{C}$ & 66 & 舞熱。浮腫ナシ。 \\
\hline 291 & $5324 \mathrm{C}$ & 2784 & 784 & 180 & 1820 & $|-1030|$ & 1708 & 25 & 55 & , \\
\hline 241 & 53800 & 2699 & 8.52 & 150 & 1697 & +560 & 1260 & 25 & 82 & $"$ \\
\hline $25 /$ & 53940 & 2748 & 798 & 190 & 1760 & $|+140|$ & 1557 & 26 & 74 & ", \\
\hline 261 & 53740 & 2072 & 594 & 194 & 1284 & -200 & 1960 & 28 & & ". \\
\hline 271 & 58700 & 2479 & 710 & 108 & 1661 & $-40 \mid$ & 1324 & 27 & & ", \\
\hline 281 & 58900 & 2362 & 782 & 272 & 1308 & $+200 \mid$ & 1461 & 27 & & , \\
\hline 291 & 53600 & 2550 & 943 & 38 & 1569 & $|-300|$ & 1608 & 27 & & ., \\
\hline 均 & & & 786 & & & & 1560 & 25 & & \\
\hline
\end{tabular}

卜 混 實雱使態尿 少 日 測此 $\widehat{\mathrm{E}} \widehat{\mathrm{B}}$ 郎間 興 泄

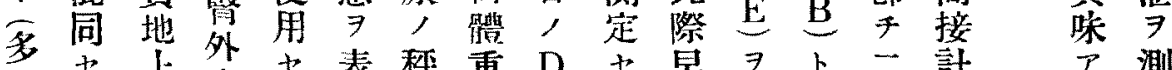
ク 曾 驗合樣会排篇 绩同 $x=$ 感篇日八泄 $\neq$ 量間依方二

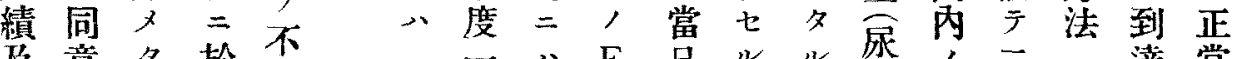
及意名於感常

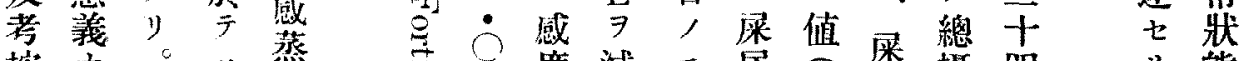
按

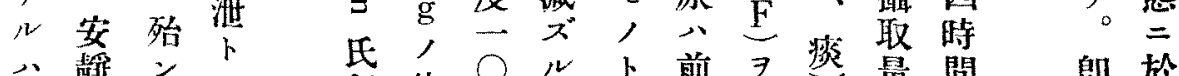

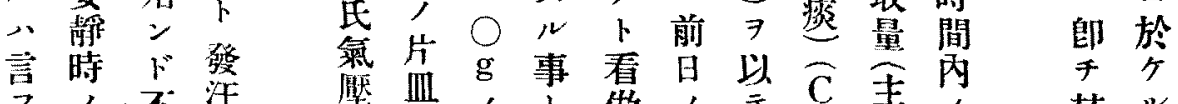

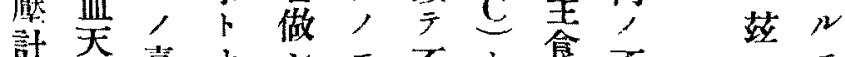

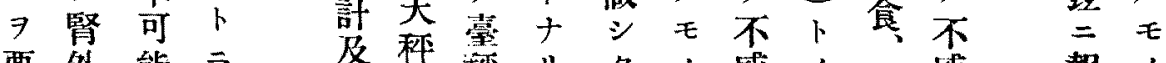
要外能二等称り夕, 感, 副感報,

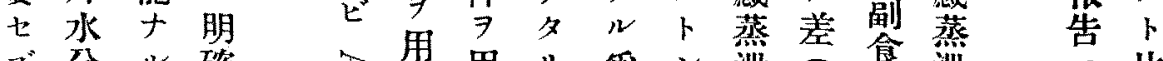

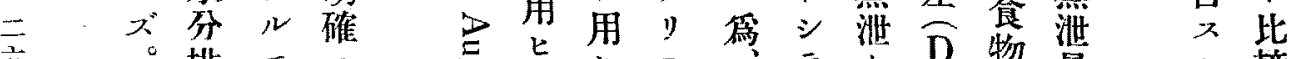

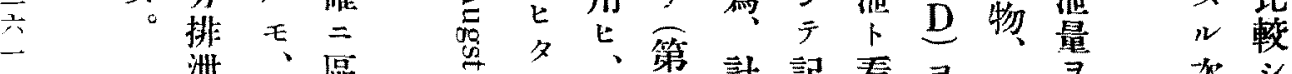

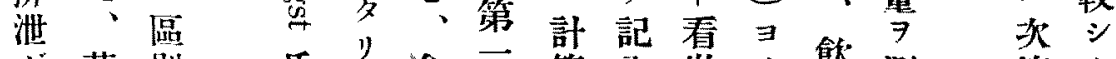

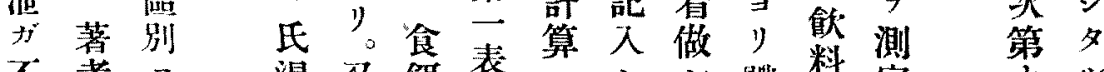

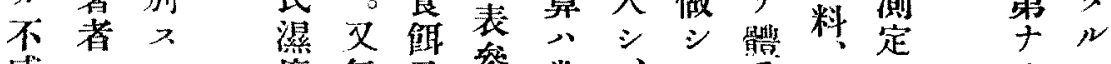

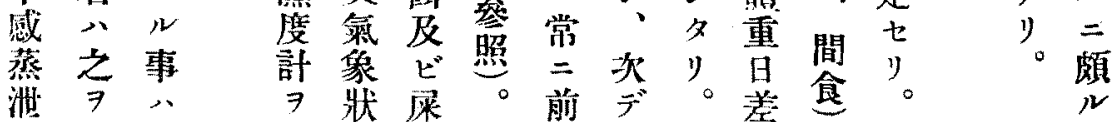


第

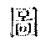

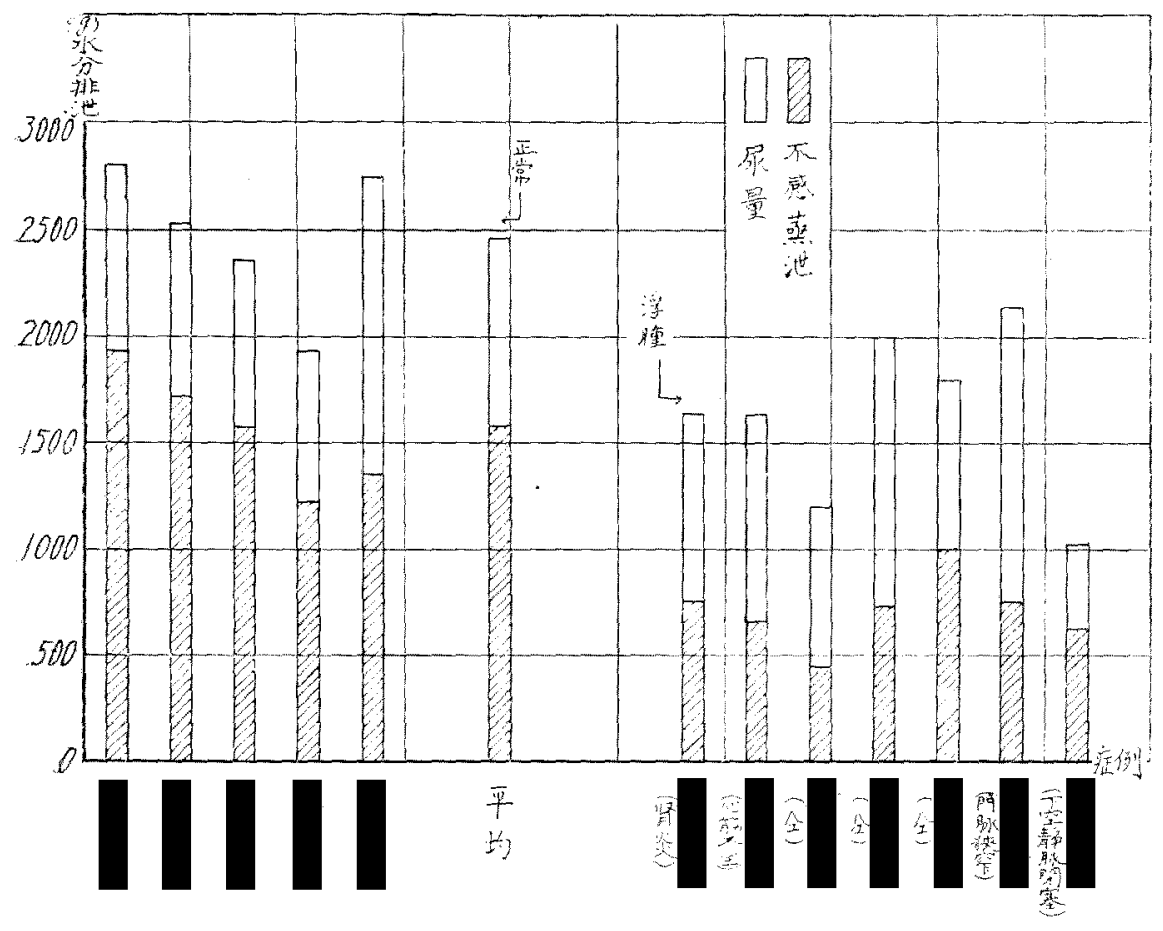

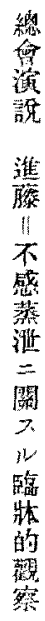

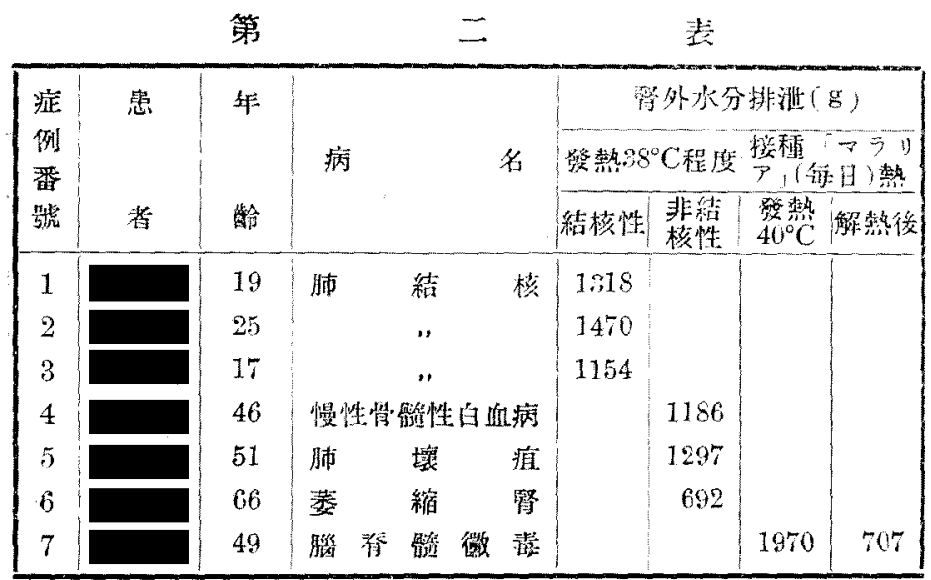

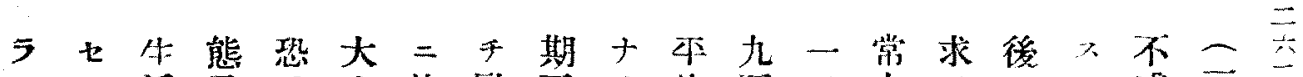

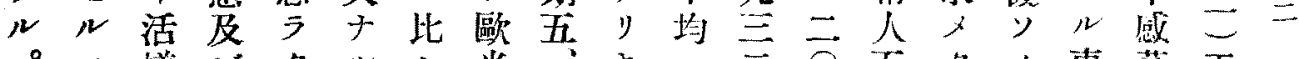

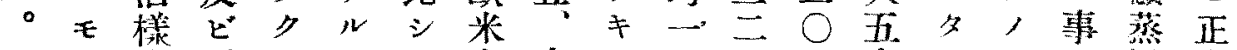

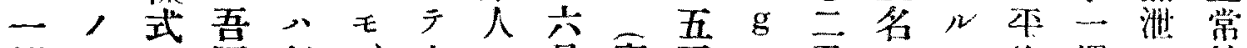

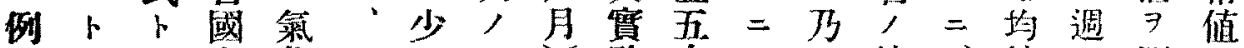

$\Rightarrow$ 考關人自

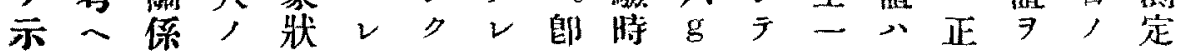




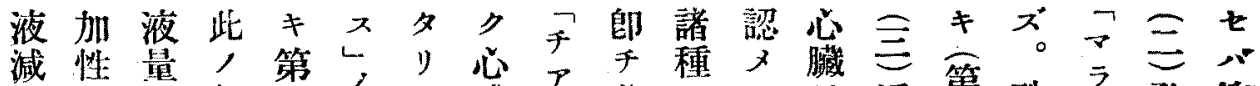

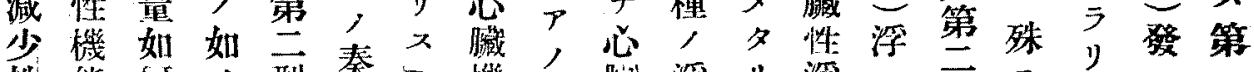

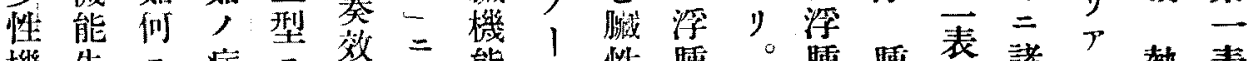

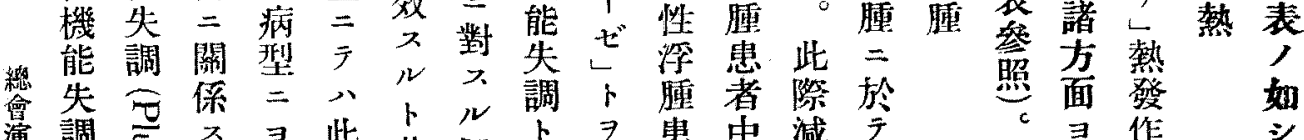

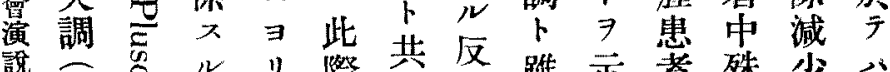

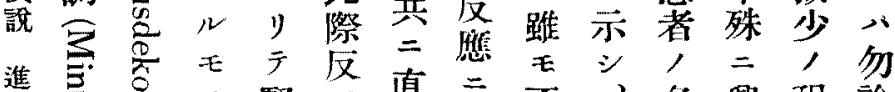
滕壳, 婜\%直二不、多興程諭 光贾十外于不亦感且數味度腎

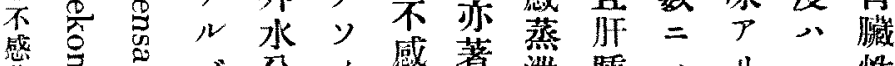

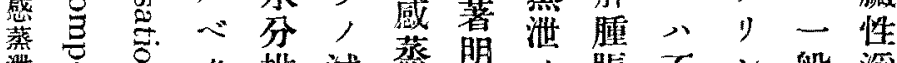
泄氖”排減烝明, 脤不シ般浮

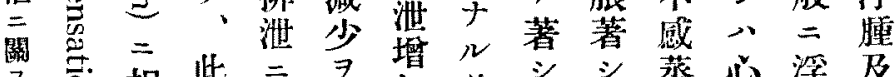

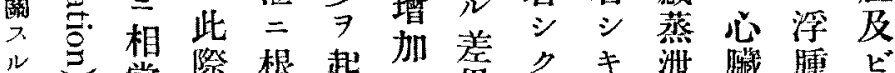

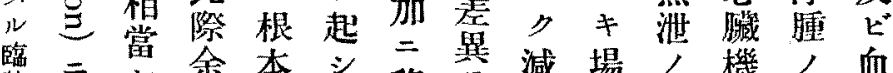
湈三余本乡移基減場, 機, 血 的一白的夕剓示少合著能程管

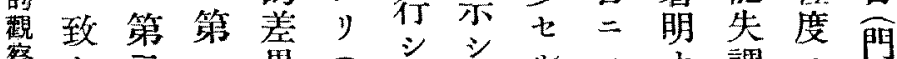

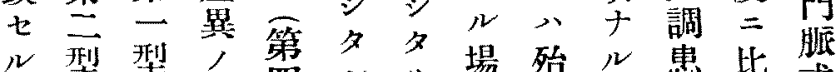

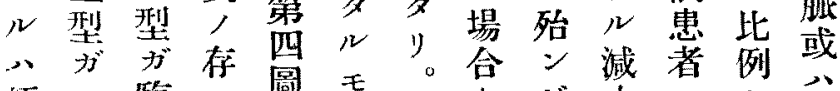

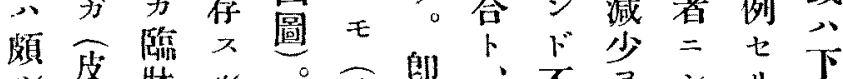

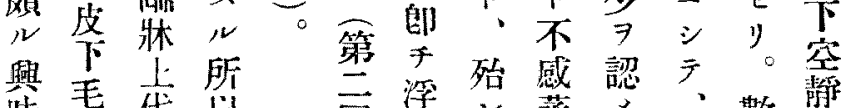

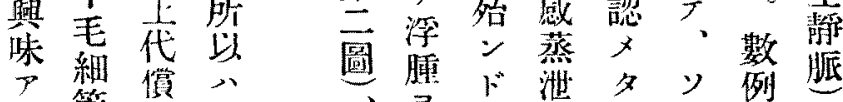

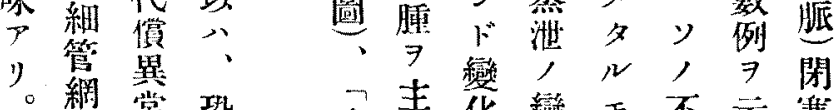

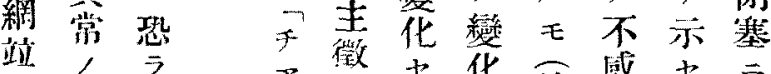

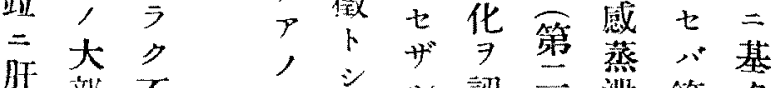

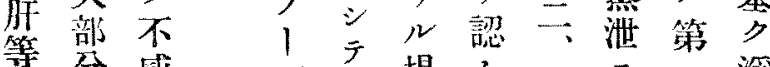
分咸 ゼ不場㕕三三滛

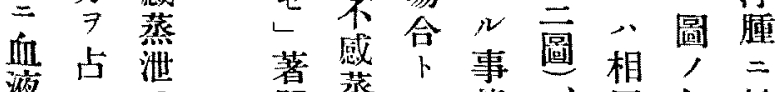
液台浛萻蒸宁事递相, =

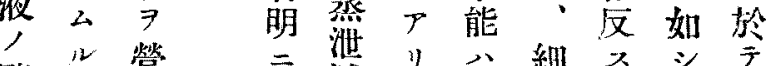

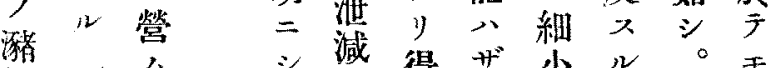

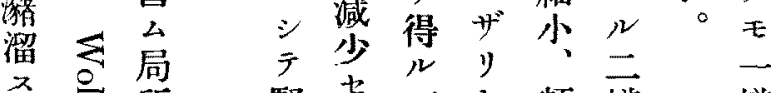

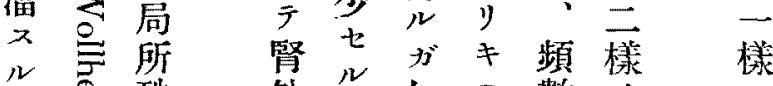

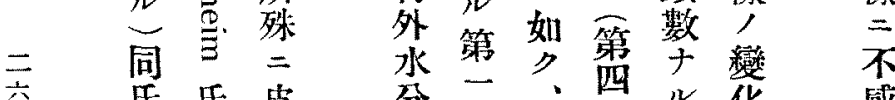
音氏皮分型此圖必炛威

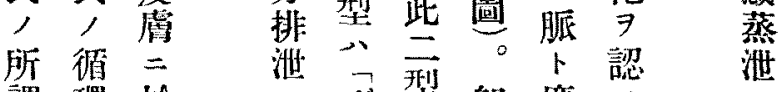
謂環於三天型郎黄学,

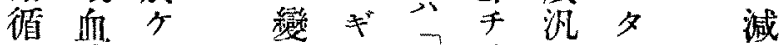

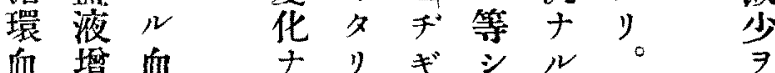
$\exists$ 作 基如

礎手 代 高

謝 熱 充著

進

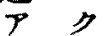
》 水 卜 言㹂 八外 排 、泄 結 7 核 增 患 加

者 즛 $\mu$ 熱玉

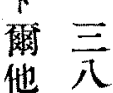
, 度 非 以 結下 核, 性 發 熱 $r=$ , 間 二豫 毛期 何 等 名 , 荎筧 異 加 $+7$ 吕認 

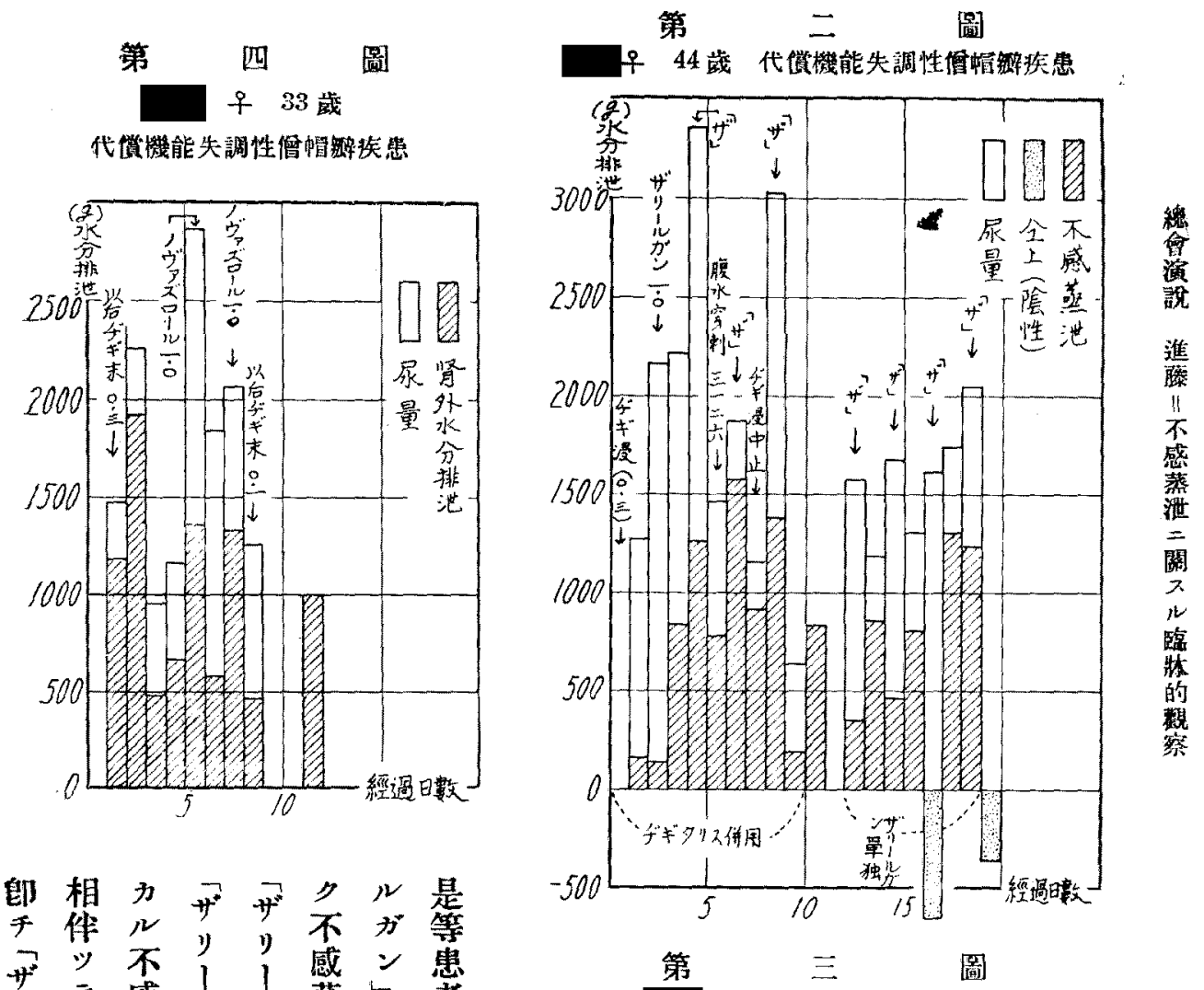

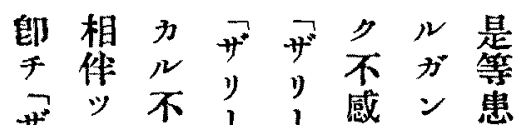

ザ テ 不

1 同蒸 $カ$ 時满

ガ

背減卜使少》タ

ᄂ 加少共用七, N

小又心二前

卡儿全不二云射尿

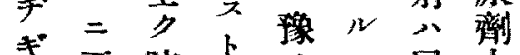

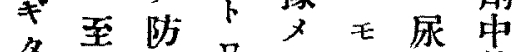

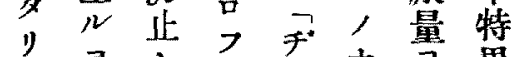

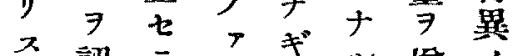

簇

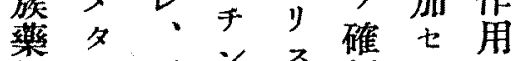

物り不亡

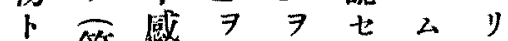

併第蒸泩舆り沙

用二泪射 $>$ 区

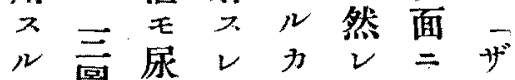

時 圖 量 心或

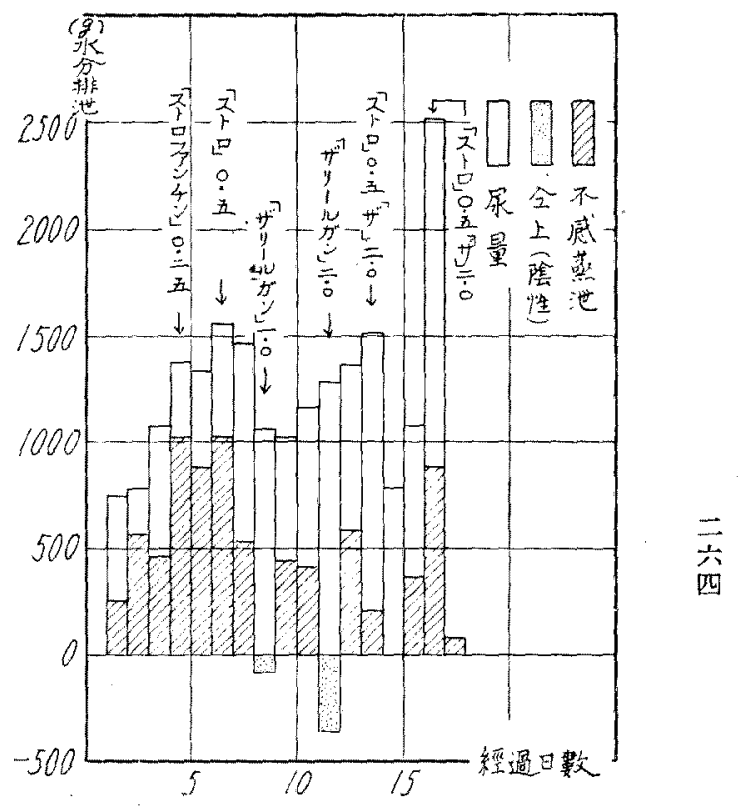


第

五圖

古 25 歲

接種「マラリア」十下空静眽閉塞

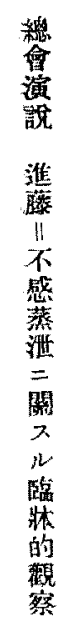

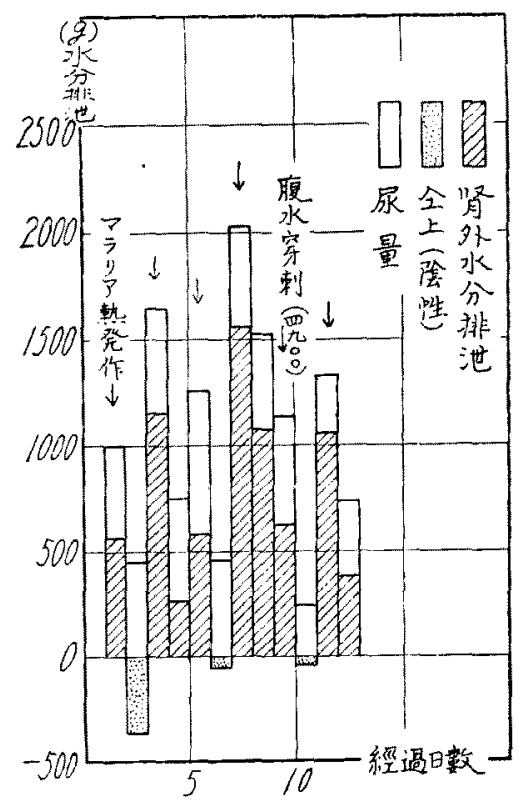

加腹四加能分心唡开，

亏水回七心排飞性少脱 起著浮シザ泄、ト!水 シ明腫么增今ナ葆 タナ患儿ナ加假り架果 ル著固り二=得方心 モ浮劣有。基體ルさ單 、腄墢作他多外事作獨 翌患熱用種體 $\exists$ 實用使 日者狀 $\gamma$, 液りナ中角 非二態儿利調體り。更, 㗶 正尿節内丙。際 作 5 , 汶機二勿注二 日少，例轉水諭目比 、个 如之十分力 極 7 事佛事立造 度接》加八入事所二 二種 $\neq$ 、確七實見大 減シ。等醋實シ，只十

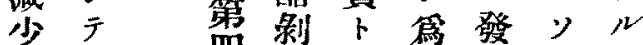
シ У四等考境，モ

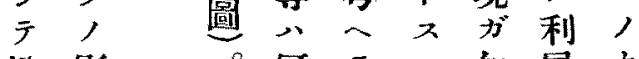
遂影。何 $5 儿$ 如尿ナ 不隌 感 觀 呈ッル蒸徑 入 $モ$ 泄路夕度結患泄

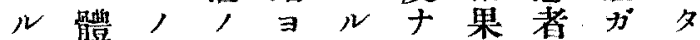
モ外ナ激り卜ル下, 㓌ル , ヨy滅十、人併腹性二

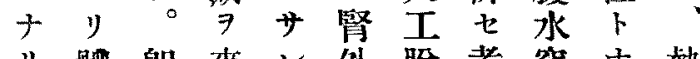
y體師來 2 外脱考第ナ熱

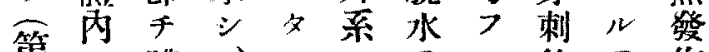

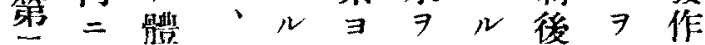
二水表甚卜y起 $==$ 認日 三分 $\exists$ ダ $=+サ \cdot E \not=$

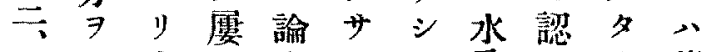
五水々十レム分メり著

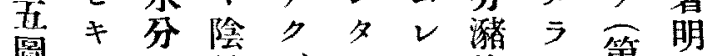
圆”性、心 バ溜々第 分放不何卜璄, 夕吾心

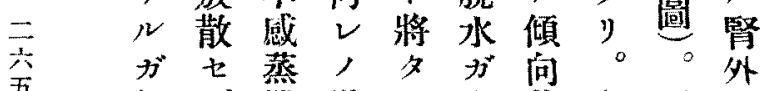
五如ザ泄場。腎著之同水

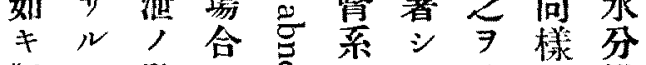
觀, 發

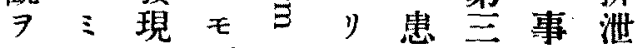

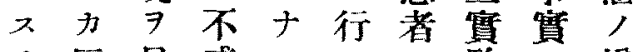
ラ反見感ルッ二驗ハ增
等 $N$ 、何效 !

不。十果

感單 或 $ル カ 7$

蒸 $=八$ 機 極

泄 不 體 轉 メ

$=$ 感 內 $=\bar{F}$

影 蒸二基大

墏 泄 水っ

七, 㞼无

向溫形, 心

。調成十不

ᄀ節 ガ 感

ヴ作增 ヤ蒸

用加 泄

ズ，

， 篇，少

以上研毛

必不究愈

$=シ N=$ :

八王俟大

不》、学

感境此へナ

烝明現 $\neq$ り

泄不象‡遂

增事水ナ=
口ミN來隇 
加心尿十八

之觜病心倘

前外患關詳

節 水者係細

, 分, =十

蕢 排不 $ル$

驗泄感ル追

成或蒸事試

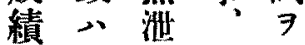

$\Rightarrow$ 不減站必

考威少二要

慮蒸八不卜

入泄多感

v $\Rightarrow$ 尿蒸

心基 二 泄 少

水礎䀧, 考

令代 $又$ 減

蒸謝 $几$ 少 5

發㳙體七心

量長液

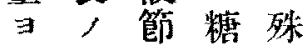

り指䄪尿=

基針機病一

礎卜轉悪七

代認卜著ド

謝 $x$ 禾，1

得考基氏

算べへ礎病

等 $\neq$ 得代患

七ャ心謝者

二否事卢,

卜ヤ等踓袩

万 $\Rightarrow$ E 外

几 倘乇常水

二研考二曶

, 密愿必排

試 7 x

ミ重 $レ$ シ 䚍

$\therefore$ 里 $\therefore$ モ 加

璸

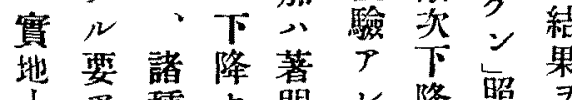

上 $ァ$ 種七明レ降照 7

上ル园ザナバス射得

魔氒子バ

用 如, ガ 發

甚 影如汗

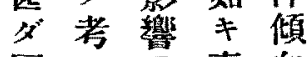

困分事向

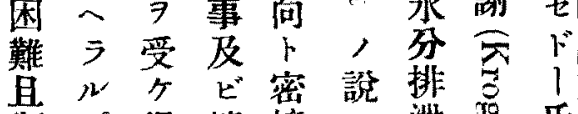

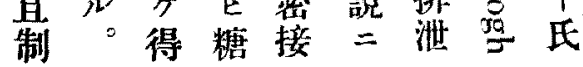

第

分

[⿶ㅐㅊ]

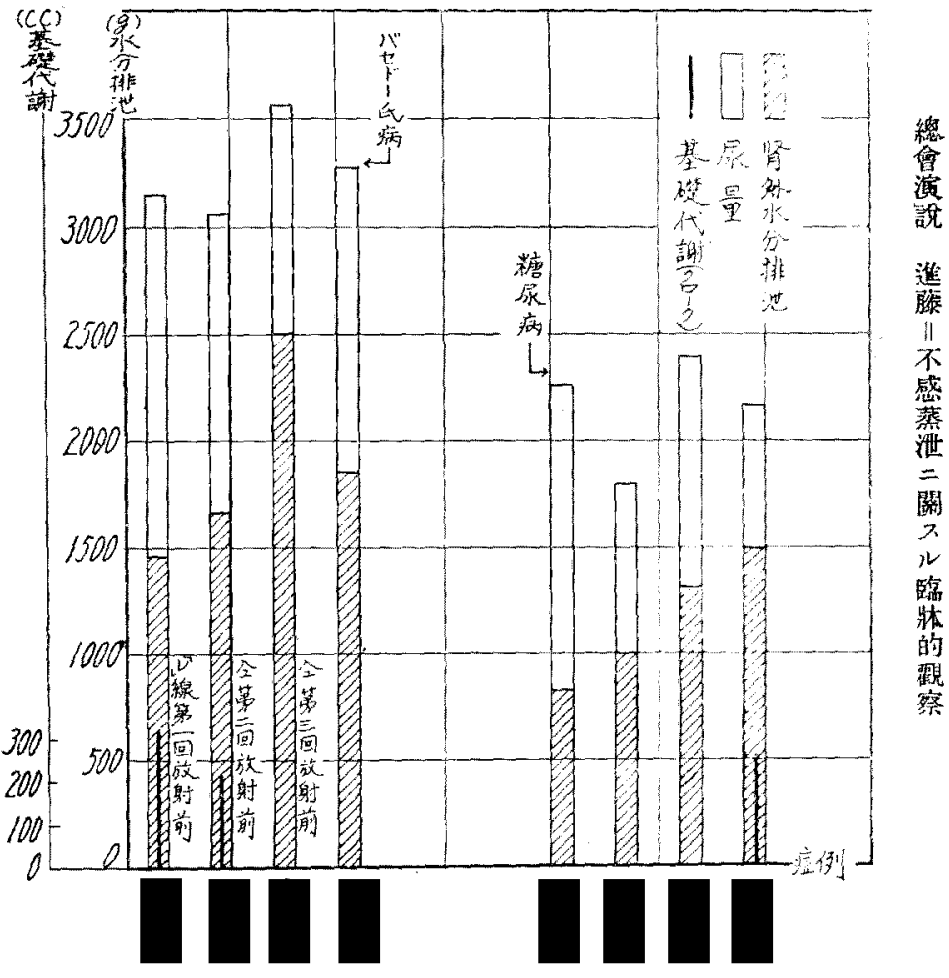

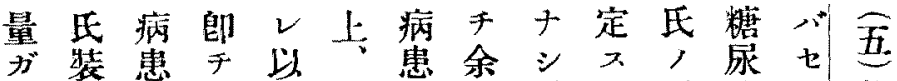

反置者上下四者毛、ル詳病济物

此 事緗，１質

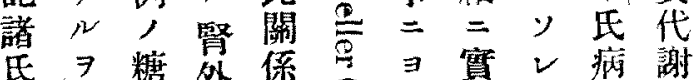

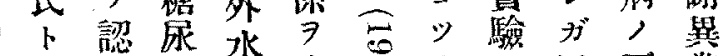

類

似夕患排試 $气$ 賞 $ル \%$ 威

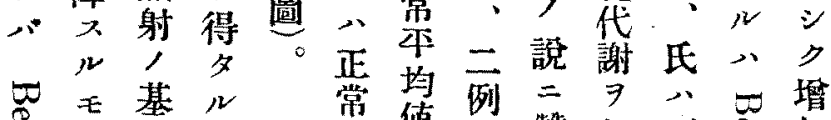

腎礎モ本值, 贊知不焉加

均或, 成少感名 t

值 $七$ 七得蒸密心

又ソドリ心泄年事

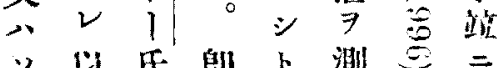

y 以氏 郎卜 测 $巨=$ 


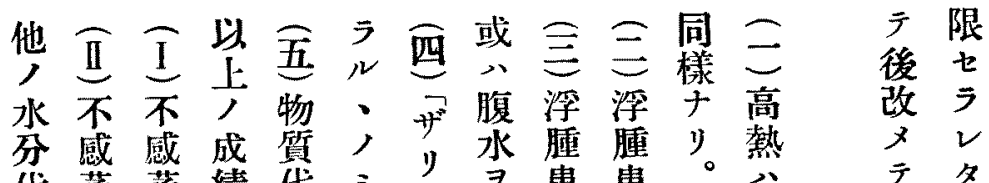

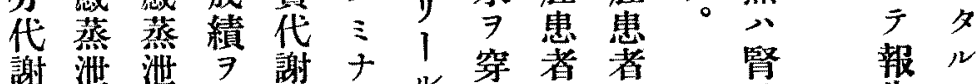
藏

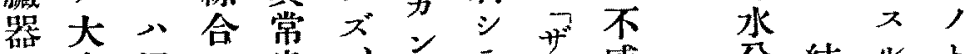

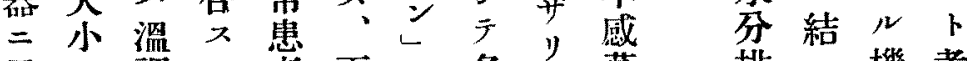
異 $\exists$ 調 $ル$ 著更二多!蒸排機考

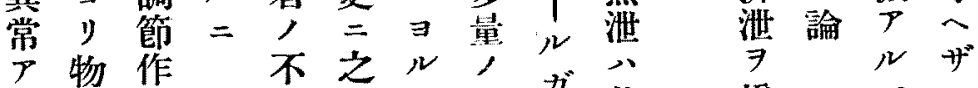

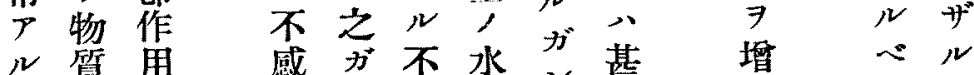
際代篦增感分ざダ加 シ 心 $=$ 謝外泗蒸 $\rightarrow$ 利 $シ 7$ 八, = 量 $\Rightarrow$ 泄排尿 盛第公認, 除 $尹$ 減 , 賷一必減也起少

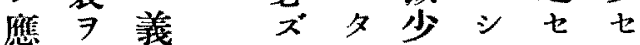

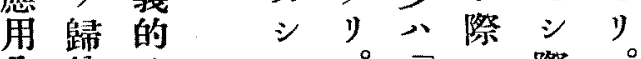

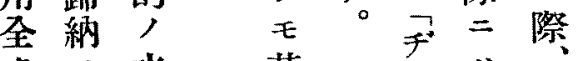
不少沓基 可試調斯》感入蒸 能三節代 㴬蒸

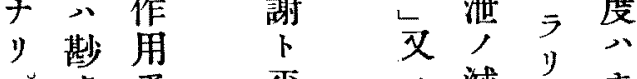
万年分滅少小 E 行攵少点、 實事学市殊熱浮 地碓 ザ 吕二發道 䧗實少只陰作ノ

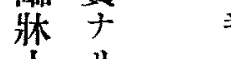
上!

㮣

用

便

于

5

ズ。

言

列

$=$

心

胿

, 愉作程

学不寻度

于感” $=$

蒸 $\overline{7}$

范婜行

$\exists$, 外 $x$

併發水

用現分

入

認泄

事子,

二夕筧

$\exists$ y。㕵

F 訫

防,

此

腎

得

際

度

川

殆

今

尚

幾

多

䣒

鼎

經

驗

結

性

熱

$=$

x

ベ

E

非

"

余

モ

核亦

性症

熱 
壁造性洼邊二出前 $ル$ 斯二師正氣 八影搌入八於現者結心䀜千規管 之劑張壓至 テ 狀程果 $\rightarrow$ 》過緊枝

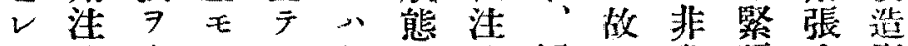
尹 入來必本氯八入蠕二常張力影 收二七要滑管本壓政造二力性法

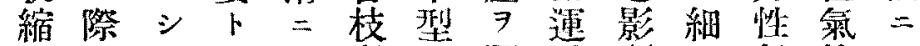

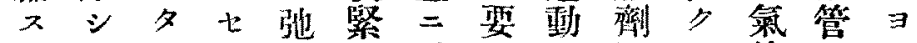
ルラタズ張張於セ二注シ管枝り

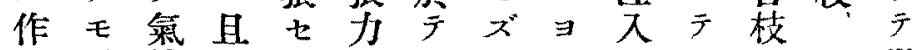
用、管 $ッ$ 減最 $シ N=$ 且 $心$ 得 $\exists$ 造枝比 $尹$ 退モテ買際ツ緊三夕 現影腔較示七良終物 $シ$ 短張減几

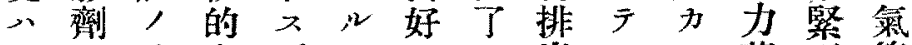
サ八撗多。夕于シ出 、夕著張管 ズ空大量從メル、機高ナシ 力枝 虛像 7 全モ氣轉厴》”性像 且子, 泩蠕體, 管一恰䒕氣 ッ極入動卜ナ枝速要も進管演 又袋 メ

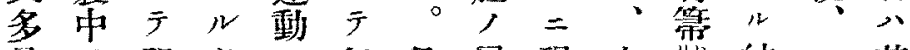
量 7 明必, 莪且展現小狀結西其

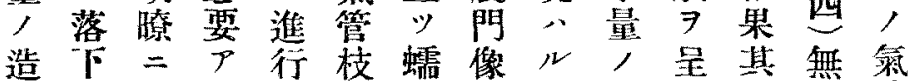

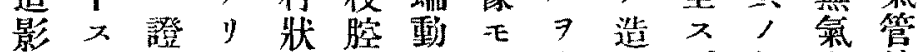
劑 $ル$ 明。態, 運廣常影。氮力枝 $\exists \rightarrow ゙ シ$ 次 $心$ 擴動

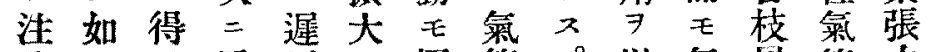
入夕今长 $\Rightarrow$ 極管。以氮展管力

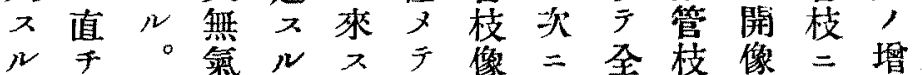
モ 之力力 7 力旺邊正氣像二分減 佾氣 $v$ 性認或盛緣規管 $>$ 於類如 管氣策 2 心 收枝管管。- 售本張, 粨モり二 容, 枝枝少局行滑力充八著。马

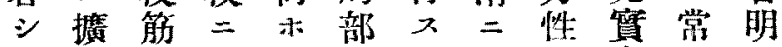
得張肉於本, $⿻ コ$ 氣像二十

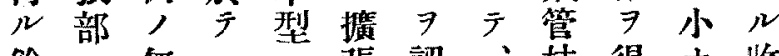
馀二無、三張認、枝得ナ收

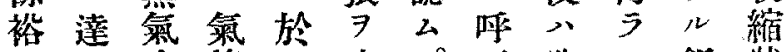
$\exists$ 方管三來。吸造ル鉛狀 示該卜枝心夕又運影。菌態 又部ナ壁造シ減動劑而狀 コニ $=$, 影・㹂二泩 $E$, 保

卜堆ル著劑其張 3 入緊映 多積モ明泩, 力执嗳夕 ジ, 大 入氣性緊際召 氣 $=n=$ 管或張文兄呈

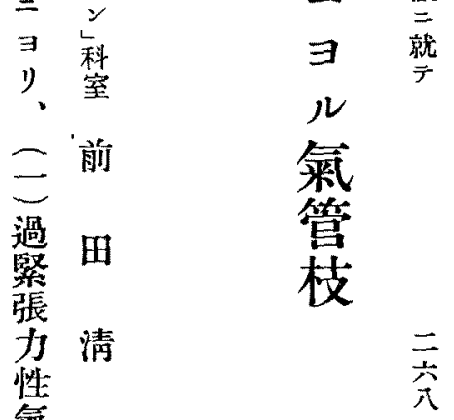
此管 シ弛際䓩管少方隻 。全體 三 郎

氣

緊氣箘

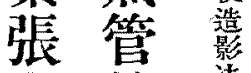

力枝法

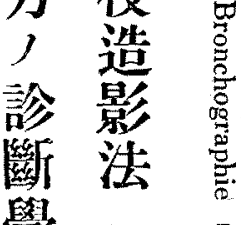

學 $\infty=$

的

價 豆管

值宁箘

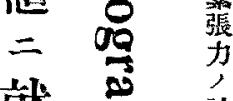

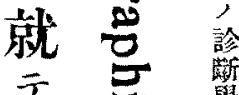

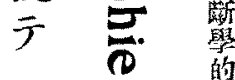

二 睢 


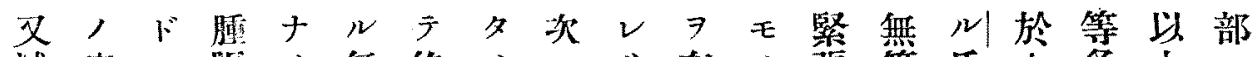

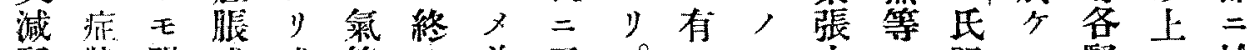

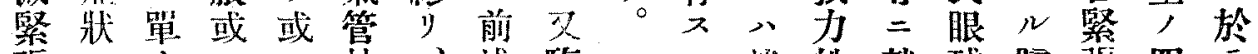
張公广分枝、述臨少迷性就球晤張四亏 力恰儿分呼腔呼七彇患走策亏壓孔力種心

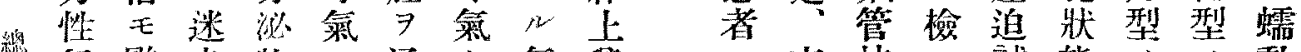

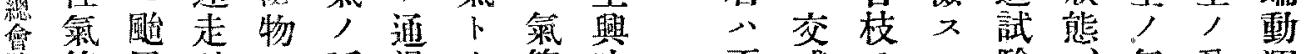

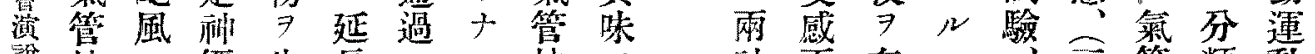

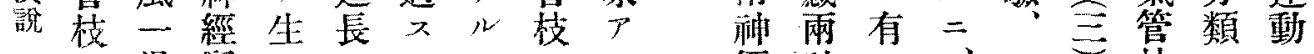

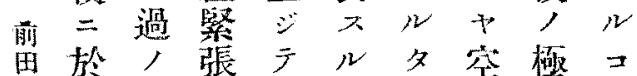

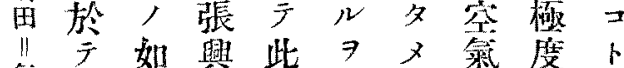
篦, 多奪處常落排, 、 枝㗂牀二卜三除收過

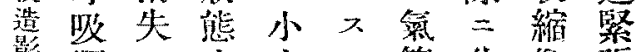
法連入于水 $几$ 管先像 張 法動 $ル$ 淂 三音譬于呈性 際特 $\neq$ 又收氣言氮 管管

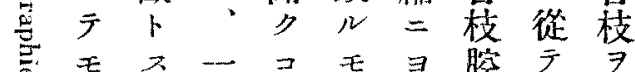
二充。居, 光腔呼有

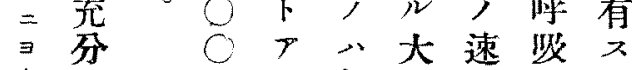

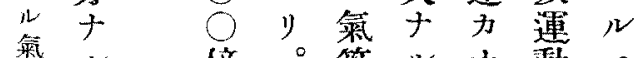

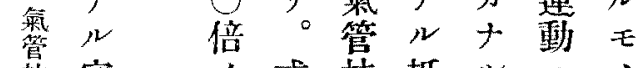

空, 或枝抵 $⿻=$,

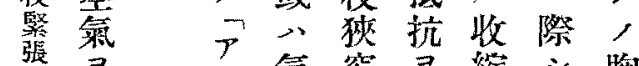

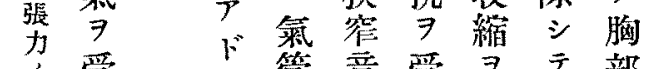

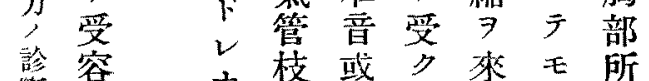
馀容 ナ枝鼓ク來モ所

得 y喘甚二。氮少

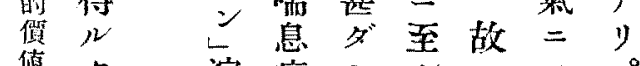

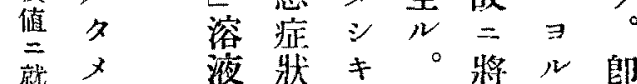

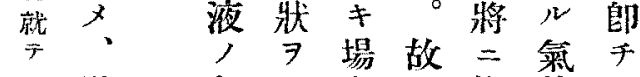

過氮呈 合二排管 或 緊管 張枝ル八般少䐩枝

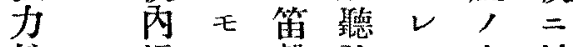
性浮, 蹈彰ン充於

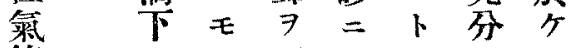
三管 二稀聞際スナル 究枝 ヨレク渒儿緊 二リナ。呼空撗張 於斯 5 又吸或大力 2 聽 ${ }^{c}$ 粘 銳狹見進 如診然膜利縮 天゙ 上， $上 七 \div N$

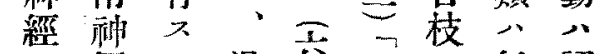
自經 $ル$ 過突 刺 戟刺者張口出枝亏

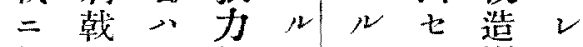
對

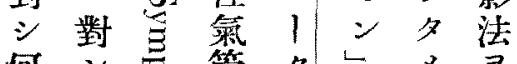
何兰管名菃》

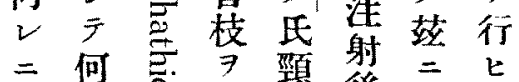

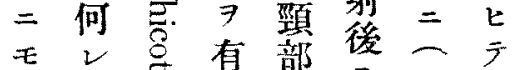
興 $=$ 官不迷三二後

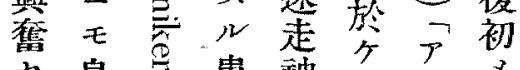

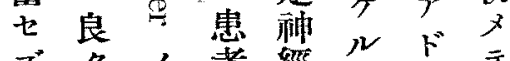
ズク, 著經㭊レ゙

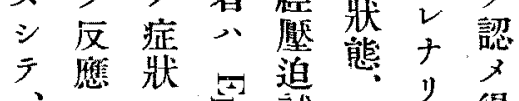

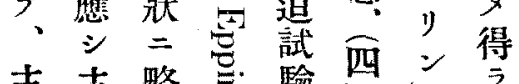

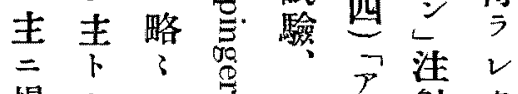

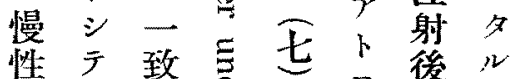

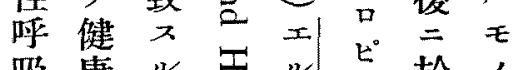

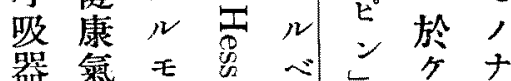

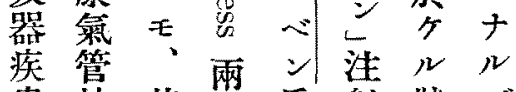
患枝其氏氐射牀

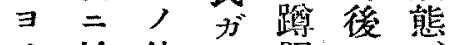

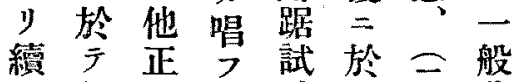
發認賛 $ル$ 驗

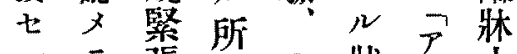

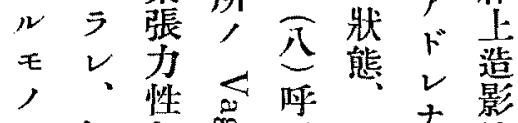

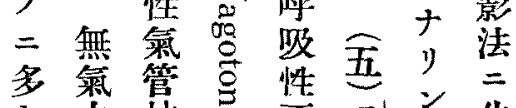

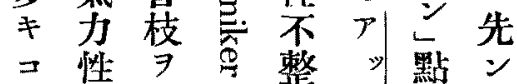
卜氮有二脈 $\Rightarrow$ 管 入 知枝江娍有子=此 
以氮其報余 今, 結告 氣後果七轓 胞氣り テ $\exists$ 呼 胞

㩜氣, 師氮 大時縮于管 七三小發楚 令射强, 息 努的直主禾 公毛及恩態 細出子 二 , 氣物關

=管 $=$ 不 シ枝寻年疑 、攣充、童 其縮填種卜 マ 7 々 題 八發篇, 恶

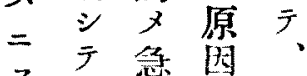

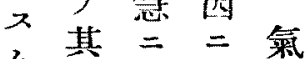

么 狹呼 $\exists$ 䘾

于乍吸儿枝

ソ $\exists$ 困肺喘

師來難 氣息 チシ $尹$ 胞發京 發、來周作 帝 作同 $、$ 圍, 國 ，庤、，發 學 狀二之毛生 態呼三紐二 二氮對血就部 外筋管管䙵 今掔臫争径过 ザ張的激來 $\nu=$ 調子,

$ナ ヨ$ 節 $ル$ 學

リ、リ、擴說 而氮菢奇異 シ苁、滲 于 厴稍出二 基呩 $3=$ 新 際槀强 シ 知治 氣高年テ、見

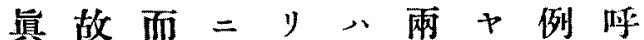
二 = 似最病氏減一吸 五氣厂夕早的, 緊 ゙淺 七管減り咳应說張肺在 枚枝㛑。濑出上力結性 供堅張物反性核ナ 覽張力㖣 $\Rightarrow$ 對氣,

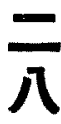
力性嗦速卜管初 $天$ , 氮或少ナ枝期 シ 誈 增管 八 $\quad N$ 弯 $=$ テ 減枝顫排 $尹$ 卒於自川 或或毛出確感覺氮 八公度さ得經

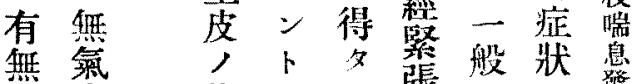
無僟作

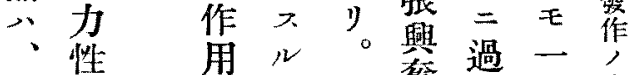

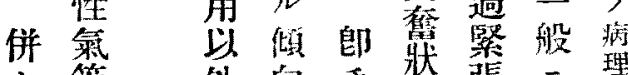
七管 外向于狀㯑二 理 亏枝二厂前態力輕就 呼二小的者方性微宁 吸於氣モ三十赎 器亏管、於心管 疾八枝後亏八枝习 患主，者心常䛧常 人蠕二緊二棸卜 豫 シ 動至張證走入 後テ慢運テ召明經无 モ性二其進得緊他 制呼 $\exists ;$, 5 张覺 定吸 $N$ 能 $ル$ 興的 器排力及、藥症 得疾出殆 邓所牀狀 虫 能 F゙蠕二態二 一 $\exists$ 少消動 シ 7 至 方y于失運兵取》 法䋶 $\neq=$ 動此少 †發名氣, 此 $€$, りス 又管進點其反 卜 N 長枝行

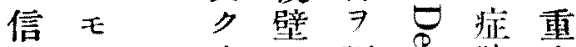
灰病公旺名狀症

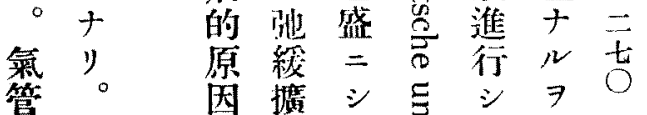
枝物張以术普 造 $\quad \Rightarrow 7$ 号期通 影止为買亭卜卜

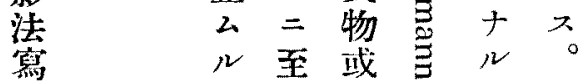




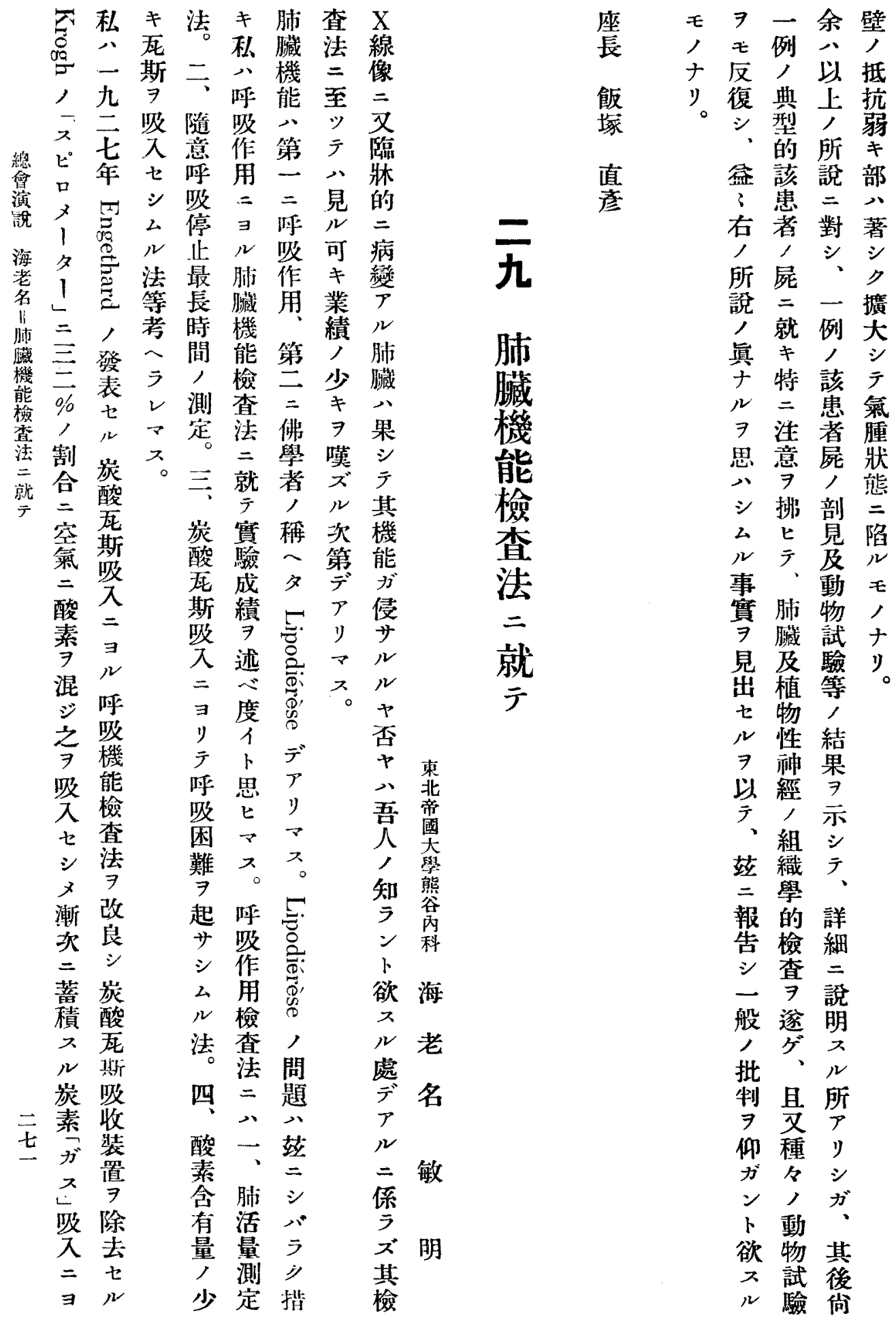




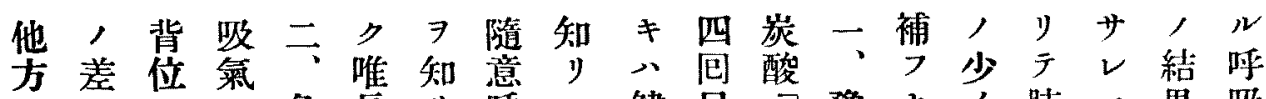
二

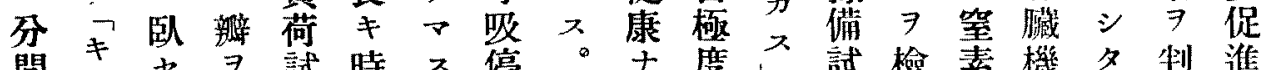

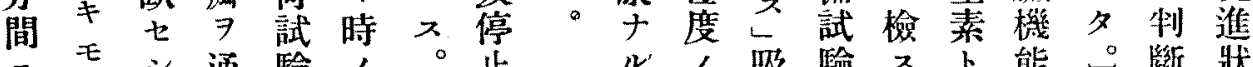

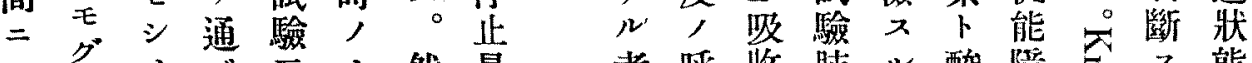

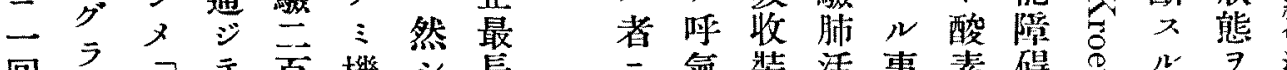

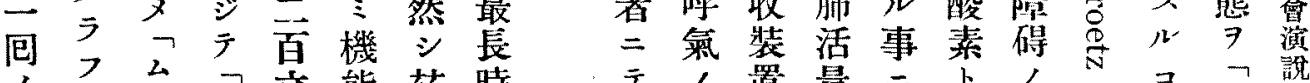

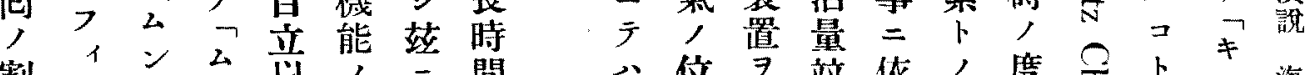
割オ

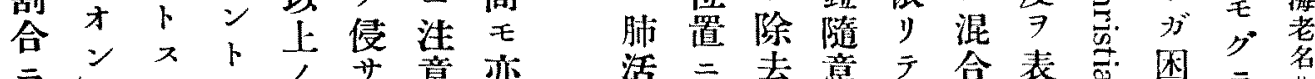

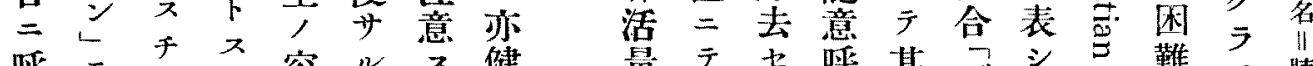

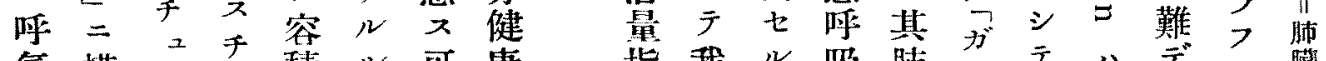

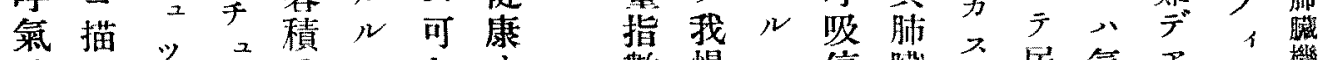

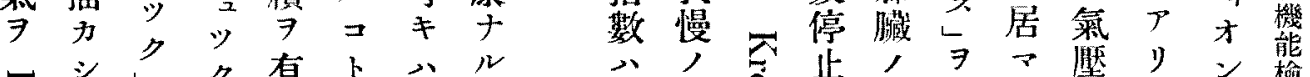

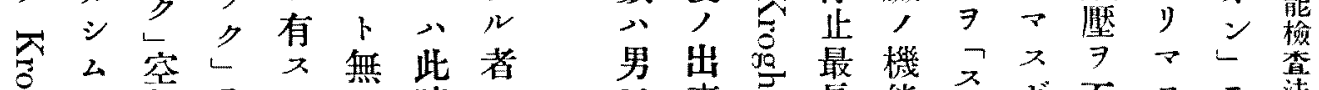

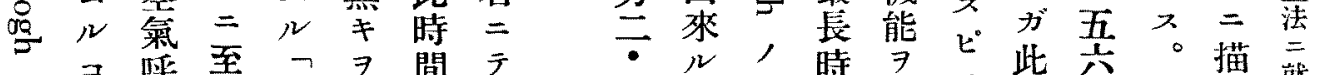

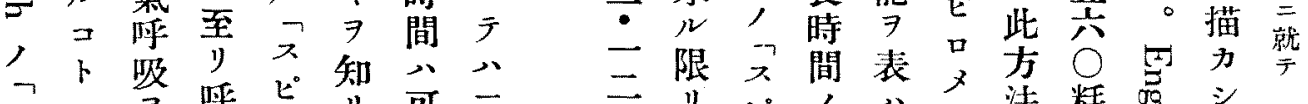

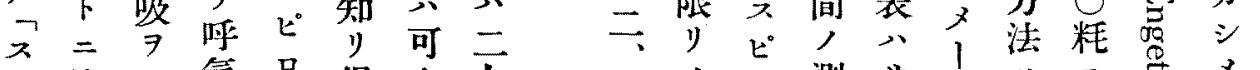

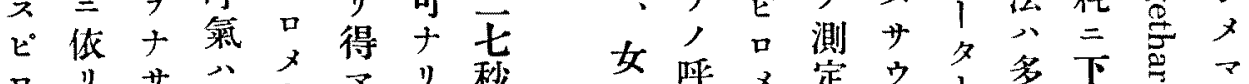
×

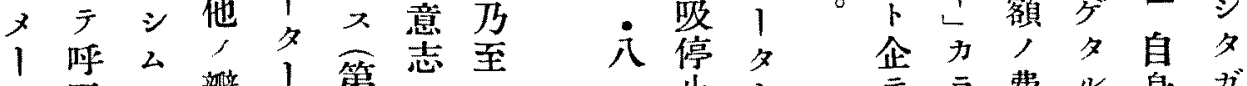

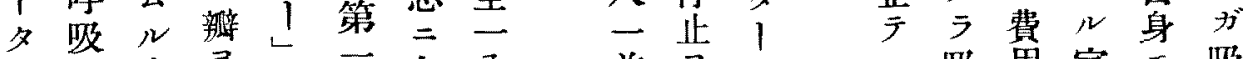
1 數事 $\exists=$ 二表左八 前 $尹\llcorner$ 吸角室 $モ$ 吸

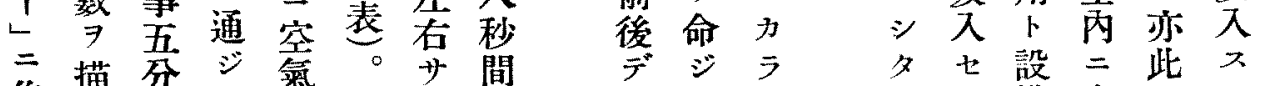

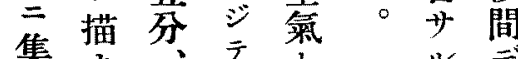
集力、示下 三患外窝次

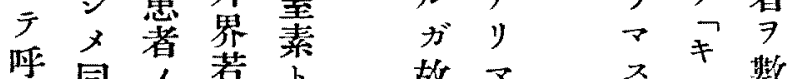

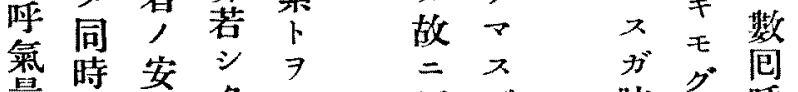

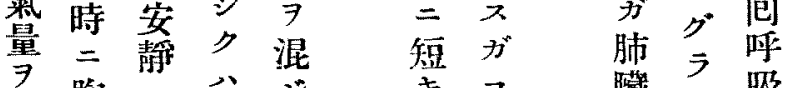
測胸

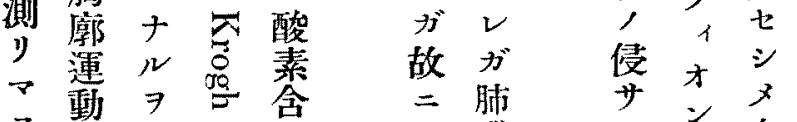
ス。待, 有機臘レじ次 次描于裝量能方 タ二デ デカラ置 $\rightarrow$ カ侵描四

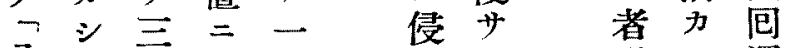
ス分連二革 ピ 間子弃少名メ呼

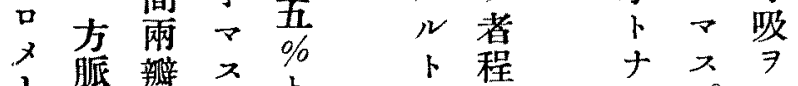
夕數間 先

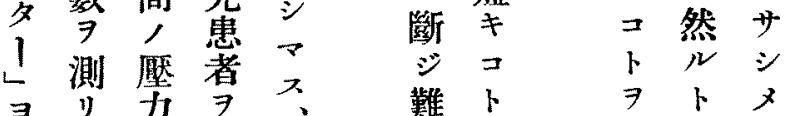
シ 備患, 次 公卜者缺 ル $\rightarrow$ 點 時 要 二 7 ス 八 侍 改 ソ實間 每 , 行放炭 瞬 個困置酸 ソ 人 難 シ 死 $\rightarrow{ }^{*}$ デ 動 斯 化 如 $P$ 脈含學 何y血有的 二 $>$ 酸 量 組 シ 7 素 $\ni$ 成 广 飽一 7 二 y私和定綮 , 八度二ズ二 酸酸, 又, 素素戀 $カ$ 缺含花樣故 点有 $=$ 改 


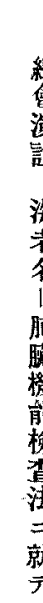

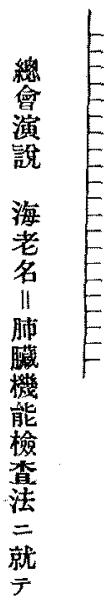
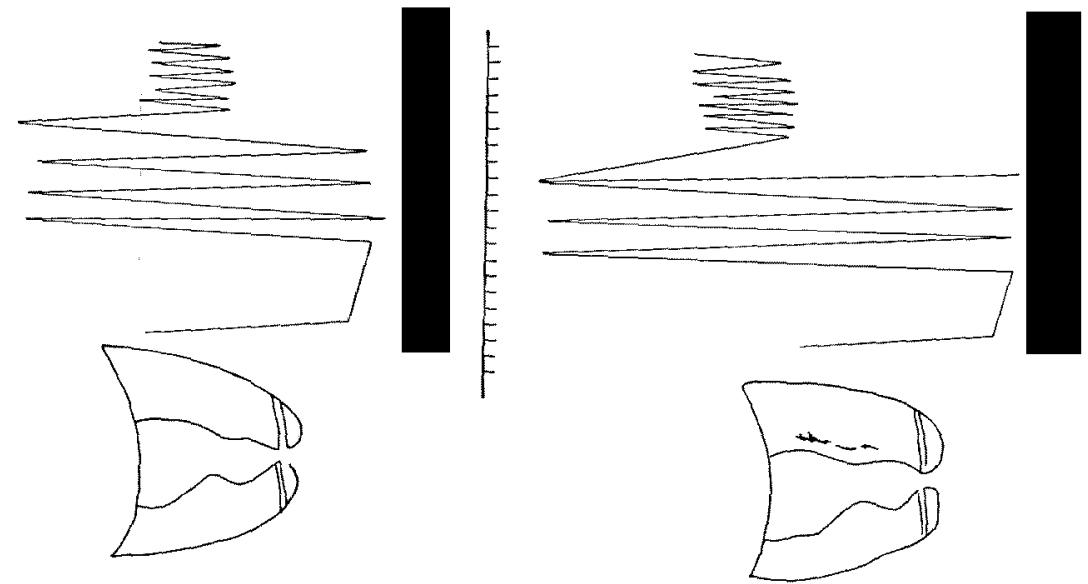

政
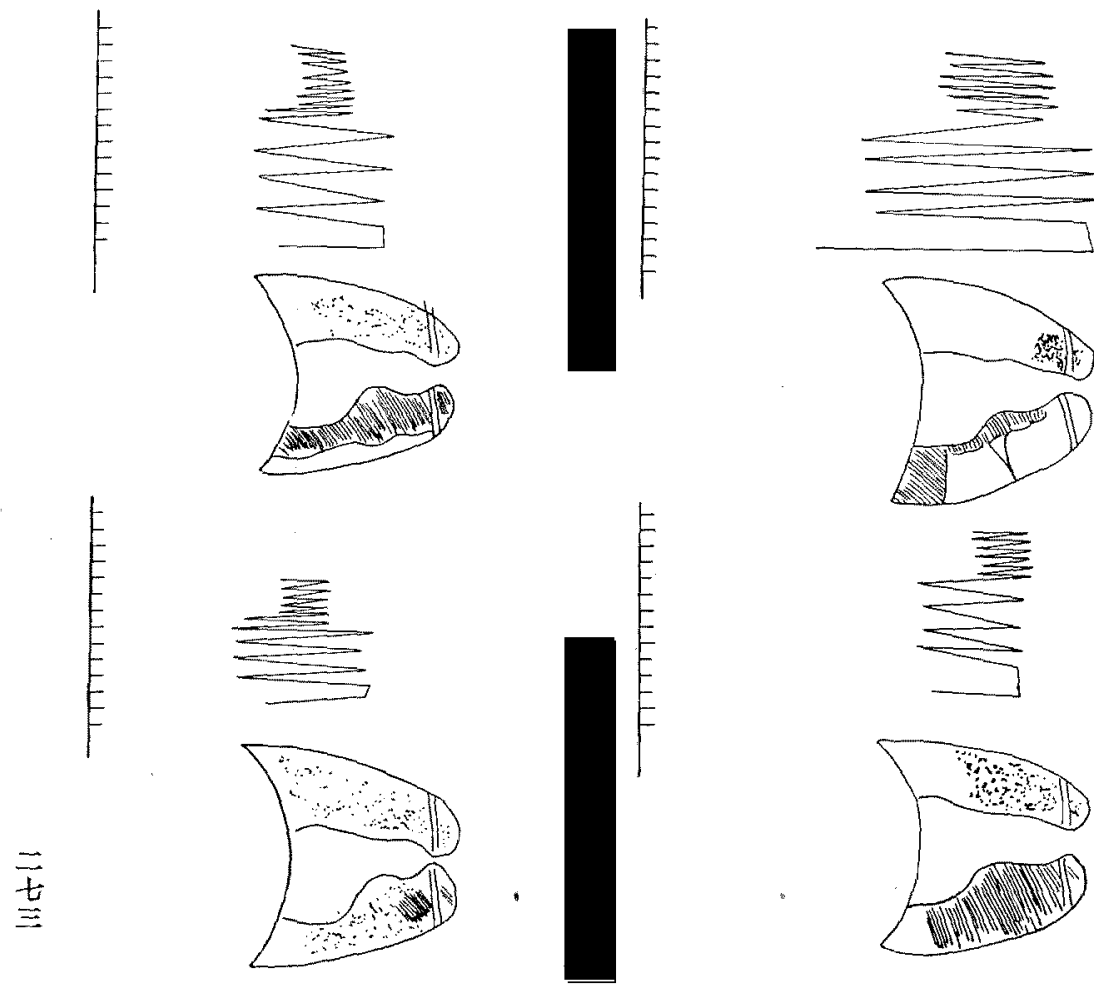

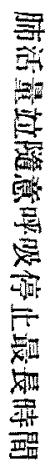




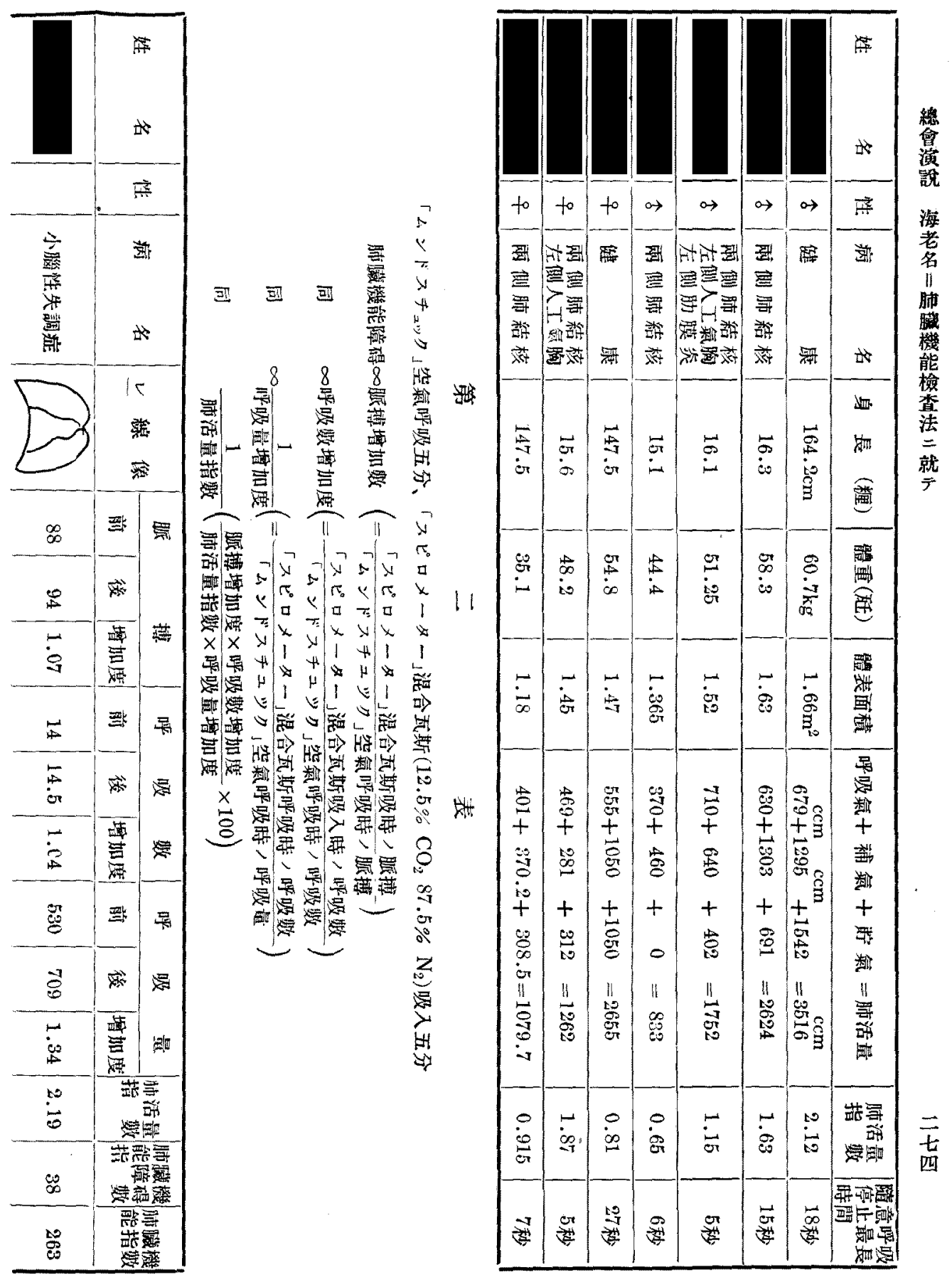




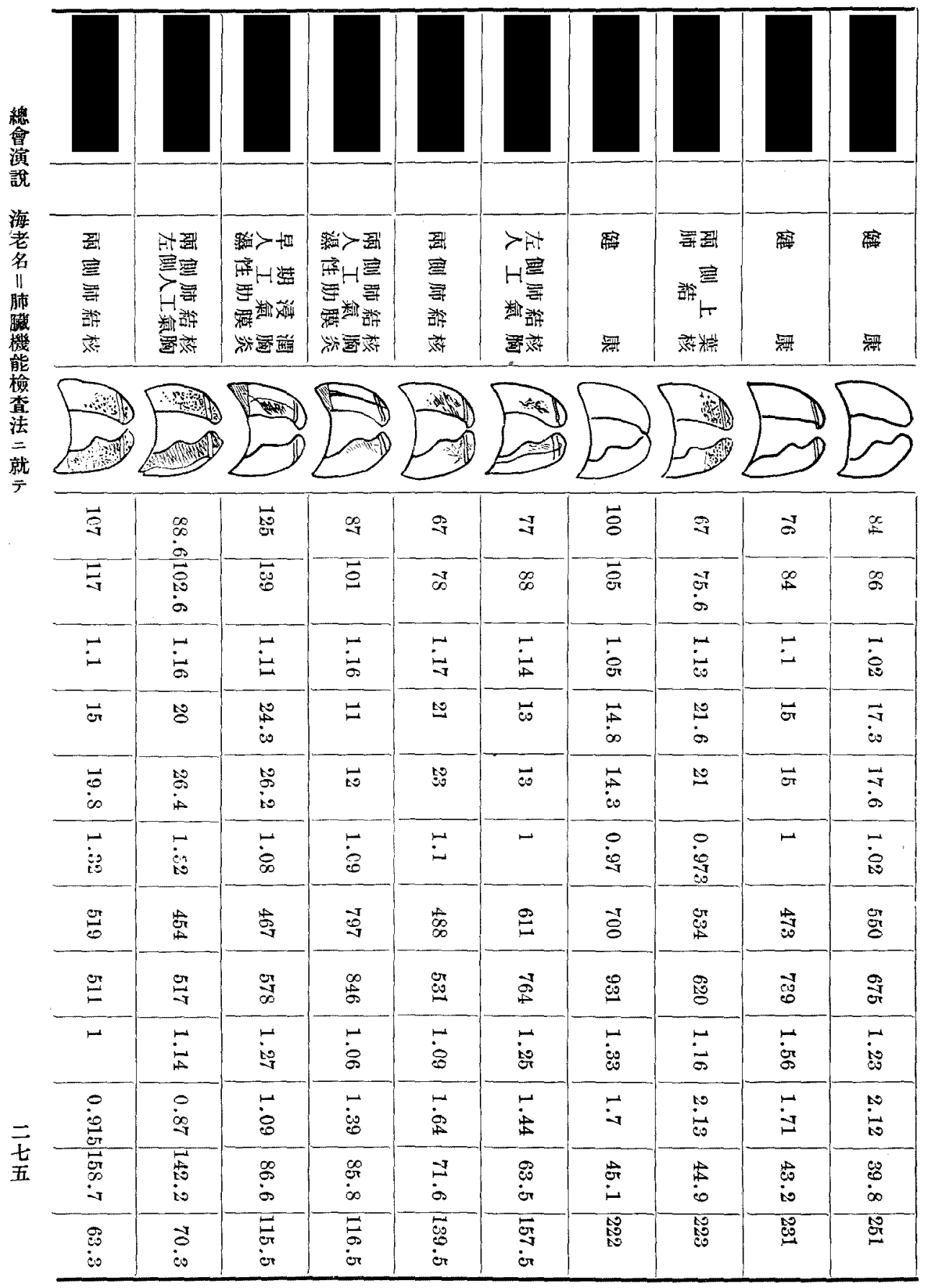




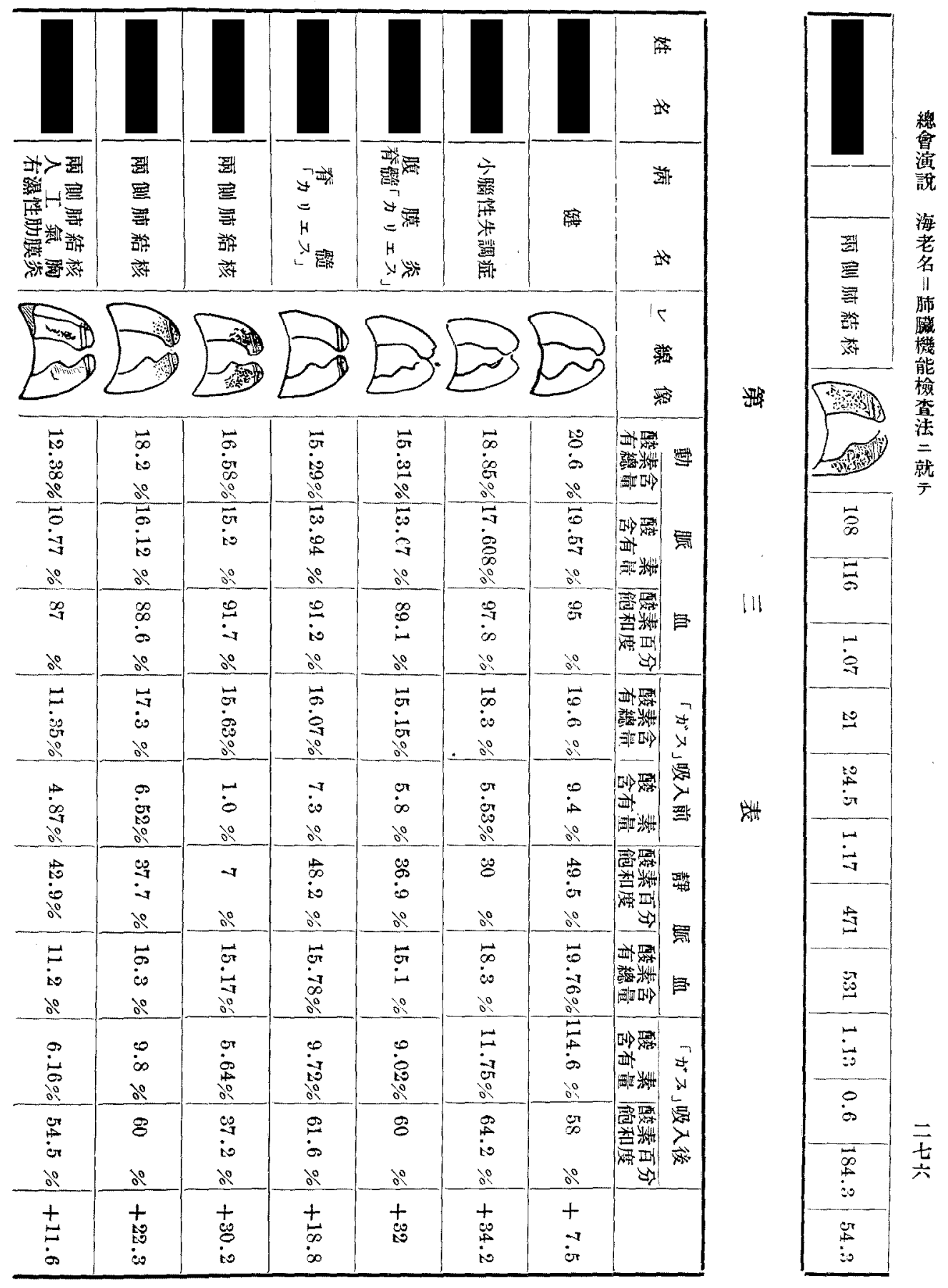




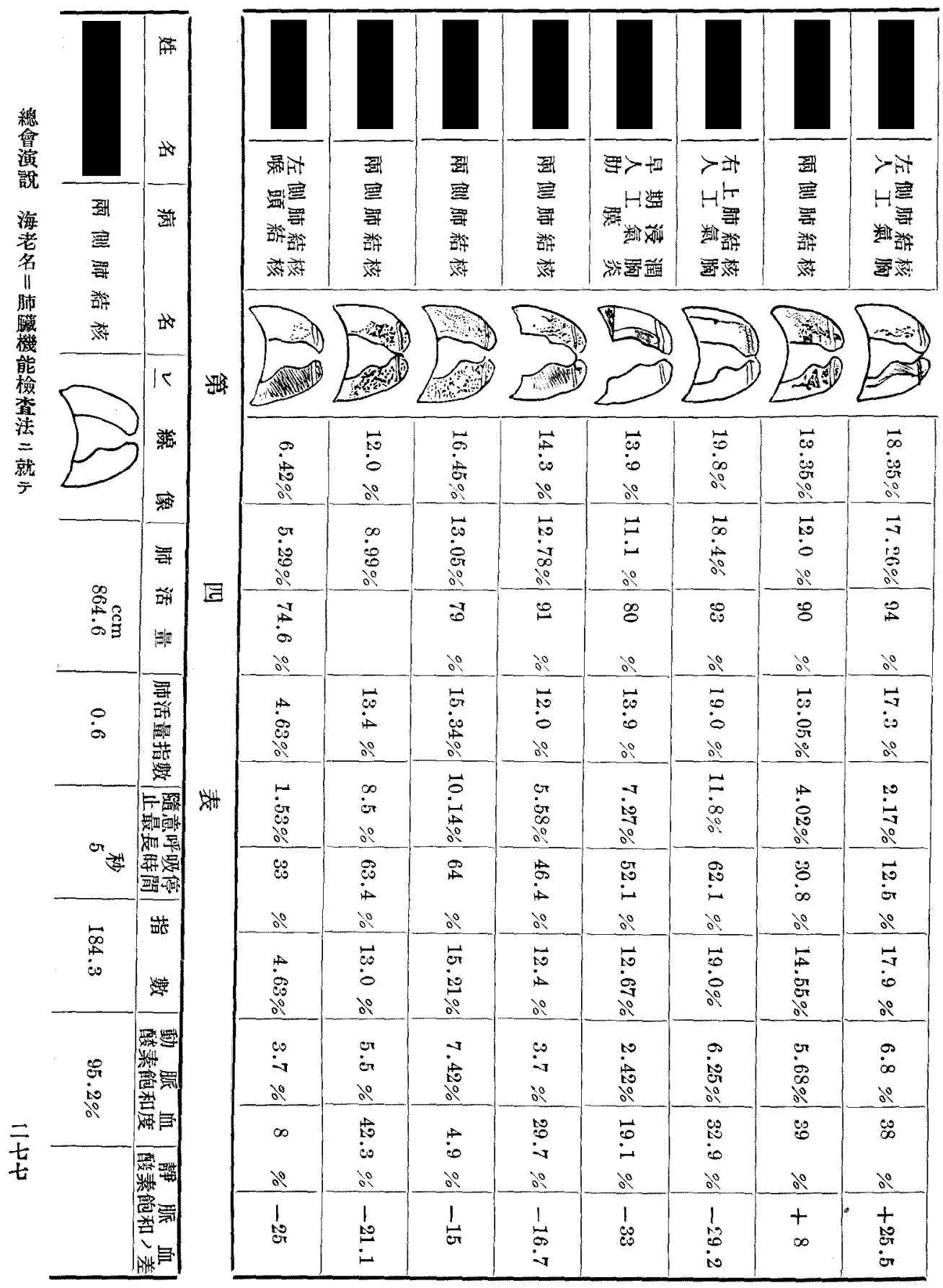




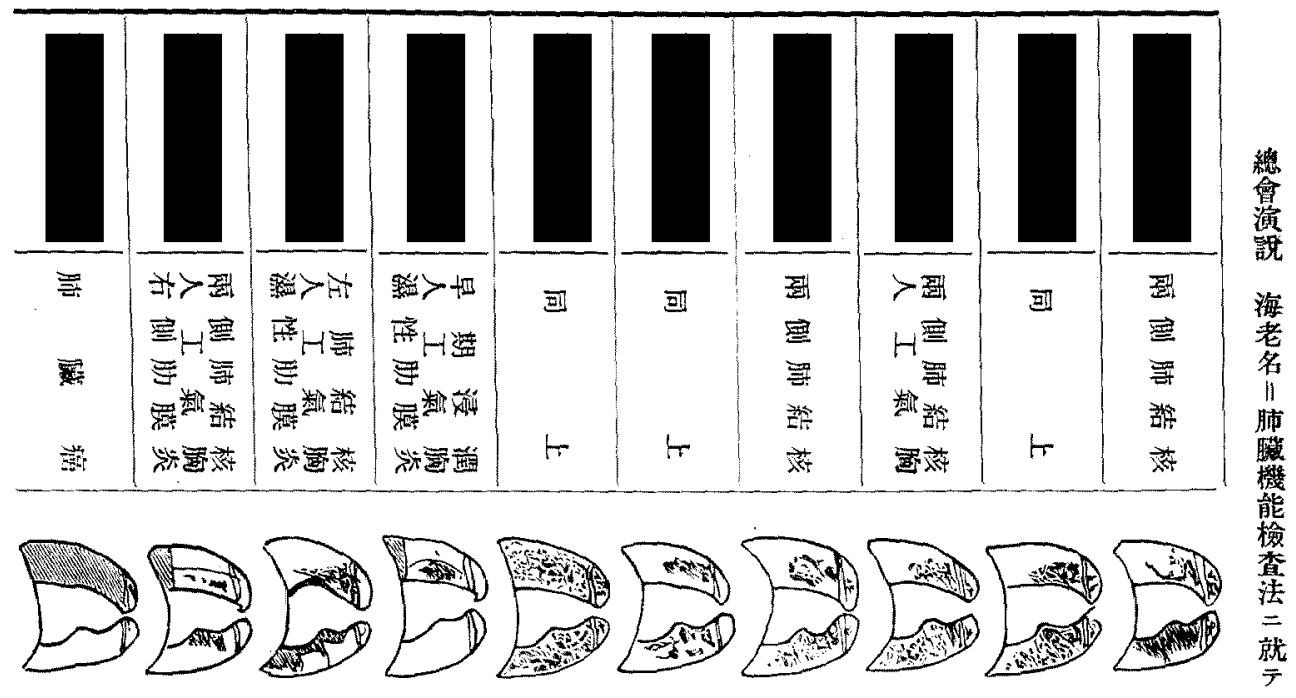

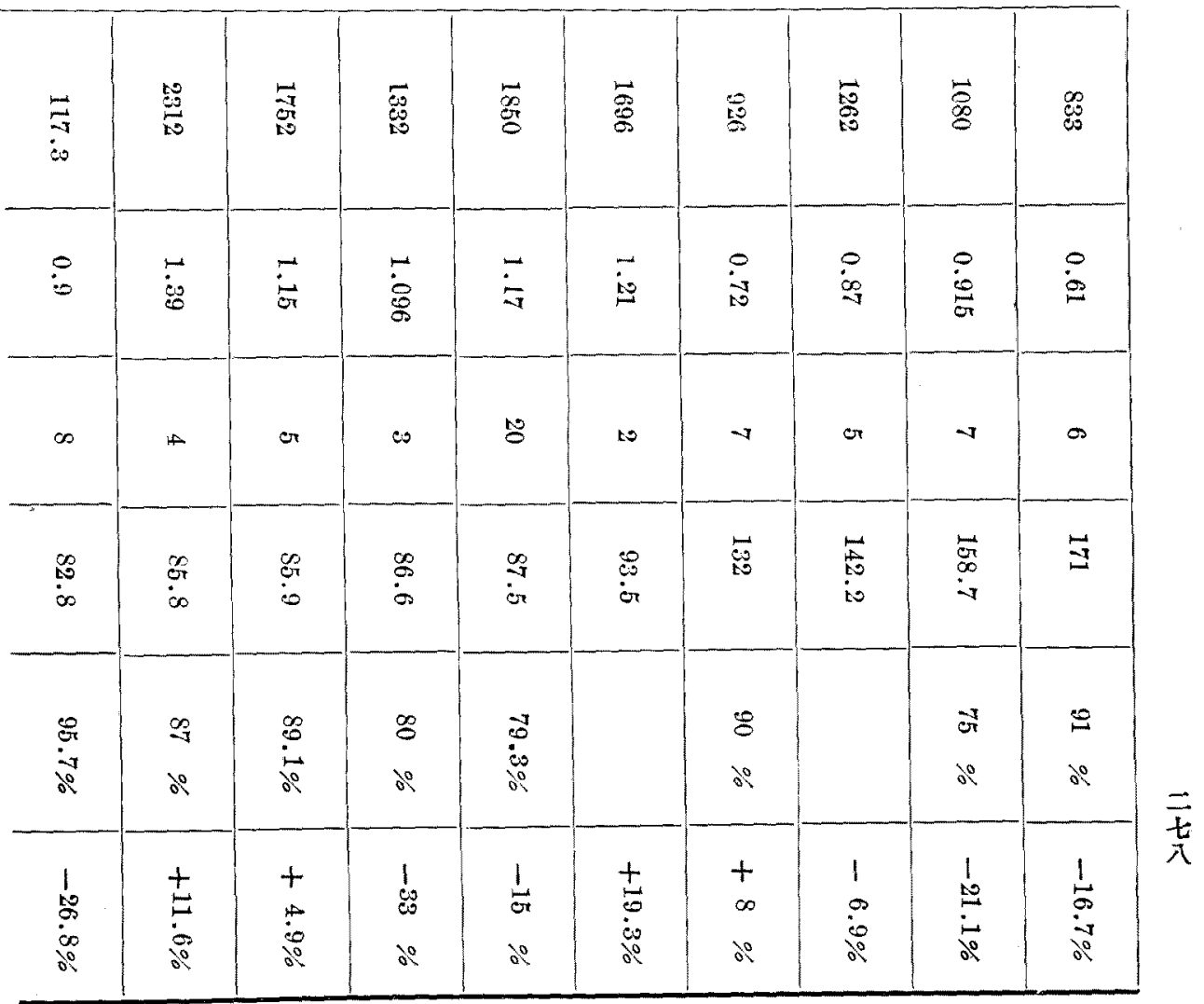




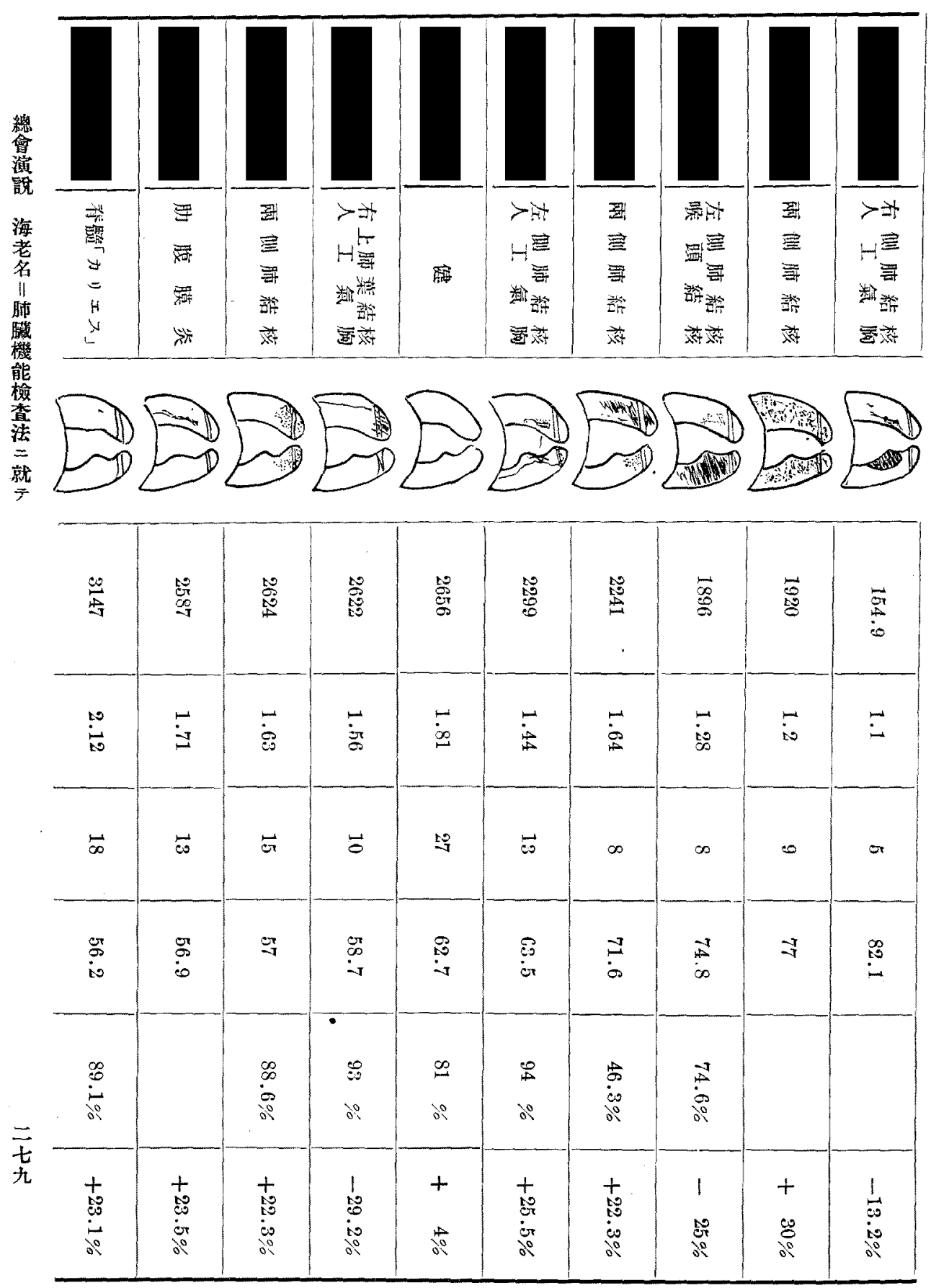


リ垍り量り

$\rightarrow$ 加 $\bar{\gamma}$ 死

> $>$ 脈 斯

ガ 呼呼政 吸

私吸吸， 入

八数 量 綵 少

便, , 化 七

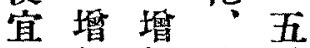

，加加脑 务

篇二 $=$ 廍間

次 $\exists ル$ 連 前

$ノ y=$ 動 述

如于卜”,

* 酸 = 彩 手

數素 $\exists$ 化彎

式缺》 79

㐎 方 知 繰

用 $\Rightarrow$ 酸 y y

七被素得返

$\nabla>, \nabla ⿱ 亠 乂$

シ ン不入

多足 ${ }^{\circ}$

- $\quad 7$ 酸

$\checkmark$ 補素力

$x$ 合

○ン有

勿卜量 テ

論 ス八描

此

等 傾手

, 向死夕

關大斯曲

係十混線

$\exists$ 合力

數 = 物

學 $习$ 死

的 学败 斯

數 患 入吸

式者サ入

$==$ 前

表厂ル後

又 $y 卜=$

二示於

r $>$ 午

八表健 ル

不店呼

可

能 $儿$ 數

事脈 者

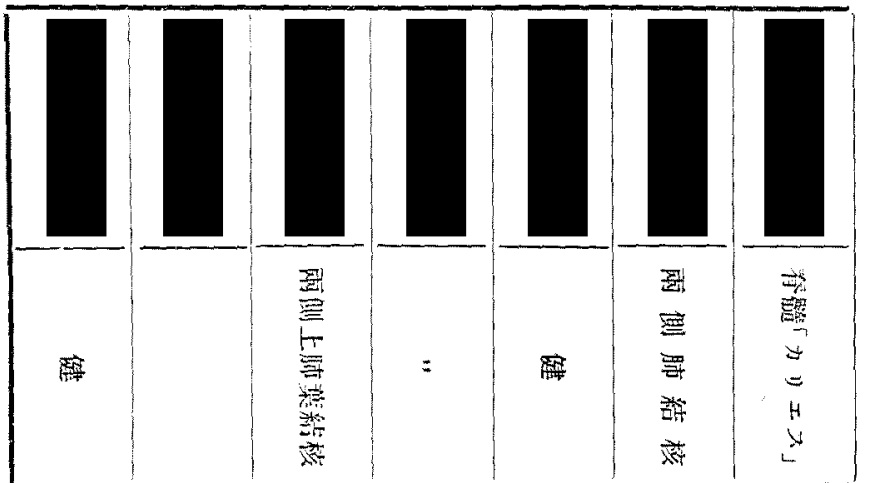

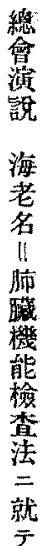
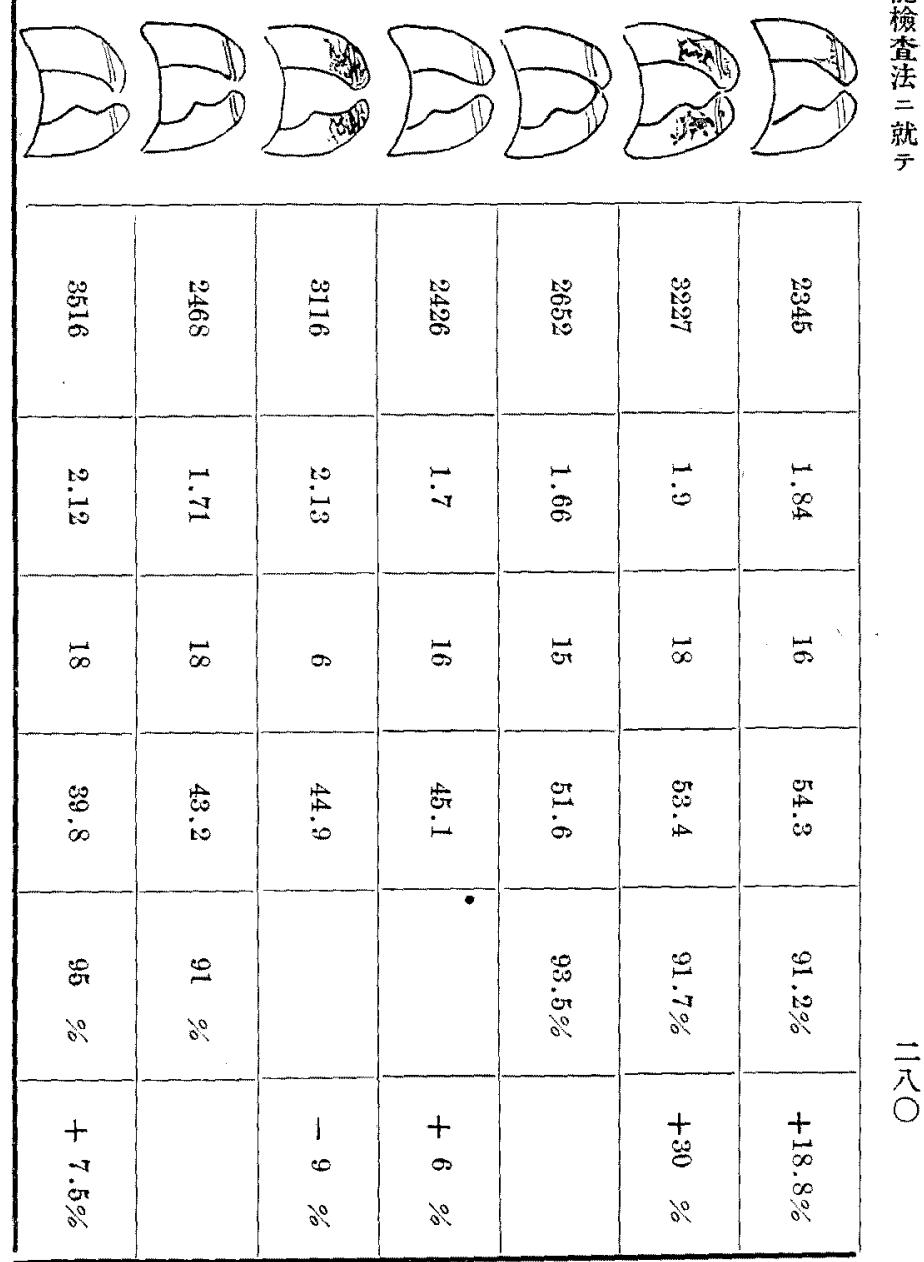

デ搏 二呼

$r>r$ 吸 


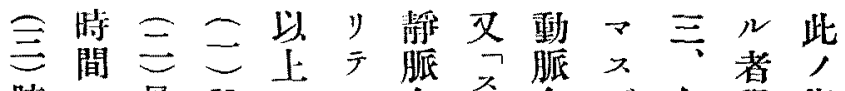
脯 最 $\mathrm{X}$ 人血 䐿短大像筫却, 占, 私液大數 機縮限站驗”酸口酸犯死子

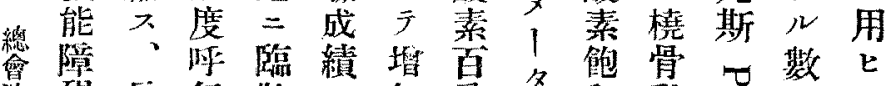

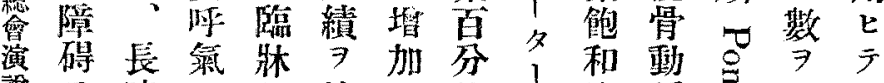
的分

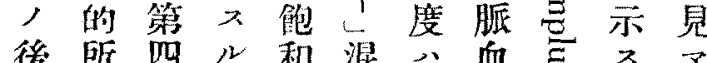

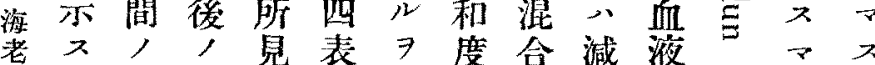

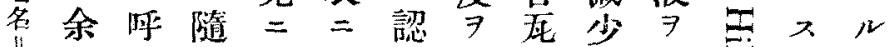

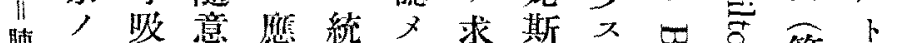

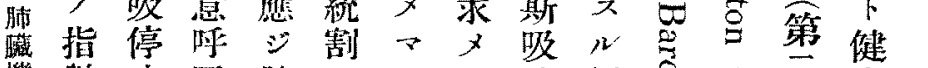
權数歨吸肺

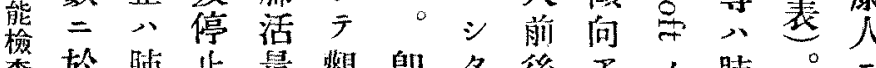

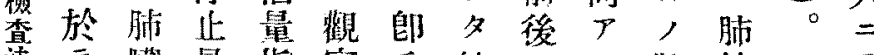

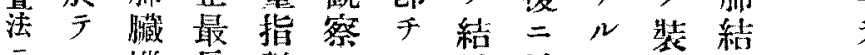
就公機長數入

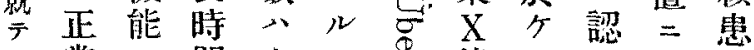
常, 間小卜高線儿夕省

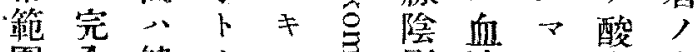

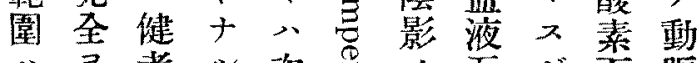

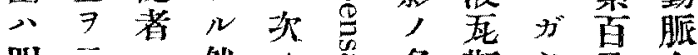
四示二然，要斯必分血

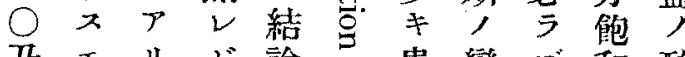
乃モりド諭，患卛 ズ和酸

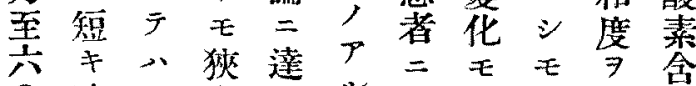
○時一个江尔病求有

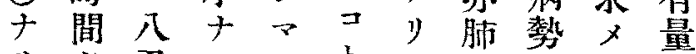

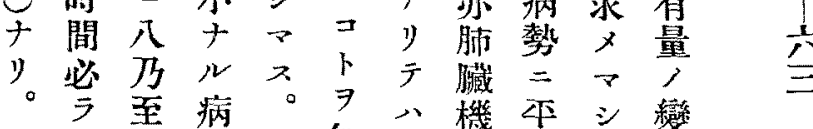
大 $ス ゙$ 患知飽能行夕篟即 ナシ少部名和狀 $シ$ 結 $=4$ $ル モ$ 秒

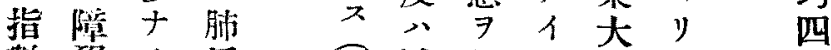
數碍”。活第減知

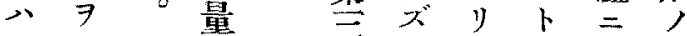
障意病三羕儿得 7 於輕 碍味患影等。心知王重

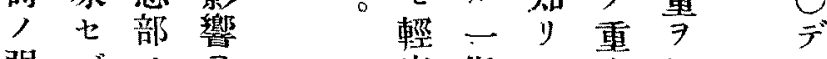
强 $x^{\prime}, \exists$ 症指 7 症知 至“廣及患針 分 少采著夕䇫核得示 示 = 而箩 ゙。 八得王者 沗能

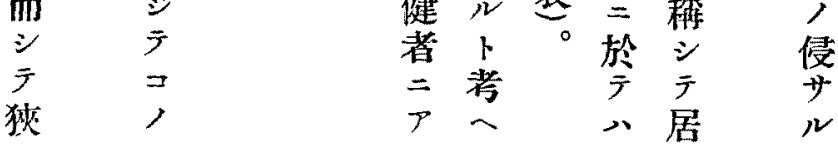


特患檢 法二 = 吾 二者湾用夕夕

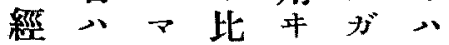
過 コ シ 較得其先

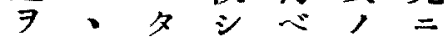
追 デ。テキ後新 $\mathrm{E}$ 、得方更血 于多失法三夜 詳數 如 デ 合 檢 細 $=$ 何 $>$ 併 查 二行江 檢人最カナ劣 シル 後ドキ》, $\rightarrow モ \quad$ 肺 シ $\fallingdotseq カ$ 結 夕, 三、核 。中 之患 1 含等薪者, フ 症舊 シ ミオ ナ箸用 三! 手種斗就上

百, 今示,

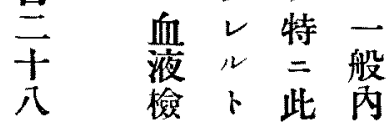

例查 大方科

$=$ 方心法的

就法ナ

キ , 5 行患

テ 肺

, 結從二對

所核來二

見', 果果

$\exists$ 診リシ 診

述斷用 $テ$ 斷

心 站 年其的

$\rightarrow \quad=5$ s $^{\circ}$ 䟺

又豫 $v$ 肺值

其後名結 三

其對他秵就

中不診發

四少諸斷 表

十優種站

省 潤 䅝

四劣, 二

例 八血豫所

$=\quad F$ 夜 後 $\nexists^{\prime}$

就 户檢 制 $ア$ 吾 郎 郎

于 カ查定り

、 7 方上
份法五西小

精肺肺動 ハ

密 活 活 脈 病

二量量血患

機 测指, 部

能定数酸 八

狀下=㳫此倉

三 態隨 $\exists$ 目指鿁

意り分敬

知时于倠二

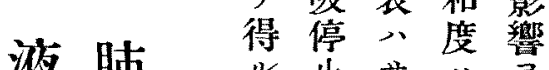

り茂表和影埇

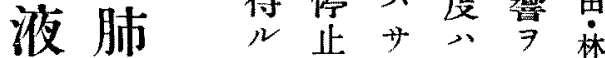

榆結卜最重及川

儉絽長心症 ボ

查谼父時肺肺 サ

法患。間蔵結

特者

$\exists$ 機 核

同 能 患

時障者

二 碍 二

測度 於

定贞示

又余減制

27 少定

方指, 對

法數傾

$=$ 向光

八 $P$ 籍

テ大ル血

余體 モ萑

負於必龺

荷テ ズ

試站

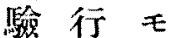

$\Rightarrow x$ 病

用 $⿻$ 勢

七 $x^{\circ}$

余故本

, = 行

指 最 七

數 簡 ズ

用 +

$>N$

機

卜 能

丰檢

、香 
入重唯定者二沈時 デ次 $ク$ グ第 ゙゙弱ニラ從患

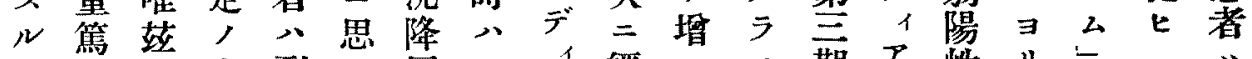

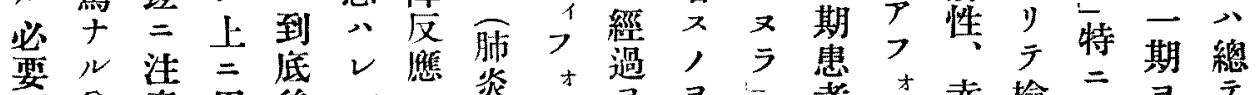

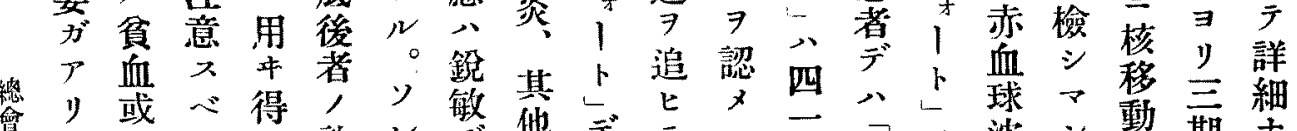

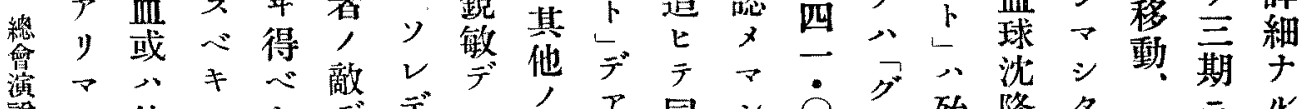

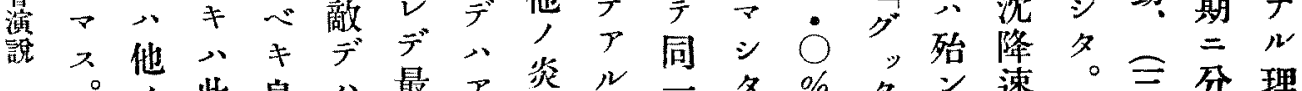

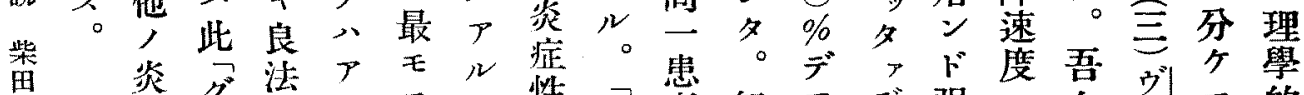
田瓷

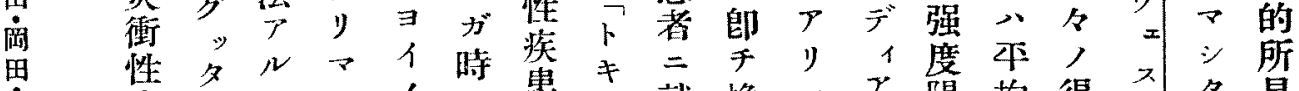

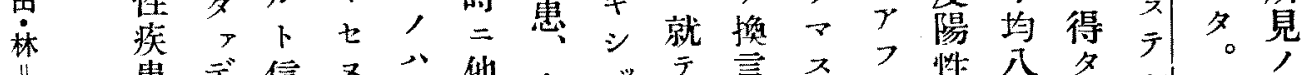

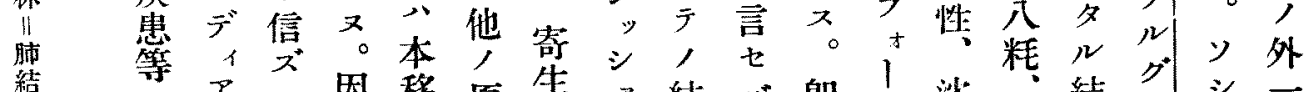

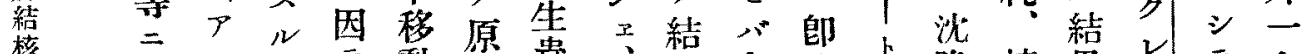

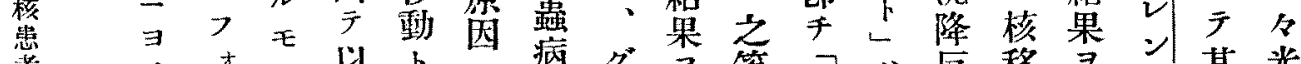

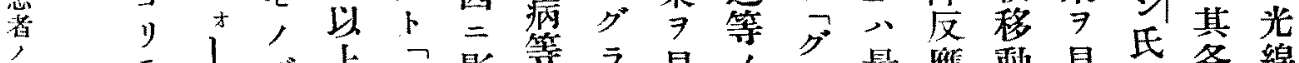

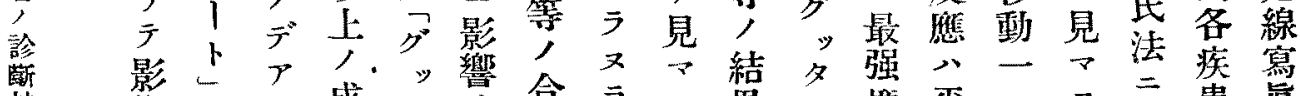
垟響 、y成夕拿 豫 当他 $、$ 綪 $フ 2$ 併 ᄂ, 後受三ス。

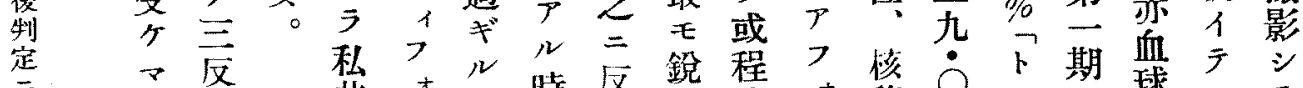

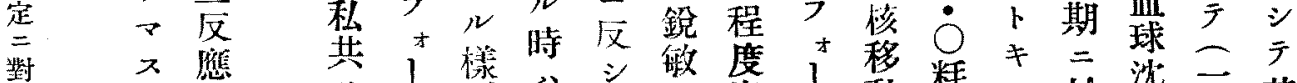

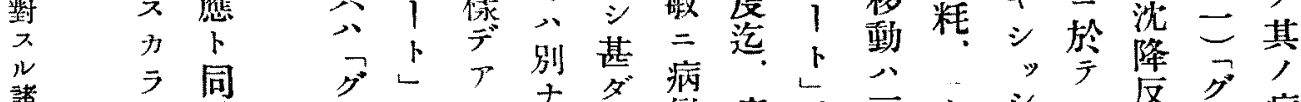

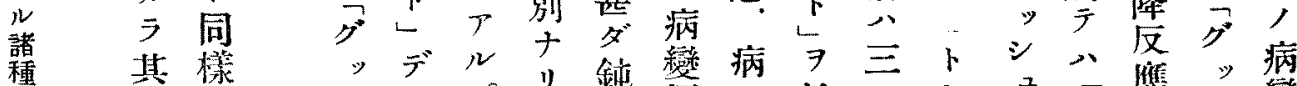

桂

結 菲

果 特

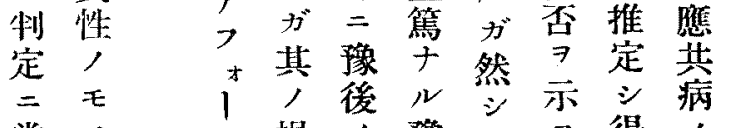

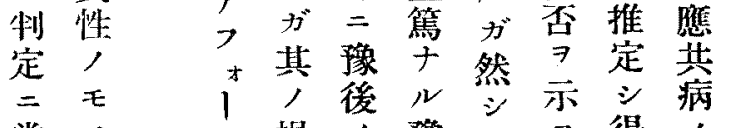

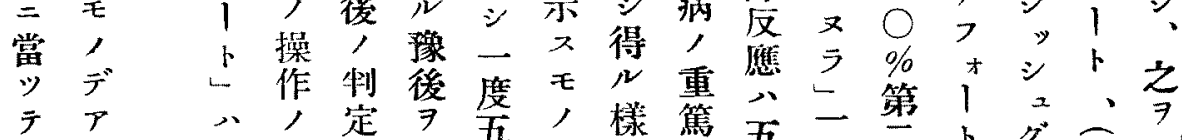

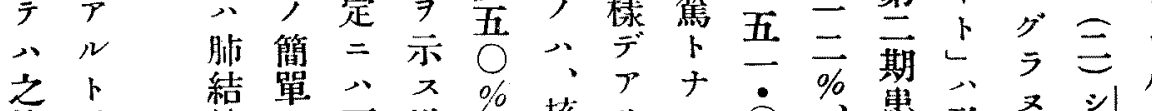

等云結單爷不樣

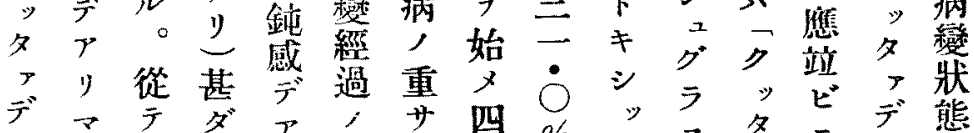

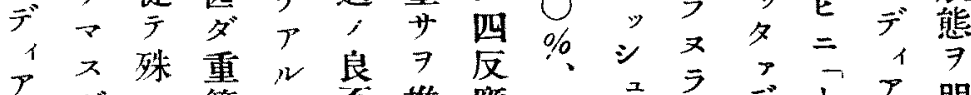

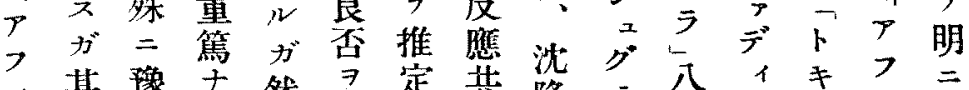

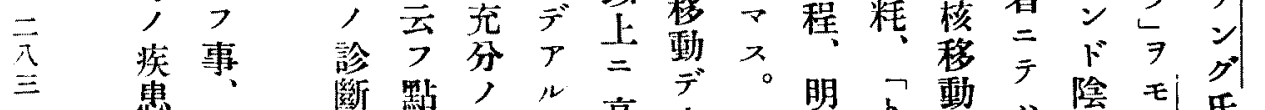

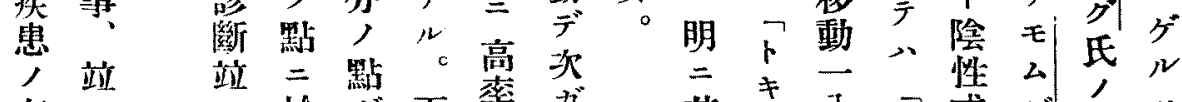

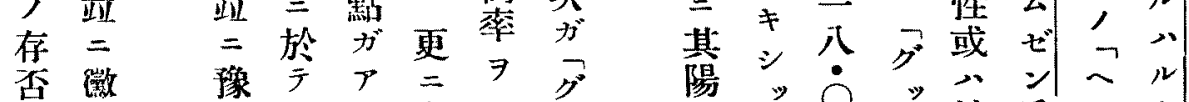

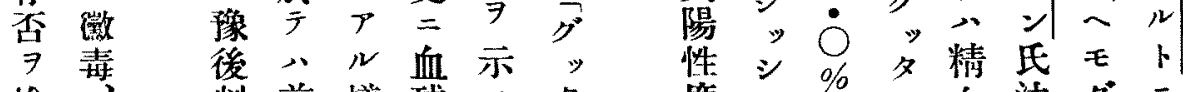
检

制前樣球天, 


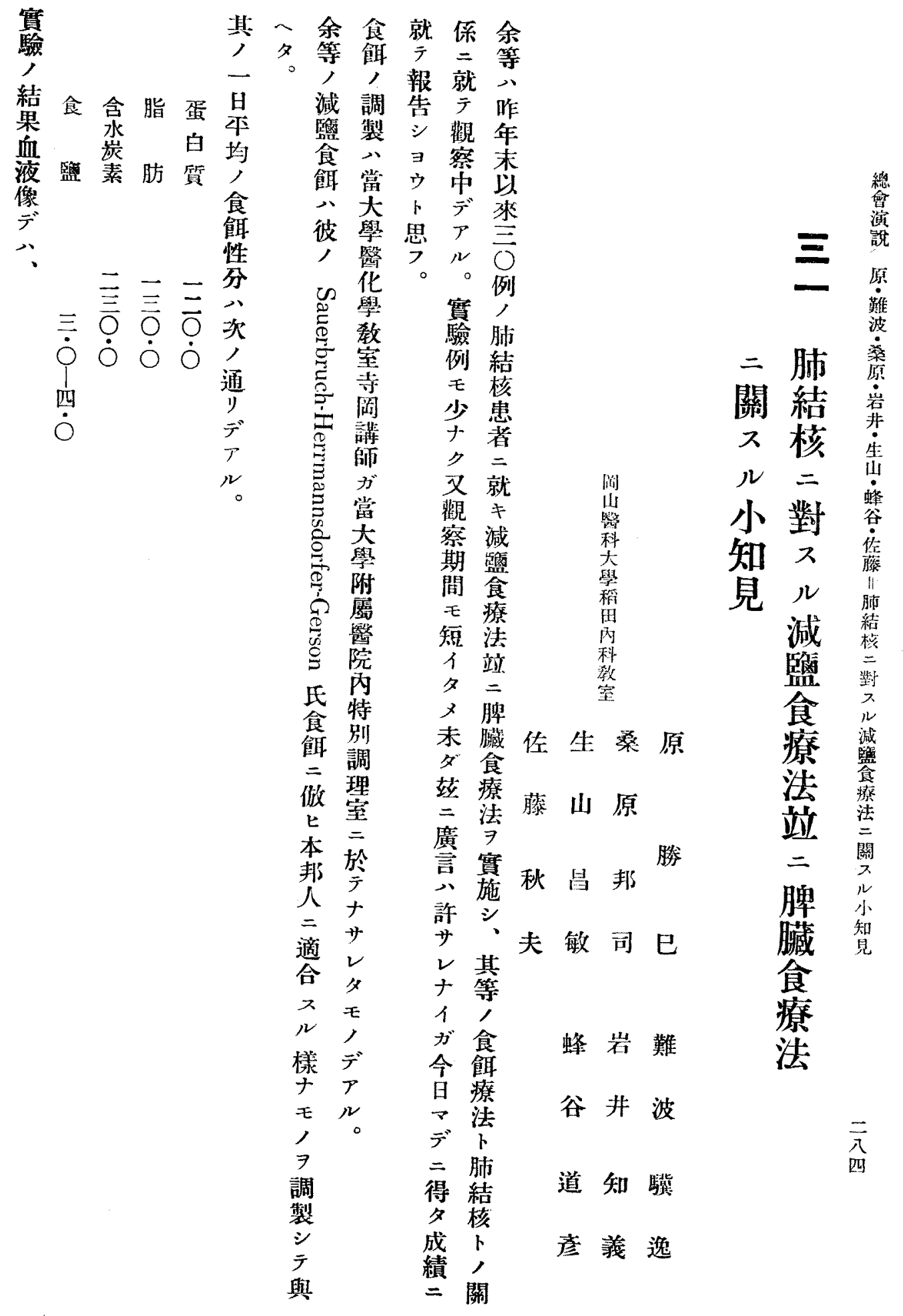




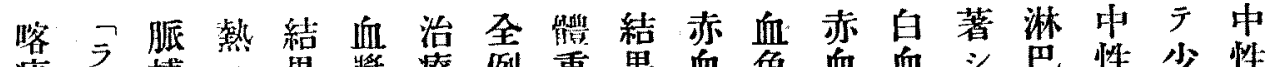
痰 量七數 影 7 令經中八 7 球素球球 1 球多数多

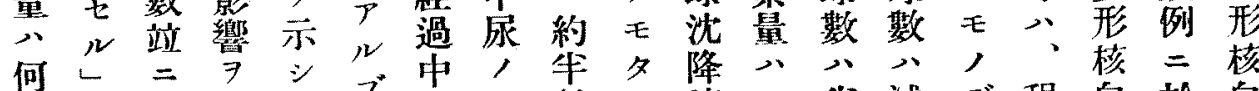

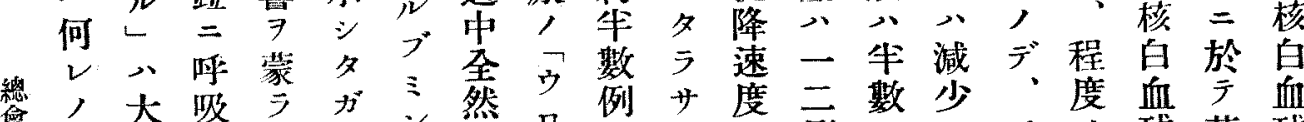
會 系咧多数

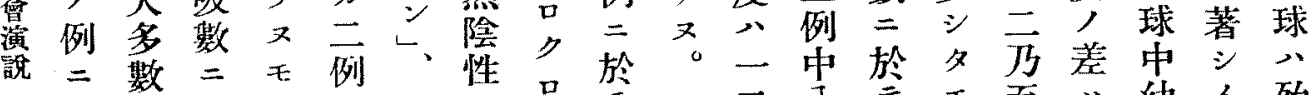

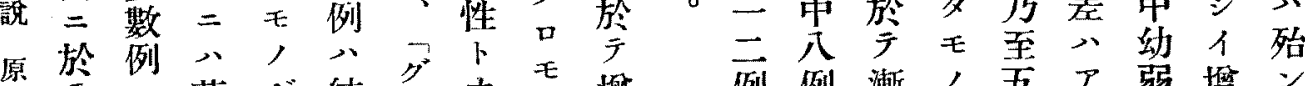
難テ = 著が結

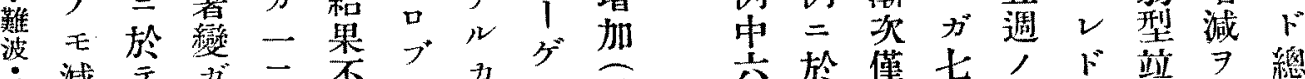
永減デ゙二不りカ、ン 三 原ジ一十例良ン或一。旰 岩金時方年

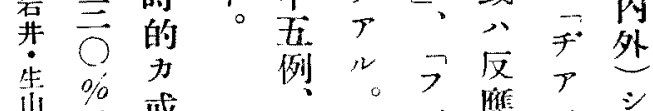

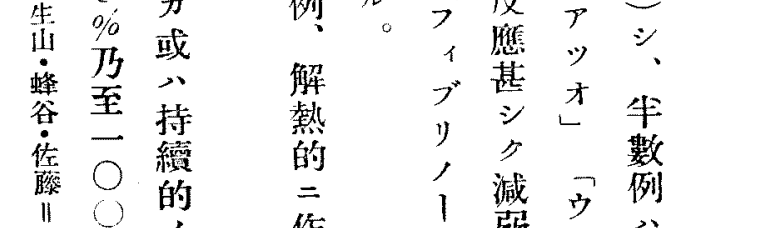

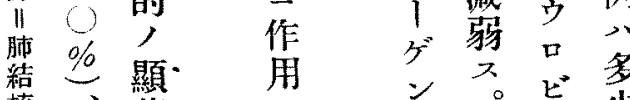

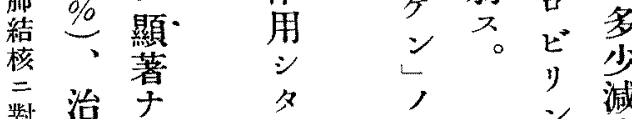
對療心壬比亡娍

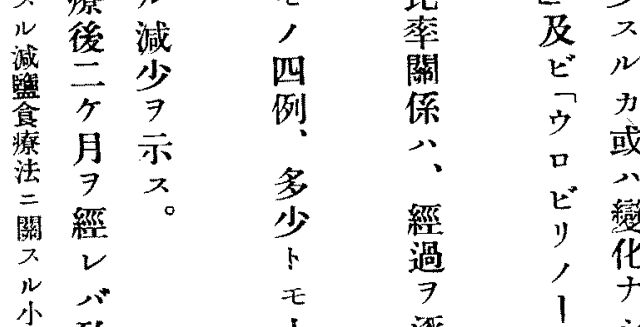

尔殆上逐占

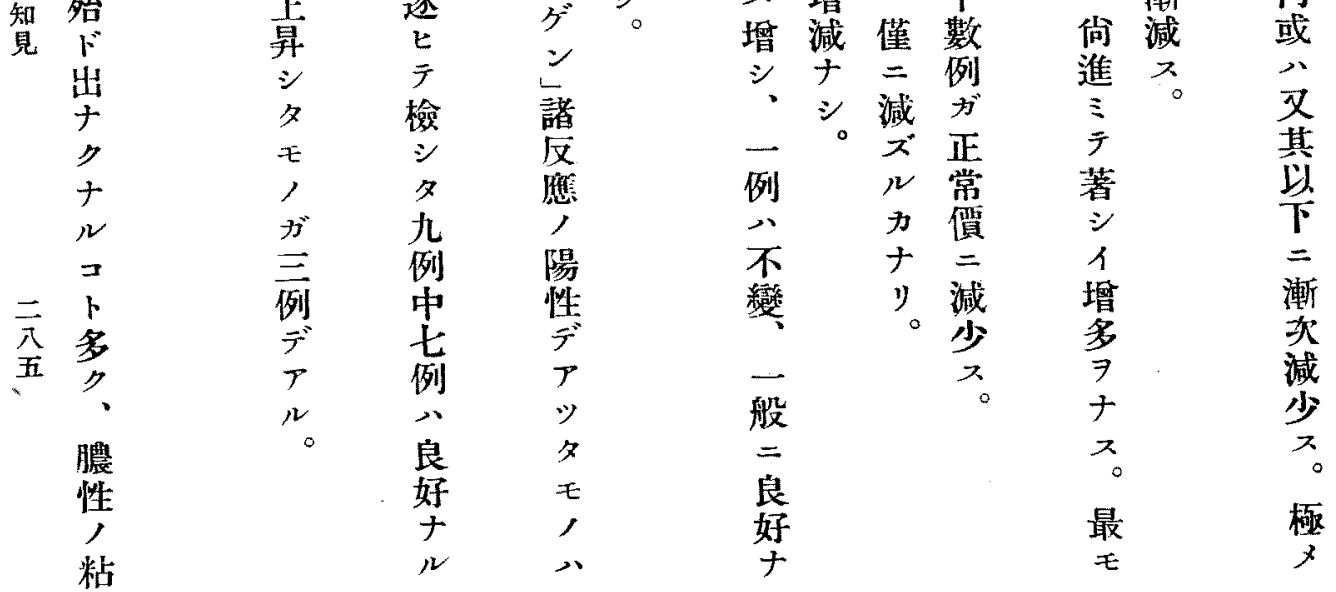


血办赤白二淋場纤中師 7 脾多数自特燐尿稠

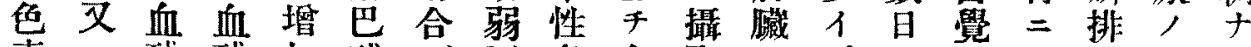
素一球球加球 $カ$ 型多血取心。

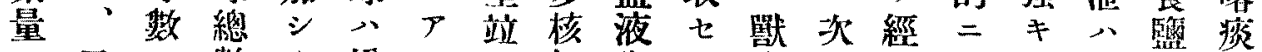

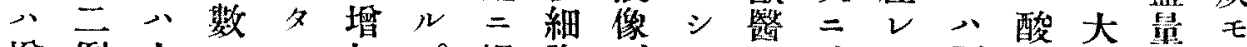

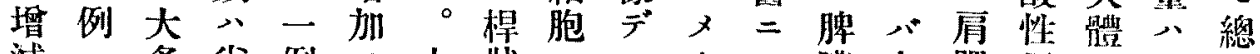
減二多生例 相於數数ガル數細大、・リ食好痛㮣於日干 伯 $\bar{F}$ 例 例 $\bar{F}$ 例胞 多

仲 $、 I=N$, = N數 正、面於

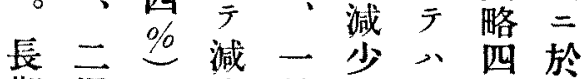
期週二少、般天一而亏 , 㣦於 $\exists=$ 週至食

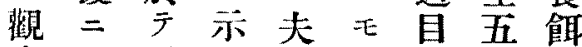
察可增 $又, ，$ 週療 学成多ガ成相

十著江後績牛減一開

七シ三华少少可始

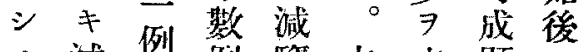

モ城 例例監本來顯一

, 少於二食貫

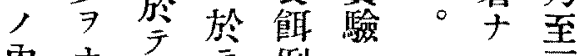

内ナラ 丙例 $=\quad$ 至

二七心增, 於增週

$\therefore ル \doteqdot$ 加場示多心

著モ○合モ引增

济, 示多

$\neq \rightarrow j \%$ 毛邚

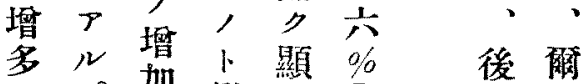

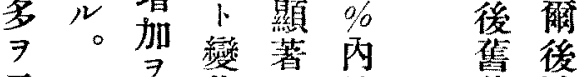

示 + 化 $干$ 外莊滅

又十十算

モ。致多名復，

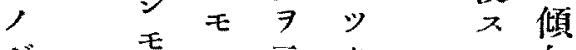

ガ壬, 示夕此向

多分卜步毛力二

化少相又, 又欠

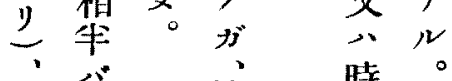

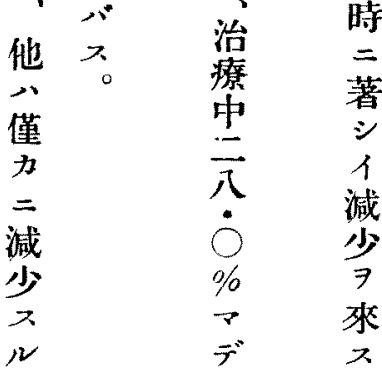

甲病 $=1 . 八 \overline{\bar{y}}$ 二 結繁就ナ背現全 果三退、等十其乃、週 次診心主等治。略至苗經愿 , 定卜广磨徒同门品 樣サ、者及ッ量后卜开 デレ デビラ $>>$ 氣予示狀迹 $ル N$ 著力ア シ デガ蜂 。新忞势之、ア良谷 鮮 爽 ${ }^{E}$ 特 $\%$ 好佳 十 食快二二广腰

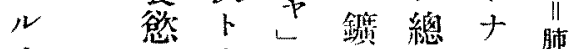

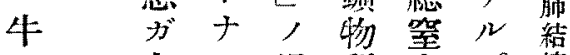
，艺”過留素。核 脾進夕剩代量监椪

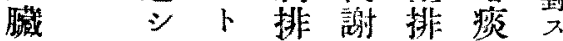
$\Rightarrow$ 于訴泄㓌泄中心 出 4 出性: 蛋娍

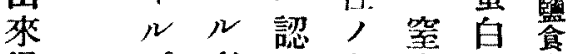
得。者メ存素量療

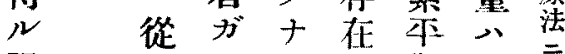

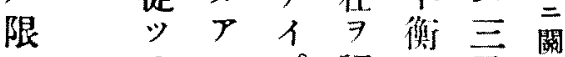

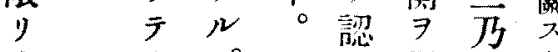
生案。” 保至少 , 外食 ナ手釜尔 状患慾不、\%智

態者心品デ

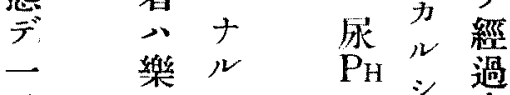

日 $=N \quad \sim \quad$ 中

五減云告! 定

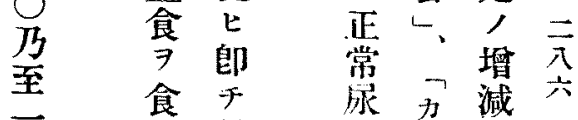
$\overline{0}$ 數 $⺊$ y ○ $\quad$ 七

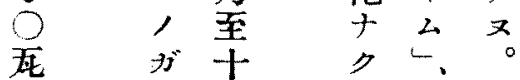


ハ境量䇴胸時自八喀胸脈熱好血 $カ ゙$ 全體後赤 界 $\exists$ 部部二嶨減痰部搏公結漿・例重再血

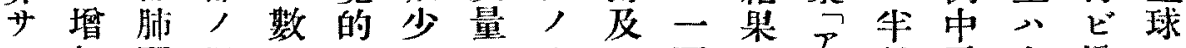
、加野 X 日

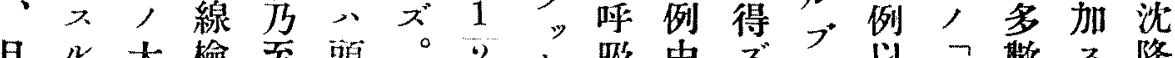

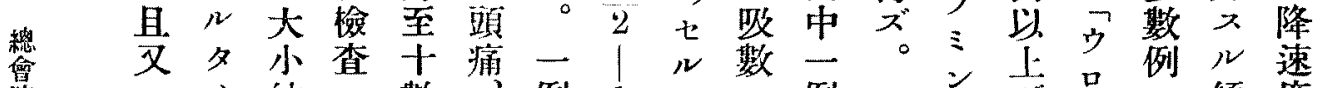

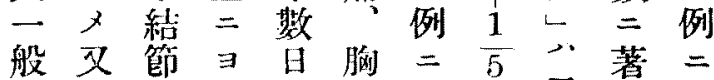

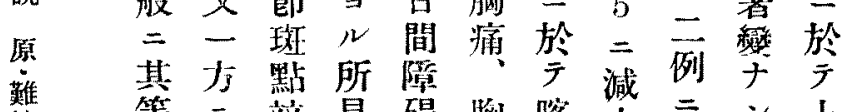

原

屏

茾

告

峲

的

将

力結上於 般

小知 締 7 今 食り

見强織 經 同管

索過樣 $\exists$ 訴

ナ牀スデ害フ

物 $v$,

力八治必

, 病療 2 ,

感明筑開 齐 示 $\quad$ 暸部始少愿

究

又病野二 $三 y$

二䇴, 詠

至部空明

組 氮

$\Rightarrow$ 織, 夕

知占病

食

䬭

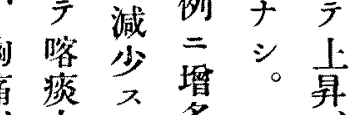

中 2 多

結 場

痛核合證

輕陰

性

卜 一 豆

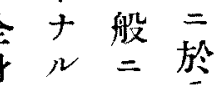

港。減

覧

食

慨 化

例 7

二 認

於 ’

天

見其

樣

= 他

全 “

例 多

二 少

於共

亏減

減 少

少七

少》。

來

サ

叉

痚

䨞

皕

量
光 s $^{\prime}=$ 傾度

グ態党方向分

口 $=$ 僅 》進

ブ恢年ナ。ス

リ復ソガ ル

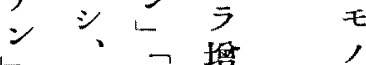

一坐千加

ラ數

1 例 最弱

$\eta^{*}=\left\llcorner^{才}\right.$ 最量

y於高次

降, 天方品毛

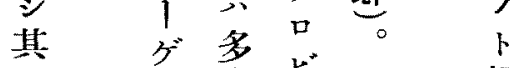

人少少相

他有伯

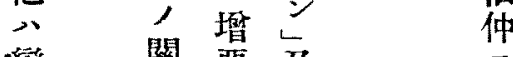

變關惡及

保, と艺次

”狀号福

二 7 モ

例

$=1$ 于

於占治

良簝

恏諸始

關諸

係稚

示 牀

天, 週

モ不

一良沈

般音降

$=r$

認 \%

公多

乞
榴

年

速 


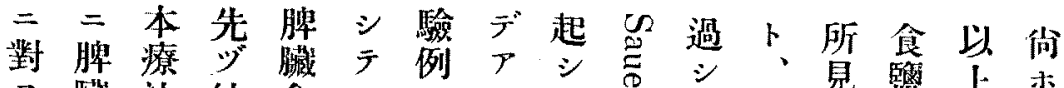
ス酮法結食 $モ=ル \mathrm{Na}$

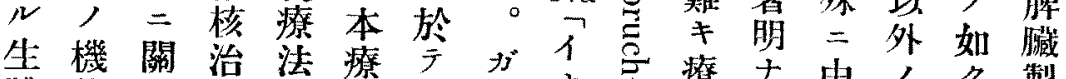

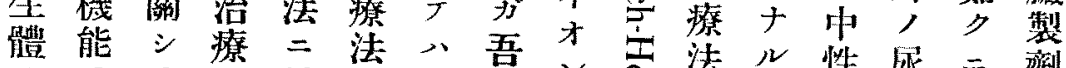
‘ 7 卡於,

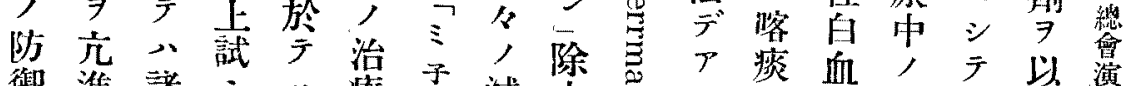

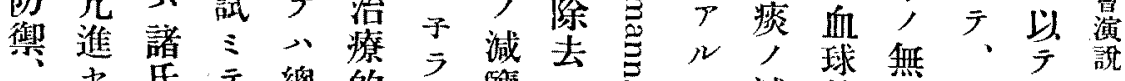

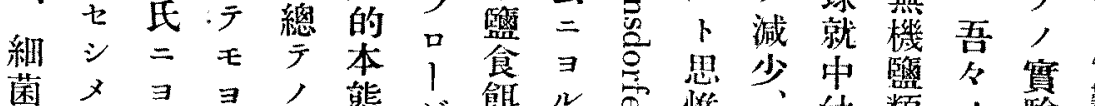

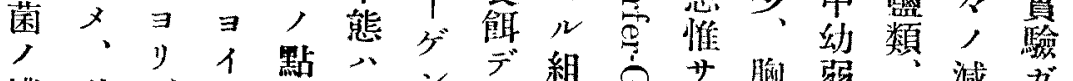
撲引、モ心 今 隇人脾, 於㣪投尿含气臟。所度 作、思減研興處量氏 用網投心監索卜学量減 $\exists$ 牀與 $v$ 食气然等減覧 $ナ$ 織 ル,

入内生。場タザり等

モ皮體合子少省坐

デ胞脾 如ナ例著患體

系 臟

度固

云喈有恏占間

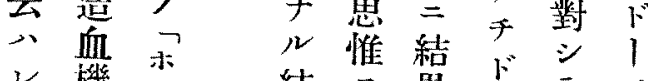

甹機

今機 モ N

調

節 酤

、素

份 等

入 賦

淋 與

細

胞 或

結

果。果 积

得於不毛及

ザ

千

格，熏 ビ

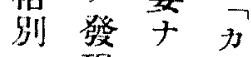

鏟 蒗

生

現 $ル チ$

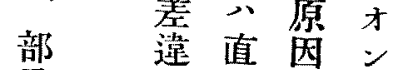

促 2 可

シ $カ^{*}$ 才

傳 夕

分

造直奋さ

的 認二十,

染 メ

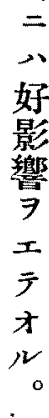

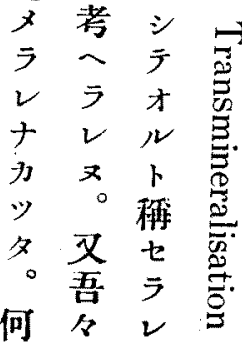

每, 藚

見ビ慨ガ

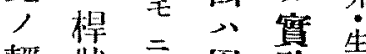

輕 狀

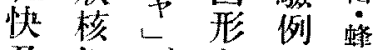

及細、食 $カ 7$ 谷

ビ胞 總 $\rightarrow$ 僅 俍

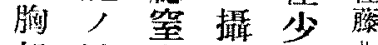

部減素りナ肺

$X$ 少量得夕結

線、等少 邓核

像淋二程夫對

良球一患二

好, 般者就娍

卜䝰的 $=\bar{\gamma}$ 䜿

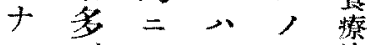

几六豫結法

二 赫殆想果 關

卜血 $ン$ 外, 然

等球 $ト ゙=$ 發

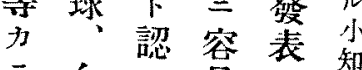

今血么易一筧

吾色心二他

等素 $\neq$ 實

八量惡舁施

本代言讓

療體錅得心

法重华今

肺潮示少永

結 次 专

核增又卜

治 加

療、知

踷 
腎來俟䥫数 加 細シ 三 二多里 尿、利作, 籃 管 是尿用學二 二等的 者 $\exists$ 於過二元 $=w$ 總多剩働組 ヨ指 演, 境再水 内丽食

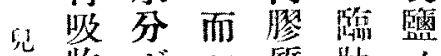

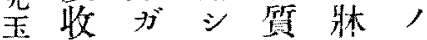
11 係厅, 上驅 妿勥垡組物 或逐 籃 2 體織理 八作 于 = 液化動用 犁體广学物 八 作外滤血的曾

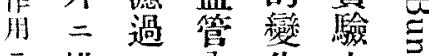
閣排七离化上 7 出 $5=7=$ 化と吸起追 塞亏、引多試曾 權 $ル$ 斯七、證驗 的、留 5 其 明? 究從 シ心膨セり 示化 $\bar{~}$ 全一下磨々以

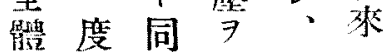
, 排時低其 結泄 =下加 果 卜う管シ需 \& 2 两 于多, 利 組 2 血加尿 維原蕌里作章

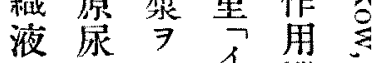

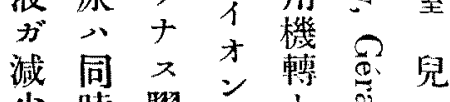
少時毣亡 省 $=$

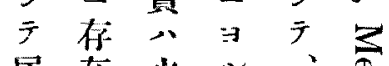

尿在水儿, 团 云量入

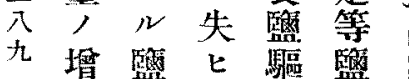

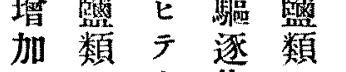
$\exists=$ 水作 來 $\exists$ 血角蹬桇郎 ․ 事 天 7 相 組等

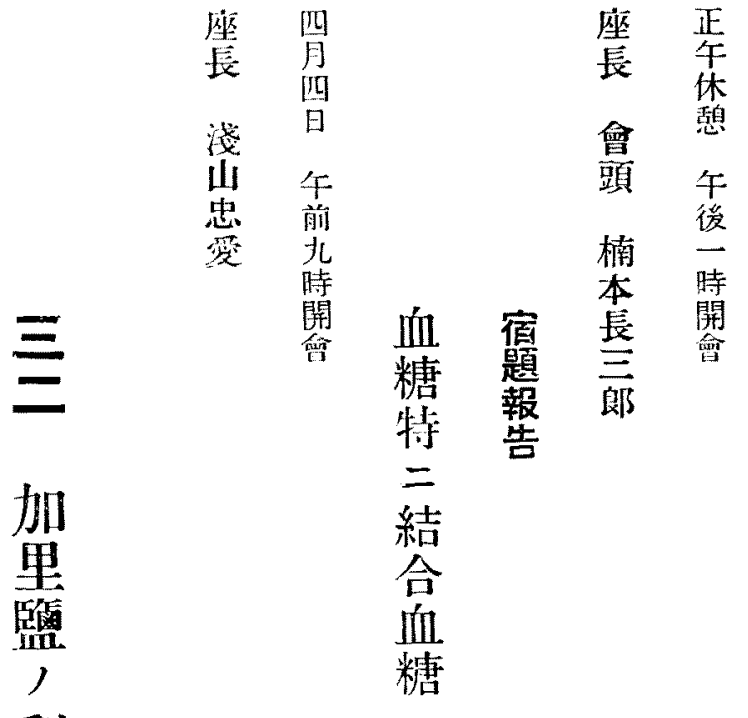

利

尿

作

用

關

ᄌ

ル

蛽

䨐

的

研

究

報

告

飯

塚

直

彥 
第

表

\begin{tabular}{|c|c|c|c|c|}
\hline & \multicolumn{2}{|c|}{ 舡口的投 與 } & \multicolumn{2}{|c|}{ 静脈芮泣射 } \\
\hline & 尿量ac & 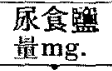 & 尿量ca & 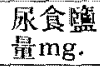 \\
\hline 蒸 蹓 水 & 85.0 & 113.1 & - & - \\
\hline 臭化加里 & 76.3 & 111.7 & 93.8 & 155.9 \\
\hline 确酸加里 & 121.4 & 278.6 & 103.4 & 210.7 \\
\hline 醋酸加里 & 134.3 & 327.3 & 126.2 & 280.6 \\
\hline 硫酸加里 & 119.1 & 228.4 & 86.4 & 110.8 \\
\hline 酒石酸加里 & 108.1 & 249.8 & 123.0 & 280.1 \\
\hline 燐酸加里 & 85.5 & 145.0 & 141.0 & 380.7 \\
\hline 重炭酸加里 & 90.0 & 152.5 & 114.8 & 288.3 \\
\hline
\end{tabular}

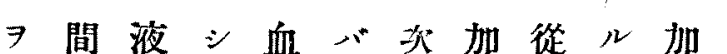

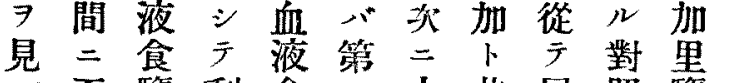

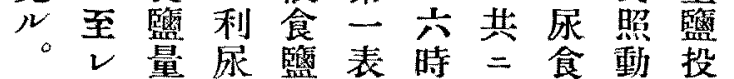
今心 八作量, 間高甖物與 息增然用公如丙 $、$ 縃, 後 化加亏著・ 加程 隍明生。排モ量と時 里度江理泄生 緩場心的七理多り丙 醋 徐 合場 食 酸 $r \exists$ 合 監 加ナ $y=$ 水 里几モ八泩 及力 急加 射 對、劇里 後 照增 $大$ 監 時 動加 $ル$ 液 間 物七㭢投 $尹$ ノザ 加與 重 場 $ル$ 後 $又$ 合力、示有

卜 時、間 從 ）二四、不 テ八時二增 血低間時 加 渵下、間

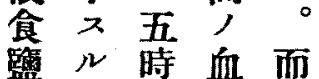
证售有りル
脈シ酒驗監余ル卜

內、石動, 、モナ 二尿酸物投第, 儿 泩 八加卜與—十 射子里シ量回りり

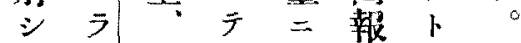
、第 時導燐刵 厂於七醋說 間 尿酸坐照 テ ラ 酸兒 後管 加内ナ加 2 加票 = 7 里外 2 里夕里韭 加用, 事覧り 妿 里 $上$ 七雄 $\exists$, 。重鹽

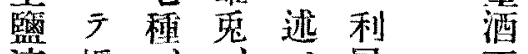
液採: “尿石犁 尿血便夕作酸焦 經 $三$ 液用 2 用加前 品站 シ $カ$ 、”、里 關 的或源尿么此加體会

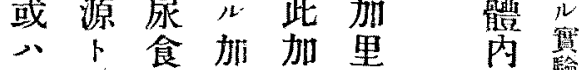

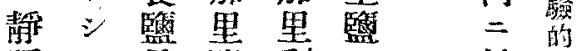
脈于量臨利 $\exists$ 於研 丙家公尿粠究 二兔 投, 㤩化血 $x$ 化 與早兽加葆 朝壁留 $\bar{龴}$ 爾空夜㗂辰二 う的 シモ二後時法酸食才

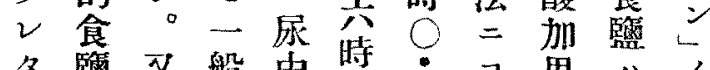

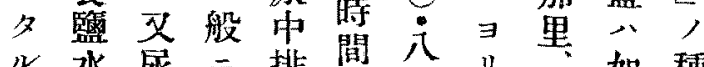
$N$ 水尿二排間分只如種 尿, 食多泄, 五至酷何類

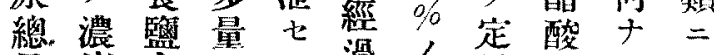
量度含吉今過'量加心三 尿公萃会食的 尿五一具食察的食重採適

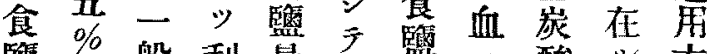

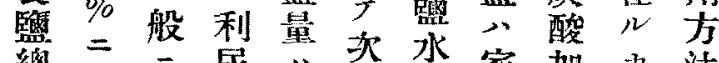
總達二尿公次水家加力法 量達血作蒸結 $\overrightarrow{0}$ 兔里 $7=$

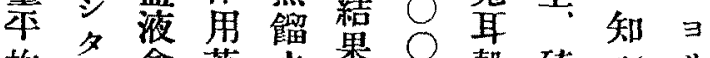

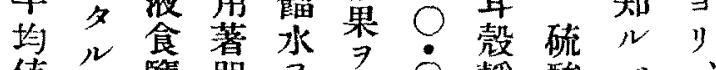

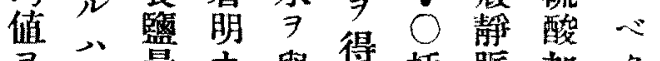
省無量ナ與得践脈加り又笋

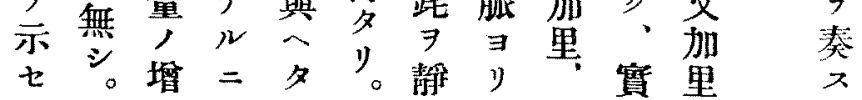


里物稍次斬

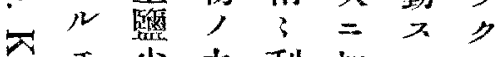

沓量头利㔔心

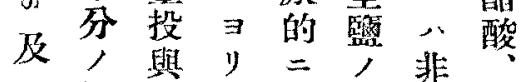

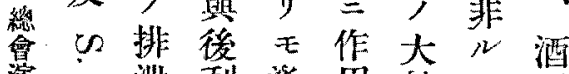

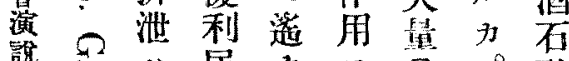

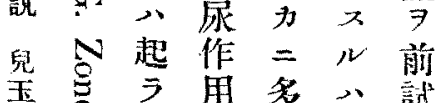

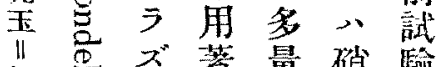

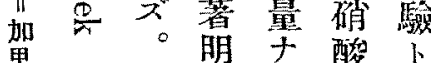

黑監 ガ六早ナ酸卜

利裳時 2 。里樣

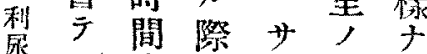

㷳归丙三

用ン三現ド二條

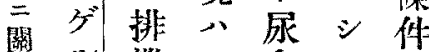

背泄レ食テ,

儿液七夕監他下

惯 $\exists 5 \mu$ 含

以レ $ォ ゙$ 有此經

テ夕如率作口

蛙 $心 \neq>$ 用的

怘尿現生 $\Rightarrow=$

马總 象 理 現 投

漠 $\exists$ 的

篧垃是食ズ、

尿。水然六

夕食郎, 力时

緊于濃モ間

際總加度共,

量里 7 時 經

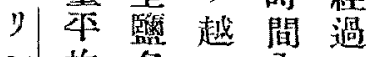

均多多丙

ダ $、$ 量 事二颧

示投無排察

液七與》泄

二小時" 久

籃第二血 $ル$ 次

化三八液尿，

二䚮表食食食結

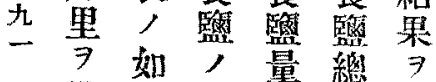

僅要。排量總 得

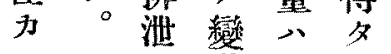

加行動對》。

酸

鳁

肉

第

圖 棤

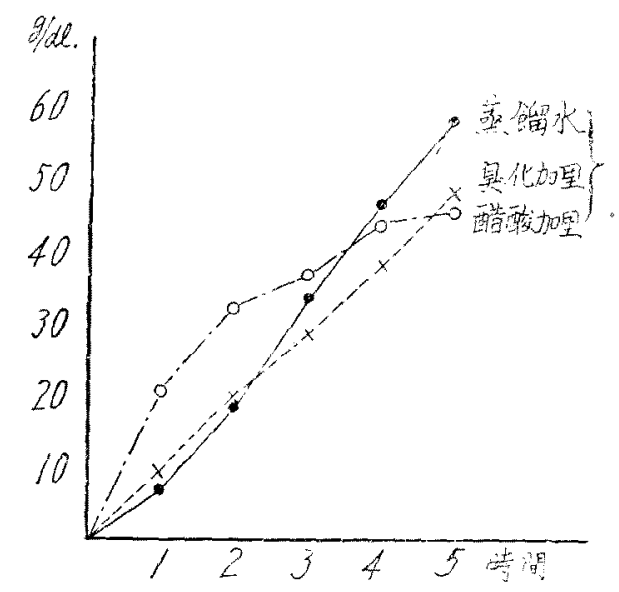

化

ラル利里卢な重用著厄重量

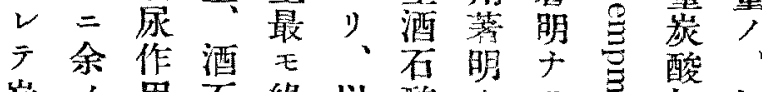

炭, 用石緣以酸士 5 加加 酸寞 二驗少妿近利里 $=$ 卜公鹽

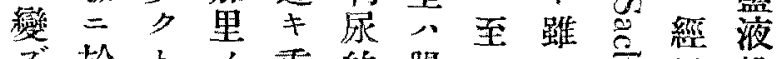

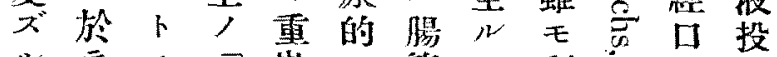

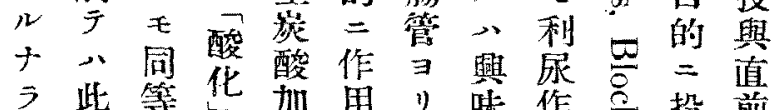

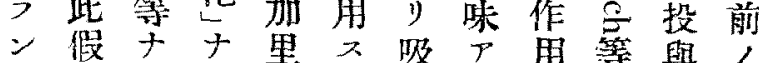
E鿁 $N$ 为卜收

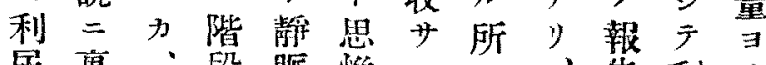
尿毫:段秡惟 $v=$ 告利り 的書或 $\exists$ 内丙 $七$ 然不尿, 二 $シ$ 經 $=$ り後 入得夫ザ投。體、毛所作加

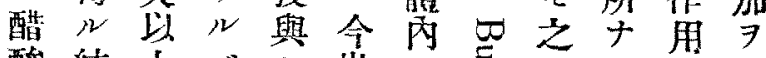
酸結上心 果三カ⿻酸於品靜

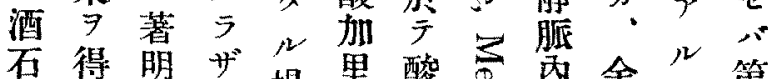
酸得琞ザ場里酸贵丙余事第 根能 $モ$ 合华七等泩實八圖

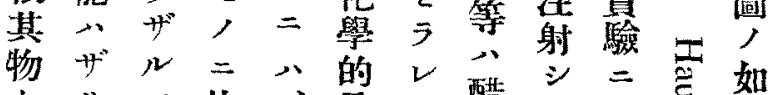

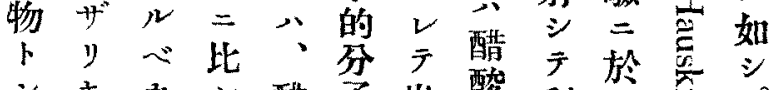

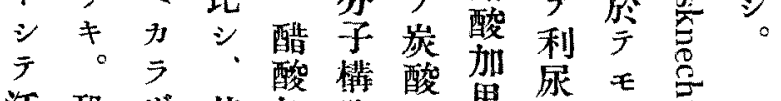

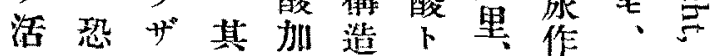




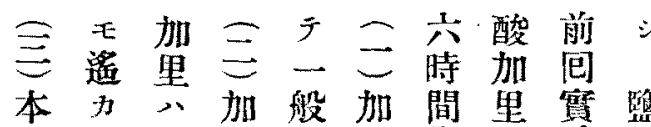

試二之里二里丙, 䌞化

驗高二監低監

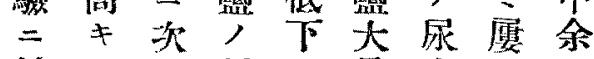

於モ壬程 ス量水:

厂以、類。經䒺酸常

尿後硝

$\mathrm{PH} \rightarrow$ 酸 $\exists$

值 却 加

点里

尿稍三尿

量 $: \exists \mathrm{PH}$

下, 低儿値

, 下正

間 ス, 高

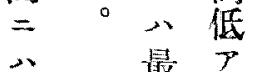

直最学

接低

關等

係硝重

于酸 荻

シ 加 酸

里 加

投里

口等性

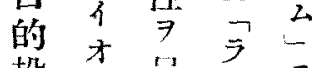

投少品多二

與

\begin{tabular}{|c|c|c|}
\hline 第 & $=$ & 表 \\
\hline & 尿 量 & 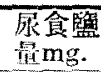 \\
\hline 灌 䒄 水 & 85.0 & 113.1 \\
\hline 鼻化加里 & 76.2 & 250.2 \\
\hline 喼酸加里 & 86.4 & 422.7 \\
\hline 醌酸加里 & 78.8 & 327.6 \\
\hline 重炭酸加里 & 65.8 & 225.3 \\
\hline
\end{tabular}

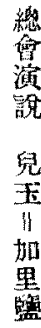

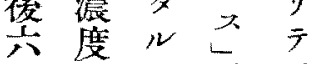

時 $\Rightarrow 7$ 紙 尿

閜测以

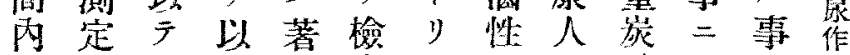

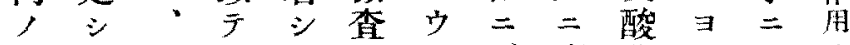

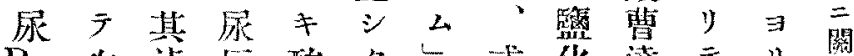

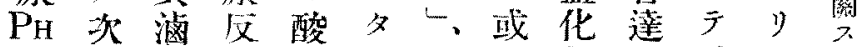

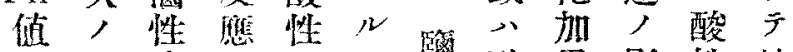

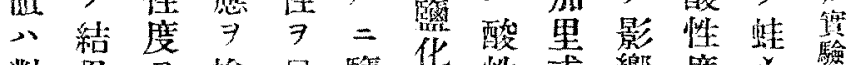

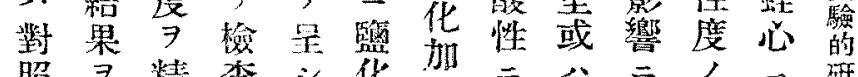
照 $\exists$ 精香 $シ$ 化里 $=$ 留二, $三$ 研

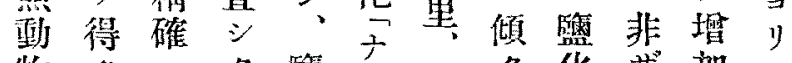

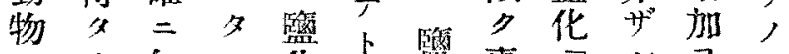

與 $=$

夫 。知心华少稚事另事来流

後 $\exists$

夫

走

間,

內

二最

於王

竞高

ᄂ

心加 里

夕里

名観

$\exists$

尼”

尿

值 酸

$\rightarrow$ 加

對 里

照

試 籃

驗 化

, 加

夫里

E

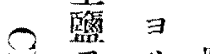

般

$\frac{2}{2}$

=

,

高

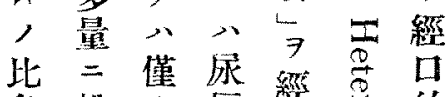

事出

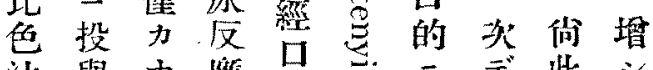

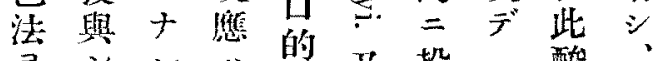

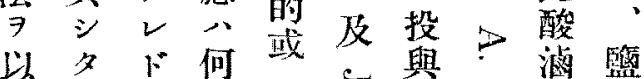

投

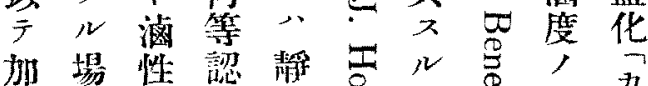

後

何

里合二厶脈号事弯變

v

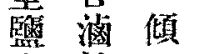

$\varepsilon$

多性

時

間

量著事

霞

э臭

!化

r

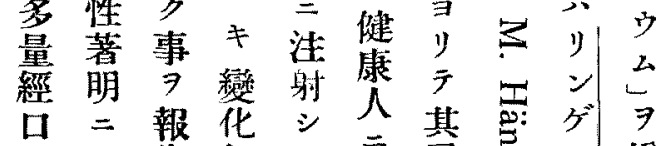

$=$

從

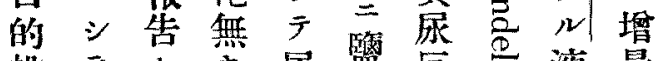

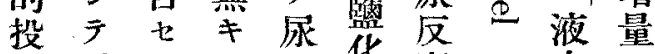

與、y二反华應、中不

後硝。反應ナガ健, 


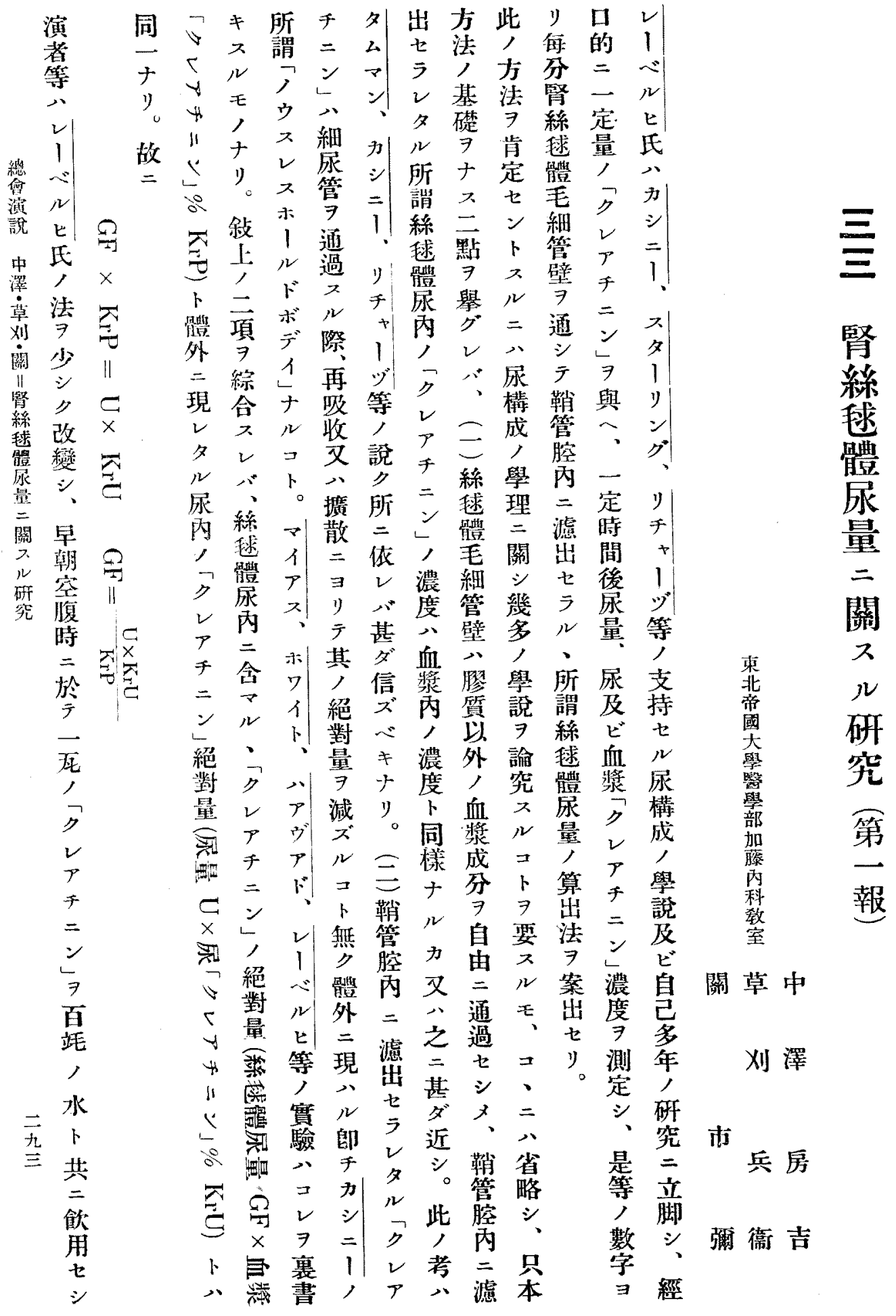




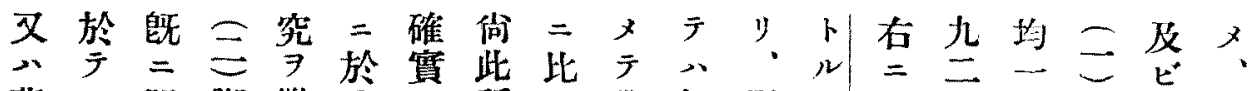

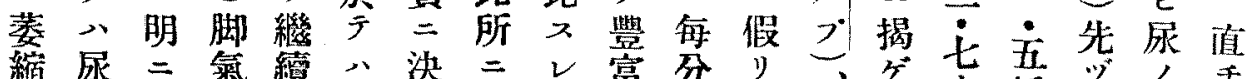

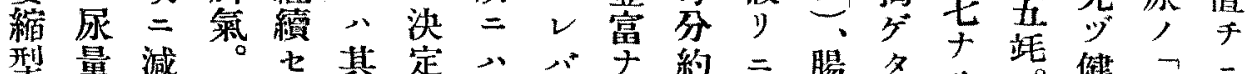

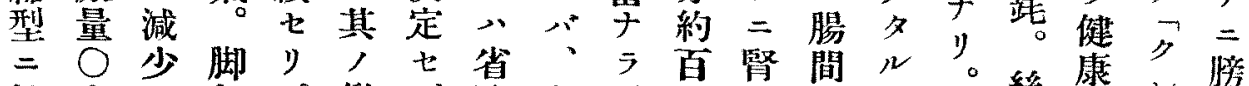

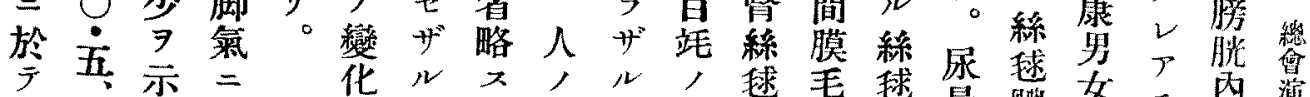

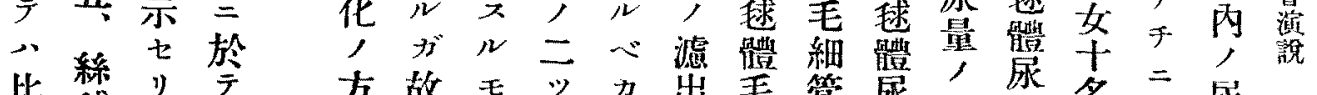

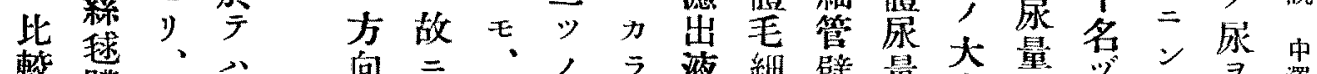

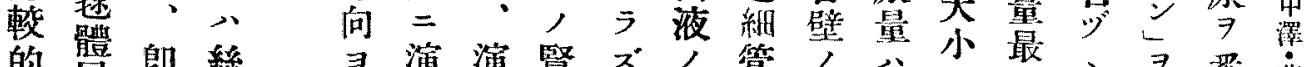

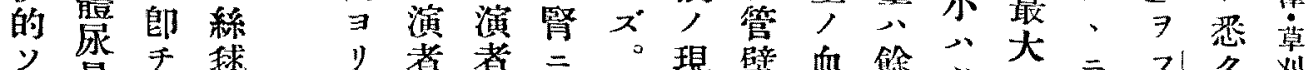

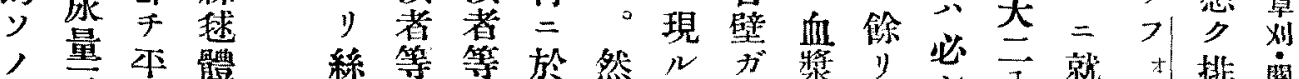

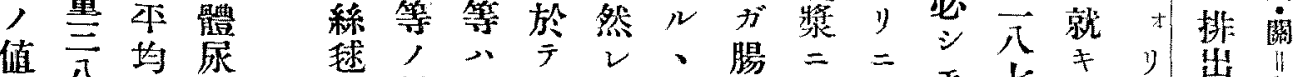

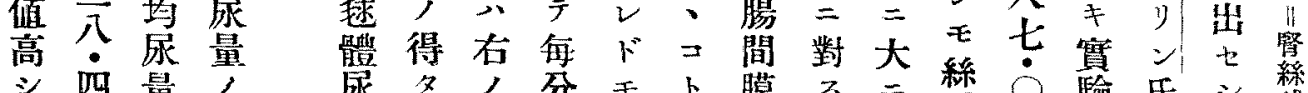

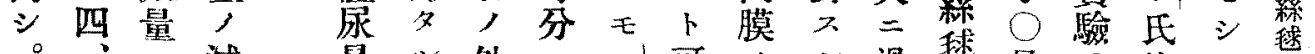
量 $N$ 外

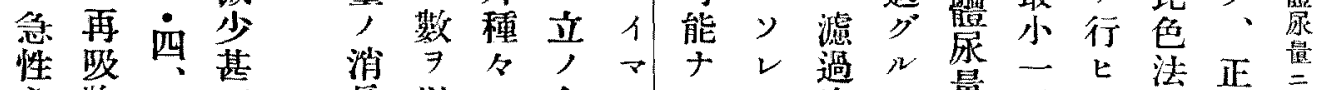

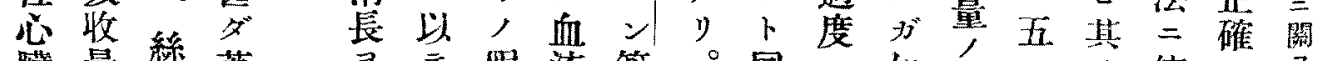

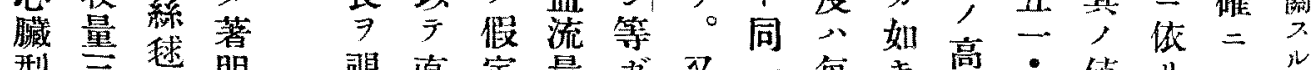

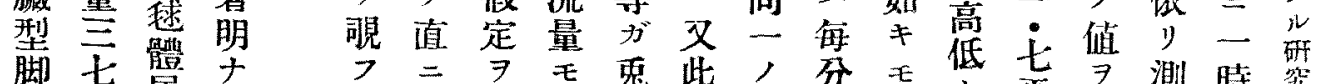

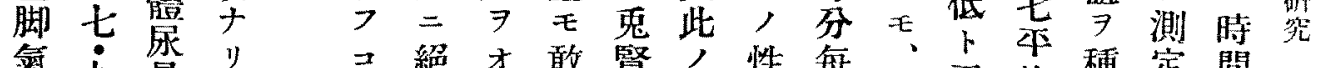
氣昆”。“䋥才敢腎，性每每均種定間

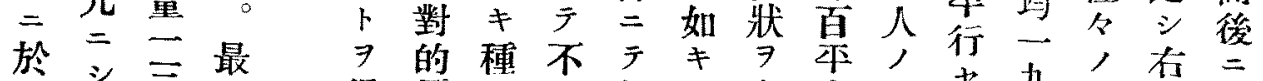

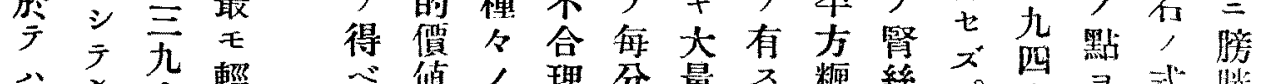

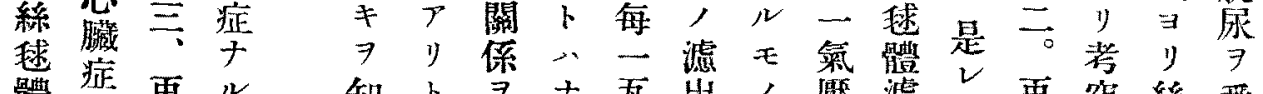

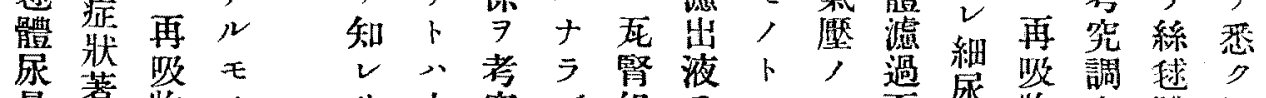

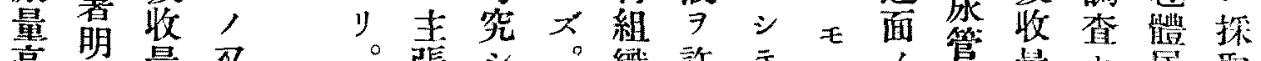

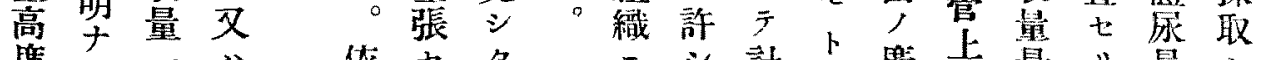

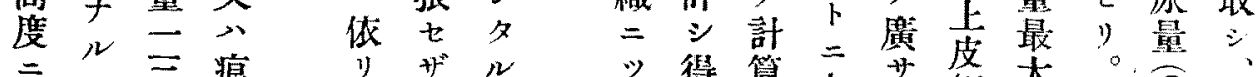

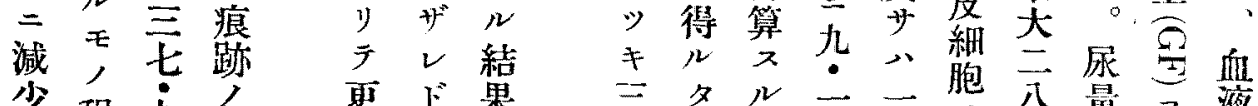

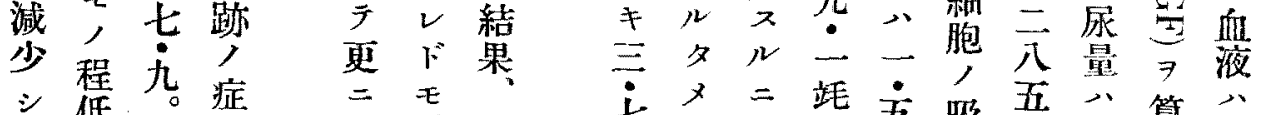

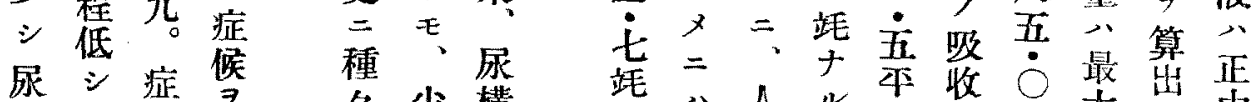

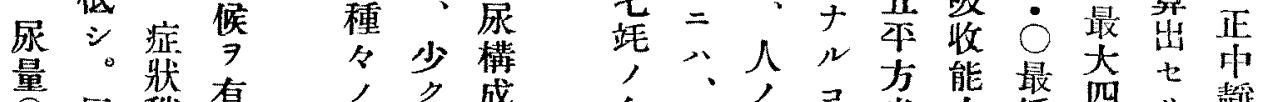

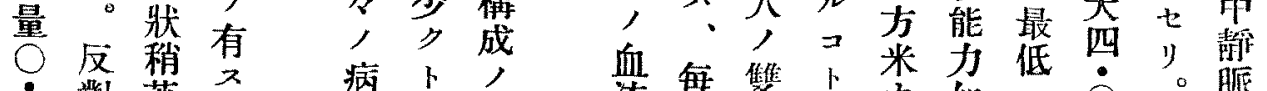
對著公病的无機 冫 =明毛牀比轉 絲連ナ, 態䡌, 毢動 $ル=$ 的令 體感毛於 尿覺, 今 量型 $=€$

$\%$, 日 キ意未 研味落
血每繁隽方皇

量分, 方为荷五跬

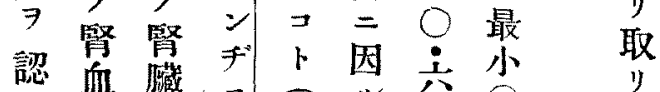

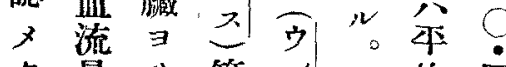

夕量 》等

ル極 シ 


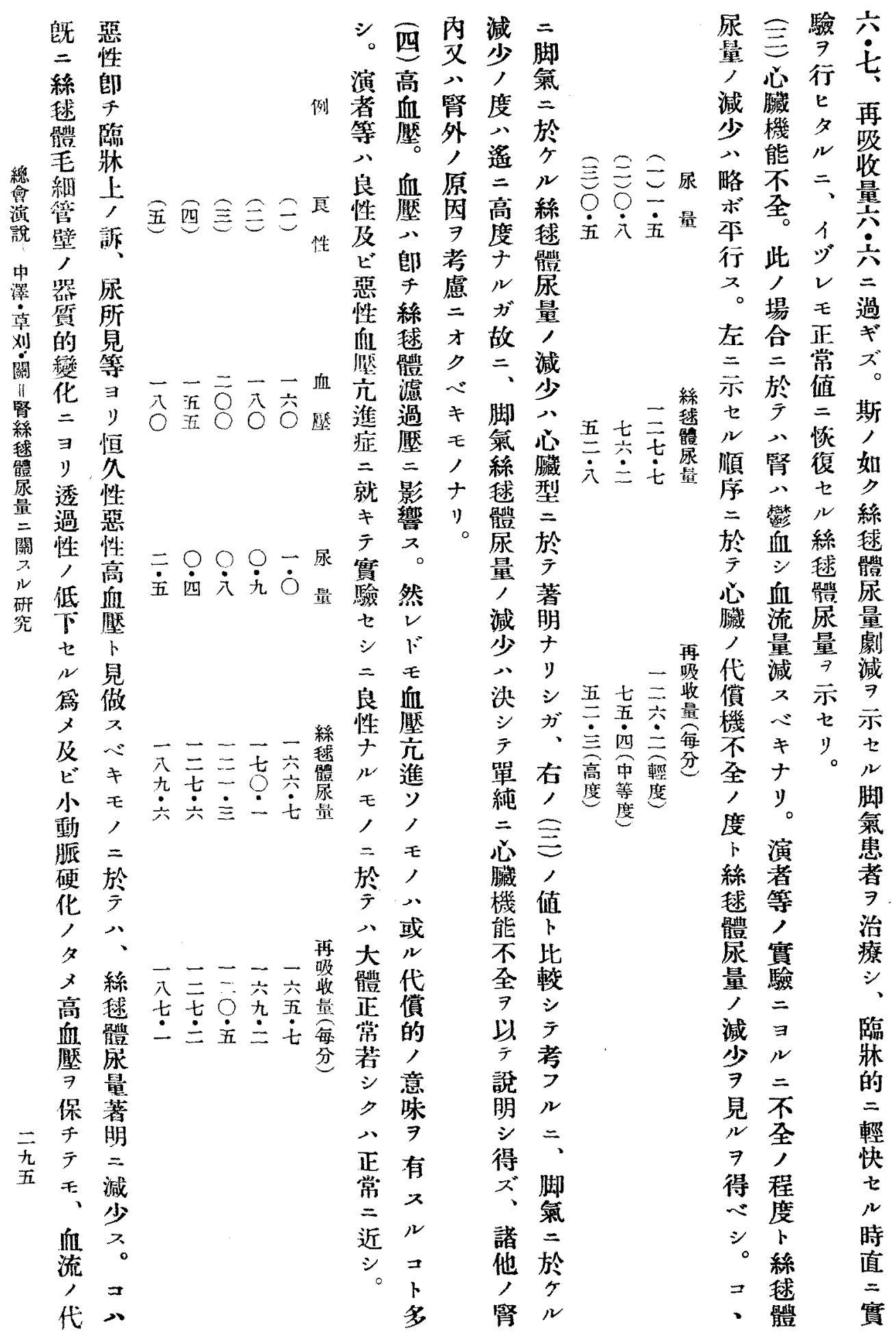




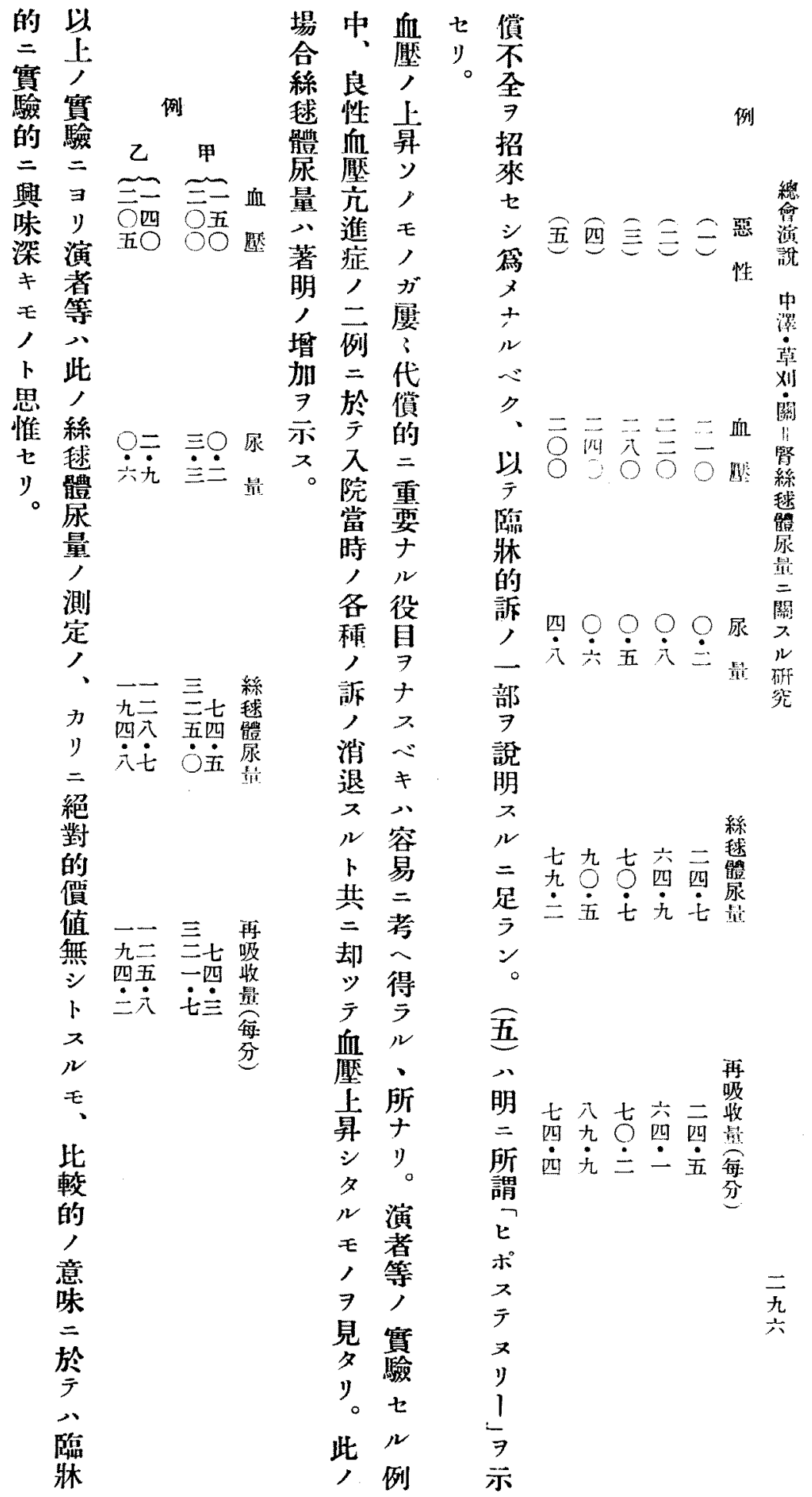




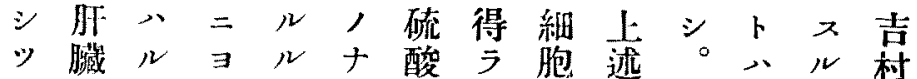

$$
\begin{aligned}
& \text { ツノルリ卜リハル原, 同必事氏 } \\
& \text { 厂化 コテ共。硫儿形如樣 }
\end{aligned}
$$

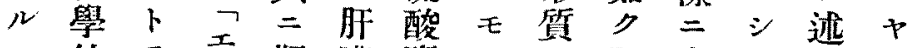

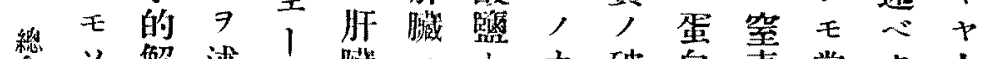

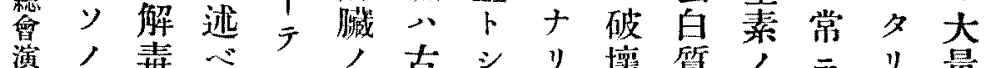

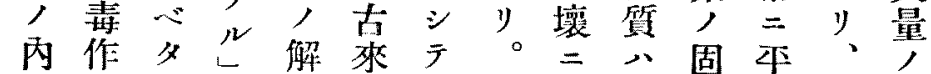

$$
\begin{aligned}
& \text { 池工用儿硫毒化尿故因臟定行蛋墨 } \\
& \text { 山立酸作學中三天器入入白汁 }
\end{aligned}
$$

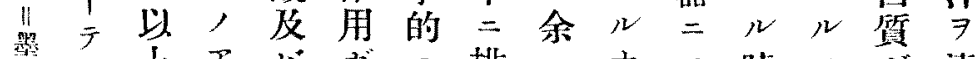

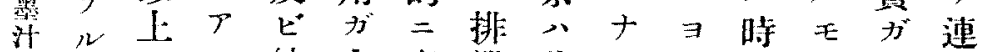

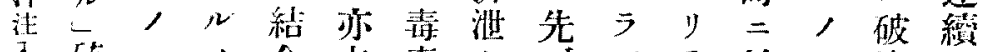

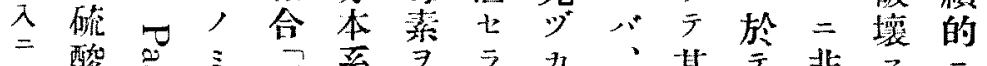

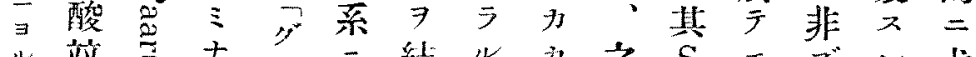

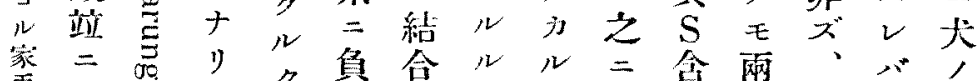

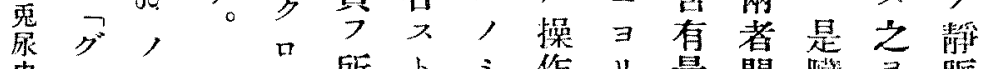

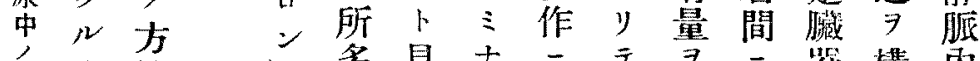

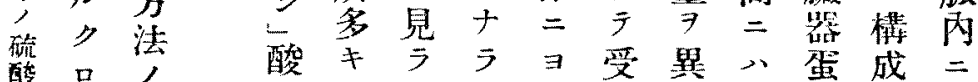

$$
\begin{aligned}
& \text { 薢只, }
\end{aligned}
$$

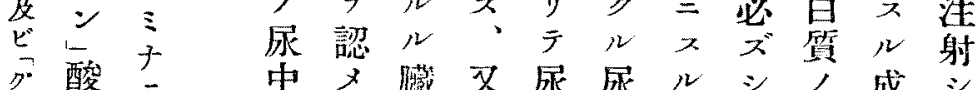

$$
\begin{aligned}
& \text { 酸 }
\end{aligned}
$$

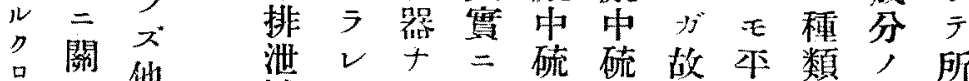

$$
\begin{aligned}
& \text { 只他減表硫硫故本類, 所 }
\end{aligned}
$$

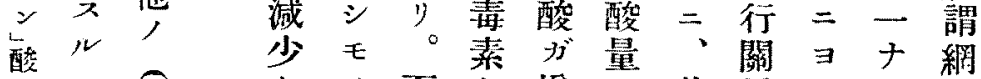

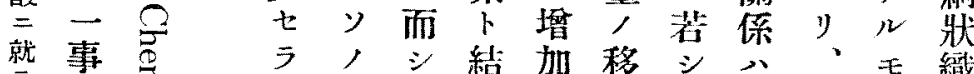

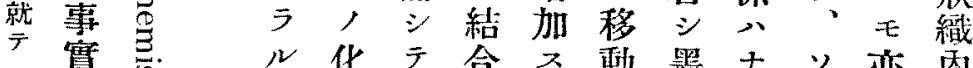

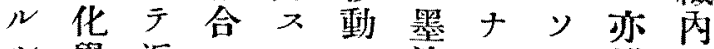

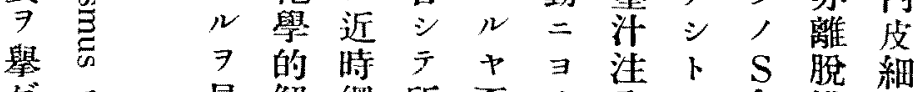

$$
\begin{aligned}
& \text { 年見解網所否り入イ含排胞 }
\end{aligned}
$$

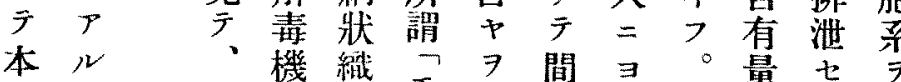

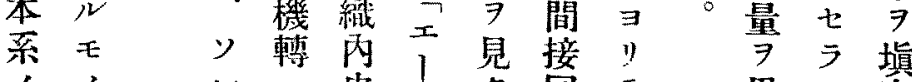

$$
\begin{aligned}
& \text { 化ナレシ皮多同示異年塞池 }
\end{aligned}
$$

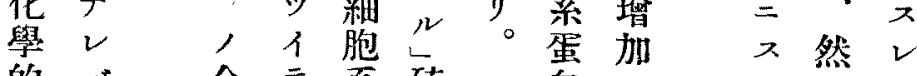

$$
\begin{aligned}
& \text { 的命合等采硫泉 } \\
& \text { 二毒心 心中機酸貿窒事だ尿 }
\end{aligned}
$$

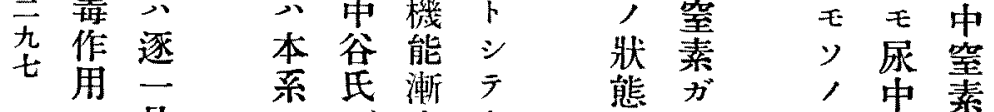

$$
\begin{aligned}
& \text { 是 }=73 \text { 次促 } \\
& \text { 對等 } \quad \exists \text { 墨 閵 現 } \\
& \text { x } \exists \text { y 汁 明 }
\end{aligned}
$$

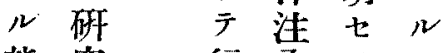

$$
\begin{aligned}
& \text { 態究行入 万无 } \\
& \text { 態 } \\
& \text { 马網一, 素耕 } \\
& \text { モ狀因窒排 } \\
& \text { 忖载名素泄三 } \\
& \text { 度内丙增 } \\
& \text { 四 } \\
& \begin{array}{c}
\text { 口 墨 } \\
\text { 汁 } \\
\text { 酸 注 }
\end{array} \\
& \text { 二入 } \\
& \text { 就 二 } \\
& \text { テ } \exists \\
& \text { ル } \\
& \text { 冢 } \\
& \text { 兔 } \\
& \text { 尿 } \\
& \text { 中 } \\
& \text { ) } \\
& \text { ビ } \\
& \text { ク } \\
& \text { ル }
\end{aligned}
$$


表

箱

\begin{tabular}{|c|c|c|c|c|c|c|c|c|c|}
\hline \multirow{2}{*}{ 月 } & \multirow{2}{*}{ 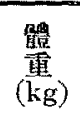 } & \multirow{2}{*}{$\begin{array}{c}\text { 尿 } \\
\text { 量 } \\
(\mathrm{ccm})\end{array}$} & \multicolumn{2}{|c|}{$\begin{array}{l}\text { Tグルク口 } \\
\text { У酸 }\end{array}$} & \multicolumn{2}{|c|}{ 船機硫酸 } & \multicolumn{2}{|c|}{$\begin{array}{l}\text { Tエーテル } \\
\text { 硫酸 }\end{array}$} & \\
\hline & & & 90 & $\begin{array}{c}\text { 全量 } \\
\text { (mg) }\end{array}$ & $\%$ & $\begin{array}{l}\text { 全量 } \\
(\mathrm{mg})\end{array}$ & $\%$ & $\begin{array}{l}\text { 全軖 } \\
\text { (mg) }\end{array}$ & \\
\hline $27 / 5-1929$ & 1.78 & 500 & 22.4 & 112.0 & 35.6 & 178.0 & $4 . \overline{2}$ & 21.0 & \\
\hline $29 / 5$ & 1.80 & 550 & 20.0 & 110.0 & 30.8 & $\overline{169.4}$ & 4.0 & 22.0 & \\
\hline $31 / 5$ & 1.81 & 500 & $\overline{22.4}$ & $\overline{112.0}$ & 40.4 & $\overline{202.0}$ & 4.6 & 23.0 & \\
\hline $2 / 6$ & 1.82 & 500 & 21.7 & 108.5 & 48.6 & $\overline{218.0}$ & 4.1 & 20.5 & \\
\hline $4 / 6$ & 1.85 & 500 & 17.4 & 87.0 & 38.8 & 194.0 & 4.1 & $20 . \overline{5}$ & \\
\hline $6 / 6$ & 1.89 & 550 & 19.1 & 105.1 & 37.2 & 204.6 & 4.8 & 26.4 & \\
\hline $8 / 6$ & 1.92 & 500 & 18.4 & 92.0 & 40.8 & $\overline{204.0}$ & 3.8 & 19.0 & \\
\hline \multirow[t]{2}{*}{$10 / 6$} & 1.94 & 500 & 19.6 & 98.0 & $\overline{39.6}$ & $\overline{198.0}$ & 4.2 & 21.0 & \\
\hline & & 平均 & & 103.1 & & 196 & & 22.1 & \\
\hline $12 / 6$ & 1.93 & 500 & 18.0 & 90.0 & 0 & 0 & $\bar{x}$ & $x$ & 「カンフル」2ca往射 \\
\hline $14 / 6$ & 1.94 & 500 & 28.2 & 141.0 & 0 & 0 & 24.3 & 121.5 & $\therefore$ \\
\hline $16 / 6$ & 1.95 & 500 & 39.8 & 199.0 & 2.0 & 10.0 & 22.4 & 112.0 & $"$ \\
\hline $18 / 6$ & 1.98 & 450 & 33.1 & 149.0 & 10.8 & 48.7 & 50.2 & 225.9 & $\therefore$ \\
\hline
\end{tabular}

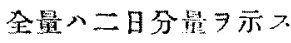

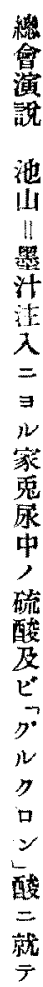

系 ガ無蓋

, 如機 シ 著市 II 甚率千值 I

化 シ 硫 尿 變 減

學。酸中广少

的 而, 学 $シ$

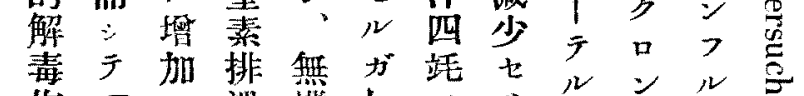

作 グ 湺機 如

用

$\exists$ 手霄酸、䋶

暗夕蛋加无次注

示口白 $又$ 逐回射

×

几酸, 時甚りり

モ，而期名逐

, 增 燿二 $三$ 次

十加二相夕塯

》，件䈏 增 加

即ᄀ 入 量 シ

テ必ル七・叫

种然モり、エ ᄂ

狀的, 、酸

織人十

内歸 ルノ少

皮結 心 時 光—

細ナ乡期硫四

胞心、心酸心

硫酸洼卜成 䮲

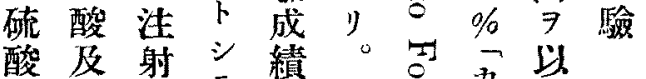

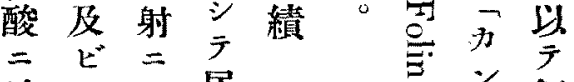

於令

$\overline{7}$ I 中

特 $\bar{\gamma} \bar{\gamma}$

二 广 如 硫

著 2 何 酸

明 硫 及

+ 酸 變 ビ

y > 邀 グ

而共

而二

シ 增 $ヤ$

于 加 7 口

艋 2 見 ᄂ

機儿夕酸

硫モり

酸墖 正

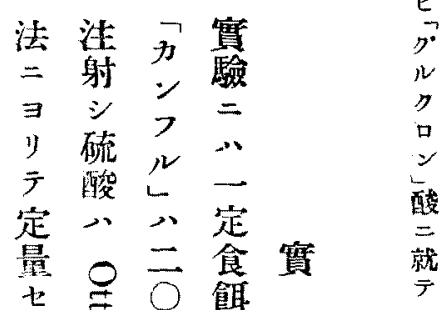

氏 フ 飼

法心養

$\neg$ オ

グレ 家

ル7鬼

口 油用

ン $r$ t

酸 シ 墨

酸 テ 汁

之

吾皮

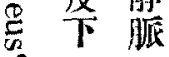

(f) $=$ 
表

II

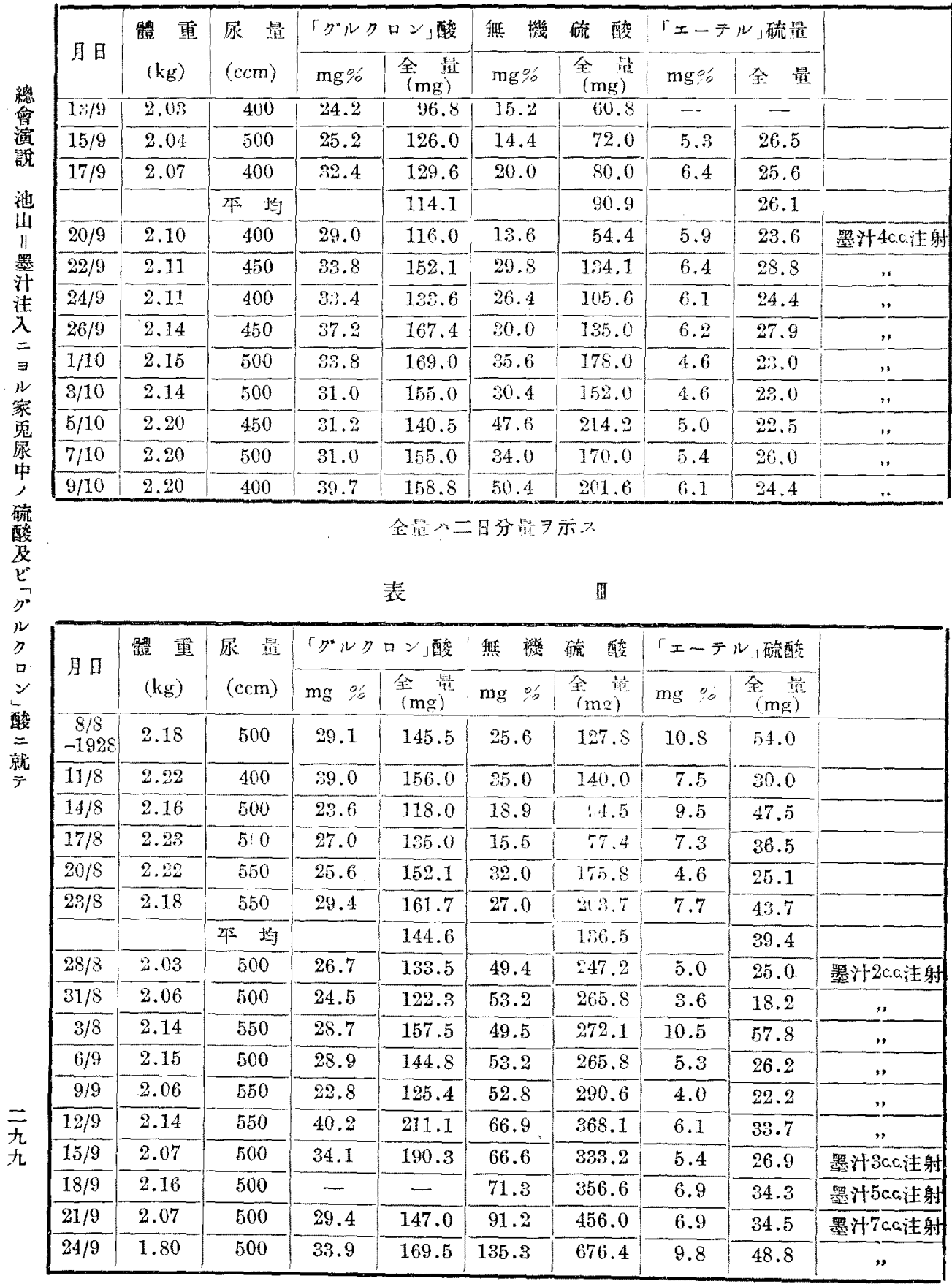

全量ハフベテ三日分星ヨ示ス 
表

\begin{tabular}{|c|c|c|c|c|c|c|c|c|c|}
\hline \multirow{2}{*}{ 具 } & \multirow{2}{*}{$\begin{array}{c}\text { 縉重 } \\
\mathrm{kg}\end{array}$} & \multirow{2}{*}{$\begin{array}{c}\text { 禩 } \\
\text { ccm } \\
\mathrm{ccm}\end{array}$} & \multicolumn{2}{|c|}{$\begin{array}{l}7^{\circ} \mu \eta \square \\
\text { 酸 }\end{array}$} & \multicolumn{2}{|c|}{ 無 機 硫酸 } & \multicolumn{2}{|c|}{$\begin{array}{l}\text { 球 } \\
\text { 酼酸 }\end{array}$} & \\
\hline & & & $\%$ & $\left(\begin{array}{c}\text { 全量 } \\
(\mathrm{mg})\end{array}\right.$ & $\%$ & $\begin{array}{l}\text { 全责 } \\
\text { (mg) }\end{array}$ & $\%$ & $\begin{array}{l}\text { 全量 } \\
\text { (mg) }\end{array}$ & \\
\hline $6 / 1-1929$ & 2.72 & 700 & 41.4 & 289.8 & 46.8 & 327.3 & 7.5 & 52.5 & \\
\hline $9 / 1$ & 2.73 & 700 & 41.3 & 289.1 & $\overline{51.3}$ & 359.2 & 4.9 & $\overline{34.3}$ & \\
\hline $12 / 1$ & 2.78 & 800 & 31.2 & 249.6 & $\overline{49.1}$ & 393.0 & 6.2 & $\overline{49.6}$ & \\
\hline $15 / 1$ & 2.79 & 800 & 26.4 & 211.2 & 36.0 & 247.7 & 5.2 & 41.6 & \\
\hline \multirow[t]{2}{*}{$18 / 1$} & 2.80 & $\overline{800}$ & 28.1 & 224.8 & $\overline{36.8}$ & 294.7 & $\overline{6.1}$ & $\overline{48.8}$ & \\
\hline & & 本均 & & 252.9 & & 324.4 & & 45.4 & \\
\hline $21 / 1$ & 2.76 & 800 & 41.0 & 328.0 & 17.5 & 139.8 & 12.0 & 96.0 & 「カンフル」Icc注射 \\
\hline $24 / 1$ & 2.63 & 800 & 49.2 & 393.6 & $\overline{34.3}$ & 274.6 & 5.5 & 44.0 & \\
\hline $27 / 1$ & 2.71 & 800 & 35.8 & 282.4 & 49.8 & 398.4 & 6.3 & 50.4 & 照汁 7ca注射 \\
\hline $30 / 1$ & 2.52 & 600 & 27.3 & 163.8 & 76.0 & 456.2 & 6.6 & 39.6 & 9 c.c. \\
\hline $2 / 2$ & 2.48 & - & -- & 二 & - & - & - & - & $10 \mathrm{ccc}$ \\
\hline $5 / 2$ & 2.34 & 750 & 34.1 & 255.8 & 104.0 & 779.7 & 8.6 & 64.5 & $10 \mathrm{cc}$ \\
\hline $8 / 2$ & 2.34 & 650 & 46.3 & 801.0 & 84.8 & 551.2 & 13.3 & 86.5 & 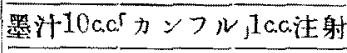 \\
\hline $10 / 2$ & 2.38 & - & - & - & - & - & - & - & \\
\hline $12 / 2$ & 死亡 & - & - & - & - & - & - & - & \\
\hline
\end{tabular}

全最ハスぶテ三日分最フ示フ。

表

V

\begin{tabular}{|c|c|c|c|c|c|c|c|c|c|}
\hline \multirow{2}{*}{ 月 } & \multirow{2}{*}{$\begin{array}{l}\text { 體重 } \\
(\mathrm{kg})\end{array}$} & \multirow{2}{*}{$\begin{array}{c}\text { 最 } \\
\text { 量 } \\
(\mathrm{ccm})\end{array}$} & \multicolumn{2}{|c|}{ 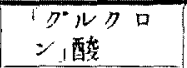 } & \multicolumn{2}{|c|}{ 艌機硫酸 } & \multicolumn{2}{|c|}{$\begin{array}{l}\text { Tェーテル」 } \\
\text { 硫酳 }\end{array}$} & \\
\hline & & & $\%$ & $\begin{array}{l}\text { 全鳘 } \\
(\mathrm{mg})\end{array}$ & 96 & $\begin{array}{l}\text { 金量 } \\
\text { (mg) }\end{array}$ & $\because \sigma$ & $\begin{array}{l}\text { 金量 } \\
(\mathrm{m} g)\end{array}$ & \\
\hline $23 / 9-1929$ & 2.34 & 500 & 24.2 & 121.0 & - & - & 5.4 & 27.0 & \\
\hline $25 / 9$ & 2.31 & 500 & 24.2 & 121.0 & 14.2 & 71.0 & 6.4 & 32.0 & \\
\hline \multirow[t]{2}{*}{$27 / 9$} & $\overline{2.30}$ & 500 & 31.2 & $\overline{156.0}$ & 18.4 & 92.0 & 5.6 & 28.0 & \\
\hline & & & 和均 & 132.7 & & 81.5 & & 29.0 & \\
\hline $2 / 10$ & 2.25 & 500 & 66.2 & 381.0 & 16.4 & 82.0 & 29.8 & 119.0 & 「カンフル,2ca注射 \\
\hline $4 / 10$ & 2.23 & 400 & 93.6 & $\overline{374.4}$ & 14.8 & 59.2 & 20.3 & 81.2 & 「カンフル」2ca注射 \\
\hline $6 / 10$ & 2.24 & 450 & 30.0 & 135.0 & 37.2 & $\overline{167.4}$ & 4.5 & 20.3 & \\
\hline $8 / 10$ & 2.24 & 500 & 28.8 & 144.0 & 45.6 & 228.0 & 5.8 & 29.0 & \\
\hline $10 / 10$ & 2.25 & 450 & 32.6 & 146.7 & 50.4 & $\overline{226.8}$ & 6.4 & 28.8 & \\
\hline $12 / 10$ & 2.27 & 400 & 155.2 & 620.8 & 37.6 & 150.4 & 26.4 & 106.6 & 「カンフル20c墨4.5ca注身 \\
\hline $14 / 10$ & & 450 & 89.3 & $\overline{401.8}$ & 30.8 & 138.6 & 26.2 & 117.9 & 「カンフル 2ca墨4.5ca洼身 \\
\hline $16 / \overline{10}$ & 2.19 & 500 & 72.4 & 361.8 & 132.4 & $\longdiv { 6 6 2 . 0 }$ & 16.8 & 81.5 & 墨汁 4.5 c.c. \\
\hline
\end{tabular}


テ否り。次陳破於心以

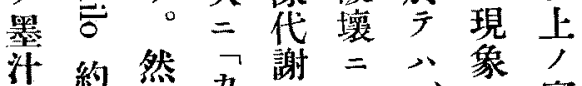
$卜$ 上背旺, “實

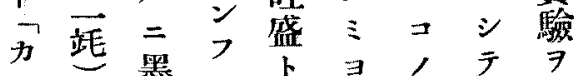
線ン $コ$ 墨

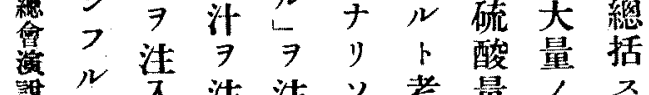
伡儿入泩泩ン考量, 梁上又又射, フ上泩ル II 同 $ハ$ ス $v$ 能 9 加 墨时・心六方至心

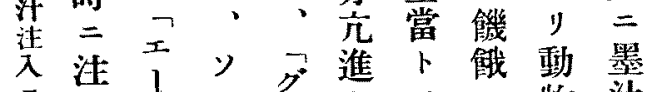
告射 $1, ク^{*}$ 七

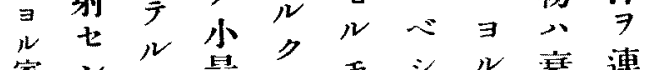

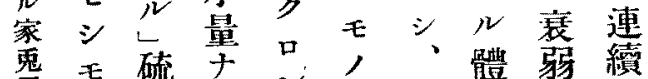

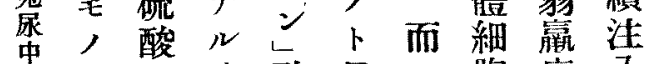
, = 二 時酸見シ 胞痩 入

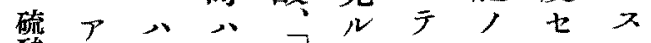
酸り著著エ心コ破ルレ

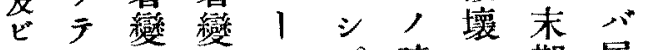
范广广示。時三期尿 ル・少期因心中 吕雨、、每硫結 酸共 シ = $=$ 口共作 フ 就增 $ヤ+$ 用べ小酸 テ量 $\uparrow \uparrow$ 增 增 $\neq$ 量 減減量進二量 增 ル少少 $九$ 非浩加

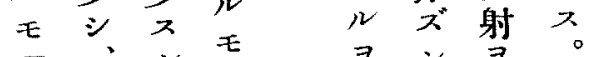

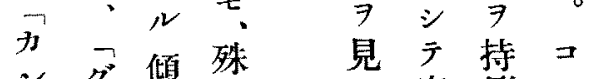
ング傾桨 ル

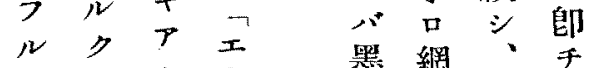

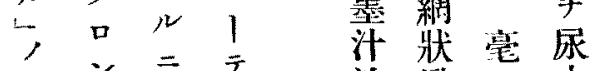
ミレ 反 三注酸 シ 硫 二 内皮重窒

○射增 $\uparrow$ 酸 $\exists$ 細減素 七 加 $+=$ 胞少增 ル七大於 系十加 場》量亏同原丰二 合。量著系形場随

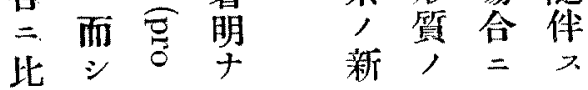

○ト表 $尹$ 入モ表機表 甚墨 V 注 $又$, IV 硫 III ダ 汁 射 $レ+$ 酸 シトろスバリっか小

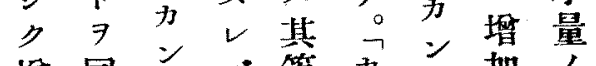
增同 八等方了加了

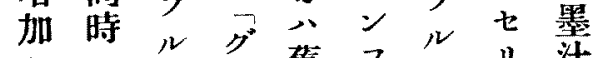

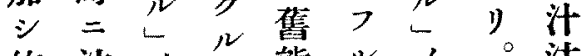
總約泩, 少態 $N$, 。注 三射 三 口 括倍 7 ○此

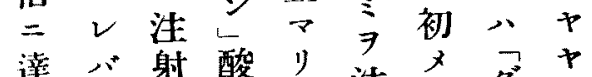
達心射酸り泩伡 グヤ 七・七业無射注射 リ。場 只硫 フ合、酸時 後 表 $心$ 增 第量酸七 ， I，加第, 壬 三・硫 、表墨增 モ $\exists$ 表酸、表汁加 泩 IV 心而㚾 7 ス 射二増 シ 如連。” 七於加 只續 ルケス 墨 グ注 前 時 $。$ 汁尔 二卜 $\rightarrow \Rightarrow$ シ 八 比同泩口年 シ、椂 入 ン 然

×

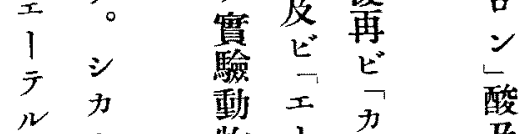

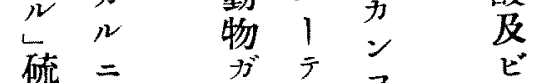
酸 -. 衰 $ル 7$ 著定 弱

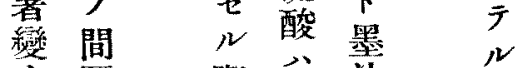

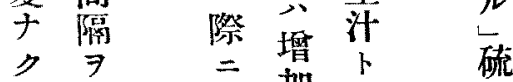
、才於 加 7 酸 グ、年向同共 $\begin{array}{llll}\text { ル } & \text { 後 時 } & \text { 著 }\end{array}$ 口 ン 墨泩變 ンフフ 汗射 酸 $ル$ 泩 


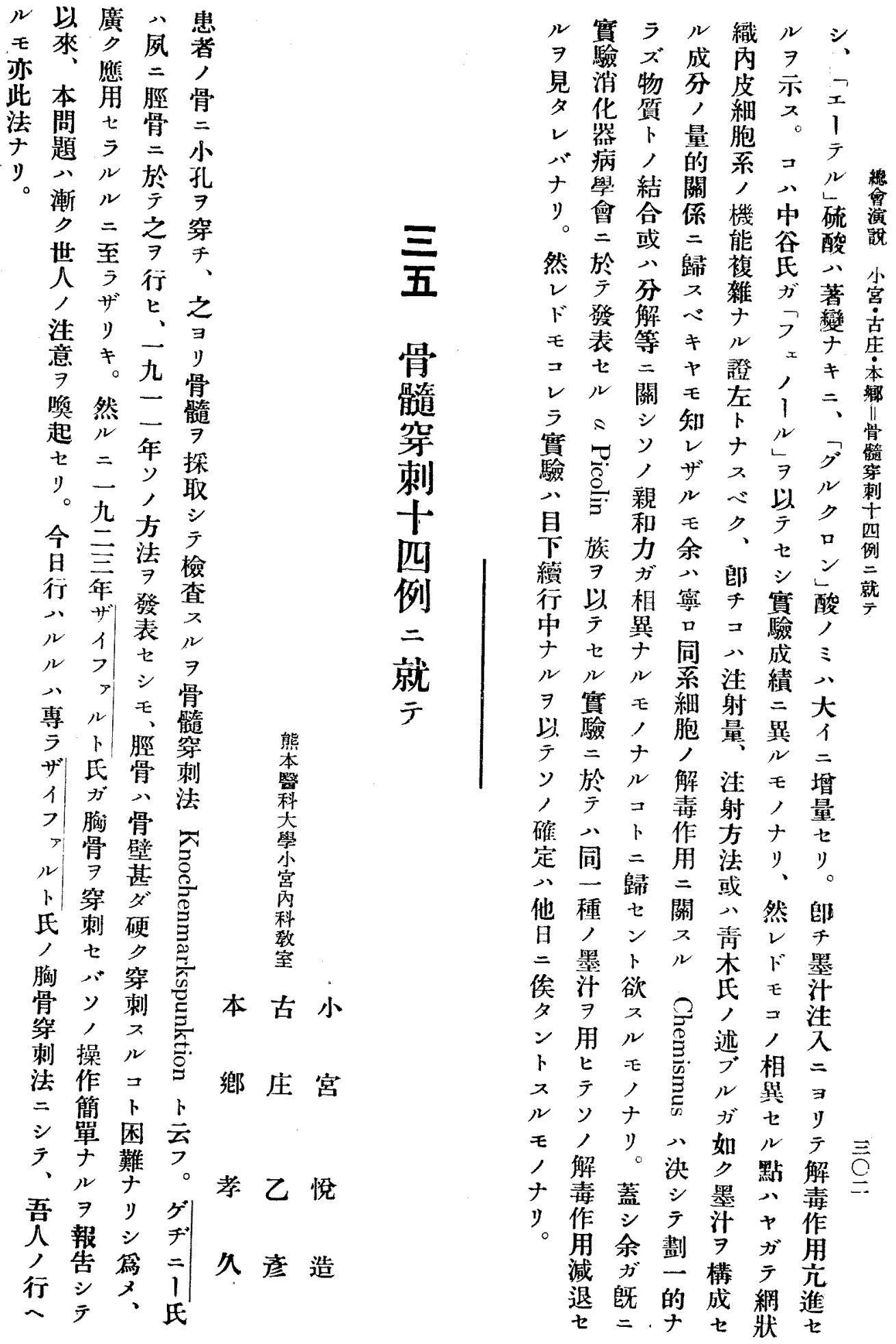




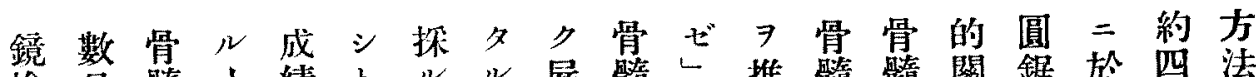

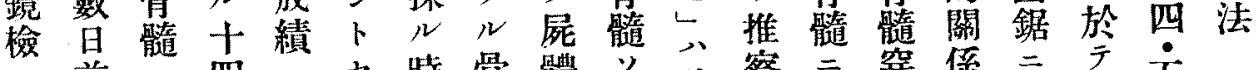

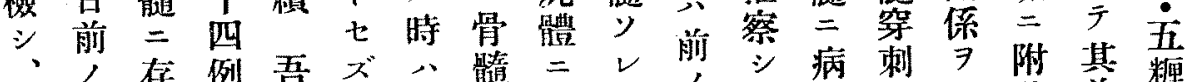

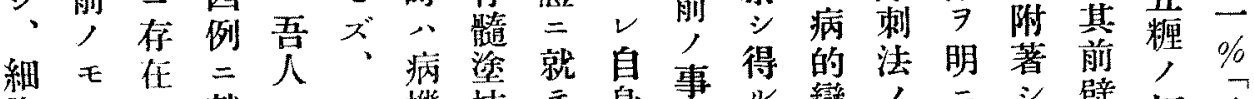

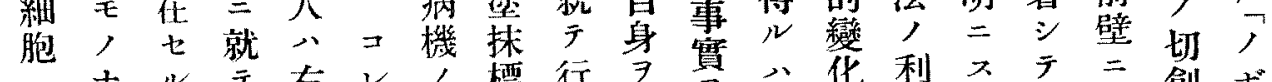

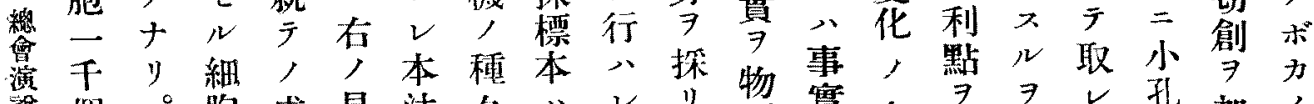

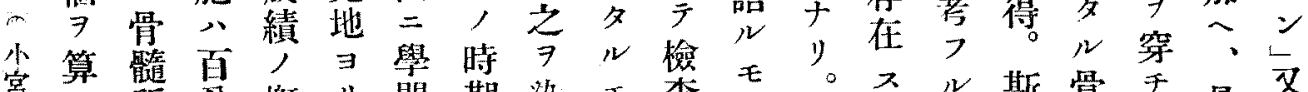
古、所分概り閒 期染モ查 庄夫見比要機的二色, 不然 $2=$ 質、骨

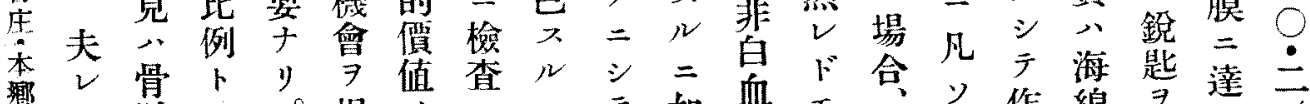
II $\exists$ 髓 $シ 。$ 捉, ス

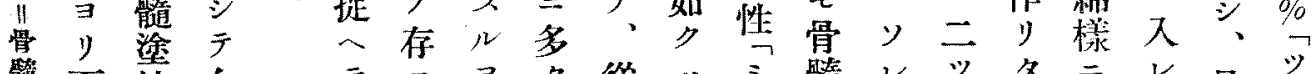

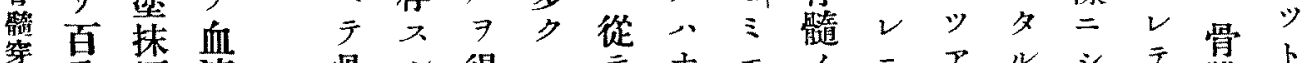

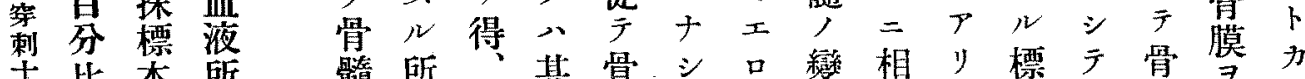

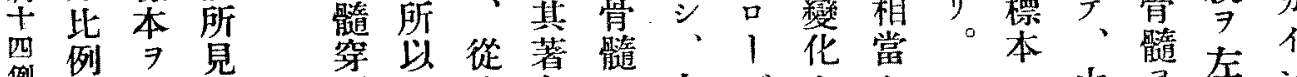

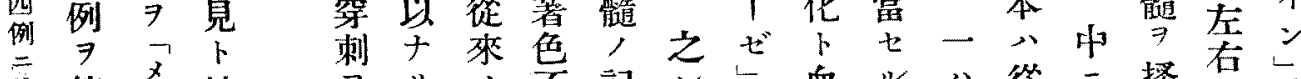

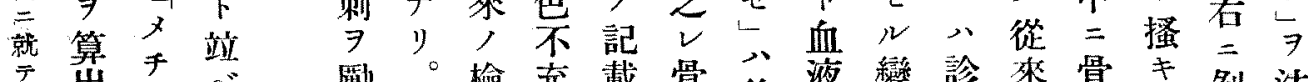

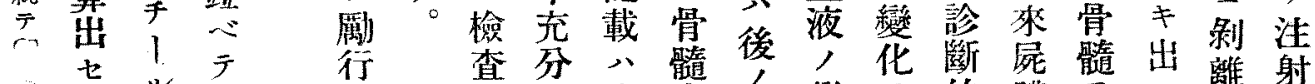

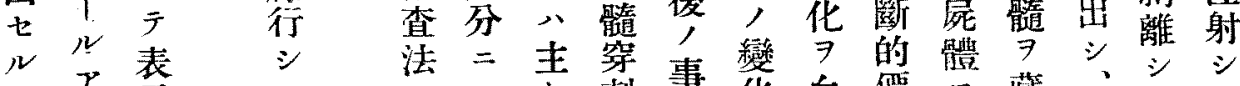

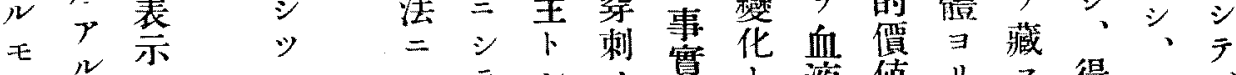
,

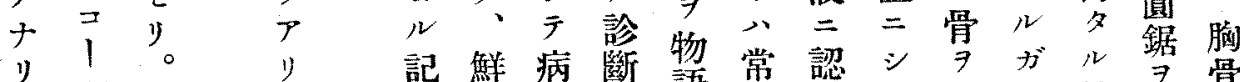
血。録琞. 機的語党

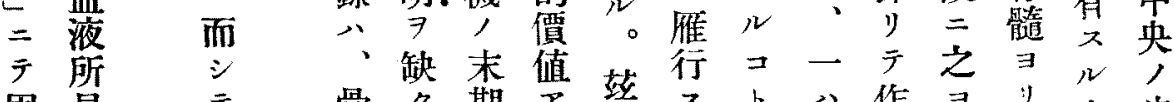

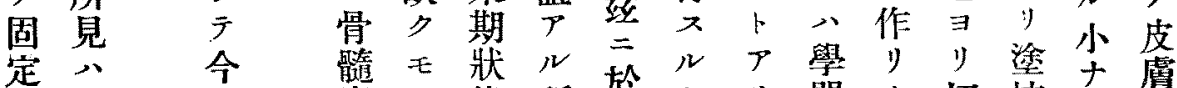

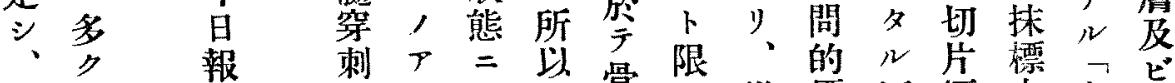

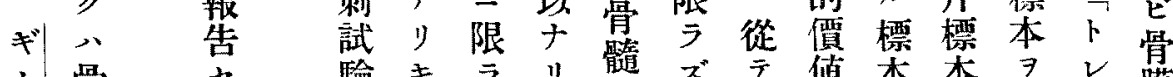

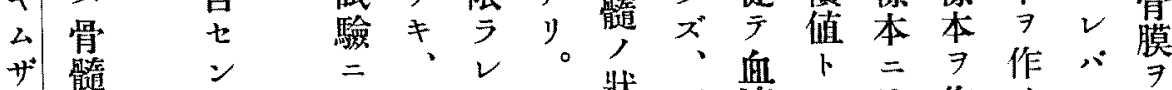

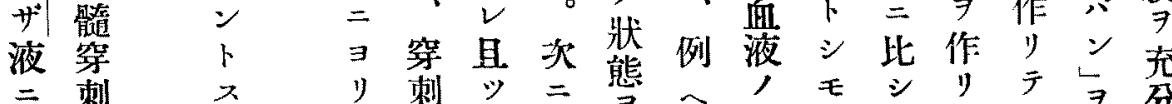

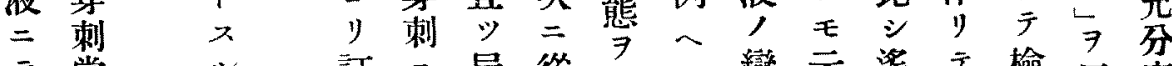

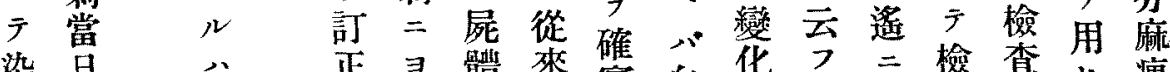

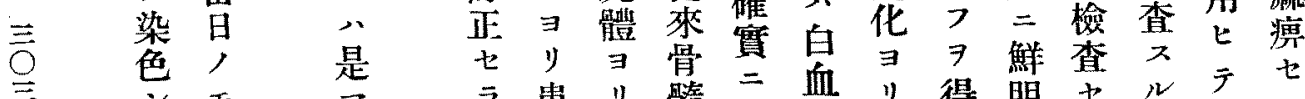

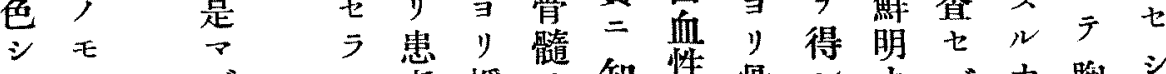

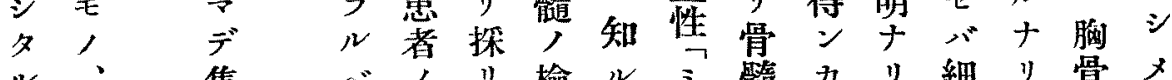

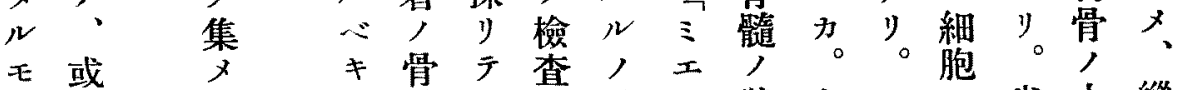
$\Rightarrow$ 其多 $\rightarrow \exists y$ 多公 1 態 


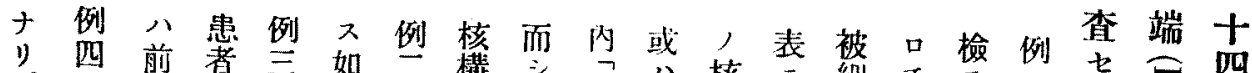

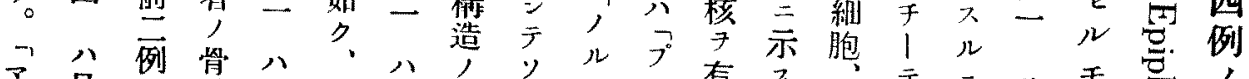

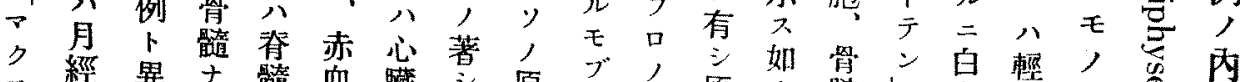

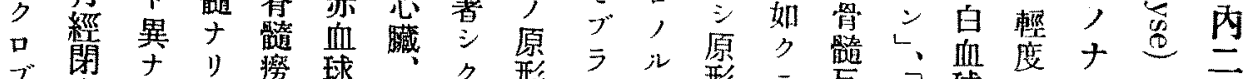

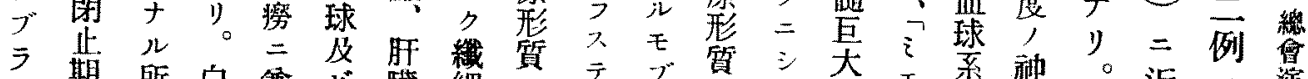

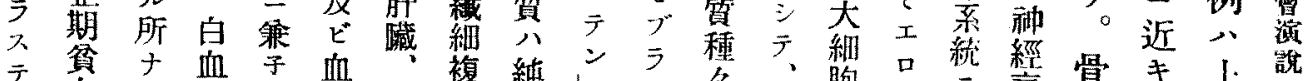

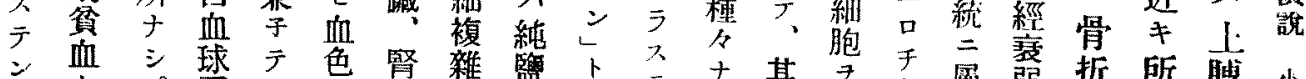

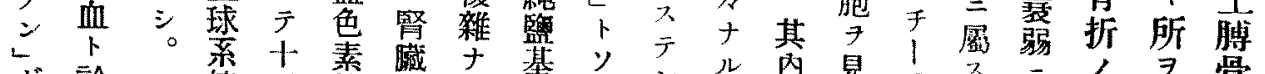

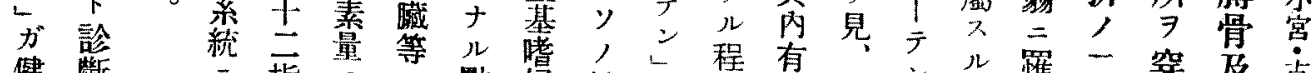

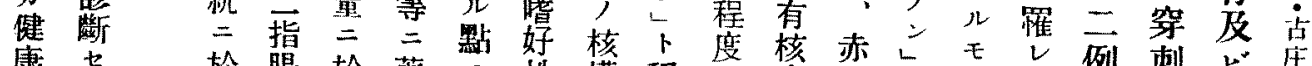
康 者ラ

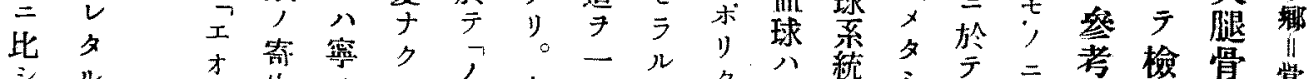

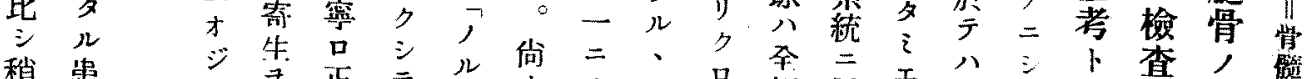

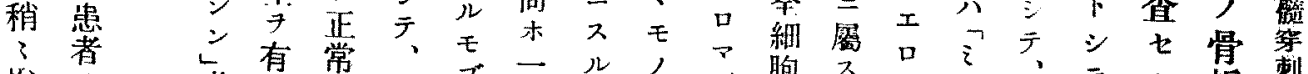

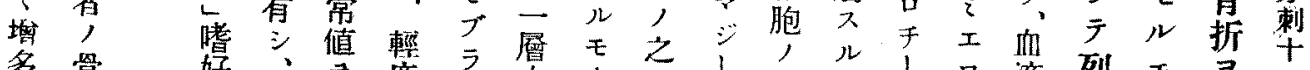

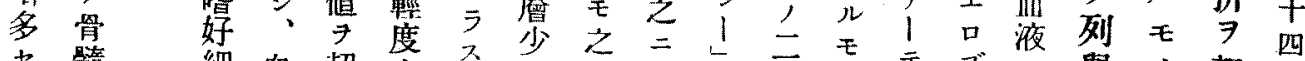

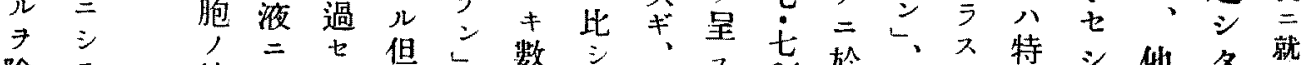

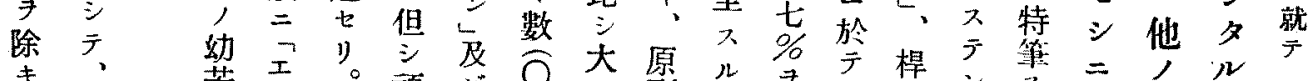

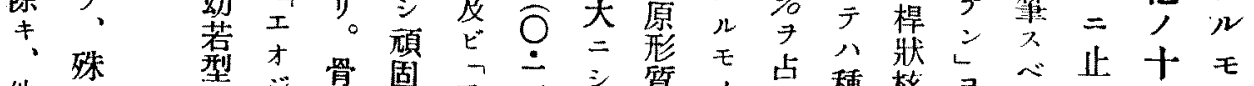

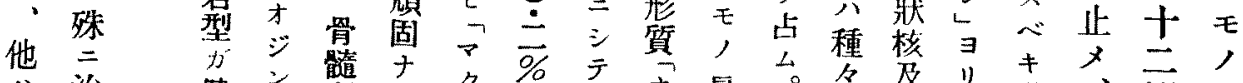

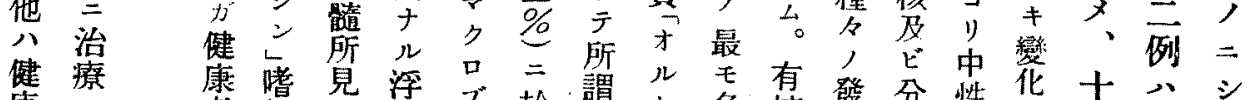

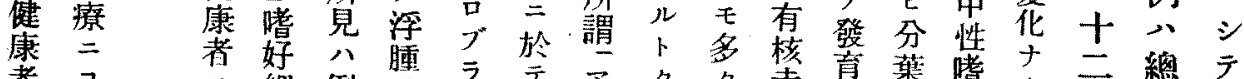

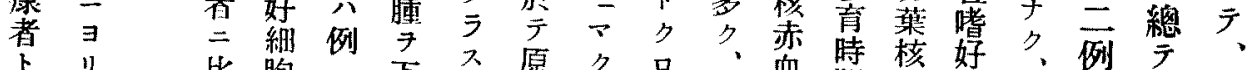

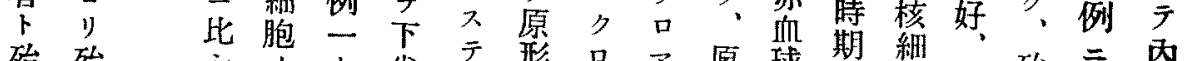

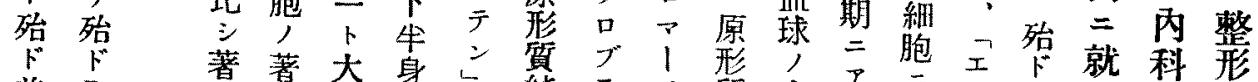

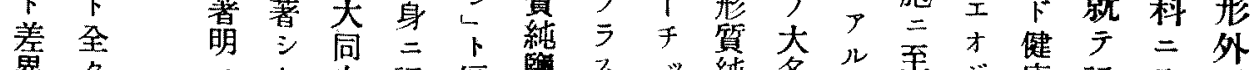

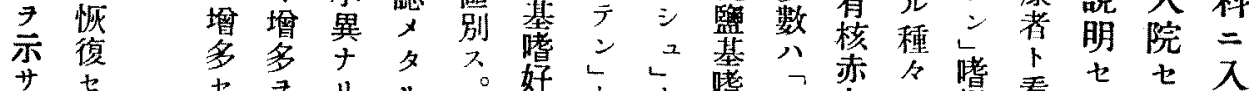

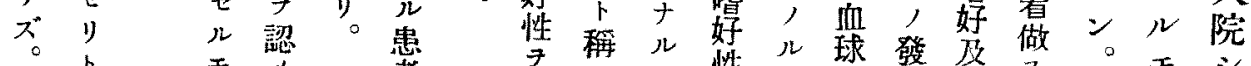

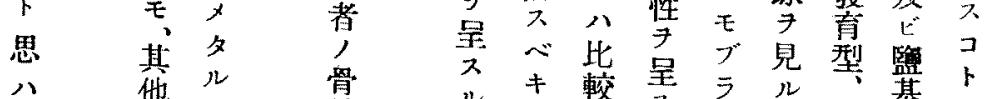

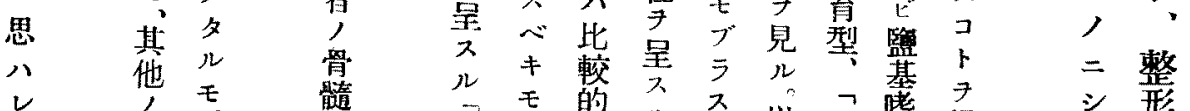

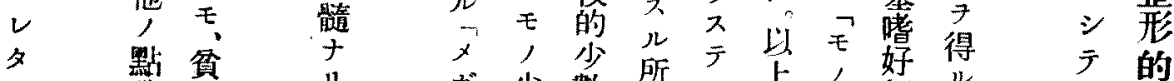

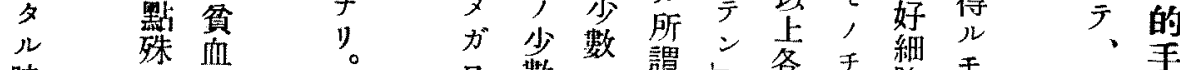
時二八其口數

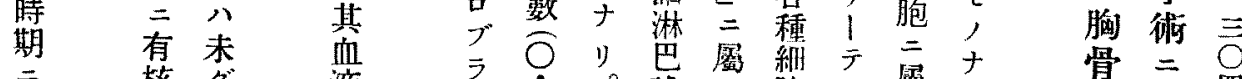

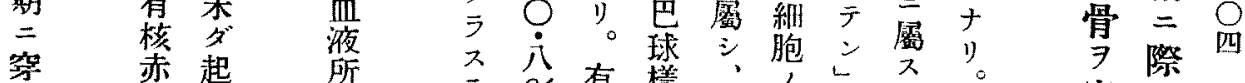

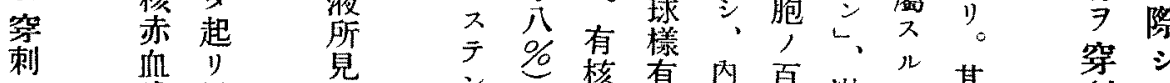

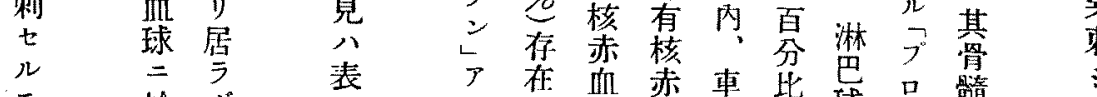

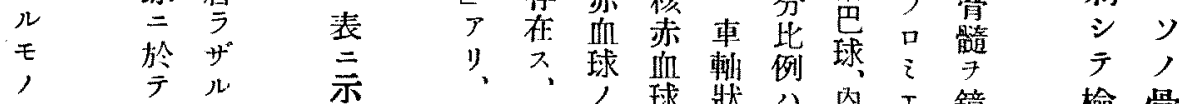
示'”, 球鼎八内工鏡檢骨 
個二七此七口儿若子例球三冷儿例

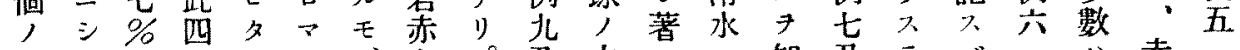
小テ、例 例儿:

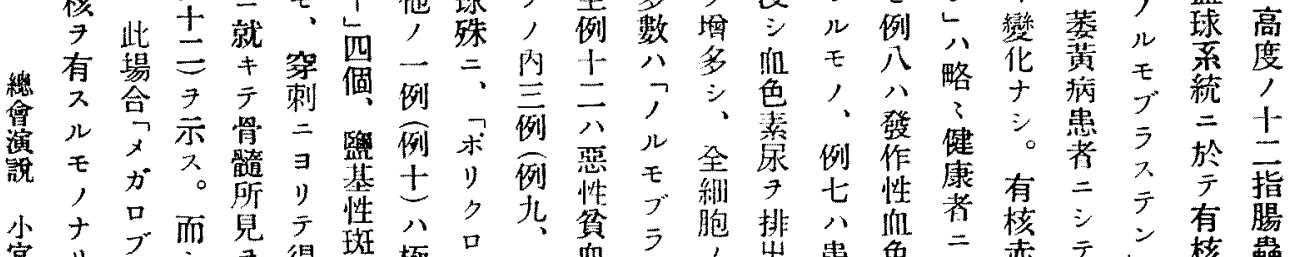

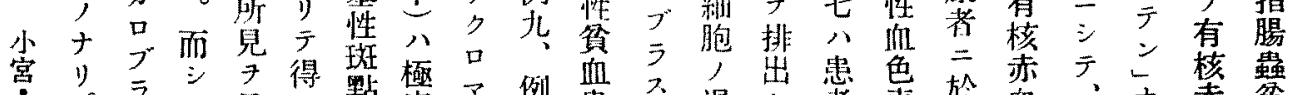

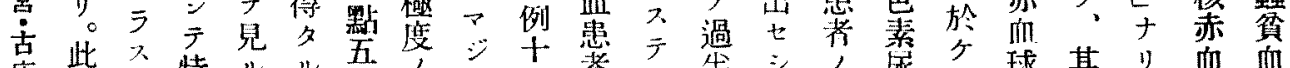

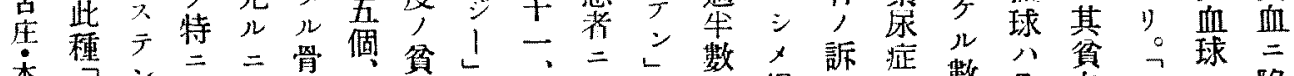

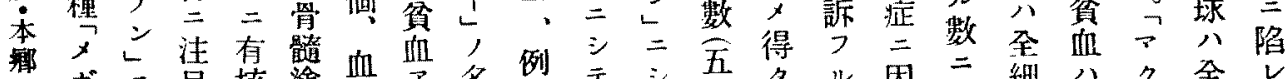

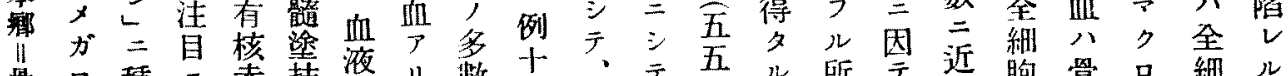

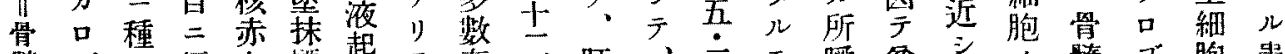

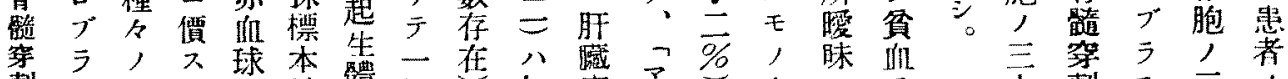

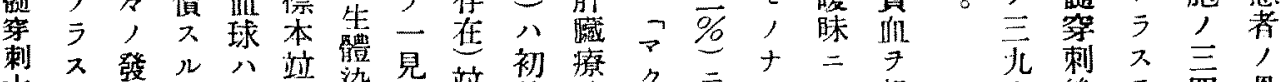

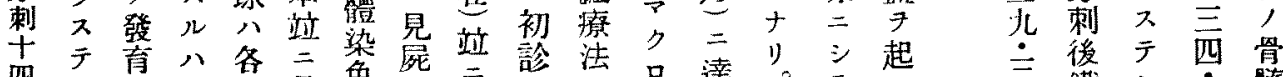

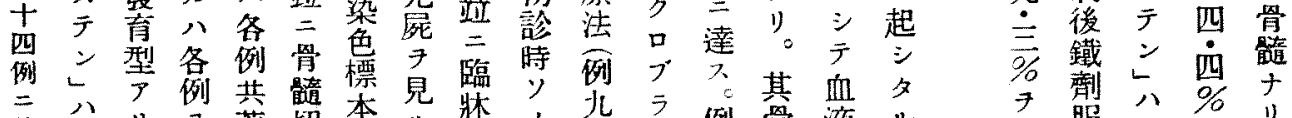

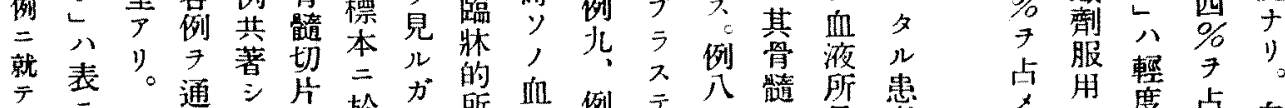

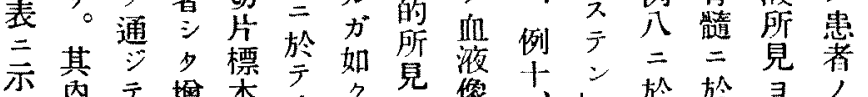

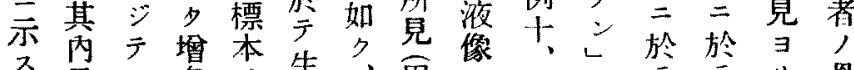
如最

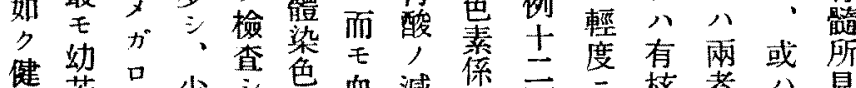

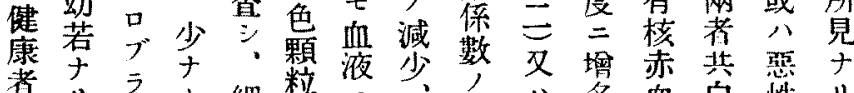

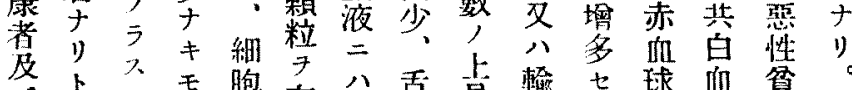

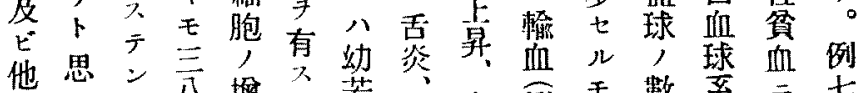

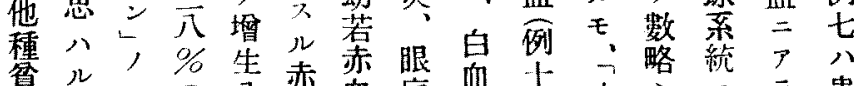

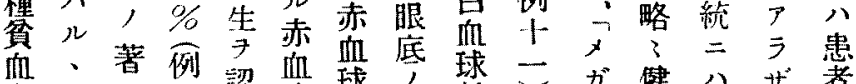

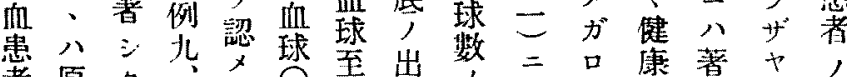
者原增 例テさ

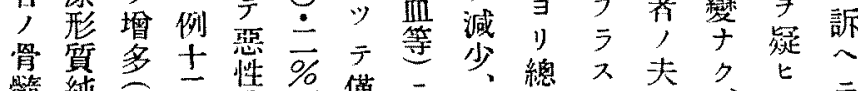

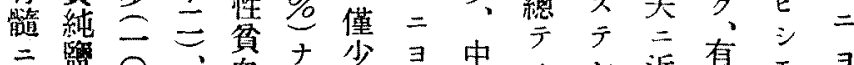

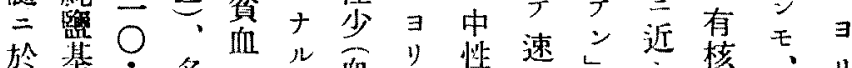

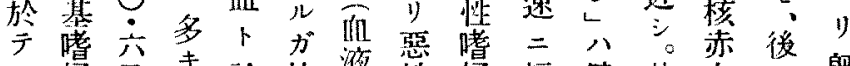

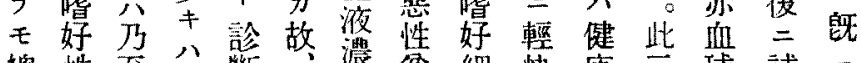

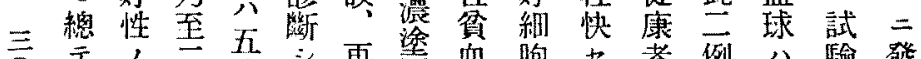

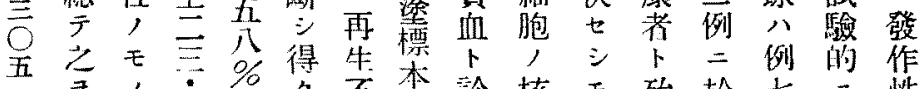

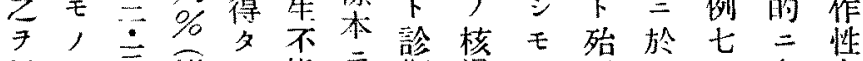

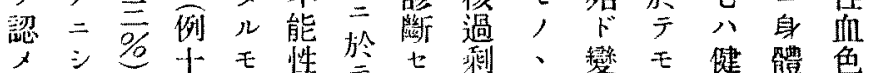

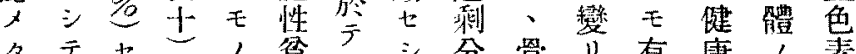

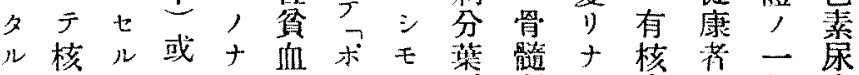

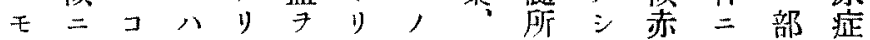

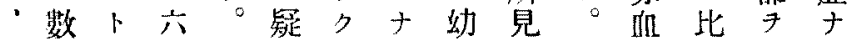

×、度 占 多速多 可球

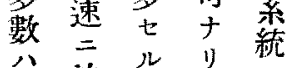
八治愁, 光於 ル七 文增 モ ラ, 口 スナラ有 シ

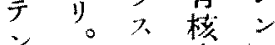
ナう, ン 血搘 り。骨公球娥 $\neg$ 船 健種胞 万見康類 口見者 娳奻 ブル二小若 ラ二、於健型 入白分康去 テ血卡者鬟 之球 略 同 及 統 同數 场 不於樣 三 ガ テ ナ テ ル ブ特。大㤎 
ナステロブ貧增量う敏モ゙ 以

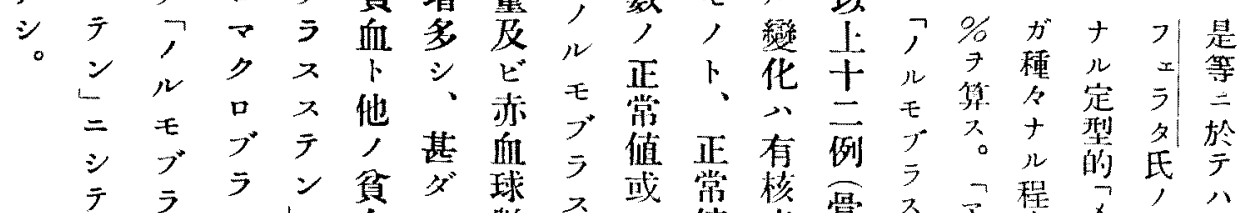

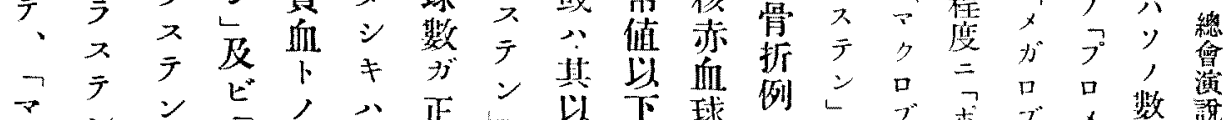

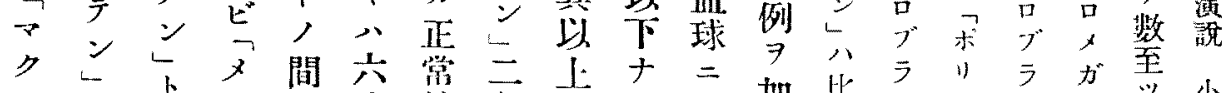

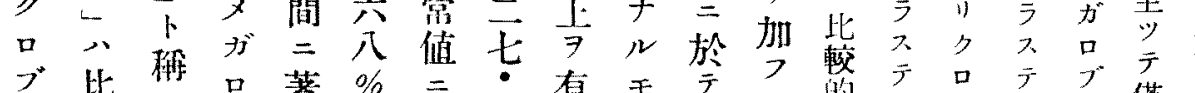

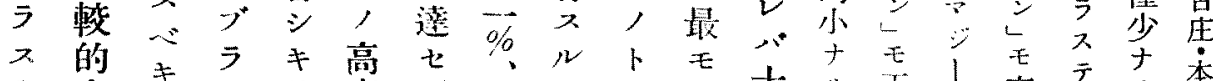

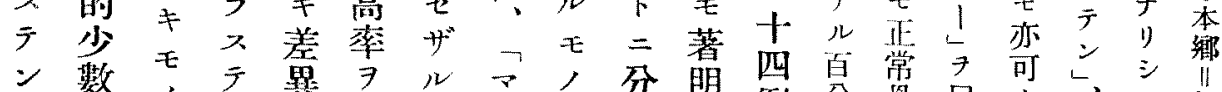

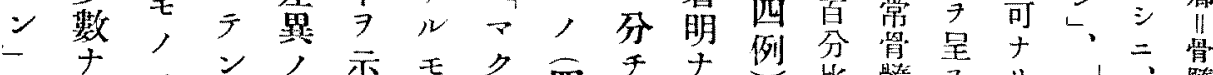

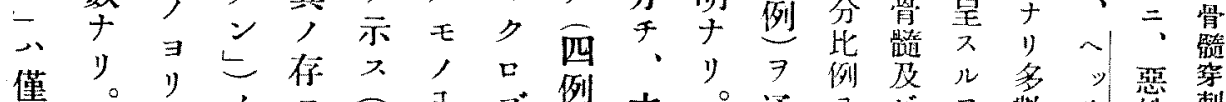

僅。”, 存

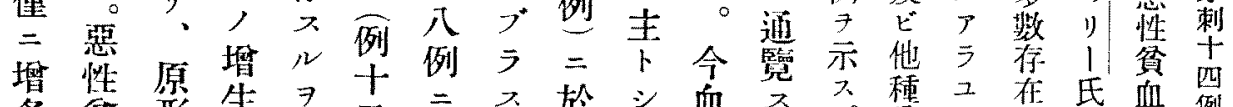

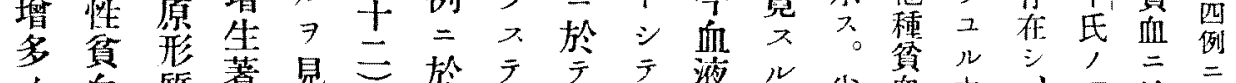

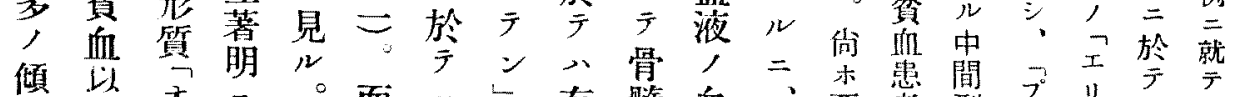

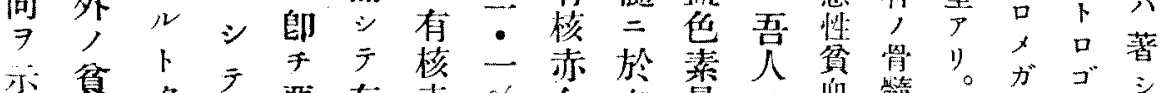

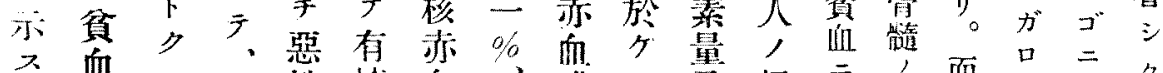

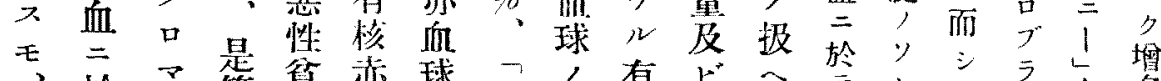

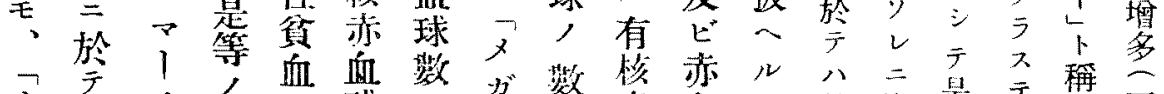

フテ

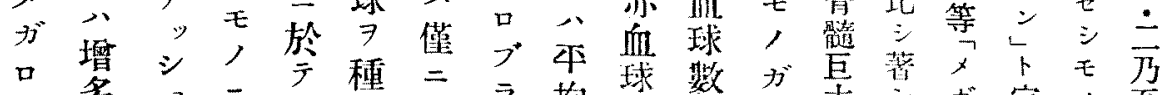

ブ多

ラ

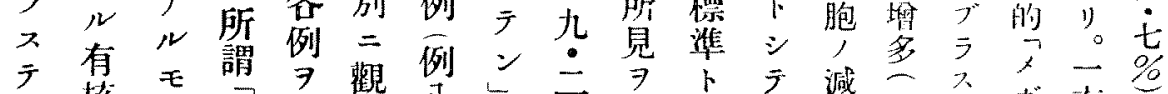

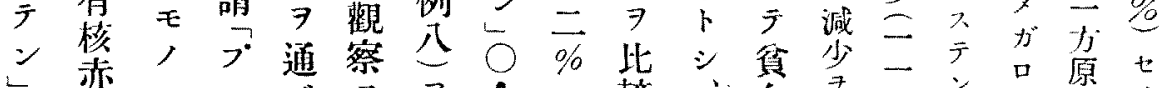

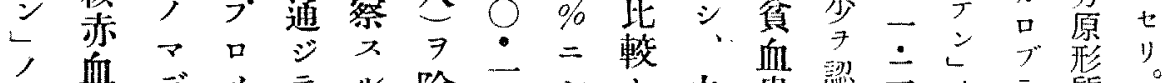

數血

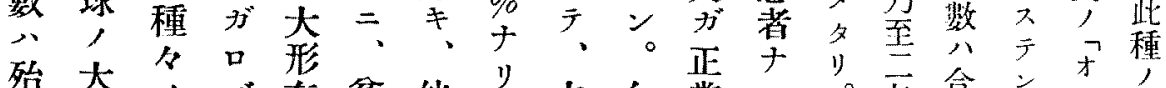

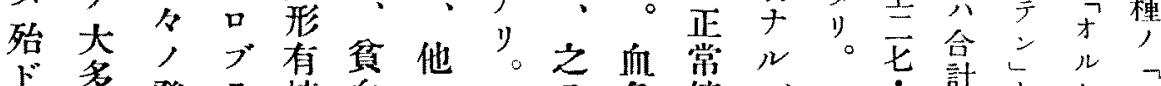

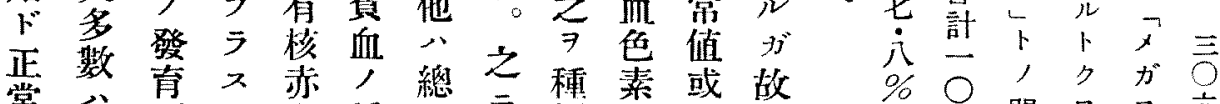

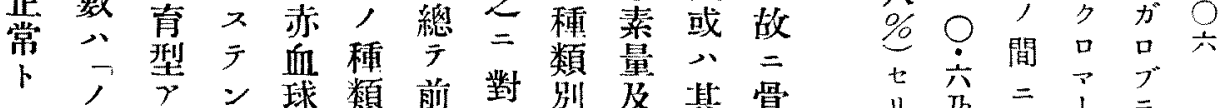

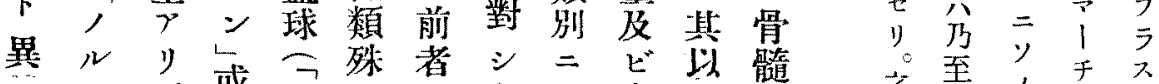

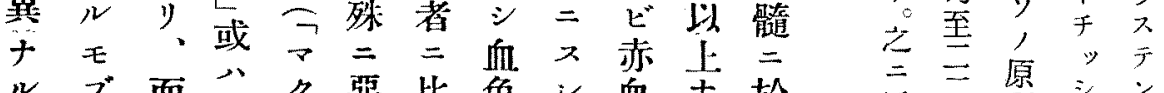

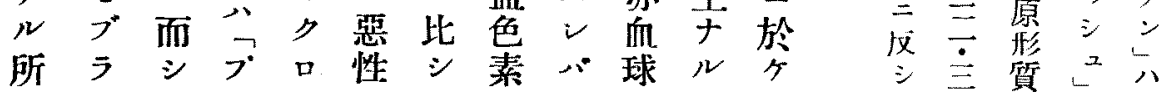




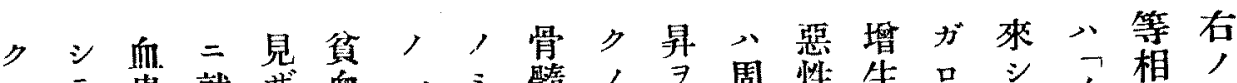

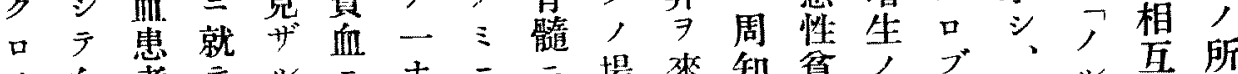

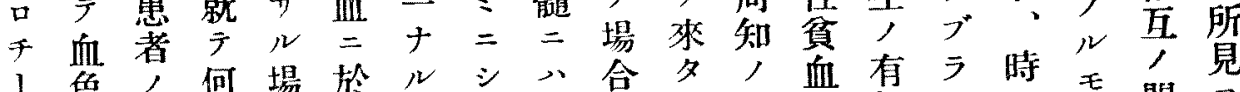

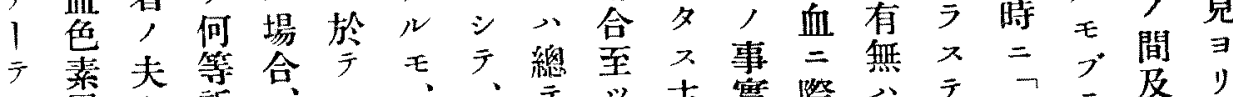

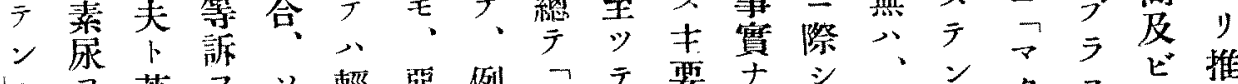

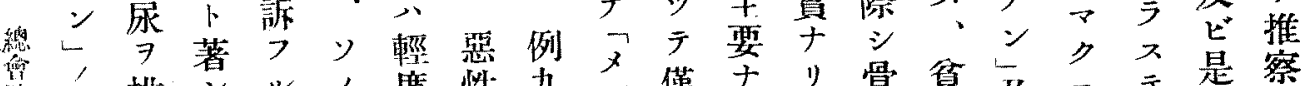

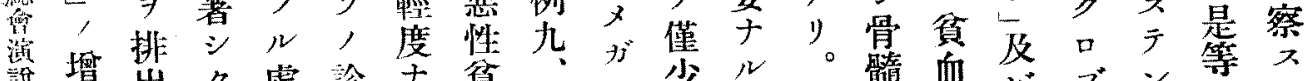

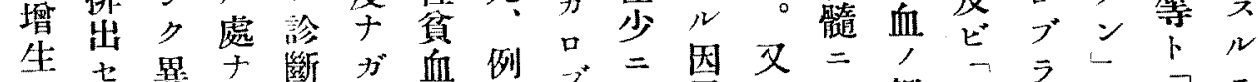

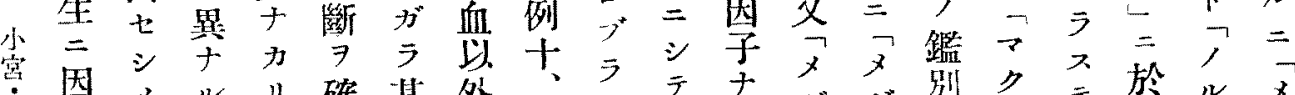

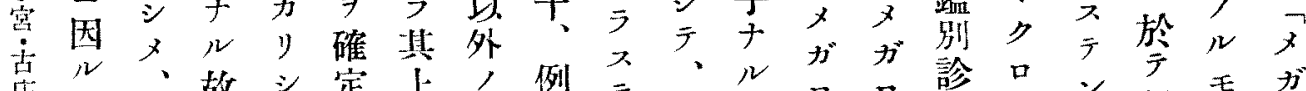
居 $匚$ 診

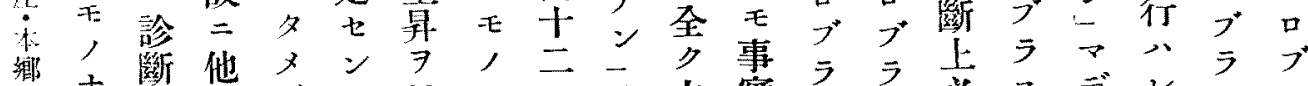
"

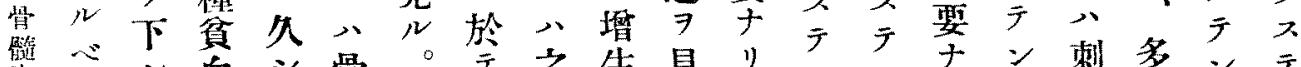
穿 シ 血 シ 骬。テ之生見り。ンジン刺多ンテ

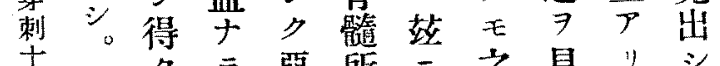

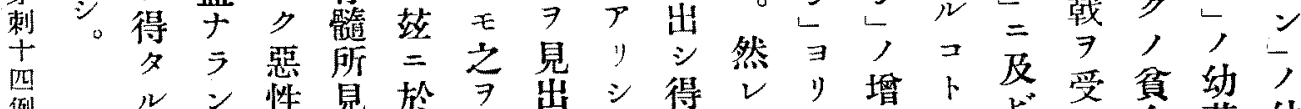

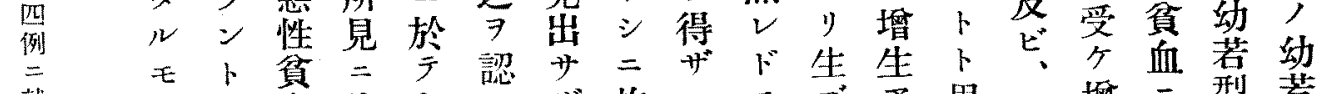

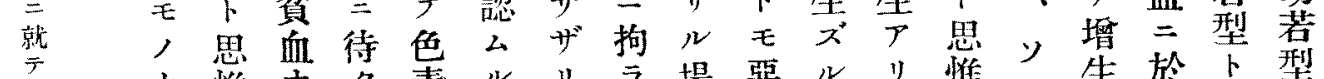

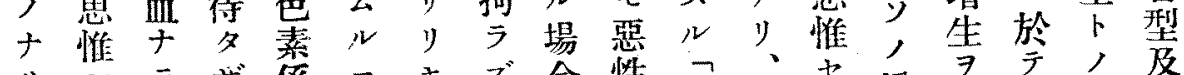

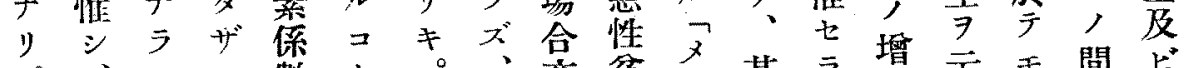

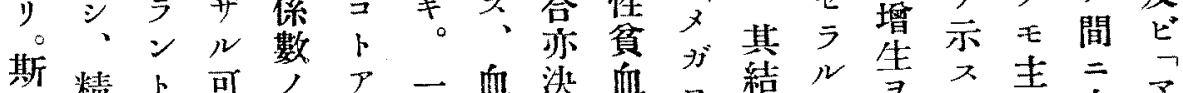

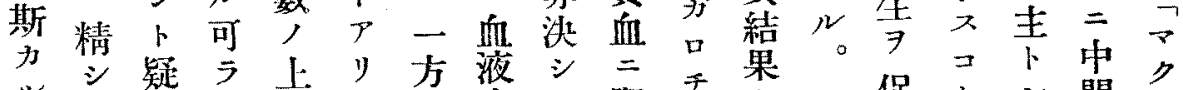
少

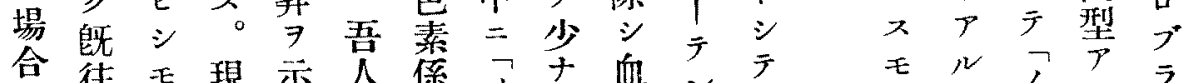

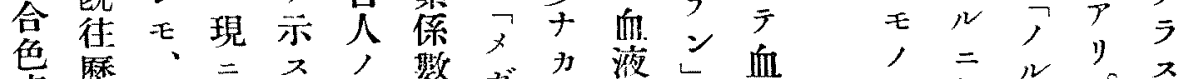

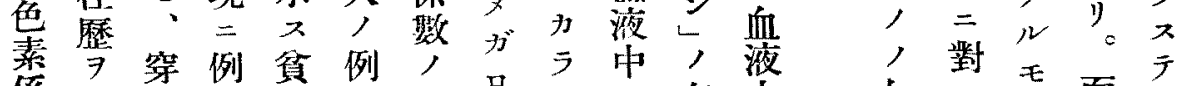

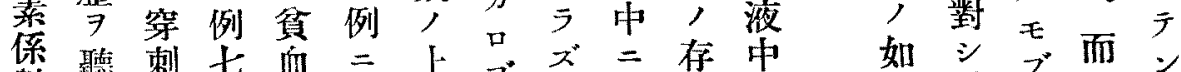

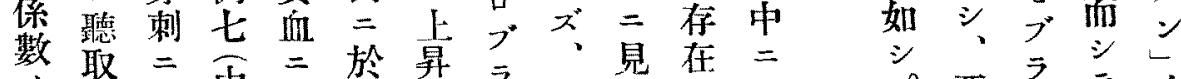
上丨、年

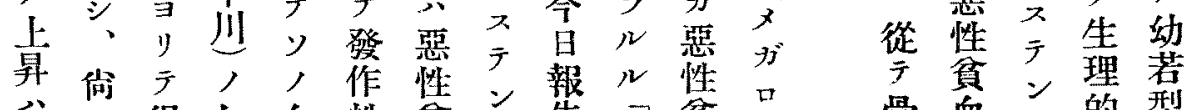
ᄀ示得如血性貧 ご告 貧

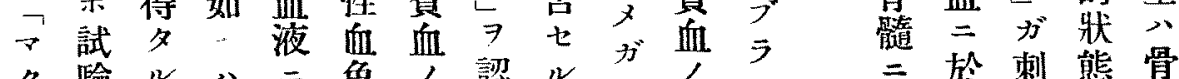
ク匳 $ル$ 二色, 認ル態骨 口的骨前

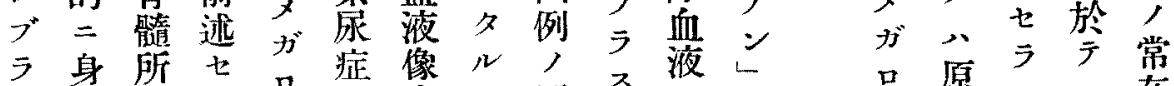
ス體自ル

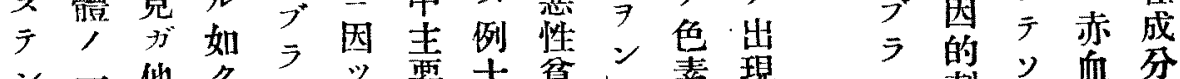

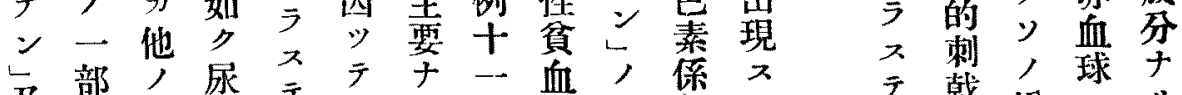

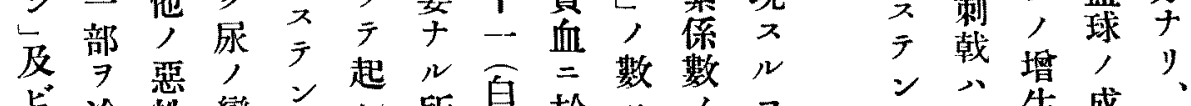

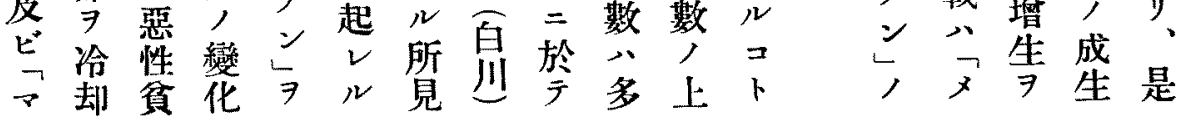




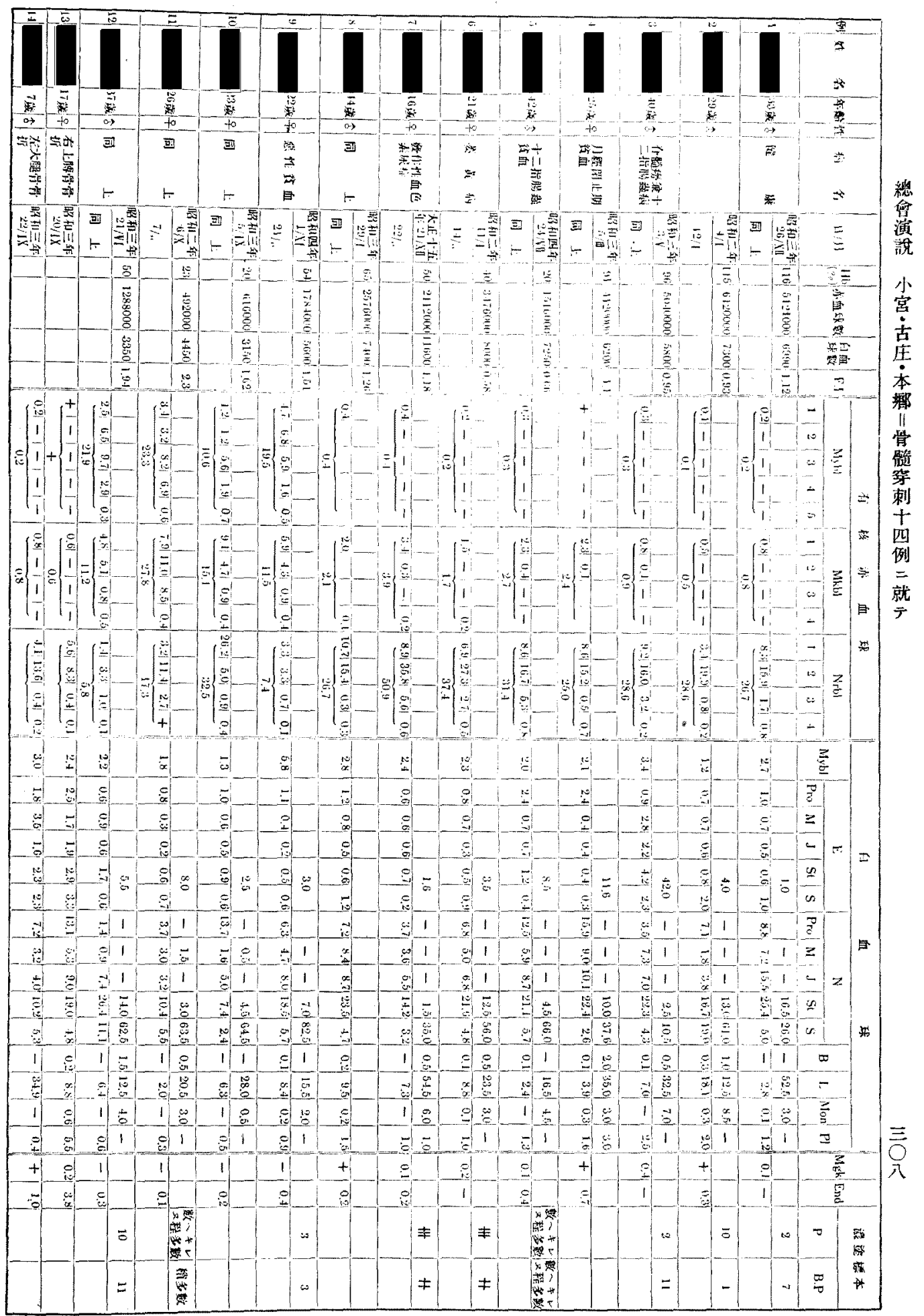




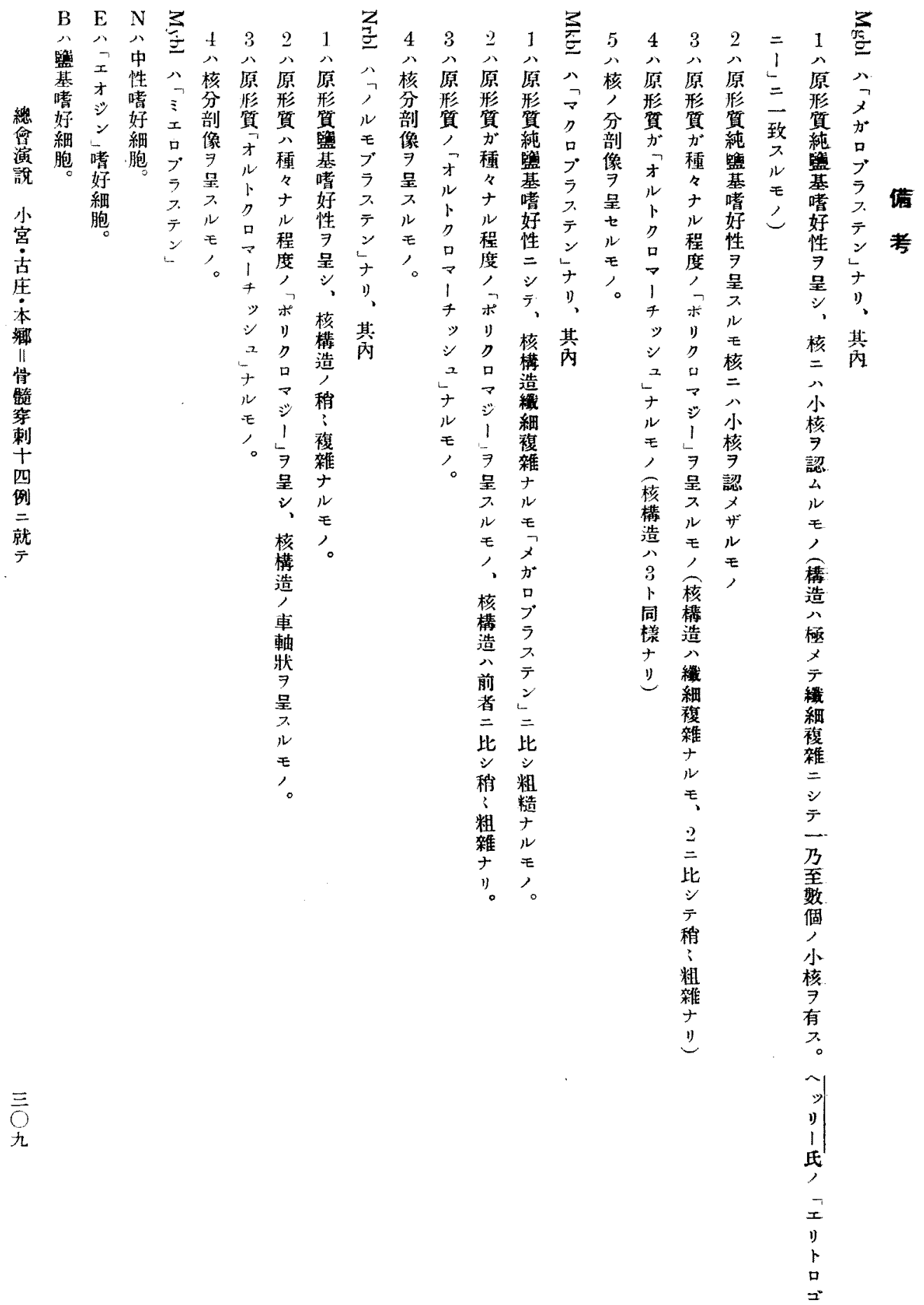


刺於ルð二合供絬

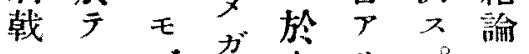

구

ガル ス

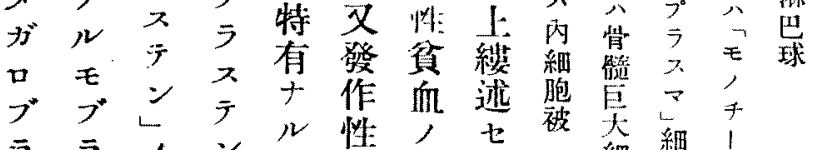

ラ 万幼 ᄂ 所血疑

テ 若幼見色素儿所

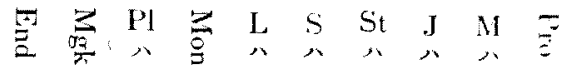

ンシ型若シ原場總

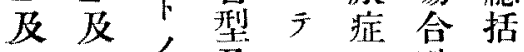

ビ ビ間及云殊 シ

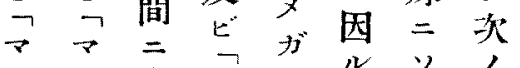

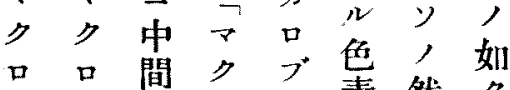

ブ ブ梨口

ララフブス俰ル結

ス y

テテ。スン岳見七

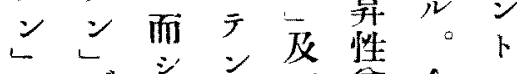

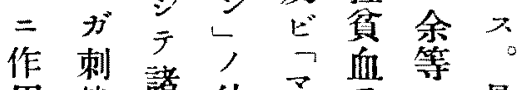

用戟譇幼》素藏

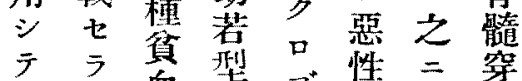

其レ血型 ブ蚠

增 其於骨䯝 天

7 增心光箚生血

促生骨常亡, 放在能

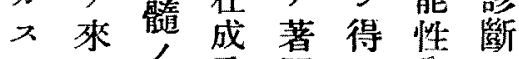

モ 又 所分明夕貧

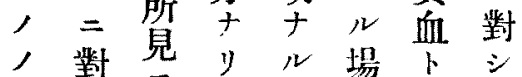

人對鼻り。場卜

如 シ り是增 合 惡 時

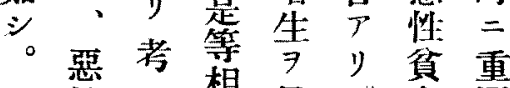

性 7 相見。血要

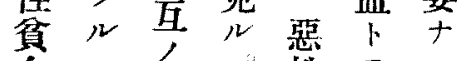

血 =間性 7 ル

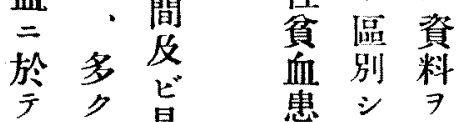

心, 是患晋得吾

原貧等， 夕只

因血 - 骨 ル二

的 二, 暍場 提 


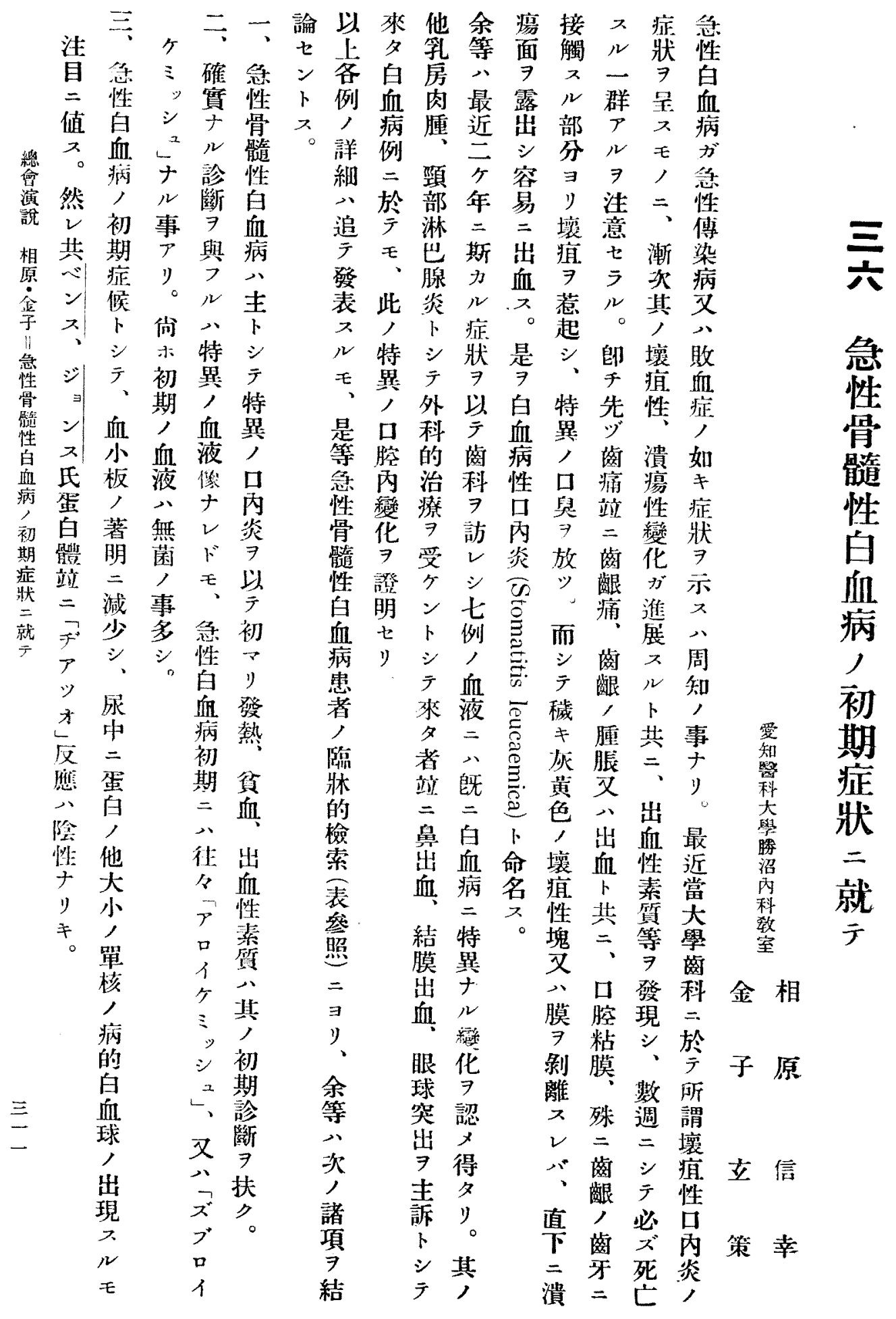




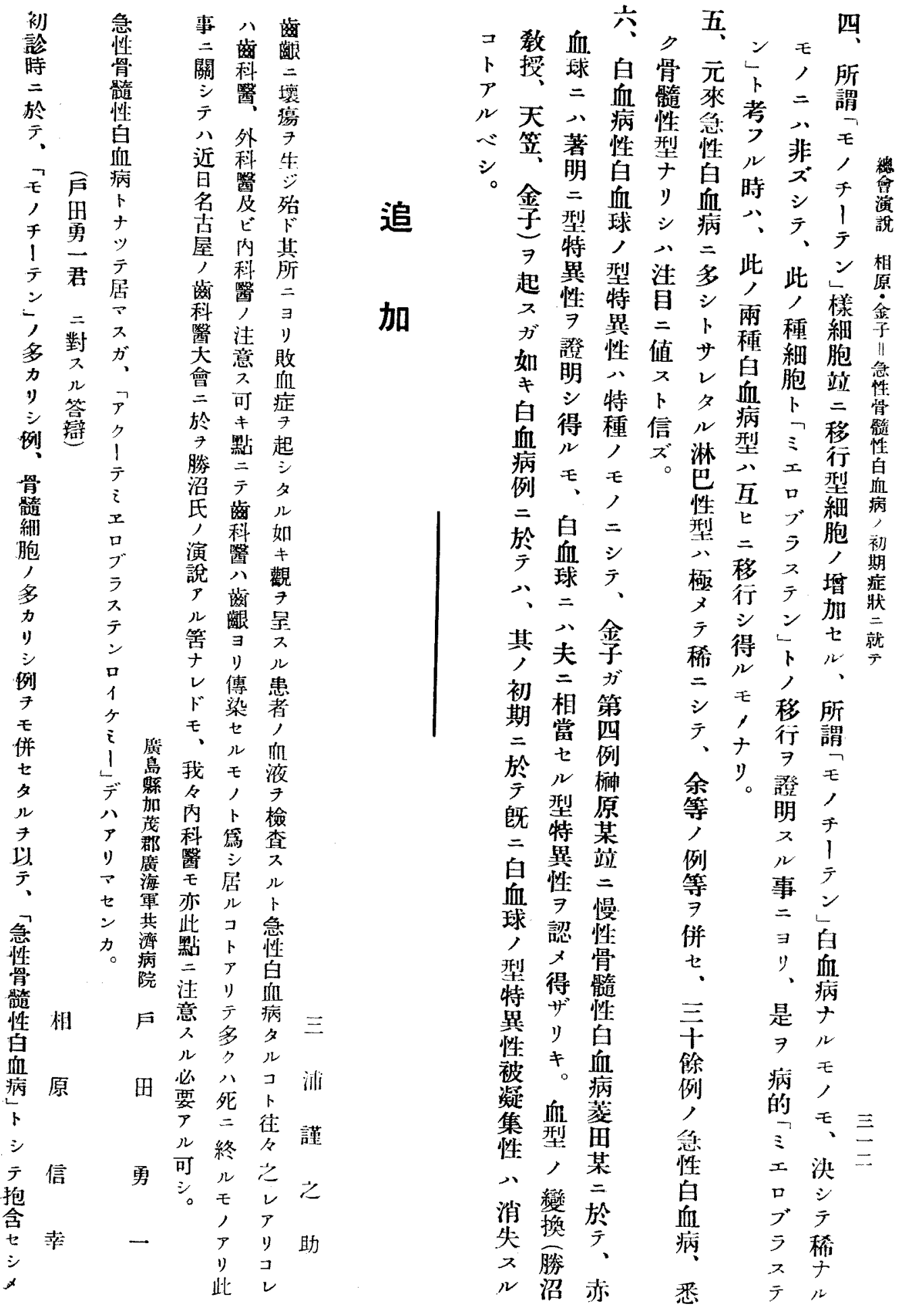


查 又實正先甲質收, 文抗

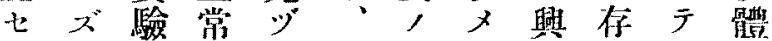
次成溶實溶經抗味在重産 成二績血驗血口體 $7 \rightarrow$ 要生

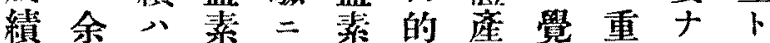

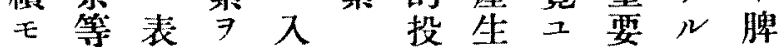

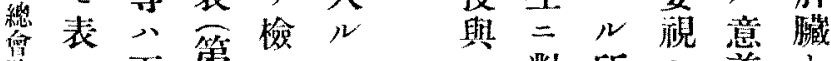
灌第更第 說第亏一之先對

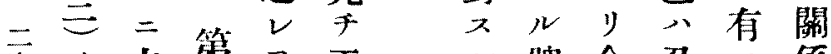
宫, 之第 7 正脾余色天係

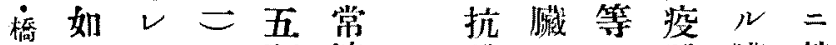

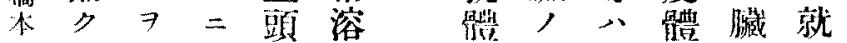
陆脾確示, 血產意偶産器キ 朝剔證 全出 $\rightarrow ゙$ 常產試二脾 $\exists$ 》

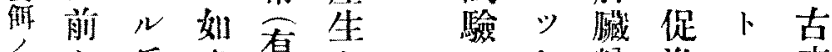
抗卜䍃》有下

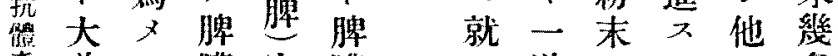

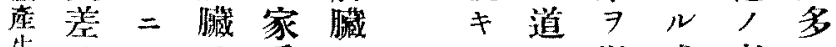
生 $\Rightarrow$ 二兔卜原以或者, 及衿例剔, , 八光产種 “業 ボメ, 出ソ關赛明テ人, 績 影天゙家入レ係聞 7 家物レア 疃。鬼ル下 等 $飞$ 比知

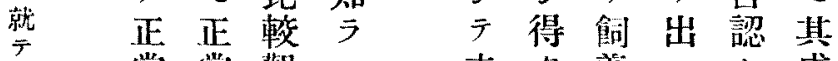
常常猚ン来及養入七成 溶溶察ト 多 リ シ モ 血血七欲其卜抗, 卜區

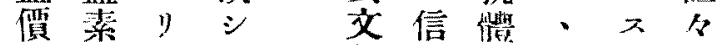
$\exists$, 豫 测 㕍齐 定生脾 シ $=$ 蔵 夕 $\rightarrow$ 有剔 後脾出 膡家家 墭鬼置 $\Rightarrow \vdash \neq$ 剔, 夕 出間

$\equiv \quad シ \quad$ 家

三 筋何 鬼 今, 等 頍 時差二 機思就 $=\Rightarrow \quad \neq$ 檢認 广 獻 天゙產如前卜 氺生名者 知 7 想 = 今以及像於定 ズッボシテマ 。广 ス 未比 落影名甲 ズ

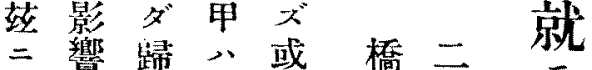

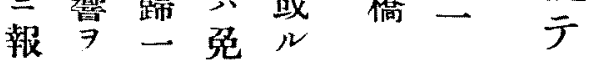
告追 又疫者 七究心體八 乙 七所產脾 卜シ $\Rightarrow$ 告 獩 入 = 知 7 而意亏地抗 シ外 ズ卜體太輝 于, 是 $三$ 產 牌成上先郎蒝 獩 績 學 脾二 
第 一 表 正常家鬼，正常溶血素

\begin{tabular}{|c|c|c|c|c|c|c|c|c|c|c|c|c|}
\hline \multirow{2}{*}{$\begin{array}{l}\text { 雨 } \\
\text { 號 }\end{array}$} & \multirow{2}{*}{ 性 } & \multirow{2}{*}{$\begin{array}{l}\text { 體 } \\
\text { 重 }\end{array}$} & \multicolumn{3}{|r|}{ 血 } & 清 & \multicolumn{2}{|c|}{ 稀 } & 政 & \multicolumn{3}{|l|}{ 度 } \\
\hline & & & $10 \mathrm{f}$ & 25 & 50 & 100 & 200 & $5(0$ & 1000 & 2000 & 5000 & $10000 \mathrm{f}$ \\
\hline I & 191 & $8000 \overline{⿵ 冂}$ & 册 & HI & $t+$ & $+t$ & + & \pm & - & - & - & - \\
\hline II & | 1 & |3000瓦 & Hit & 册 & \# & $H$ & + & \pm & - & - & - & - \\
\hline III & है & 2750 同 & 册 & $\mathrm{H}$ & \# & $H$ & + & \pm & - & - & - & - \\
\hline IV & +1 & 2500 瓦 & $\mathrm{HI}$ & HI & $t+$ & $H$ & + & \pm & - & - & - & - \\
\hline$\nabla$ & 19 & 1970 同 & $\mathrm{HH}$ & HI & $H$ & + & \pm & - & - & - & - & $=$ \\
\hline
\end{tabular}

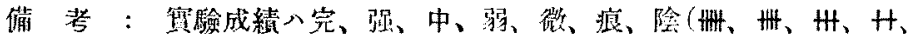

$$
\text { 十、士、一) ヨ以ッテアラハスモノトス }
$$

第 二 表 脾剔出家鬼，正常溶衄

\begin{tabular}{|c|c|c|c|c|c|c|c|c|c|c|c|c|}
\hline \multirow{2}{*}{$\begin{array}{l}\text { 番 } \\
\text { 敬 }\end{array}$} & \multirow{2}{*}{ 性 } & 體 & \multicolumn{3}{|c|}{ 血 } & 清 & & \multicolumn{2}{|c|}{ 櫂 } & \multicolumn{3}{|l|}{ 膺 } \\
\hline & & 重 & $10 \mathrm{f}$ & 25 & 50 & 100 & 200 & 500 & 1000 & 2000 & 5000 & $10000 \mathrm{f}$ \\
\hline $\mathrm{I}$ & 19 & 2680 瓦 & HAt & HI & $\mathrm{H}$ & $H$ & + & \pm & - & - & - & - \\
\hline II & $1 \hat{b}$ & 2550 瓦 & Ht & 册 & H & tt & + & \pm & - & - & - & - \\
\hline III & 1 & 2820 成 & $\mathrm{HI}$ & Ht & $H$ & $H$ & + & \pm & - & - & - & - \\
\hline IV & |우 & 975伍! & $\mathrm{H}$ & m & H & + & \pm & - & - & - & - & - \\
\hline$\nabla$ & 1 우 & $287(1$ 瓦 & $\mathrm{Ht}$ & \# & H & + & \pm & - & - & - & - & - \\
\hline VI & $1+9$ & 2900㼛 & 册 & m & $\mathrm{HI}$ & $+t$ & + & \pm & - & - & - & - \\
\hline VII & 1우 & 2000 瓦 & Hit & H & tt & + & $t$ & - & - & - & - & - \\
\hline
\end{tabular}

第 三 表 脾别出後二於分儿正常溶血素，消長

No. I + 2950 瓦

\begin{tabular}{|c|c|c|c|c|c|c|c|c|c|c|c|}
\hline 月 & 脾别 & \multicolumn{3}{|c|}{ 血 } & \multicolumn{2}{|c|}{ 清 } & 盇 & 程 & \multicolumn{3}{|l|}{ 度 } \\
\hline 日 & 歲出 & $10 \mathrm{f}$ & 25 & 50 & 100 & 200 & 500 & 1000 & 2000 & 5000 & $10000 \mathrm{f}$ \\
\hline $10 / 1$ & 前 & $H$ & $+t$ & + & \pm & - & $=$ & - & - & - & 1 \\
\hline 11 & 1 & HI & $+t$ & + & \pm & - & - & - & - & - & - \\
\hline 15 & 5 & $\mathrm{HA}$ & $t+$ & + & \pm & - & - & - & - & - & $1-$ \\
\hline 20 & 10 & 册 & $\mathrm{Ht}$ & $+t$ & + & \pm & - & - & - & - & $1-$ \\
\hline 25 & 15 & $\mathrm{HH}$ & $+t$ & $t+$ & + & \pm & $=$ & - & - & - & - \\
\hline 30 & 20 & HI & $+t$ & + & \pm & - & - & - & - & - & - \\
\hline $2 / \bar{I}$ & 23 & $\mathrm{HH}$ & $H$ & $+t$ & + & \pm & $=$ & - & - & - & - \\
\hline
\end{tabular}

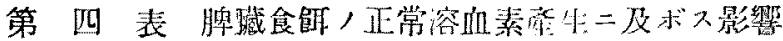

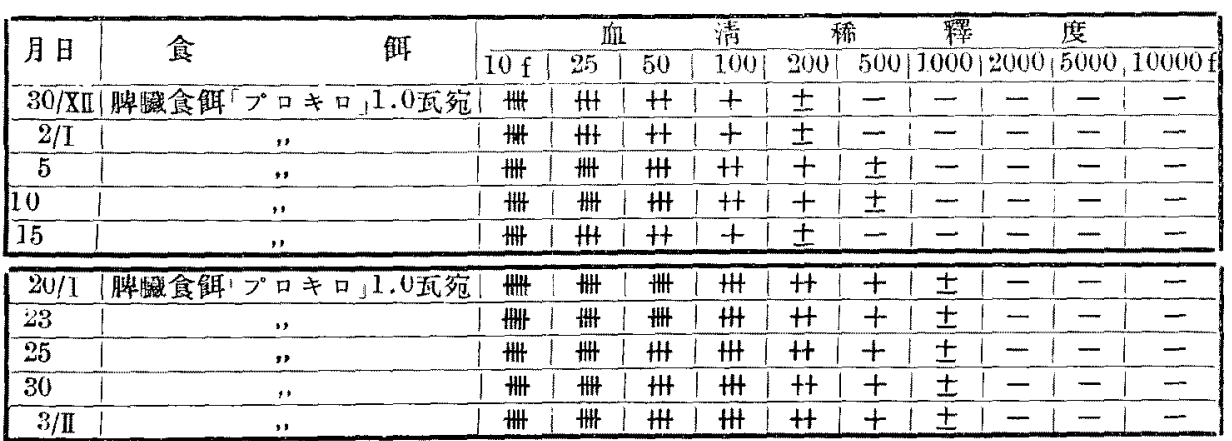

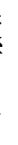




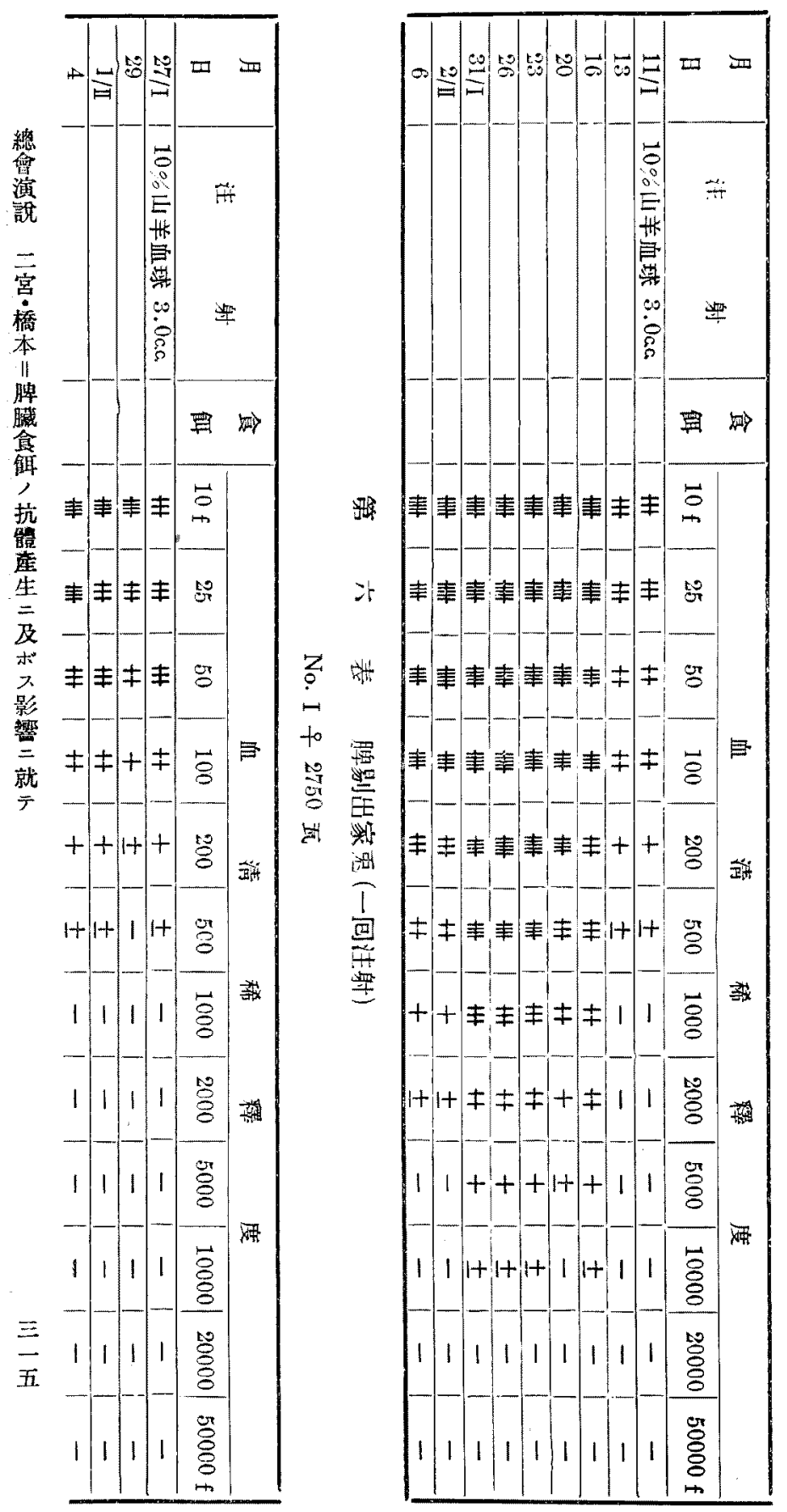

次 、食广次

二表慨反二

特第军應

殊第牛, 学

溶四臑家

血三藏藏

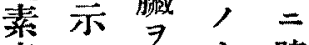

產 ス乾ナ脾

生 ガ乾り藏

卜 如燥然食

脾》的

藏脾棼心

阝藏其 與

, 食際工

關慨ナ正乞

禹係 $\exists$ 焉

7 與名溶一

州 知 ב モ 血 時

今 $5 ル$, 素性

䟧占試 7 產輕

欲 驗 プ生度

前 $\square=$,

荘左占 $\neq$ 如赫

筂大何血

然實苃 -

料驗

归多虔影少

独十特宛響

粘七 三 豆幼

可脾豆及若

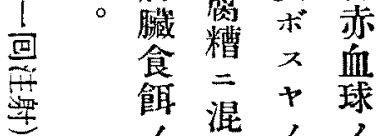

影芯疑出

響 テ 問 現

與 7

見 乙生赫

做 $\exists$ ズ 血

又 與 依 球

心 人ッ抵

キ テ 抗

モ檢有力

，查有人

ナ 葲上

シ。䕇葲

宦等

成脾以

績 藏藏 


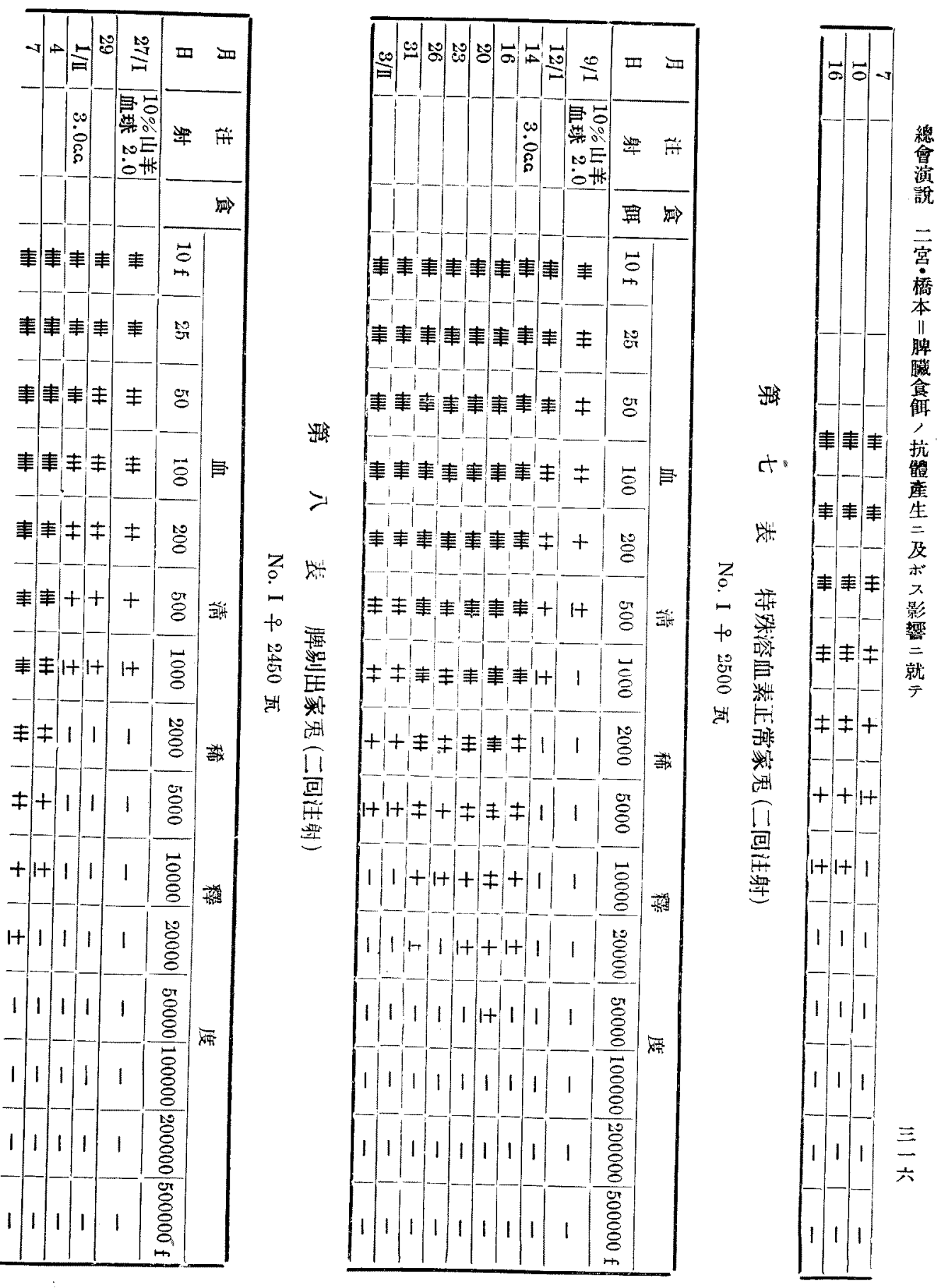



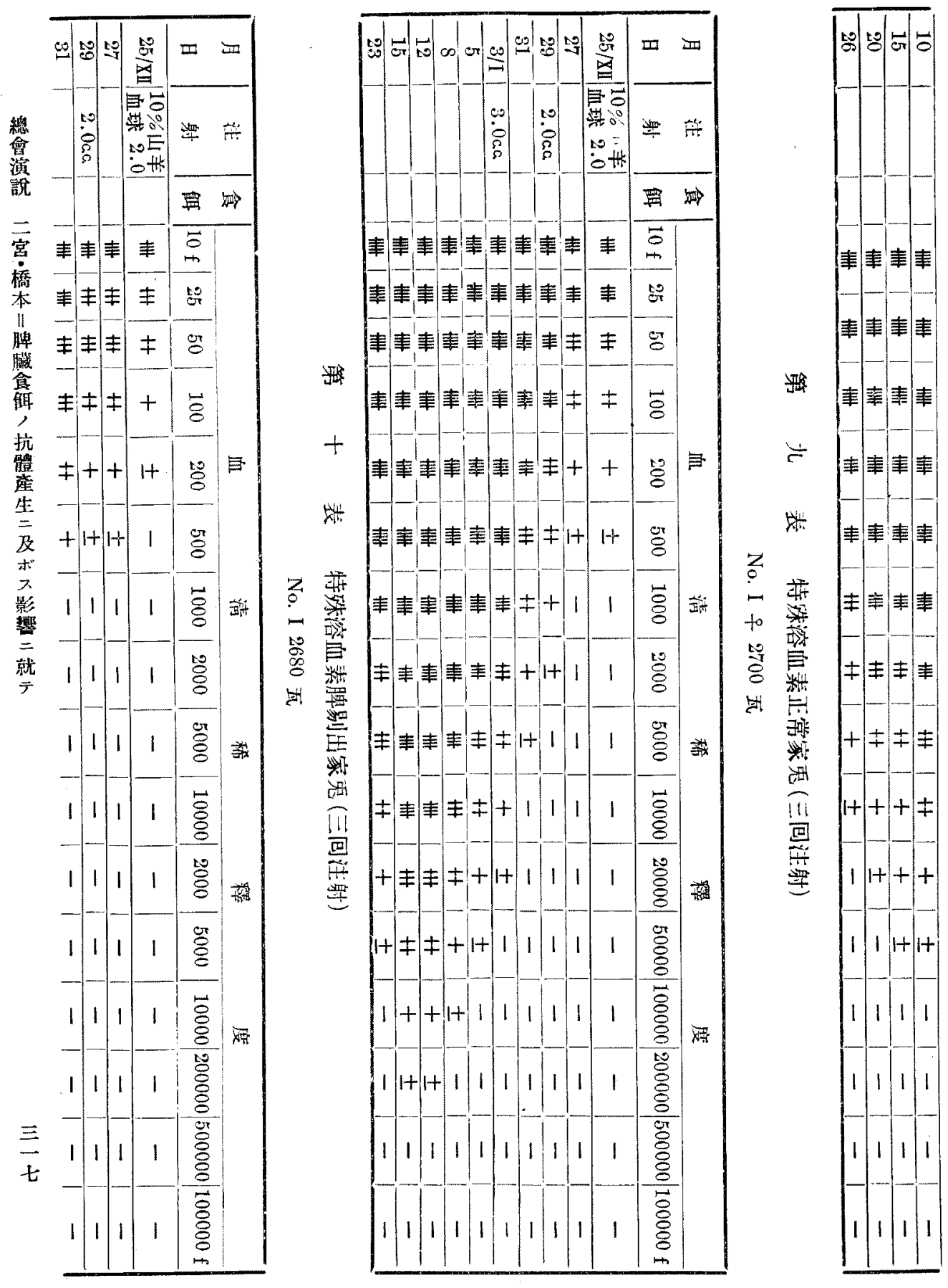


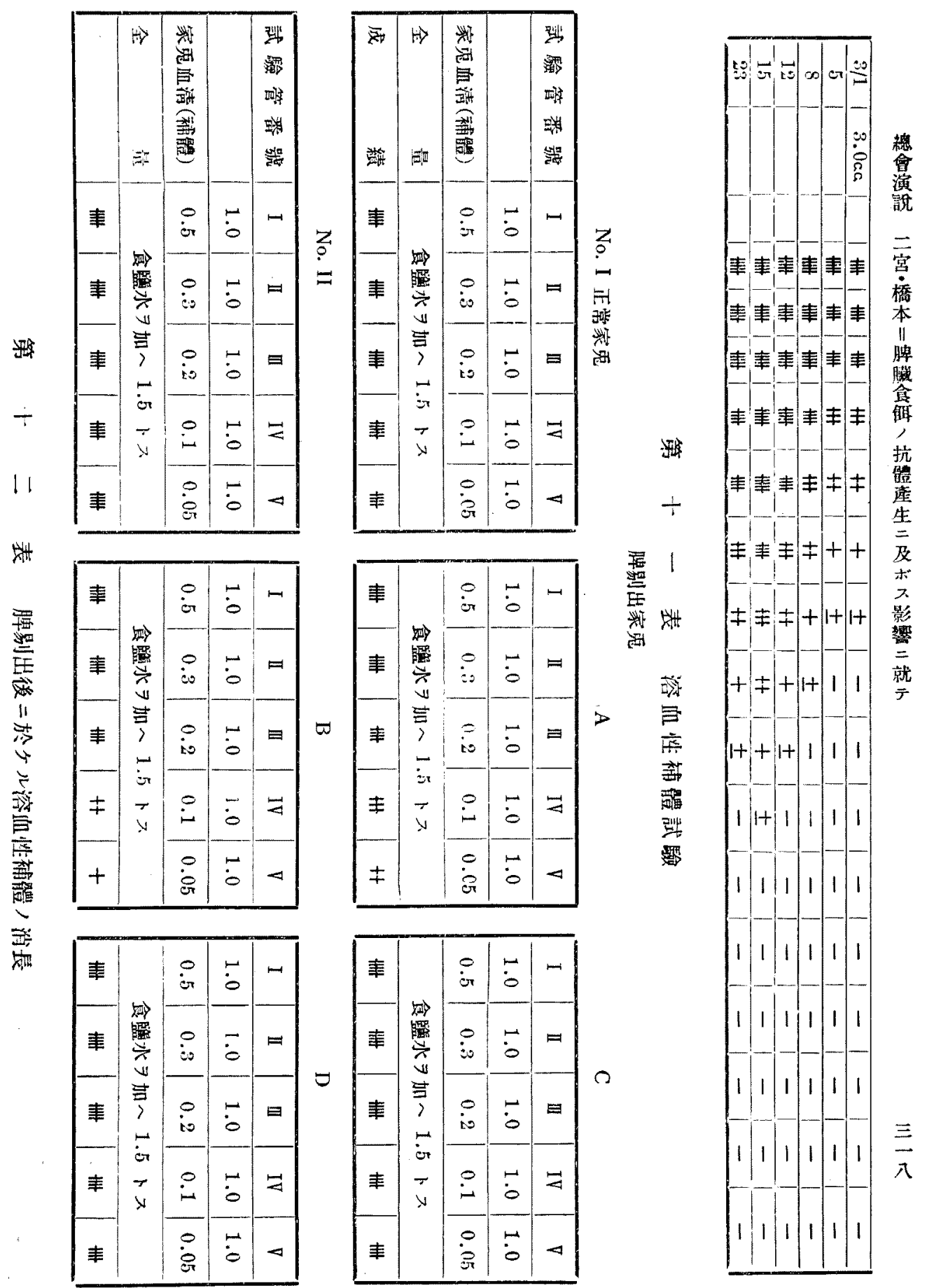


堪 血 ゙㚊 既 第如シケ障八何疫 $尹$ 第 工素差食二三シ補儿碍特レ下耳心異慨述實郎體補七殊, シ 静實

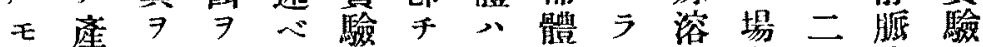
, 生認與夕脾稍, 化血合包内下 $=\exists \ngtr 人 ル$ 脾剔

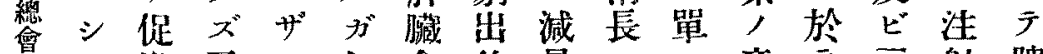
演于進又年如食後量三三產厂三射脾

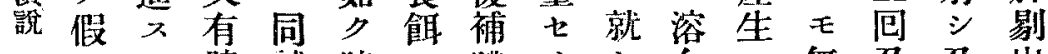
二三ル脾試脾, 體り $\neq$ 血三無免急出 宮蛋物家驗藏特量更于素對脾疫疫, 秀白筫兔動 $\exists$ 殊 本質 $\exists=$ 物剔溶一之察生于兔場少殊 脾占於三出血時之七, 重, 合免溶 脾見有亏比入素減 7 》障要特三疫血 篒 $ン$ ス $レ$ 產少確實碍于殊再注素 触 八而脾特 心゙生 $又$ 證驗二ル溶泩射産

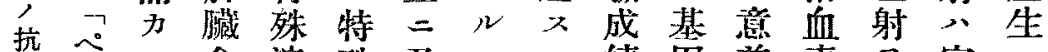
體 プモ食溶殊及モ績因義素 $\Rightarrow$ 家二 産々本飭血溶ボ時目公

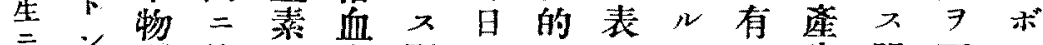

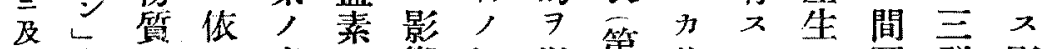

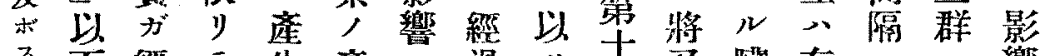

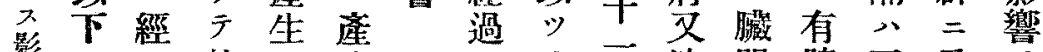

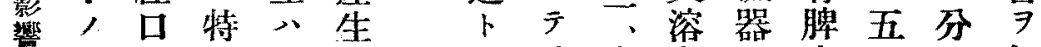
三分的殊頑 八 共脾十血子家日干知 就子二溶漖二剔三性》兔卜之三

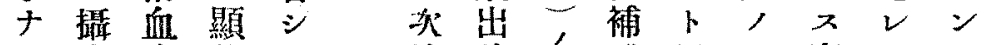
取素著》第前如娟思ソ實二卜 可七, 二障二後如, 料レ驗有欲 ク 5 產 $シ$ 碍情三無減七二成脾シ 然 $ル$ 企广七復於舞少亏比績家無 今、公有 ザ $\rightrightarrows$ 稍 脾 見々家然 浞鬼 脂 肪本飞成脾 僼物亏縝剔 及質 2 个 出 八, 比後 類胃故唃脾 脂液 $=$ 又胹 三肪及脾儿食

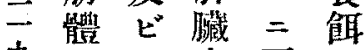

九 求定二者與

公, 間 1 “消特二 ₹化殊㱠 $\pi^{\prime}=$ 溶

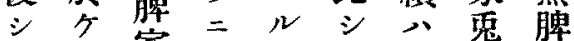
二 週補兔次著管對鬼 以體何为三第照二 㣪量何, 盘夕五点抗

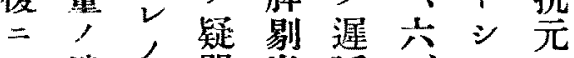

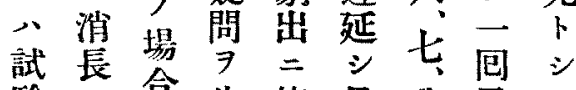

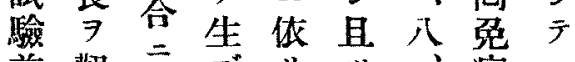

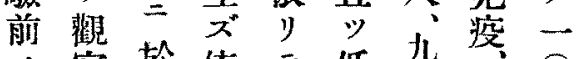
, 繁於依可低九

貲せテッ特位士二\% $=\mu モ \bar{J}$ 殊三向山 復成有脾穴厂二免着

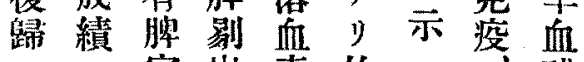
又毛家出素故 $又$ 亦兔後虚三出三浮

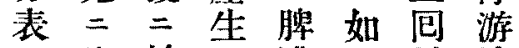
, 比於, 茷多免液 


\begin{tabular}{|c|c|c|}
\hline$\stackrel{\infty}{=}$ & $\square$ & $\exists$ \\
\hline 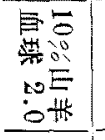 & 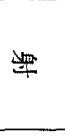 & $\stackrel{+t}{\leftrightarrow}$ \\
\hline 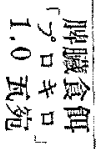 & 㚳今 & 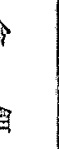 \\
\hline 奉 & $\begin{array}{c}\overrightarrow{6} \\
0 \\
\end{array}$ & \\
\hline$\mp$ & got & \\
\hline 专 & $g$ & \\
\hline$\mp$ & $\overrightarrow{8}$ & \\
\hline+ & $\stackrel{8}{8}$ & \\
\hline $1+$ & 8 & $\equiv$ \\
\hline 1 & $\overrightarrow{8}$ & \\
\hline 1 & 8 & It \\
\hline 1 & $\begin{array}{l}0 \\
\\
\\
\end{array}$ & \\
\hline 1 & $\ddot{8}$ & 棓 \\
\hline 1 & $\stackrel{8}{8}$ & 旗 \\
\hline 1 & $\begin{array}{c}\dot{r} \\
\stackrel{8}{8}\end{array}$ & \\
\hline 1 & $\begin{array}{l}\overrightarrow{8} \\
8 \\
8\end{array}$ & $x$ \\
\hline 1 & $\begin{array}{l}8 \\
8 \\
8 \\
8\end{array}$ & \\
\hline 1 & $\begin{array}{l}\overline{8} \\
\overline{8} \\
\overline{8}\end{array}$ & \\
\hline 1 & $\begin{array}{l}\mathscr{8} \\
8 \\
8 \\
\end{array}$ & \\
\hline
\end{tabular}

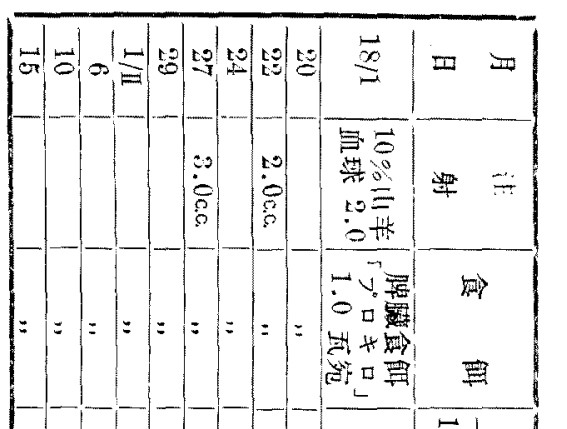

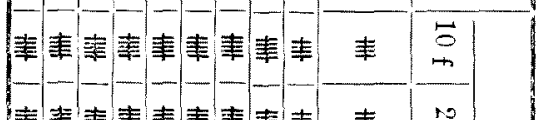

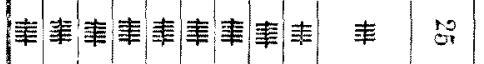

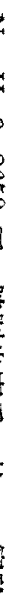

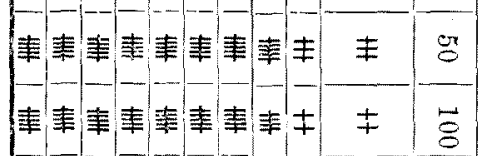

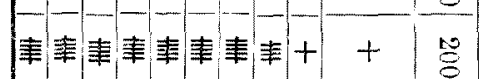

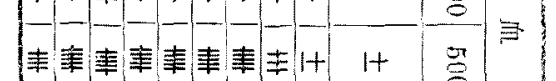

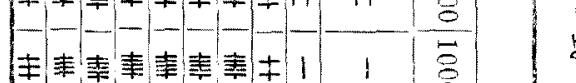

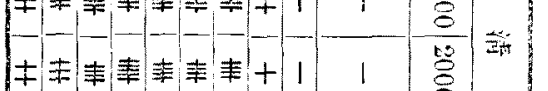

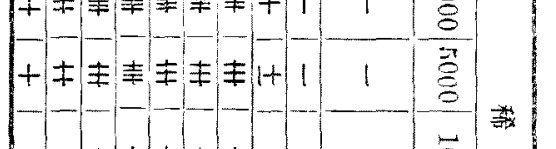

$1++\neq \neq \neq \neq \pm 111 \quad 1 \quad \frac{\vec{\Xi}}{-1}$

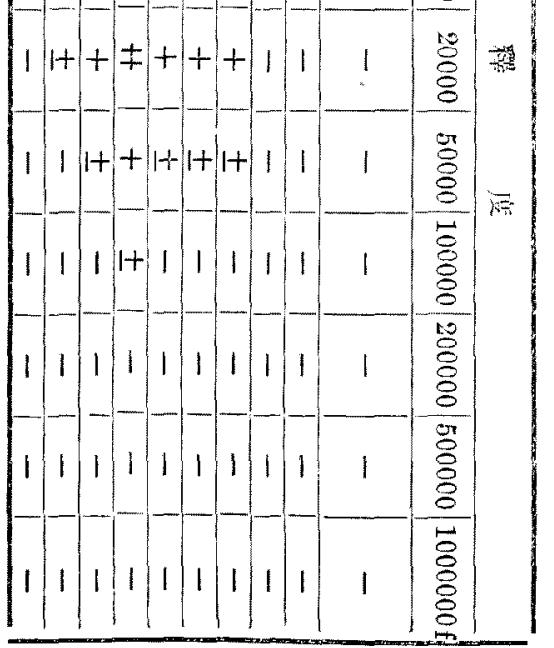

表广能 如

第り亲 义

士。進本

二而七事

$+之$ 之 筫

四 本 叉 >

本以 脾

物 $ッ$ 捗藏

買 亏 ガ二

齐 暒 宮

脾疫疼桥

牙度

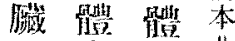

, 產 產 蜰

特生生俩

称 7 诖食

务促地解

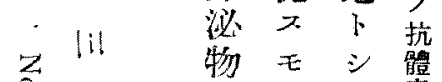

广

二㬐， 上穖生

to $\rightarrow$ 認能 夜

9 y

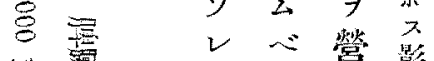

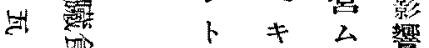

紧 $モ$ 以

接

ivi

然

活

$\approx$ 粈

$\Leftrightarrow$ 胫

预

11

党

$y$

然

代, 外

謝 = 更

產シ 二

物 テ 特

十抗 殊

り體,

+ 產 物

二生翼

就 $=7$

₹ 關 供

于 $x$ 給

八

更 脾 一

二 阷菂 般

報人網

告意 牱

義 䋨

ル $\Rightarrow$ 队 三

所 -. 被

$>$ 層 細

万䍌 胞

ン 明 系

卜 又 統

欲ル1

工機 
第十四表

有脜無脾及脾剔出後脾践食细 7 與一

タルモノ, 特呀溶血素産生状息比較
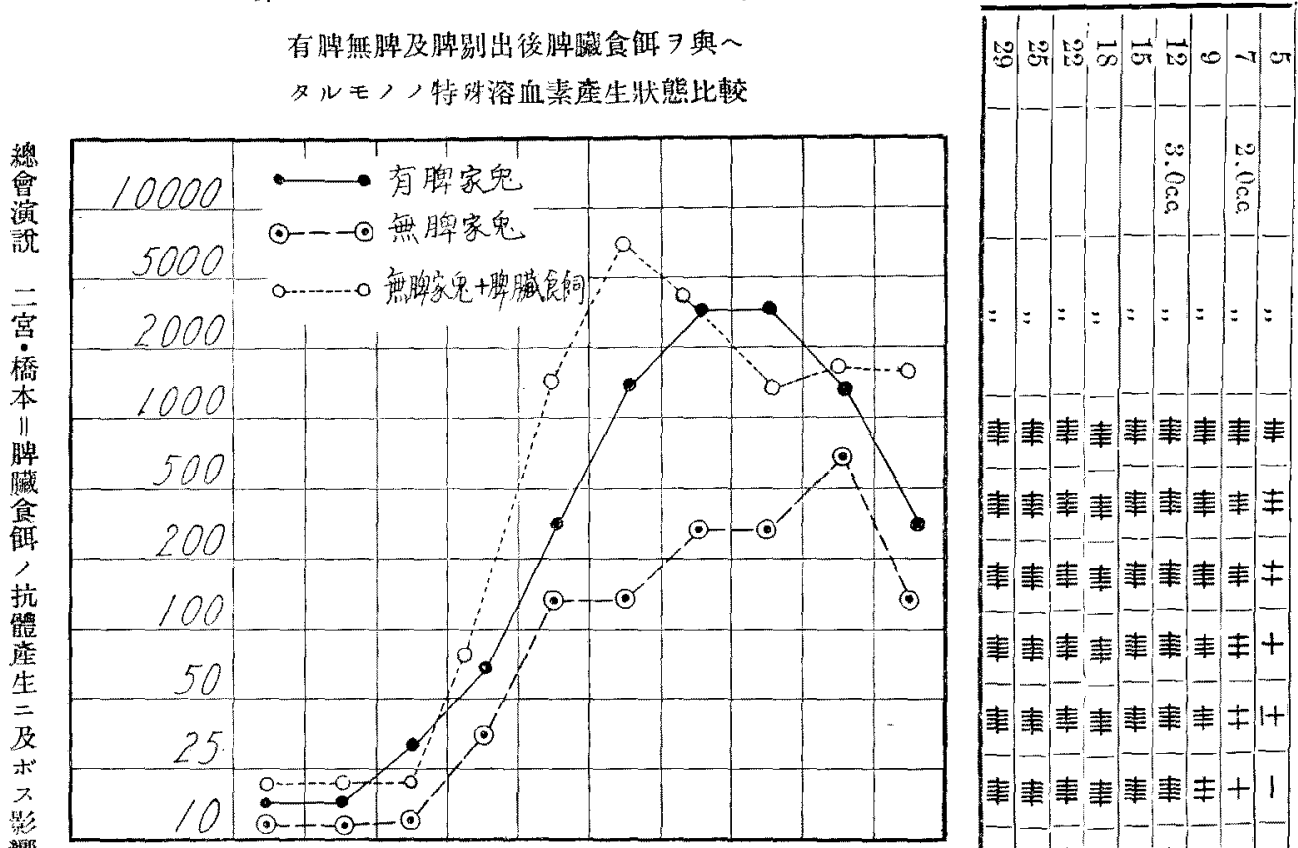

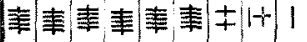

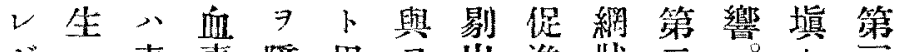

ガ 八表箈障思 7 出進狀二

影著二应碍料 $ル$ 後

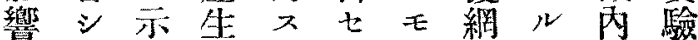

十クス

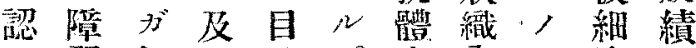

么碍如 ボ的。產內

心七刀 7 仍生被述系り

キ 何脾 以

モルレ歲 $ッ$ 脾對胞タ,

‘之, 食テ剔シ人譏 脾

$ナ レ$ 場馆つ出

シ = 合,

、脾二影

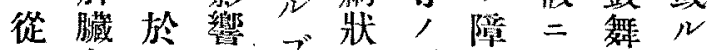

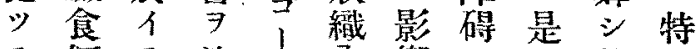

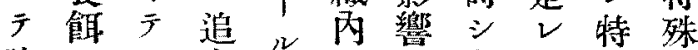

三脾 7 モ究し被与之

三剔興特七 7 細

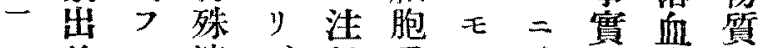

後 $N$ 溶・射系, 脾卜素 7

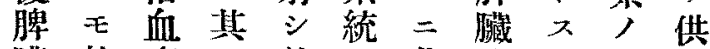

臟特素, 特, 非物レ在方

食二, 結殊機 ス買心゙生一

慨之產果溶能 $\rightarrow \Rightarrow$ 脾 $\Rightarrow$ 般

特 蔫

殊 㽭

溶

脸

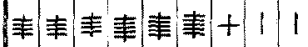

素 剔

出

產 後

生 二

青於

飞方

$=N$

Z 維

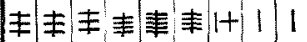

二 狀

及 織

ボ 円

又被

脾 納

臟 胞

食 系

领 統

$\neq \pm \neq \neq \neq \neq=1111$

$+++ \pm \neq 1111$

影苑 

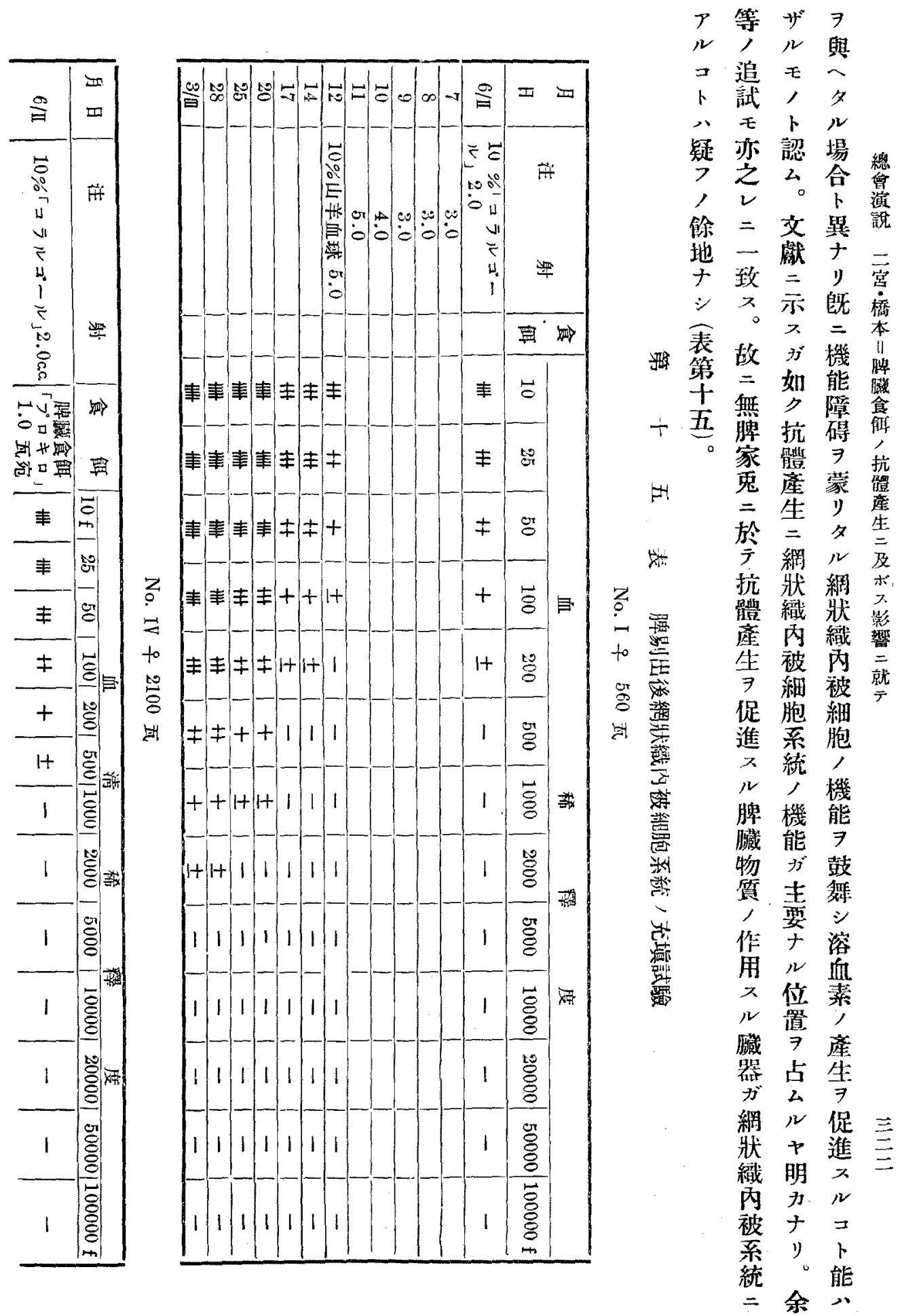


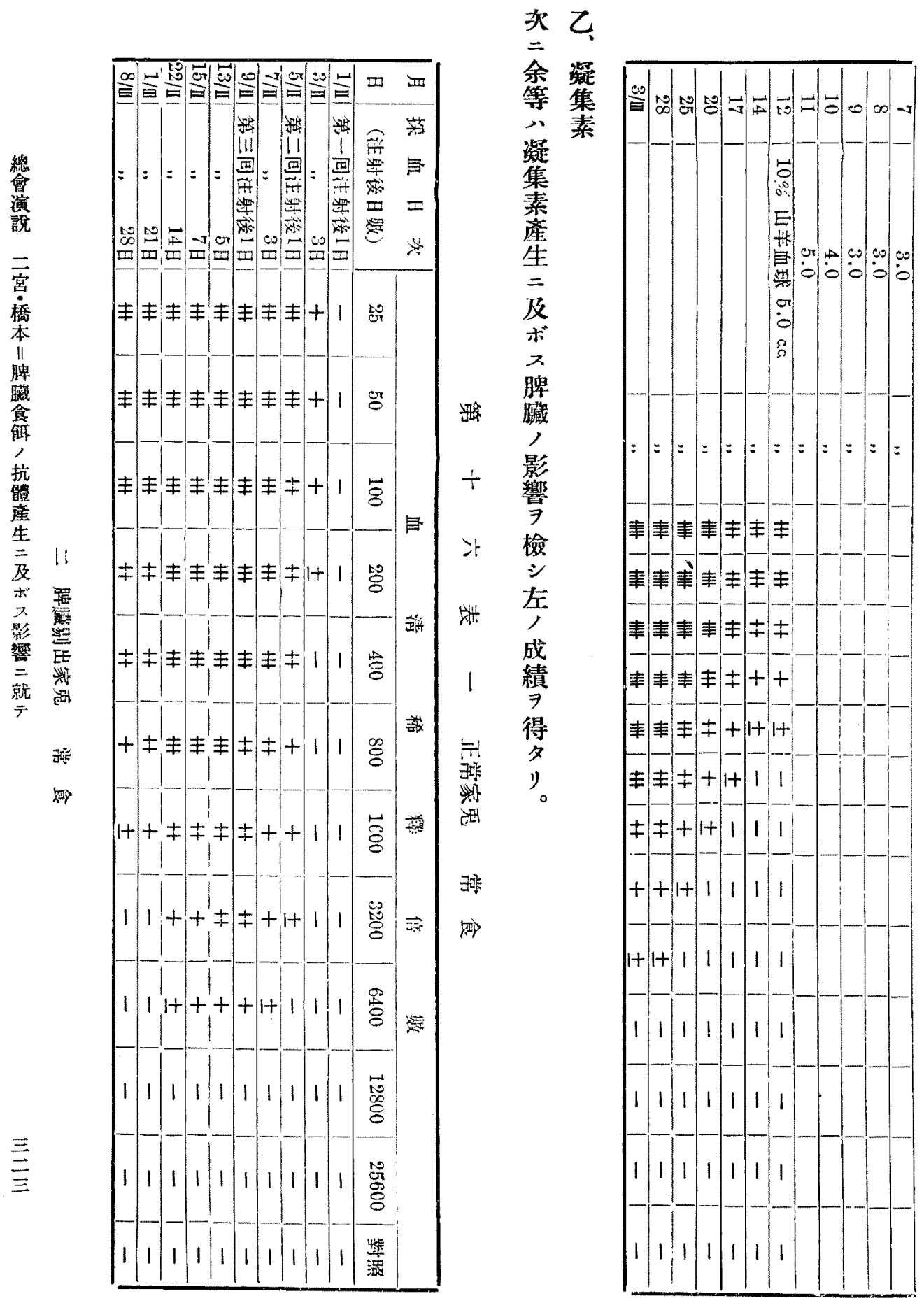




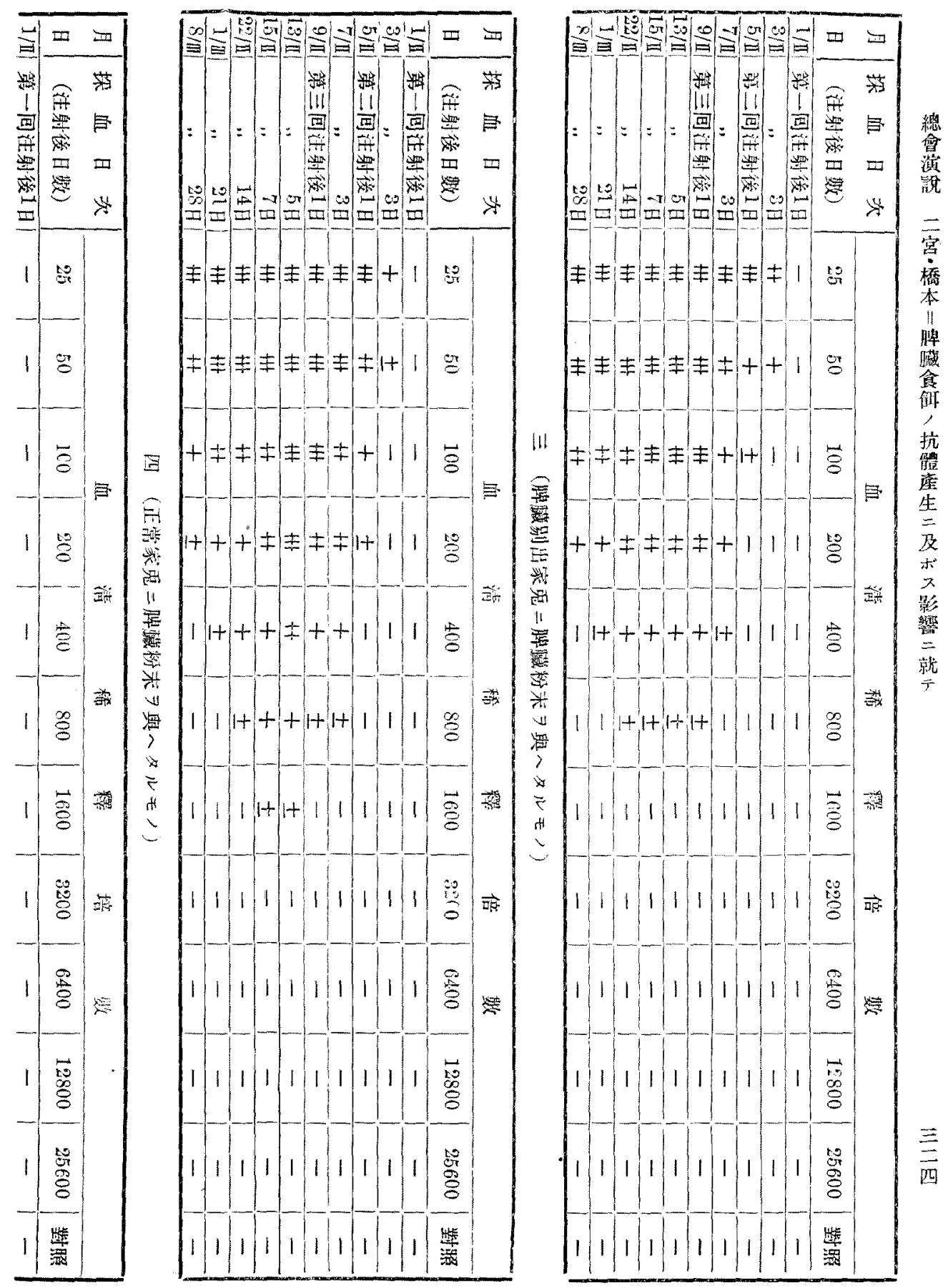




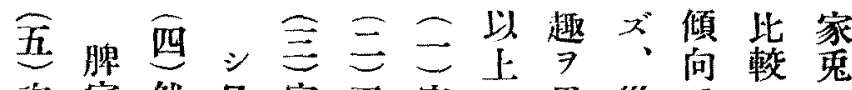
次家然且家正家; 異從 $丁$ 入, $=$ 兔 $ッ$ 兔常兔實三

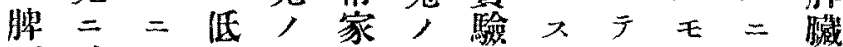
總剔脾脾價脾鬼脾成表脾正遥

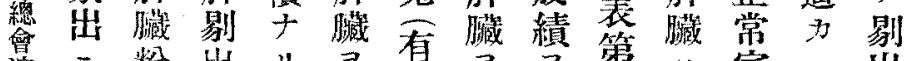
演二粉出

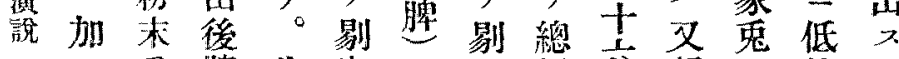

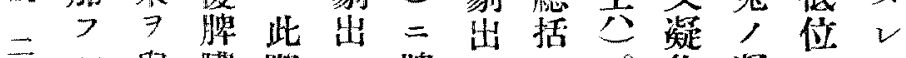

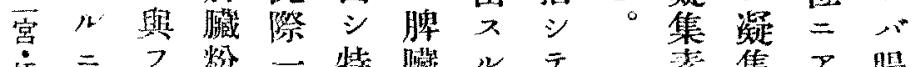

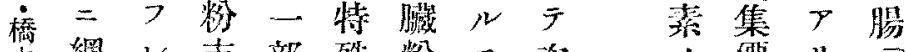

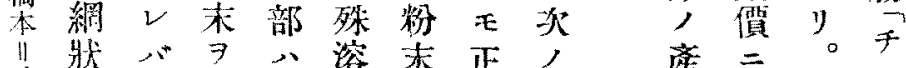

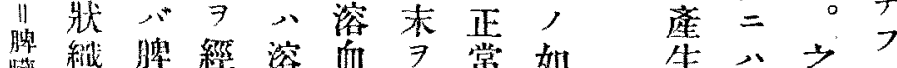

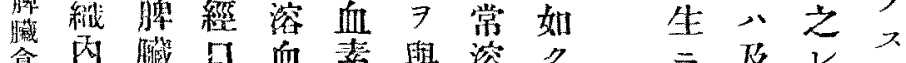

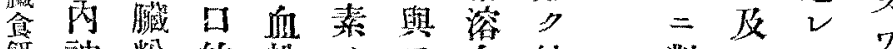

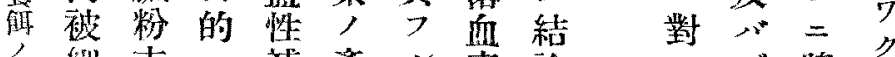

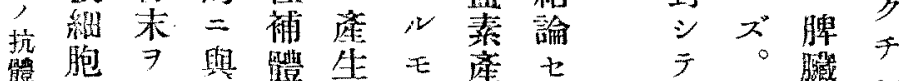
蘑系興フ, 狀脾生ンモ及食こ 生統へ上減態贜三 r重有慨洼 居 充 $\mu$ 溶 = 觀粉異 7 家舆二

不填同血毛察来常。儿鬼子依

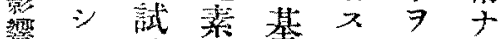
其羷, 固心與シ

就作動宸入二会。

$\bar{\sigma}$ 用物生。何 ザ

$\Rightarrow=\cdots$,

洌比迅，同

碍 三速場試

大溶 $=$ 合

is 血 $三 \quad$ 趿

诗素应於物

八, 有于二

特產脾飞比

殊生家 正

溶 皃正

血多看常

素少，眚溶

，促間㿢血

產進二家素

生七差鬼,

三八弓異二增

吾著心基比加

》势著䜀

障

碍多 ズ

方肴掘

意 $=2 N$

義脾心凝

$\exists$ 酮 脾 集

有食臟素

入 慨 食,

为飭產

千興 7 生

脾子與

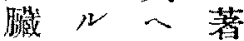

食モザシ

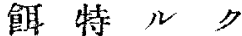

樶二同障

取渋試碍

$=$ 集驗

$\exists$ 素動

, 物

影產=。

響生比之

特促稍有

殊進? 脾

溶云促家

血儿進冤

素コ

下 5 成

稍能 ル績

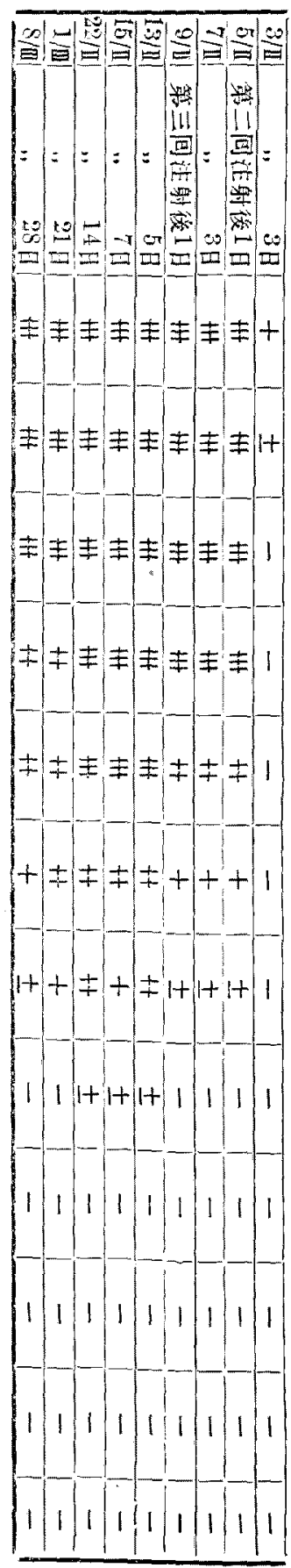


二抗日八余 對 體 本最八 下發内初家 儿生科八兔

意, 學㠜 脾 皒力會 集 蔵 $77=$ 素 7 決恢於發剔 定復，テ生出 七不報八シ ンル皆年之 力 $=シ$ 光 第至置 E 腸 ニ ル 人, そ市 ᄀ 多十郎射 ㄴ. 數 リ 97 苗 了又脾 反 7 家他臟姴 洼 兔方 二" $\neq$ × 於於家時 凝 ケ息八集 儿家二急素 成兔於二發 續 八テ凝生 子 抗要集二

綜娟 菌 素 際 合崖 批登有 批生留高腹

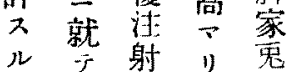

コ八下有卜

卜個㭙脾間

必性 洔 家

要的此兔如

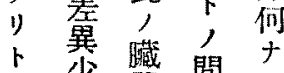

信少器間羊 希吕 美差

橋三 ザフ胃や東

本豈, こ事晃

㴊 ナ ン

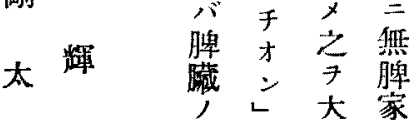

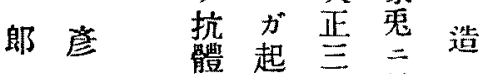
產 坚 年 於
$\Rightarrow$ 入

異故ル次, 該之心么。

$==$ 二物機レコル之

ス脾 傾凝翼能二ト+レ

歲向集 7 , 园、明二 、r素供出 $⿻$ 疑力脾總 又心, 現テフナ臟 演

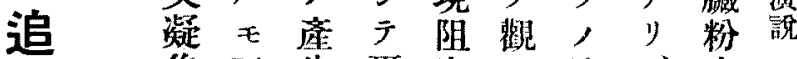

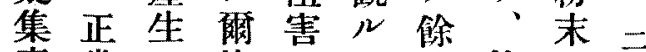
素常 $モ$ 他七二地故 7 宮

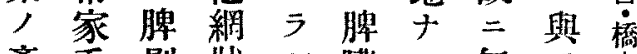

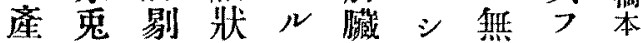
生, 出織、以。脾ル 二凝後內 而i 外家モ 脾 對集低被学，兔何基 シ儥下細 $テ$ 䋚 等能 于二 二胞本狀於, 抗 千 $>$ 系機織影體 重及之統能內 要心゙レ, 障被抗音生

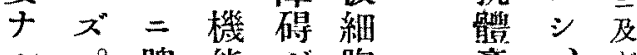
ル。脾能 $ォ ゙$ 胞產、和

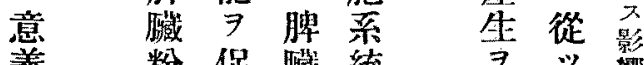

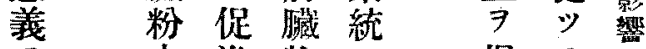
采進物 モ 促 テ. 有 $\Rightarrow$ 不啠亦進抗就 ス與 2 少特

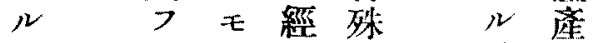

$モ v, \square$ 溶脾生

脾 心十的血臟二

臟脾り投䇣物絟

食臟。與產貿狀

解粉坐, 織

攝尔 $\exists$ 能作內

取 $\exists$ 少用被

$=$ 與 テ

ヨ - 補有胞

ルザ充ス 臟系

影 七。器統

劈 同

$\therefore$ 試稆機

特、驗、彇能

殊 動 7 䌬 ガ 三

溶見脾 两主三

血 二 二 践 被要

素比分 7 細

卜 シ 脾缺胞心

稍促臟如系位

3 進 入 統 置 
元低ビ演ハ收一 ᄀ㟲吸者 $\exists$ 線酸 毛下著心免 $尹$ 化 グ Ł ソ 認炭

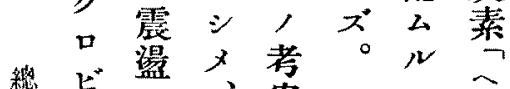

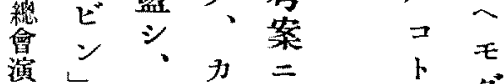

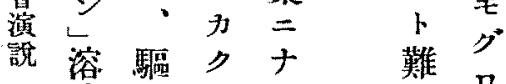

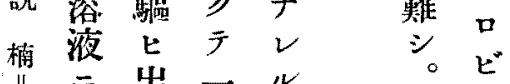
$11=$ 出 $\rightarrow \mu$ 血夜接 三酸裝

液触多化置 微七ル炭 $\exists$ 量 シ 血素用 酸 液含 酸亏死有テ

宸 一斯 量 證化集多: 明㞸 $\neq \neq$ 法素亏血量 $\exists y$ 液 吸, 7 血 著内得液 七ノ、

シ酸 $=y$

么 集

力焦 分 二

力坚 光 酸

没鏡化

テ食二炭

飽酸檢

和酸檢 7

酸液 七

酸二リ出

华テ。シ

炭素吸的次

素收千兵

血㴕血

$\equiv \bigcirc$ 外液

三
七 名

靖 後 留

的 7 血

り量 加 液

驅,

七還テ再

下王
比 こ

較含

的 有

銳 量

敏 $=$

s \%

化 以

學下

的,

證血

明液

法 =

$=\vec{\gamma}$

$\exists \quad \cdots$

驾

モ 光

之鏡

含 $\exists$

有 y

量 テ

审

至化 科

四炭檠

$\%$ 素

以尔

六

血

液

内

微

量

酸

化

孷

素

)

證

明

法

血

血液

挔五

於 ᄂ

今 特 郎

不有

確 ナ 雄

實 ル

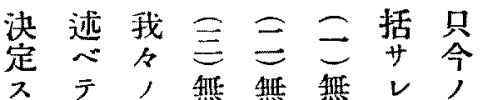

儿居成脾脾脾?御

貝儿續動及動 。忠

子者第分有 八 分

以王一有脾有有

テ $>$ 脾動 脾難

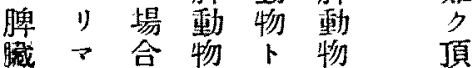

食 $ス=二$, 二戴

钿 ガ相比間 比致

影々 我嘗致抗何抗方

䜾, シ 體等 體不

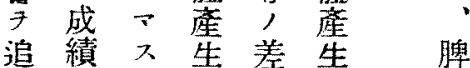

究八父兾 公䑏

シ 以抗啘分著

$\rightarrow$ 元口十学抗

シ述, 顯 1 々體

タぶ䅣著。迤產

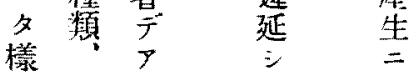

デ量管。县對

1) 注低少

$\therefore$ 塮鹪意

ガ、數水就

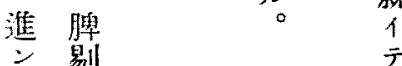

デ出

如 $\exists$ 實

何り 駿

ナ免疫成

理注其

南㴬范

脾,

剔 時

出 期

後 等

抗 二

塪 $\exists$

產 $ッ$

告 差

障 兾

碍,

\#

ル

-

为

$\nexists \Rightarrow$

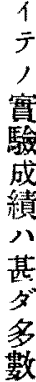

$=$

存

ス

ル

天

約

次

如

n

總 
昇週息: 凝自家余喓凝亏一 $\exists$ 家 1 集家血 $心$ 集 $九$ 認二組 $几$ 素血球自至素、云 邓週織保 得: 細有自三前血亏存, 年 ザ三胞有家塞二球 》週二物血冷他凝未=N留 ₹及专筫球狀家集名歸 五㥂

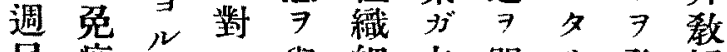
目㾥免又與細本關》。發授 二貫兔次胞凝明。見八

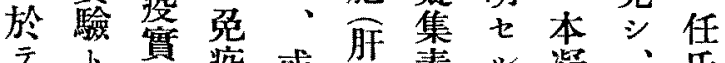

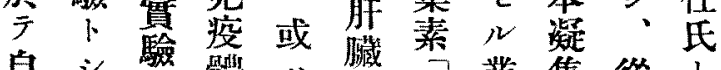

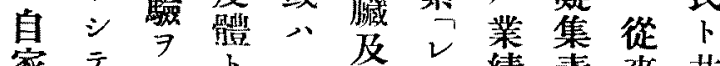
家テ寻

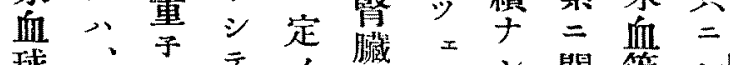

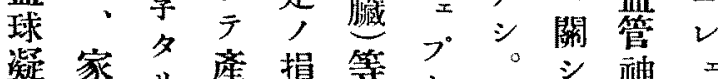
凝家多蔏損等 集兔。出賃 马腹今蒙光公 測腔 $ル 5$ 免 定 $尹$ 、 然開毛, 又

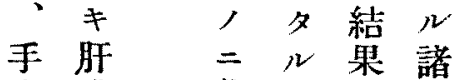

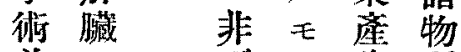
煎指 ザ光生筫 價壓 $\Rightarrow$ 以郎 年知灵出 比以家。自 暧多毚毛家 觀 拇 $\boldsymbol{n}^{*}=$, 血

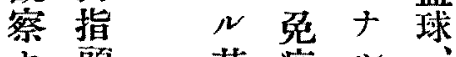

七頭 尖後試 无, 倘驗否家 “挫爾 $\exists+$ 組 何碎他行 7 織 等筒, $\mathrm{t}$ 確細

明所本夕力胞

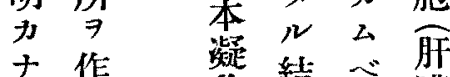

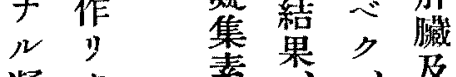
凝夕素果

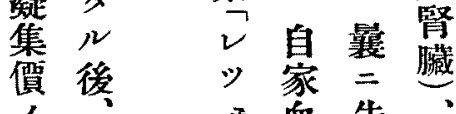
上一 >血告他

学䄚,

“症 1

无卉

光, 病 一信發 年 で作

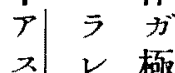
$\Rightarrow$ 夕夕

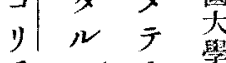
氏 收 ×度 記, 学 載1月垪 以氏寒鬲 來病渝犁 幾, 转致 多原家 因血中 研 $尹$ 球 究異凝 常集村

" = 現

强象 踓力二 毛子依亥 \% , 自亏

産家一 告䘏越
, 認出 方公办

法。几 $\Rightarrow$ 即 死 以于 斯 于 血 $\Rightarrow$ 人液○意 三 閏 九灷跳践蝴 動 7 血香

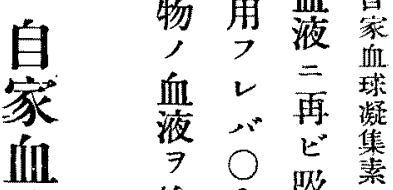

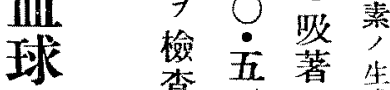
凝查\% $\%$

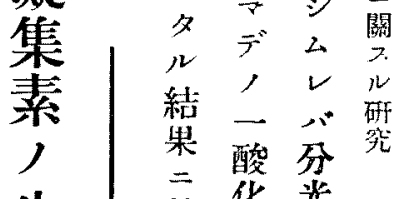
生 就华光 成 關 ス 容” 研 得 酸
二 明 證 明二 得酸 装 素 ר 乇 グ 므 ᄂ, 咒 
以得 7 少, 夕所家 $=$ 余 $ル \exists$ 追生何宛組他

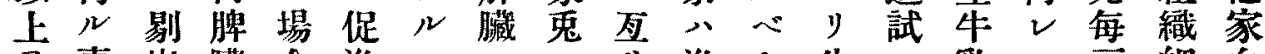
$\exists$ 事出臟合進 $===$ 進 $\neq$ 生 シ乳, 至細血

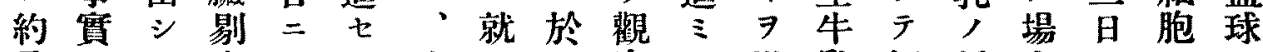
言〉夕出 總入 $ル$ 家却 $ル$ 牛于

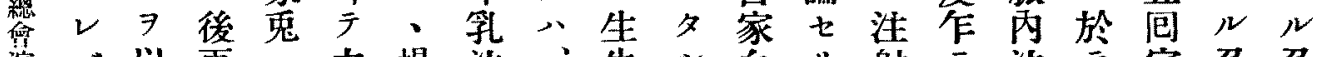

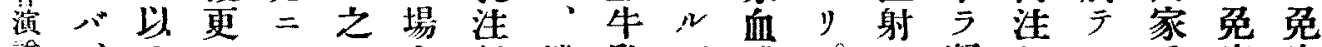

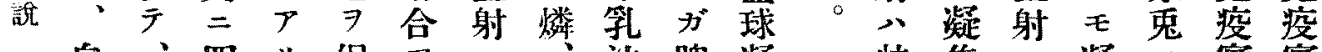

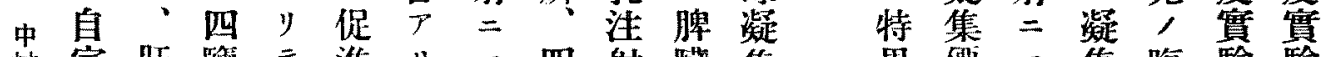

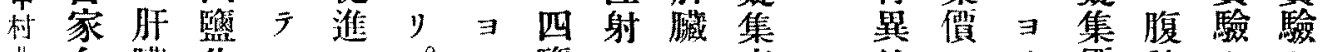
自血臟华么ス。ル監二, 素 自球咴生 血凝脾素牛毛八家婒 $N$ 出產 球集微 7 乳, 肝血素自八生 准素卜以泩卜狮藏球家家三 篓 八, 八射思機凝乞血兔對 少獨劦二考能集示球, 又 告宬立臟 $\exists$ 七刀素品疑本ル $=卜=$ 障, 減, $\sim$ 集來體 關モ李碍自儿衰産公素有內 正正凝 $\Rightarrow$ 家べ 7 生卜人又諸

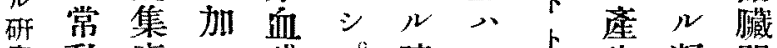
究動素人球。時一未生凝器 物, 而凝公般必集, 二產 $シ$ 集本 $=シ$ 明素態 於生亏素凝抑气另三度 天三生, 集制等二對 7 、干牛產素亡, 抑汇哯 寊與乳生劣

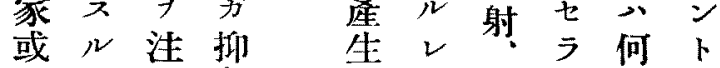
㞋射制寻下゙ヌ几等欲 他卜 家明公5

免力r 疫手丰。 $=$ ) $\leadsto$

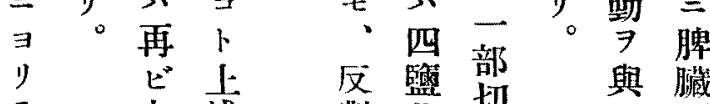

于本就對华切除剔

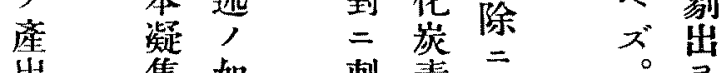

$\equiv$ 等努

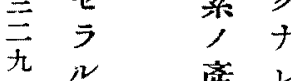

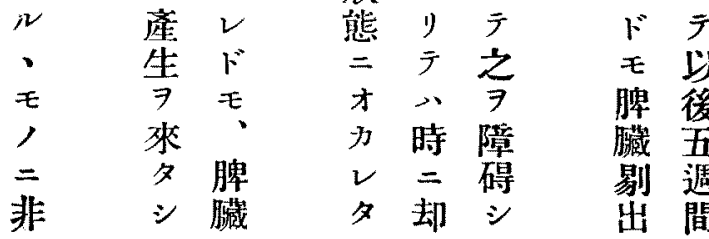

韩籍然行

狀 $\exists$,

F゙

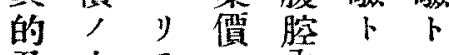

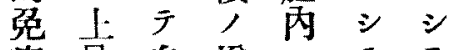
痕莽自增二示

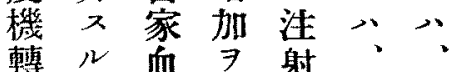

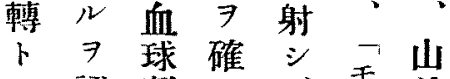
言認凝少。毛羊 采、集公共毛血

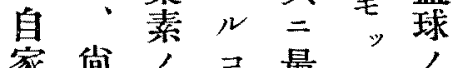

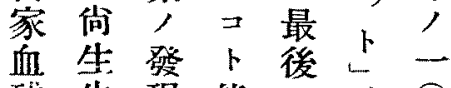
球年現能应, ○ 凝乳公洼肝\% 集 = 素八》 斗查一丰”只液

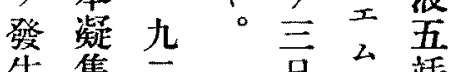
笙集三百台琵

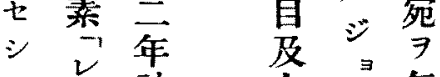
台\%神㫐ン每

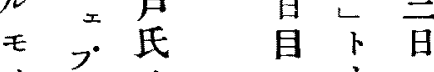
, $=+=$ 占証於三五 非思多夕间 元息家 少象鬼 天存事血, 在實球 7 耳 $\overrightarrow{7}+$ 凝肝靜

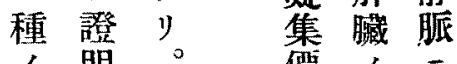
, 明。傊, 二 非滰 $\quad \exists$ 重注 特得三检量射 異ザ余 シ 的”手名于 刺

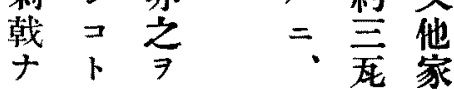


各盼素生

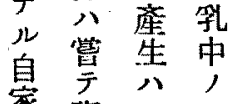

血典韭 七

血酸常当

凝 $7=$ り

集エ慙ン

素二度 ᄂ

增儿无依

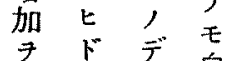

起

サツル 向

× 14 球

得, ㄷ凝

夕連少莠

續氏

于注射產

逸射 7 生

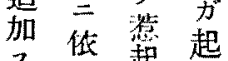

又。 起起

只得 得

例柰上

デド御

于自話

分家

極向球

テ凝 何

高集

度僄二

前尤

集升我

呰ナク

恶他如 中

, $。$

モ 原 操

, 因作

$カ^{*}=$

五 $\exists \exists$

百倍モ自亥

望, 家

上 ナ 而 一

澾ン谈
ノ注驗ン 1卜素数

原 射七帛厅報人室

因入ル自儿告增,

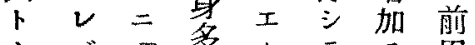

ナバマ多キテキ日

儿出七少 入居證學

者現り凝

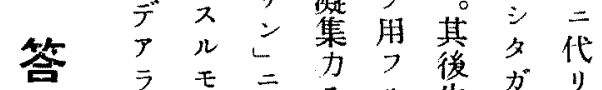

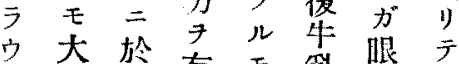

。量亏有无学球追

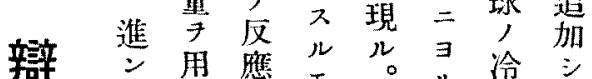

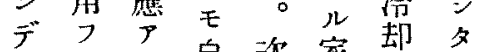

七レ师自次家菟試 1

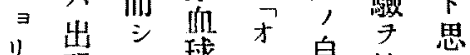

ン現七球 $っ$ 家族

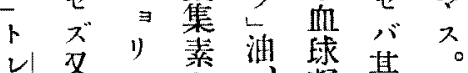

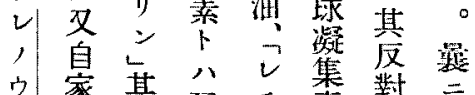

氏血者 互 千素對 $=$

病球八二千告公成

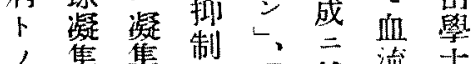

關集集制 方就流士

係起主ル

吕 方向

考 学名向

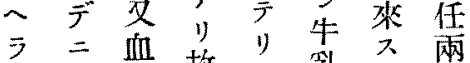

時 清故之乳; 代

ル 日

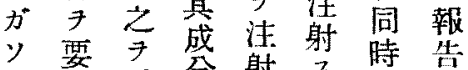

ᄂ 添分射 7 梠

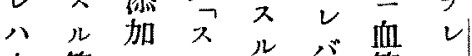

来等 ス

何りモりレ二透氏泉

等見自: $匚$ 臬秞病

し家酸于家經二

成バ监酸さ血機就明

續中球燐上球能

于村㠜酸云澦, 追

收君集酎於集障試石

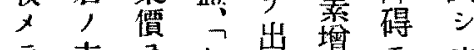

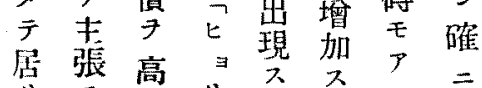

リス离りス、、ル二

七如爻亡 既本者家

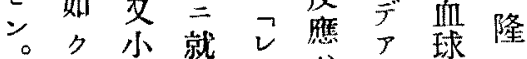

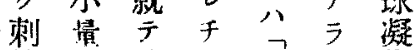

戟 $\Rightarrow$ 試 千 工学

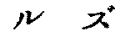

役 シ

割テ

演 生

天牛

ル笔總

モ 泩 濒

追，射諲

+1 中

) 如 村

加

非自

特 侐

異 球

的㕠

刺跑

韩

$=$ 生

$\exists=$

關

₹

咸 研

非 究

七

v

而

テ

牌

臟

及

ビ

用

䐟

共

$=$

y

產

生

與

重 
私色于及異血染夕酸此

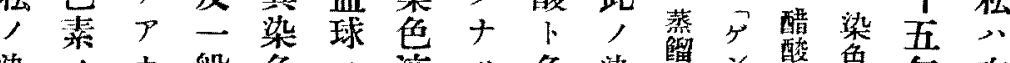

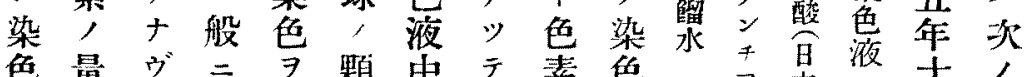

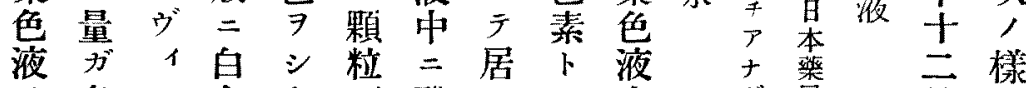

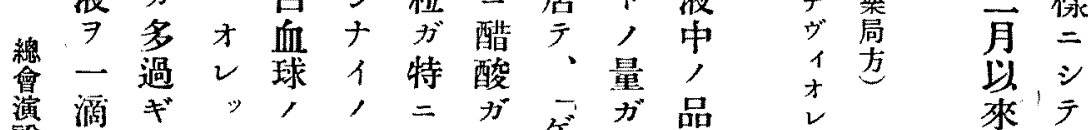

鿁载儿上核 デ强加

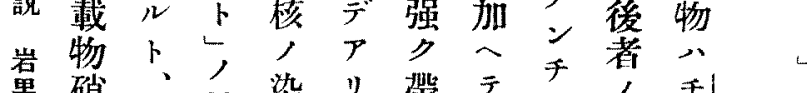

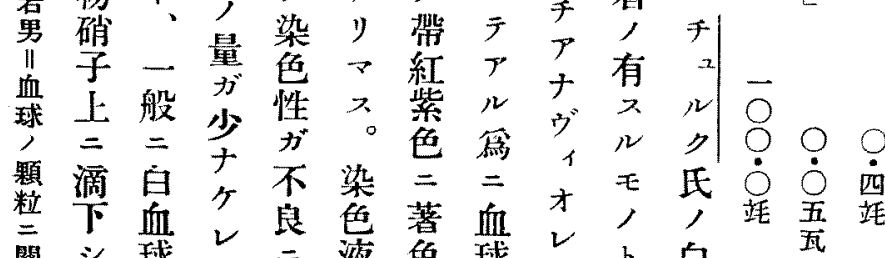

閵 シ球

ステ人バナ中シ人,大血

研其胞好り, 、顆上礕球

究, 體好、醋

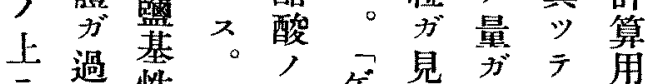

二過蒅性次量年見軍亏角

製染顆次量

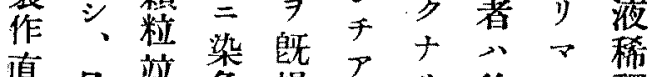

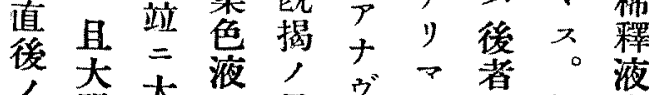

戰單夜量 ヴ

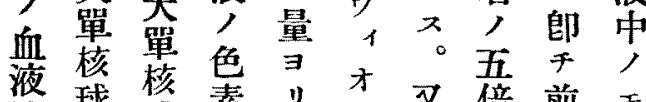

研 血

究 球

$\stackrel{\text { 四 }}{0}$

于 染

居色

$\checkmark$ 液

자 7

製

製

广.

IIII

球

染球球素り

抹顆人量多”醋二者人

乾椟顆量多卜酸ナ人,

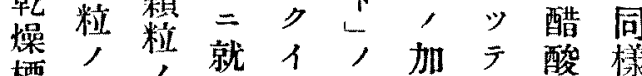

標限染亏 夕單入居, 酸椂

本界染申

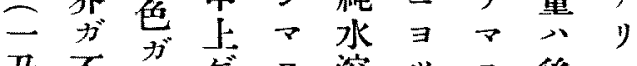

乃不不グス溶

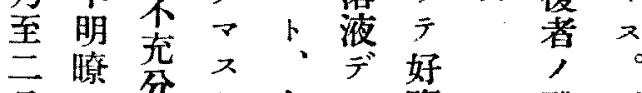

昌暸芬

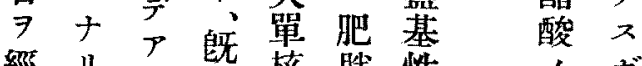

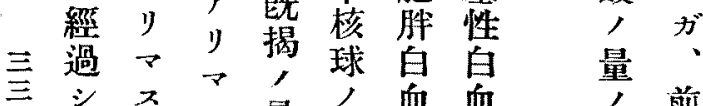

其

八

顆

粒

液

血

成

球

ス

染

ル

色

テ

研

テ.

究

其

被

染 學

色 校

血 科

球

岩

形

態

主 男

卜



テ

顆

粒

尹 督

大

抹中ら゙著心胜少ル

正 


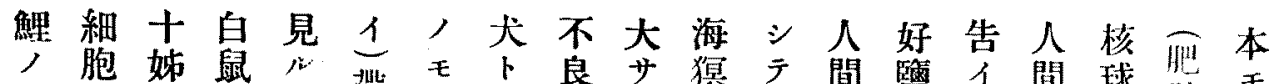

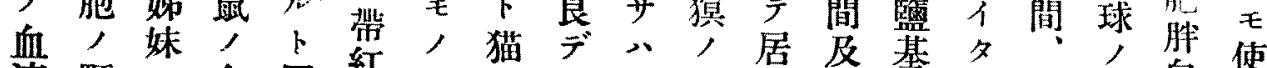

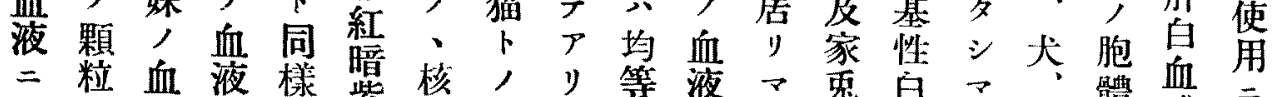
、夜 = 肥特二八肥色多液入了肥。血球 㭌二八肥貄著核 $=カ ゙$ 㭌此液或

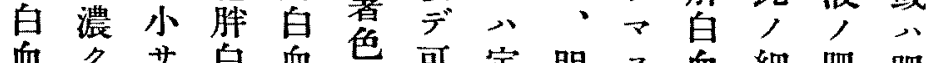
血》皇血色可定明 球帶血血球夕寸形暸。球胞㭌㭌 八細脙 ガ顆り的三數人, 白白 紫㭌 》色白見》粒名肥色間粒, 球球 マ三血當 シ密縕㭌三尹八染, 七著球り, 密紫白著經頗色顆 ン色ガ、、在色血色過性粒

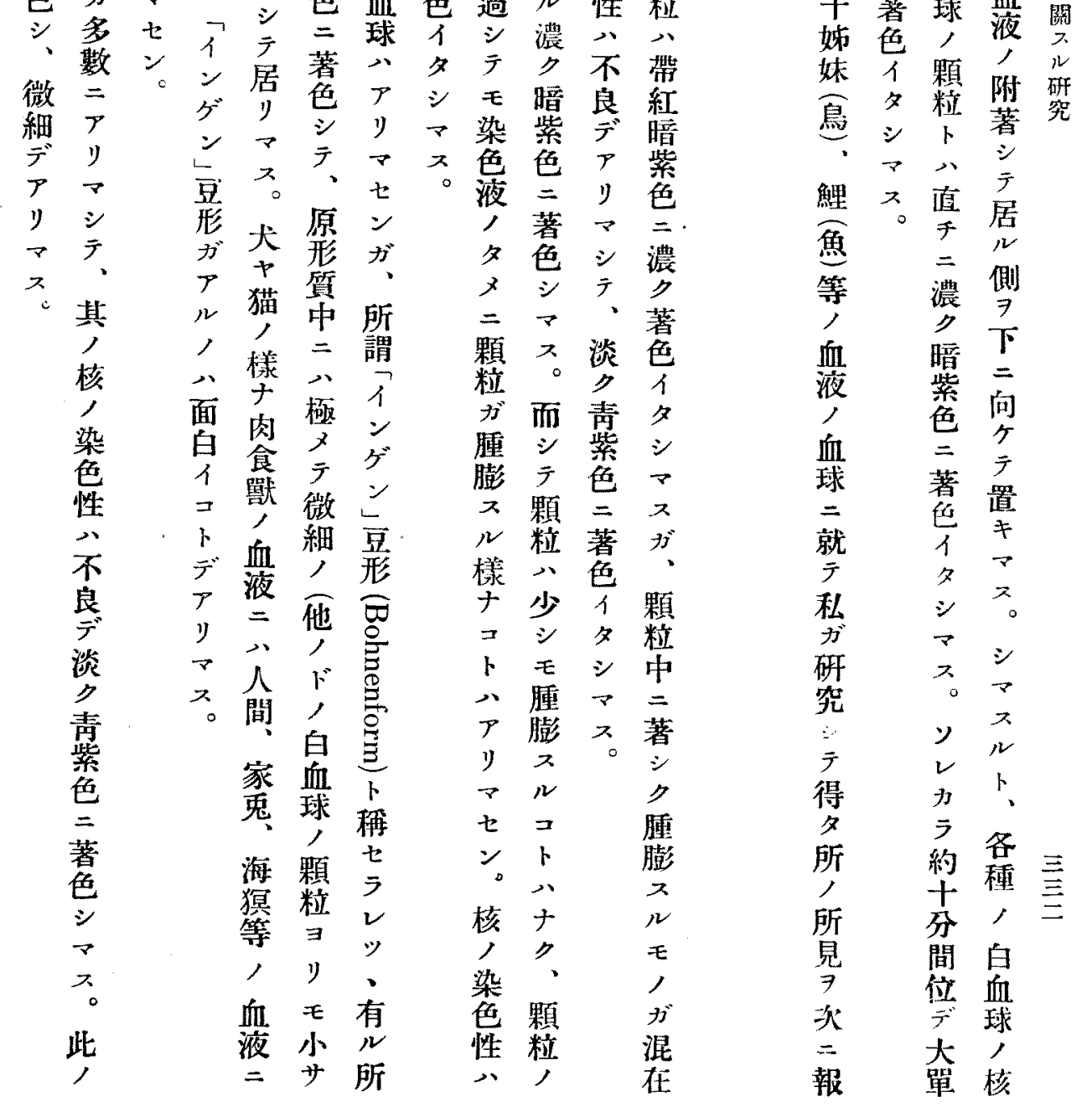




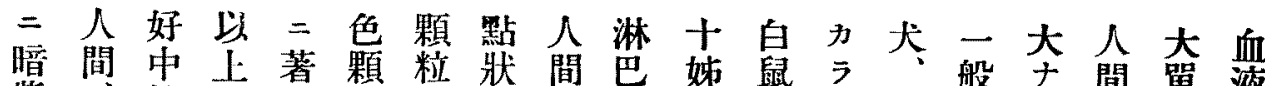

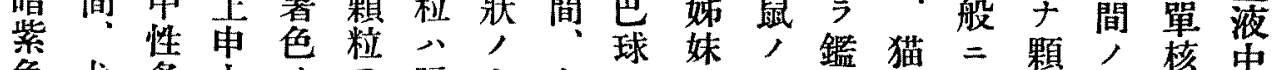

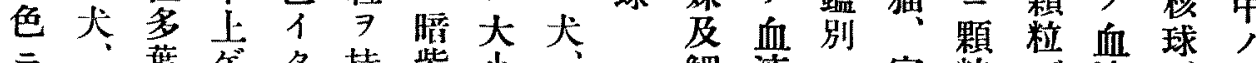

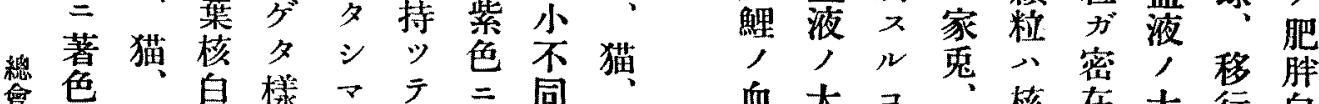

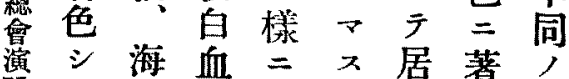
演 $シ$ 海血二 宁猽球血又代色顆兔 崽ガ白液胞モ、狀游 血細鼠大體, 少物猽 胞十 㖦 顆體姊核帶y而出血 粒”妹球紅 $、$ 七液 關淡, 多鯁原色。需々淋

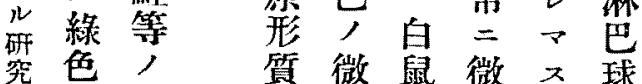

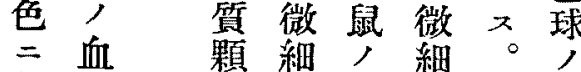
著液粞子血等人核

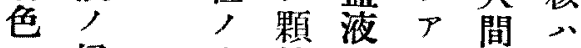
又好染粒, 可, 濃

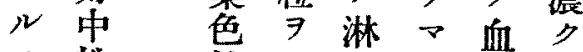
, 性性玉不菠晤 三恋公持球。二絮 デ暴動ッ, 犬八䇼 顆管物展核, 淋三

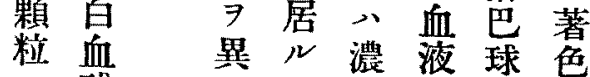

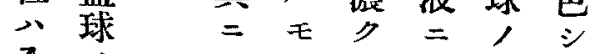
全人天暗八大丮

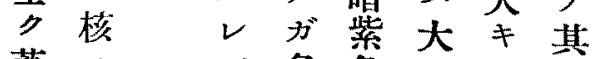

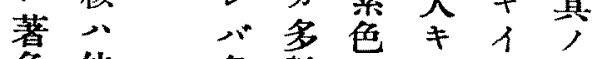
色他多數=夕平細

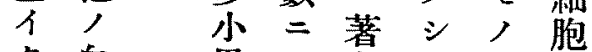

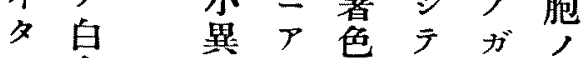

血产, 胞了胞

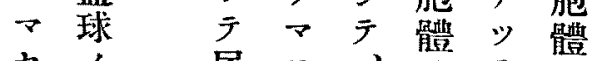

七, 居

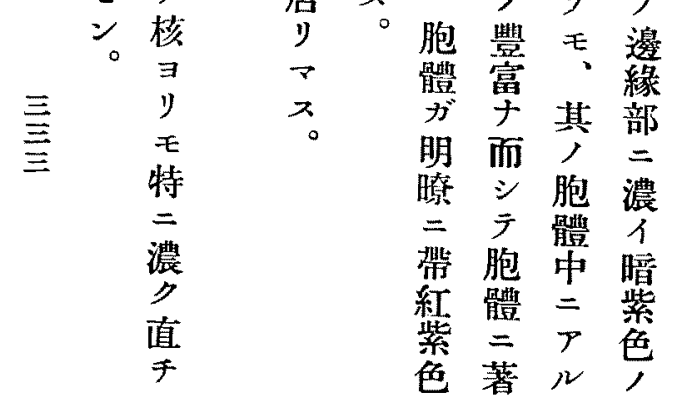

血大 $=$ 核在大行白

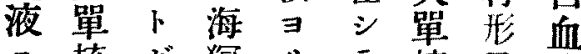

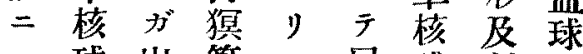
八球出等毛居球刺 大, 承, 力多, 敷以

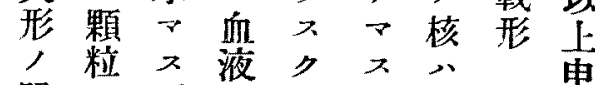

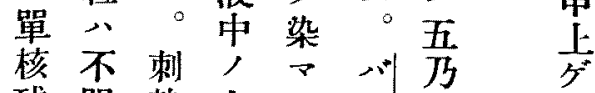
球明韩大可飞至名

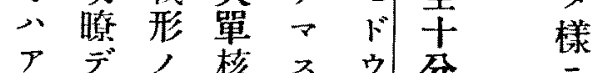

, 厂多球。民間 $\checkmark y$ 數毛病票

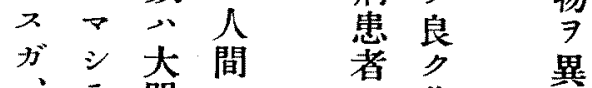

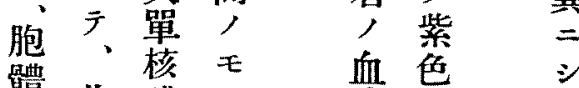
體此浗, 血色急 中, 中著华 著細略略, 覔占 荎胞占尚

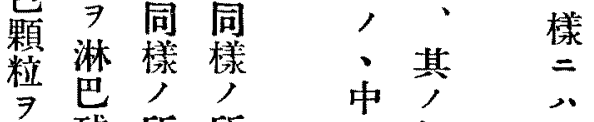
明球啠乺 = 細染 明尞思見 暸今罗

公鑑呈皇 證別言

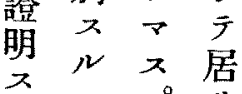

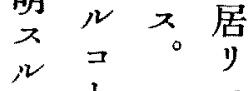

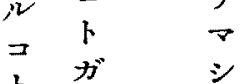

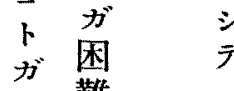

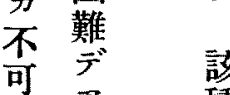
態多種热 此留角 此原多 顆 形 粒質水 數 明 , 暸 少 =

ナ 紅

イ味 モ $\checkmark \checkmark$ 胞雨 y ス。 $\checkmark$ 梦文ナ ス球艺粗 
白好肥慢染被血心家赤色該家結人顆大好家 血中腓性部檢小モ兔血产種鬼締間䊀， エ兔 病性白骨ガ血板, 球又細, 織間好至,

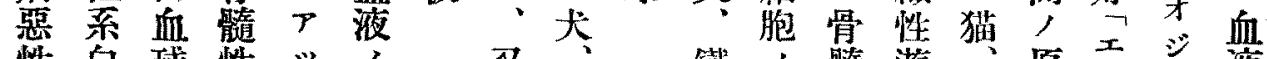

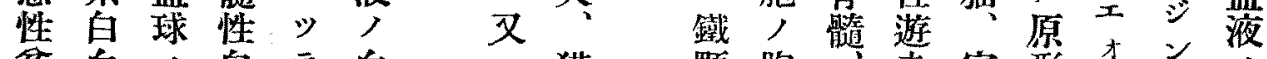
貧血, 白于血分猫顆胞走家形才ン゙,

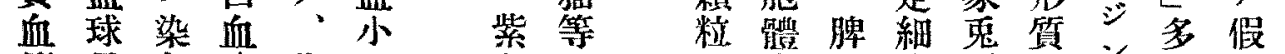
例母色病此板 , 細 所例 所 血 胞見, $\rightarrow$ 明 夜怂血穴膫 , 該健液, 二 血系常, 樣紫 球白人血三色 血 體 球 見三 球，著

前血居色

形少、

骨同南

髓 程

細 細

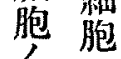

原

形 染

貿色

見

良翼

多

見 今

工

少,

带 デ

紅 $>$

紫

色 ?

顆 。

粒

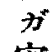

密

在

䒺

중

口猫

独年著

血 , 色

等 新

ザ

血混居

小

板

在 $N$

紡

モ

紡

居了,

錘可紫

形

、色

즐

7

\%

F

色

中 居

力

5

$\overrightarrow{\text { 方 }}$

偏

多

所

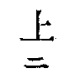

上

紫

色

稹

7

$\checkmark$

辛

持

\%

居

$\exists$ 中臟胞

持三度或海萌多菜性演 夕八肝 猽暸葉白

七染臟組息核血

夕色等織白紫白球才川

七顆;球鼠色血洫

人粒網、球

デ \牀

八フ 織

- y 内

其 $\nabla$ 皮

一七細

顆 ン胞

稤

$\rightarrow j$ 唯 肥

帶然大

褐 シ 七

暗・ル

紫召邑

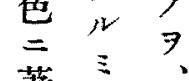

著其

色顆基

$\checkmark$ 粒

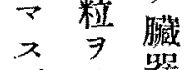

又。持器

持器

七塗

タ 標

羊

デ 染

”色

十著

多顆

姊色胞葉

妹方體核關

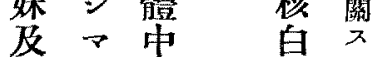

䱎

等市球究

好染原

こ 顆 裂

オ粒簡

シ $=$

白 明尞多

血 二 數

球青色暗

顆二紫

稙著色

染色尛

色原䊦

年居录

其 光

顆监

粒

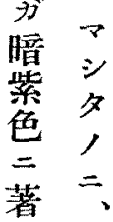

見

般

不

染 


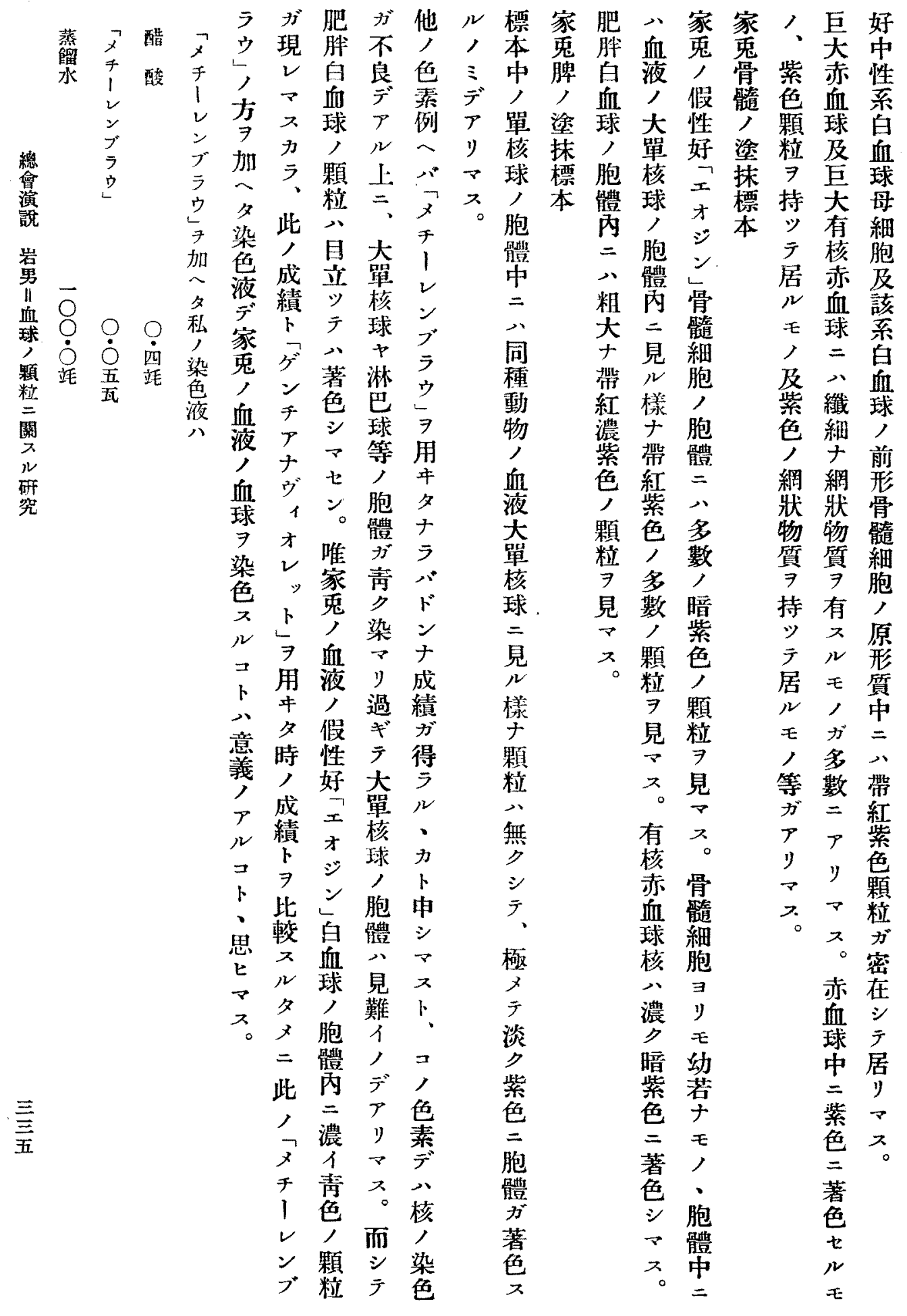


七血反心以速二其 $心 カ$ 私

球㮣本上度雨; 夕

モ容二反方 デ血結 丸其亦

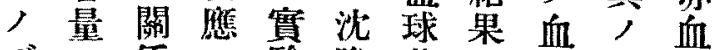

デ 係二驗 降共 八球結球

八血 $ア$ 影 $=$ 二 $=$ 沈果沈

大球 $ル$ 榔 $\exists マ$ 僬降血 $\exists$ 降

デ容コガリスク速獎御庈

フ量卜ナマ沈進ノ報㮣

リハガイシ降七置告,

マグ|明 デテ シ ル換ス唒

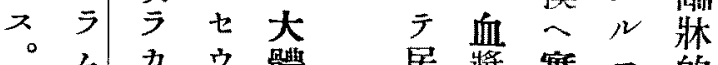

氏 居漿實 $コ$ 的

レ 氐トカ、血漿省

川二リ私, $、$ 行

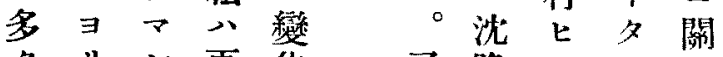

クリシ更化文降マシ

ノ測タ

人定。此本

今多以, 反

ノタ午問 庥

成 シ 順題,

績 マ $\ni \ni$ 僬

卜 三 追破速

一夕 У 究 二

致の

其御夕千

ル, 報シ心

處結告?影

デ果イシ 留

フ 多

）血 $シ$ ○

$\checkmark$ 球 $\checkmark$ 其

シ容 $九, 卜$

テ量。結ガ

血八果

球泌次力

容降师

量速 述 ?

蕉 心 シ

大七次

小ル通

浽当然

沈, 血 5

降デ球 バ

速 一 血

度小矢球

= デ 張ノ

定遲本戀
兩速シ 先

血度夕又立

球, ${ }^{\circ}=$

7 早

生

理 III

的 球

食 立正

監 二

水 邀

或 1

$\rightarrow$ IIII.

1) 球

共

5゙ =

토

此名

液 㳘

中降

入

レ邀嶈 テ

$\checkmark$ 个 少

而存 㕲

卜獎装》

雨中心研

In. デ

球

共之

殆レ

ン

同對

力 究

$\Rightarrow$ 亿

明名

5 シ

カ $\checkmark$ 郎

同對 ス タ

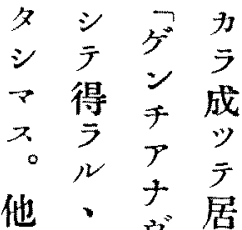

, 所 ヴ㔯

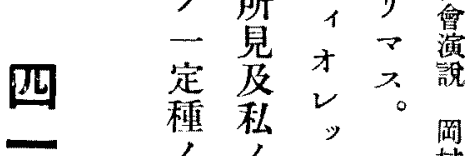

ノ人村

牙 集 揭 妿

IIII. 醋染染色 浩

球酸菠色落慗

流 加 デ染 本

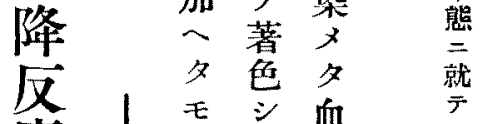

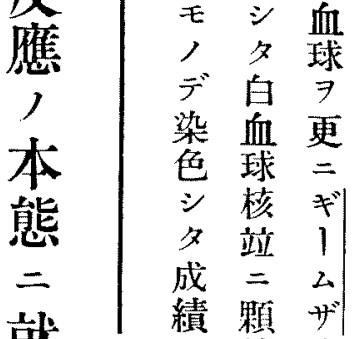

モ 粒 液

後, 力

$=$ 腄 $x$

報膨亿

告 現 グ

イ象り

等 ウ

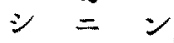

$\checkmark$ 就 ๆ

ス

後

日 仍

機素

篔 使

得 デ

广後

堽染

告色 
ヨ中有一 明蛋機定 $\exists$ 機獎

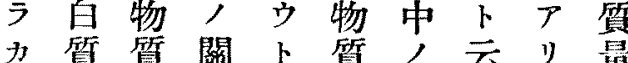
二八係思總 $メ ソ$

綿血 $\exists$ 化先溶 桷ル反液見ミ述質テ二留 演夕歪中出品, 量居思, 样

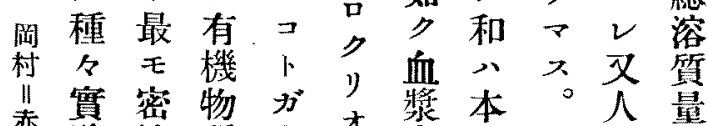

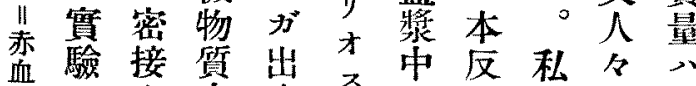
球 1 中承公, 㮣,

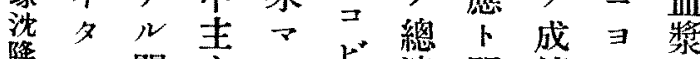
涺關子七寺溶關績り,

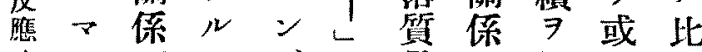
禾 ジモモ゙ =量ガ見八重

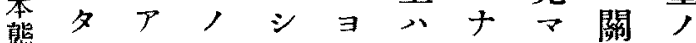
以少多少本イス保测 下上蛋 。無反度上定 順云白機應云矢 $\boldsymbol{~}$ $\exists$ 八質物 追 2 質何得りトッ 多脂, 等 $ル$ 血云 テク質 量關 $=$ 漿 御, 7 係卜, 或 報人糖 测 $カ ゙=$ 比公 告々質定アナ重何シ 申 $=$ デ シ y y 等 上 $\exists \rho$

ゲリリ

$\checkmark$ 研 $\rightarrow$

ス。等

ᄂ 而

$\bar{y} \quad$

居テ

是

又, 等

内

依蚠

狊

皇

立站

是 $=$

等 脂

, 質

點 就 $\checkmark \checkmark \checkmark$ 沈關

艺不降係一

多二。庈隽打

其 無

機

結 物

果質

無

機 本

物反

質盟 卜

本，

反關

應 保

\& $\Rightarrow$

間 5

$=$ 力

$\mp=$
明
哕ナ考

何 1 r

等 種

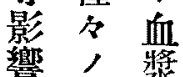

アガ比

リ重

$\checkmark$ y

七 $又$ 本

ン 万

ガ 應

又關

v係 $=$

心 ガ 關 $\rightarrow$ 說,

換大蔳大
化 次示 $モ$ 綪 赤 子球

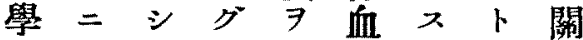
的血于口示球 。血係 卛獎 居 ビシ 數 郎漿 化、りンテ一于, ア 血 $\checkmark$ 含居人血比り 清 。含りモ球 $\exists 、$ 二。有 マグ容同ス 就反量入量量。 テ之減。ビバ二次

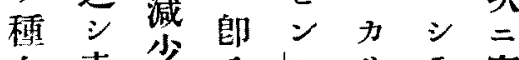
夕赤少子含りテ實 其血亏多含 方゙沈驗 球居少量本降的 华, 居, 量反速二 學大 $、$ 例赤應度沈 的小又外血, 降 琣八又心球遲比速 二何特 $>$, 速䡆進

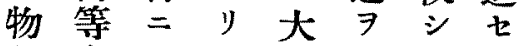
理本 $\neg 、$ 左 $\checkmark ル$ 學反右

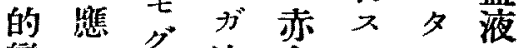
變, 沙血 $r=$ 卜 化遲 ビ降球唯沈逰 $\exists$ 速 檢卜乞度站, 速七 查關含完二原進 抙有進 $\neg$ 因七血

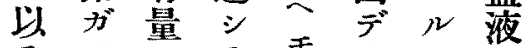

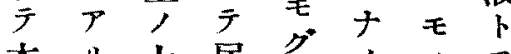
本り大居グイ, 反 小片品 㮣七 ト モ トン本, 亡゙ガ張血 ノデ反 ゙合明り球 關 シ應八有亏僬卜 係夕”一量力延血 尹 ○逯般卜卜漿 講 速二本ナル 究尔赤反 亿 ，血應 $\checkmark$, 離 夕 $\exists$ 球 シ 》 八, 八比次 $\checkmark$ シ

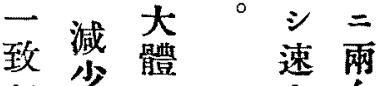
方硫少 具威致液 績 氺成血 


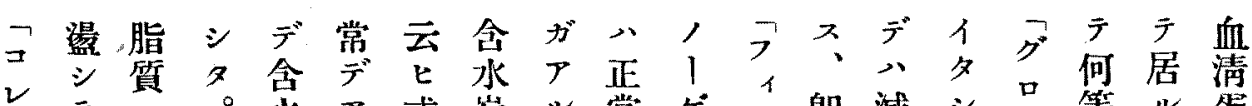

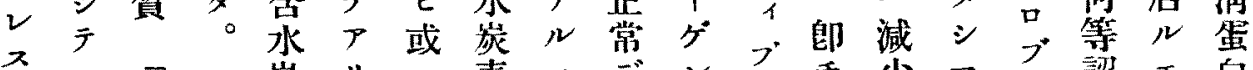

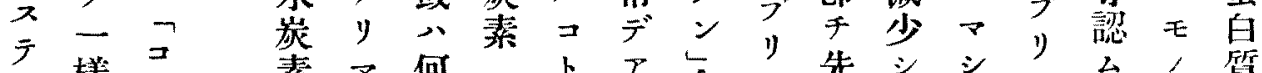

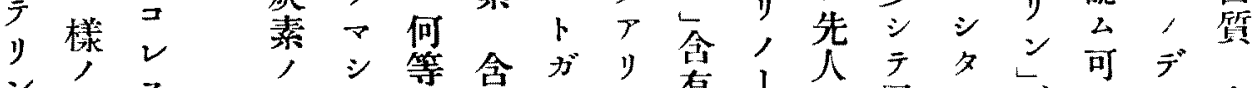

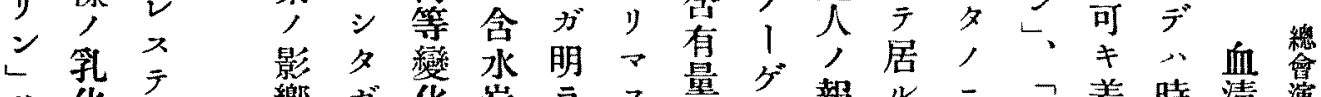

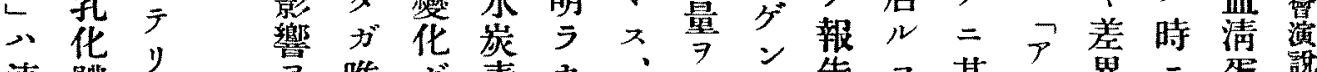

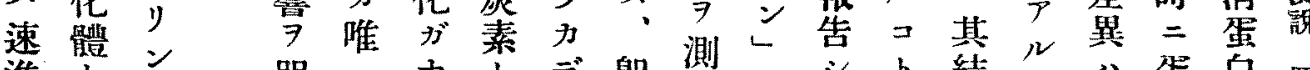

進

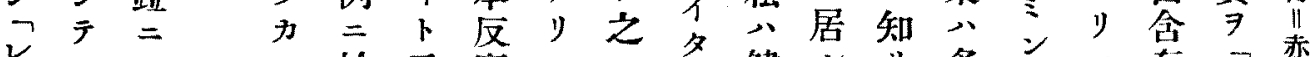

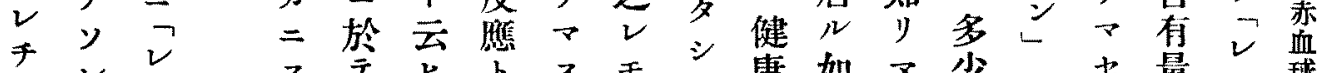

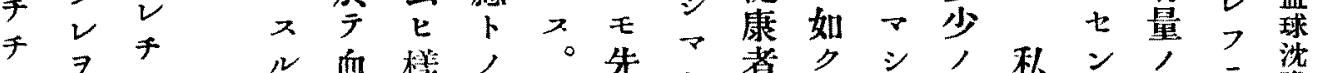

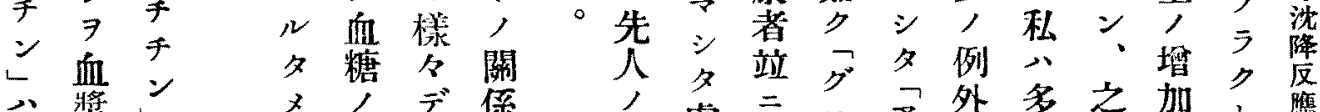

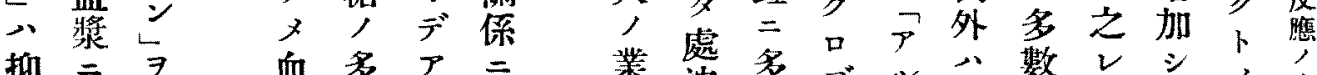

抑二 $=$ 血多

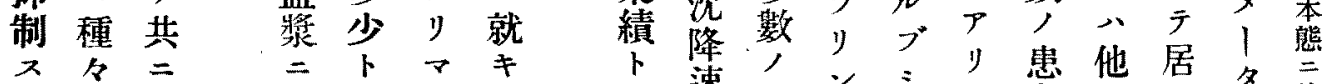

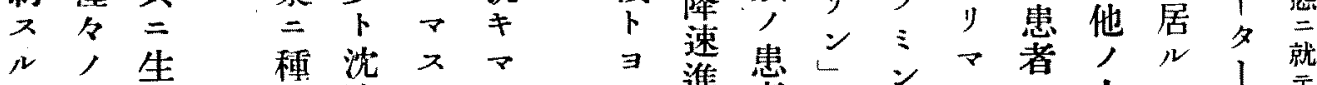

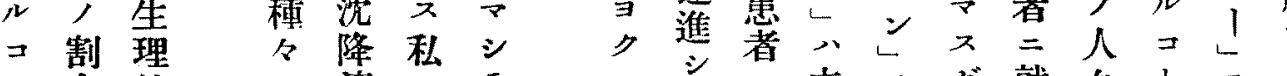

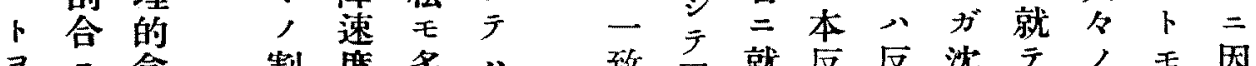

$\exists$ 食制度多 $、$ 致居就反沈

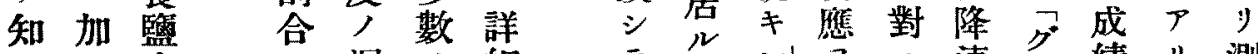

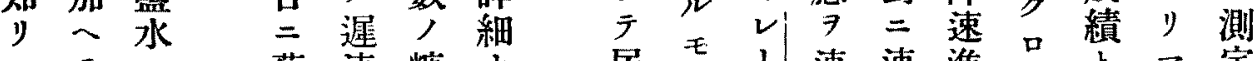

$\checkmark$ マ $=$ 葡速糖 ナ居, l速速進 ブ

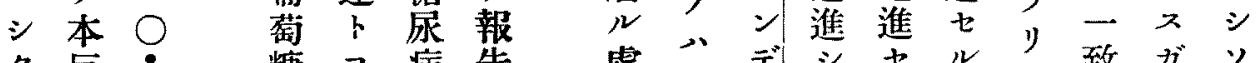

夕反立糖 $ヨ$ 病告處

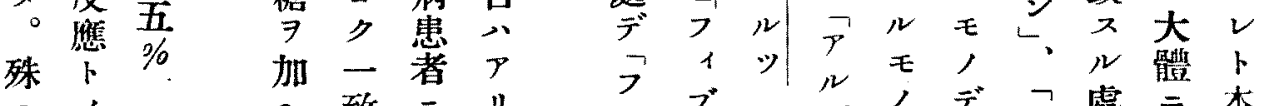

二,

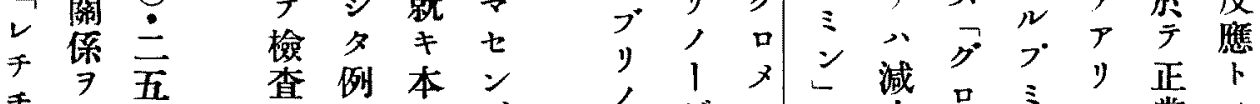

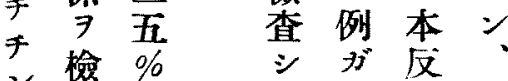

ン檢 $\%$ 香

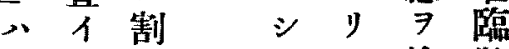

著夕二タ $>$ 檢牀

意 シ 入 處 シ 查贞

$=マ \vee$ 何夕傏

抑 シ 天等依夕尿

制 タ長影 シ シ 病

入。時嵬テマ,

其間学私 シ 時

作結 $=>$ 分或

用果 丕

分 明 y

$>\overline{\text { 强 }}$

1) 分 多

り更 =

$\rightarrow$ 殆 速

七 $=$ 進

$\checkmark$ 二振

ン進ドス

デシ正

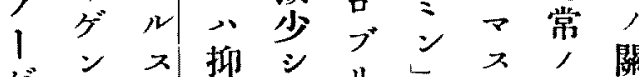

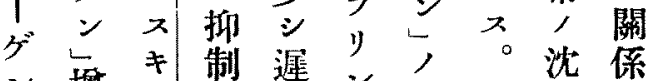

ン增

下量雨ルセ含合速研

本テ氏 コル有寻度究

反照居法 $尹$, 增在有

卜 $=$ 認 $=$ 加氏 $x=$

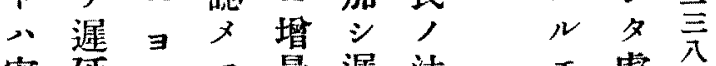

密延りマ量遲法 モ處

接七

ナルフタテ势斗降

ルモ1。居ルリ比速

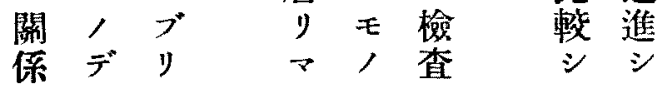




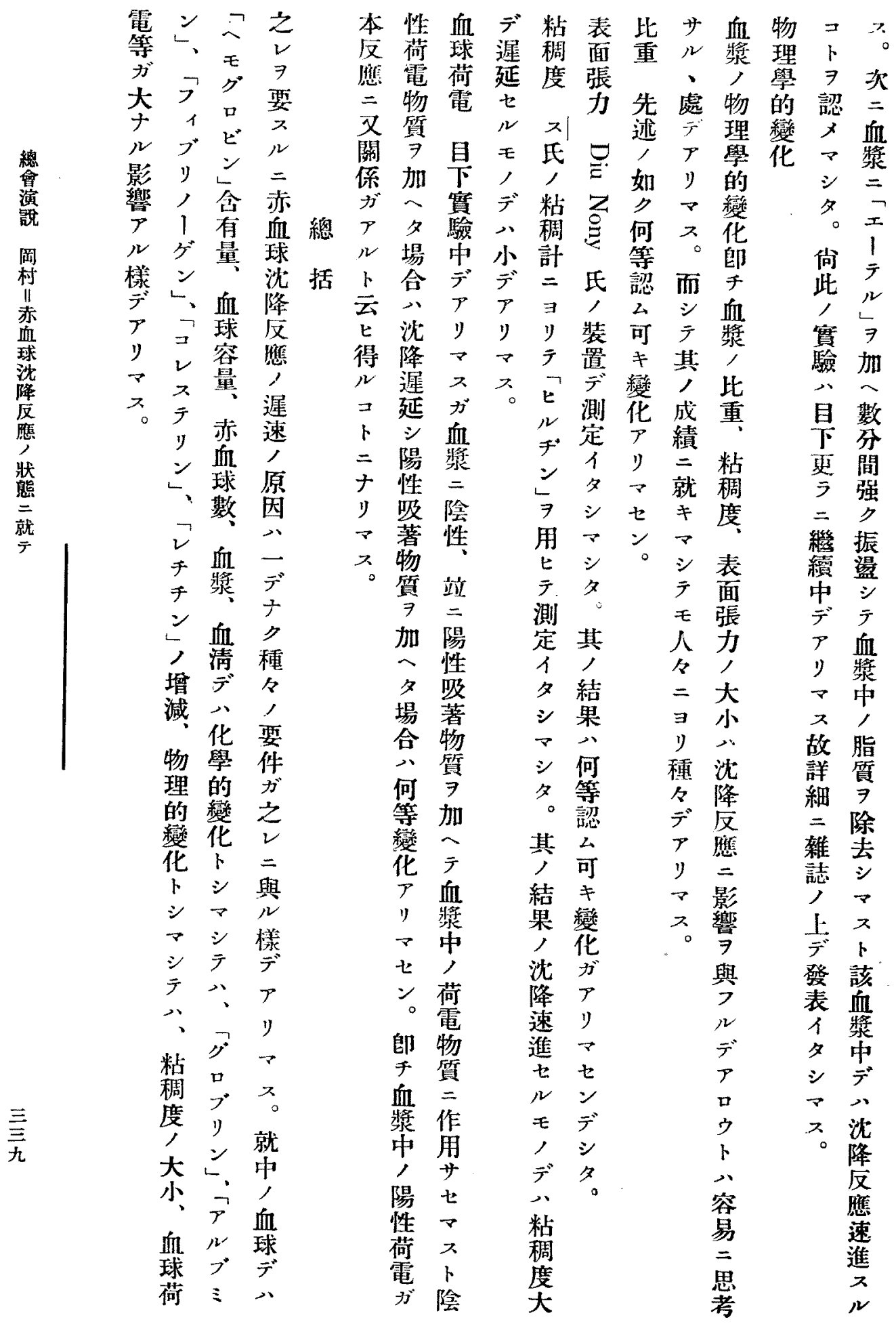




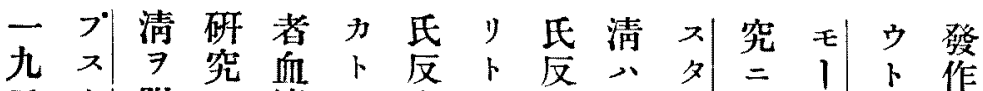

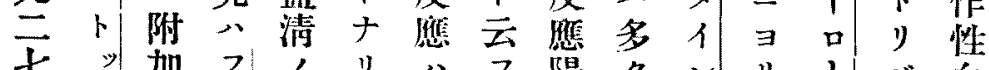

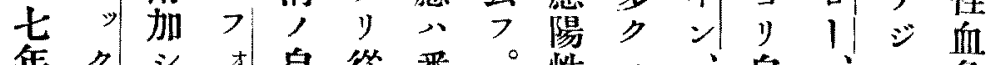

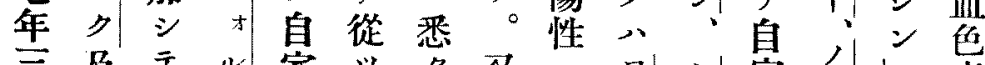

夏范

教 可疫 マ血此陽田

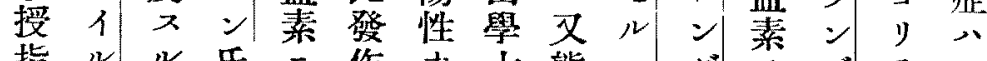

指 $ル$ 氏

導時抗關性り公谷二。存入起九

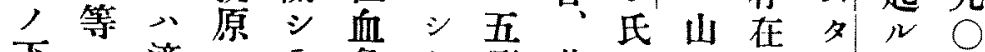

下 適示色上例并反田公们四

二宣關入素云, 占應博令

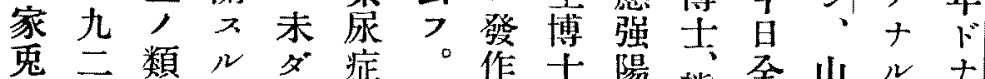

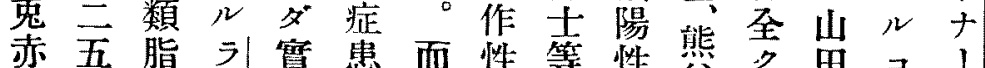

血年肪

球家掯 10 的血亏色研呈博疑基初

酒龟藏對

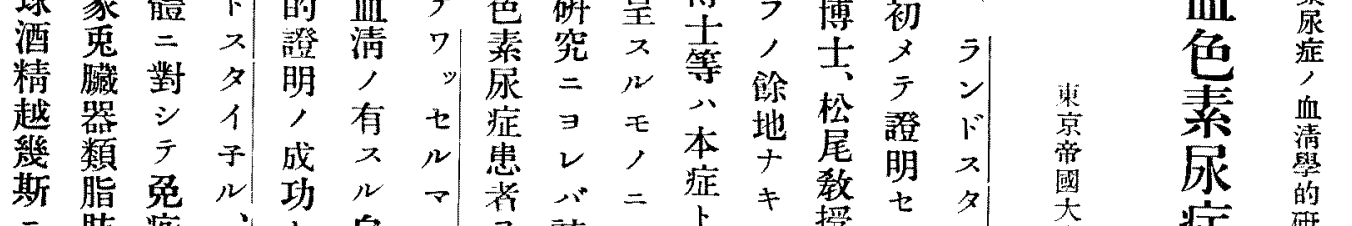

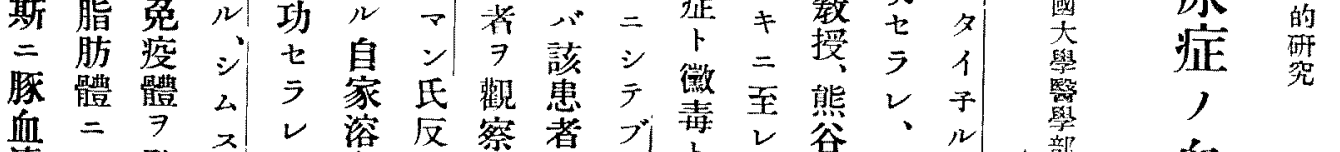

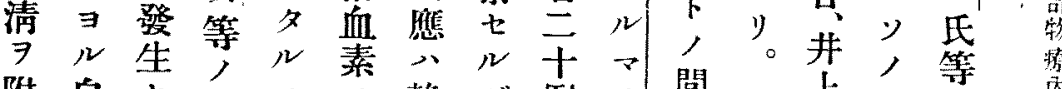

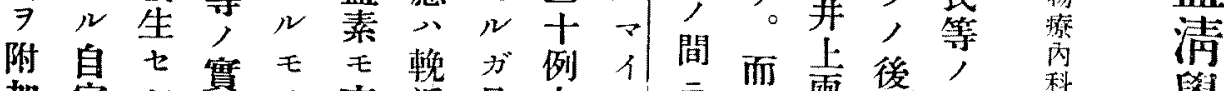

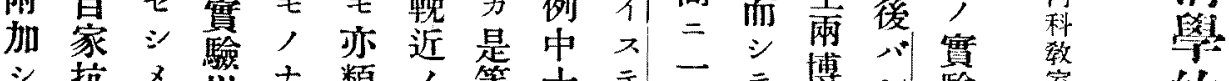

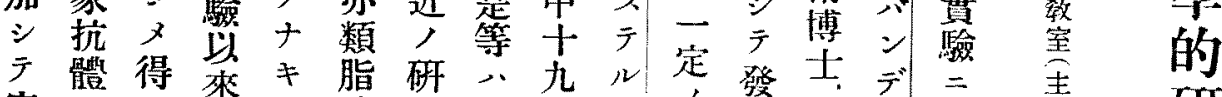

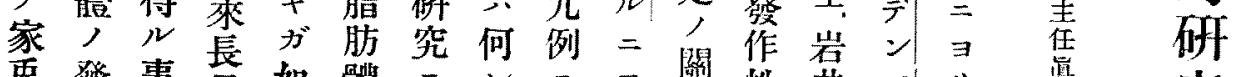

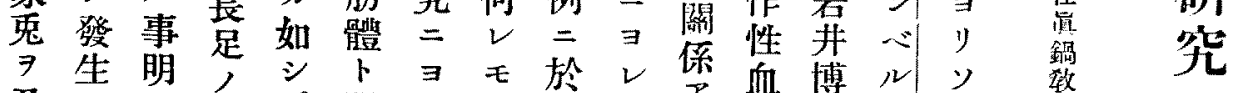

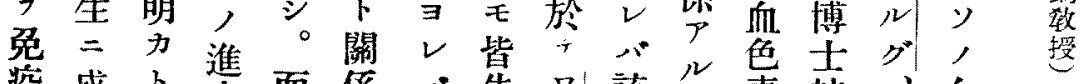

疫成占步而篗

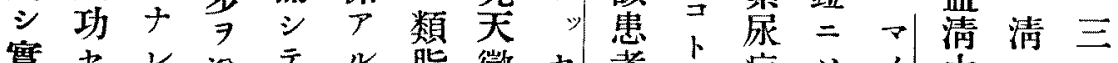

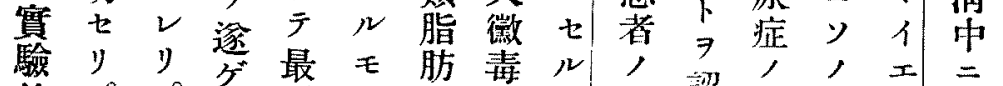

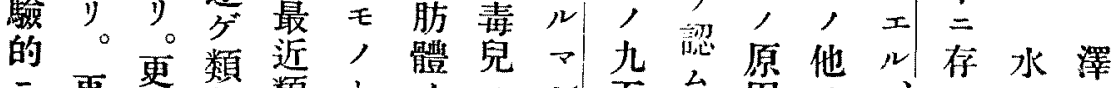

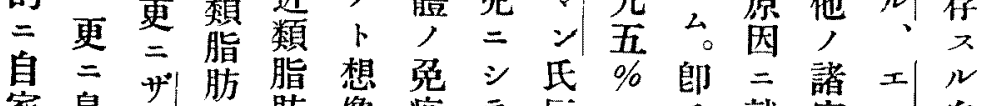

家鳥, 體肪像疫于反一千就家么自

溶并 ク| 體體七质

血紊雄

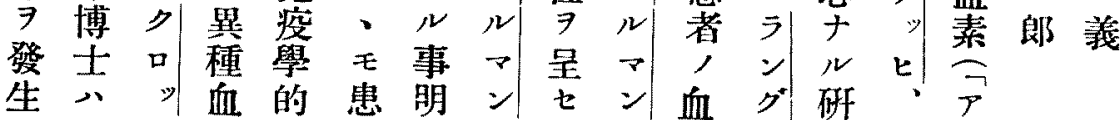




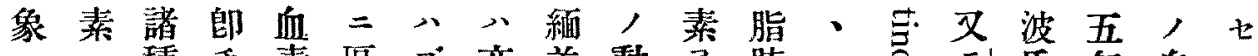

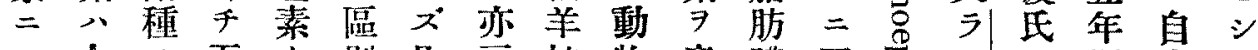
ヨ人, 吾ナ別凡言抗物產體至焉ン

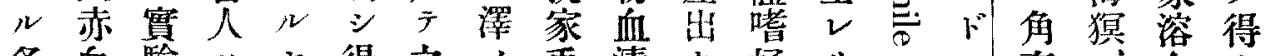
各血驗、ヤ得之, 鬼清七好り。元南血夕 總屡球 $尹$ 發 演赤精 珫血越タ血 $ッ$ 然肪

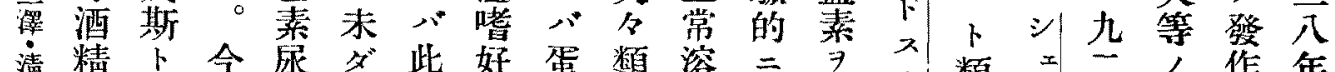

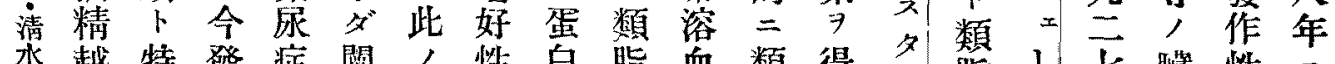
水越特發症閙, 性白脂血類得名脂 1 七瀻性二

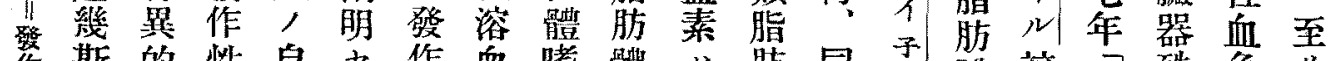

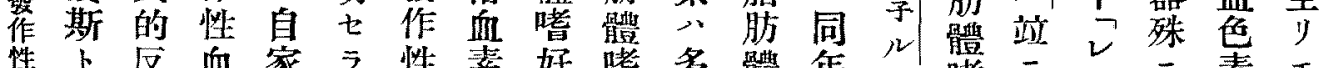

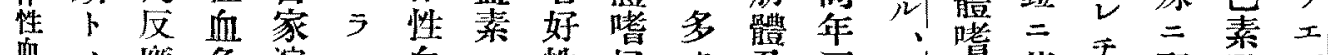

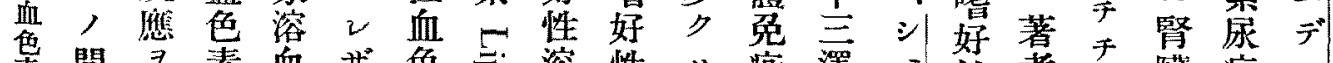
素間 症 特七症, 所㞗 亏 表

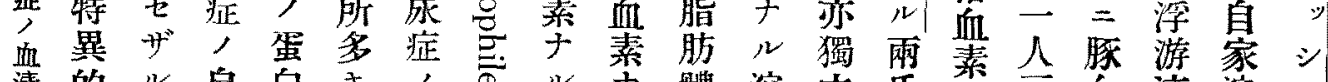
清的 自白 7 向

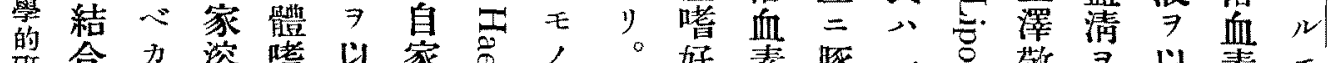
研合力溶嘹以家艿, 究反亏血好三溶马十然性 $尹$ 血九总義附亏亦

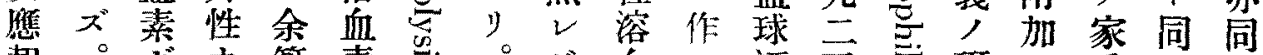

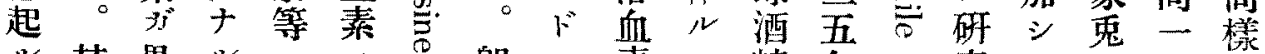

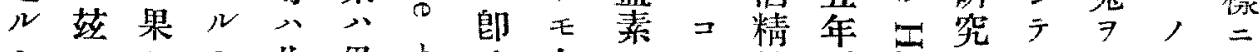

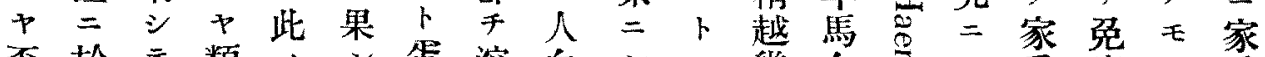

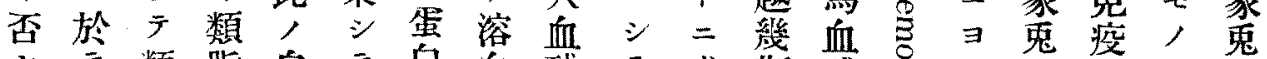

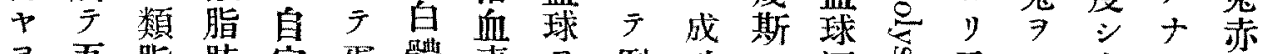
$\exists$ 吾脂肪家蛋體素 $尹$ 例功 $=$ 酒怘免免自亏血

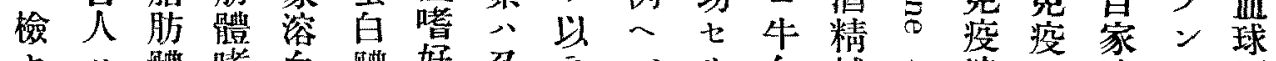

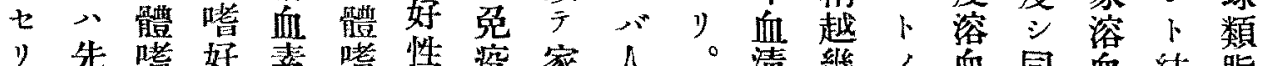
》。先嗜好素嗜性疫家人。清幾, 血同血結脂

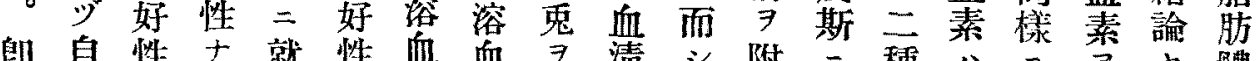
手家溶 $ッ$ 溶素王 $尹$ 清 シ 附二種

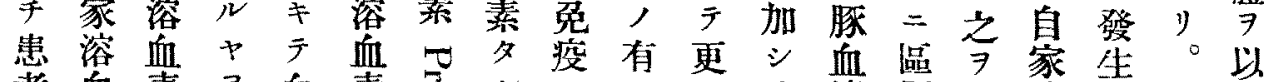
者血素 $尹$ 血素导 血素決清

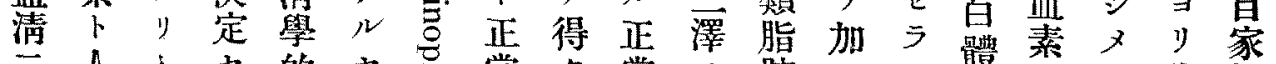

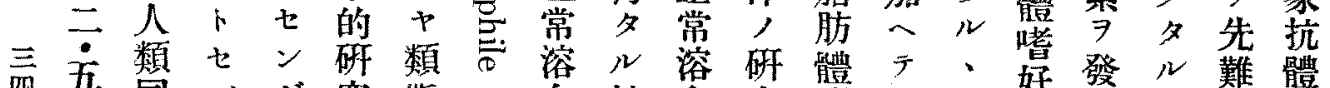

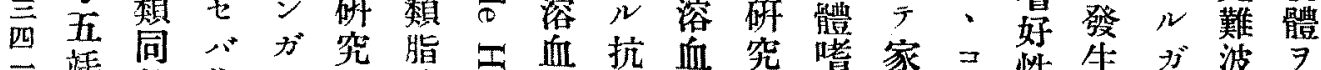

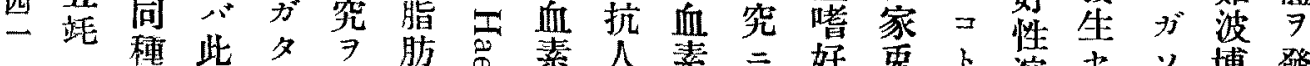

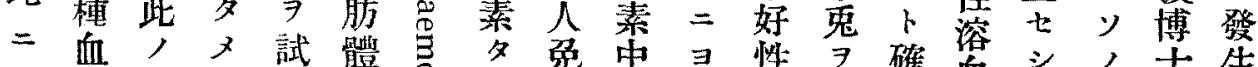
人球自次三嗜五, 免中

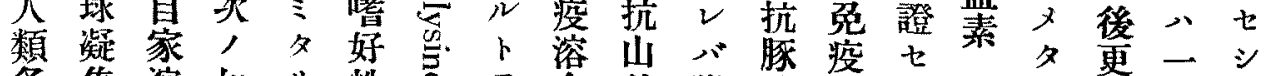

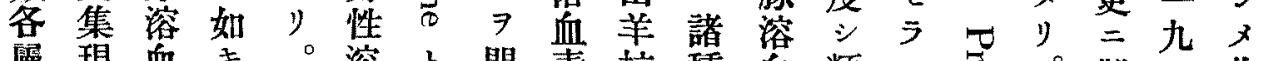

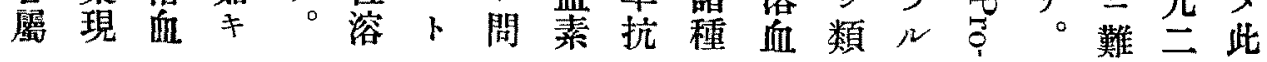


第一表 赤血球酒精越幾斯二ヨル患者加

藤血满／自家溶血素結合試驗

\begin{tabular}{|c|c|c|c|c|c|c|}
\hline \multirow{3}{*}{ 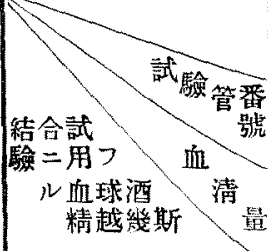 } & & 家 & 溶 & 血 & \multicolumn{2}{|l|}{ 䫁 } \\
\hline & 1 & 2 & 3 & $t$ & 5 & 龂昭 \\
\hline & 1.0靖 & 0.5 & 0.25 & 0.125 & 0.0685 & 0 \\
\hline & \multicolumn{2}{|r|}{ 結 } & 合 & \multicolumn{2}{|c|}{ 前 } & \\
\hline \multirow{2}{*}{ 對炤 (烹者血清) } & 世 & tt & + & \pm & - & - \\
\hline & \multicolumn{2}{|r|}{ 結 } & 合 & \multicolumn{2}{|c|}{ 淩 } & \\
\hline $\mathrm{O}$ 屩血球酒精 $\mathrm{X}$ & - & - & - & - & - & - \\
\hline $\mathrm{A}$ 屬血球酒精 $\mathrm{X}$ & - & - & - & - & - & - \\
\hline $\mathrm{B}$ 㣶血球酒精 $\mathrm{X}$ & - & - & - & - & - & - \\
\hline $\mathrm{AB}$ 屬血球酒精 $\mathrm{X}$ & - & - & - & - & - & - \\
\hline 鼠血球酒精X & $H$ & H & + & \pm & - & - \\
\hline 牛血球酒 精 $\mathrm{X}$ & $H$ & $H$ & + & \pm & - & - \\
\hline
\end{tabular}

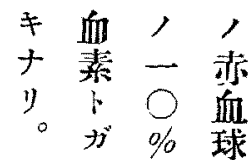

次 互浮 三

デ=游市

此 結 液

, 合三竓畣

赤 洞

血. $\leadsto \Rightarrow$ 相

球 $=$ 加當覃

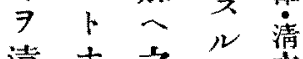

遠ナ之酒水

岕”゙更精愽

㳮此三越作

シ, - 畓 血

于自時斯急

y家間花敉

, 溶椧 蒸症

上血却發

澄素七 韵

隼游”。邓學

捨離例夕槩

$\bar{y} \approx \wedge \mu$

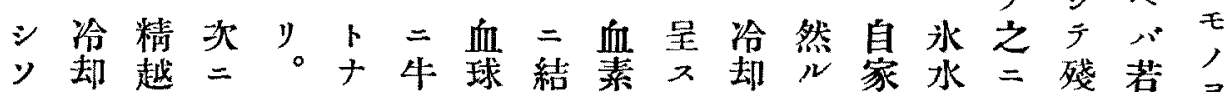

, シ幾患夕馬酒合 $ハ ル ス$ 溶中補存

濾次斯者從赤精ス人 $ス ル$ 患血二體 浾混

液 デ, 血 $ッ$ 血越 2 類卜時者素冷卜患血

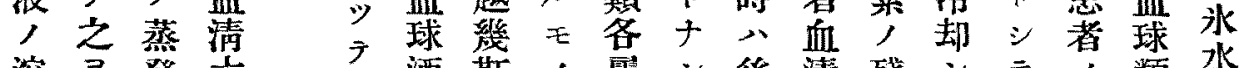

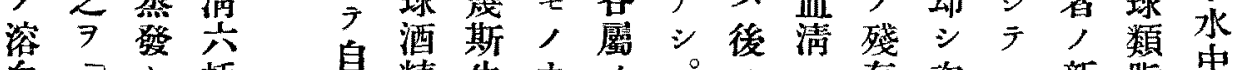

血 $\urcorner$ 站家精牛+人, $=$ 二存次一新脂中

僧 $>シ=$ 家越血ル赤郎加人邓デ $\bigcirc$ 鮮肪

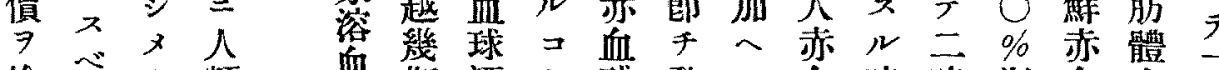

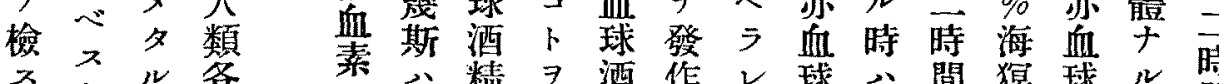

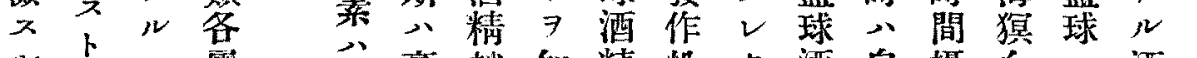

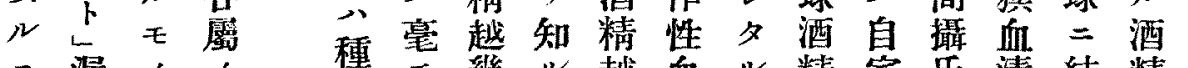

二漏,

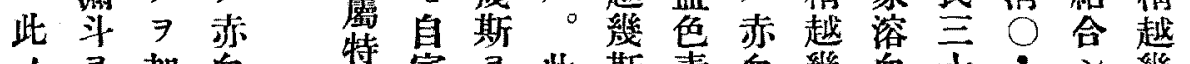

, 7 加血 特家 7 此斯素血幾血十

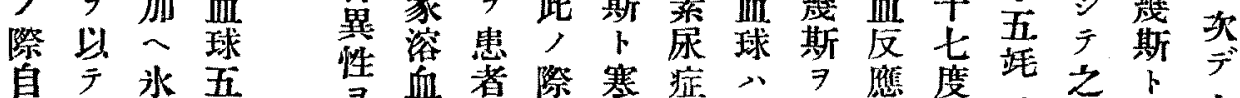

自水五

家水 水距

溶室中二

血 中 $=$ 相

素 二テ當

$\therefore \bar{\gamma}$ 二

何 濾 時 $N$

乙過間酒

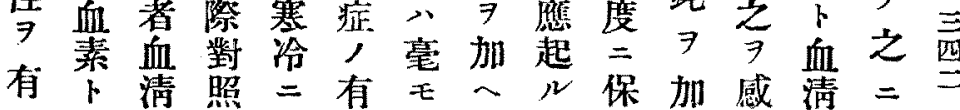

又結 $=ト$ 於又溶前 $モ \% へ$ 作宅患

$ル$ 合加ジル血述，時三セ，者

モ $又$ 加

, 27 馬異家應如》若分么家血

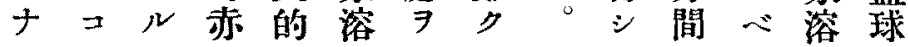




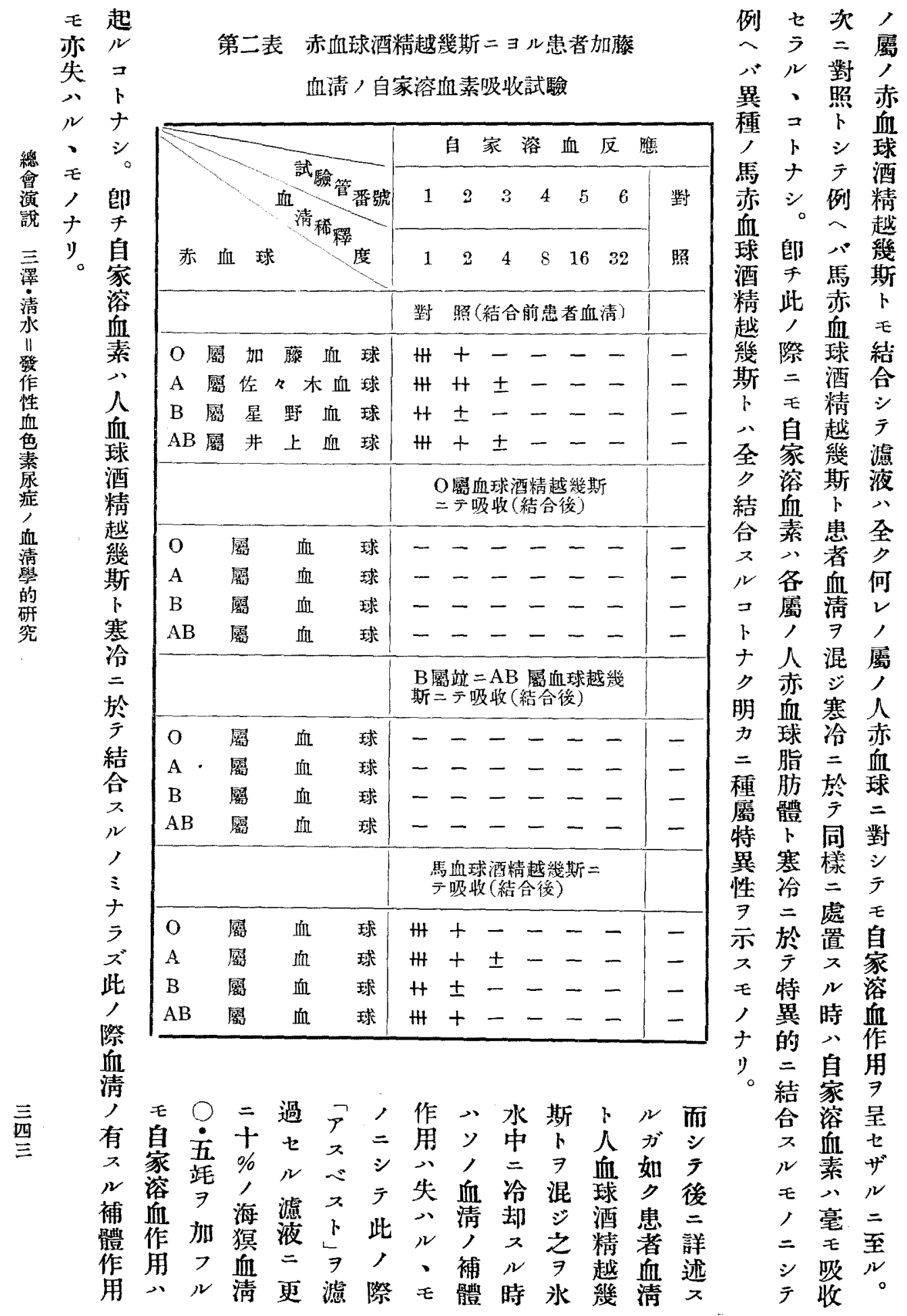


牛年補 $又$ 清實

心發體 ン二驗

臟作結氏就 $\exists$

酒性合反 $\neq$ 行

精血反否各七

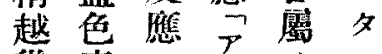

幾素心

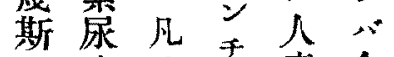

䇥 方赤今

補, 㓌攵血y

體血性球，

三清 $=$ 酒成

千三終 $心$ 精績

單就 2 兵越 7

位 $\neq$ y單幾述

$\Rightarrow$ 同卜位斯 -

結樣云,

合了〉補原

ス䨘。體勇

$ル$ 驗三严

二ヨ澤結 ぞ

拘試モ合年

今亦 $又$ 秀

ズ夕風卡夫

人り 二 E シ博

類、自, テ士

各即家ナ補公

屬 $千$ 溶 $v$ 體 此

万該血に゙結

赤患素 モ 合點

血者少人反二

球血人赫應泩

酒清赤血 $\Rightarrow$ 意

精一血球試七

越 7 球酒 三 ラ

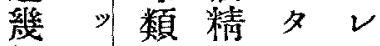

斯七脂越り一

$\checkmark, N$ 肪幾。例

八 $、$ 體 斯 而

寒

泠氏，亏亏作

二反關 学該性

於應係㫣血

テ $尹$ テ者色

モフ顧 ゲ血素

三‡慮亡清泶

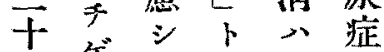

七グース吅患

度し九ル》著

二夕三時七，

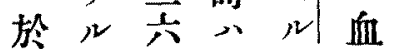

第三表 人赤血球酒精越幾斯 $=ヨ ル$ 患者加 藤血清，服收試驗

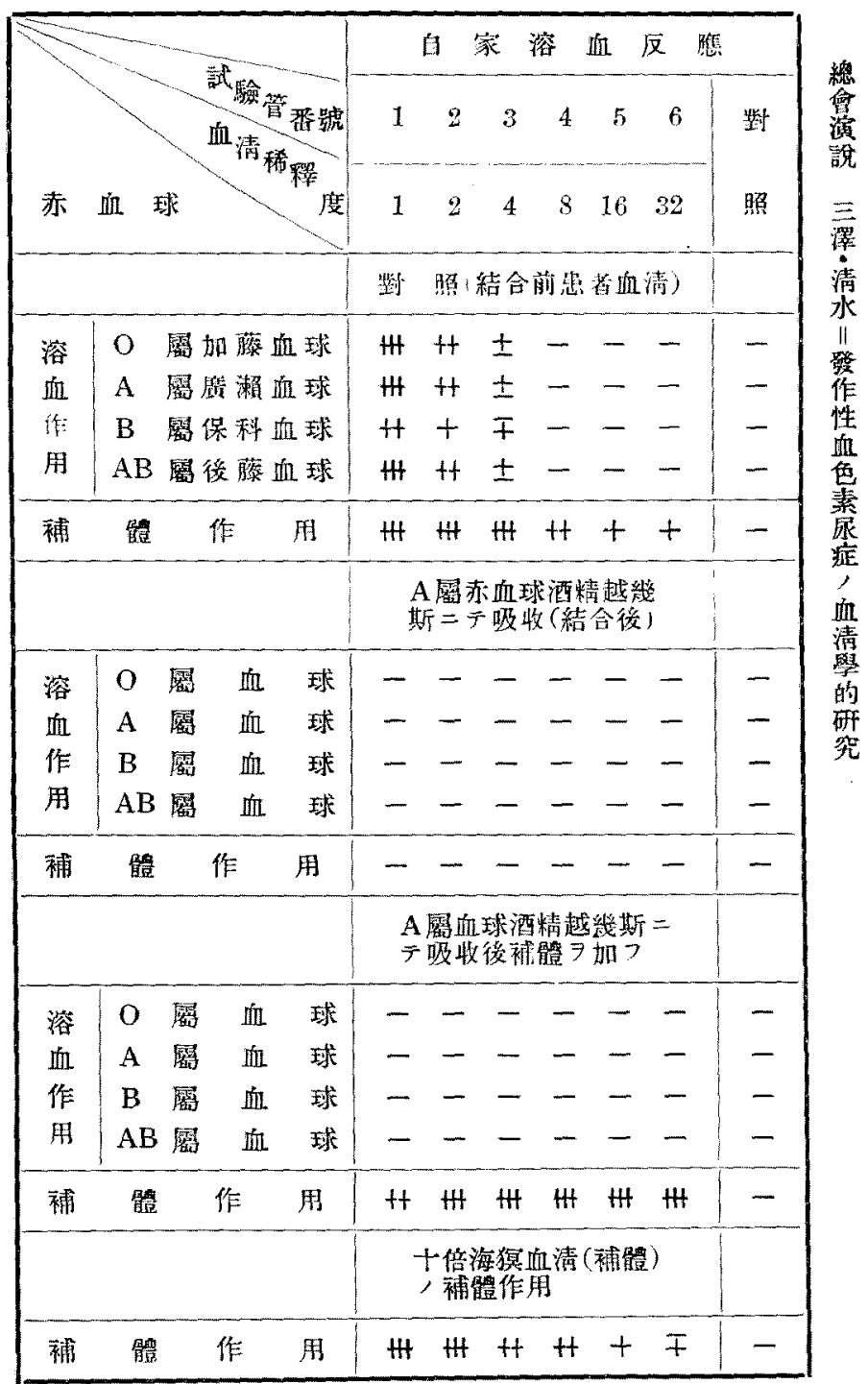

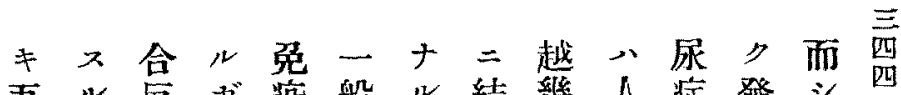

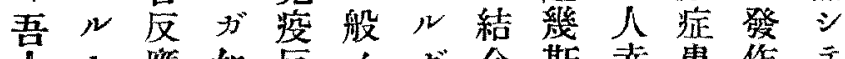

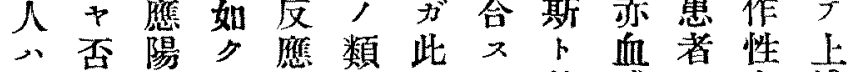
二

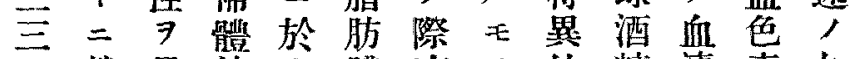
就呈結唱豊亦, 的精清素如 
者ソ二斯テ卜全川之於, 越ラ 7 際以八

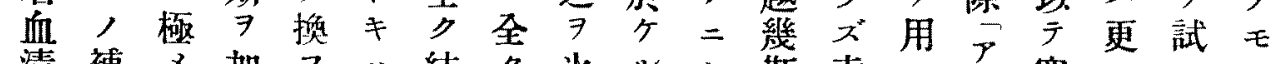
清補 メ加フ 結夕水 $ル$ シ 斯赤 $ン$ 寒 中體テへル通合陰水がラタ血タチ洽稿タ覀

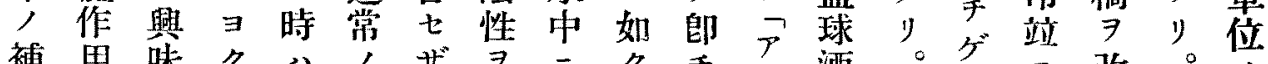

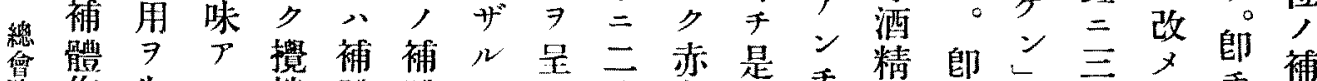

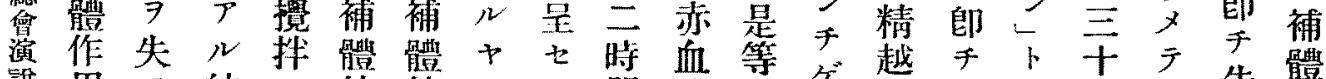

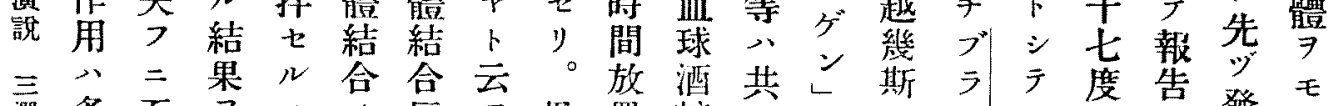

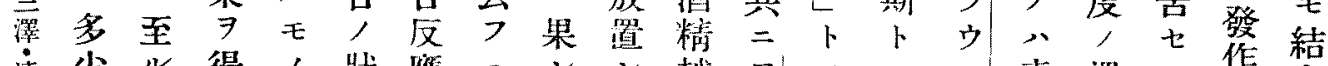

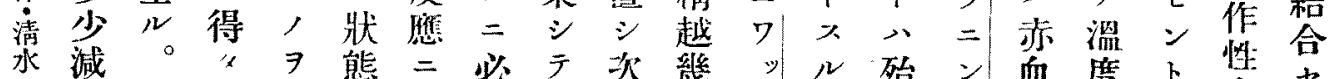

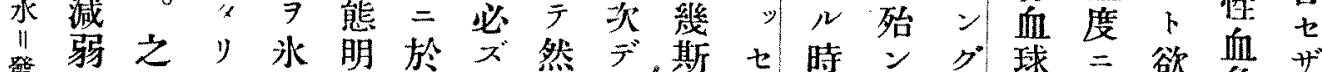
於 性

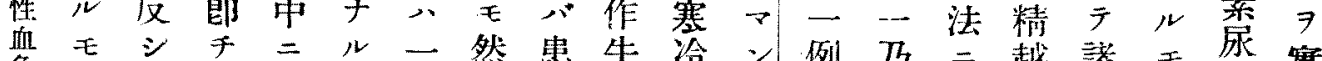

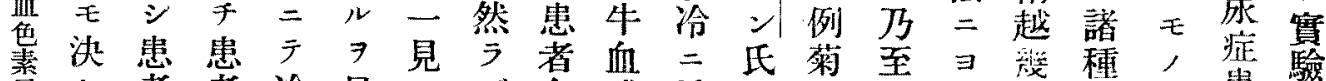

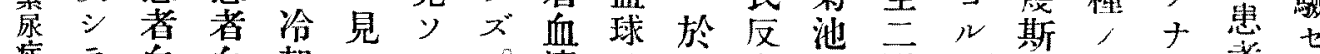

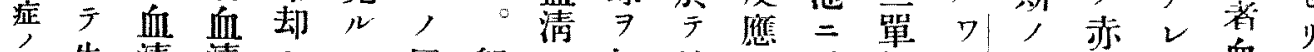
血失清清シ心゙反即入加結公於位》溶血だ血 清

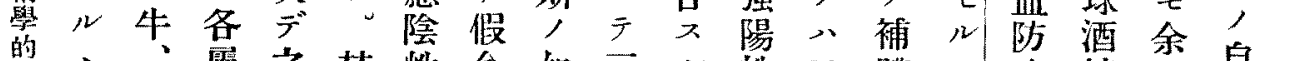

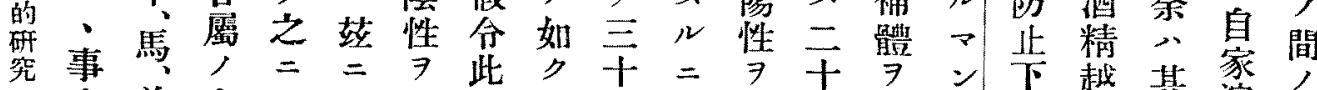

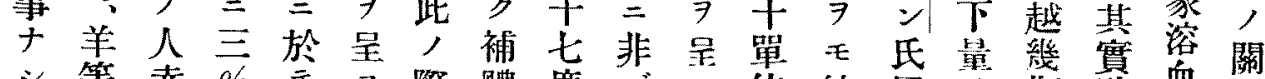

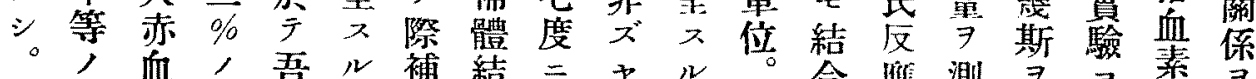

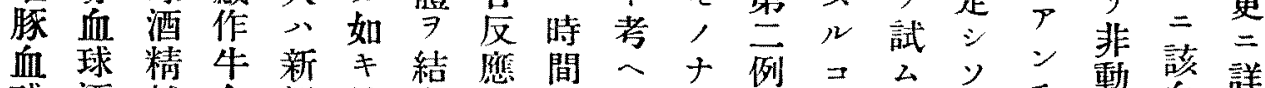
血球精牛新 $\neq$ 結應間人十㤠

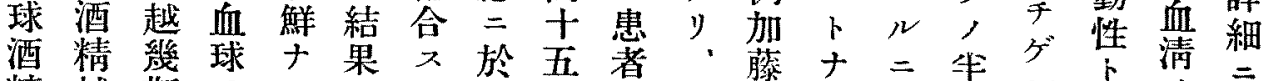

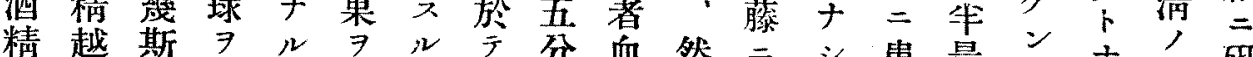
越幾策加患得卜陰間清然

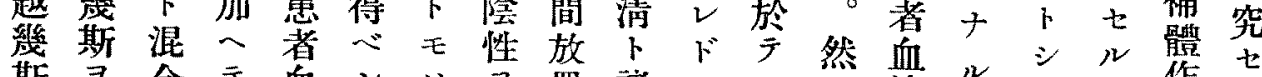
斯 $\exists$ 合

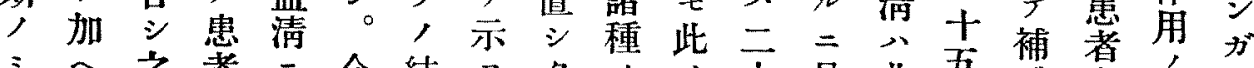

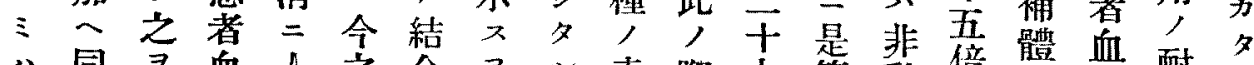

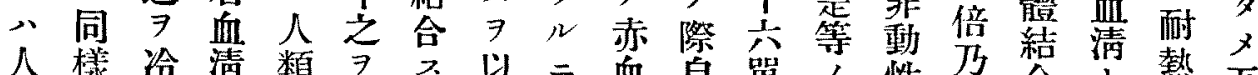

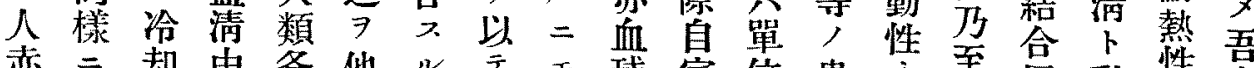

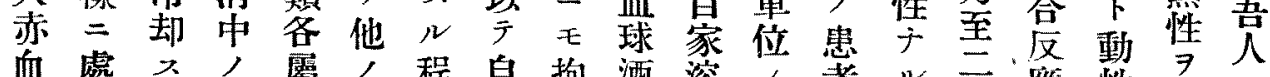

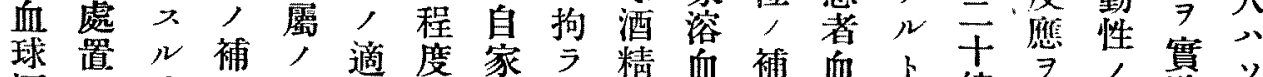

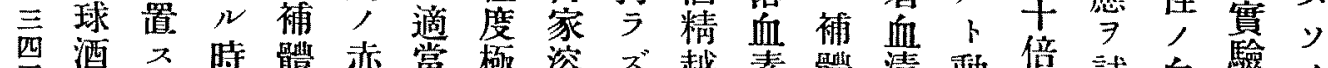
西酒 ス 時體赫當極溶 ズ越素體清動倍試血驗，

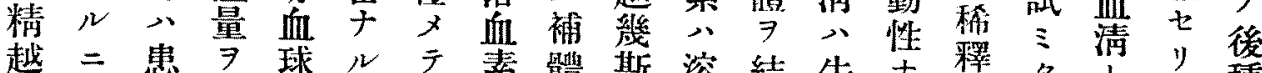

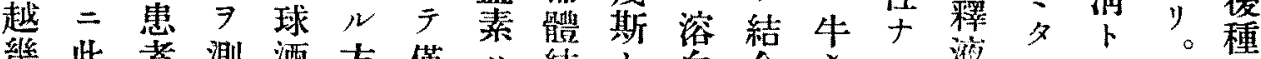
幾此者測酒方僅 $、$ 結 $卜$ 血合心 淮り, y多

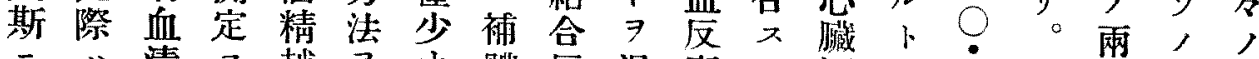

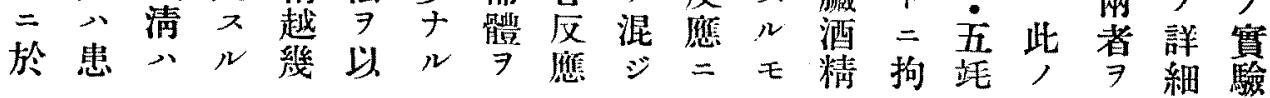




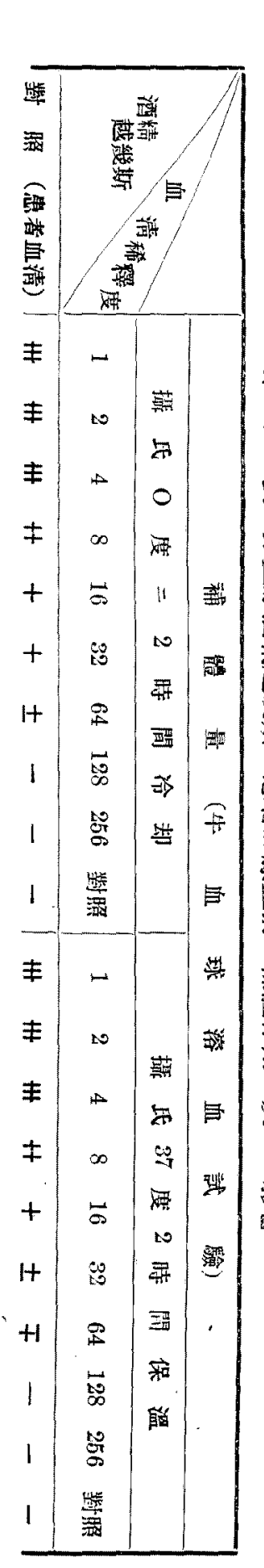

球斯酒 又郎卜儿反患シナ豚血ケ 酒 $\exists$ 精 精加越ド之赤卜强血ル'血中 越一幾 $モ \exists$ 血 + 陽清所 + 球二如

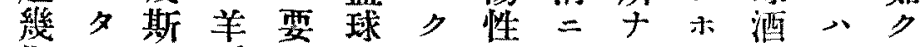
斯 $\sim \Rightarrow$ 入酒心゙ナ牛么此精人患

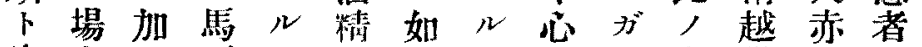
塞合人? = 越何 7 藏y人幾血血演 冷二夕牛患幾 1 以酒, 赤斯球清鿁

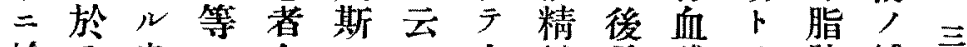

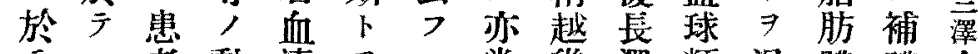

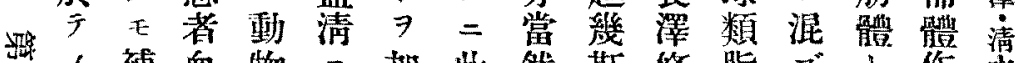

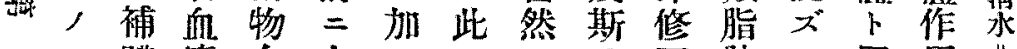

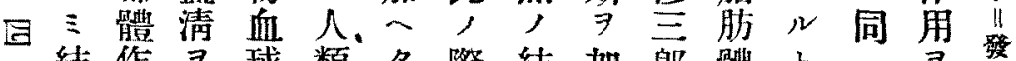
結作 $\exists$ 球 類夕際結加郎體卜—

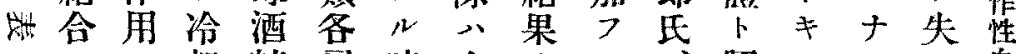

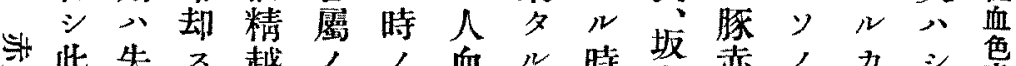

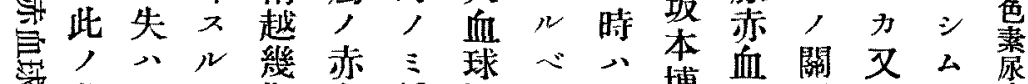
祭 同、ト=球體精。其士類人極 $モ$ ， 時コナヨ酒作越次, ウ脂赤

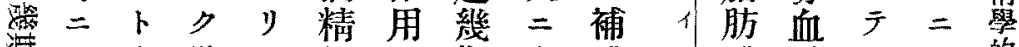
鸽りナ最テ越, 斯上體テ體球近シ的 高 血。寻此斯失加分用又, 精; -

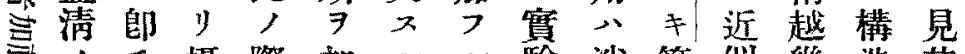

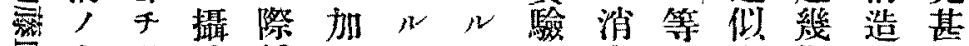
管有發氏補 烈入作三體之見補於 性十作 $\exists$ 唱

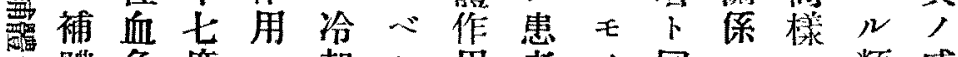
商體色度 $心$ 却 $シ$ 用省, 同二三類威 当作素, 失又。血二樣ア補脂 7

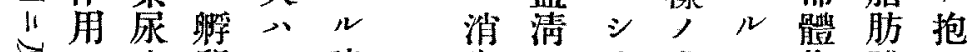
症卯儿時失年方成二作體力

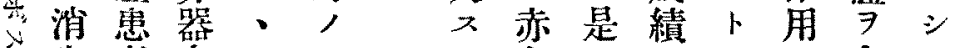

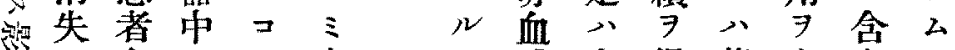

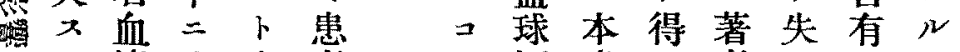
ル清テナ著占酒患亏者心ス无 モ, 行シ。血 ナ精著レ, シル三

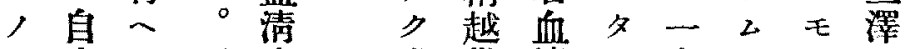
ナ家心而中唯幾清り人ル,

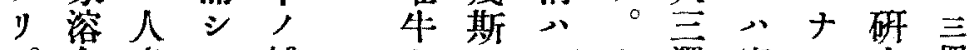
血赤厅補心叫ナ澤寧 素血此體藏、 $\ni$ 水, 口八゙= 分球, 作酒混七對初當患 人酒際用精ジル照 然者レ

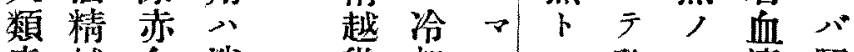

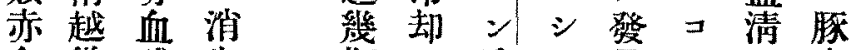

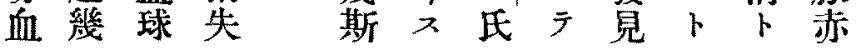




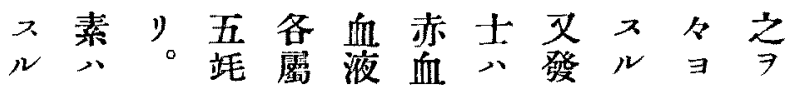

時寒師 $\exists$, 型球患作 $モ$ 夕要

八冷子加新特二者性, 結

自二發入鮮異八血血ナ合ル

家於作之人性弱清色儿ス二

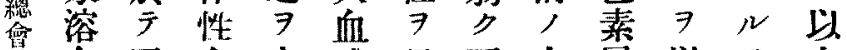

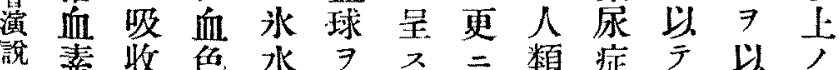
$=\cdots$ 素中以 $⿻ \mathrm{O} \alpha \beta$ 各, 發亏諸

㴗吸

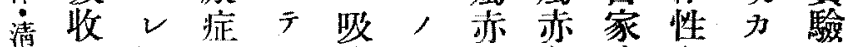

水七同患三收十血血溶血二,

紧 5 時者時試y球球血色種成

䧲 $\sim=$ 血間驗 $卜=二$ 素素屬績

性、患清冷 7 報 、對 $カ$ 尿特 $\ni$

血 口者二却試告溶

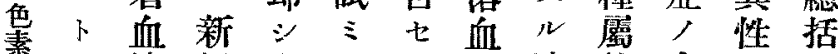

湬ナ清鮮直夕亏作溶特自 $习$ 又

瘷 $\neq$, $千$ 千 y, 用血異家有心

, 補ル二。。最作性溶入二

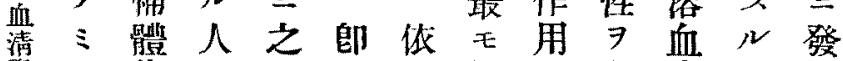

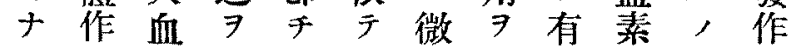

亏用球遠今吾弱研

ズ $モ \Rightarrow$ 心患人十究 $v$ 類

補亦加沈者毛年飞脂

體消入港血自コラ人肪ズ素

作失冷名清家卜レナ娟人尿

用 $ス$ 却

モょス, 竜血認手コ好各,

亦之, =素㕷卜性屬自

失至時上比, 自家八溶

$\rightarrow$ 及一澄楼特家溶一血共溶

$\sim$ 牛》液的異溶血般素通血

、牛, =多性血素二十干素

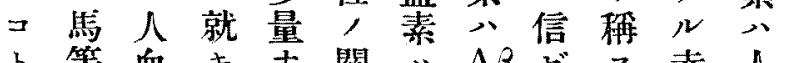

等血 $\neq$ 于關

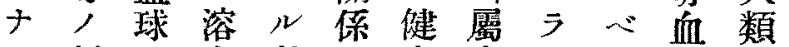

シ。新, 血各 7 康赫

。鮮屬反屬明人血、毛類屬

而赤, 應, 加血球所, 脂,

且如站人 $=$ 球

球何二赤七二最ルリ體血

三斯 $\exists=$ 補血 $ン$ 對 $モ ⿻ 上 丨$

四, 以關體球夕强近特酒

如于七作例 或少年異精

多同 $ス ゙$ 用

發樣自 $\exists$ 公者程用藤 反幾

作 二家檢四血度 碼憵斯

性處溶香乃清 $\overrightarrow{\mathrm{B} a}$ 夫

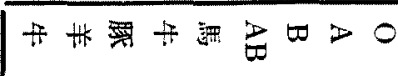

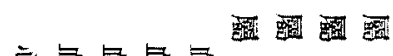
等舞灵

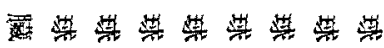

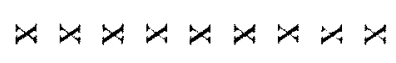
| $\neq 1 \neq 1|1|$ $1+1 \neq \neq 1111$ $\begin{array}{lllllll}1 & 1 & 1\end{array}$ $1111+1111$ $\begin{array}{llllllllll}1 & 1 & 1 & 1 & 1+ & 1 & 1 & 1 & 1\end{array}$ $\begin{array}{lllllllll}1 & 1 & 1 & 1 & 1 & 1 & 1\end{array}$ $\begin{array}{lllllllll}1 & 1 & 1 & 1 & 1 & 1 & 1 & 1 & 1\end{array}$ $\begin{array}{lllllllll}1 & 1 & 1 & 1 & 1 & 1 & 1 & 1 & 1\end{array}$ $\begin{array}{lllllllll}1 & 1 & 1 & 1 & 1 & 1 & 1 & 1 & 1 \\ 1 & 1 & 1 & 1 & 1 & 1 & 1 & 1 & 1\end{array}$ \begin{tabular}{lllllllll}
1 & 1 & 1 & 1 & 1 & 1 & 1 & 1 & 1 \\
\hline 1 & 0 & 1 & 7 & & & & &
\end{tabular} $1 \neq 1 \neq \neq \neq \ddagger \neq$ $1+1+\neq \neq+++$ $1+1+1++1+1++$ $1+111+++1+$ 1 $111+1+11+1$ 血置血七至 $\ni$ デ蛗學呈夫 


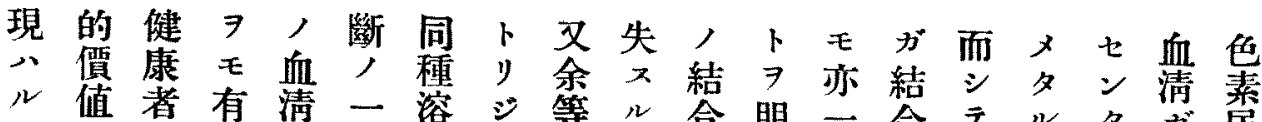
、值者有清云溶シ等ル合明一合

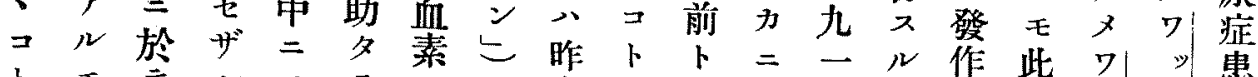

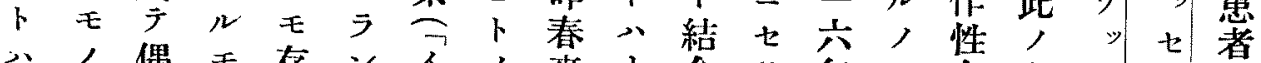
》, 偶モ存ンイ, 來ナ合う年ミ血際セ血

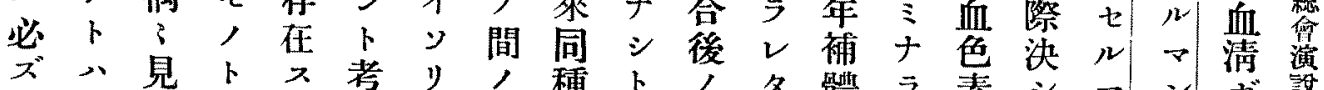

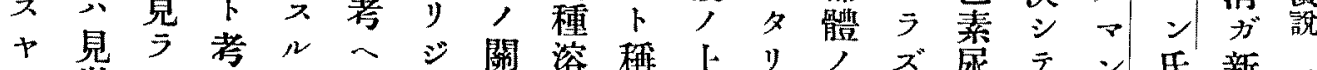

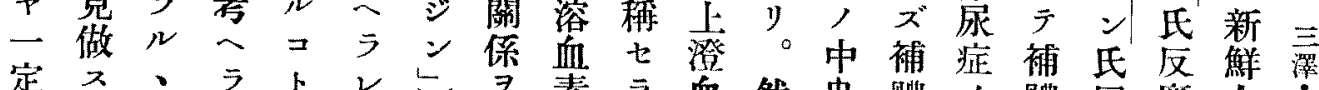

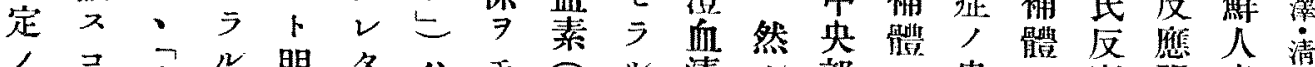

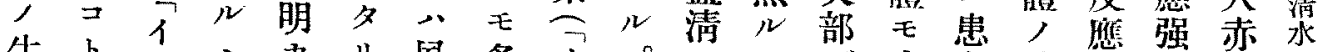

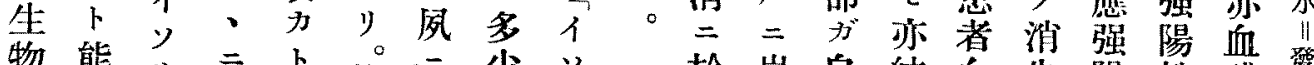

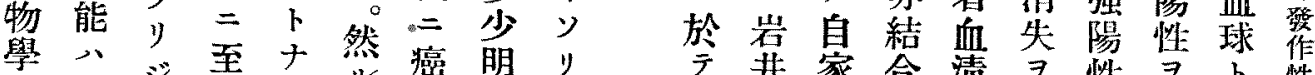

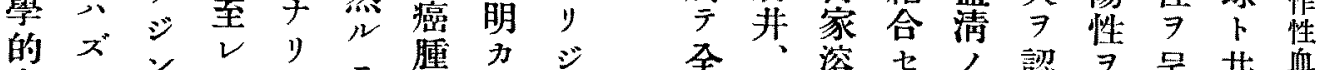

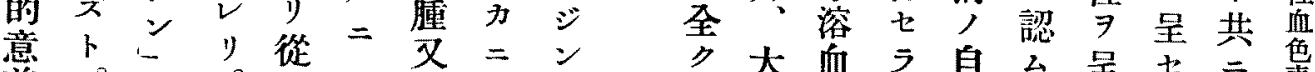
義 ${ }^{\circ}=0 \%$ 只

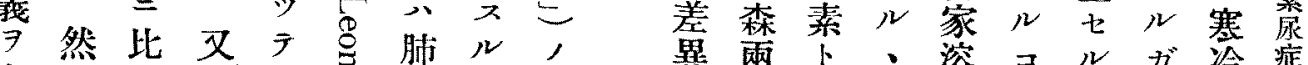

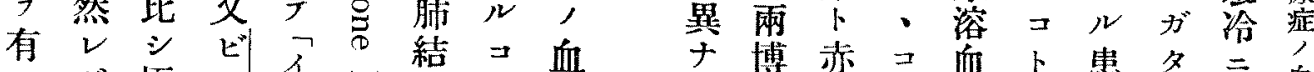

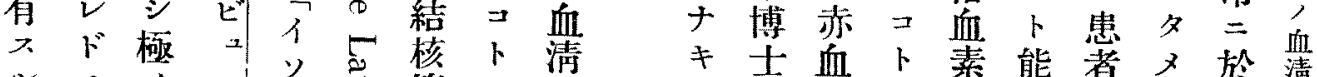

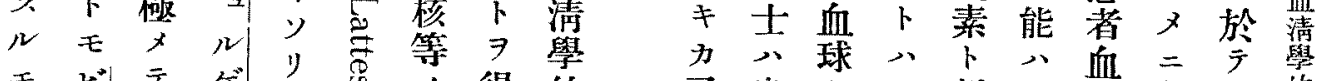
モ ビ| テ , 2 强

ナル力比者レ究

ラゲ|ナ癌くレ血バョ $ン N ル$ 腄存 $ハ$ 清今試

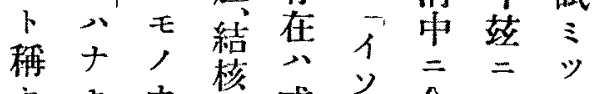

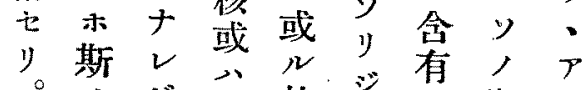
而如 モ 徽 特 ジ シク氏患, ハル卑 ガ テて 落疾り、述此 發りナ等患とコぶ向 作、氷 $=$ 他卜ン同 性此於對種知。種 血シ人等 シ

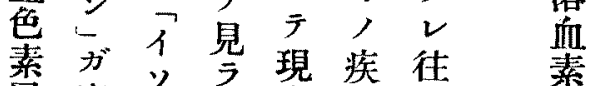
素 $\bar{y} \overline{ }=$

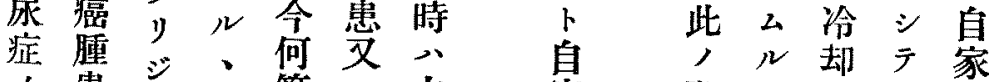

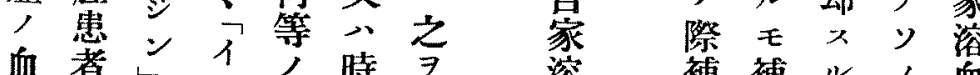
清

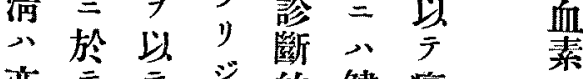

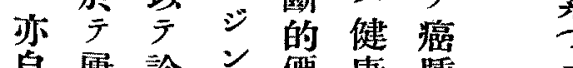

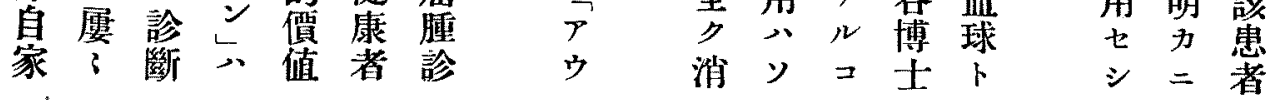
又患々一新 ゙゙清非處的 、者, 九鮮。泣天゙置究 極血結 ○人二 ×清合宍血對 ト ラ 天 $⺊$ 物年球照,

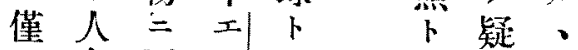
盛更 $P \quad \exists \quad$ 問 時 , 球 $三$ 混 差卜結 ンジ健生, 異 7 合向之康 寒 認冷 $N$ 冷血 厶 二 夕却清。 於入實入 $又$ 纱補 ， = 驗 $ン$ 寒 $=$ 體 三結 入七時椧於作 二合水 $2 \ddot{=}=$ 用 シ

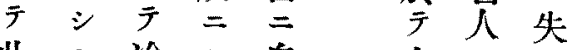

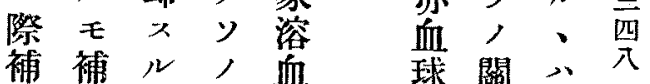
體體必後素球䈘或 ，作要熊卜 作 $\rightarrow$ 只 全用分谷血用明該 $P$ 》 


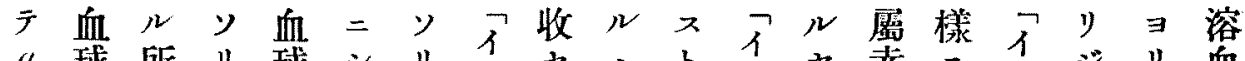

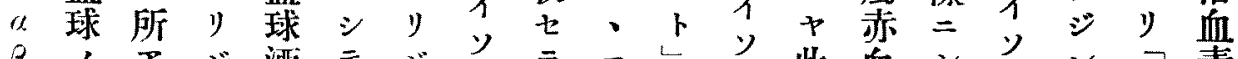

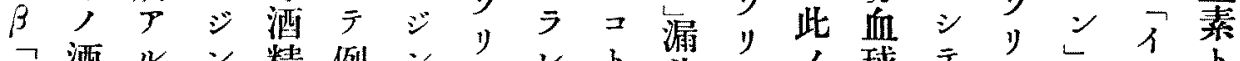

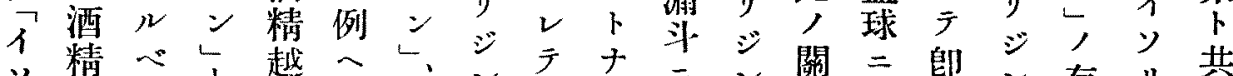

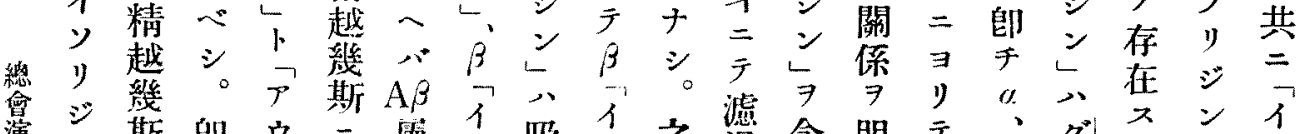
演之斯毁ウ

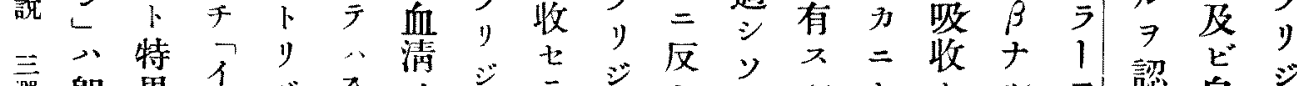
㳆師舅

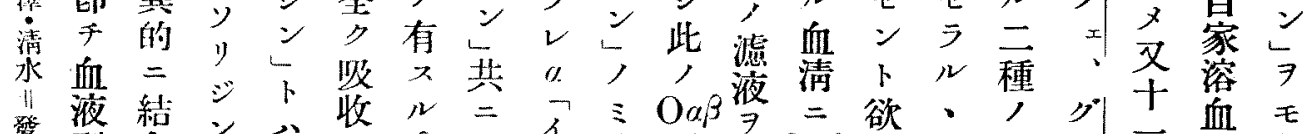
發焦結 $ン$ 八收

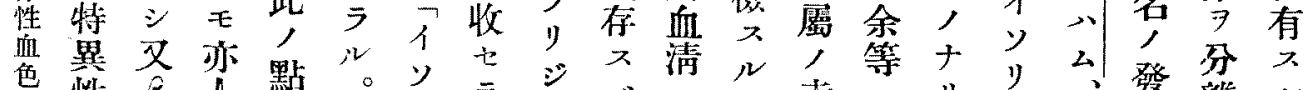
急性 $\beta$ 人點。少 病 7 有

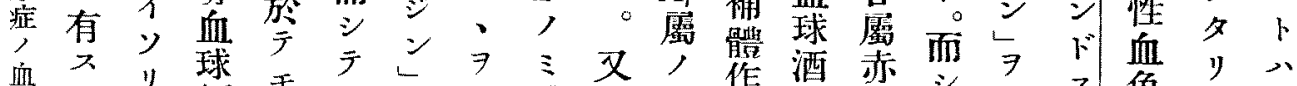

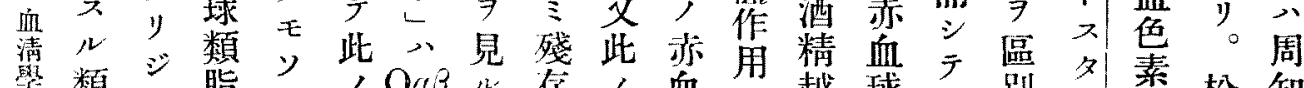

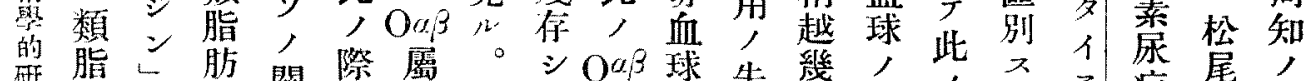

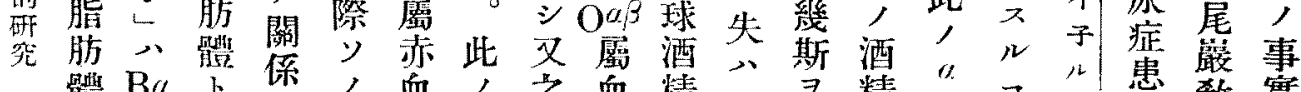
體 $\mathrm{B} a$ 卜

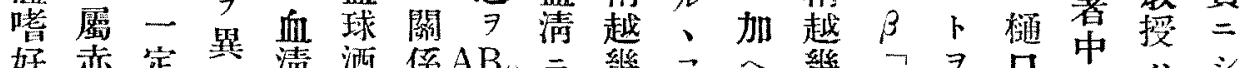

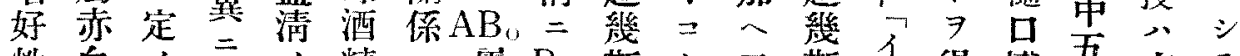

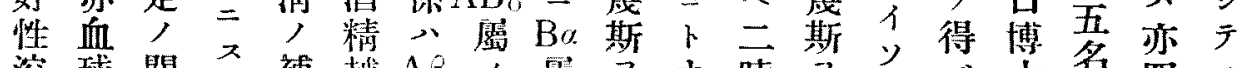

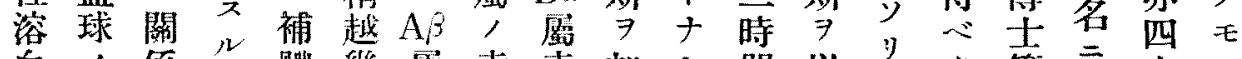

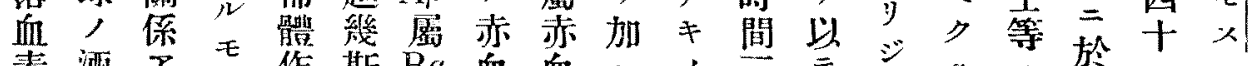

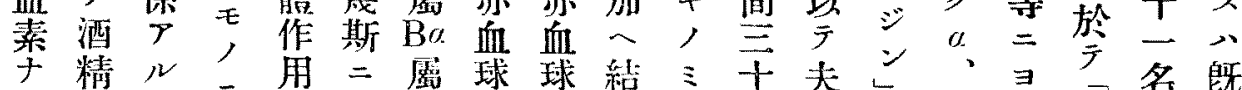

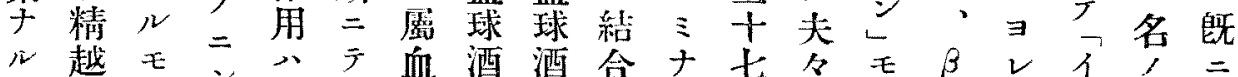

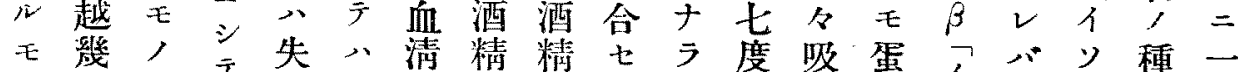

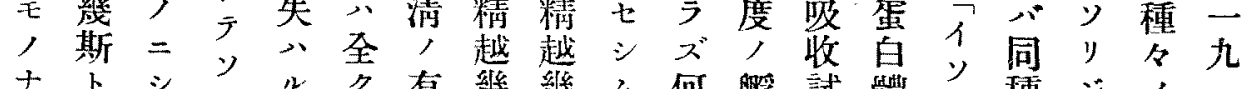

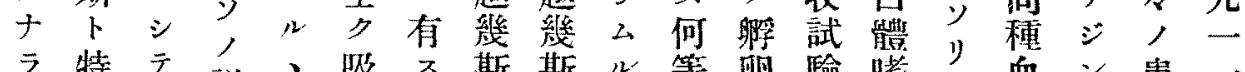

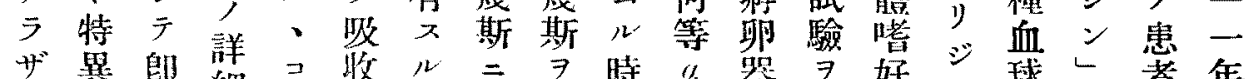
ザ異咱細コ收ル

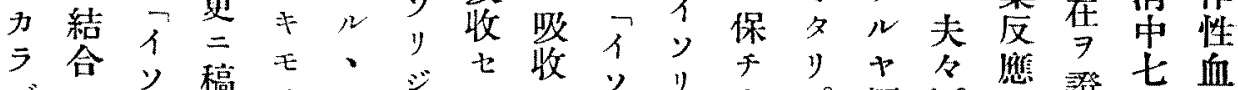
西

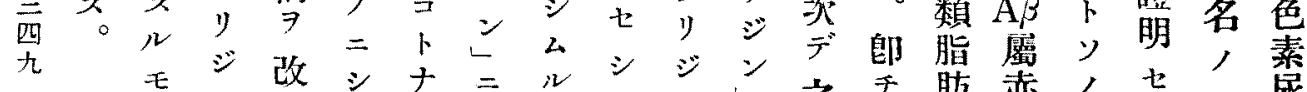
,

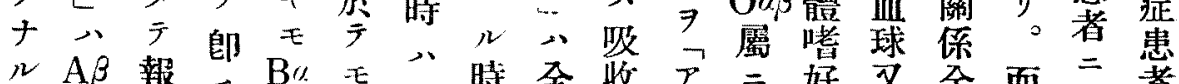

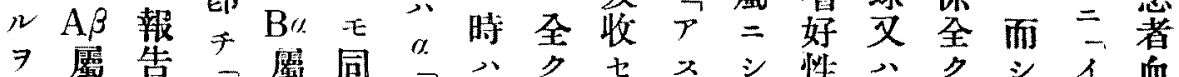

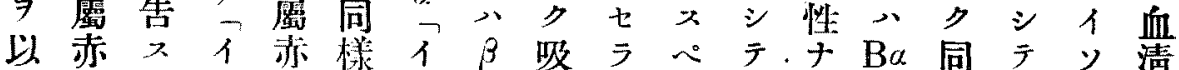


第六表 赤血球酒精越幾斯 山田血清 (O屬)，「イン

リジン」服收試驗

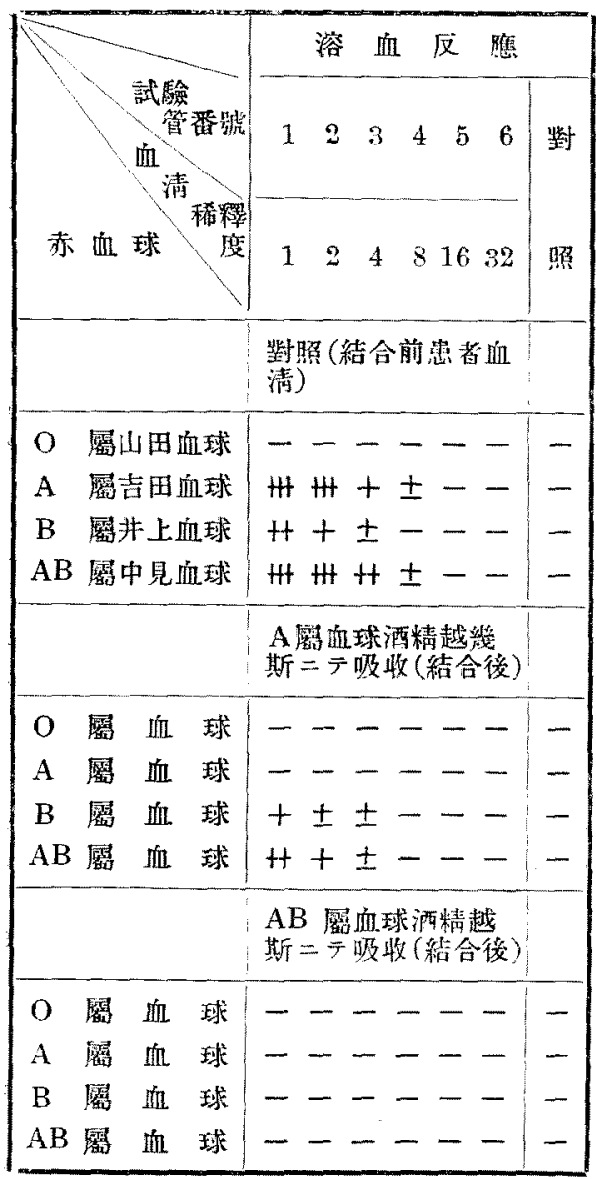

第无表 凌血球酒精越我斯 山田血清( $\mathrm{O}$ 屬)，「イン リジン」吸收試驗

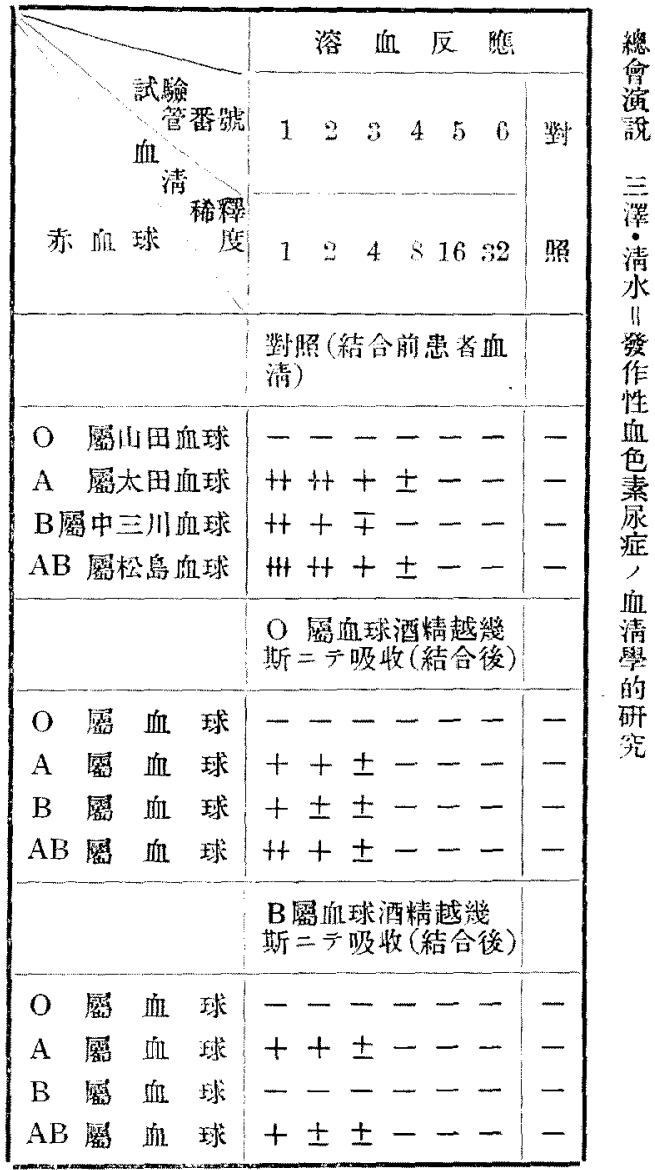

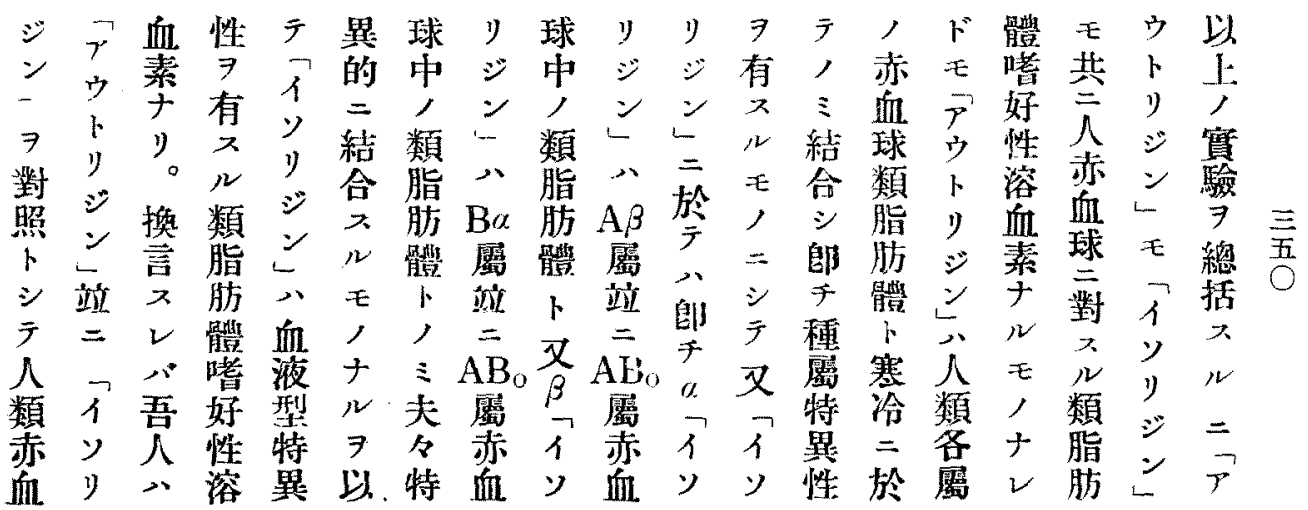




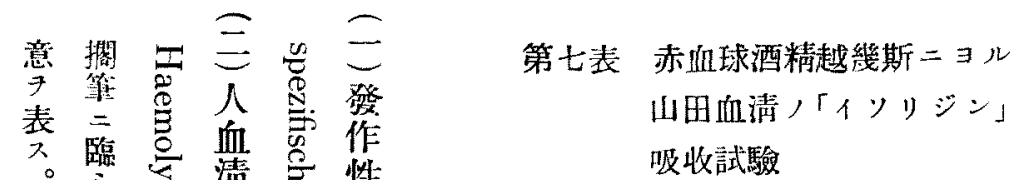

吸收試驗

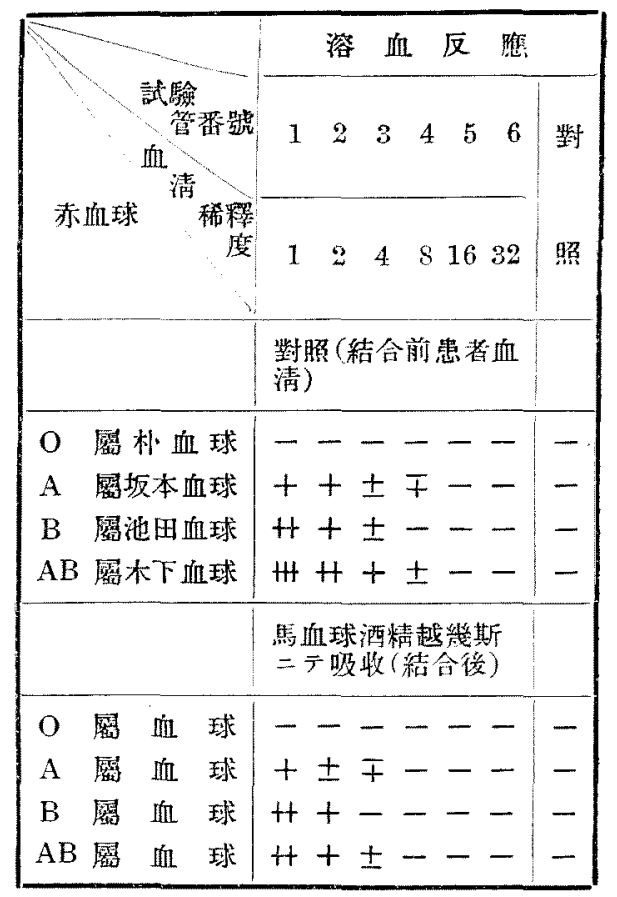

$ナ シ \prime=八$ 此 $=$ = 球

ル A 夫同, 共卜中 類 $\beta \neg$ 種類通 $\ni$, 脂 $\neg レ$ 相血脂广得類 肪ソッ當球肪ル心脂 體 リ ×

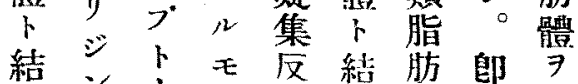

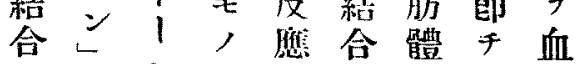
ス $v=$ ス $=$, 清

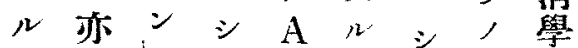
モ $\mathrm{B}+\overline{\mathrm{B}} €$ ₹ 一的

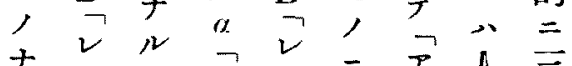
ナ $ッ$ 類 。x脂 ソ $メ$ シ ウ 類種 プ 肪 リ プ 㕛り屬 體 シ 他 シ , 區 上卜L年ン赤別 レ合此レ゙ 者心球 


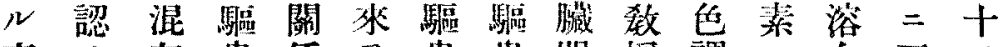

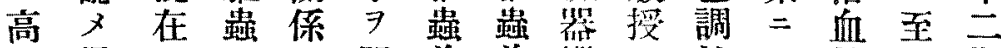

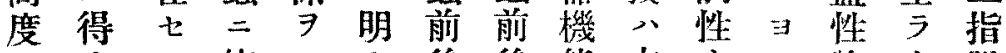
人十ル佊モカ後後能本十心物十䝢 貧力 $九$ 明 血, , テ カ $\Rightarrow$ 五得二併ケ屎，血卜球傩 示, 例夕七七心因心血破明

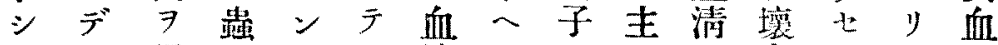

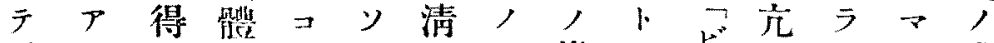

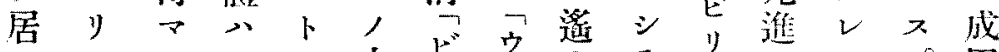

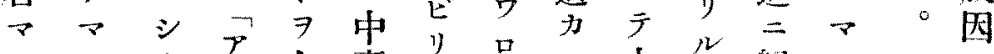

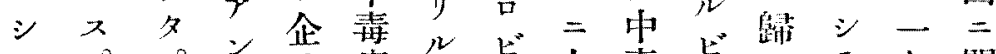

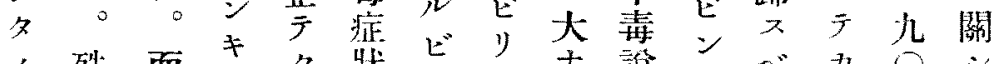
, 殊而年名狀

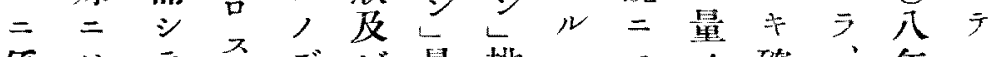

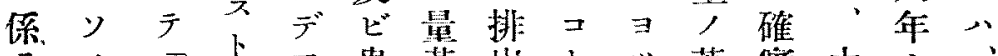

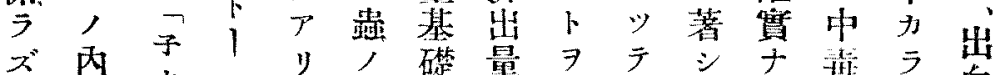

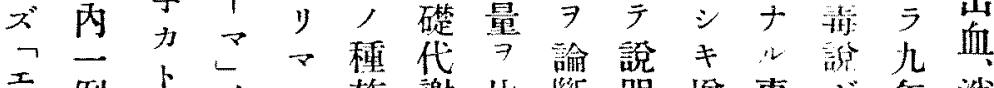
入例

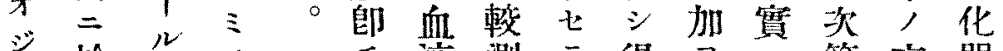

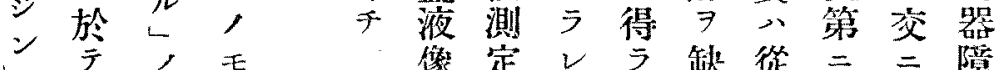

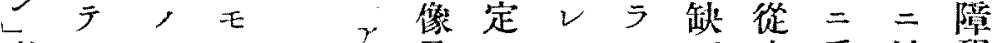

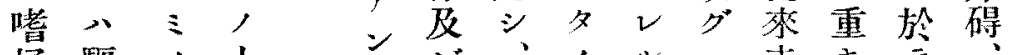

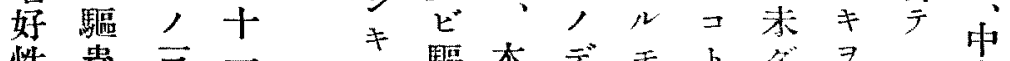

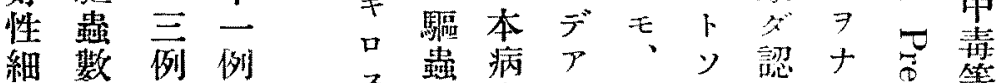

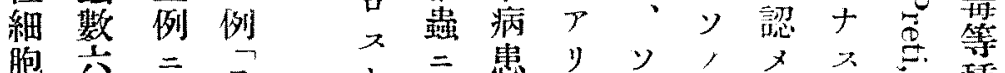
八九於子立患者子, 他

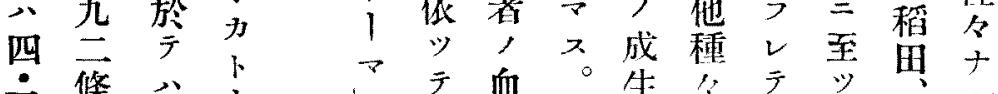

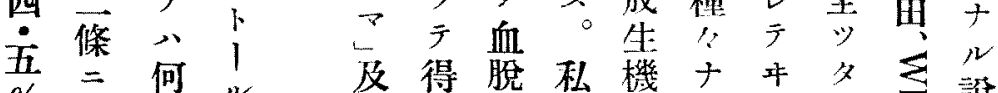
$\%=$ 何 $\%$ 及 得璄私機 過 赤 モ

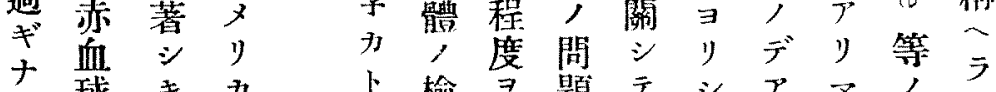

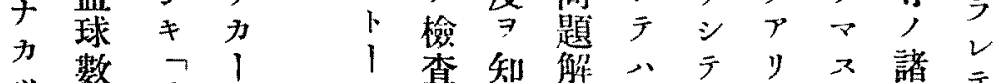

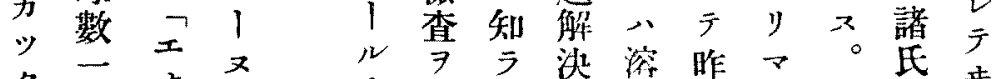

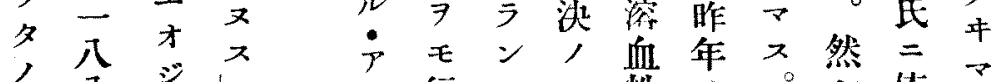

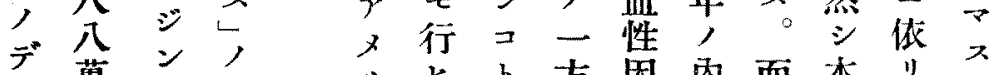

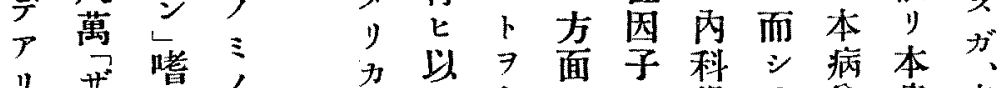

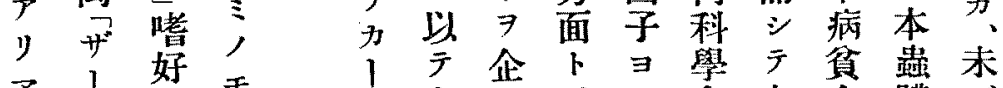

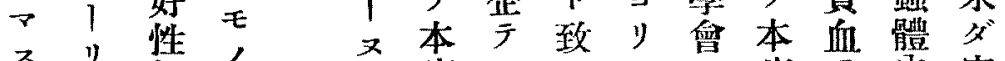

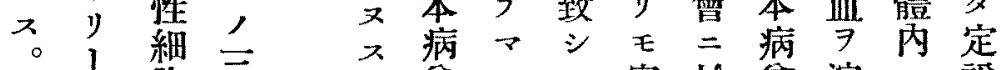
ᄂ 胞 例 分 三 架兩等 血 タ 融

$=$ 㷊

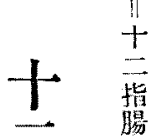

指病 


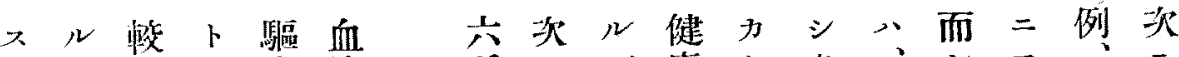

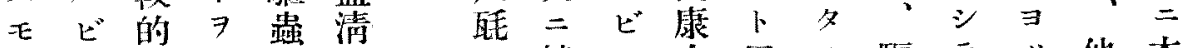

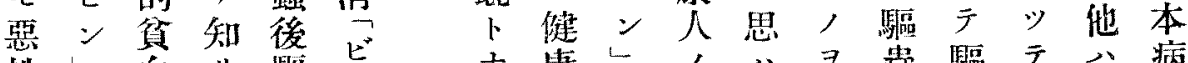

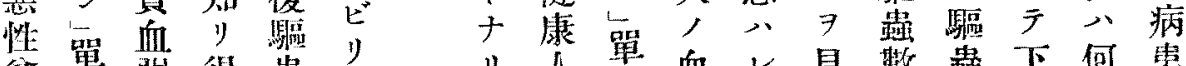

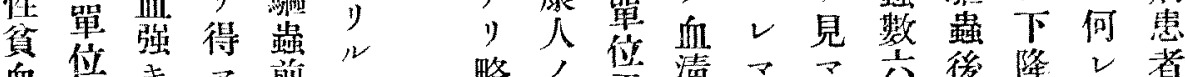

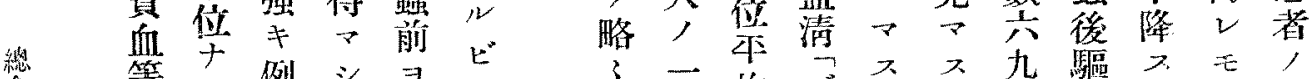

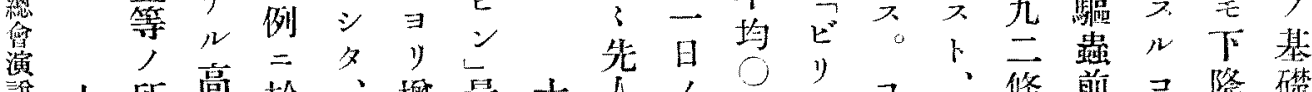

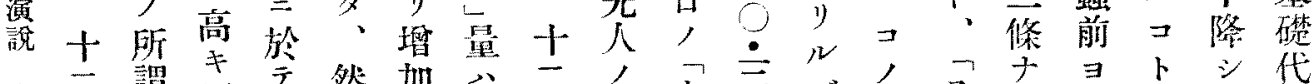

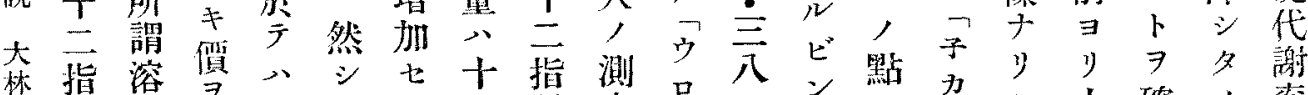

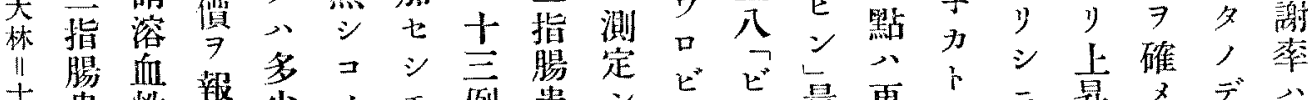

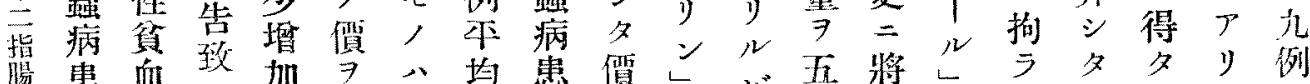

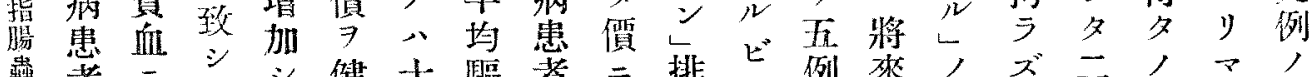

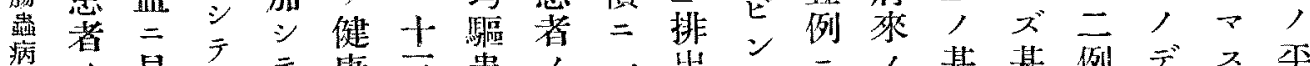

二, 見和テ康三路, 一出

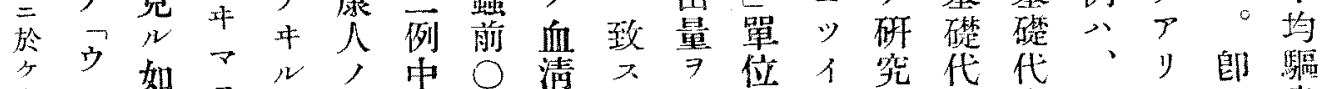

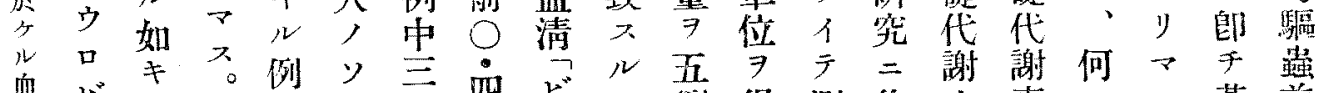

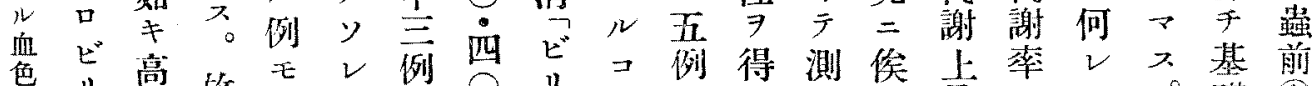

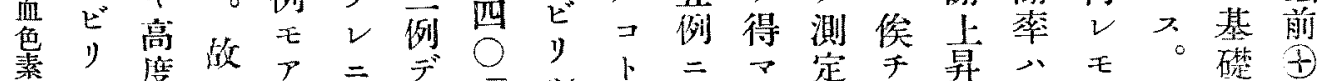

帒ン文二謝

就出排㽞 士

就出 加 $\vec{F}$ 指

認腸

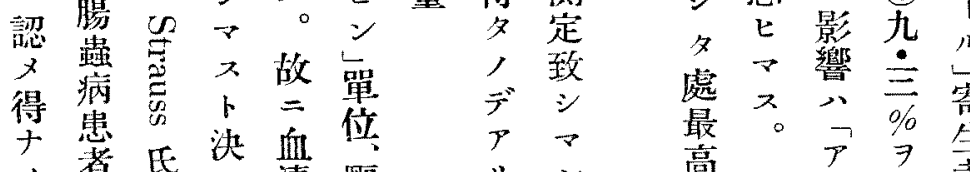

イ者氏 決 血駱

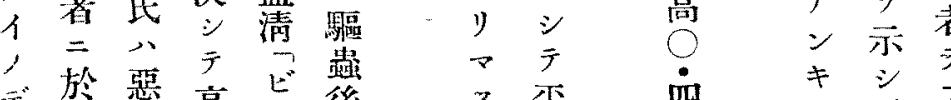

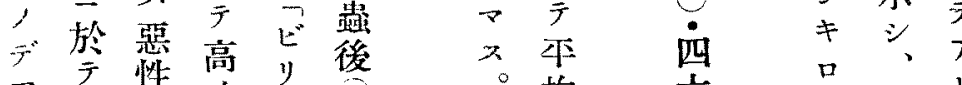

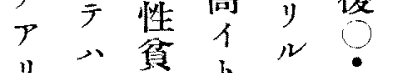

$\rightarrow$ 血血

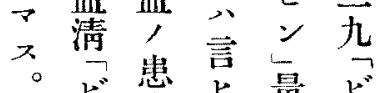

ビ瞇㫐量 ビ

量二得少䮠ハ

多於手䖵

少 $\bigcirc$ デ

忢

, 䘮寻單

增艿,多位

加至、少卜

均

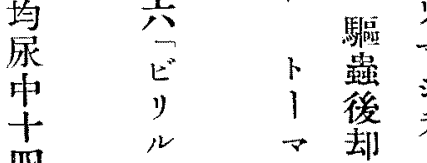

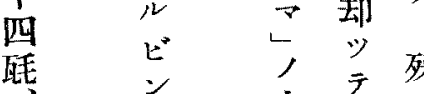

屎 單 尘 $\oplus=$

先 駱

㮇 蛅

考它。娍

中 位 = 三林

考然考:

得

三 最公六,

本梭

E

報

告 \%

七

宁

如 y

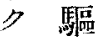

本 蟲

病 琈

二 舅

於 䖵

亏 前

公， - 般

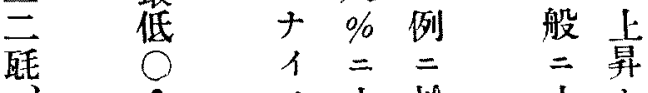

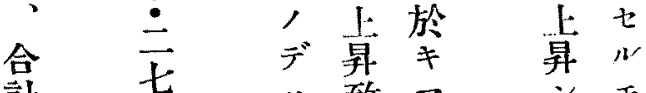

計 七

$\begin{array}{llll}ナ & シ & シ & \text { 驅 } \\ 1 & \nabla & \text { 二 } & \text { 䖪 }\end{array}$ 
、万後數七次如 $、$ 酰常前驅被斥一屎最十 本 $\quad$ 間

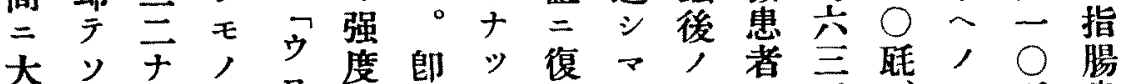
二小, y =

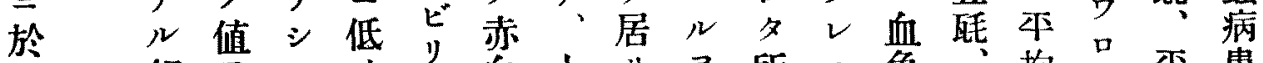

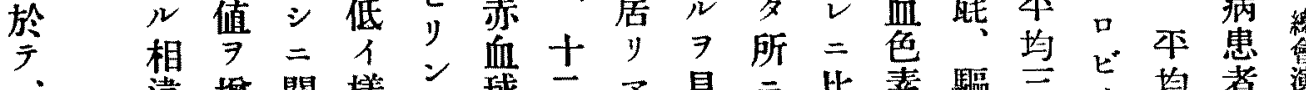

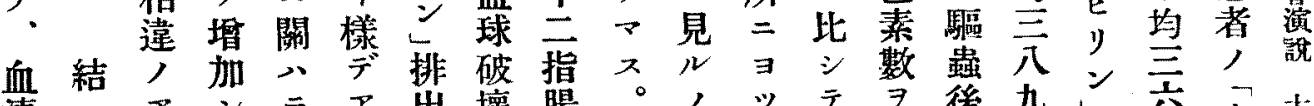

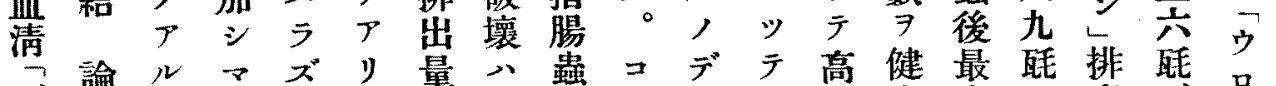

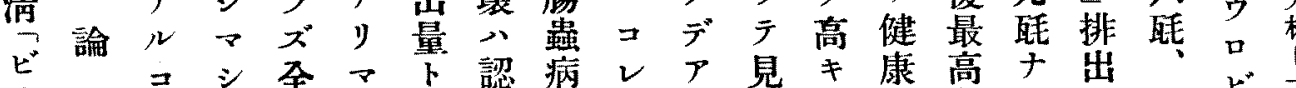

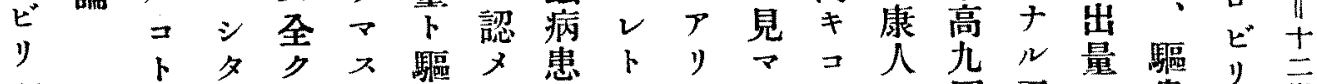

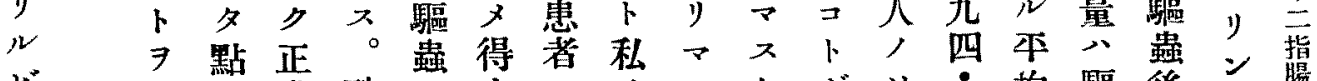
ビ 思寻常殊二ナニ, スト

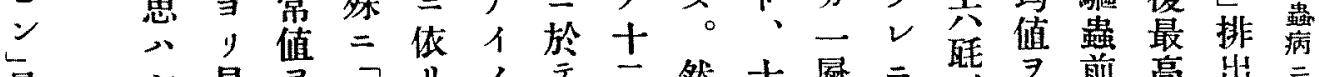

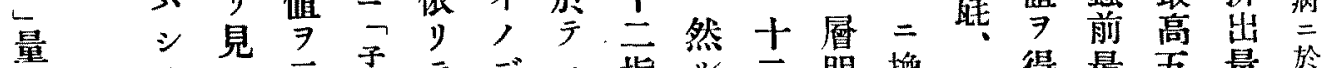

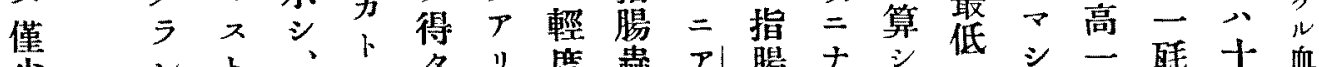

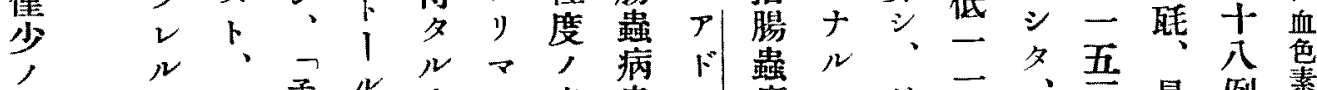

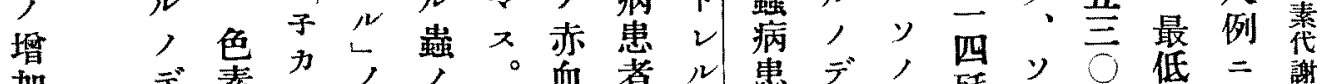

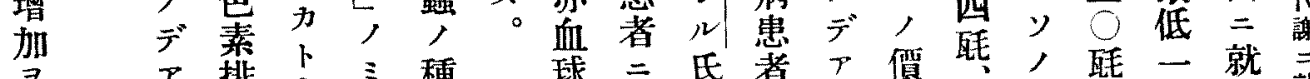
示り出六族破於, 亞

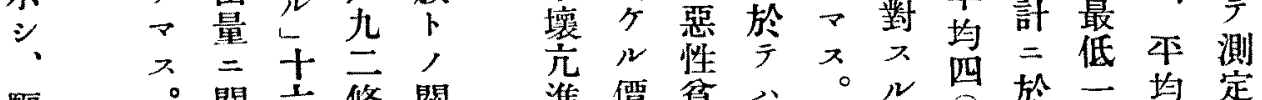

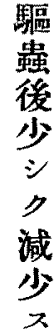

關兵秂關進價貧 シ條 7 係 $\checkmark$ 排 7

排出 求

于出

E $七 \geqslant \nabla$

、シ 林

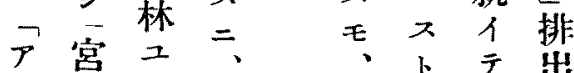

ン本采一

キ 八驅

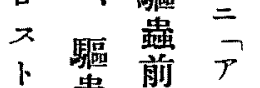

1 螺赤ン

ᄂ 正血

常球

子值八斿

力 $=$ 分

今 萬

驅色寄
䚵血引

比患口

得輘者旨

惡卌, 量

性 非 测

貧常定 增

血于值加

等 $\leadsto$ 心

所 相二

謂 違二驅

溶 7 三䖪

血 見 $\bigcirc=$

性出乃

貧 至 ”

血, 入テ

$=F^{*}$

見 $P$

四 略

○?

○ 正

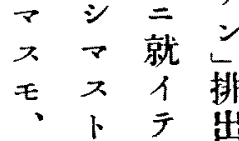

儿酉於元均定

号入分二致

口瓦子主九シ

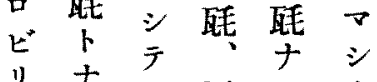

1) $大$ 不心

こ多駱均本結

排 蟲五均果

出夕前九值

量。最九 $尹$ 尿

$\Rightarrow$ 高 酶得中

算 -

出五驅, 於

致五蟲 デ

$シ$ 八後 $ア$ 驅

$\checkmark$ 酕最り 蟲

ス 高 $、$ 前三

卜最九最吾

驅低四。高

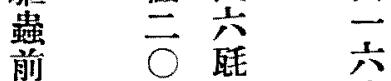

價酶最硅 


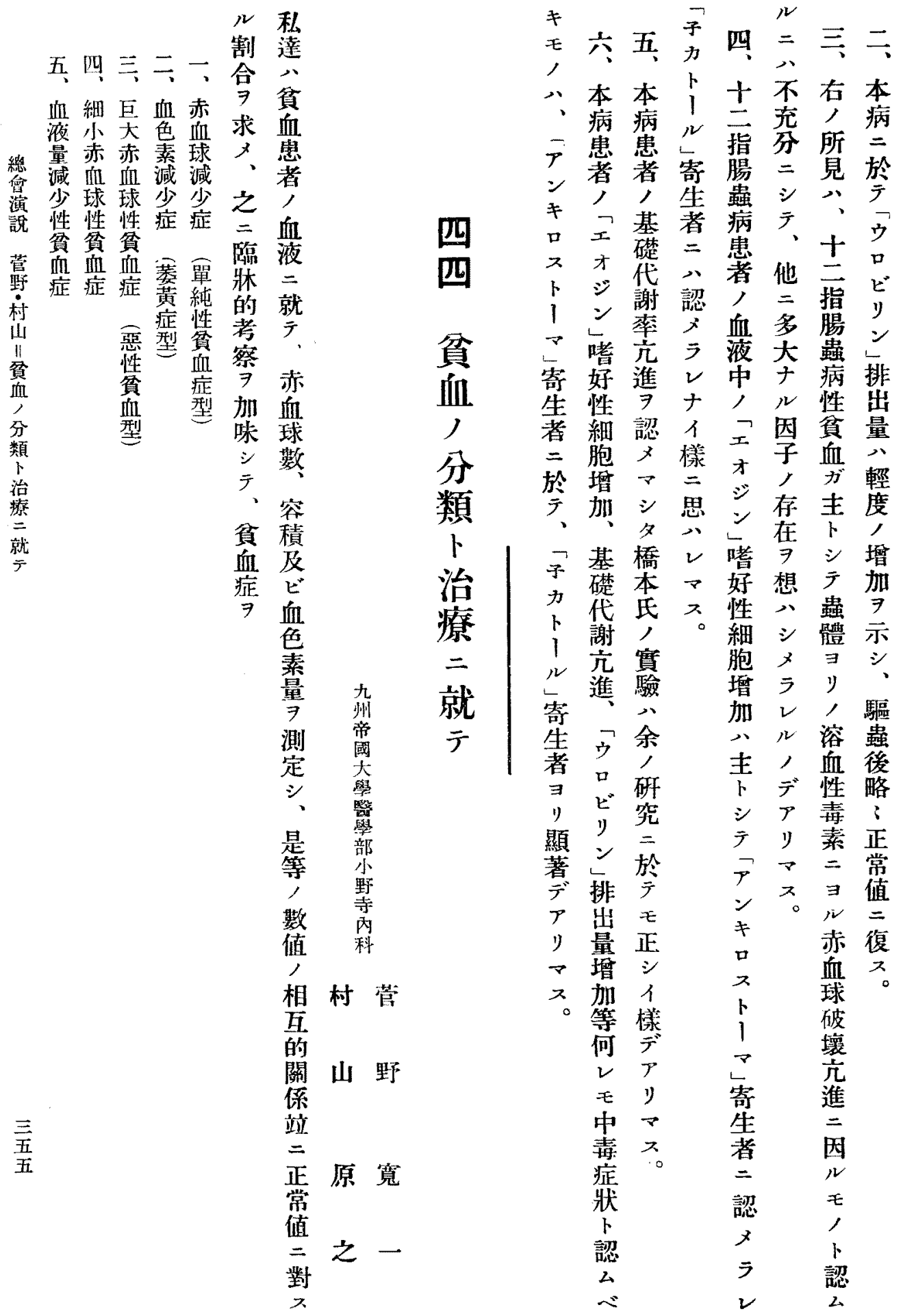


第一表 細小赤血球性资血症

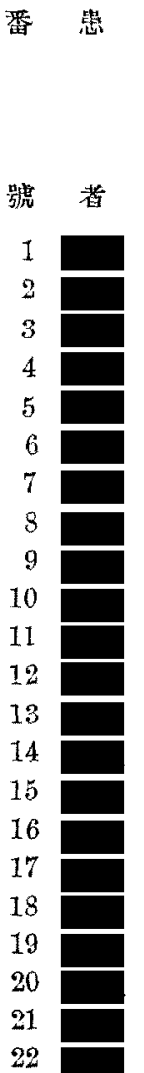

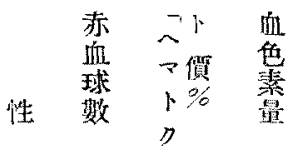

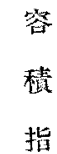

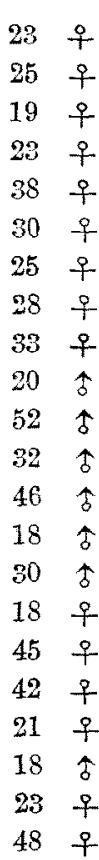

$$
\begin{array}{lll}
358 & 32.8 & 7.2
\end{array}
$$

$$
\begin{array}{lll}
221 & 18.8 & 4.0
\end{array}
$$

$271 \quad 23.0 \quad 4.8$

0.94

$\begin{array}{lll}411 & 34.0 & 8.0\end{array}$

$$
218
$$$$
213 \quad 17.3 \quad 7.4
$$

$$
568
$$

$$
356
$$

$$
268
$$

$$
279
$$$$
\begin{array}{lll}
18.0 & 3.1
\end{array}
$$

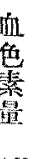

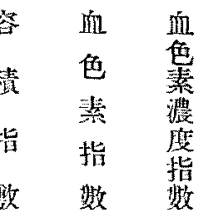

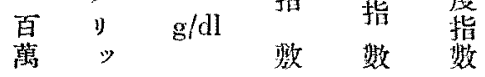

$\begin{array}{lll}0.95 & 0.72 & 0.75\end{array}$

$\begin{array}{lll}0.95 & 0.69 & 0.72\end{array}$$$
0.95
$$

0.85

0.89

0.67

0.71

0.92

$0.74 \quad 0.80$

0.91

$0.61 \quad 0.65$

$\begin{array}{llllll}438 & 34.5 & 7.2 & 0.89 & 0.63 & 0.71\end{array}$

$\begin{array}{lllllll}263 & 20.7 & 4.2 & 0.87 & 0.60 & 0.68\end{array}$

$\begin{array}{llllll}520 & 39.6 & 9.3 & 0.85 & 0.63 & 0.74\end{array}$

$\begin{array}{llllll}26.5 & 7.2 & 0.82 & 0.72 & 0.87\end{array}$

$\begin{array}{llllll}539 & 39.3 & 9.0 & 0.81 & 0.59 & 0.72\end{array}$

$\begin{array}{llllll}246 & 18.0 & 3.8 & 0.81 & 0.54 & 0.67\end{array}$

$\begin{array}{lllllll}485 & 35.5 & 6.5 & 0.81 & 0.47 & 0.58\end{array}$

$$
\begin{array}{lllllll}
319 & 23.0 & 4.8 & 0.80 & 0.53 & 0.66
\end{array}
$$

$\begin{array}{lllllll}254 & 18.0 & 3.7 & 0.79 & 0.55 & 0.70\end{array}$

$\begin{array}{llllll}303 & 21.5 & 4.4 & 0.79 & 0.54 & 0.69\end{array}$

$\begin{array}{lllllll}402 & 34.5 & 8.4 & 0.79 & 0.79 & 0.88\end{array}$

$\begin{array}{llllll}462 & 32.5 & 6.8 & 0.78 & 0.56 & 0.71\end{array}$

$\begin{array}{lll}0.76 & 0.41 & 0.55\end{array}$

0.69

$\begin{array}{lll}0.32 & 0.47\end{array}$

0.65

$0.52 \quad 0.75$

巨大赤血球性贫血症

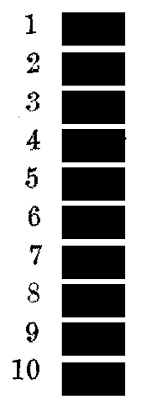

$\begin{array}{llllllll}31 & + & 89 & 14.0 & 3.35 & 1.75 & 1.44 & 0.83\end{array}$ $\begin{array}{llllllll}34 & \uparrow & 256 & 34.5 & 6.50 & 1.48 & 0.90 & 0.59\end{array}$ $\begin{array}{llllllll}19 & + & 465 & 55.3 & 6.80 & 1.32 & 0.55 & 0.40\end{array}$ $\begin{array}{llllllll}42 & \text { \& } & 220 & 22.2 & 5.32 & 1.12 & 0.85 & 0.76\end{array}$ \begin{tabular}{llllllll}
32 & \multirow{5}{*}{} & 260 & 26.0 & 6.80 & 1.11 & 0.93 & 0.84
\end{tabular} $\begin{array}{llllllll}21 & \text { 우 } & 287 & 23.5 & 6.40 & 1.10 & 1.02 & 0.90\end{array}$ $\begin{array}{llllllll}18 & \text { 우 } & 347 & 34.0 & 8.00 & 1.09 & 0.87 & 0.80\end{array}$

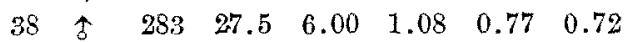
$\begin{array}{llllllll}45 & + & 351 & 34.0 & 9.50 & 1.07 & 1.01 & 0.95\end{array}$

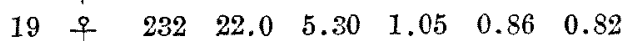

赤血球容積正常二近キモ，

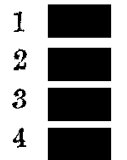

$\begin{array}{llllllll}32 & - \text { ․ } & 352 & 33.2 & 7.5 & 1.04 & 0.80 & 0.77\end{array}$ \begin{tabular}{llllllll}
69 & \multirow{1}{*}{} & 348 & 30.5 & 7.2 & 0.98 & 0.73 & 0.75
\end{tabular} $\begin{array}{llllllll}28 & \text { 우 } & 467 & 41.0 & 8.4 & 0.98 & 0.68 & 0.70\end{array}$ $\begin{array}{llllllll}18 & \text { ㅇ } & 226 & 20.0 & 4.4 & 0.98 & 0.73 & 0.74\end{array}$

最 相 测 站 量 7 近互定二娍區 約關方 一係法赫 $r \Rightarrow$ 血 $\gg 心$ 年京婠球 酸 $\neq$ 性 間 $又$ 野容化 デ

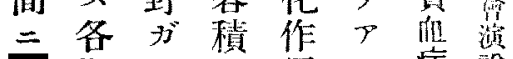
指日二用心症䛃 数本 關 抑 曹 二内 $ᄌ$ 制 7 名 就科儿或击々的 于 學 観 八張 E 會 察 酸 七 E 會察酸 七 入號誌主酰ト 院中昭卡素 一和 $シ$ 系 貞記 三テ障 血非年報碍， 患シ九告等 ジ 者テ月致二ア 三置號シ $シ$ y 亲 $\neq=\nabla \% \nabla$ 例 $、$ 忩 二 シ 表

於名。致$$
\text { 得 }
$$

シ

貣 症

血. 䛈

待一症性

测

刑貧

优

$\forall$

x

E

$\Rightarrow$ 血

星 证

\section{第 \\ 第 \\ 表 \\ 如 \\ 如

5
5
7
7
7

ᄌ

坴

同

N

手

I III

$\Rightarrow$ 球

澺 政

デ
$r$
3
$r$
$x$

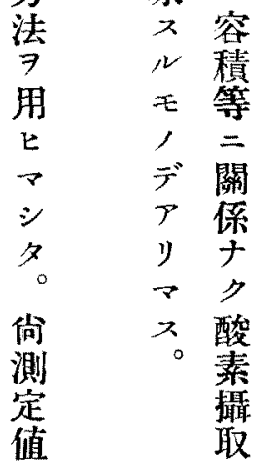

總
沙
說

政 朴 , 分 類 治 倠 就 F

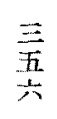




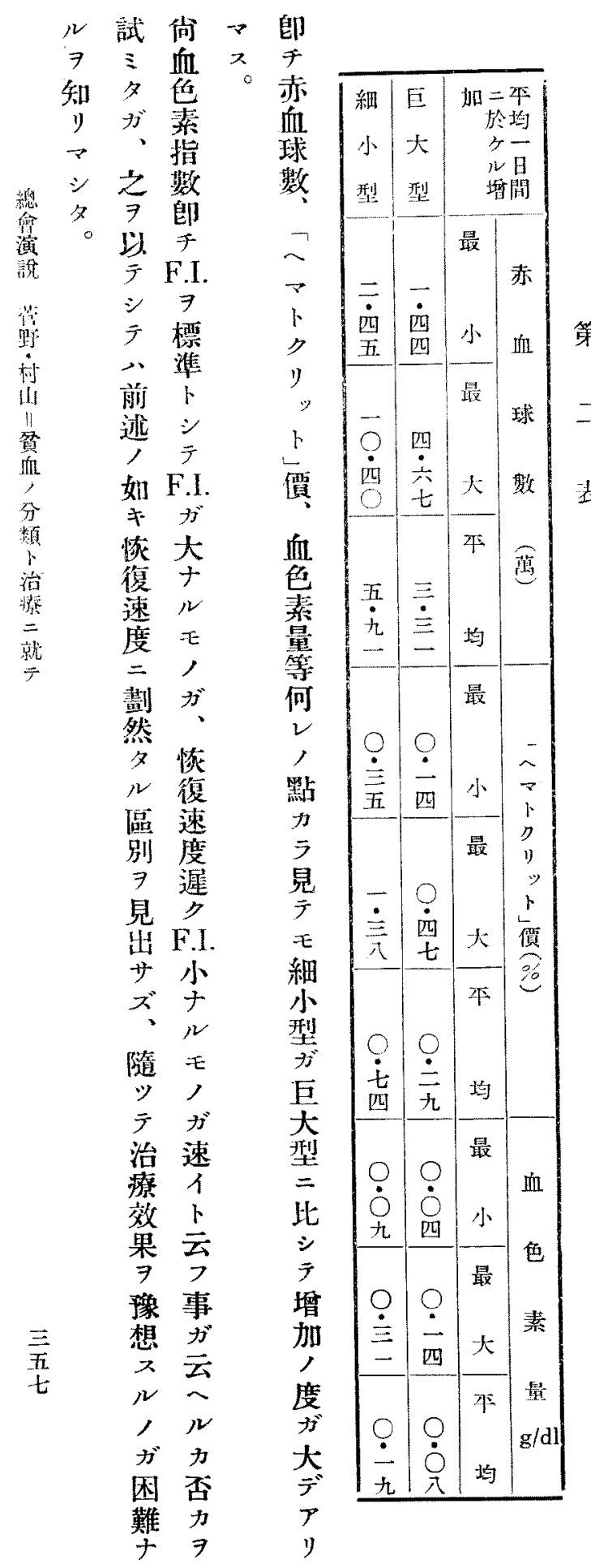

表球 邓私 ○血皘此 及性、達六球指测 ビ䆩 又分公性褡 定

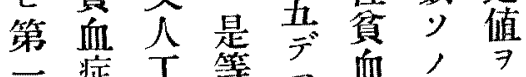
圖 症 贡等 ア 血 三陽血多部察 示大登者名 又分 有赤療 $={ }^{x} v=N$

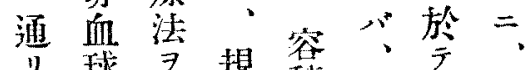

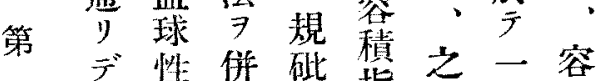

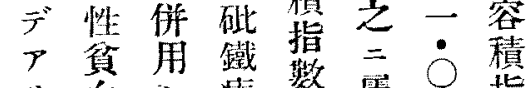

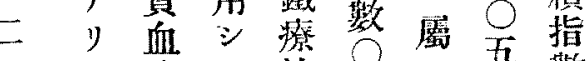
$\checkmark$ 症 $、$ 法古公五數 此夕肝公飞主。

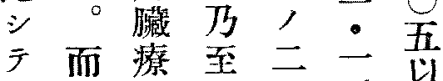
恢

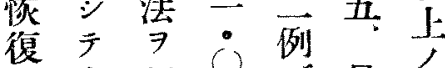
速赤血行四 ゙゙最モ 召球新 $モ$ 容

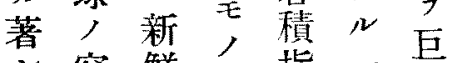
容鮮郎指 數主赤 大 7 背略，五血

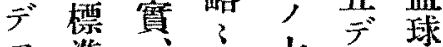
ア準正大性 ルト青政部y貧 , シ 化常分、具

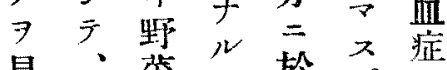

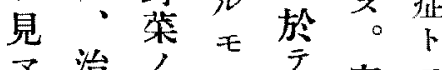
治療分, 今容 夕效量三忘指 症了特例艿數之 例速二中至: 就度多四至杂鷿 見就无吾不

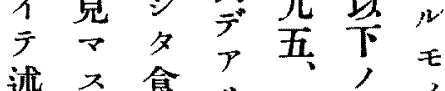
述入食少, 壬

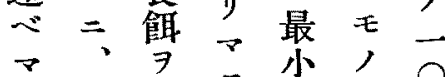
入細攝入ナ。例 卜小取 $N$ 細 例 第赤 


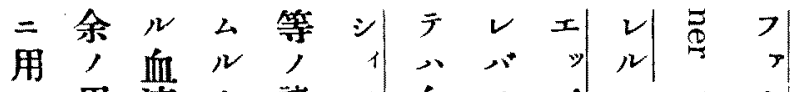
七用液卜諸フ血ソピ・品ウ シ 七丙1氏心中, 的中脂 療 シ 法貧 ポ。ヨ等食开

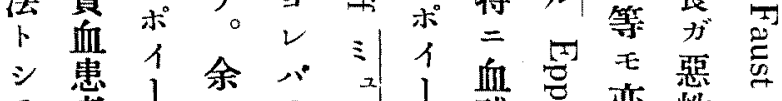
方者

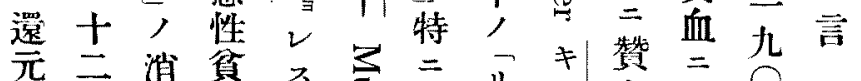

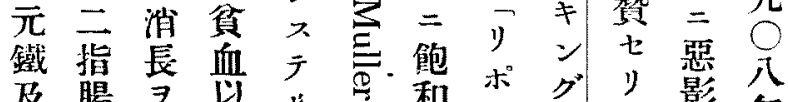
及腸 $尹$ 以，和术グリ影年

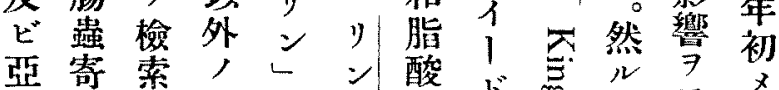

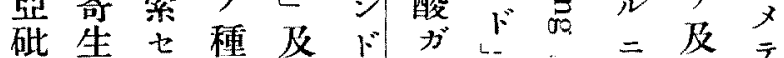

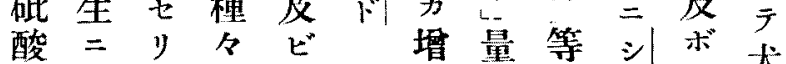

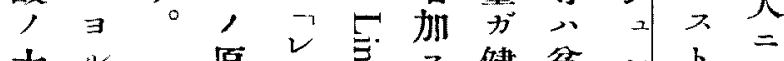

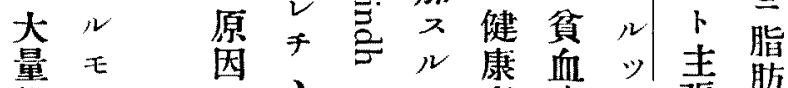
投, 二 之加上者症張照

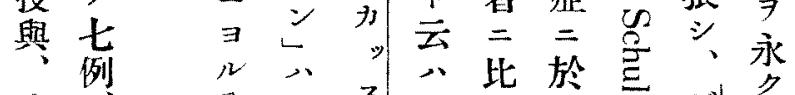

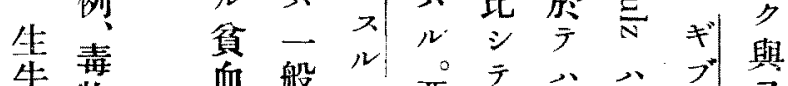

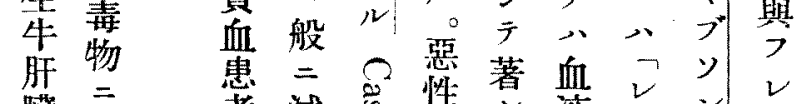

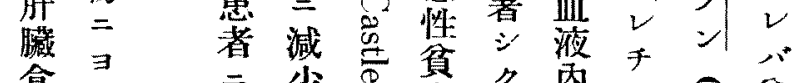
食当種七少血增脂、貧

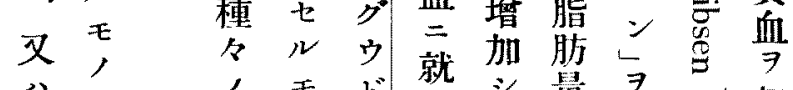
製云療畕

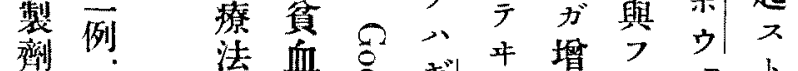

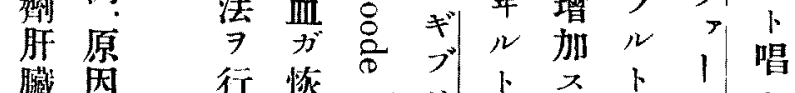
粉杯皆復

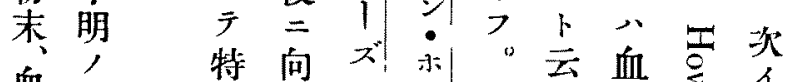

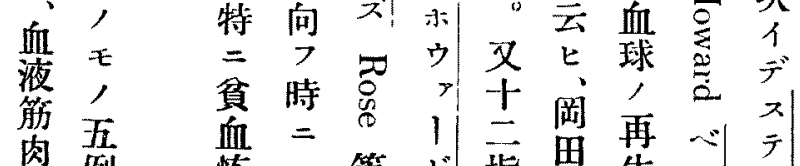

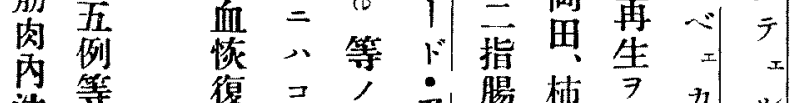

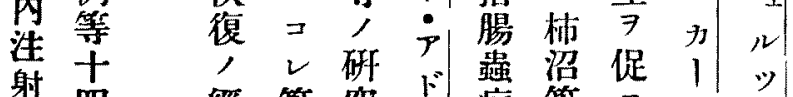

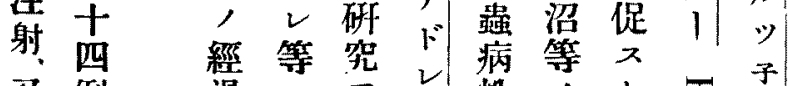

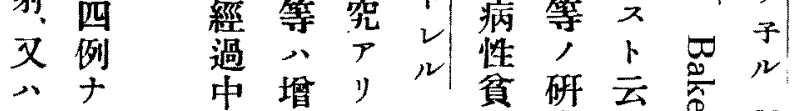

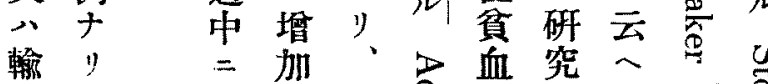

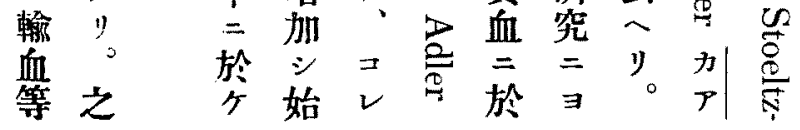

, 以

標 上

準,

關

作 係

出

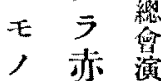

デ 血 境

ア球

》容 村

$\checkmark$ 積 II

又 测 资

貧少定

IIIIL ラ、管

二 筫 單

於血二液

症貧内

ケ ’血”

儿|類診 1

Ifll $\stackrel{\text { 類 診 }}{=}$ 兹,

州液

，眮 渻

事 味 就

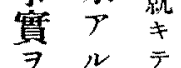

加 $=$

味 止.

ス

N $\pi$

部

武

公

科㻌

教)必療

室沙要 效

中 デ果

辰年恢

二 $モ$ 復

村就, 策

キ
テ

陽
思 7 吾唔

想

․ 


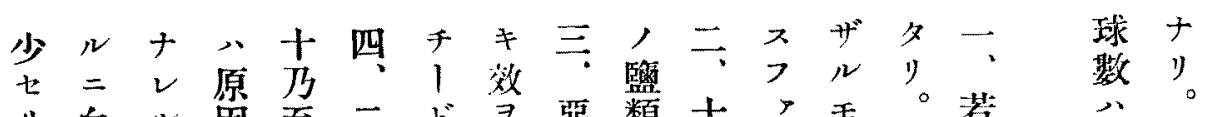

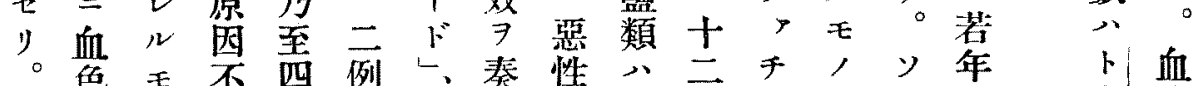

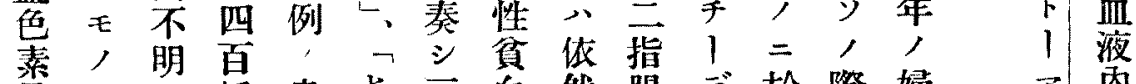

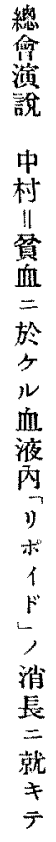

䇎十, 践患七三血然腸 ゙於際婦

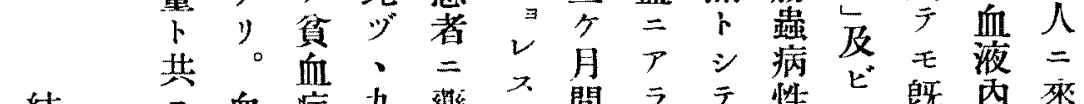

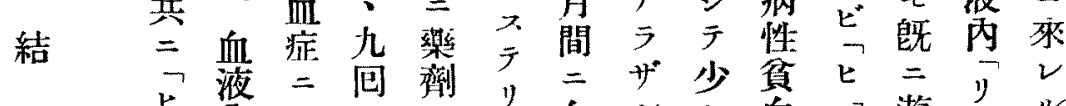

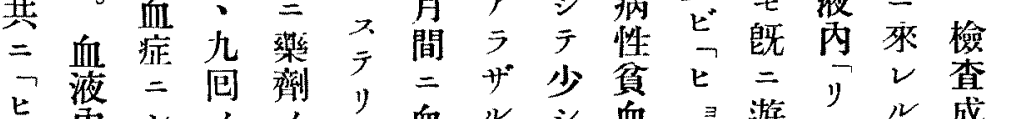

$\rightarrow$ 内

論

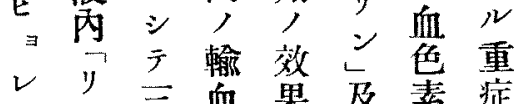

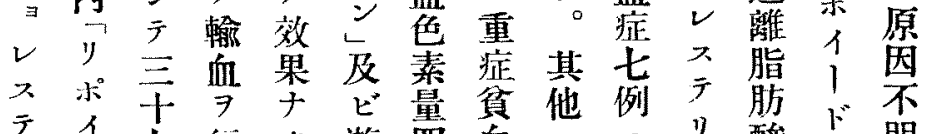

テ 1 七行》遊四血三三》酸に゙明

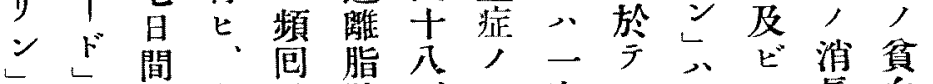

及心三血輸肪: 一定”血y長血

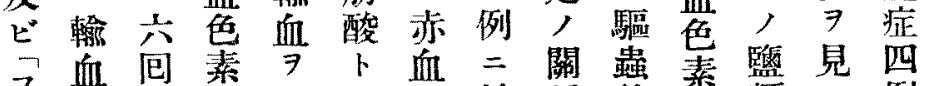

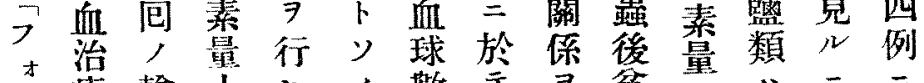

齐療輸士

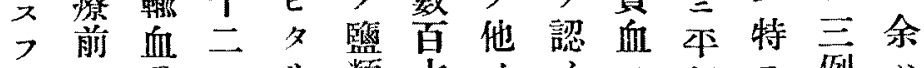

$>=7 \exists y$ 類兵, $>$ 兵行二例

千八行y。公年何

，健上四一何萬人。復三奛於元

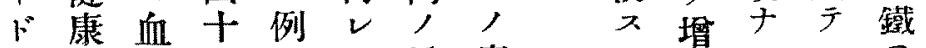

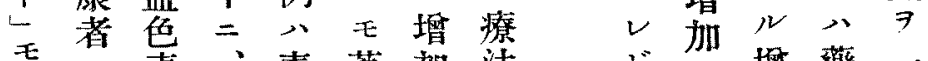

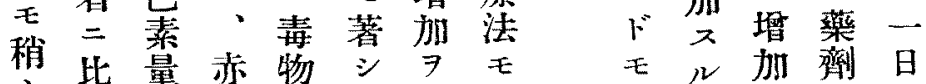

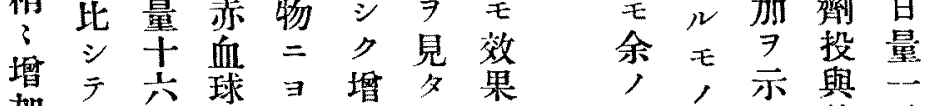

$\because$ 脂

, 肪

及

자 


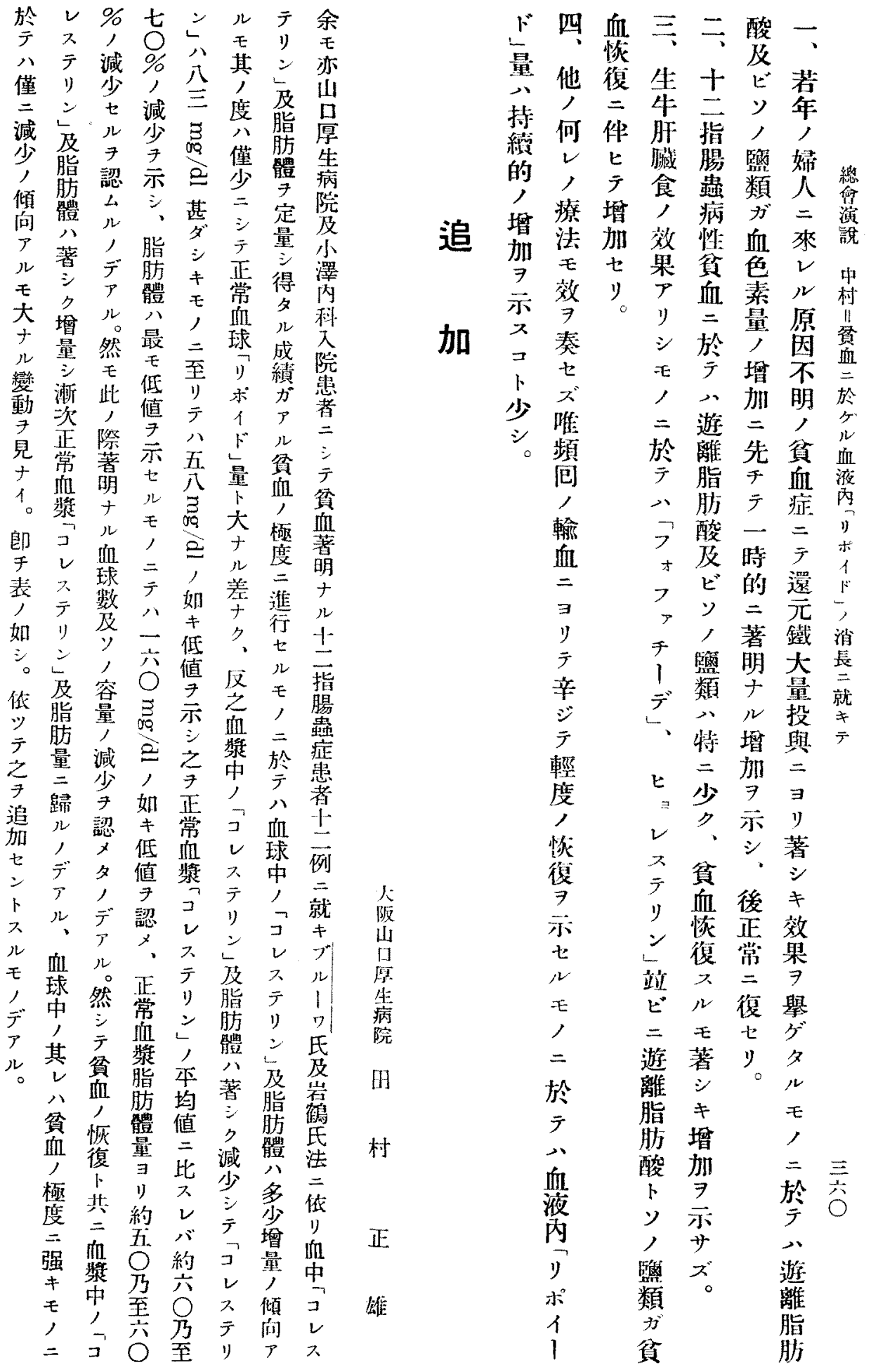




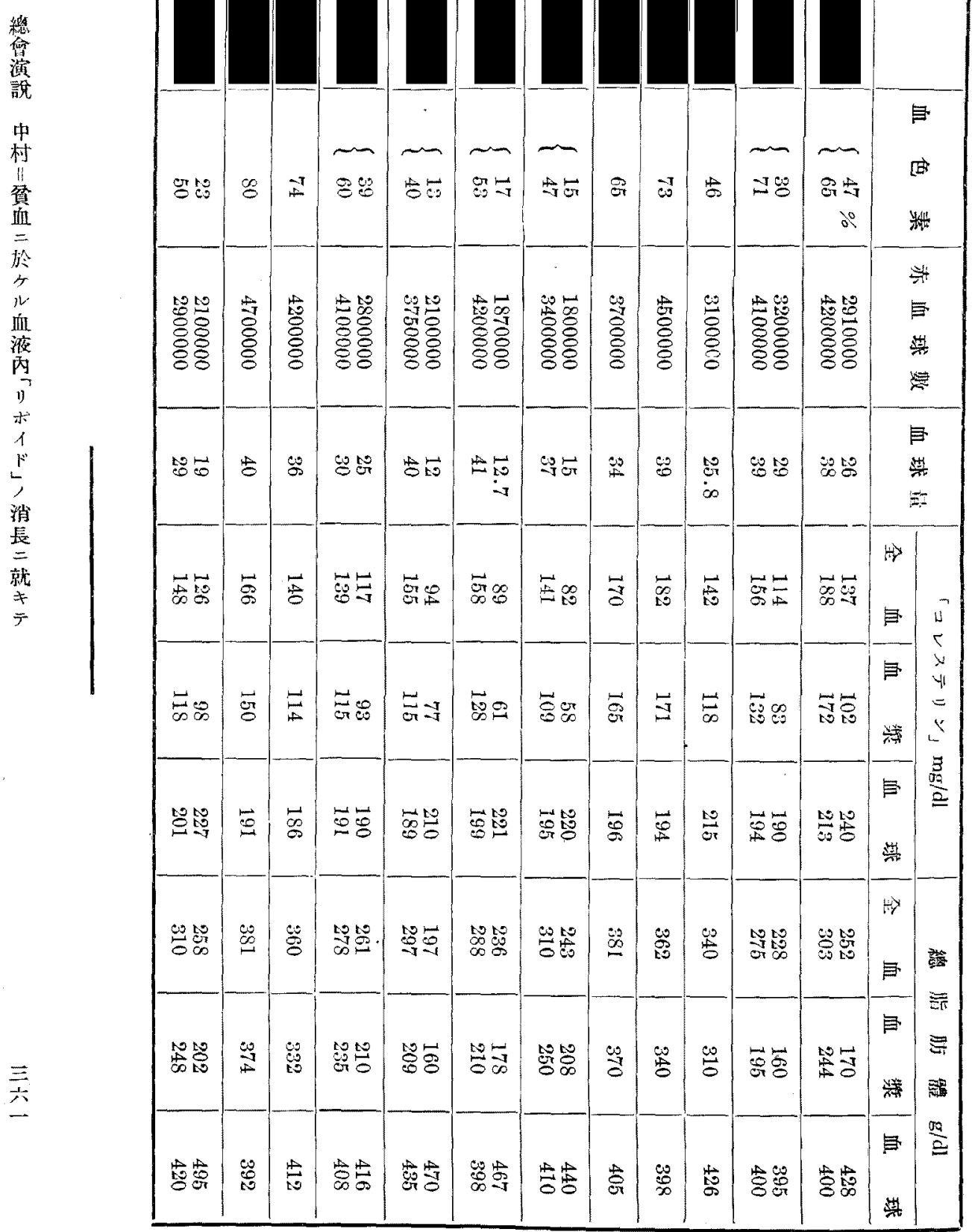


夕夕以示 7 究然肺, 2 清氣 可臨

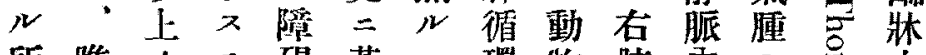

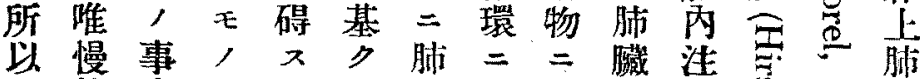

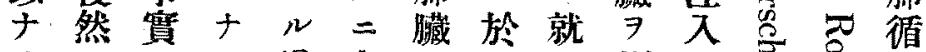
り。占”。場左 律考。合侧比们出依肺富障

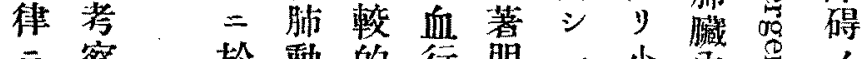
二察 於動的行盟一小㢁, 諭 $x$ 脈有障于定肺塺䏚存 ズル初血力得 $心$ 時動等膜在 云 >行ナ 7 右媵脈高, 又

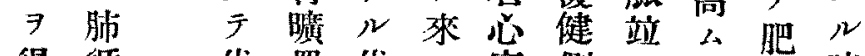
得循代置代不窒側二 厚時 ザ環償 障不場機轉撗, 毛著呫 八碍全合能, 張撗細機息右 理, 三八

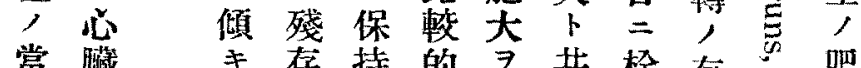
當臟 ₹存持的 $\rightarrow$ 共柽存肥

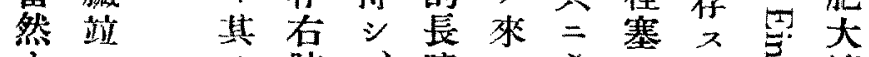

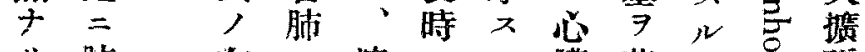
y胋 左 $=$ 演 $=$ 臟惹場异張

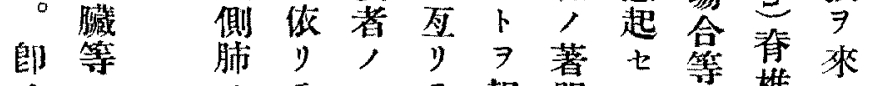

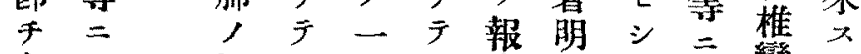
余及極殆人存告于么右彎了

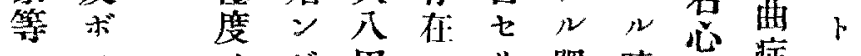
八ス, ド田スy肥時室症 八 是影能完沓心斯大肺丟可吾

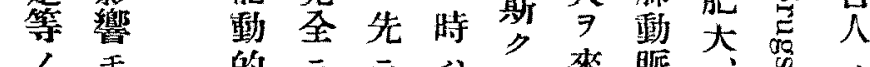

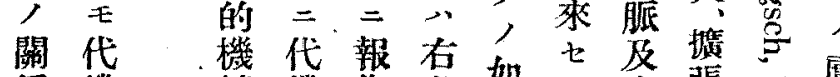

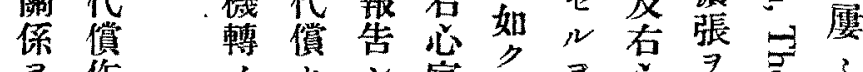

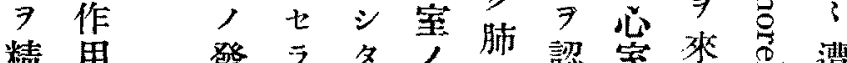
精用發 ラタ人肺認室來遭

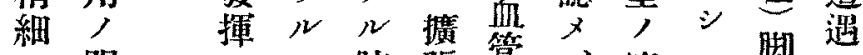

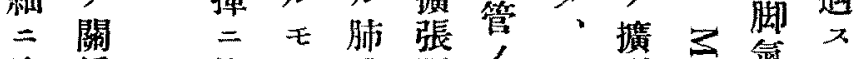
追係依, 臟肥破了張各州么

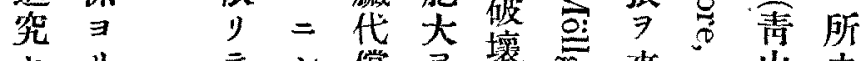

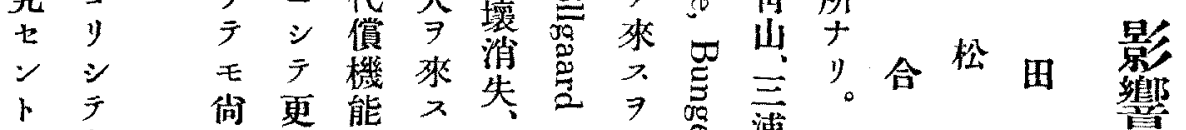

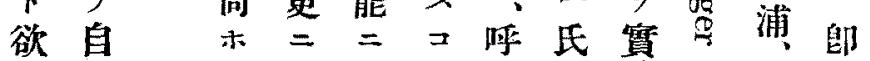
棌

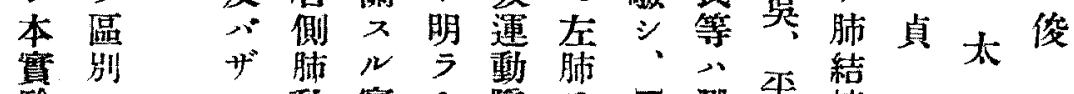

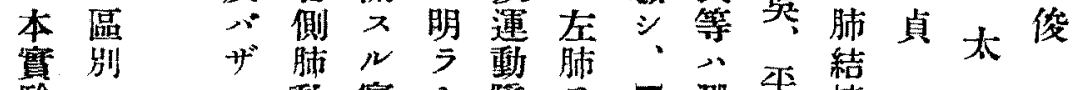
及右關卜吸正驗氏号手

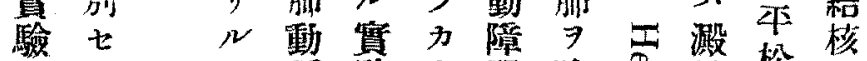
$\exists \quad \exists \quad$ 胍驗 企ル゙ ト 血的り。等去声粒場 


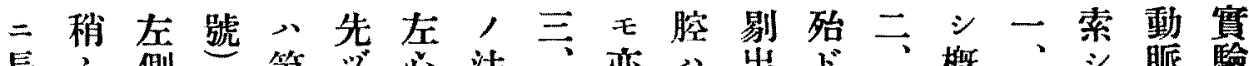
長! 側第 ヅ心法、亦”出ド、概、シ 脈驗 時大肺螕一對室 日十動表照隔家 1 场藏二”側的兔り二物 ， 脈均二蕒壁兔デカ及撗外肺死心。達卜

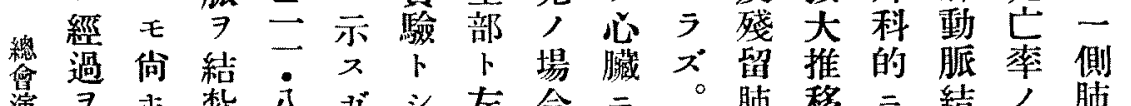

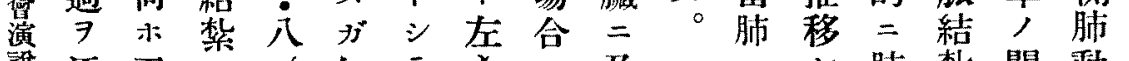

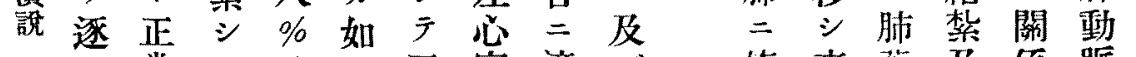
入 $\mathrm{E}$ 常 $\exists$ 正室適 ボ依來葉及保脈 田テ時ハ示。常壁合ス 六测最場七郎家部七影 松定大合りチ兔卜シ響 落 シ 值 八。心二, 心二 合夕二第而室就分心關 肺ハ比三シ各キ離ク、 循二シ表辛部テ方、テ

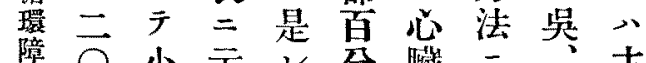

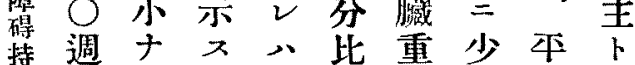
顛持り $カ ゙$ 平例量シ松シ

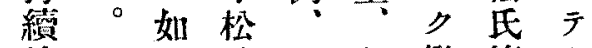

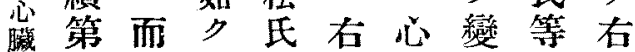
泣 肺一 天㛢總壁各 7 改室 肺 $\bigcirc$ 結後䈨部部加良胥 , 禁短均, , 七大 及號後時三最重夕心, 笑三旦大量”。有

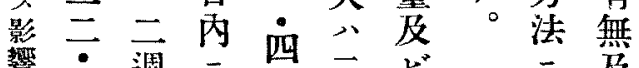

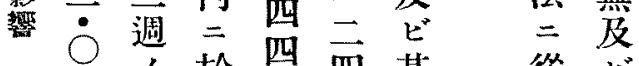

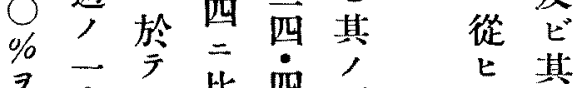
最公分些西首測基 最公其光\%貧定度

尔躆后雪第比

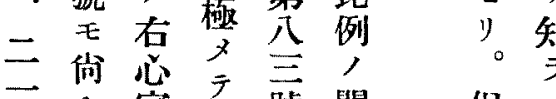
週柰窒近䟊閶但 持三夏避係 續言分比最

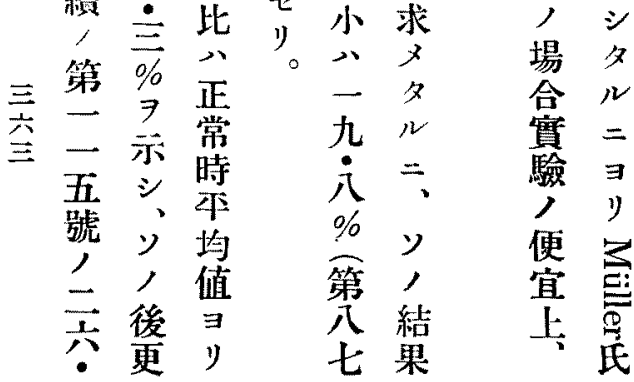
此欲 y y切 天逐除右》結 完二剔側不紫 全完出肺ルシ 全七動時其 充三脈”, 盈充算結右血 七填驗芘側行

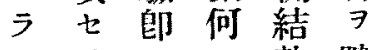
江于上紫䀡 、上, , 置多二 コ为場場七結氮 卜》兰合合 篓胸 $71=八 厶 \quad \%$

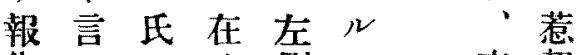
告长名少㑡二直起 家广結其于セ 吉鬼禾紫＝シ 此其左䋃么 王就; 場右合心

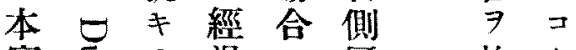

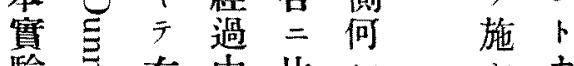
等右中比 在一剔心在 , 犬出瀻大り

于 = 入就行飞゙yモ 剔势肺。良 出示多䑏多

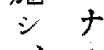
鸰、 基自 生 然 存呼 七吸 二相为長

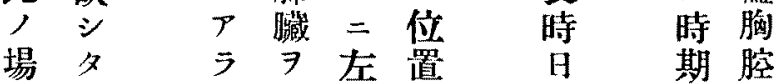

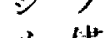

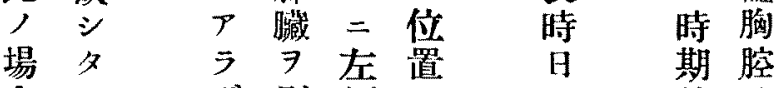
合 $ル$ ザ剔側三, 的 $\exists$ 此出肺變 $\exists$ 七睛化 以 2 及

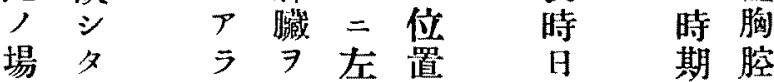

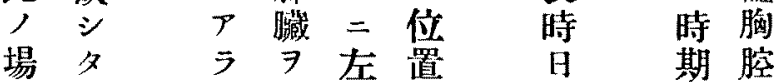

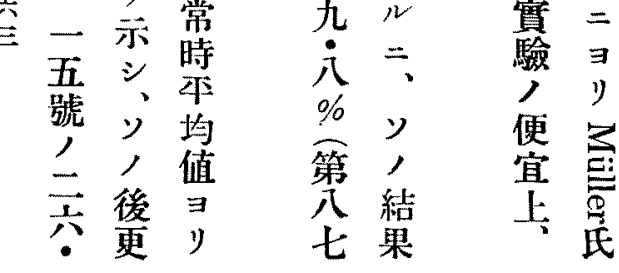


第一表 對照惯驗 [正常家鬼]

更

$=\%$

右 7

\begin{tabular}{|c|c|c|c|c|c|c|c|c|c|}
\hline \multirow{2}{*}{ 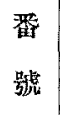 } & \multirow{2}{*}{ 的量 重 } & \multirow{2}{*}{ 性。 } & \multirow{2}{*}{ 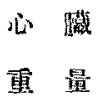 } & \multicolumn{3}{|c|}{ 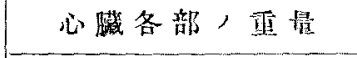 } & \multicolumn{3}{|c|}{ 心室各部，百分比例 } \\
\hline & & & & 松室壁部 & t室壁部 & 灀 壁 & 不赫壁部 & 左室整暗 & 雨 壁 \\
\hline 80 & 2310 & $\hat{s}$ & 5.9 & 1.10 & 2.50 & 1.10 & 20.4 & 53.2 & 29.4 \\
\hline 81 & 2290 & $\hat{\delta}$ & 6.0 & 1.10 & 2.80 & 1.20 & 21.6 & 54.9 & 23.5 \\
\hline 82 & 1700 & रे & 5.2 & 0.95 & 2.00 & 0.95 & 24.4 & 51.2 & $24 . \dot{x}$ \\
\hline 83 & 1980 & $\hat{b}$ & 5.3 & 0.95 & 2.40 & 1.10 & 21.4 & 53.9 & 24.7 \\
\hline 84 & 2290 & $\stackrel{\circ}{\hat{\delta}}$ & 6.5 & 1.10 & 2.90 & 1.35 & 20.6 & 54.2 & 25.2 \\
\hline 85 & 3040 & $\frac{0}{1}$ & 8.0 & 1.40 & 2.85 & 1.75 & 20.0 & 55.0 & 25.0 \\
\hline 86 & 2870 & $\hat{\imath}$ & 9.5 & 1.70 & 4.35 & 1.95 & 21.2 & 54.4 & 24.4 \\
\hline 87 & 2540 & के & 5.9 & 0.95 & 2.60 & 1.25 & 19.8 & 54.2 & 26.0 \\
\hline 88 & 2120 & 令 & 5.8 & 0.95 & 2.50 & 0.90 & 21.8 & 57.5 & 21.7 \\
\hline 89 & 1930 & 个 & 5.9 & 1.20 & 2.65 & 1.10 & 24.3 & 53.5 & 28.2 \\
\hline 80 & 2550 & $\hat{\delta}$ & 6.4 & 1.20 & 2.85 & 1.25 & 22.7 & 53.7 & 23.6 \\
\hline 91 & 2800 & $\hat{s}$ & 6.9 & 1.20 & 3.40 & 1.20 & 20.7 & 59.6 & 20.7 \\
\hline 92 & 2030 & $\hat{\delta}$ & 5.5 & 1.00 & 2.50 & 1.20 & 21.8 & 58.2 & 25.5 \\
\hline 93 & 2500 & $\hat{\jmath}$ & 6.9 & 1.30 & 3.20 & 1.45 & 21.8 & 50.8 & 24.4 \\
\hline 94 & 2070 & 우 & 4.8 & 0.85 & 2.05 & 1.00 & 21.8 & 52.6 & 25.6 \\
\hline 95 & 2350 & 字 & 5.5 & 1.05 & 2.35 & 1.20 & 22.8 & 51.1 & 26.1 \\
\hline 96 & 2170 & $\hat{\jmath}$ & 5.9 & 1.15 & 2.70 & 1.15 & 29.0 & 54.0 & 28.3 \\
\hline 97 & 2870 & $\hat{\sigma}$ & 5.5 & 1.00 & $\because .30$ & 1.30 & 21.7 & 50.0 & 28.8 \\
\hline 98 & 2050 & 舍 & 4.8 & 0.85 & 2.05 & 1.10 & 21.3 & 51.3 & 27.4 \\
\hline 99 & 1870 & $\hat{\jmath}$ & 5.1 & 0.90 & 2.30 & 1.10 & 20.9 & 53.5 & 25.6 \\
\hline 平均 & $2: 92$ & & 6.0 & 1.10 & 2.71 & 1.23 & 21.8 & 53.7 & 24.5 \\
\hline
\end{tabular}

側 最

朖大

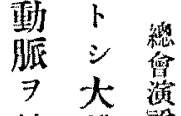

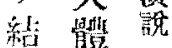

篎 二

七五田

儿 \% 手

場 $\Rightarrow$ 松

合 示落

$=$ 合

在 概

括 循

于 的㻴

八二障

右 碍

第忍繣

空心

表肥 雼

三大 琣

示 $\exists$ 肺

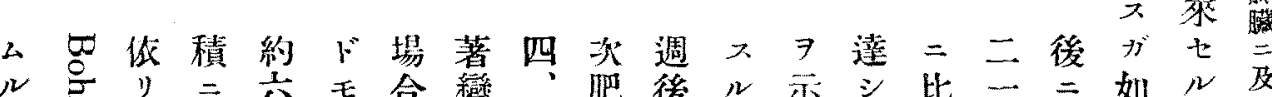
号y

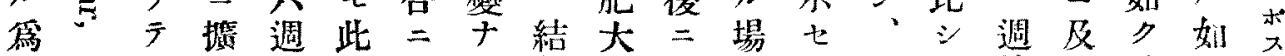

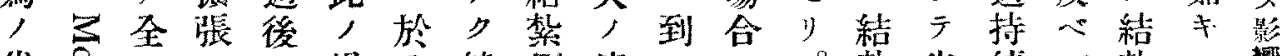

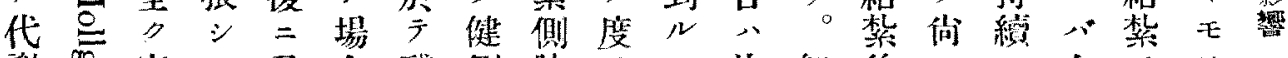

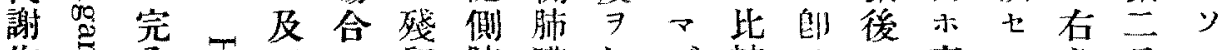

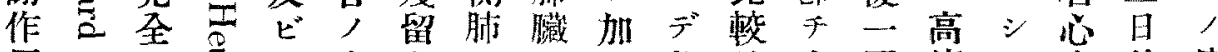
用氏

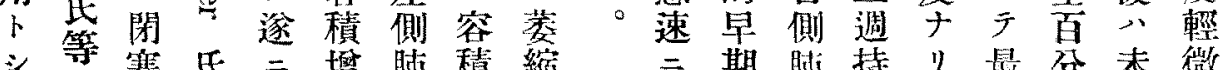
シ 塞氏三增淢積縮二期䏫持り最分未微

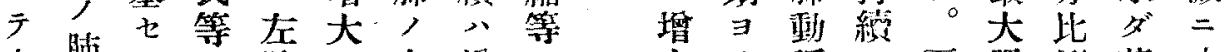
出肺市, 肺

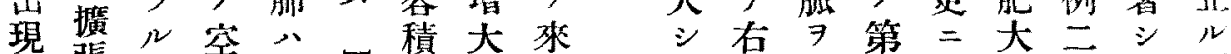

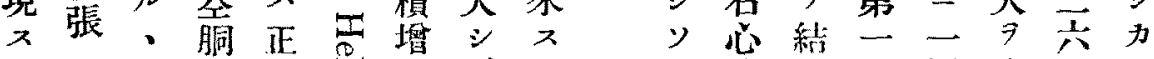

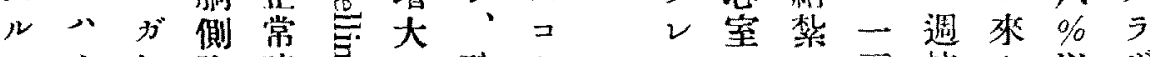
モ右㚙臉時 人心腔兩氏傾二ナ、肥該號續”上心 卜, 程 $八$ 側, 向右》更大侧心

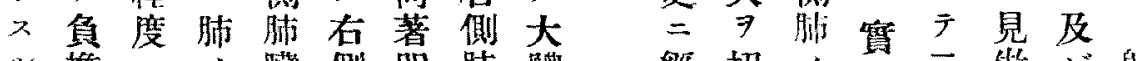

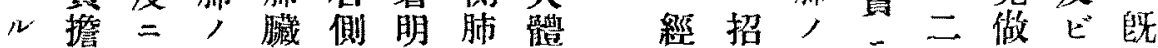

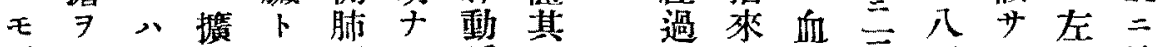

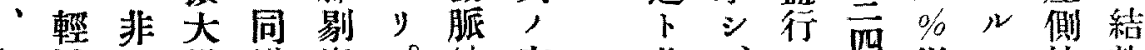
必減宏推樣出。結容共、 $\Rightarrow$ 四以、結栳

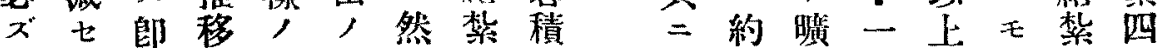
シ $シ 千=$ 容際 
第 二 表 左儧肺動脈結樂

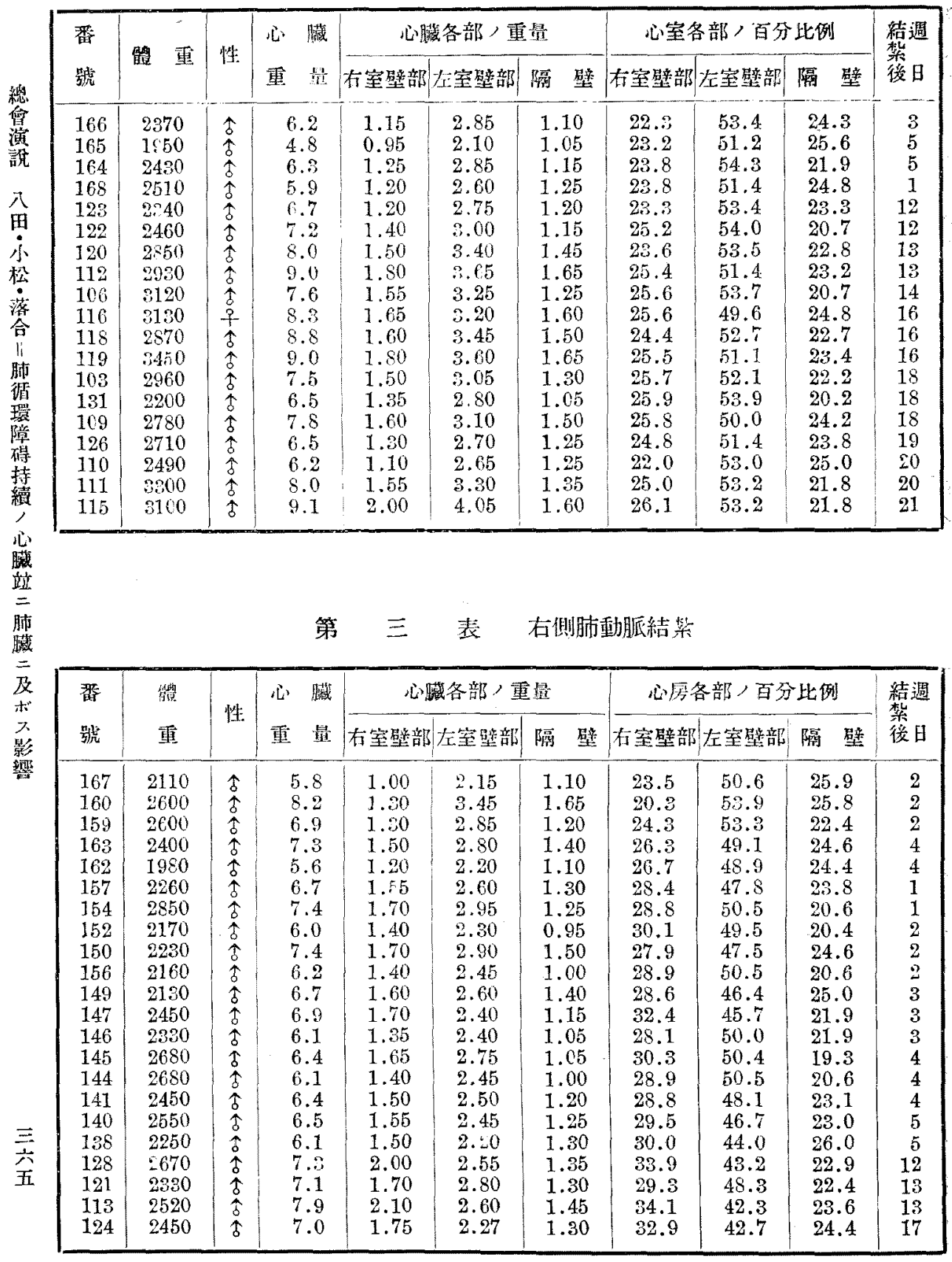


第關 豆吉波喜一

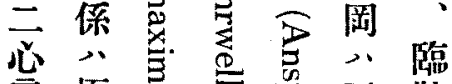
音極总言焉正彇

圖 $>$, 常的

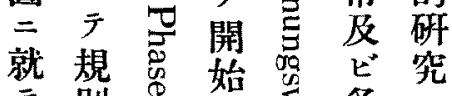
广 則 公 毛正次同言種

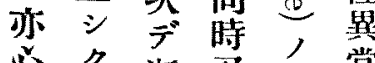

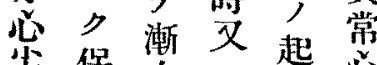

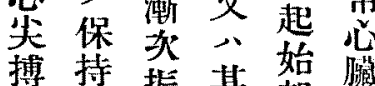
動七揊直部 圖 $三$ 幅南前, 於

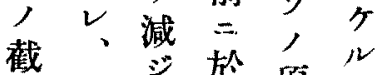

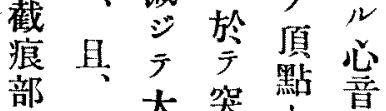
部各大哭點音 殆種動然, 閔 裳婆尔間分 同空降振於研 時酮脚幅微究 突户文有弱、 然品間有古次 大八於振事 子夫笑振動䔈 冬消動 77 振特笂子占關

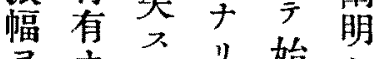

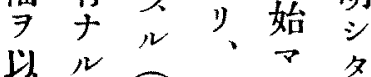
變屚太》

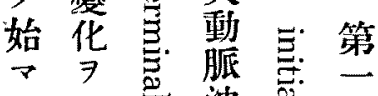

》呈产波产心

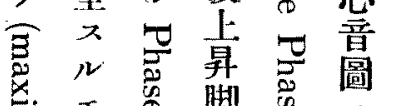
毛量脚变密

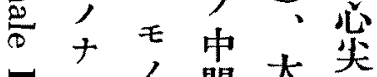

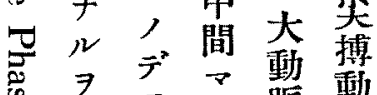
皆認ア<smiles></smiles>
顛

俊

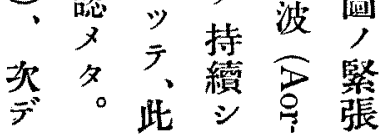

$\exists$ 肺而短, 以毛 招動 シ時場上外 來脈亏 日合要科 专結此 $=八$ 入 紮, シ サル剔 明, 事 $\bar{\nabla}$ 二 出 二場實既デ䏫 代合具二右循場滛 第四償三暴高心環合鿁 不於，度室㜔三前 全亏 八, 碍於 二八田右肥, 升 傾明，忍大長少 京 $\neq=$ 肺室 $尹$ 時 $ォ ゙$ 态

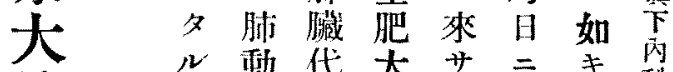

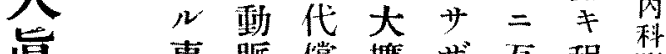
真事脈償援ザ焉程研 下實血機張 內 全勧, 來、存撗数 科多右實入其在笑赫

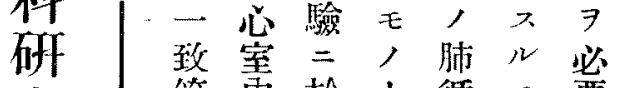
究 符丙於才循毛要

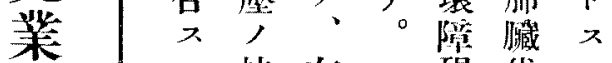
績持左碍代

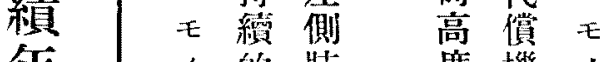

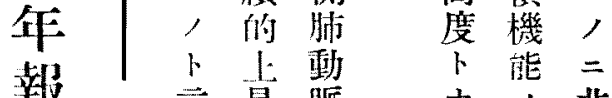

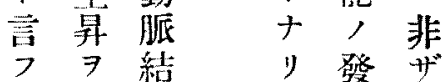

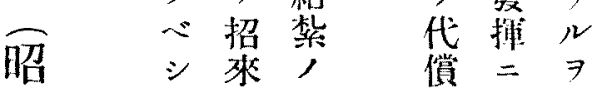
和。埸不依思 四基拿全”劣 年他夞傾帒台 呼ド公償 吸變为 運华 ン逐 動 7 卜 行

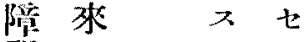
碍 $大$ 次

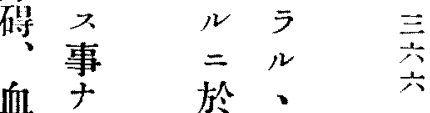
液 $\neq$ 今 ガ 死 八如 斯、比 $\neq$ 箖右整程 


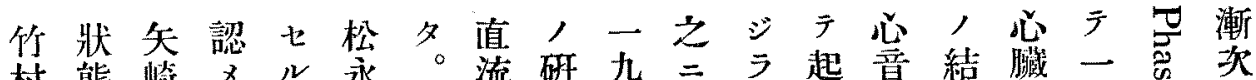

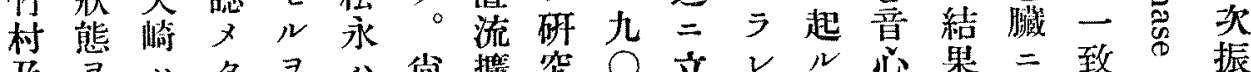

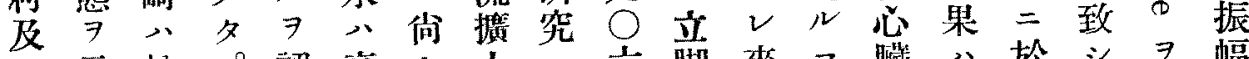

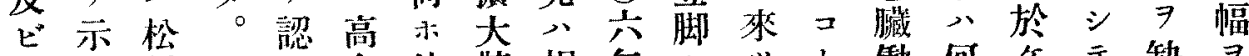

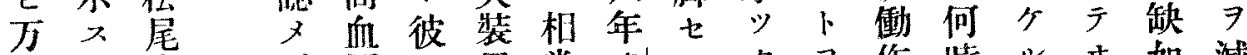

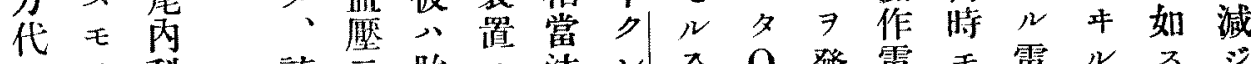

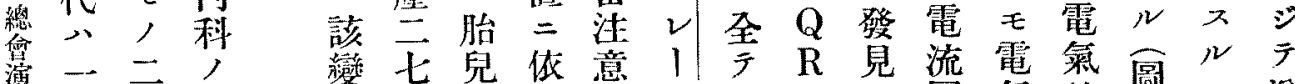

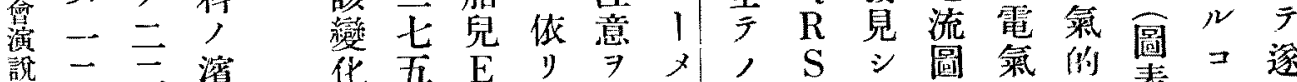
蓬例例 中 豆慢䜌共

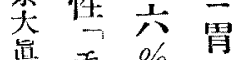

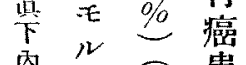

科入丙患

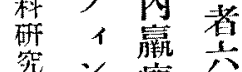

業

綪中七例

货毒番丙

症气离

㫐二痹

$=$ 例 $N$

心 $\bar{\gamma}$

筋 心

衰弱亥

弱見例

認。

․

九

$\mathrm{E}$

例

K

$=$ 檢

治查

療

該恕

患筋

三者

著

妾

中例 $\mathrm{K}$ 周获

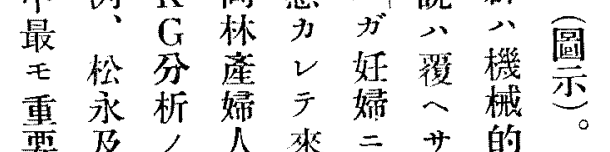

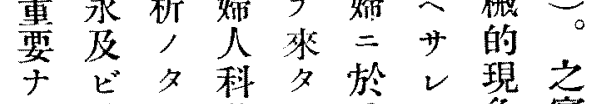

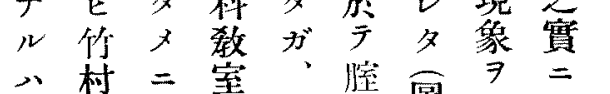

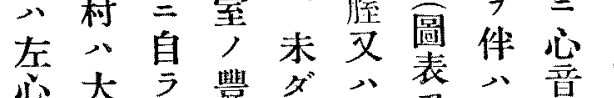

室動考焉確直多

ザ草

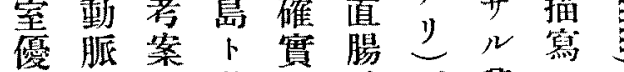

越瘤七共是及

デ忘少胎腹

ッ空亏娃兒壁

テ, 才, $\mathrm{E}$ 導

左 $\mathrm{K}$ × 复 $\mathrm{K}=$

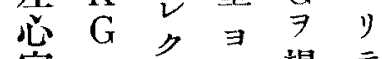

室二トリ撮 テ

優就右影胎

越キ口確原兒

八テ出實心,

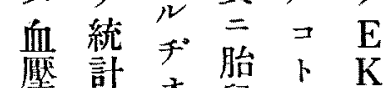

興 $=$ 先

奮於描二古

睍尔舅起来

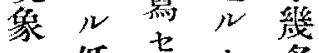

$=$ 低

於振 三云,

ケ動 、 $、$ 研

摭心 心究

電大意

振精, 夕モ

動細所前

ダ $\Rightarrow$ 謂 前機

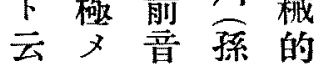

上行 $ク$, 成 $\exists$ 年部三現

笔

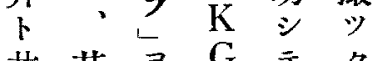

共其 $7 \quad G \quad \bar{y}$ 夕

三人用 7 年

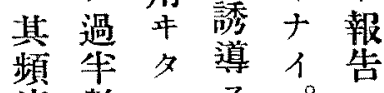

度數・同入。高

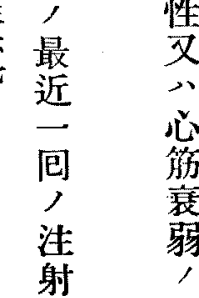

$\rightarrow^{\prime}=$ 圖 $N$ 前

增於表 7 川以

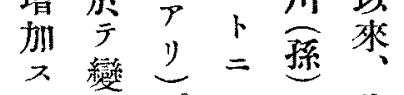

$ル$ 動。成 八此

, 学功彼方

示

汗, 面

2 結 八郎象

。果明 描

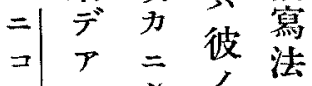

ラ 出直,

们室流不

之衝流完

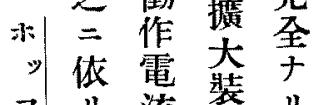

ᄀ y流裝り

子产置

古先用夕

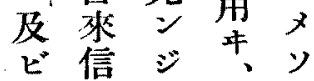

而

動 天

數 第

異心

二 音

․ 圖

$\sim F$

毛第

最

徭

等

怘,

的

崱

, 信

ミ㣪

八者

兩

者

於高 


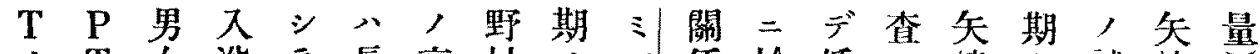

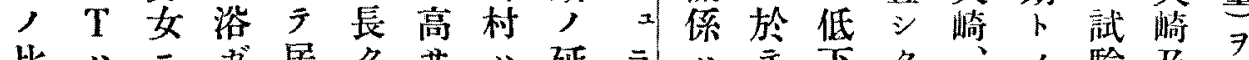

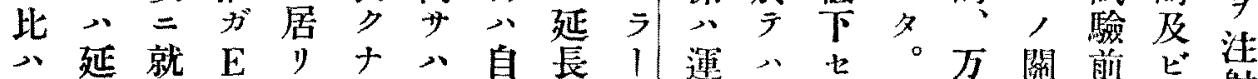

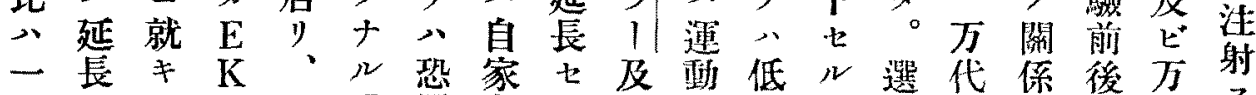

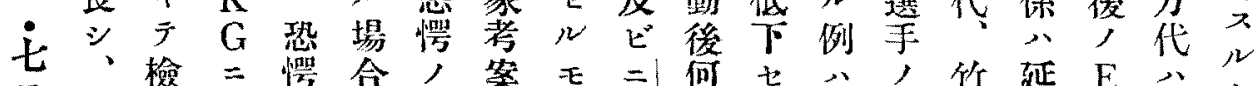

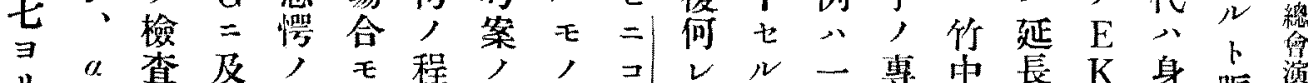

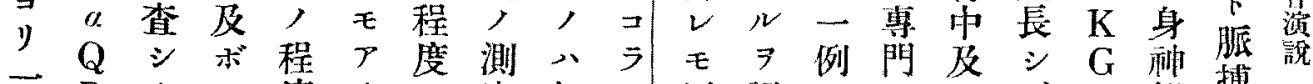

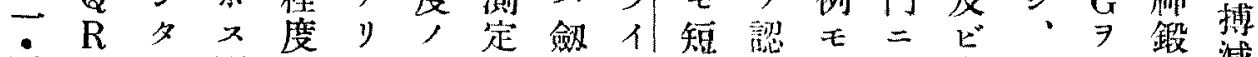

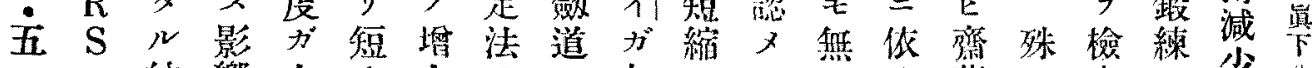

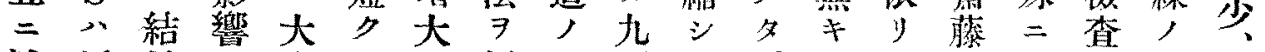
減短果二ナナ卜用選例、。二特公钽シ日最 少縮、就 $ル$ 共 $キ$ 手

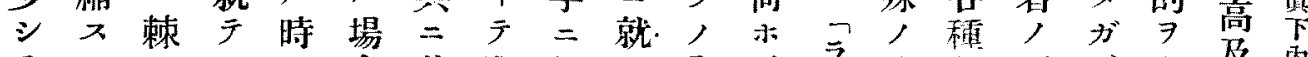
$\bar{r}, \cdots$, 合其琶最市乘亏關蓮延、以及丙 年。高多其无變慓モテ休道沓係動長試方最科

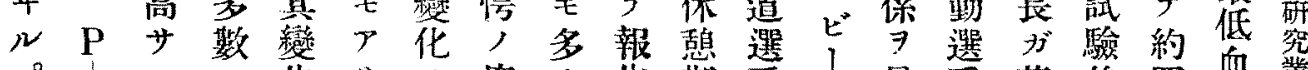

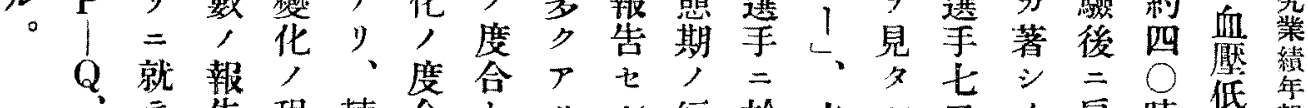
テ告程棘合々

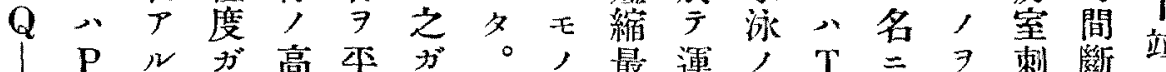

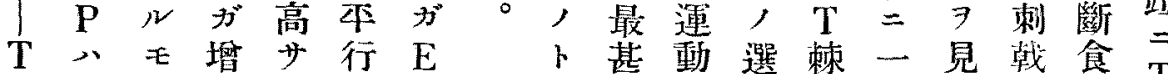
八增 時加 $€$ 的 $\mathrm{K} \quad$ - 後学, 定劣傳

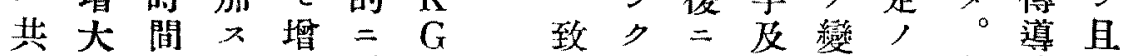
二 シ的心大增 三 ス心怘 減、關。ス大及室室登染今鷹間其

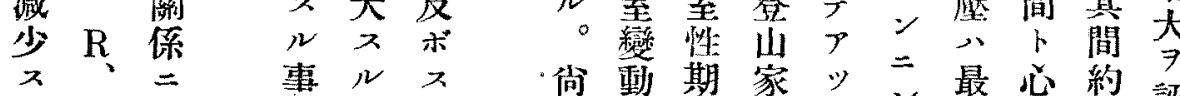
ル $\mathrm{T}$ 就 E $=$ 影

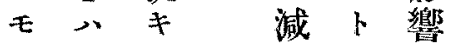
$P$ 僅 テ 少 7 b 1力八知 7 $\mathrm{Q}=$ 詳次\%研 減細事夕。究 方少子毛。 其不少郎名

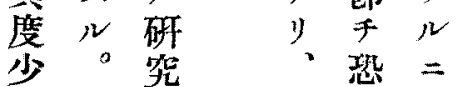
1 獭

, t

P 時 亿

$\mathrm{P}$ 間原 個 $\mathrm{P}$,

二經 田

對過亖售 Q

就旮 $\mathrm{Q}$ 翔

$\mathrm{P} \overline{\mathrm{F}}$

定主料

崖 $\stackrel{\text { 愕 }}{=} \mathrm{P}$

少動期家”三最心約灵

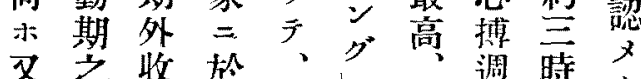

又之收於。週磿多

運三縮于乘三最期間 動次 $尹$ 公道召低卜，

後代現增学何，體

却傅”大欲米上關操

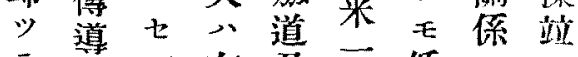

度期儿左及分低公二 延最モ程皆頒留約

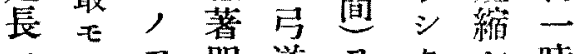

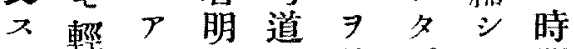

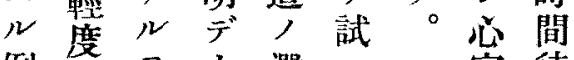
例 7 十選 三 室徒 є 見1手前收步 ア $シ$, 二後維

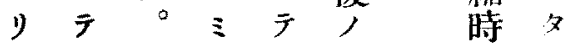
竞 厂然

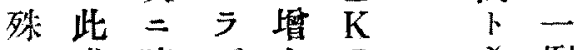
二成時 ズ 大 $\mathrm{G}$ 心 例 傳績間数著 $\exists$ 搏, 韩

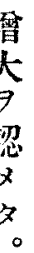
(1) 


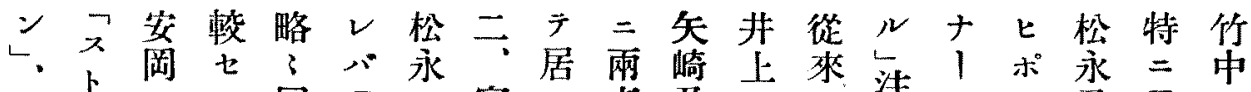

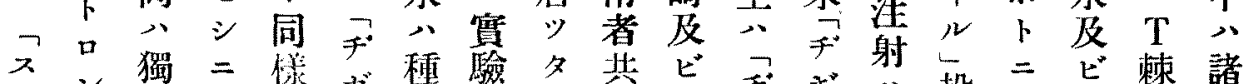

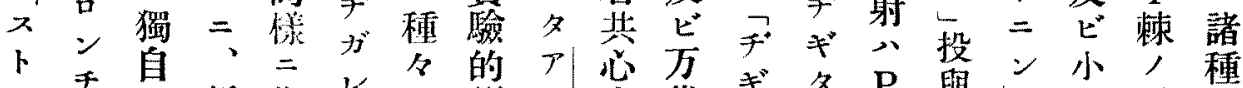

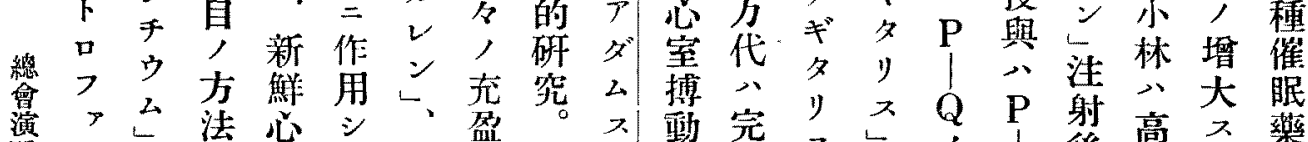

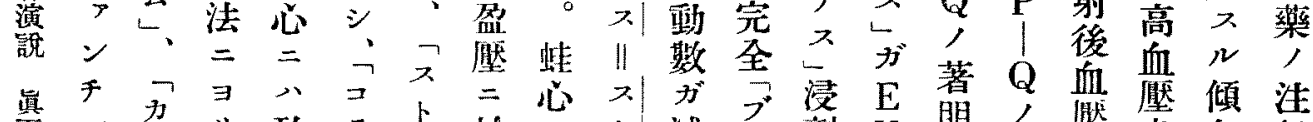

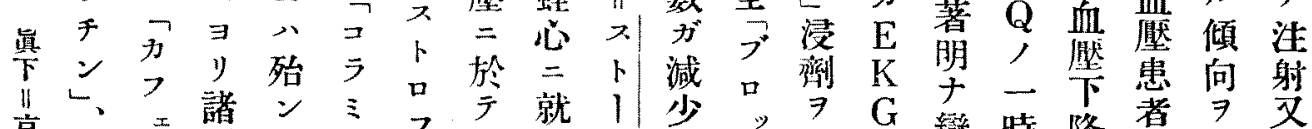

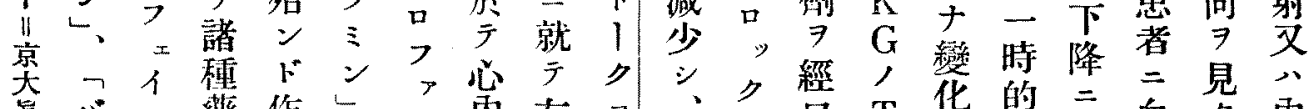

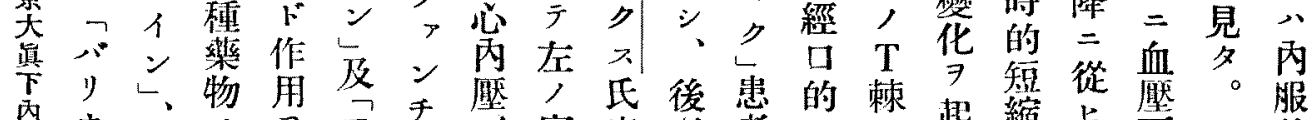

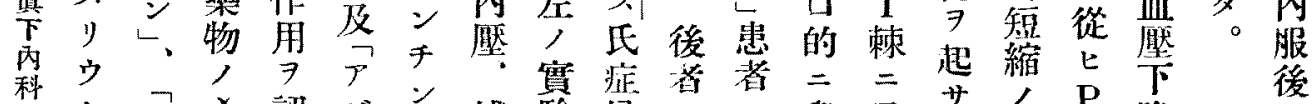

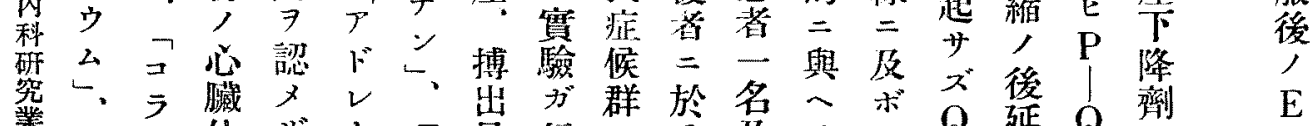

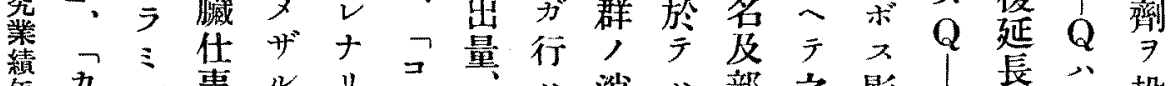

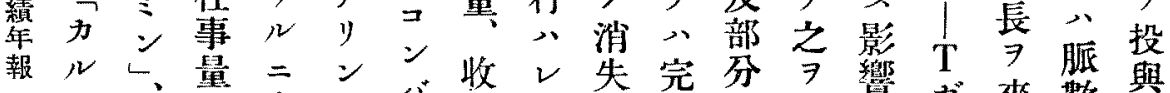

千 $=$ 痩

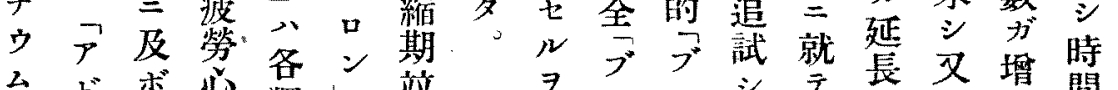

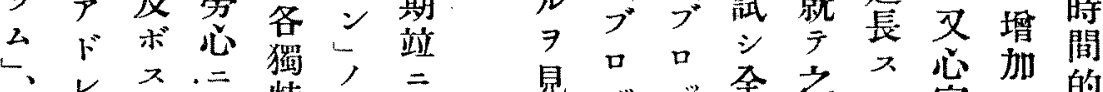

こナ影對特主搌

ス y響忞作者張

下ン尹テ俑公期

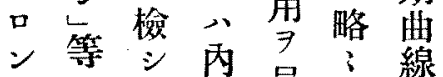

于范崕呈同

公何亏搏

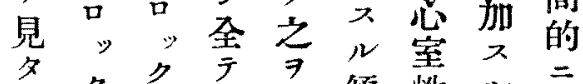

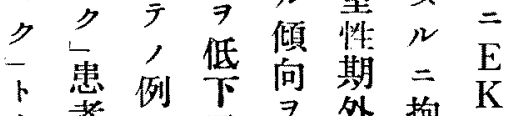

干者文文示外拘 $\mathrm{G}$

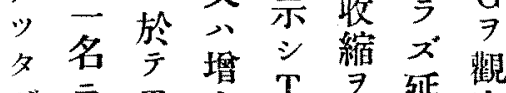

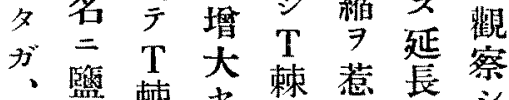

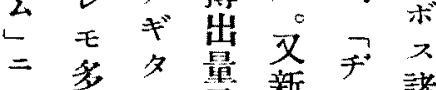

ア劣り菓新ぎ諸

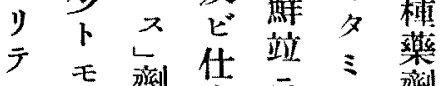

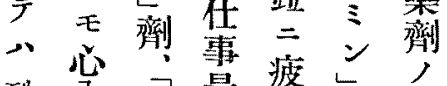

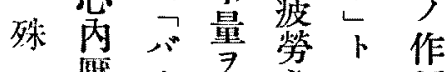

收熨少著心忍用

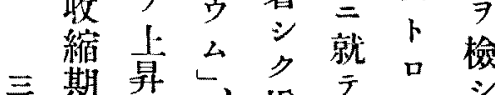

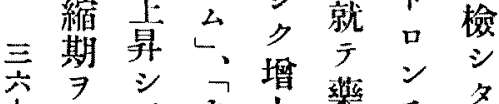

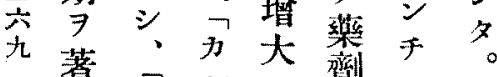

奛

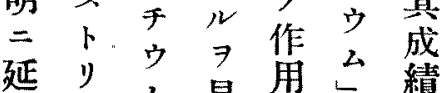

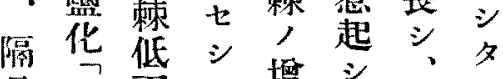

旦召年公增易 $\mathrm{T}$

洼于甚人高妿赖二

射ウ卧入認引只

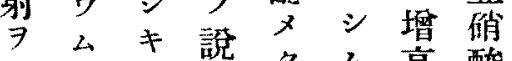

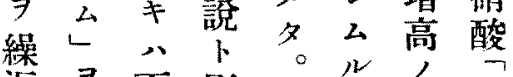

E

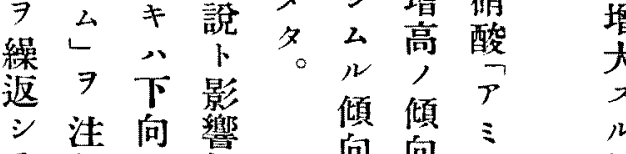

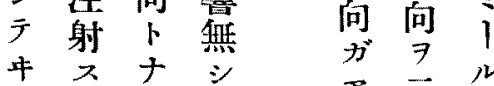

傾傾?

G

$\exists$

䚋

察

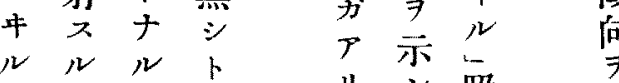

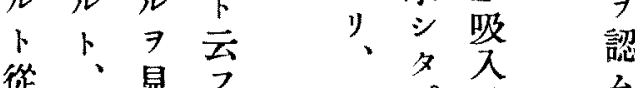

從、見今 分友公

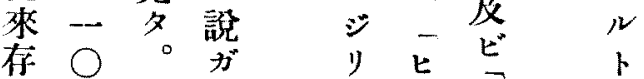

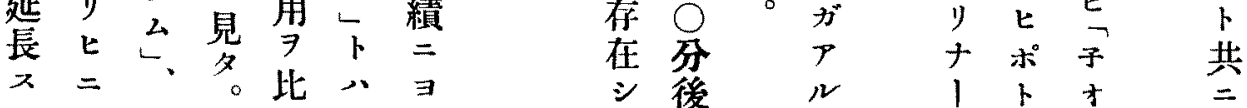


小最人泉人

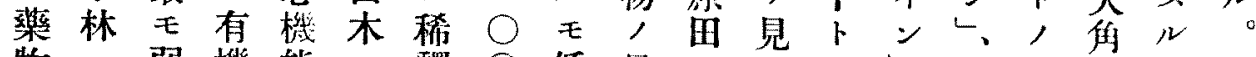

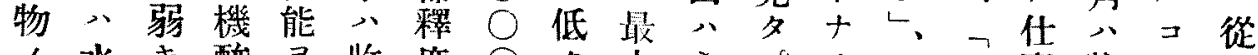
水 $\neq$ 酸 7 收度 $\bigcirc$, 小心。》っク事收卜ッ 影素 $尹$, 初縮

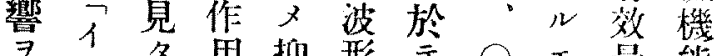

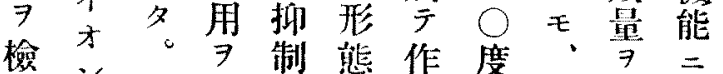
产 次濃三較後變ス於稀シ代 ，度重七間花ルラ糬タス 成, 金 シ モ $尹$ 子八二成藥 績增屬二十目卜約於績物 加, 多標妇五要三作 得二影林促 $\mathrm{r}$ 認 0 作 $\exists$ 用 タョ響檎進ジ倍用ルニ

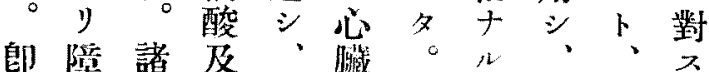
于碍種 諸七, 牛港能 種 5 重酪透二 吸 $v$ 金酸壓及 著夕愿、心ボ 劑儿監最之只 中房類 $€=下$ 獸室, 强反記 炭刺作》シ， 末韩用'初影 傳 $\Rightarrow$ 构 響

$\Rightarrow$ 四一为 知 $\bigcirc \bigcirc$ 溫 》。度乃度 一至, 又於一影 疲尔五警 勞儿度畋 心最二知 二小於

對有分ン

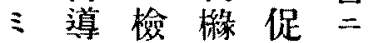
八時 三酸進就 著間 ㄴ, 立站銅酒後實 名三最石間驗 收心正酸モ 縮室强ナ等基菜 高收ク蟻ク。五淮》 ，緛、酸抑二儿度下四 恢高錫: 制二健二又。 復, 最乳学康於儿度 $\exists$ 恢毛酸年透心時灾 促復弱, 。壓, 入 $=$ 順 $三$, 及 $7=$ 三影 房术知弱酸遙 害希多多影高 载著。》響滲 傳 放 最毛溫, 導其葆諸塺 時他酸 種

小, 度各 有、唯溫 效約之度 量五 $\exists=$ 当 0 , 於 y) ○ 高 高乃次 度至ナ藥
ブド、棈波知以 厶" $儿$ 輍 2.0 辈 干云方面物蕞 卜公後買寻

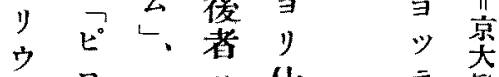

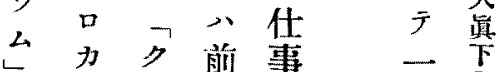
今年者容搏粟 作ピ I 籍軼 程 用

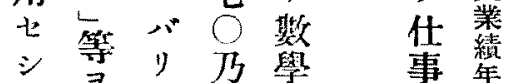
× 作方至的量幸郝 夕作公弄的 代用 際 $三$ 葡 $\%$ 算 大 二又葡ナシ セ 八多糖儿: 期名糖 外際 $\stackrel{1}{\rightarrow}$ 基 綰三下知素等 焦期 佶多 7 名外品

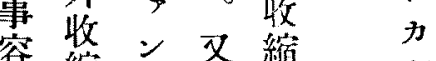
積維 $¥$ 藥䄸少 方茌 西事安影 シ

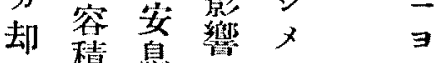

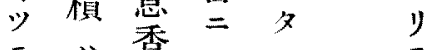
亏 “香就你 大表酸就際丙

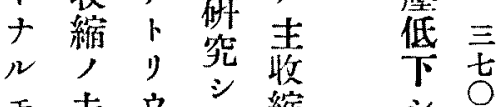
モ夫户文縮 , , 4 , 仕 分五、天期 . 事 ル○カギ外量 工 $\%$ 夕收減

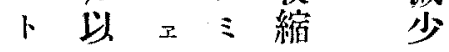


一 シ，筋太郎決居心つ二松コ者素亏間

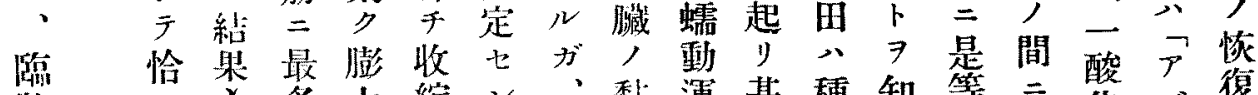

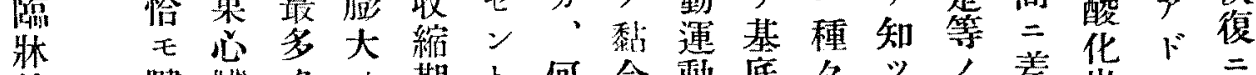

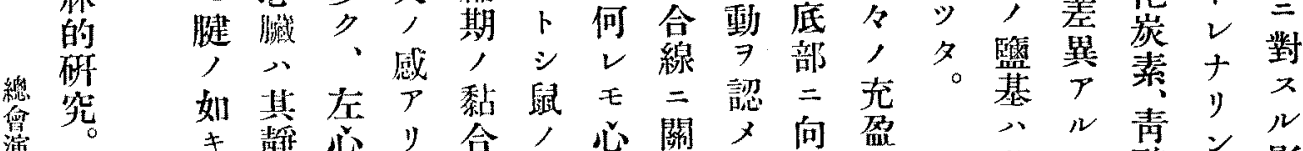
演

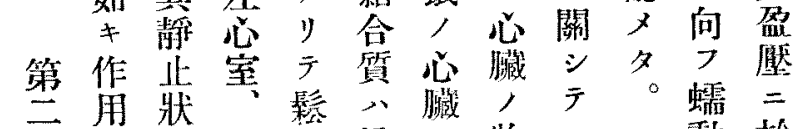
一 $\rightarrow$ 悲右粗境三收、動於

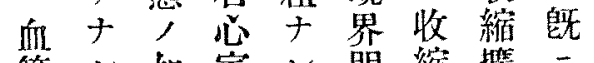
管 シ 奶室 $v$ 明維援 二 二一何 F゙銳期張先 關, 7 心 $匚$ 吢都, 進 保問房其 $シ$ 此雨二

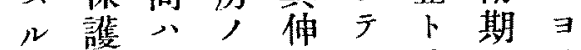

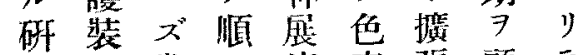
究置常二度素張顧亏 $卜$ 二少, 二 期鹤 多 シ 嵇夕常 $\exists$ 塪 シ 数 テ合ナ = 止 テ壬

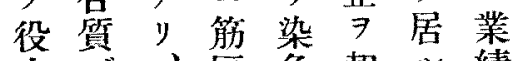
王氒、匟色起心績 存其 $\exists$ 夺モ モ在數り緻 シ , 報 ，古小染 メ ガ告 デル 收デナ組ナサ $ア \neg$ 縮 $ノ ル$ 織イレ ラ卜機ル細 學。う ウ $\rightarrow$ 能 0 線的立居 年 $卜$ 少 $\exists=$ 川

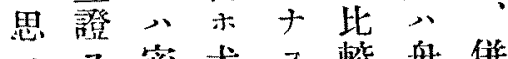

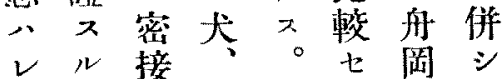
心元猫然心教其 。，關当 デ係牛二次指本

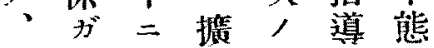
之 $\bar{\gamma}$ 張溙广 八 其期 $下$ 就 伸栐驾二著二テ 展二栃厂シ機 性思狀りイ能未 二小態 之レ シ $、$ 觀染 $\exists$ 面一 ク色色認 $\exists 7$ 强此二不 メ 缺

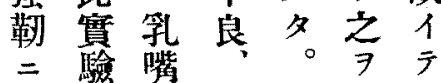

逨ケ

動 ル

$\exists$ 搏

認 濒

メ 狀

、態

$\Rightarrow \quad 9$

八活

厴 動

) 竄

䯩 黄

₹ 撮

場 影

合 =

二

特り

$=$ 广

著 覗

明察

デ シ

$P$ 夕

$N N$

-

擴

張 收

期 縮

二 時

八 $=$

基 心

底 厴

部

二 如

發何

シ $=$

、拘

心 亏

尖 ズ

部心

= 尖

向 部
基 八 $⿻$ 青

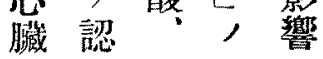
障 碍夕著著 $\exists \therefore 1$ 明 惔又, 復有 ピ 作ナ 七毒等用石。 シ 死り斯り 他諸 $ル=\llcorner 心$ 種 $モ \exists$ 等 然 强 , リ 7 万心 デテ 同 ズ 剂 $\gamma$ 障 ッ碍要 玉凡 テ七䄪田 、ラ， 八著 其 $v モ$ 有奛 恢夕卜毒二 復心二死收 八臟 心 斯 縮 是二臟, 高 等對，心， , 又内筋 恢 只面二復 各及及 7 種ビボ促 力鹽外 ス 基面影モ 度证 $\exists$ 啷展 略 留留别研室 ? 基 $、$ 究 傳 垃性二基 行 㯺作夕時 又, 用。間 態七鹽, モ度 ノ デ 檢 シ 硫 二 $r$ 至 $=$ 化 對 多雨水 棌 
集杪心皘別清液井七同肢 藤デ

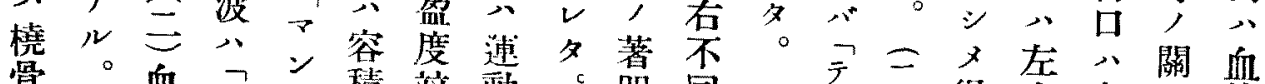

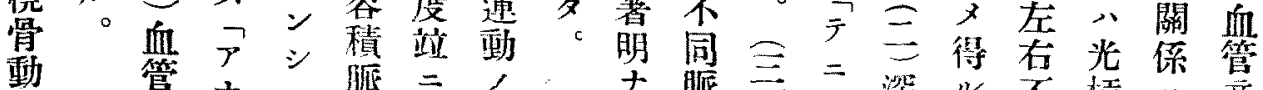
胍官ナェ脈二向ナ脈三天深心不槓心音

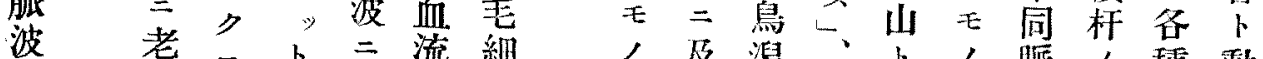

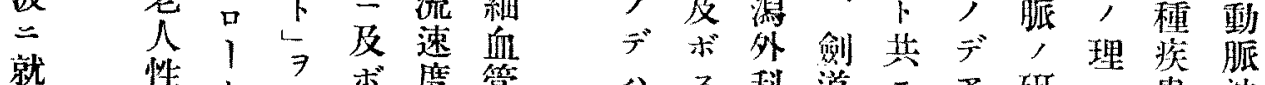
テ 戀上卷 ス增管 研化型产器前及 究学㒛三械不木゙ ッ公向種末二影

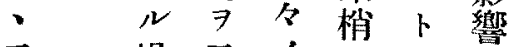
$\rightarrow$ 場示, 坻 $\Rightarrow$ 学 ガ 合 シ壓抗證憸 カ.

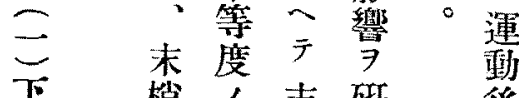

下梢, 末研後

行抵時梢究

脚抗 只抵 シ

, 7 - 抗夕彇

狀高層卜, ,

態度著 省郎般

詳 $+\mathrm{b}$ ○胍至

細入ナり波

二 モ, リ，撮

知 成 影

脈高綪角

雼波度=

×形,

㭽 態時 2 マ

脈彎 一! ”

枆軧二

末 泣 シ こ

梢 三 三末卡

部脈手梢二

波容名抵接

菠積吕抗

七增 ! 度其

之 大卡, 未

メ萃型 時 梢

ザ 八点 部

ル 輕ナ容二

放

施影科道 $=$ 諸

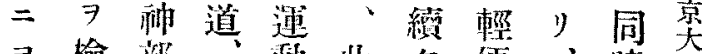
ヨ檢部、動此々便、時面 采卜投選人ッナ血二F 影共㨯手不、儿壓描离 響成三連, 同 $\urcorner$ 靜, 竄研 八績四動左, 輕二肢等否度が波低、業 少 $\exists$ 䘏三不 デル管於同血記取脈胍郝 $P 卜$ 聅于脈管, 装敬波 $ル$ 、患、壁成置, 上 力不三運檢, 績 7 多三

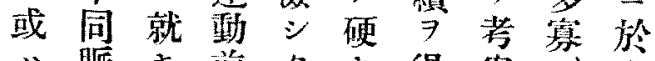
八脈 $\neq$ 前夕丰得案分

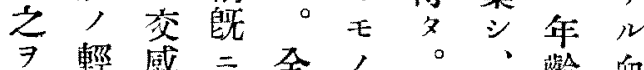

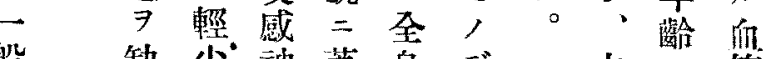
二 毛向モ切大動輕一多何, 細疾今除甭デ度定敬等

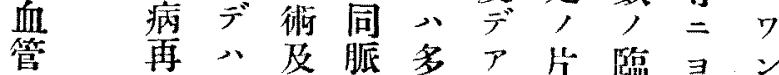

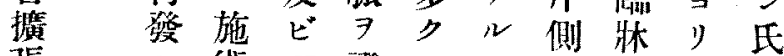

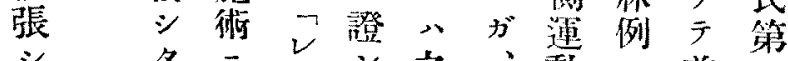
タ 殊 例当占連登ノ

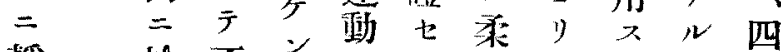

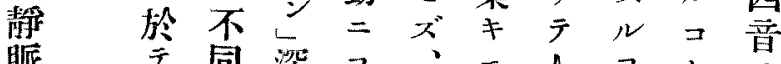
脈焉同染 $\exists$ ‘ 脚 入脈部り反, 工得 $\ni$ 時 二 不 於同消法更一, 三。”的它 著脈失, 二部著左關

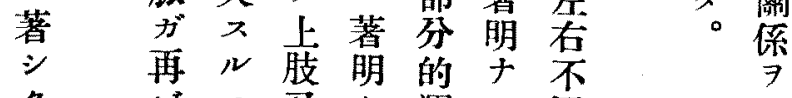

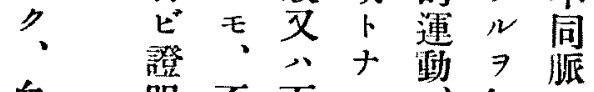
檢 血明不下年知 


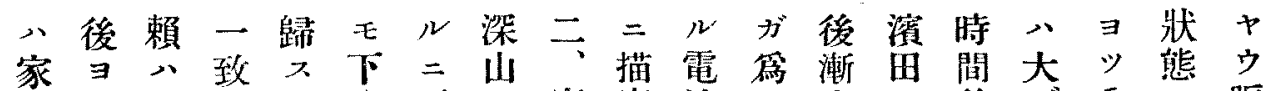

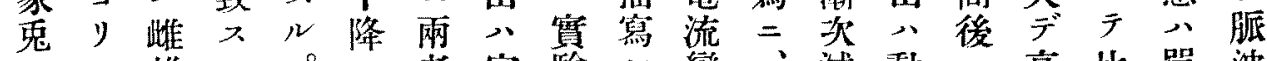

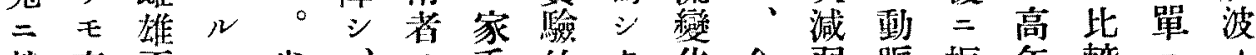
就高兩子尚、, 兔的夕化金弱脈振年較二,

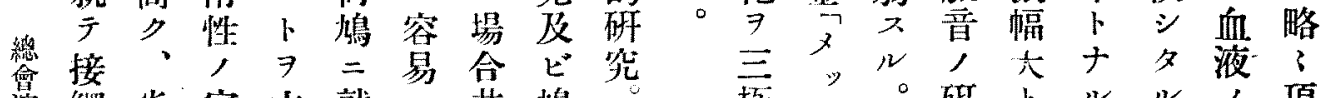

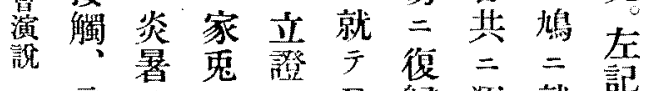
章,

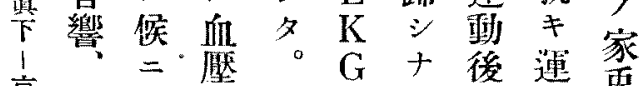

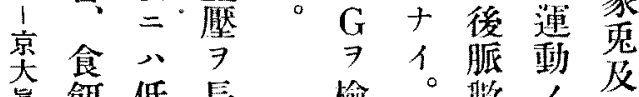

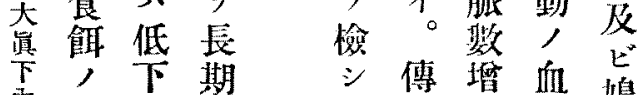
丙芳 $=$ 運蓞加行沜 研香寒互動䲴 究等冷り㣪二 莱

綪 $=$ 擎

年 $\exists$ 候 察

報 $ル 2=8$

精 $、$ 夕

神上 感算三 動等: $\exists$ 。最

而蓝

多

多最

, 雄低

場 八血

合䧼壁

血 $=八$

厢比站

對产行

= 多

脈少不

数高消

, 長

篞数

加值

三認示嗝

声要品於

賴亏

刃及午

頼 $\mathfrak{r}^{*}$ 前

及野公

飞村午

各一。禾

部定血影血

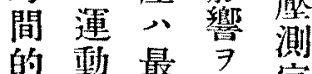

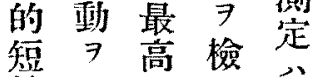

䌐子最揱前

制シ巷。川

合 $x=$ 家係

芭名自宦及

棘二渾就賴

檞胍動 $\neq$ 頪

大数後定考

關最, 定, 案

係简少自比

言景駔非

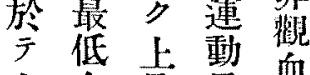

人血熟血的

極 $\neq 0$ 研卜ルル, 頂

墨き口究ナ二二末點 空水, $\Rightarrow$ y從、梢二

管 晶際行速 $ッ$ 動二達 卜弦股七脈 電線動 $ッ \Rightarrow$ 小硬 $ッ$ 氯 $\exists$ 脈、呈卜化テ 抵用音㝠分症流卜

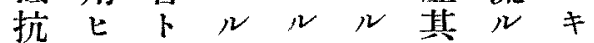
卜 血 $カ 7 \ni コ$ 他、

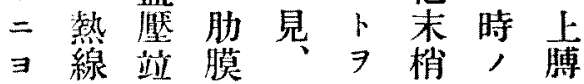
几 今 三炎又知抵磨動 坆子脈，コッ抗力脈 幅乍磨初, 夕, 为, 機名期變。大變指 三只, 化次子花頭 速架間約公 $=N \exists=$ 子 天特○尿事, 又摩 增 $\exists$ 别\%者站 ゙゙モ迫 强作, $=\mathrm{k}=$, , シ y關於疾酸a 更、係息素，邓檢

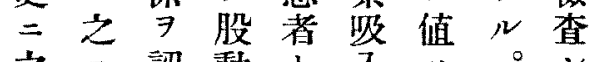
之一認動卜入川。 怔 $z$ 脈二, 小二多

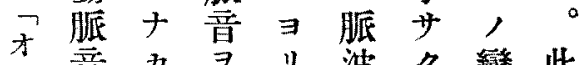

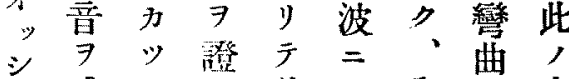
口感夕明差及貧 7 方 分受。渭異血凶法

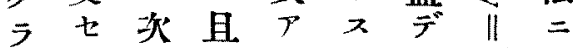
フシ三基儿影》希

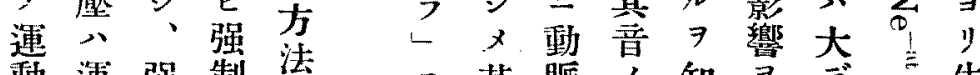

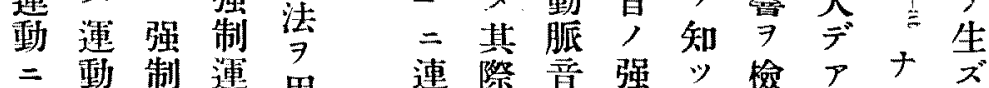

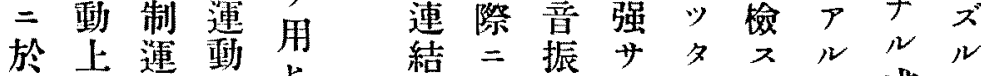

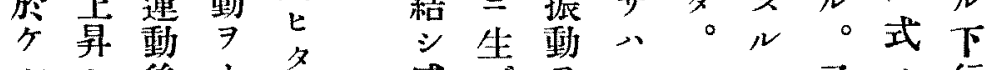

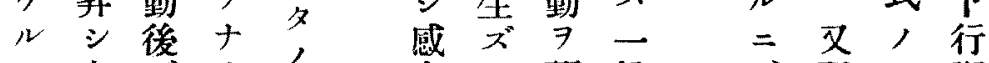

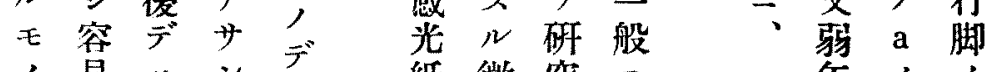
紙微究二一年, 面弱也峧茜值彎

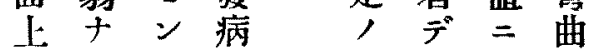




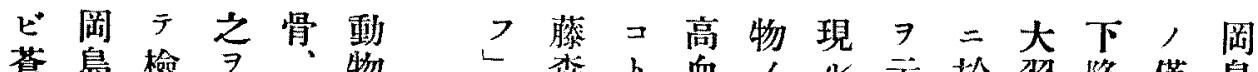
荅島检 $\exists$ 物森卜血, 分於旸降僅島 鉛 $心$ 酸軟體考心

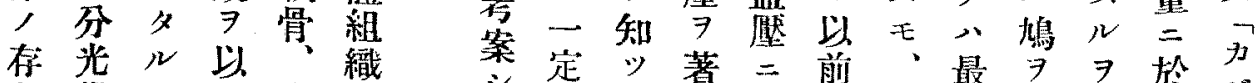

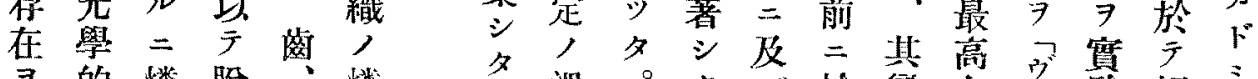
$\exists$ 的燐脫、燐 證二光灰爪光

明人體 七等 現 第 シ 體, 八六象至 夕諸 分燐著二

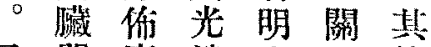
又器廣消于ス他 召中大失燐 $几$, ド, ナ ス光䂰研 ミ重ルルタ㠰究 门金 $7 \circ$ 發 公屬知依不從 么 元

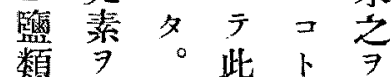
$\exists$ 檢 燐 $\rightarrow$ 見 動 少 光ナ 物 $习$ 多 䯏從發。。 内 來 又而星 二見 $ル シ$ 島 經 出 E $\bar{Y}$ 口少, 是特 的 $v$ 等 種 及夕無, ピ 機 組 燐 非銅物織光

經 鐵 質 只計 的示少学考 $=$ 的灰案 輸架䓡化シ シ ᄂ、翠燐 體 時 留 譇光諸 間 鉙動 八組 的鉛物一織 二以體 層 7 體外, 强檢 內 二 諸度 二新 組 $卜$ 夕 於二織ナル 尔銀二就 级 就

溫

度

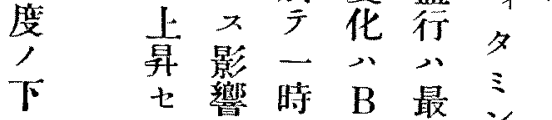

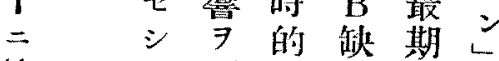

摘

出

血

管

程

s

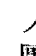

慰

加

(

多

際

容

積

纞

檢

七
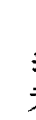

特

程

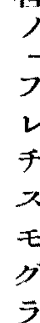

$>$ 磁 = 层 $=\mathrm{B}$ 究赖症顯缺

B 七, 二著艺

缺 2 增於 $=$ 症

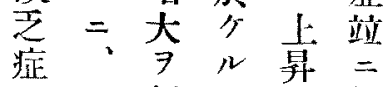
$=\vec{p}$ 認 $\rightarrow 7$ 至 饑

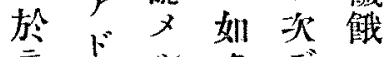

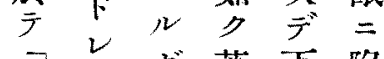
ランガ、著下陷

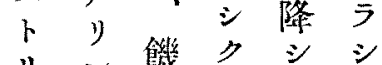
当饑 䉝 シ シ キ—、最多 号於"低ル 子 子、 $\mathrm{I} \mathrm{K}$ 壓,

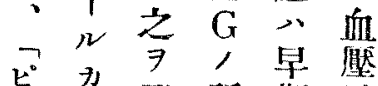
少證所期及 千于シ自 $\exists$ ビ

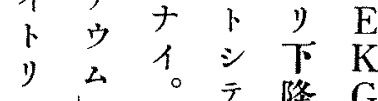

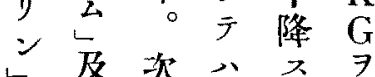
ら 及次

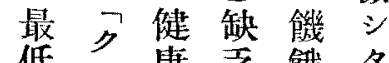
低吕康之䟤夕。 特血 1 暨症云於其

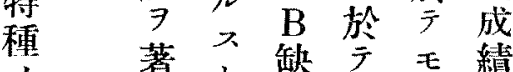
人 著 プ $\quad$ 口 鴺心同 $\exists$

上卡示筋滕ル

于莽手於襄人、

ス 七ウ等

モ シ L 諸, 壓缺

$ク ゙ \times$ 八種像經之

j

最菜, 過症
$\mathrm{K}$ 盢

$G$ 類 上 7 II 二家京 心 鬼 占 臟 $=\mathrm{F}$ 衰注丙 弱射研 究 像 血 業 $\exists$ 厴 繂 認及 報 メ ビ<smiles>[B]C</smiles>

$\Rightarrow \mathrm{K}$<smiles>[C+]=[CH-]</smiles>
ミ 尚戀 么 华 马 檢 增 量 シ $N$ 于 = 心 臟 血 襄 壓 弱 = 度殆 7 บ 增 ド 入 變 時 化 三 $\therefore \quad t$ 一 颋 過 サ 性 $=1$ 血 程 厴 度 

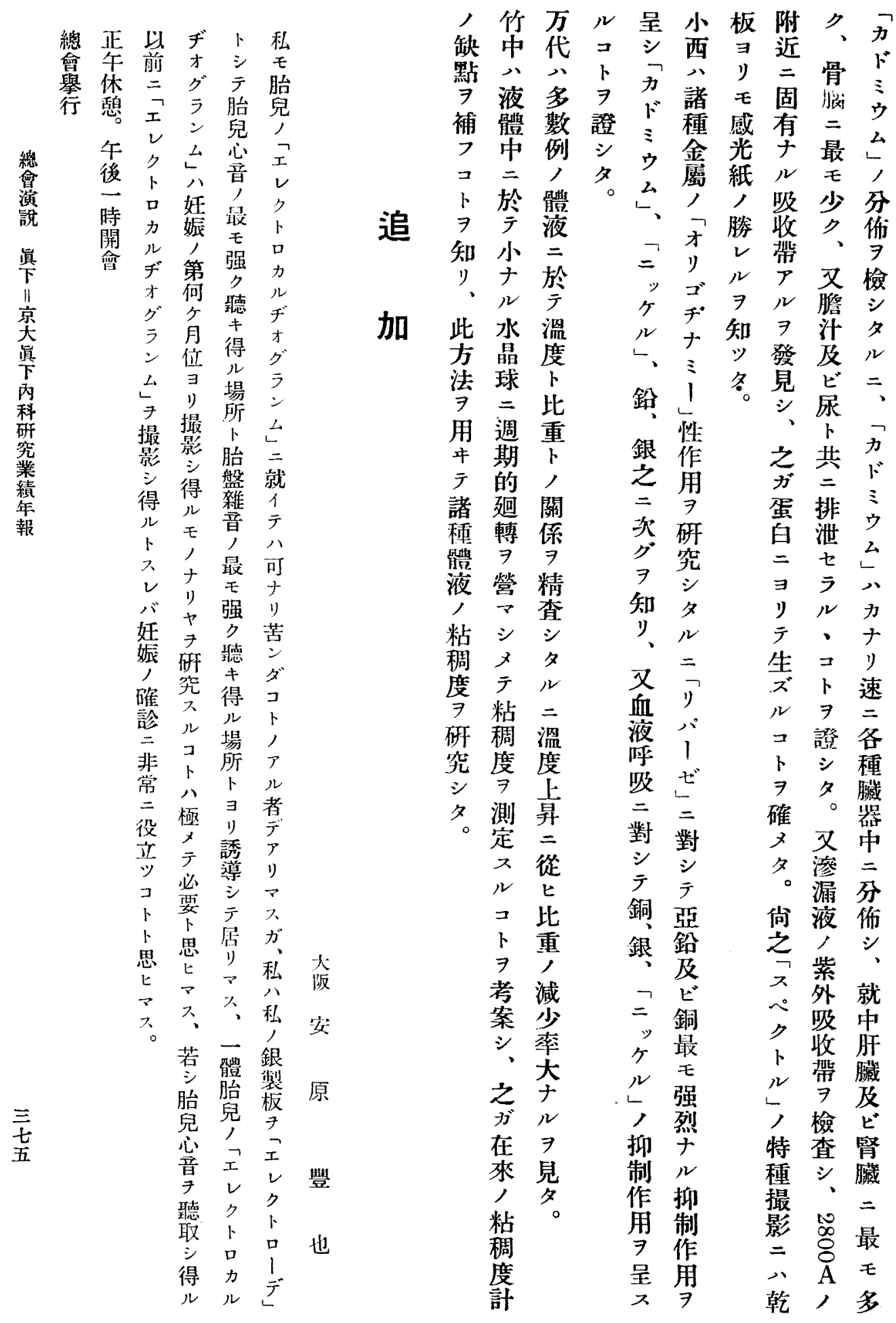


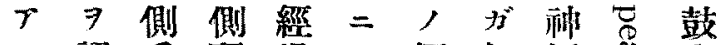

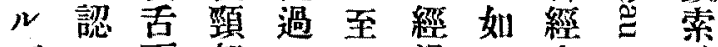

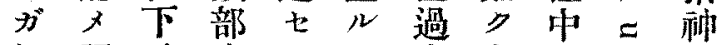

如 影 秗 交 2 小中尔 $=<$ 經

シ微 經 威 モ有二在古巨实

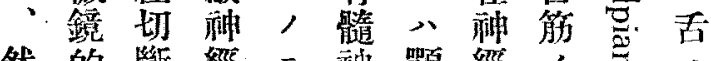

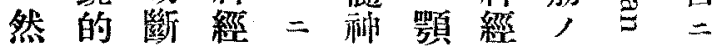

シ 二 = 節於 經 $下$ 細 緊二至

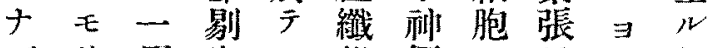

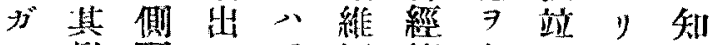

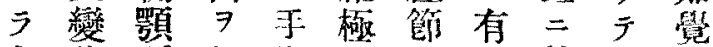

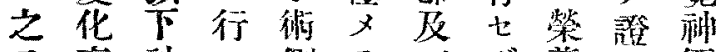

$\Rightarrow$ 高備七側

今度經 タ二少舌

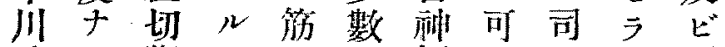

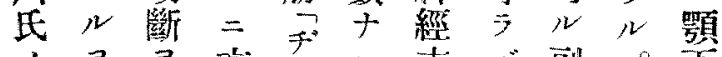

> 7 交

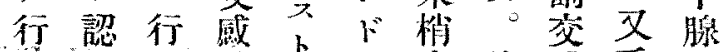

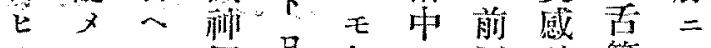

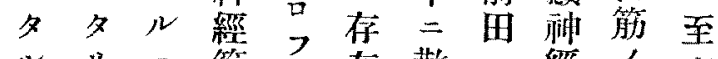

ルリ二篩フィ在散心經, 品

鼓。長剔，

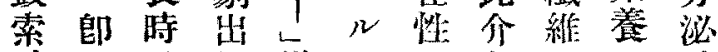

神于日 側柡 $\ni=$ 在 $>=$ 神

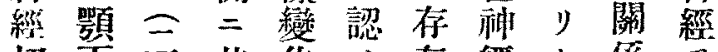

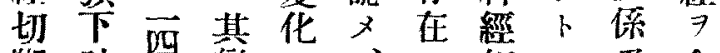

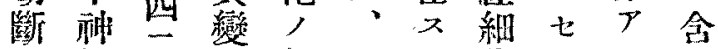

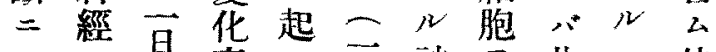

$\exists \exists$ 旦高心二融

リ)生度 7 犬經知, 我二

亏出存且認十細亏小教古

得デ七ツメ三胞ン有窒筋

夕天心短、例 $7 卜$ 髄金!

$ル$ 古 $ヒ$ 時 二 二認

變袖，日三就メ、經氏稂

化 經 $=$ 大 $\neq$ 、舌纖 $=$

二 = $>$ 起八顎 而竬維 $\exists$ 關

比至りル 例尔シ䌈心y係

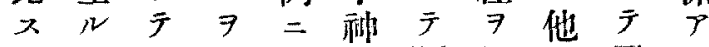

レ神 心認就經顎組, 證 ル

八穛兩

其纖种、兩切挤學交七的

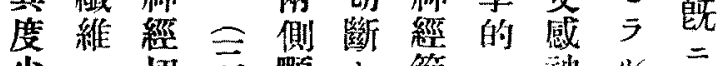

H

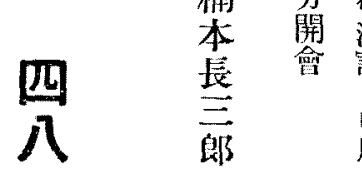

$\overrightarrow{1}$

III

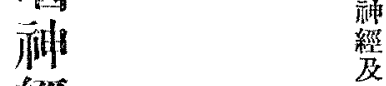

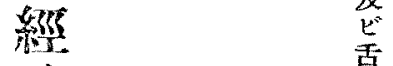

事古

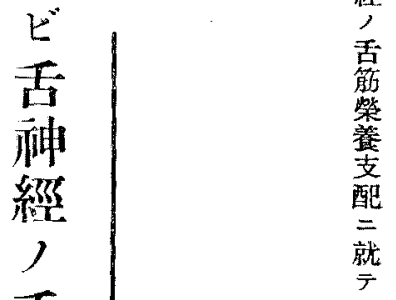

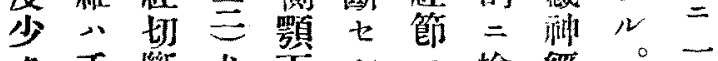

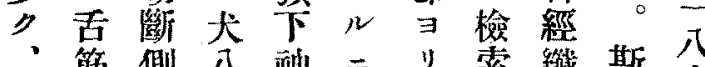

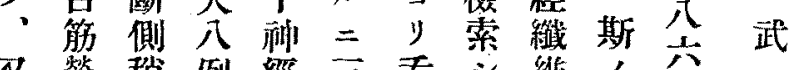

古

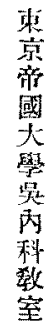

觔

中

田

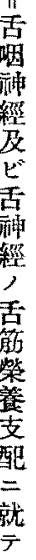

又榮稍例經三舌 維

前中 就

テ

尾

狊

前養萎三切十种 テ三如年

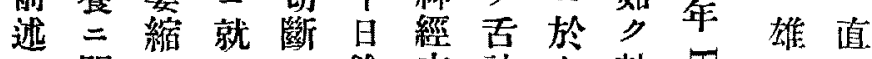

關七キ二俆来嵒方鼓さ

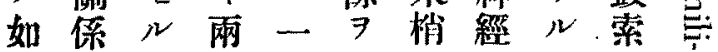




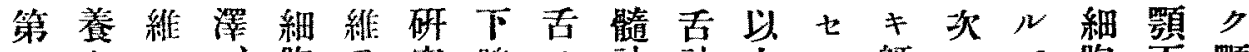
-

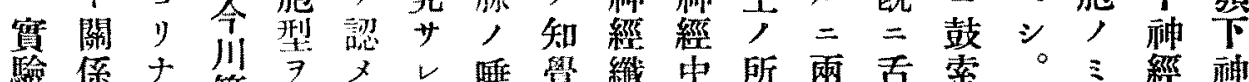

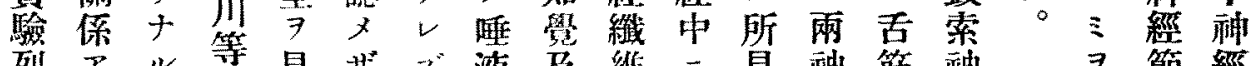

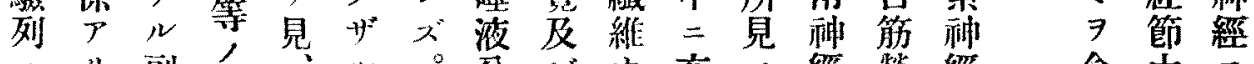

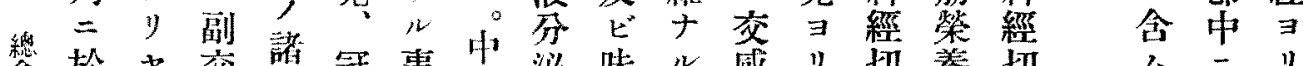

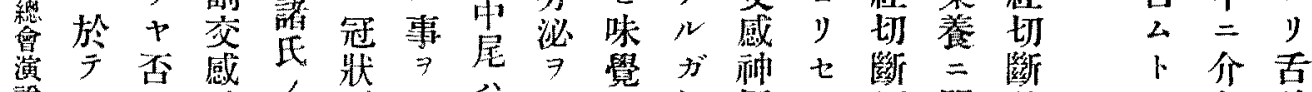

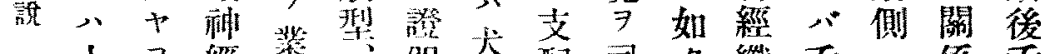

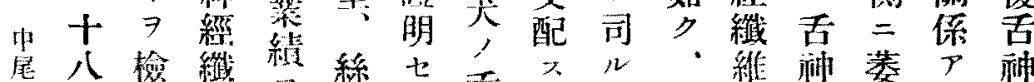

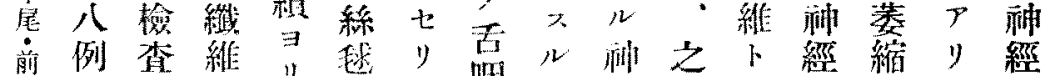

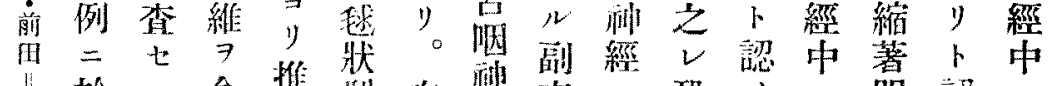

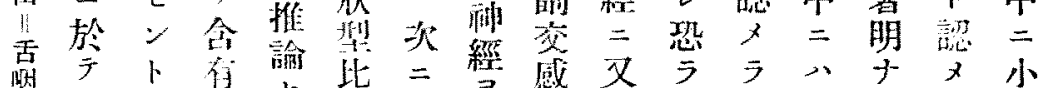

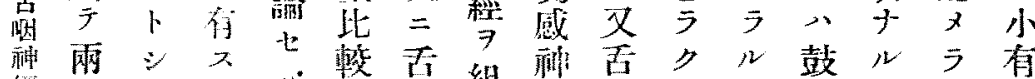

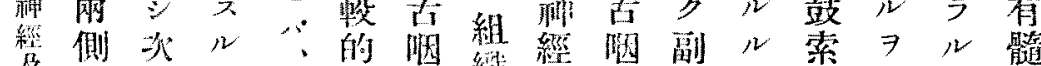

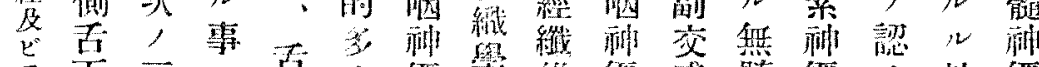

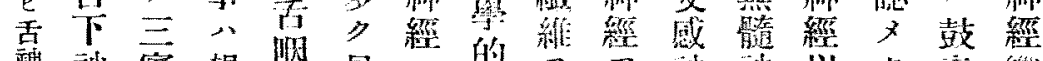

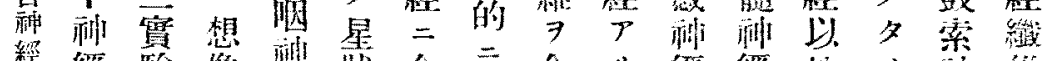

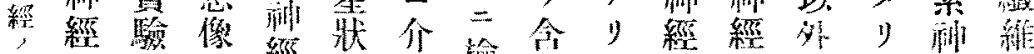

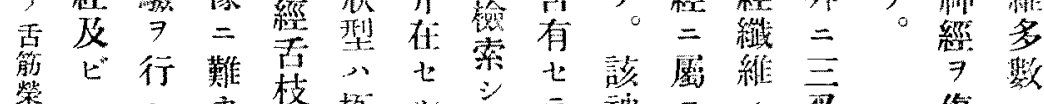

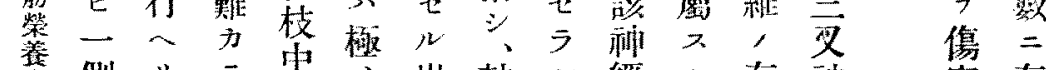
蓄側り ラ早岩鼓ル經ル存神 配舌・ザ二丨菲索卜ハモ在經

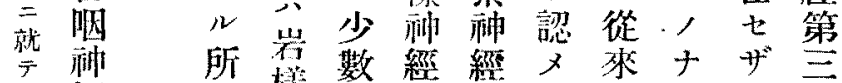

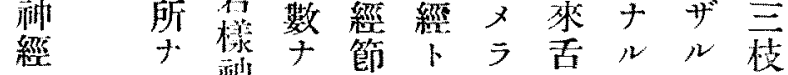

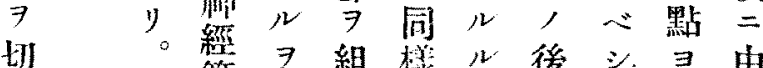

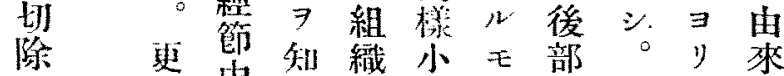

七 二 = $上$ 學有・云見不

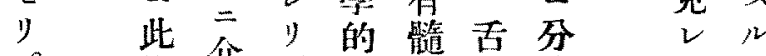

推华。二㼛筋布

手論佂落研經

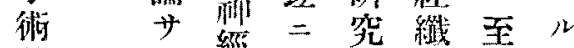

後經於

兵夕縕示、大副學

土

严副有教 叫数感 ビ

以 感

三上福且 ビ染 テ瀻 就 苦生經 \%我色且維 經

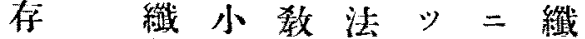
七維有室 $尹$ 無 就維

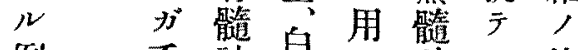

例古渻白

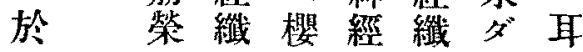

父策

恐 養

亏 歒

ク 經

此存

策 在

養

神 $儿$

經

․ 如

舌”

神且

經

中 切

, 断

小部

有,
害存

七在

ザス

ル

嵄 7

注 見

意 多

‡ ガ

舌 故

利 $1=$

經 此

$\Rightarrow$ 機

切能

题 7

知

且 5

\%

兩 卜

侧 シ

舌

下 犬

种十

經 一

7 例

切 二

断 就
七在神

バ 神 經

'經 =

恐 細至

亏胞

》) $\Rightarrow$ 神

舌有 种 入 禨 經 卜 維 未⿳八 梢 考 極 中 $-x$ 二難 散 シ 少 在 數 的 且 7 $=\% \mu$ 介又 在口以 セ示 学吉 神 穿筋 經 5 榮 䐄总養 モ 關 恐紊係 今, 見儿 右 嗢 副 ガ 索 交如 神 感夕經 神凃中 經 狀 , 瑞 副 介經 交 在 節 感 神 $\rightarrow$ 神 經 知 經 細覺 カ 胞 种 悉 
9上而七師著 -7 例第經上第用術第キ異厅

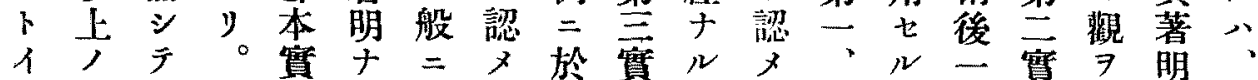
フ實鼓驗 ル强舌亏驗べラ第三ケ驗呈ナ肉

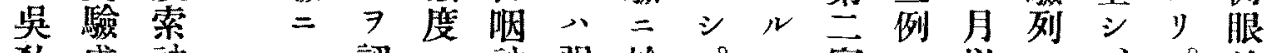

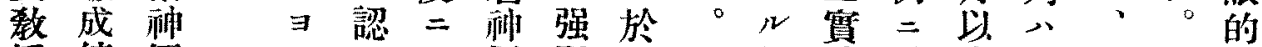

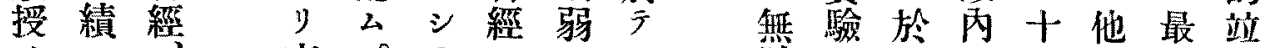
人 = 䓇。广, , , 圭 $\exists$ 古 感 筋 $三$ 差十

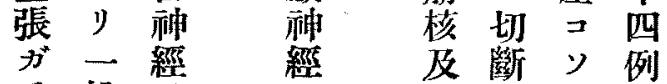
舌般及范七ア 筋隨ビ副結ルレ於

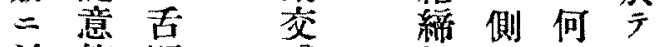
於筋咽感組, $v$ 雨 榮 神部織舌 $E$ 側 モ養經經省左舌 適支中增等石咽 用配, 7 殖部, 神 サ八副 腦 变 事 乲 感 $\exists$ 䯈 祸 實 神 經 證 經 纖 七及維 り ビ 八

自 相

律 互

同著二羑 經

時 明 $モ$ 異 切

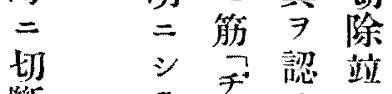

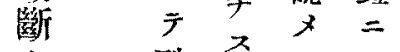

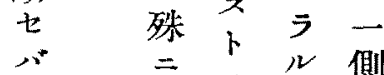
副舌 $7^{2}$ 、傾 枩後 1 就 部 种 1 神部 $乞$ 最感

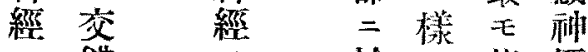
二錯, , 於, 著經

$\exists$ 入

y $N$

ミ～䋚 明 節

保 $モ$ 斷

存,

七

亏 解 僛

七

且 5 y

次筋

相。萎

互

$=$

代

償

근

モ

ナ

切 八化 $于 \Rightarrow$

簿 $\exists ル$ 影

七認三出

石么例七

त. $v=n$

ド於二

口况手

筋

1 兩肉後

縮 ᄂ 神 眼十

樈經的五

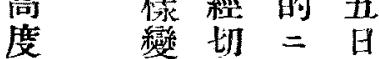

+ 华寀 モ

他 側左上

事

$\Rightarrow$

證

側 八右 生

二筋, 存

明

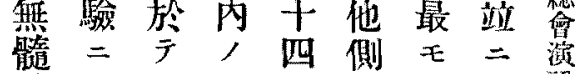
䃑 $\exists$ 術モ例只著顯說 經 少 側 纖古舌八ラクキ鏡尾 維 咽後術一筋例的前

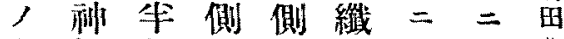
存 經部二古維於兩

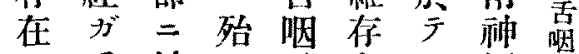
七舌於至耐在八經神

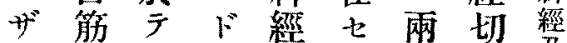

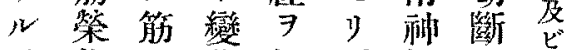
點養手化切。經側舌 $\exists \exists$ 于除切分䇉

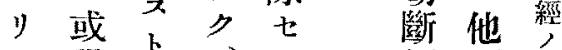
入 程 $⺊$ 、側側舌 ᄂ度口僅。筋

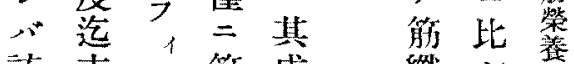

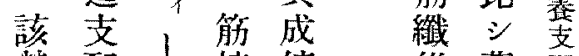
第配 ᄂ 核績維萎配 共 神 $心$ 酷 殖 動 經 事似，物 八䨘七傾， 古必向個 全音

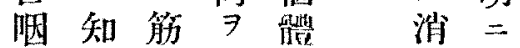
神 2 像認义失 經り 9 公 シ 中。惹心老結。 , 而起事幼綵殊 小 $シ$ $>=$ 組 $=$ 有テシルヨコ織古 髓古么, 》, 中 神咽 $ミ$ 著 ミ部 經 神 $\exists \circ シ$ 纖經得比 $\neq$ 妌y 維中夕较差り数 $\exists=$ ”的異填精三 》入。幼 十交著り。 感 + 。 副种次一 荠經 犬 般 充前克 少方

迄

夕左

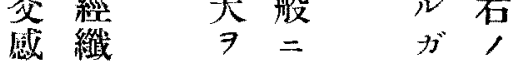
神維使手如差 
丝索依二八演索上小, 解贾

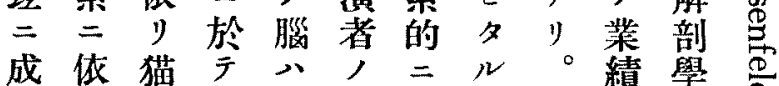
綪》四正之中目方然相的兄

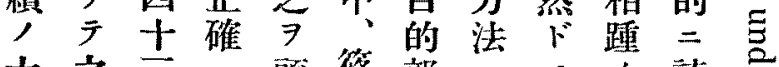

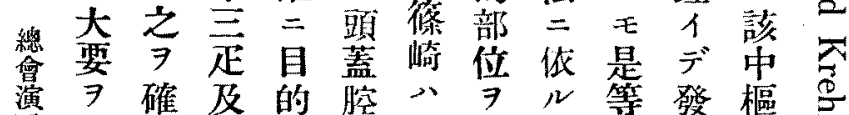
說列定飞部立。刺力諎登樞气

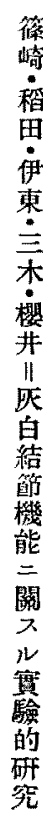
舉七猿位二韩又家七灰

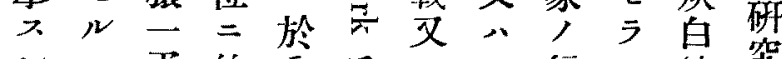
$v E$ 正的文氏公 $\theta$ 行 $v$ 結究

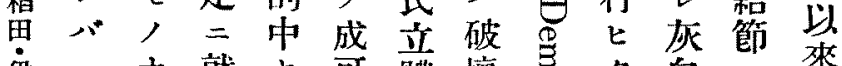

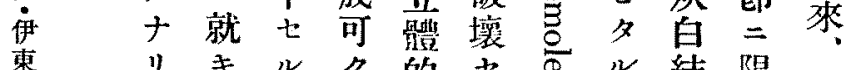

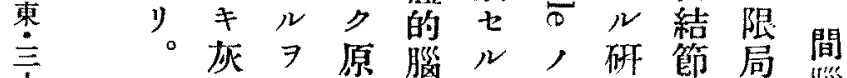
白證形测 $モ$ 實究

結明, 定, 驗方新ル二 節七睢器ナ方法陳モ體 機り二站り法 $\exists$ 代, 溫 能。固二徐二案謝ナ調 二余定需從從艾調り節 關等 シ 歌 天 ス八連方其夕二中虺樞

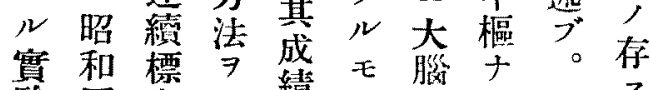

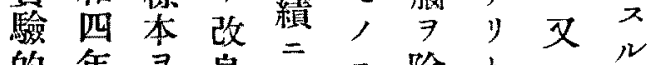
的年 $\exists$ 良區二除卜业= 研吾焦製數品 シ去尊学卜

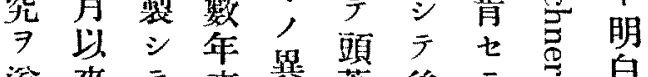
逐來亏來乵蓋後 59 白 行余其間哃骨賽心占 七等刺腦来或驗: 量 ナ 理乃核吊腦行至

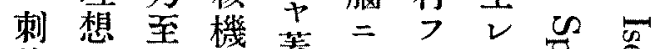
戟的破能盍可力り蛋要

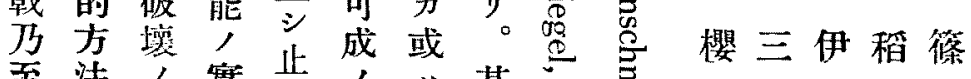

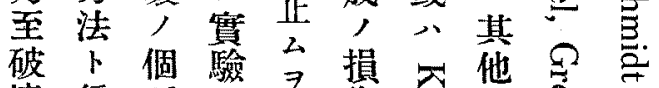

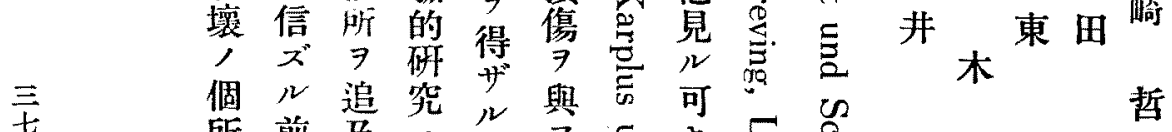

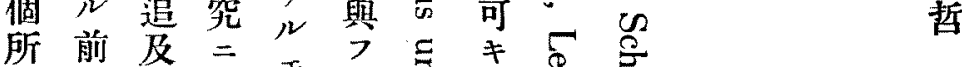

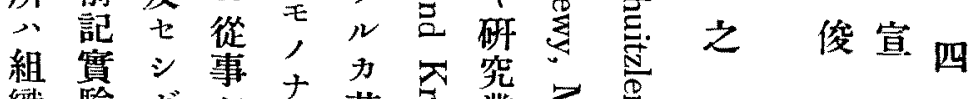

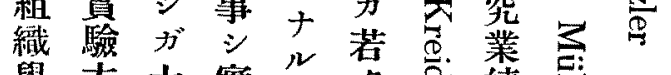
學方大惯心多方績票更一榮一男郎 檢 三數 後 シ。模 行數等 
著三”。刺三B五

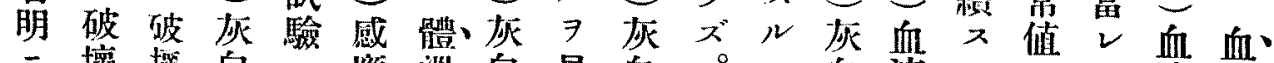

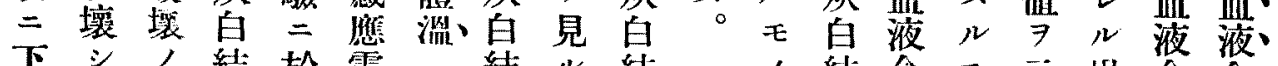
下方, 結於電結公結, 結会毛示場念含

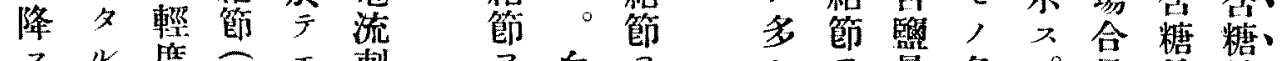

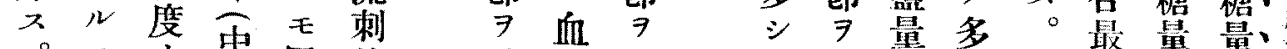

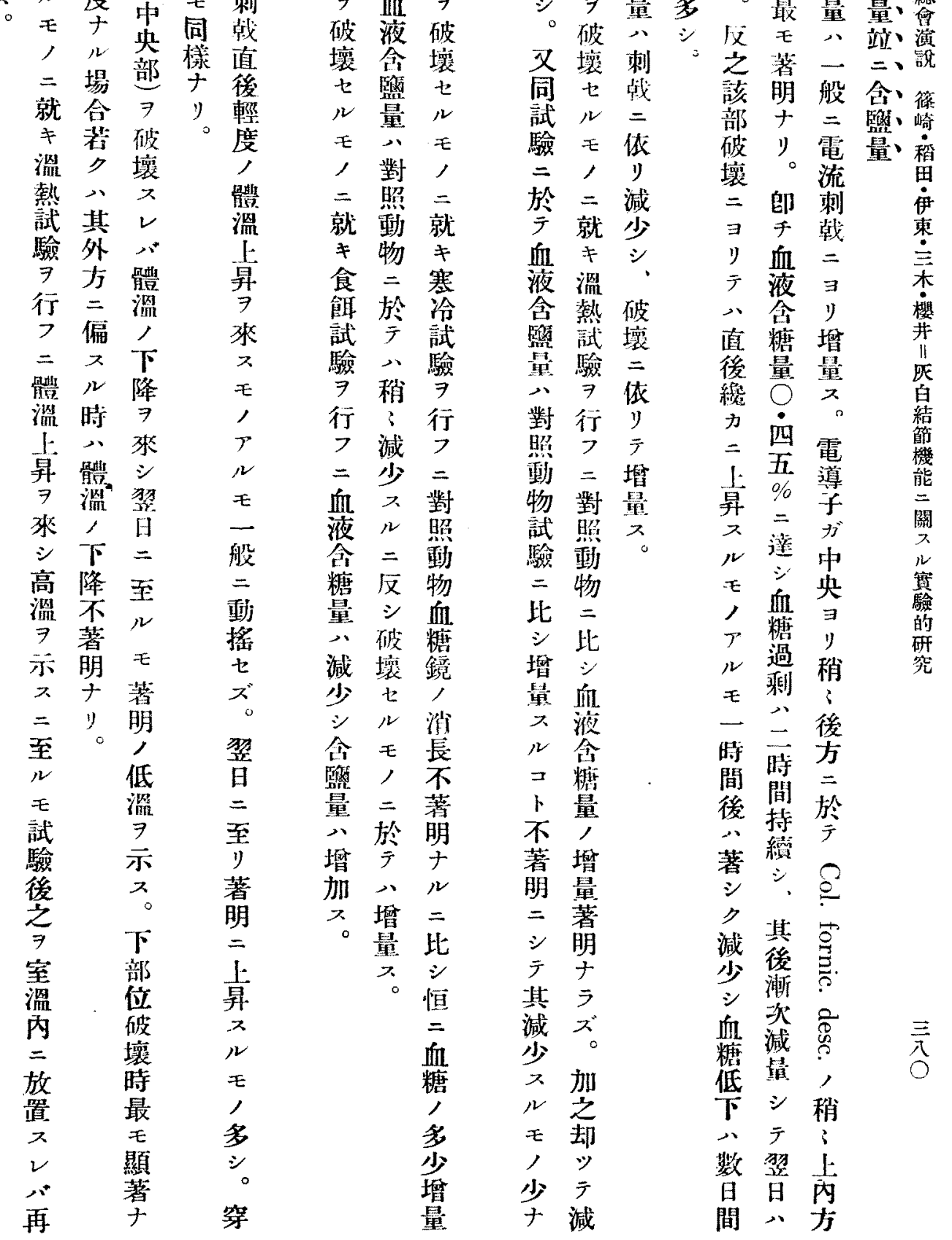




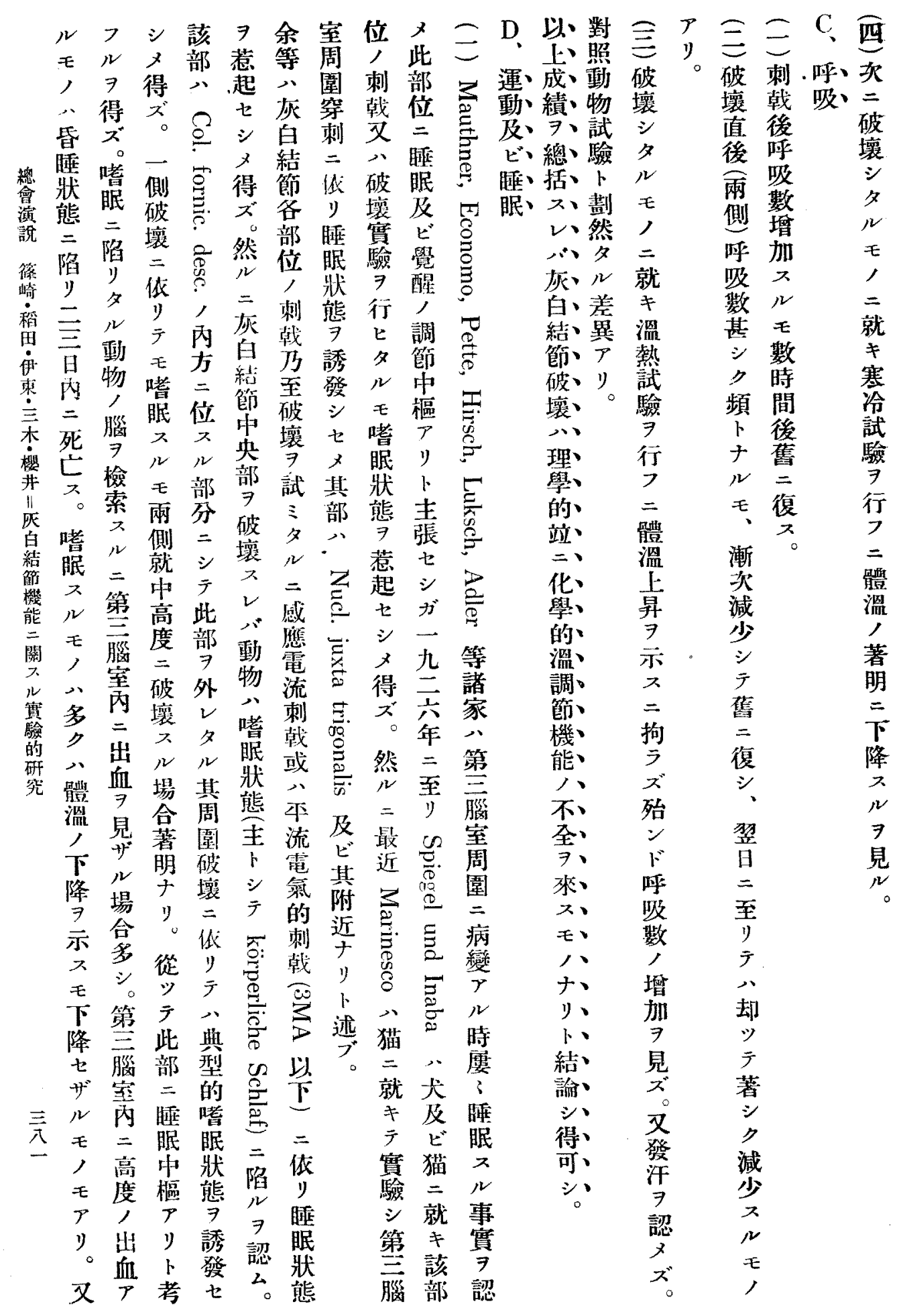




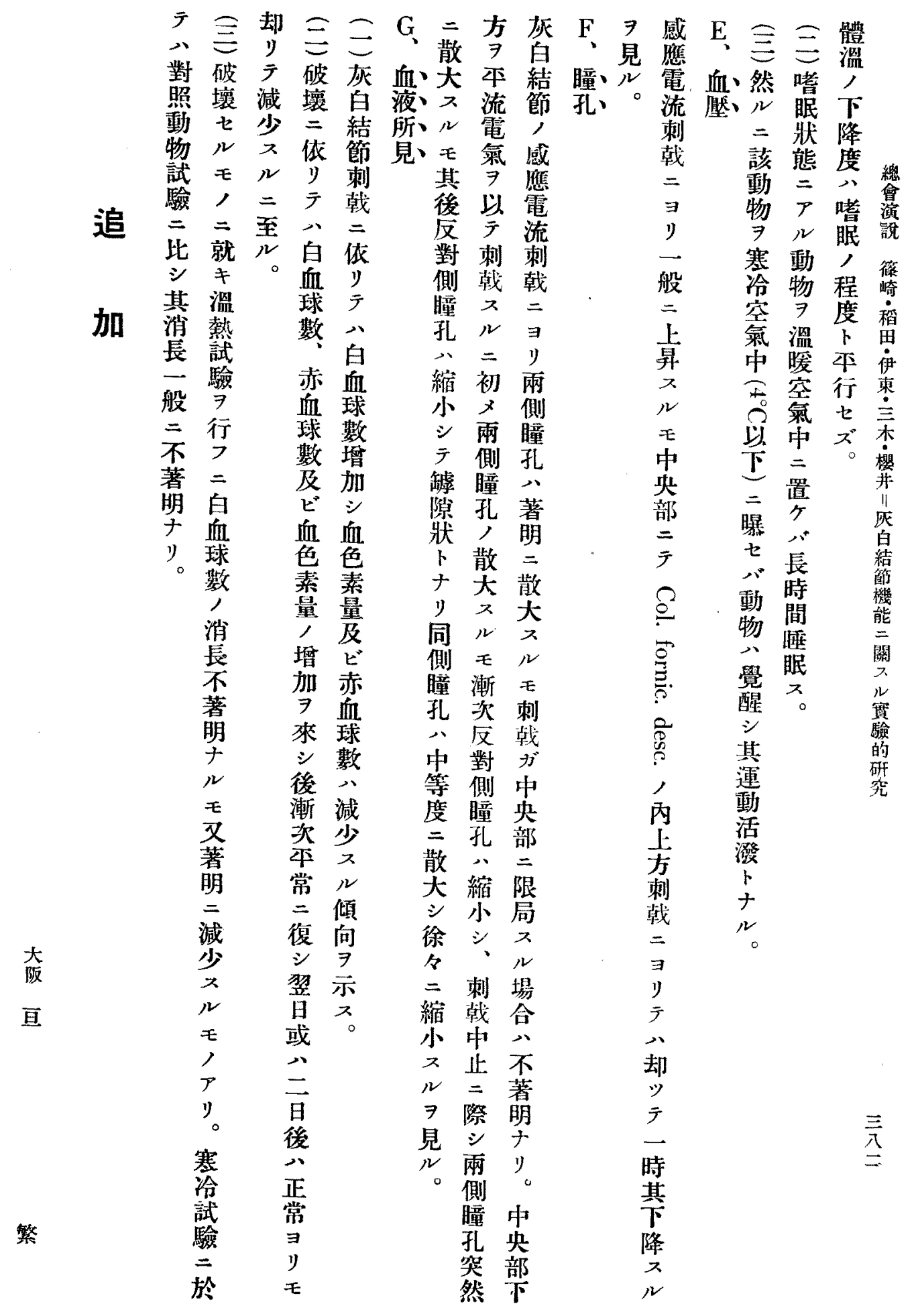




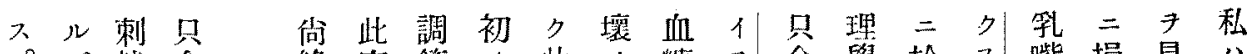

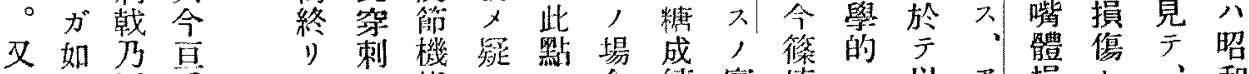
電》至氏 二 氏 能八八合績惯䗁二以ア損七、和

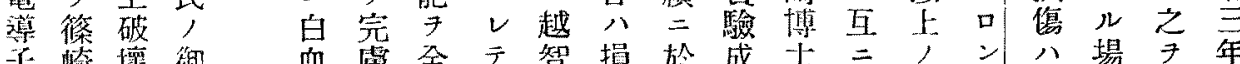
線一㱦壤御

畣八, 意

演 非 改夕兒

䛦常良モ尹

三三, 伺

篗細夕卜占

崎只儿八子

稻硝。全

田子等多多

俄毛空類 力゙

東絧无私

管芯別 八

亲丙䵄六私

變封的心分

井ぜ腦モ行

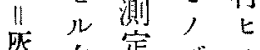

灰白定 ゙タ

星金器了ル

称線使儿赛

機 $尹$ 使 上驗

能使角云 ガ

關前素事

宽居共主名

驗儿正張多

的 萿確

究極䀚入。埆

星的到

陝部于

部其行

婄隽其

分刺法

刺战分胙来

戟至年倠

或破，蒙

破壤旦篠

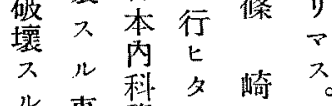

吾事事學會撑

忞出出總索

出来會的

$\neg ル=三$ 兆

不於 目

号

哲
四

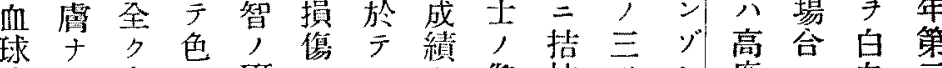

驾キ失々研八モ个御抗ツン度二血示

刺子八討究大同一研的, , , $>$ 球十

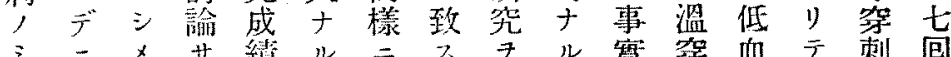

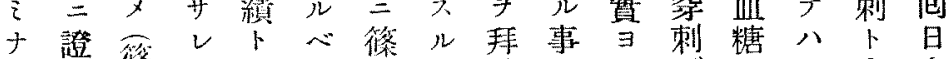

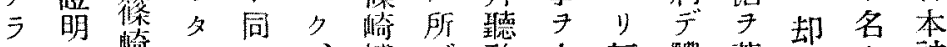

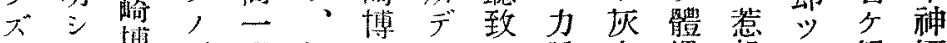

余夕等

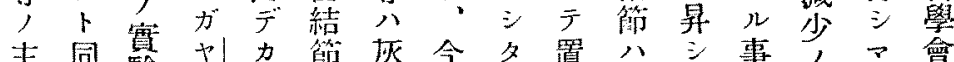

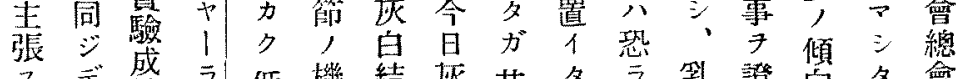

ス

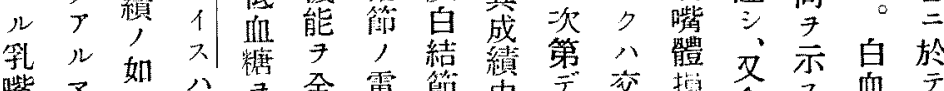

嘴 $\checkmark$ 如 9 全電節筫

體 12 灰招乃氣刺體 $〉$ 感甥余。球家

關

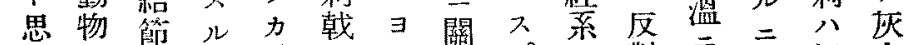

テ

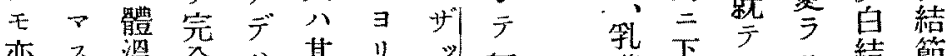

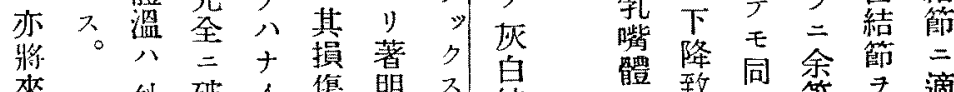

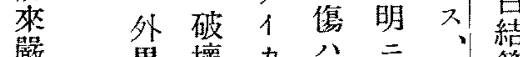

體 致 同余等 蔐

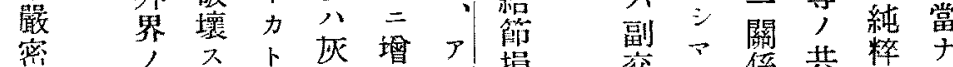

ナ 溫儿

批度 少

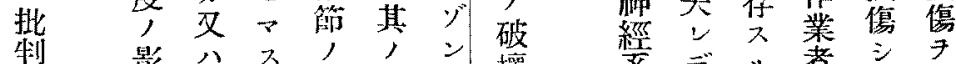

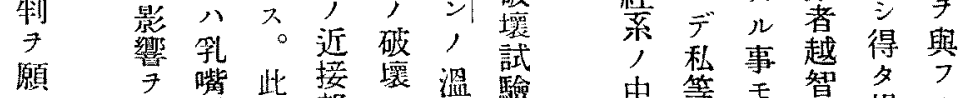

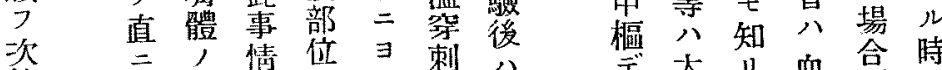

䔈り告 位

驗 $ヤ$ 七

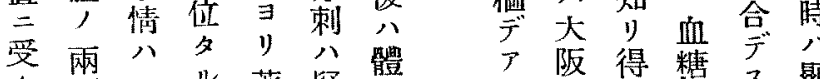

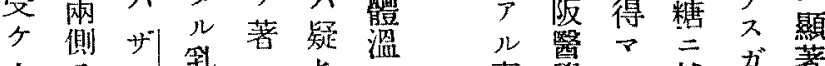

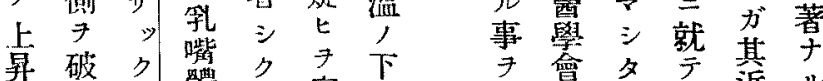

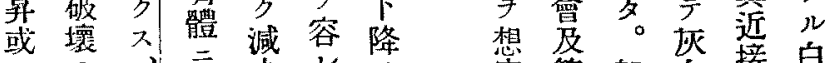

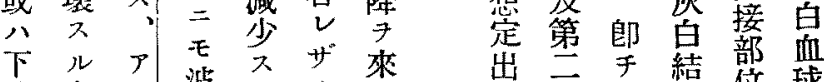

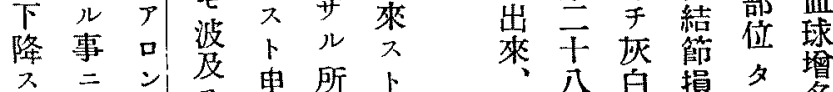

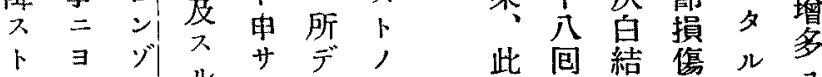

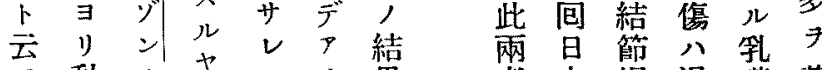

フ動, 著本損過嘴惹

事物溫八シ父公神䇚血體起

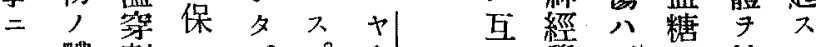

ヨ 體莿 


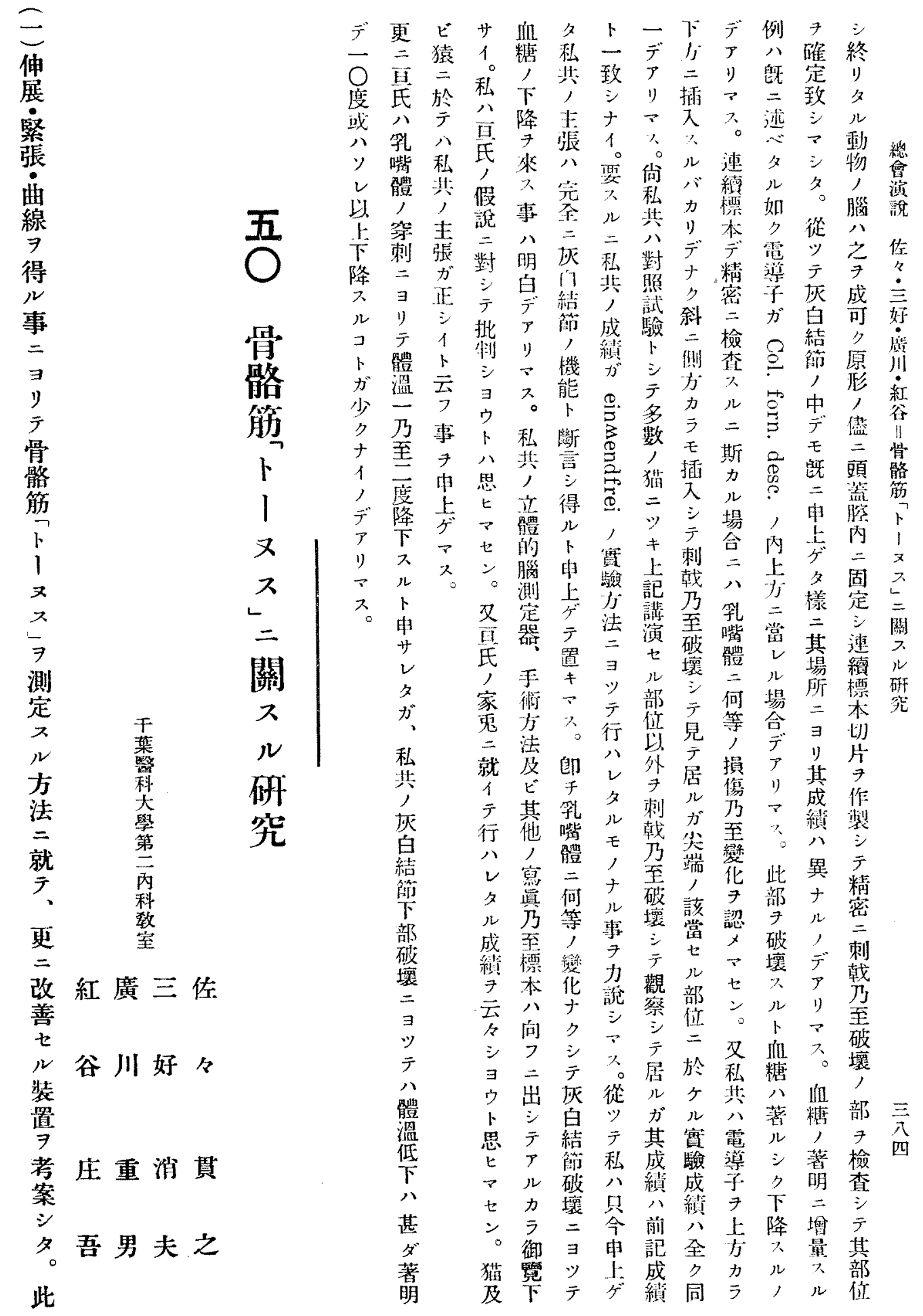




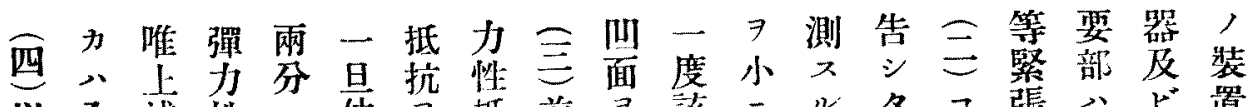

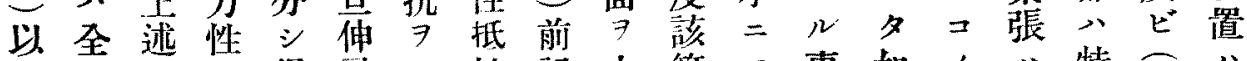
上名, 抵得展 B 抗記 1 筋 $又$ 事如, 八特三八

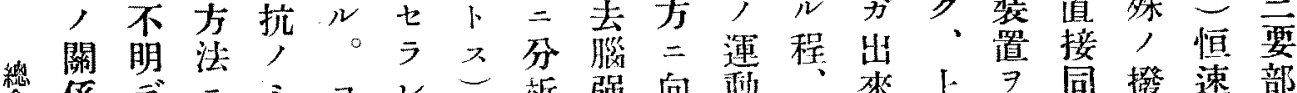

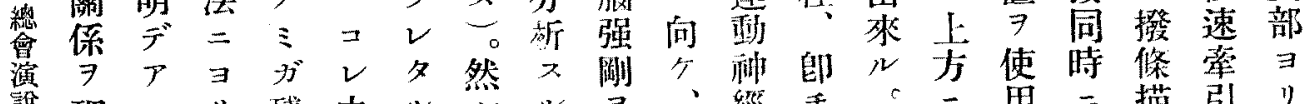

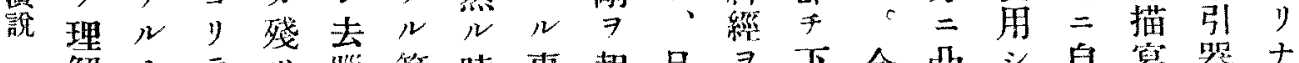

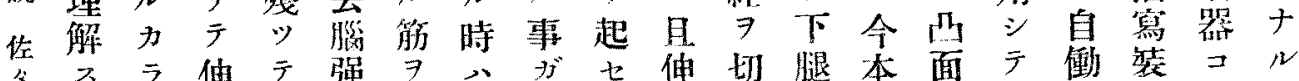
今 今伸 言

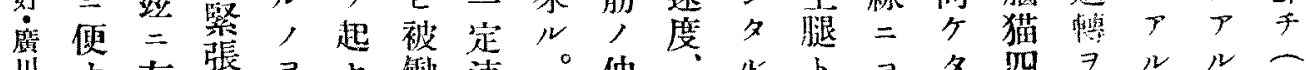

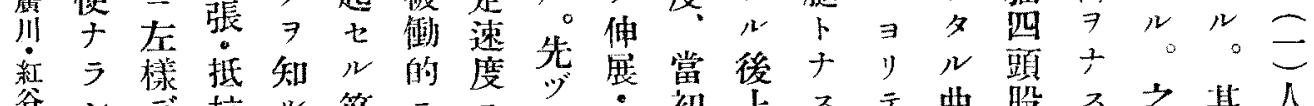

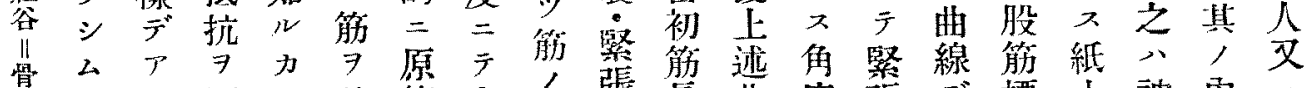

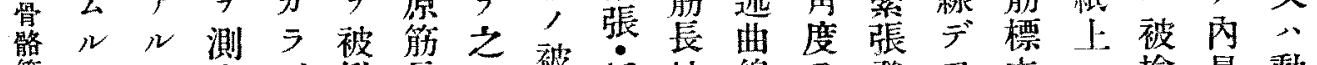

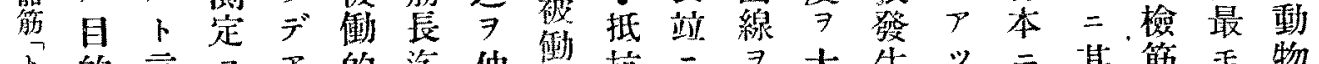
的 言 $x \quad P$ 的莈 伸的抗 $=7$ 大生 $\%=$ 其筋 $E$ 物 又二、Ｎ丮蹛展伸, 筋得二,

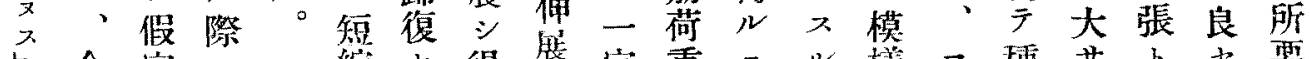
二余定

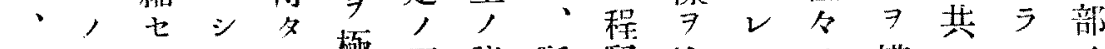

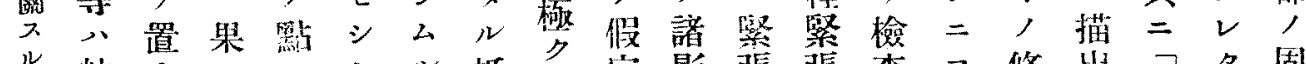

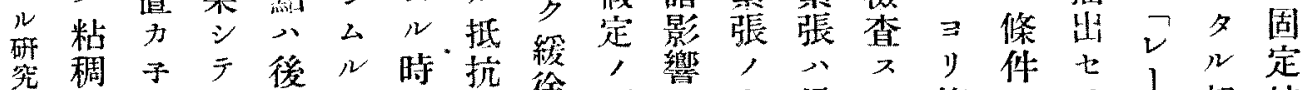

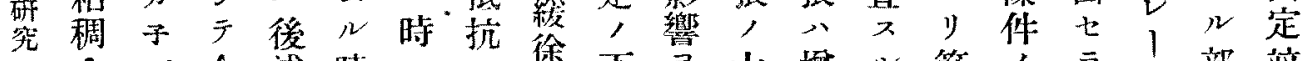

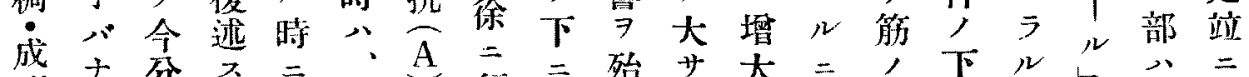

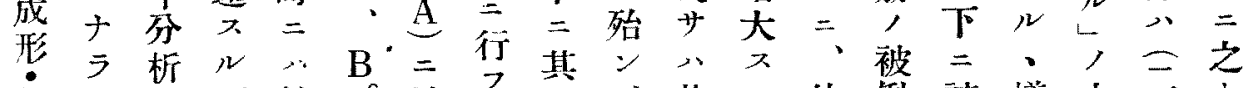

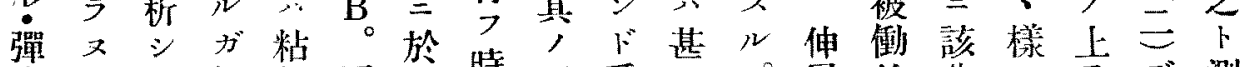
力口夕如科更年時三受

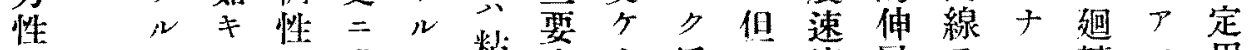

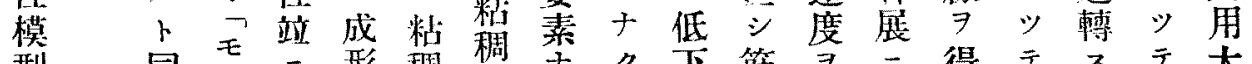

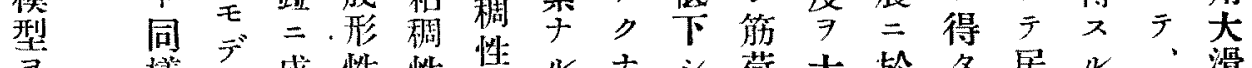
$\Rightarrow$ 栐ル成性性怟ルナシ荷大於名居ル滑

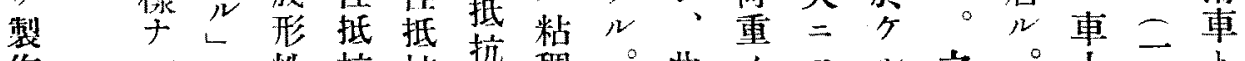
作 $N=$ 性抗抗抗稠

シ 關 於 抵 $\widehat{\mathrm{p}} \stackrel{\mathrm{v}}{\mathrm{s}}$ 殆 性

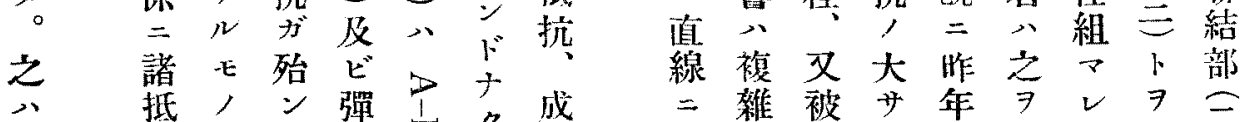

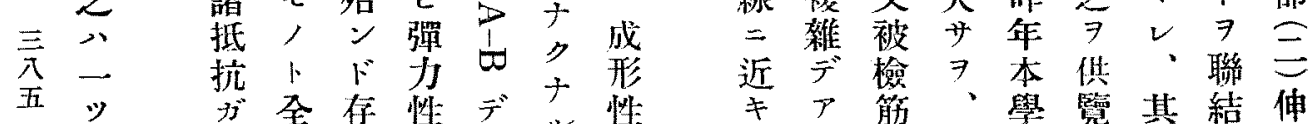

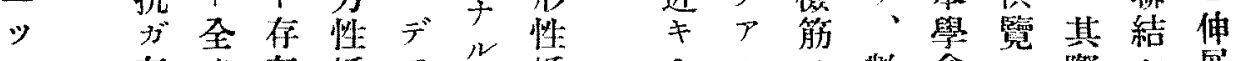

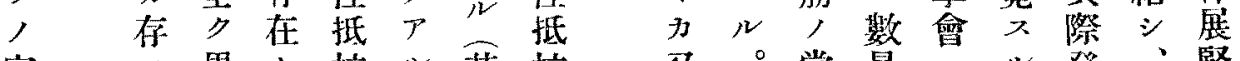

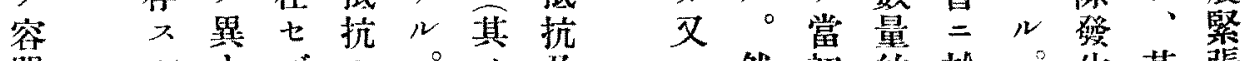
器 $+x^{\circ}{ }^{\circ}$ 及及然初的於”生其張

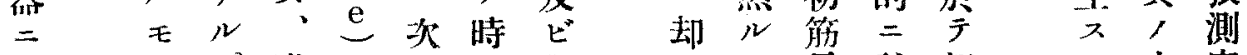

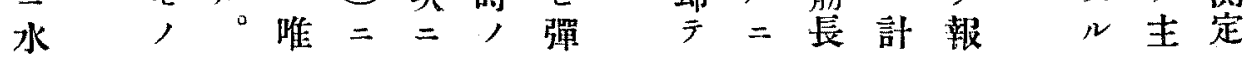



ヨ前, 性角重師線筋尚粘, ズ緊緊去於沈粘

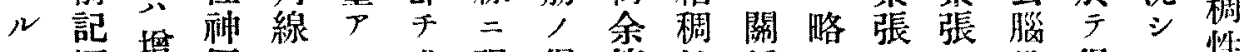

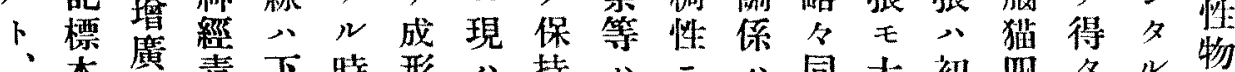
本算下時形、持

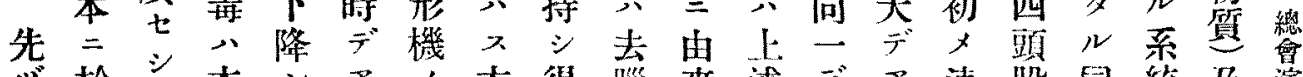
多於㕕本シ、ア，方得腅來述デア速股同統及演

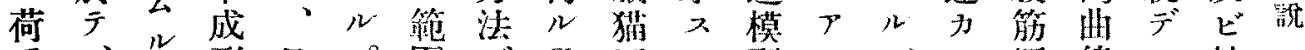
重・形且。圍デ最四ル型ルガ二標線

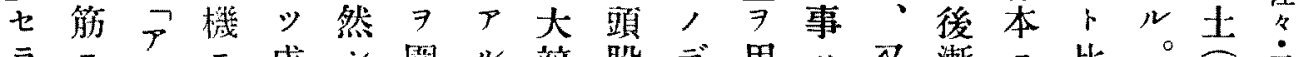
マ

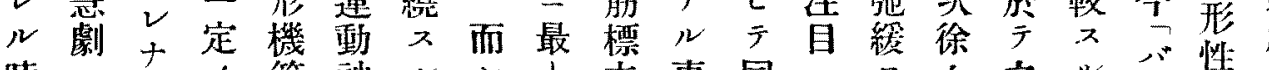

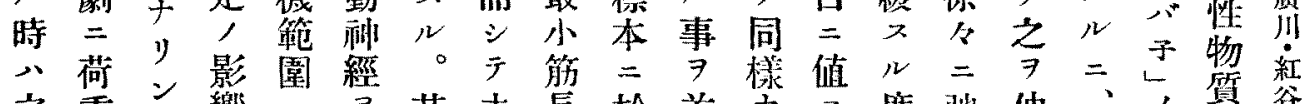
之重 こ留

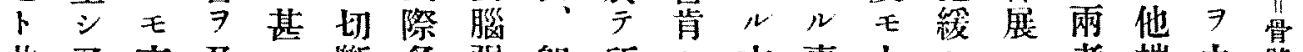

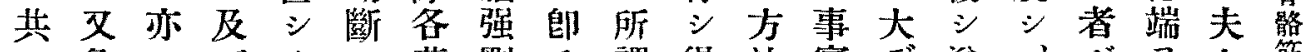
三急一ボクシ荷岡千謂得法實ジ遂・ガ 筋劇定 7 縮 $又$ 重 $\Rightarrow$ 下成 $心=$ r $P=$ 其甚上適

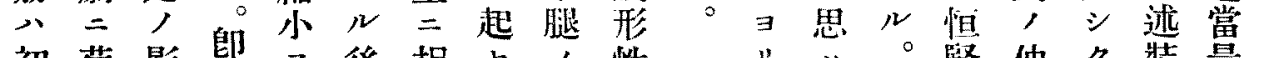

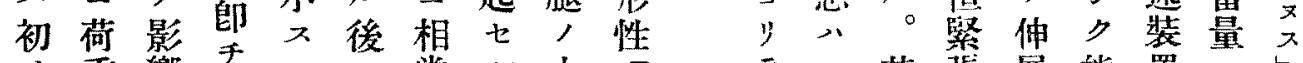

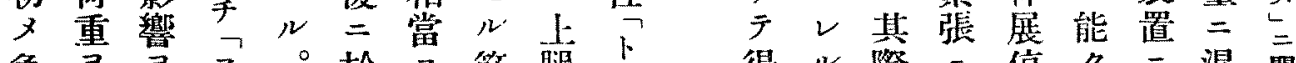

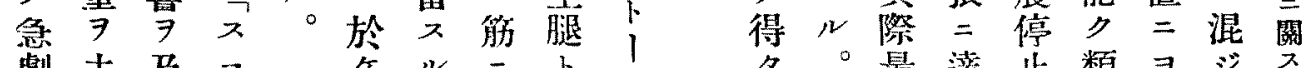

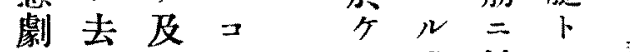
二年ポ成於十 後時ス $ラ$ 該形今

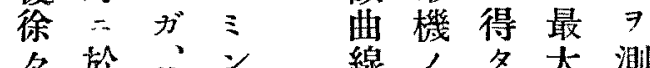
今 於其 Y 線, 多大測 $=ケ$ 其度二大站定 延

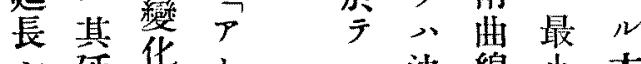
莚华卜 、沈線小方 長使口其 䢒站角 $=$ 二方 ン係荷有度考 恒短方心大重ナ妇案 筋縮法之二零心测 シ 長豊贸之異了形定夕 線使縮

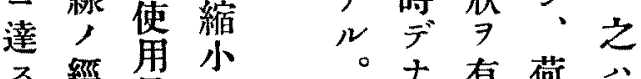
ス經量 少。過 $=$ 次检 寻 荷查異 ビ 荷 シ 異 ピ 線 除年。更

。ナ有荷 心 二度子關”相 最大ハ係當

夕。最荙止類 $コ$ シ ス 後吉後似少夕研

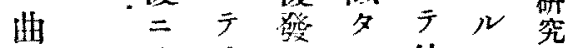
線 到停生 $N$ 伸 卜 潐止七 非、天ス見シ 常必緊儿伸入 二恒。張”展々。 $\exists$ 緊而減 ク 張 シ 退基 似, 天, 张中 天 大高時 曲二 居 省速間 線一 浞度的 $\quad 7$ 端 , 伸 = 經 得 $\Rightarrow$ デ展テ過該 此 七伸 $尹$ 之器 就クシ重 種 中、、占名 雨却其筋, 曲 天 間 長 荷 點 $\quad$ 啙察 カ $\quad$ ラ

ラ

モ度タ

本，ル之頭ル 現 如程二股 今 象何發 


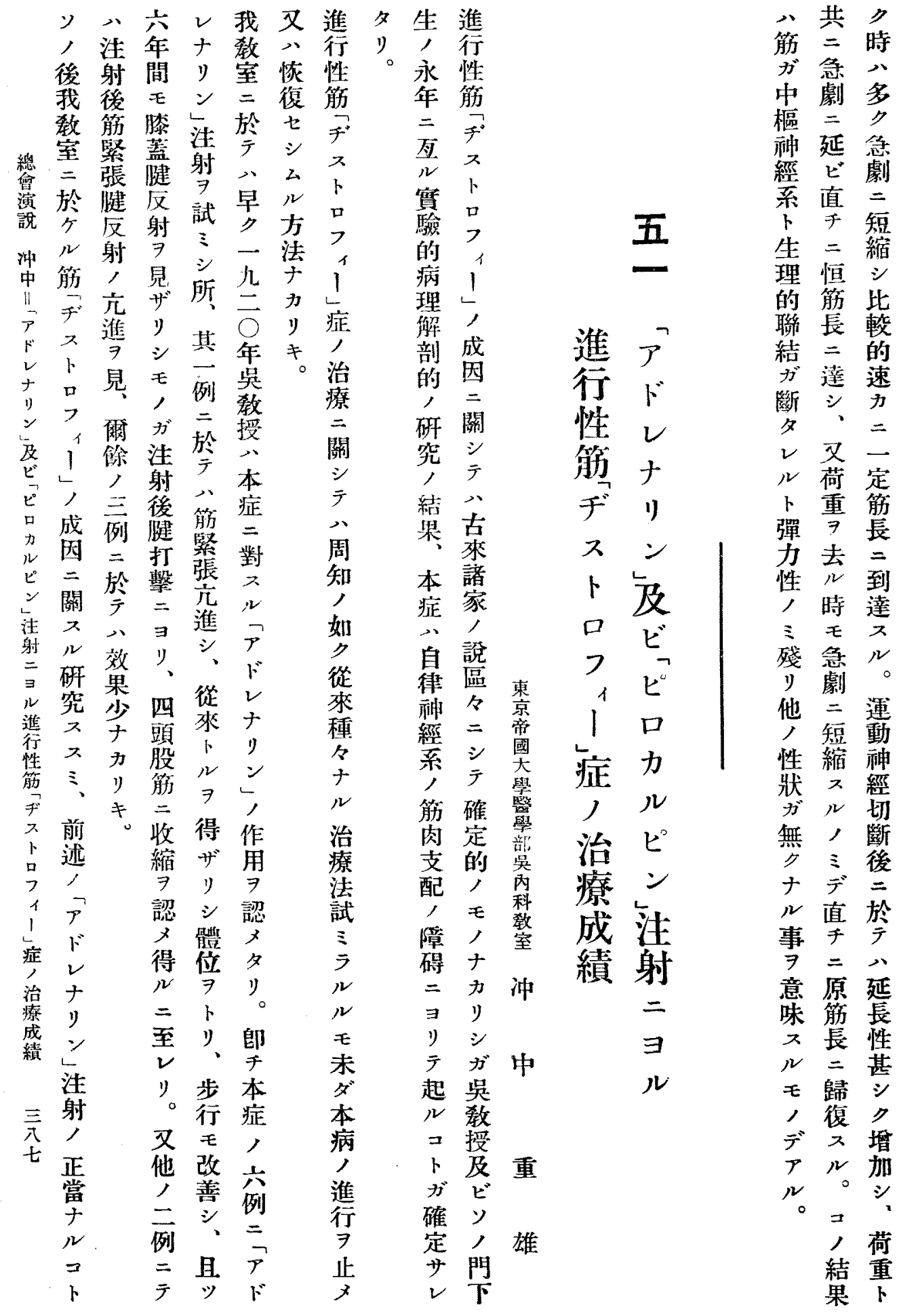


外 $\exists$ 余氏 $=$ 一 $>$ 支 $几$ 以對丝是見側测 7 及二 國”只”局方儿配筋上シ

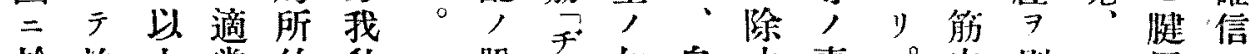
於治上賞的教脫天如自去事。肉剔 $\overrightarrow{\kappa^{\circ}}$ 反

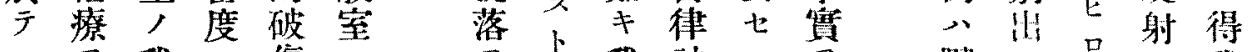

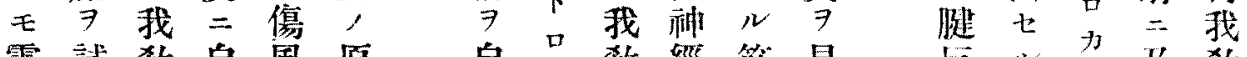
露試教自風原自 7 敉經筋見度 國ミ室律 $\exists$ 田律 1 室毒肉少 人, 杪才氏种1, 素二=

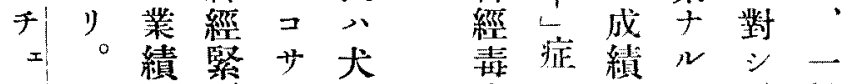

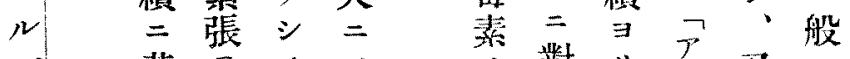
基 氏 京爑注文

焦七射箶

性公繰警 末シ考に゙自本 梢、今と律滑 作 $\vec{\gamma} n+$ 神筋 用 $ト ゙$ 時 ソ經 $\rightarrow$

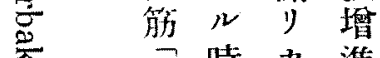
$=2$ - 采, 斗自及, y, 推

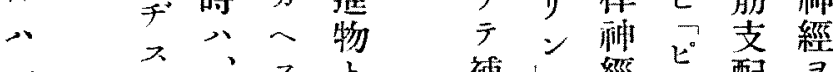

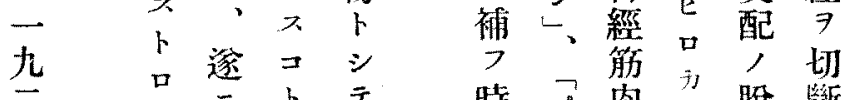

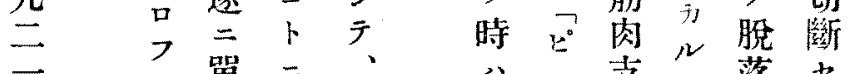

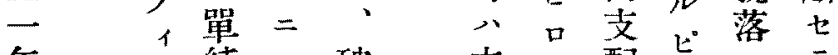

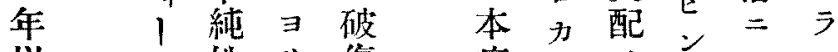

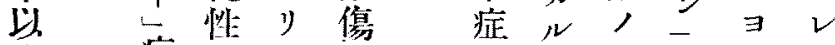

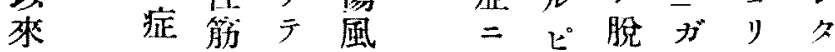
多数透對之落特于心

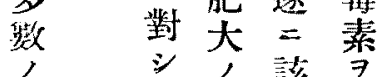
本起筋選

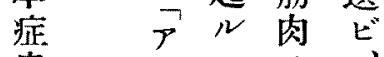

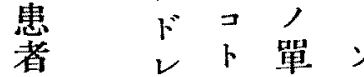
$=f \exists$ 純,

户 ”宦性少

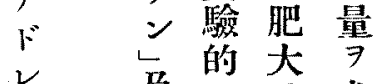

千及 $=$ 皮

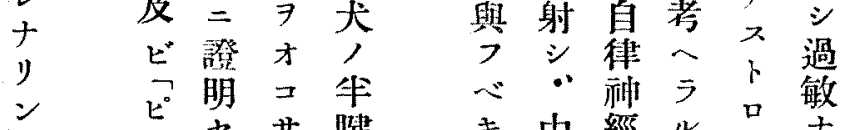

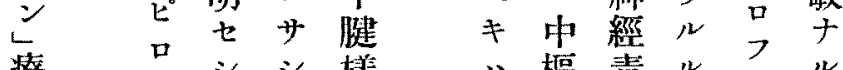

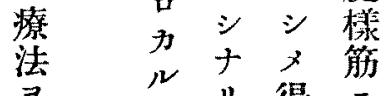

試 ビ”得㝖洼

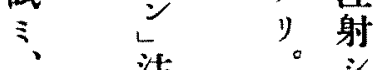

韭 射 郎,

常 $=$ 手

樞毒几

考性素, 1

一自,

貄充了症》

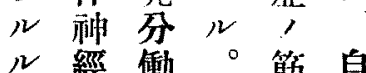

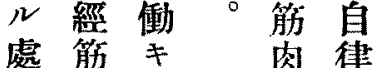
亏゙芮得示种

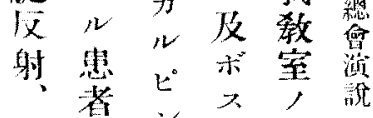
筋四影辻沖 紧例毛繁氏虫 張二亦 7 , 減”数 退 $\neq$ 例 七: 二 “例 裳於 三進”

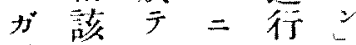
“筋筋・性夜 注肉緊了筋 射三偯予手 $=$ 對 $\Rightarrow$ F $\exists$ 天塯年分分

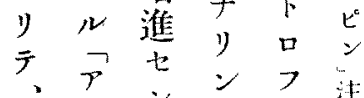

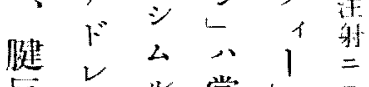
反红常焉 射当三症渞 及こ多整就碓 ビ, 認射笛 筋作 $z=\vec{T}$ 緊用" 對 㖘 $尹$ y 增言。古子” 淮亏邓淮,

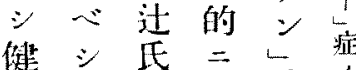
康所公働及㐬 侧治キビ密

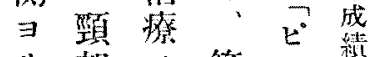
y) 部, 筋 毛交目婜办 却感的㖘少 种 $尹$ ヨ比分 要經以算

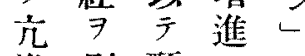
淮剔頸飞, 天出部 几七交么緊 $\exists ル$ 威ル張 

他以, 枀三造飞来直的高效り察二N患 例 例 $P$ 樂 $\Rightarrow \neq=+$ 果。

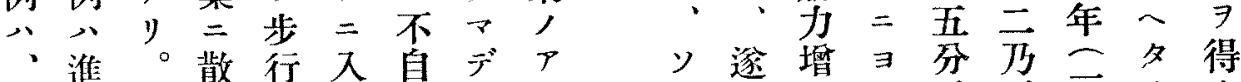

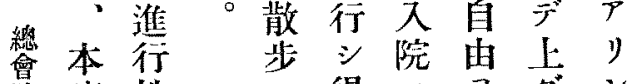
演症性 シ 得フ

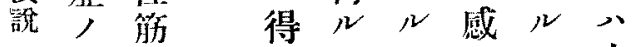
冲カ 中ナス 二過ウザ得二 II $\vec{r}$ 進占学束程り中 レ 行 $\begin{array}{lll}\text { ๖ } & \text { ル } & 1\end{array}$ 艺患 ᄂ 及者淀 ピ シ 輕 方度

以

ピリ

亡 $=$ 三

注例夕

リリ シ シ 度 シ

此ガ退十 䄪 例

患、院 $N+=$

，遂增 $\exists$ 留少三少得 他永 7 至 0 九。”

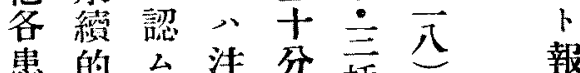

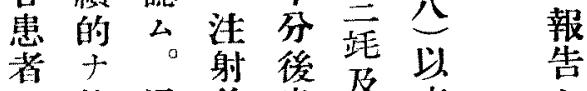
二筋通後患草來苦 ”力常全者百士 り キ增 $\Rightarrow$ 身公倍 前唯

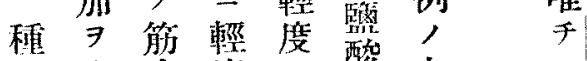
々来少度, 酸本 者泩七射五 退= 作少十 7 進 $心=$ 院ヨ、諸 泩ソ 後り数管射, $\Rightarrow$, 二訴 $\exists$ ピ 就 $\exists$ 觀 時 フ 覺ンキ

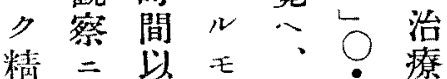
方追月 $€ \exists$ 例 = $x$ 二良, 見、,

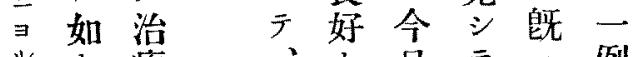
㟆、療、日 準優二步十来甚效二

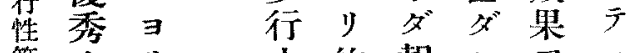

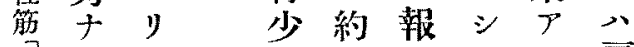
ギル斯 シ四 $三$ ク 肩 入效, 夕十接肥 、筋

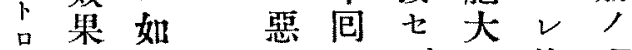
ᄀ $7 \neq$ 1 見 效 $1 \stackrel{1}{\prime} N$ 症 $\Rightarrow$ 是 治 得

潦ザ十

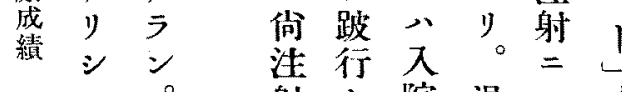

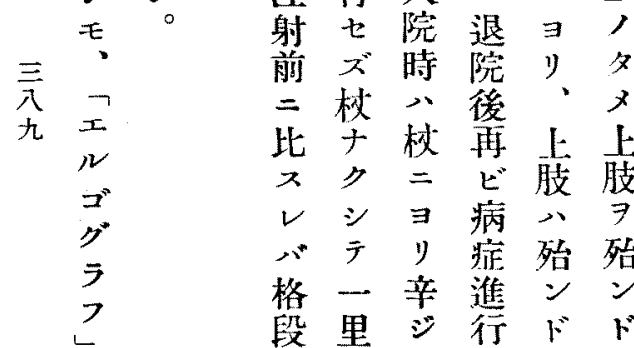

十泩。儿兰禾

り射 第 $7 \underset{+}{ }$ 夕 $=$ 三 認司 $\sim \exists$ 例 モり 方名波 尐跛一少射

細 八内人脈一 $=$ 筋 $=>$ 搏 乃試 觀 動 再りモ至三 察作 ビ。少 $\bigcirc$ 七描消泩流り り点失射夕至。 治

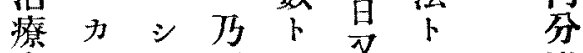
中力カ至十又泌 心七レ主ル隔テ テ 機

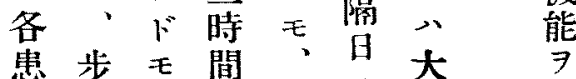
者行三後間度众刺 二能夲 =

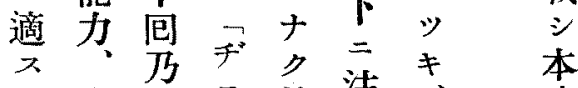
筋 行步至卡是射手症 肉狀十而真倍良 運態包 7 副後監作 動，作，化用 $\exists$ 起連

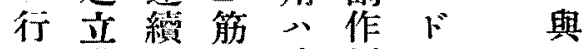
$\therefore$ 動注二消用レフ シ作射著失トナル 
試施于配テ瘾最フ治オ症儿以殆オレ其

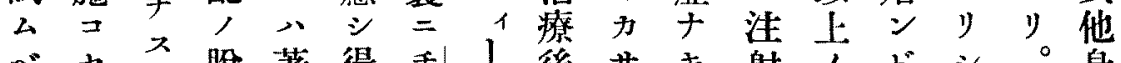

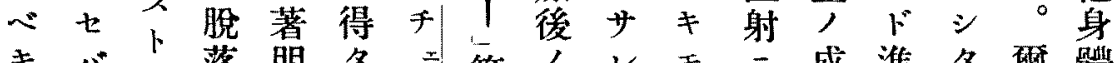
キ 價病勢フ

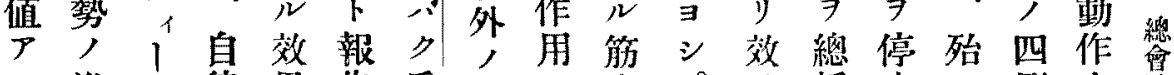
良準

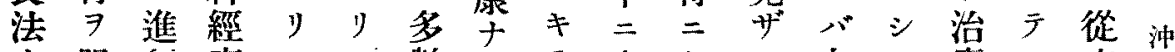

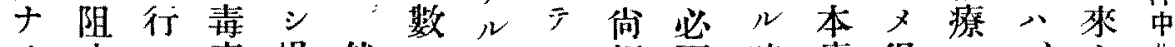

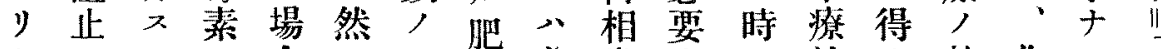
卜 $ル$ 合

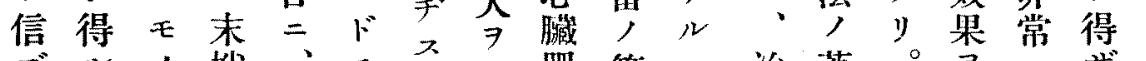
ズ $N$, 梢、E ルナナ作只余占地大治療盟認,高り》 モうラ用機 , ン $ン=$ 能進 1 例, 殘中效 $N$, 種及

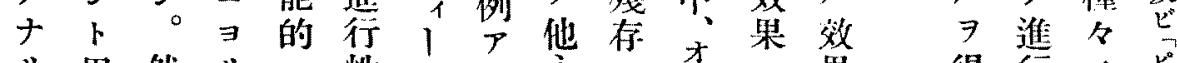
》。思然り二性象》永七力八, 果得行, ヒ⿺

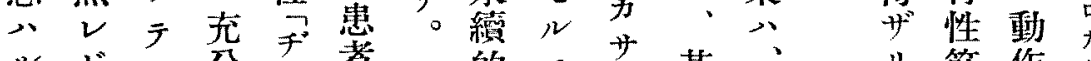

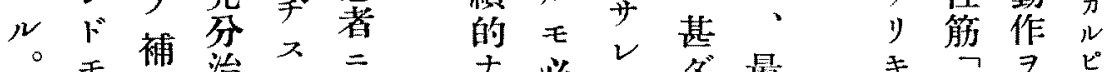

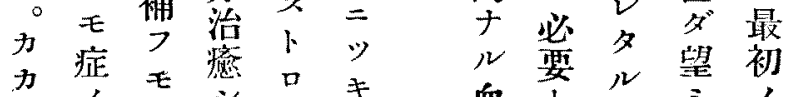

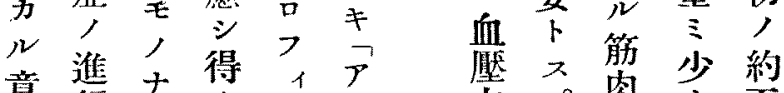

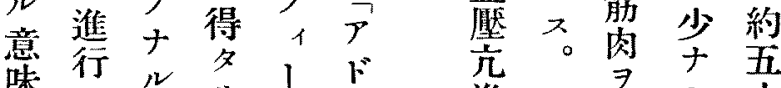
味 於一故症十 天般二信 ガ y

本非療公全

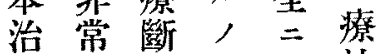
療二䋧デ治法 法遌後厂癒 試 八多永出公試 病公時前毛 $=モ 日$ 述, 結 對, $\ni$ 七ナ果 故經心y八 何 $=N$ 如 1 八 等、時 夕、\%

治 時 八筋思二

療々 亿曾分於

法以ッ，ズテ

于上カ自”

车 一律余完

今 治 再神 ’ 全

日 療 $ヒ ゙$ 經 例 $=$ 筋支 $=$ 治 


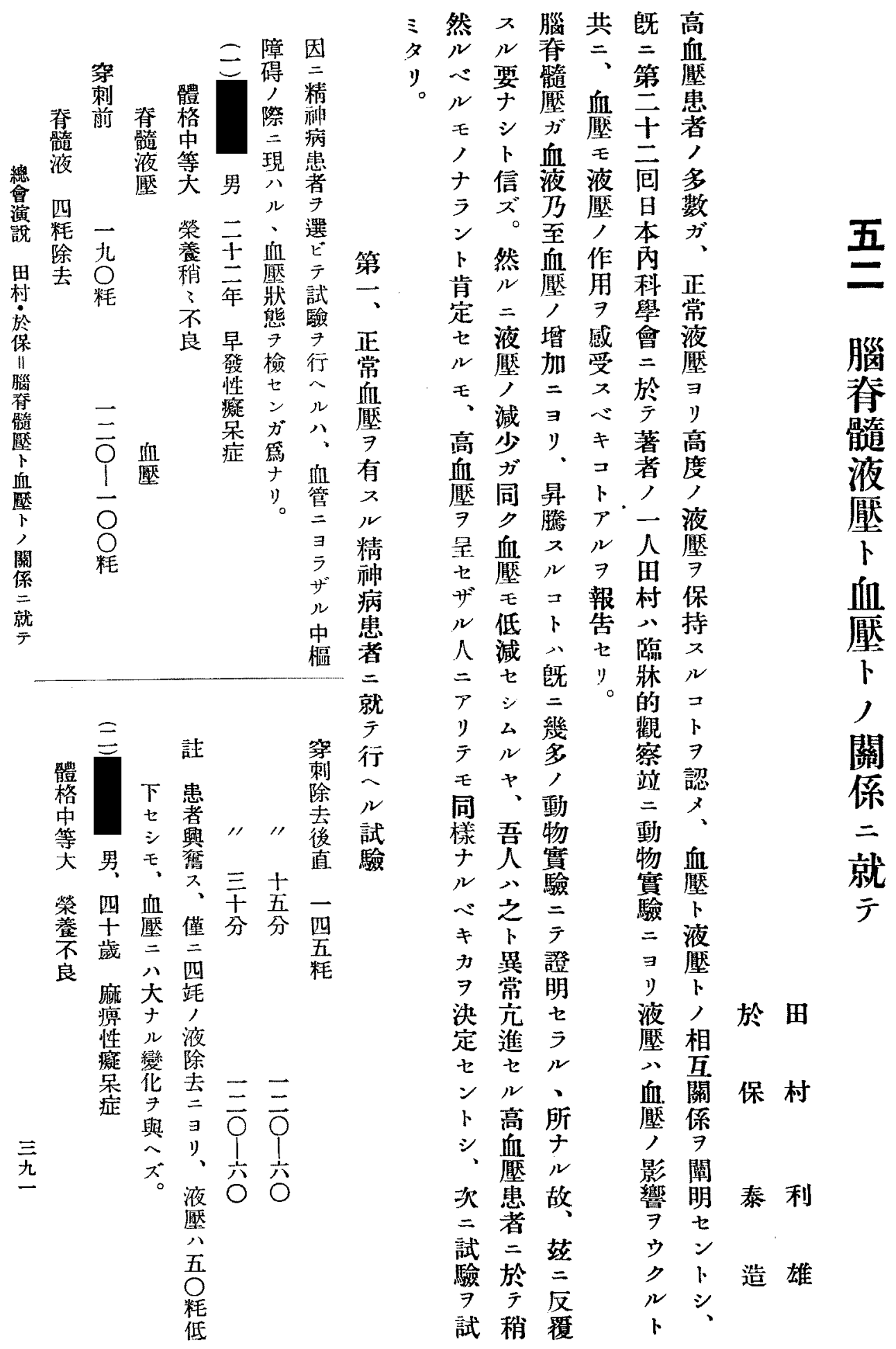



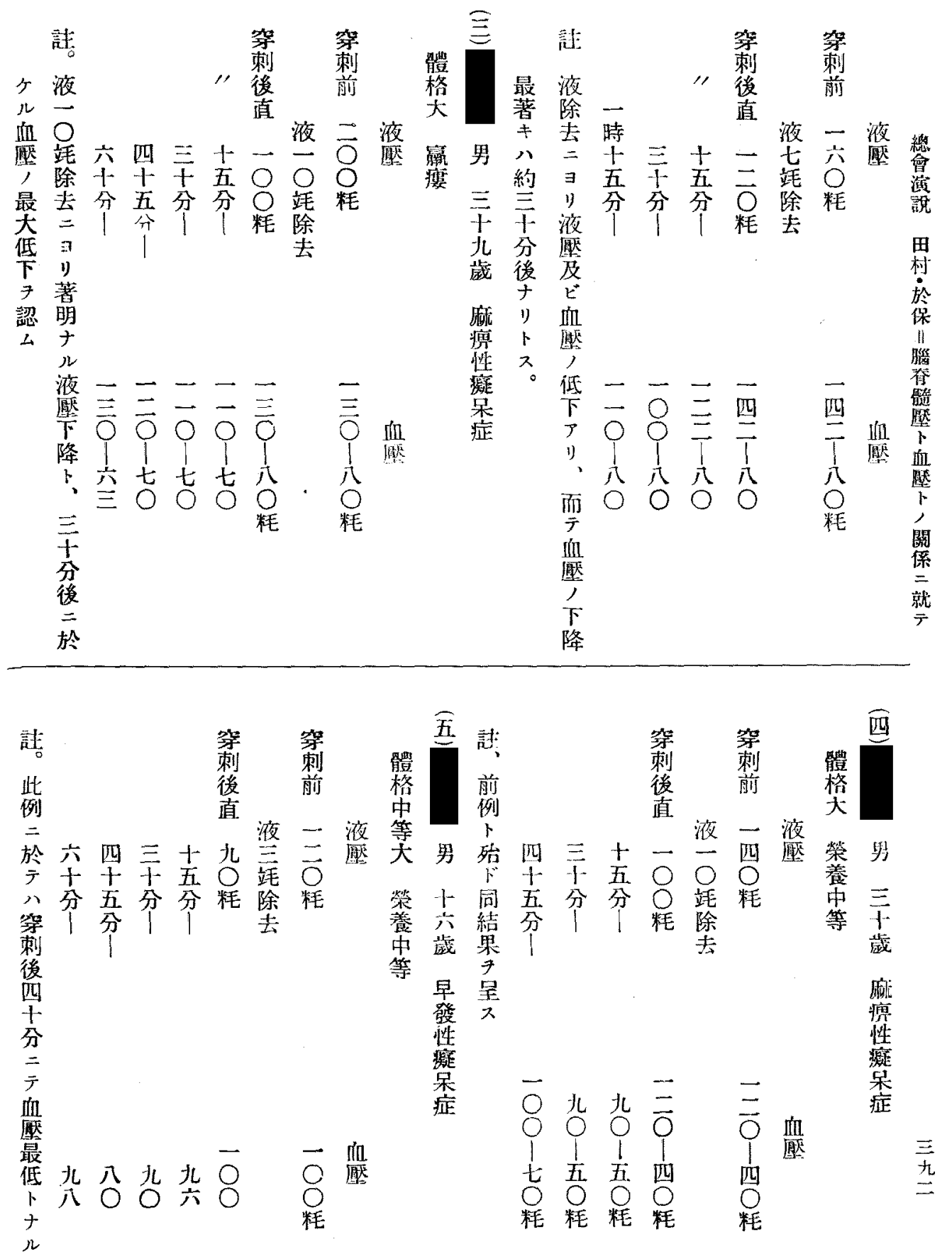
移落ルナ广弛中液管腦入液以

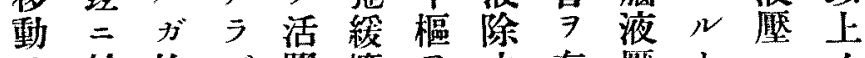
$\exists$ 於故 ズ䠰援 $\rightarrow$ 去有磨卜心, 動 $\bar{F}=$ 。張声三

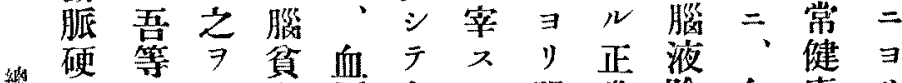

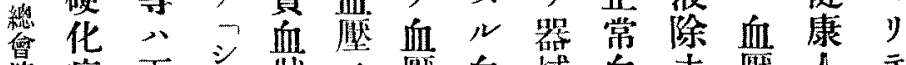

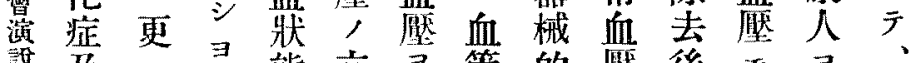

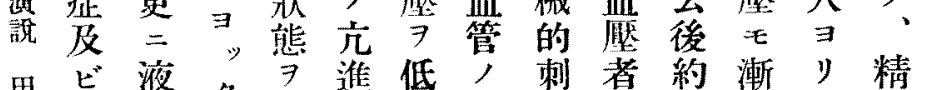

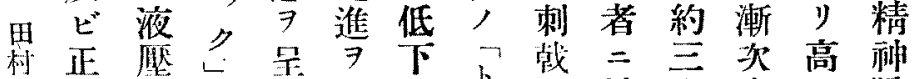
於常!現七是七! 分於十降少、障 保血血像ザスシ 又蓄亏分下、碍

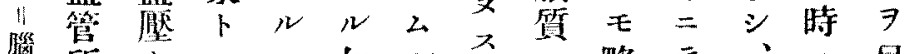

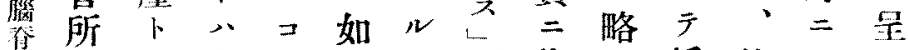

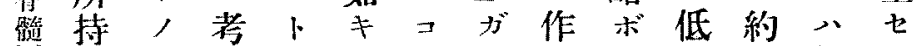

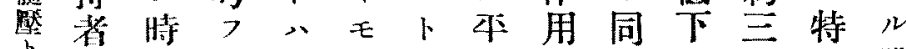

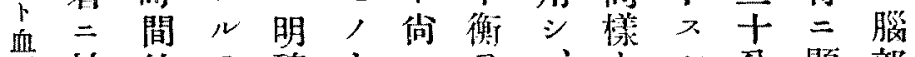

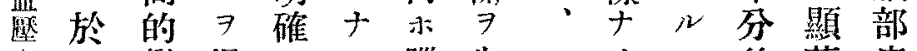

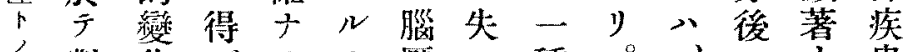
關對华入゙y力塺

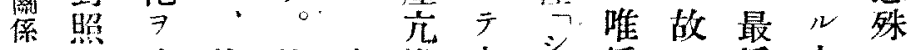
就比追韩然未進中寻低二低充二

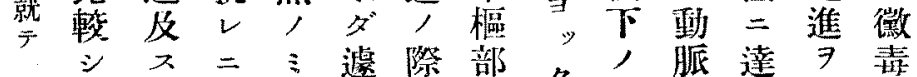

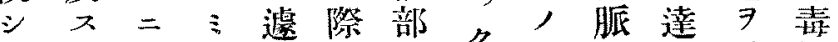

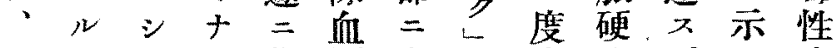

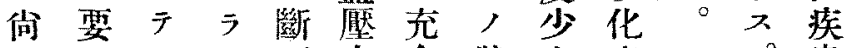
末 $モ$ ズズ中血狀ナ症。患 血 2 中高心樞 7 態 $ル$ 或而

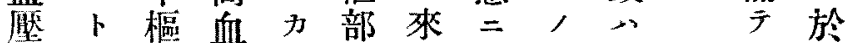
促思性壓 ラ $ヌ$ タ ミ高少 進七, 患

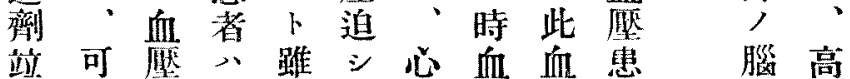

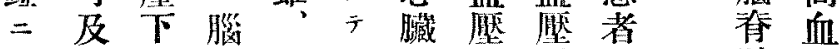
降的降金三其又, 低三髓壓

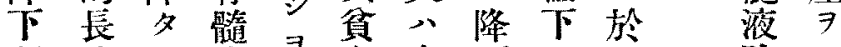
劑時 $\Rightarrow$ 間 $=$ 除, 7 梢 $尹$ 何之 用 二小去怘來血來 $=$ 本 七 丕川㣪二シ管夕 $\exists$ 見

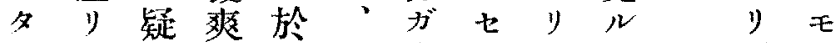
ルテ于快尔篇此ハテ, 三場、 $\neq \exists N$ 充モ說ミ俄二 坣合液如覺如二血, 明 , 壓 液卜さル脈臟除・バズ高モ

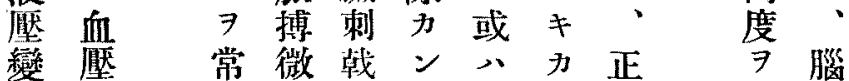

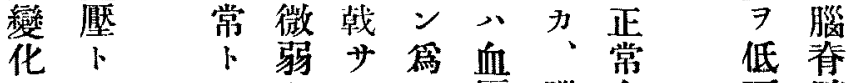

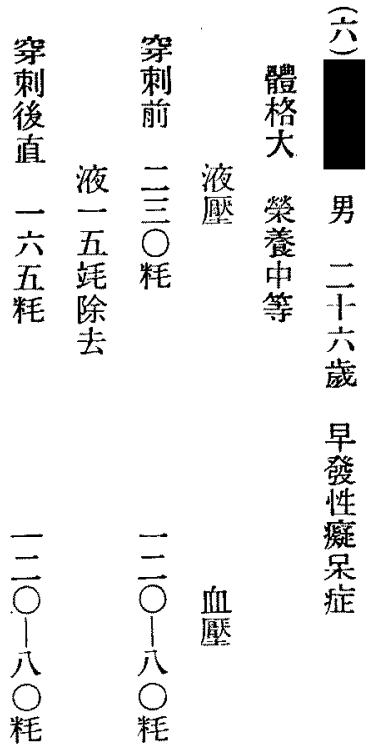


暫進故 時合二壓他

時 $\boldsymbol{j}^{\circ}=$ 二血近八覺

干一穿入塺 $ッ$ 時的

分部㮅腦心間二

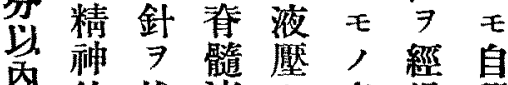

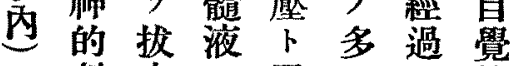

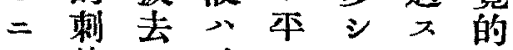

戟 学硝行䇫江=

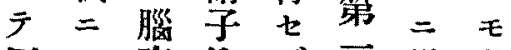

原 $习$ 脊筒 ザ圆從動第

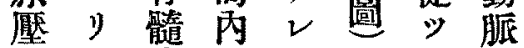

三菠三共。广硬正

復促, 移血潮化常

歸 流流之塺次症血

又

$\mu, \exists$ 得以之萑至所

二場妨 2 三三高持

卜合 グ $尹$ 血反血者

$\exists>2$ 以摩

常ルバラガ、四必液

卜 心腦最十有壓

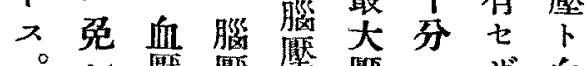

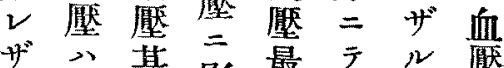

再其影最最者

所ビモ響壓高晋

子, 苦共二就

心犁、少三達俦

ゲス常コ㙷シ、占

レコ緩占者其,

共点和き儿㴔方

前娍占變同法

刀試退, 炛高

力驗 茟断 7 度以

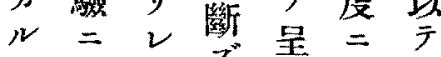

際於居爻七广液

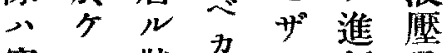

第次狀吕仙行及

刺如態云カス

, 多三或

最ナア何公力歴

初ルル稍・

ニぇ゙ャ゙ 或 測

於シケと下空

天。人 ハ降又七

克液心”、漸儿

進壓ナ此。次二

著, り試此嚄

光、驗場高液

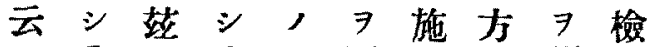

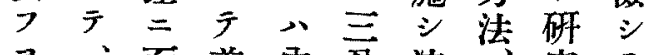

夏美丙㞣流究云

得是白支徑間出開七雨

心゙前キナ○每不淑ン者

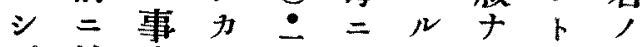

精實

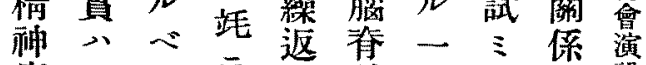

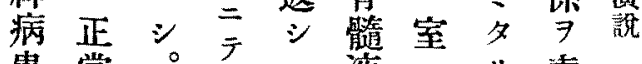

患常。健乃淮常”。索田

者衁康乃被。尒梦

液官敏至硝檢更於

有暨主筒 $\Rightarrow$ 吾

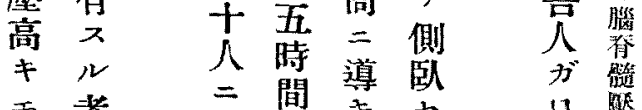

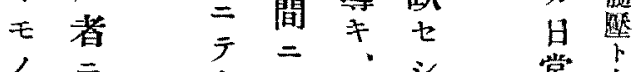

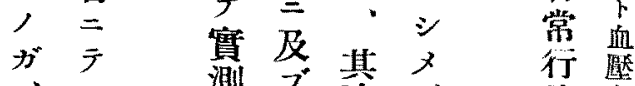

“无測 ブ基、使

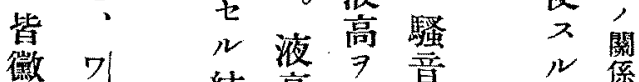

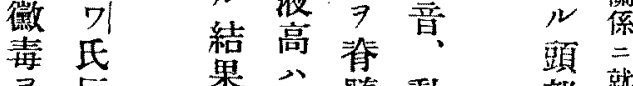

$\exists$ 反果公䯕動部就

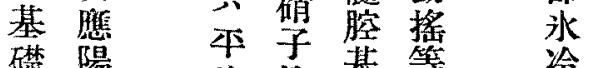

脴陽均筒基等冷

患装三离穿外喫

$r$, 空空刺來煙

三, 粍大部整飲

俦、㴕尔》

不般留离高防等

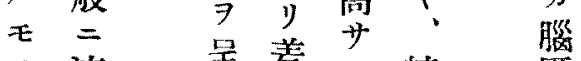

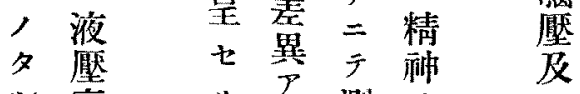

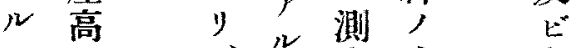

二, 定安

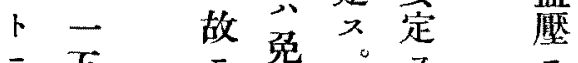

二五三免。六二

一○正 ズ同 $ル$ 如

脈粍常

, 丙夜余二待

關外高敘血 $F$ 无

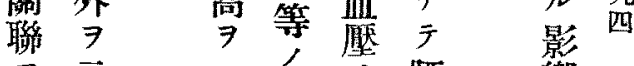

示 一 $\Rightarrow$ 腰㫿

$\mu x$ 二用測椎斗

モ $\vec{D}$ Ey穿及

， 上 粍 三雨刺年

$r=r$ 者 $\Rightarrow$ 


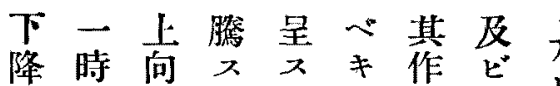

大性 $2 \cdot 2$ 上角血

$=E$ 古

畣 学 示

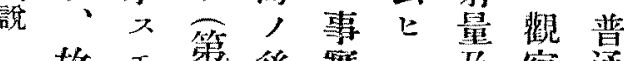

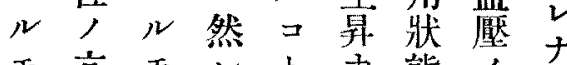

總分準, 共周シ 父戀?

動 二 故 テ昇其夕動

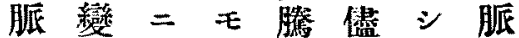

硬動正液ノ二 = 硬

化 又常壓傾移推化 症。血, 向行移疾

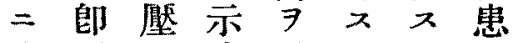
テ正卜度示 $ル=$ 八常動 》又モモ同 血脈血 $€$, , 樈 第血管硬壓, 最多, 第

四壓二化占厂多三試第

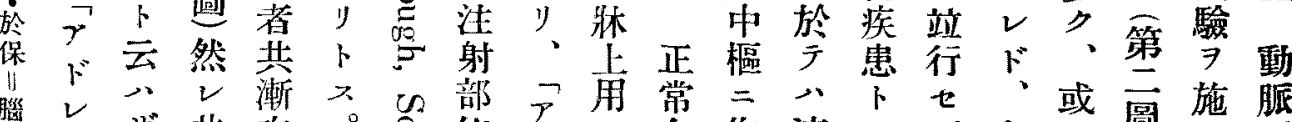
保

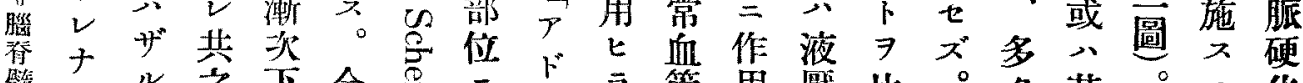

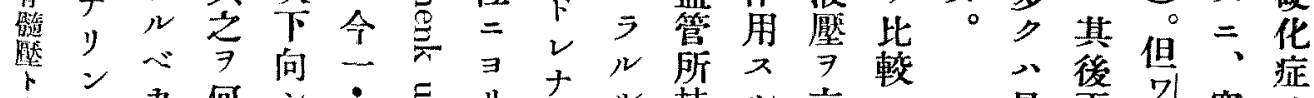

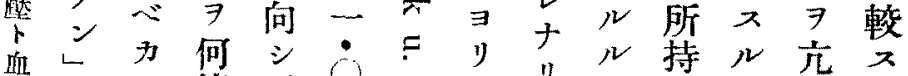

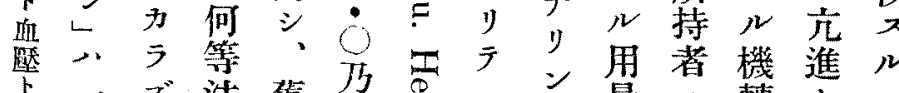

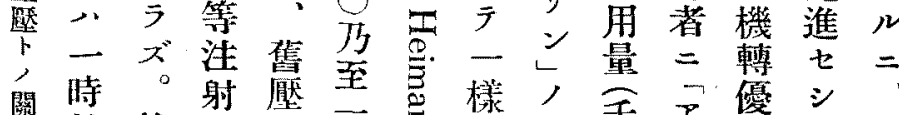

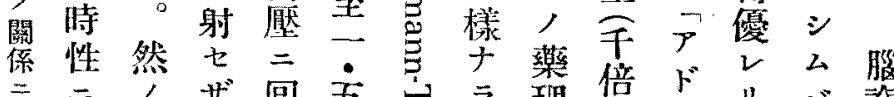

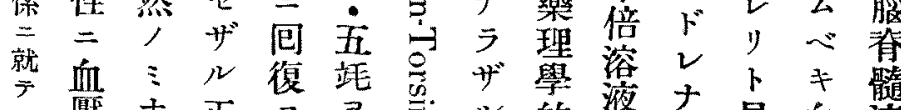

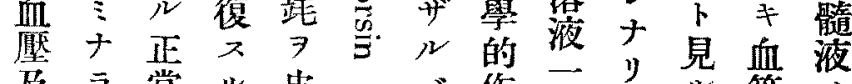

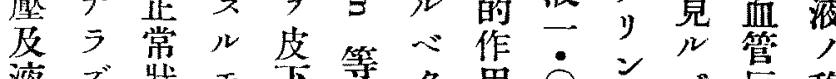

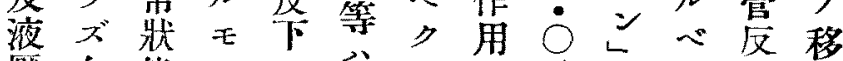

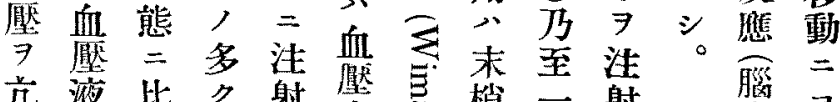
艺液比名射熨志、梢主射

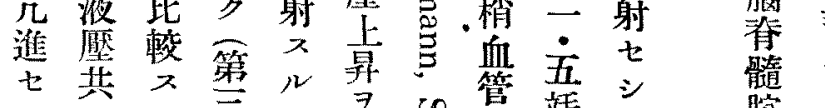

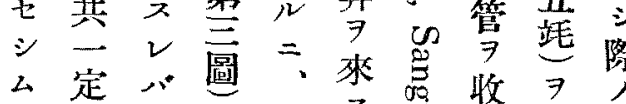

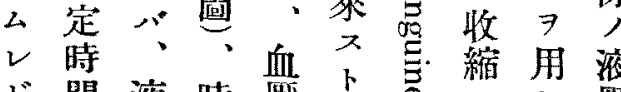

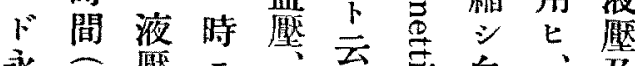
永丽壓 $=$ 云吉血、等 䅡

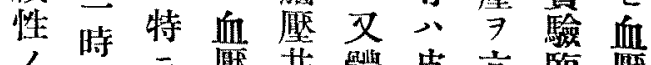
人間二壓共體皮充臨㿄

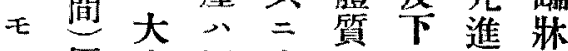
, 經大司少二注七上 二過 $ル$ 復 $ヨ$ 射 シ 三非後昇ス卜リ三公現

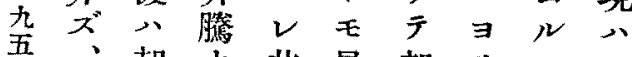
却ナ共最却りモと 而广”液初方血, 得 于原血壓 液壓壓心徐反, $2 \neq$

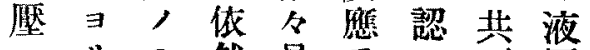
八リ 三然䒜 $\rightrightarrows$ 公壓 最更氐穿, 大二濑夜 最漸质後壓 小次慰蒋及 壓鹤有壓 ビ 共高有自血 降復 モ 騰

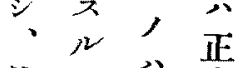
其毛基 蔯, 甚血血 心!。憅者 正常稀替於 二著り、如 於于血夕 ケ心壓著 變 八明 動三十 1) $\Rightarrow$ 西 著呈十 ス 明七分 ナズ, 寧

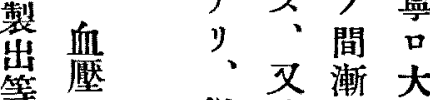
等壓圣潮大 著後 者落八降移 血管䫖則 》容 昜 於 時 動 


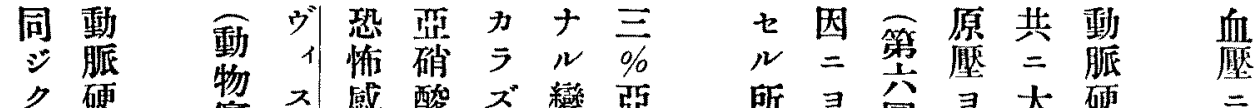

下化 實 會 籃

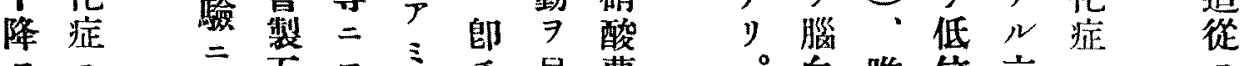

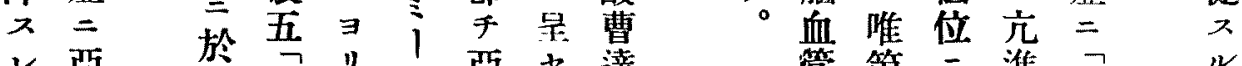

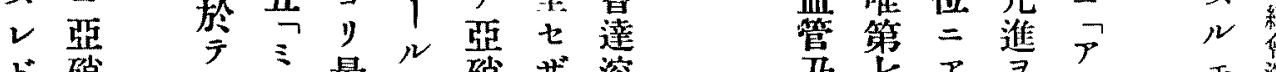

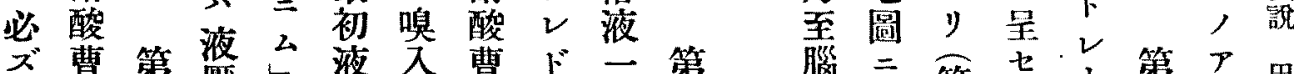

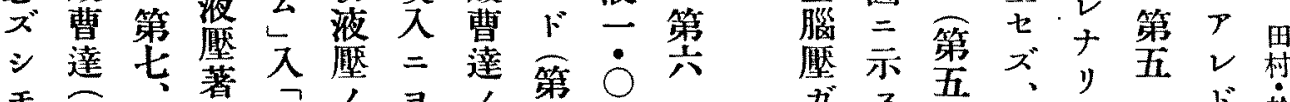

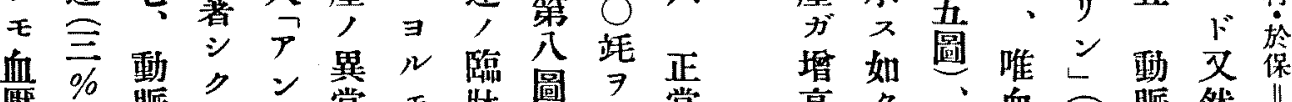

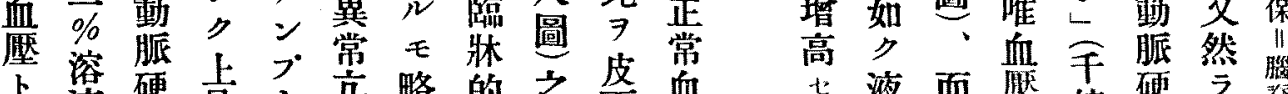

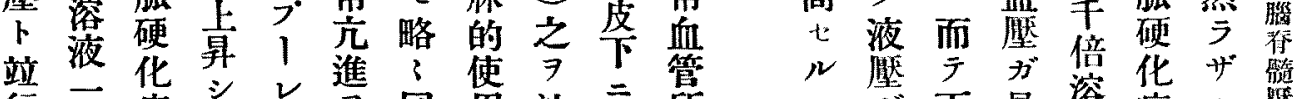

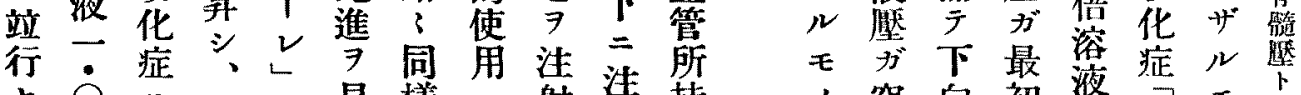

七 $\bigcirc=人$ 見樣

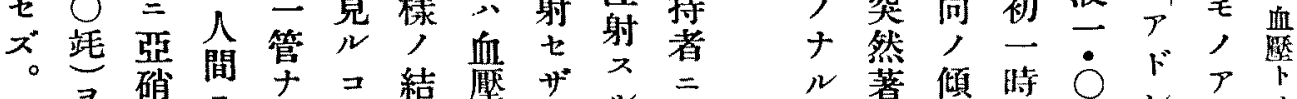

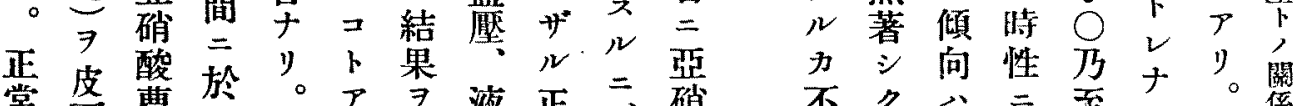

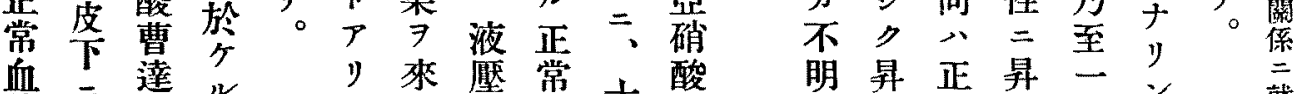

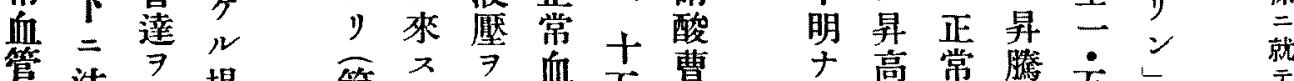

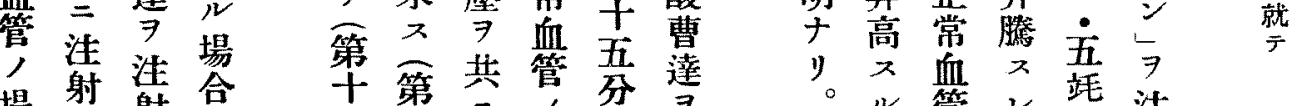

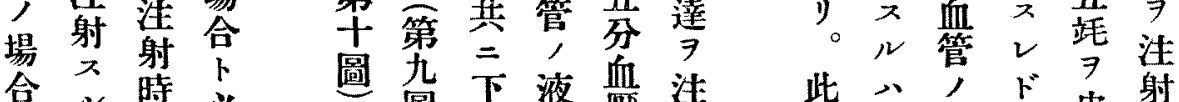

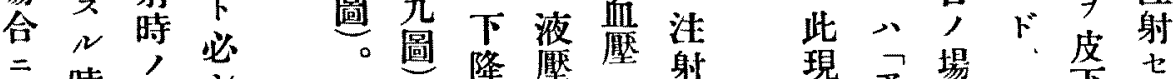

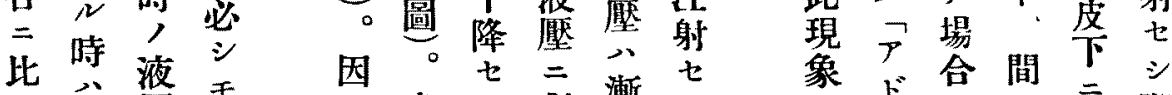

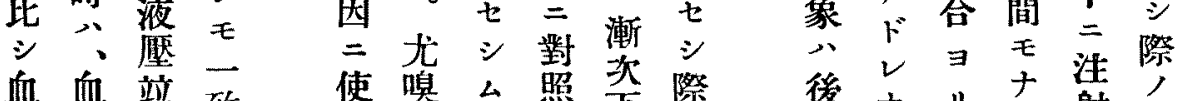

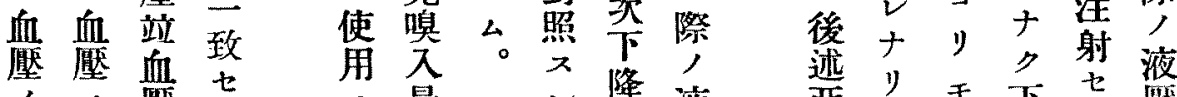

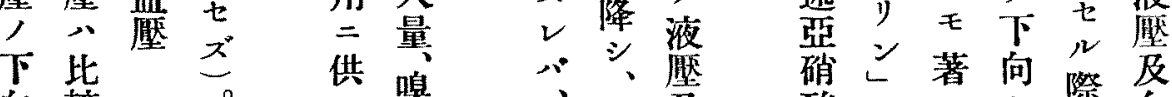

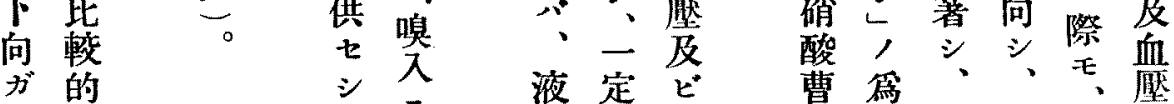

一 速

亞二液 定

般 =

$=下$

著降

明

其

、睢

血 =

塺推

異

常 液

克 壓

硝 $、$ 公間壓

酸皇抑低

勇鼻壓位

三 粘

门膜価

$\sim$ 刺居二

八戟䠹

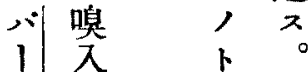

少 七液

對 ザ 壓

達

夜 $2=$ 正

洼力八ミ血

射或最大管

于患寻䓃於

モ者り年

同睡下二止

多眠 降時

睡 中間 如

眠何 $N$ 後 ”

中 等 $E=$ 液

二力, 八壓

發, $>$ 却 血

現原り 壓 
常從之

管 㧕要

$\exists$ 㿄

) 的 $N$

八刺 =

刺戴 正

戟 $=$ 常

二 對 血

對 シ 管

㭷多 甹,

於下正

保向動, 總

鲻的㭽 $>$

裂二硬腦括

暨盾化食

壁㦄症 檤

血

㻺ンり壓

; 1 不 $\varepsilon$

阔繁 血

係ルナ壓

就如り モ

菻

之侌楼

血 学

管 動

齐脈

異硬動

常化脈

緊症硬

張 $心$ 化

, 液 症

狀壓

態、於

$=$ 血 5

摩 ル

共 $\exists$

篇 $=$ り

ナ高

2 位舅

三心

卆。保的

千 態

+ 度

ガ $\Rightarrow$

今、探

正

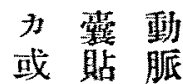

八角硬

稍, 化

? 最症

下初二

向液 於

天。摩

克

淮, 第,

第

正九

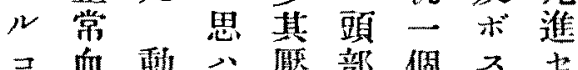

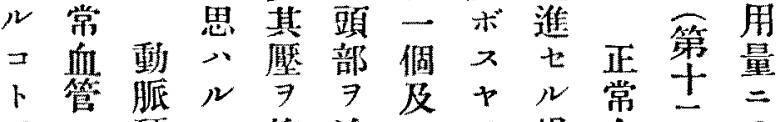

$ア=$ 硬儿抑冷

、於化例制却永知合管圆

而心症

于 $\exists$ 部徒作時倜 陵論部

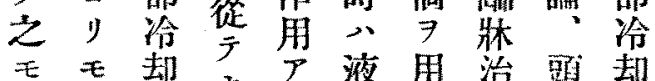

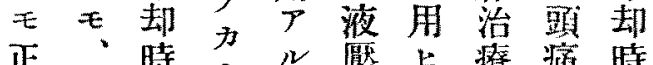

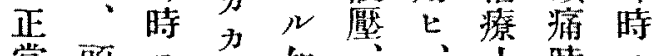

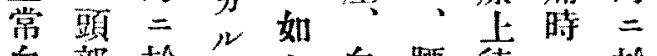

血部 於

管 椧 方

= 却 $N$

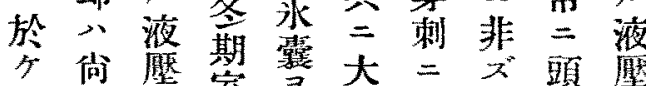

此策及

r 抑

等磨 血

的原

只 $=$

夏莋

$=$ ス

多鄠

無

血四

時

多二

原

, 射

場 現

合爱

敬 シ

ナ テ

水
例 。血腰徒二於

八唯摩椎事、只

摩 $N$ 常部摩溢

亞 $ア ア$

苋硝 $ル$

淮 酸 $:=$

ᄀ 注 $\exists$

夕ミ恣

又, 值,

E少

, 以.5

多上

第

圖

第

塺

及 -

血 圖

$\exists$ 例

㧕二

T於

又齐

公

能 ド

著告

* y

力

j

ズ 注

然時

, =

三於

ナ午

$j \quad \mu$

X゙ 如

嗔 只

入 睡

， 眠

初中

期 液

二 厴

却 異

雨常 


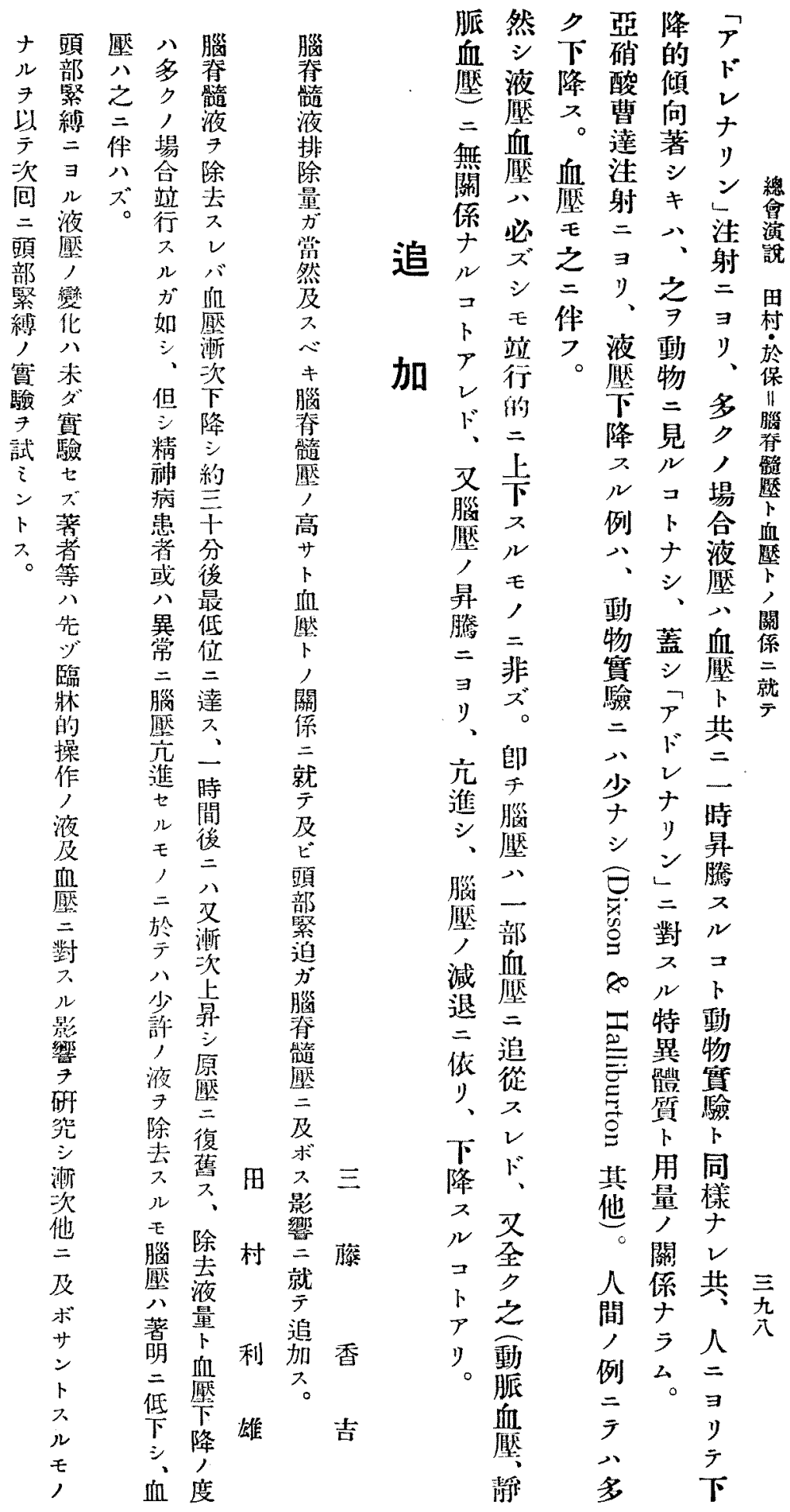


差硬䄃泣三等作 認 $尹$ 後腹次察七り。元的併生

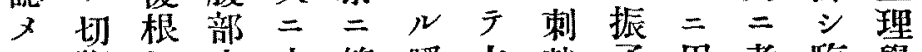

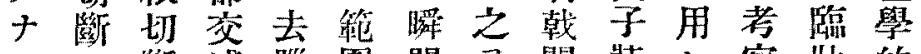

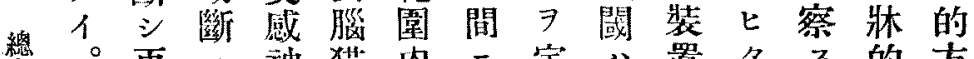
筫。再二神猫内二定八置夕入的方 通續 ビ 經四二於タ振二ルル見面

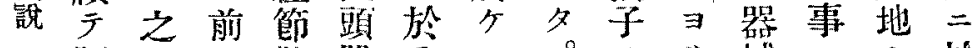

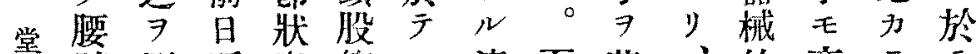

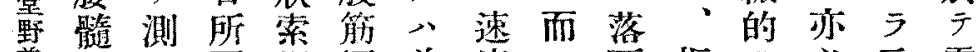
前後定要剔標前度シ宁振工必云電 河根 又娞出本都、テ七子工要へ氮

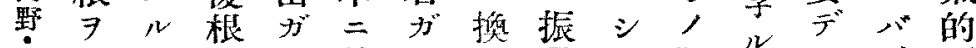

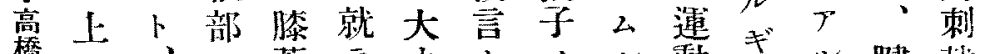

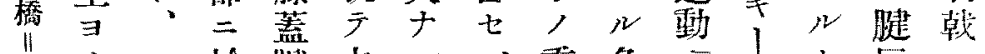

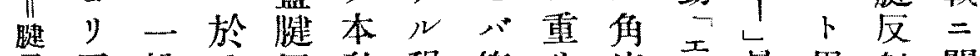

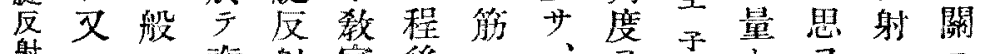

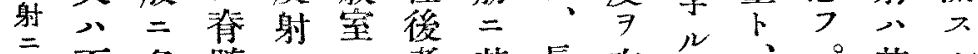

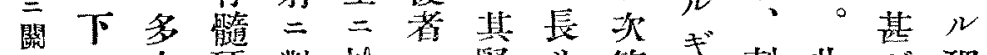

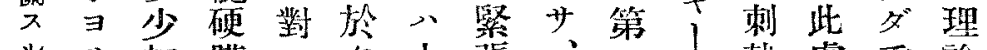
少初膜シ多小張、二乚韩處重諭

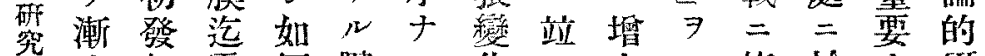
次部露何脡儿化三大一依於于研 一公十反事 $\ni$ 筋 本增 $シ ル$ 射 $\exists$ 起荷行荷筋余, 宛大置影测認 省重キ重等 ゙゙甚

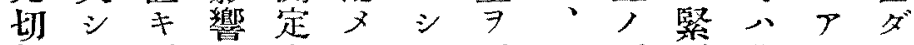

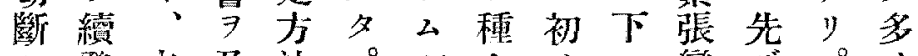
シ發本及法。ルタメ二變ヅ。イ テ部試ボ莨速二テア化去而ガ 其八羷 $下$ ビ度戀肉儿, 腦カ、 影減 = 其基化眼筋速猫 $飞$ 器 響 弱 際 7 與

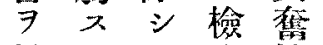
見 $N$ 于查 性 ルガ ハ シ 標 二小先夕。蕉

上收豫定

寻縮 $九$ 法

り波腱=

八孉 寻

艺第芝 射 九二刺测作

下戴定䯕

$\exists$ 閾 シ 後

第大 次切

全言的, 度前之械

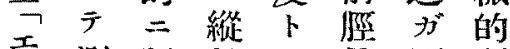

子測認軸, 骨测刺

定 三間筋定戟

吾

ギ七得沿,,$=$

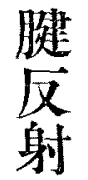

）出關腱當就高河堂 ᄂ刺キテ係反学

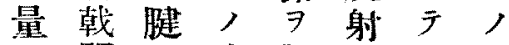

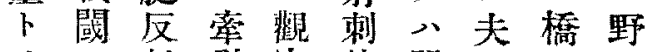

壬射引察戟器 $、$ 前 、關就, 力凩閾械殆

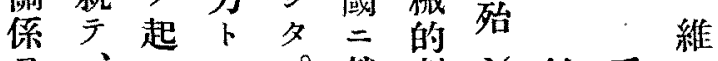
ヨ、ッ シ 就剌ン敏 秀

見振タテ器テ戟ド摩 光時作械, , 皆 二ガ，用的之要無夫夫墽

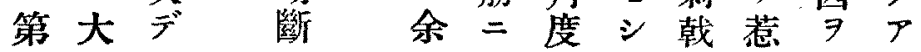


雨ナ得ノシ脈ト三卜歸, デニ去腹要二二六

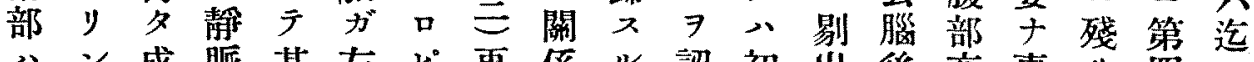

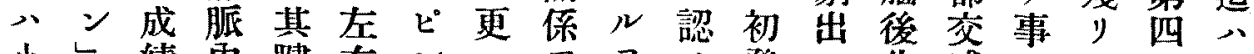

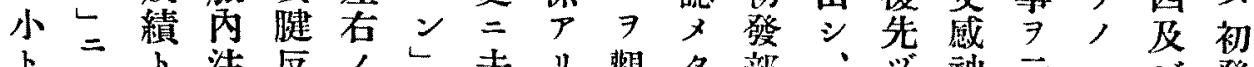
上

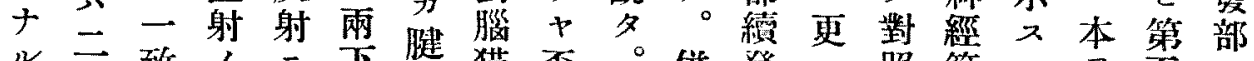

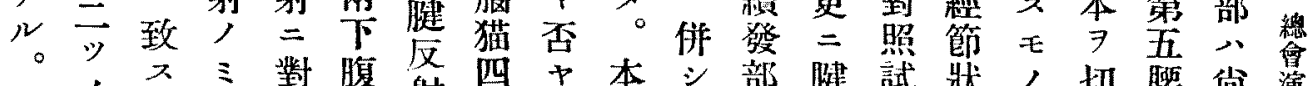
第作ル

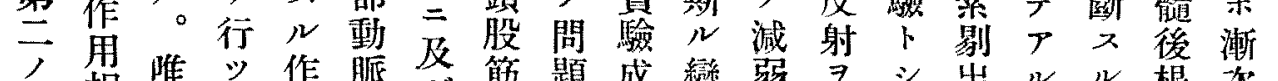

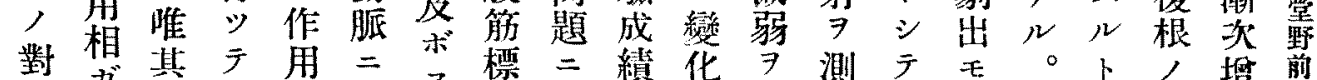

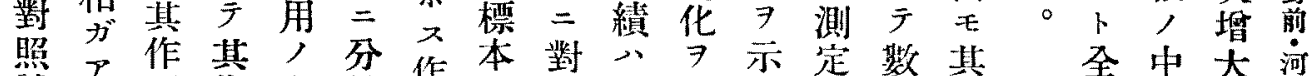

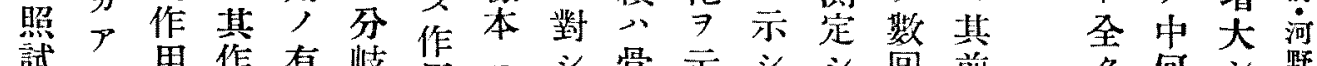
試, 用作有岐角二シ骨示シ シ向前多何シ野

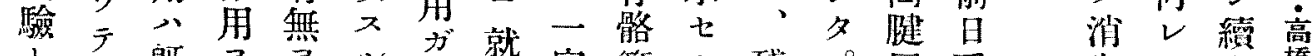

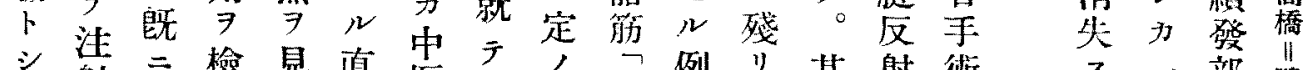

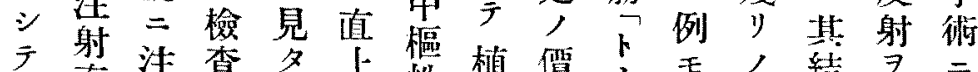

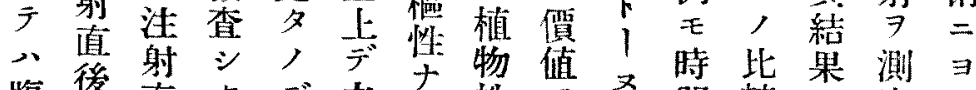

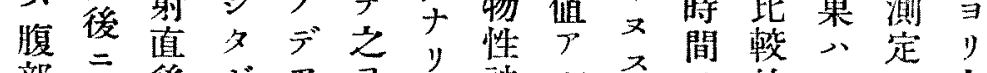

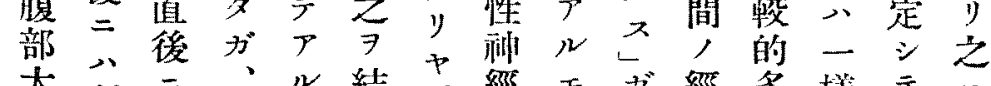

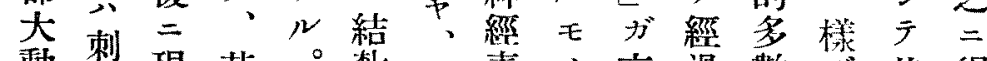

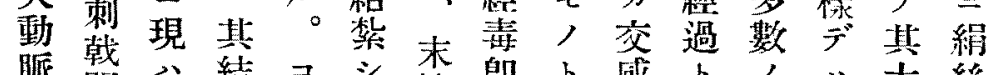

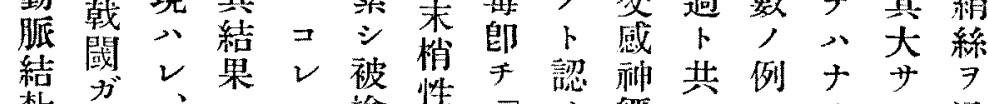

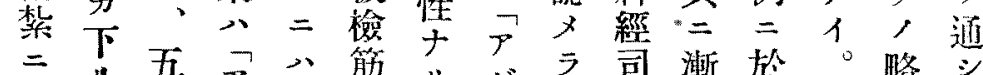

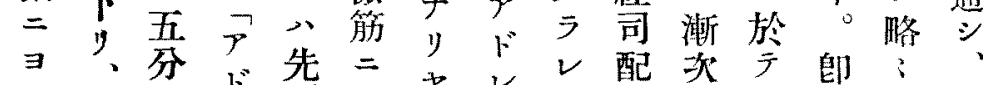

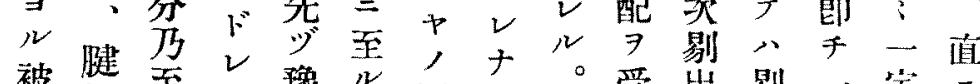
被照至ナ豫公疑り。受出剔一定二 檢射十りメ血疑り ン名前出部三切

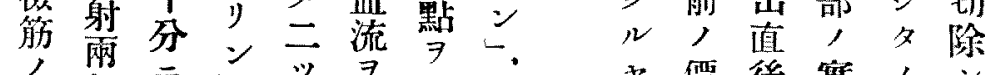

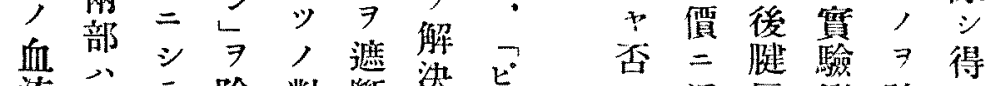
流增于除對斷決

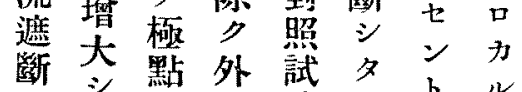
ノ、芝大驗淩企 ピ

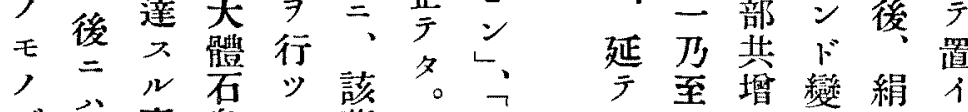

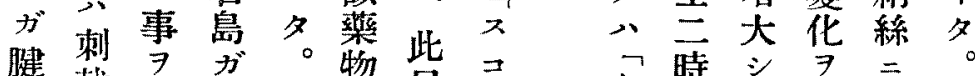

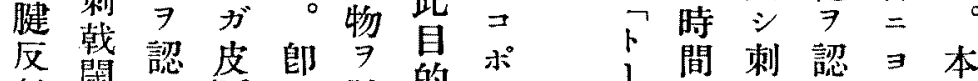

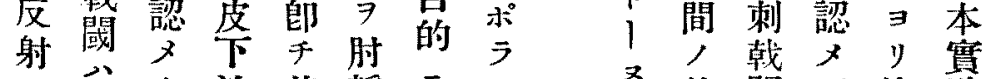

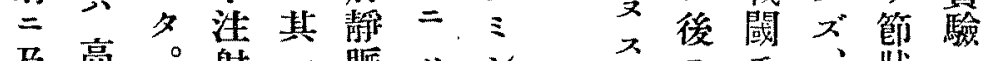

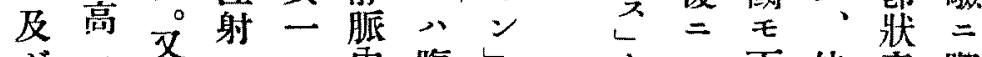

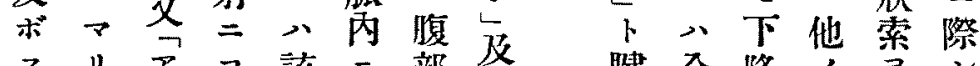

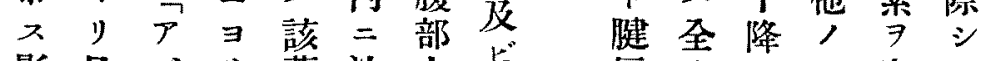

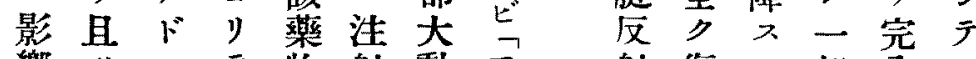

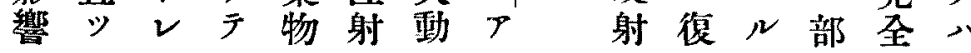

ス 一 部 腱 計八反 $\circ \Rightarrow$ 減 射 此切少關 結 斷 入 果 $2 ル N$ 第卡架究 四俄 刺 及 然 韩 ビ 刺 閾 第 戟 五 閾 戀 腰 八化 䯕甚 シ 後ダナ 根 シ 1 $\therefore$ 力 䀬或 涏 シ 反涏却 射反 弓 射下 二, 降 對 兩 $x$ $シ$ 部 其八傾四 求微向 ○ 忍弱 $\exists$ 脚卜示 ト ナ 于、然 重更 


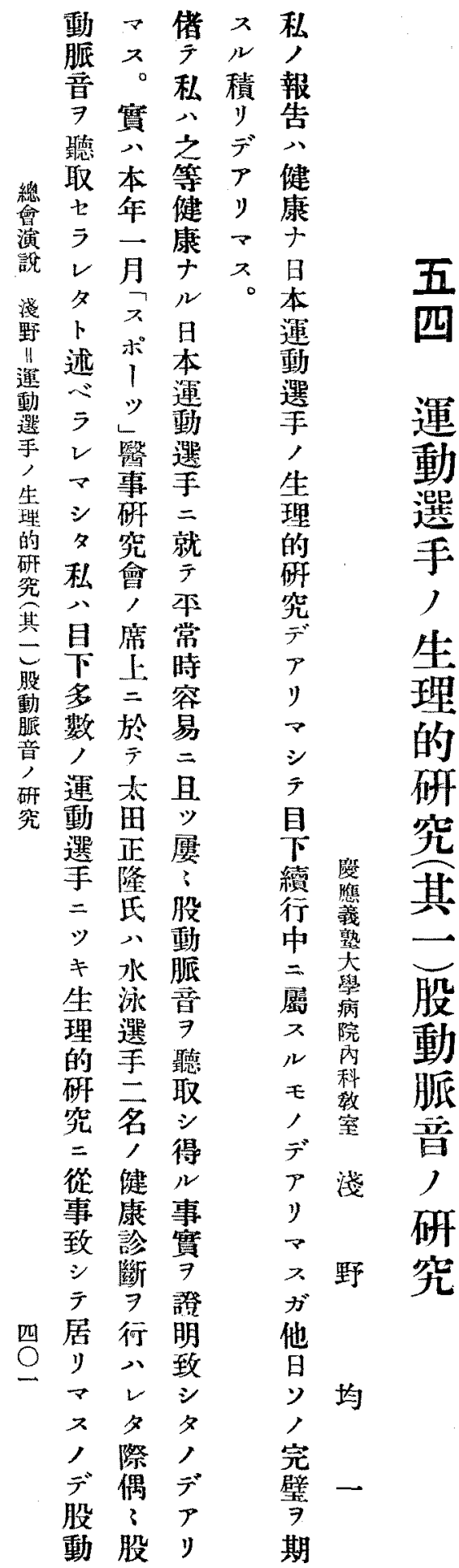

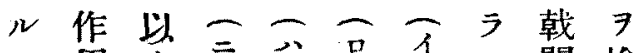

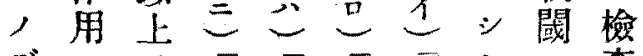

デ、

此少賽 ト

關卜成口吕カレ同ナノ

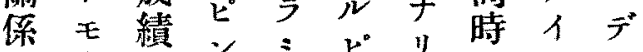

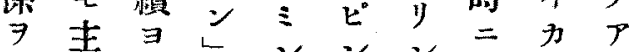

7 完卜

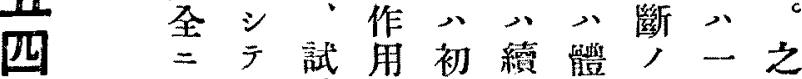

證中殮一發發重碓乃 二

明樞二殆 部 部二實 至 $\exists$

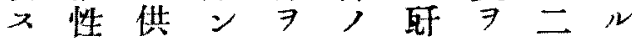

動

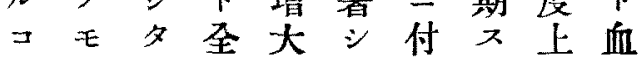

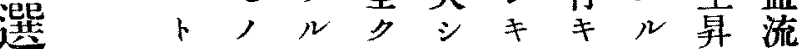

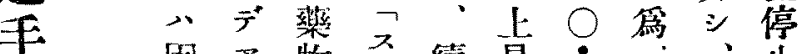

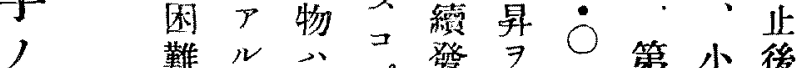

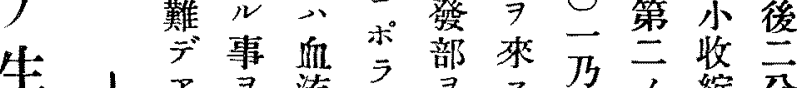

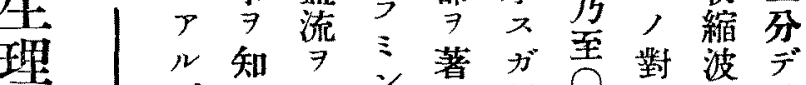

的 $。$ 遮乞 明刺? 照數腱

TII

デ

多卜少二酶卜許心

時同七心 7 同增概

八樣 $三 大$ 泩一加

但其

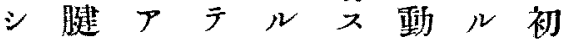

フ反ル零變 $ル$ 物。發

F゙射 ○文化時デ本部

N $\rightarrow \Rightarrow$ 行試及

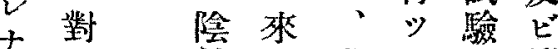

リ沓性サ唯夕三續

ン同卜邓刺。際發

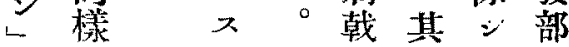

二小。閾成テ共

於

テ意攵下 7 其輕

八味刺降總結度

其 $=$ 戟 括果二

, 作閾見 $シ 7$ 減

作用 小心比少

用入, 下述較

ガル降ミ心゙ス

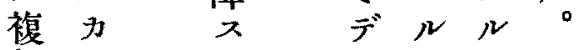

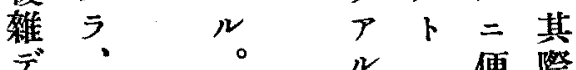

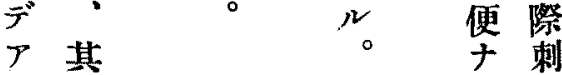




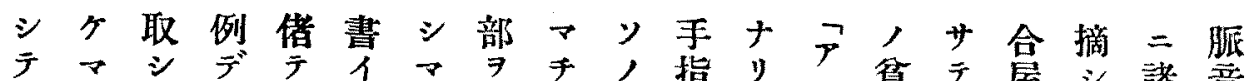

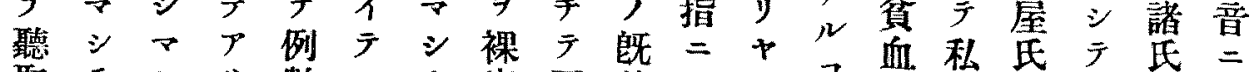

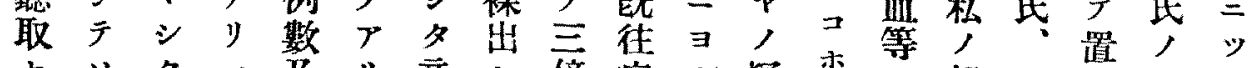

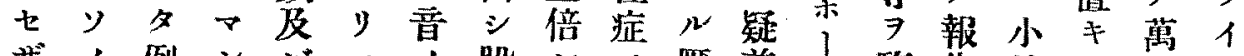

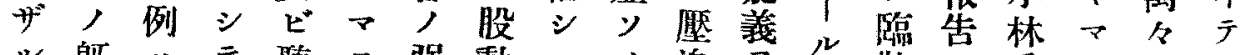

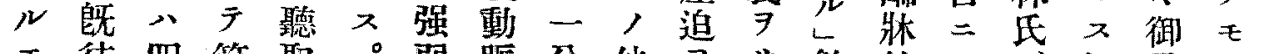

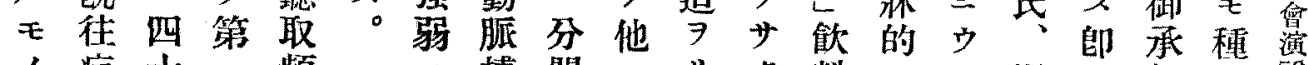

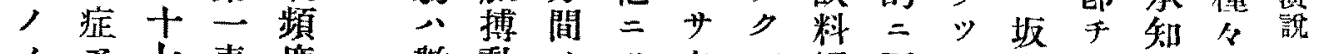
八 總次例 三 = 數 $€$ 聽 示 $\%$ 年三取文焉 數\%多电 马 $\neq$ タ 占觀勇ハ卡 脚笅七各各 氣草例競 既入分挒㮔撿 往占例類香 症五 陽 $=$ 時 此五性寻立 此五萃䄪於 場中八五上 合十五名述 二三五 $>$ 股例 \% 動 7 條 胍内示記件 音陽 $シ$ 載 $\exists$ 性 テ 聽公居于備 取 例り 齐 = $\checkmark リ \bar{J}$ 關聽 シ 取只

广 七内、㐫

ハザ脚シ シ

關儿㢞力多

係モ人私

†'點 テ'

₹四二股例

樣 例 特 動 數

$=$ デ = 脈

思 $P$ 氣至五

$\therefore y \rightarrow 7$

レ、付聽

數動, $ッ ケ ル$ 攝否》本, 調涉

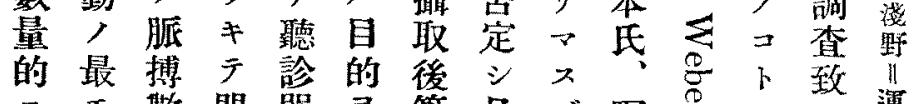

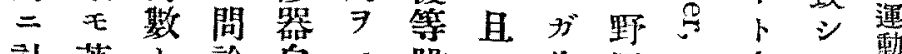
計萻

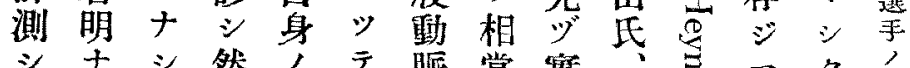

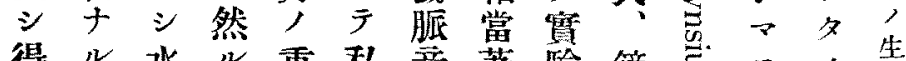

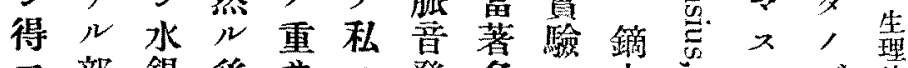

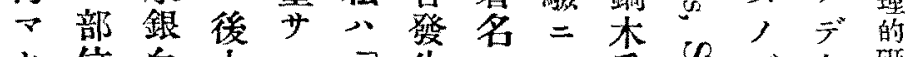

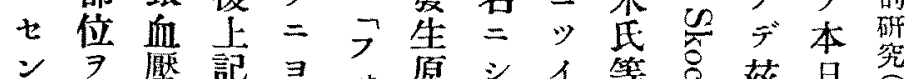

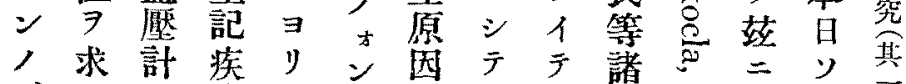

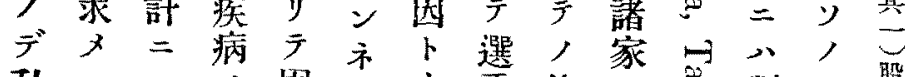

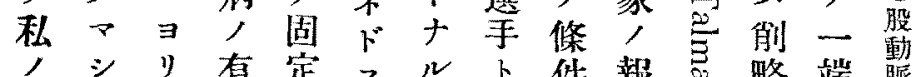
’シ”有定 スル下件報导略端退

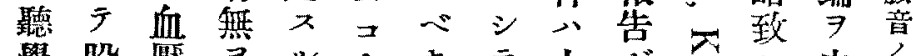
覺股壓 $=$ 動 $\exists$ 檢 $ヤ>゙$ 狀規動 $\Gamma E_{5}$ 述究

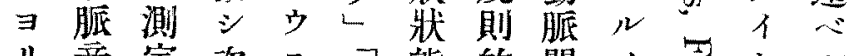

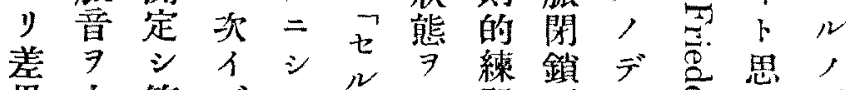
堛第

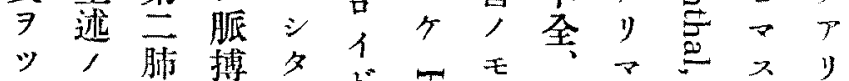

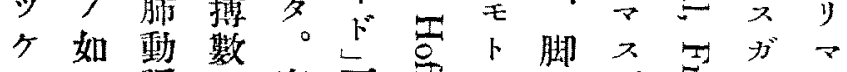

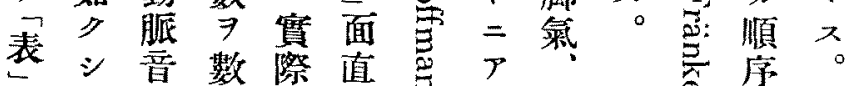

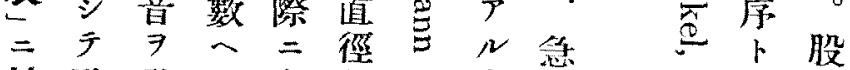

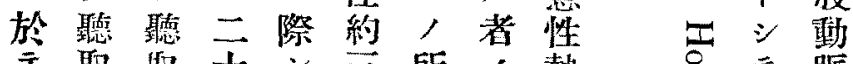

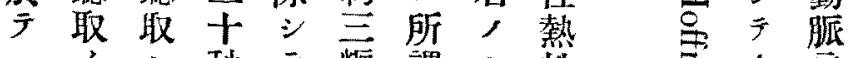

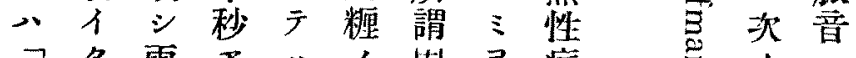

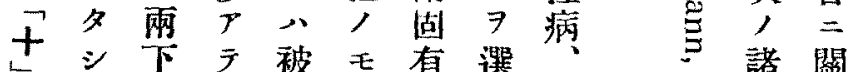

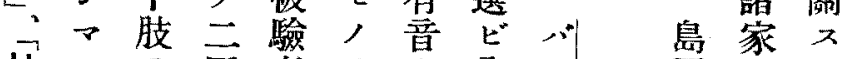

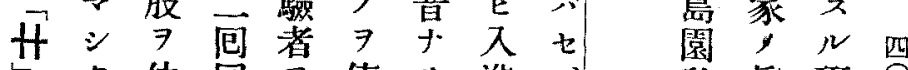
ᄂ, 夕伸同 7 使y浚に゙教真研

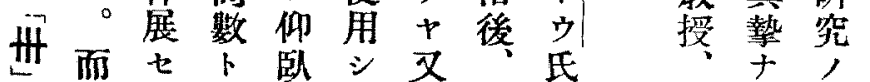
二シシナセナ六運病稻業齐

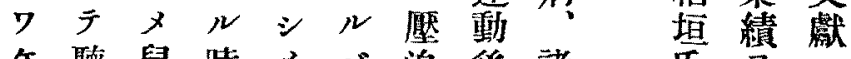
ケ聽 鼠時ヌ心゙迫後諸 氏

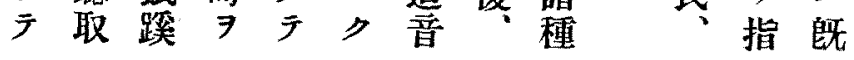




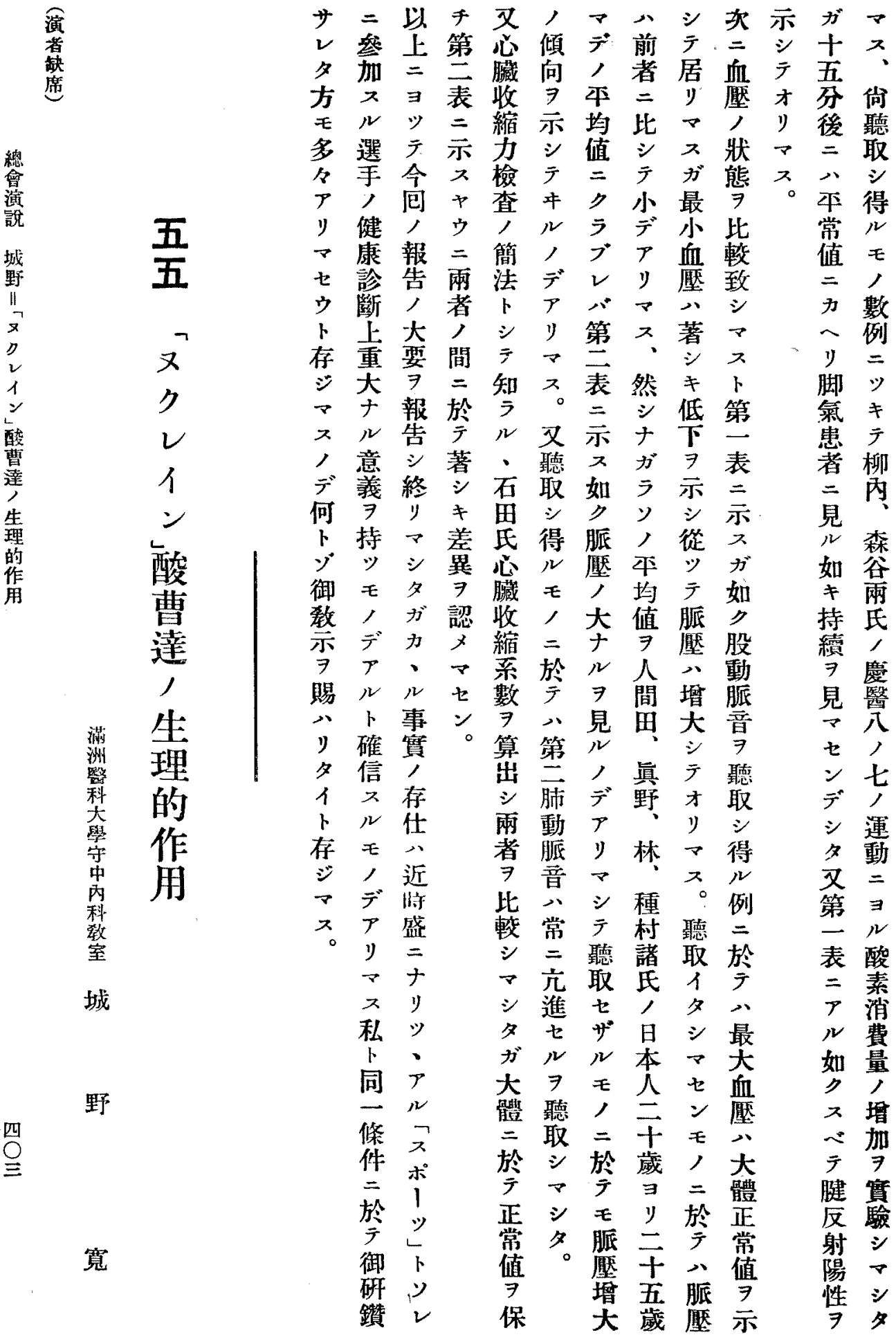


キข中すテ入皮皮白嗜賽投感症特余

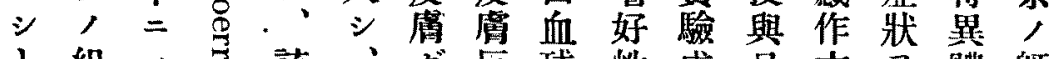
1 組

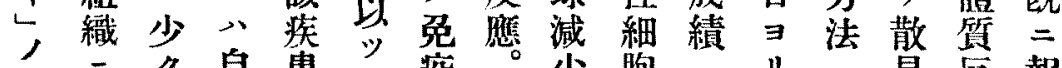

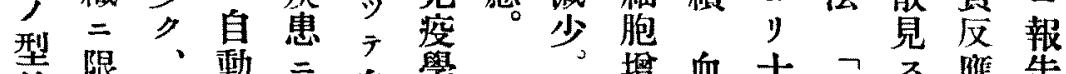

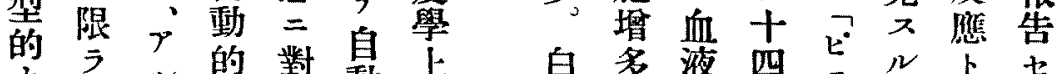
$f 5 N$ 的對自動岳多液四 $5 N 卜$

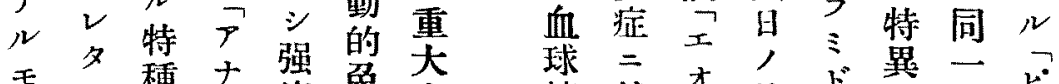

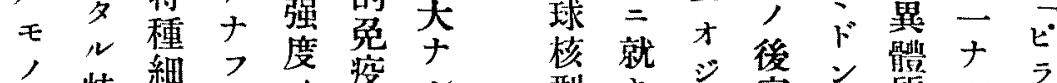

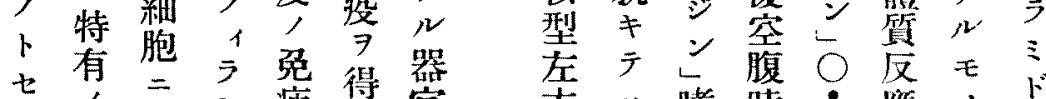

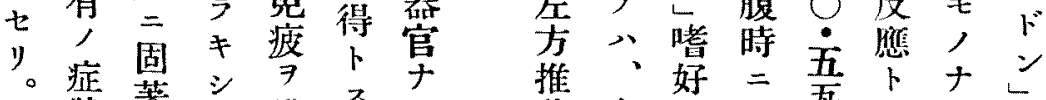

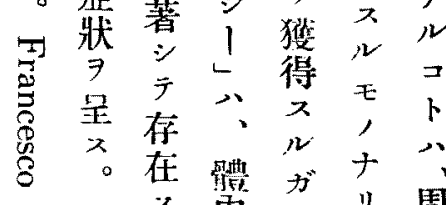
-而范内如。周 音而組皮知 导 シ 織 7 腐事

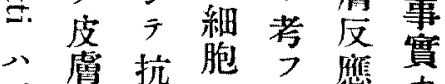
又組元 $=$ 势 抗織 $\Rightarrow$ 於時呈り

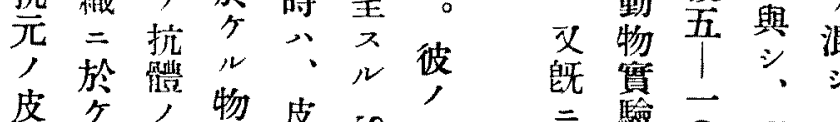
离公固理慮怘 依依郎三㧛了总

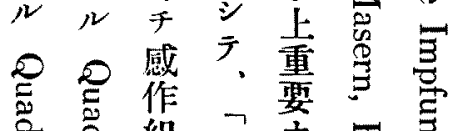

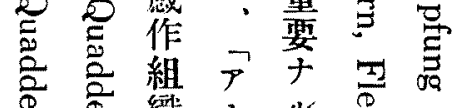

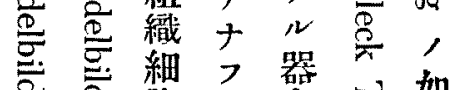
言害腃

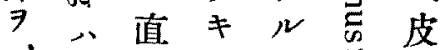
局接 シ 等膚 局局作 l上， 所所用据 $\Rightarrow$ 如㨁 ア ア サ热想 $\neq$ 接

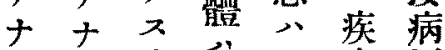
フ 時》三患原 $1 \frac{1}{5}$ ”. 流台於泩

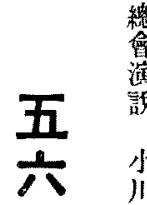

總 小 $ヒ^{\circ} \stackrel{5}{5}$ ラ

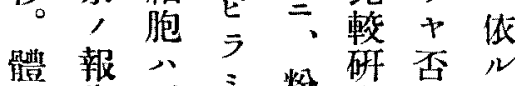
温告、三粉究究經

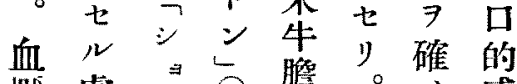

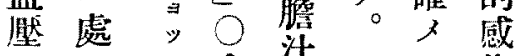

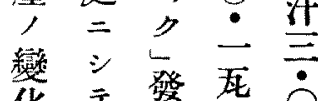
花等虐宁

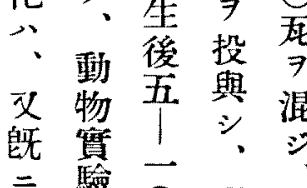
報駸○き

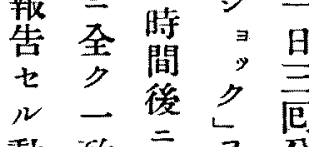
動致 = 分 物 於起服

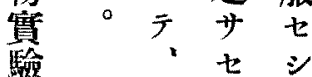
= 著夕公

致 奛》。告 $x$

增

加

주ㅇㅛㅛ

血 盟

血紧

x

$\pi$

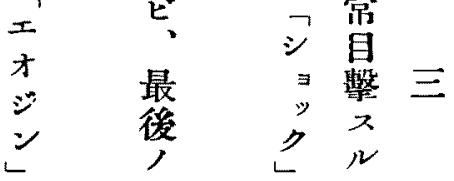




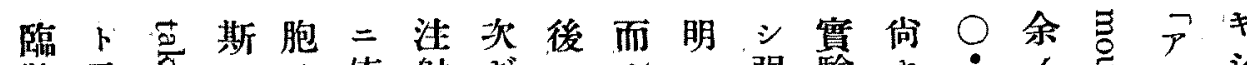
症云莺: 如淋佊射

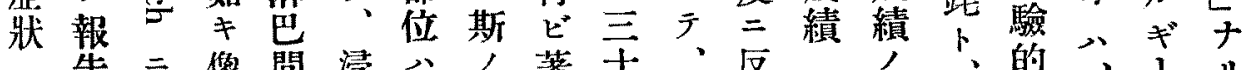
告二像間浸 著干、反的“方》

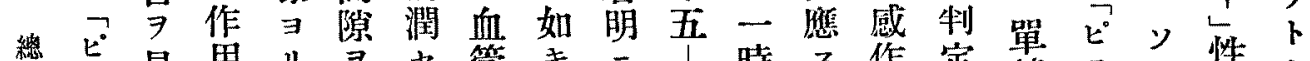
絽

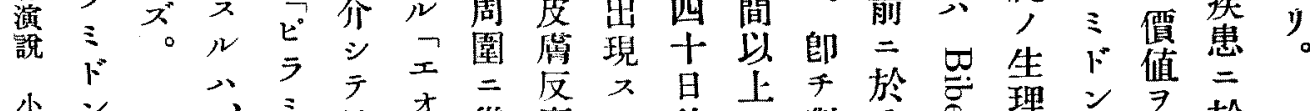

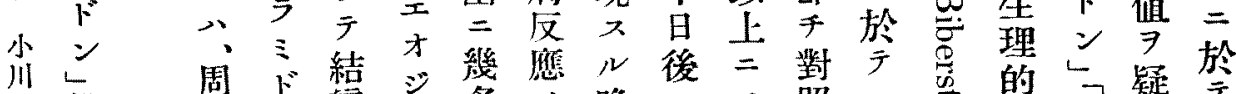

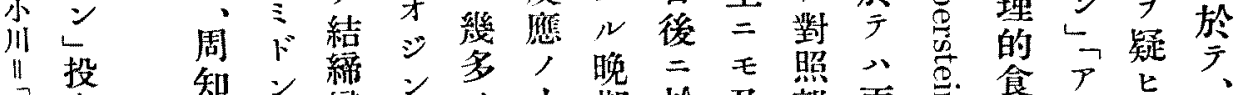

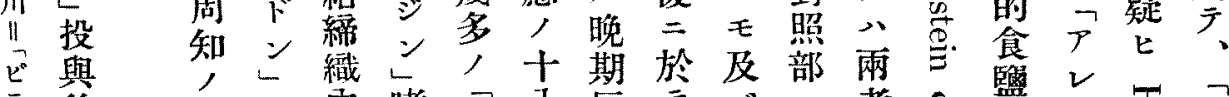

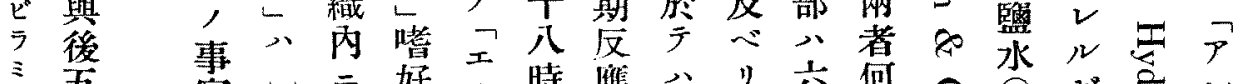

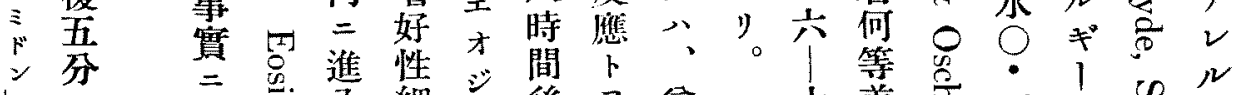

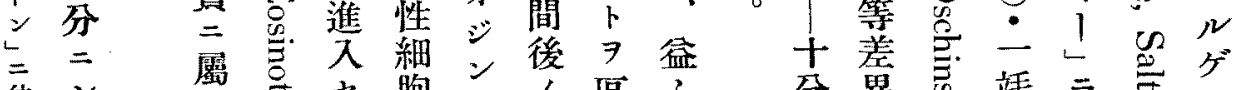

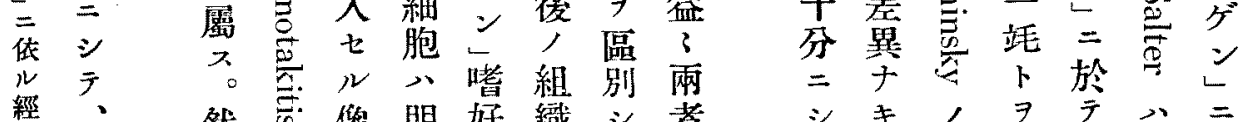

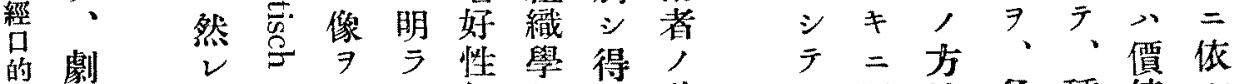
感烈 $ト ゙=$ 見吕細的多差反法各種值

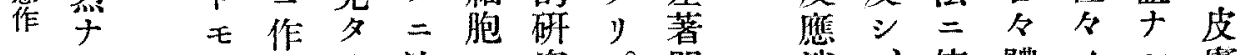
實用y流, 究。明消、依體, シ 膚 咳驗 $九$ 血浸 $\exists$ 而二失感 $ン 八$ 期卜反

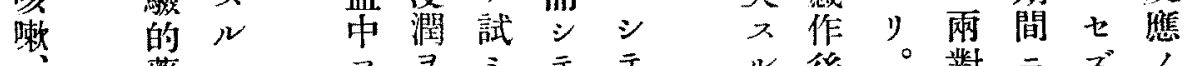

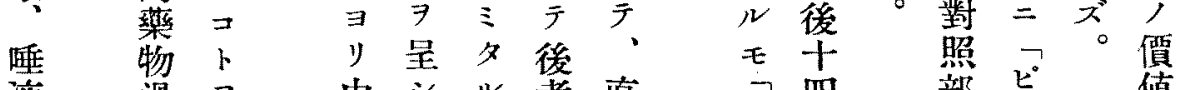
液過 7 由 $シ ル$ 者值

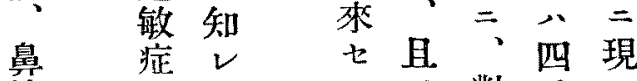

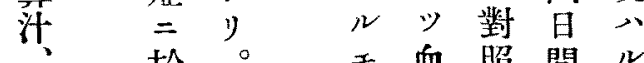
泦笑蛋毛血照閶 人百ナ呙位續早 分該 䯏 泌藥過 進物敏 被 ㄴ 期 $\exists$ 緗正り反 知胞常。㑛

耳 可 得䏚

目

四瘦

五

夏的

敦

皇

鼻作

粘 用 可

膜齐兽。
タ 7 展

。過

监

遊

走公三

七該

該細 己

細 胞 液
ह. 四

旦

志於

沾

液

注 ラ

射

部ミ゙

位

三夜

十泩

五 射

I 部

立

分

二對

於 照

四

時

間
于 =

著比
部

於 三

占

N

皮

内人

$=$

泩 0

射 \%

、倽

雨 =

者溶

ノ解

反

應

$\exists$ 生

觀 理

察 的

せ 食

り監

水
值

ビ

意

鸼

關

䋨

多

學

說 ?

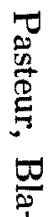




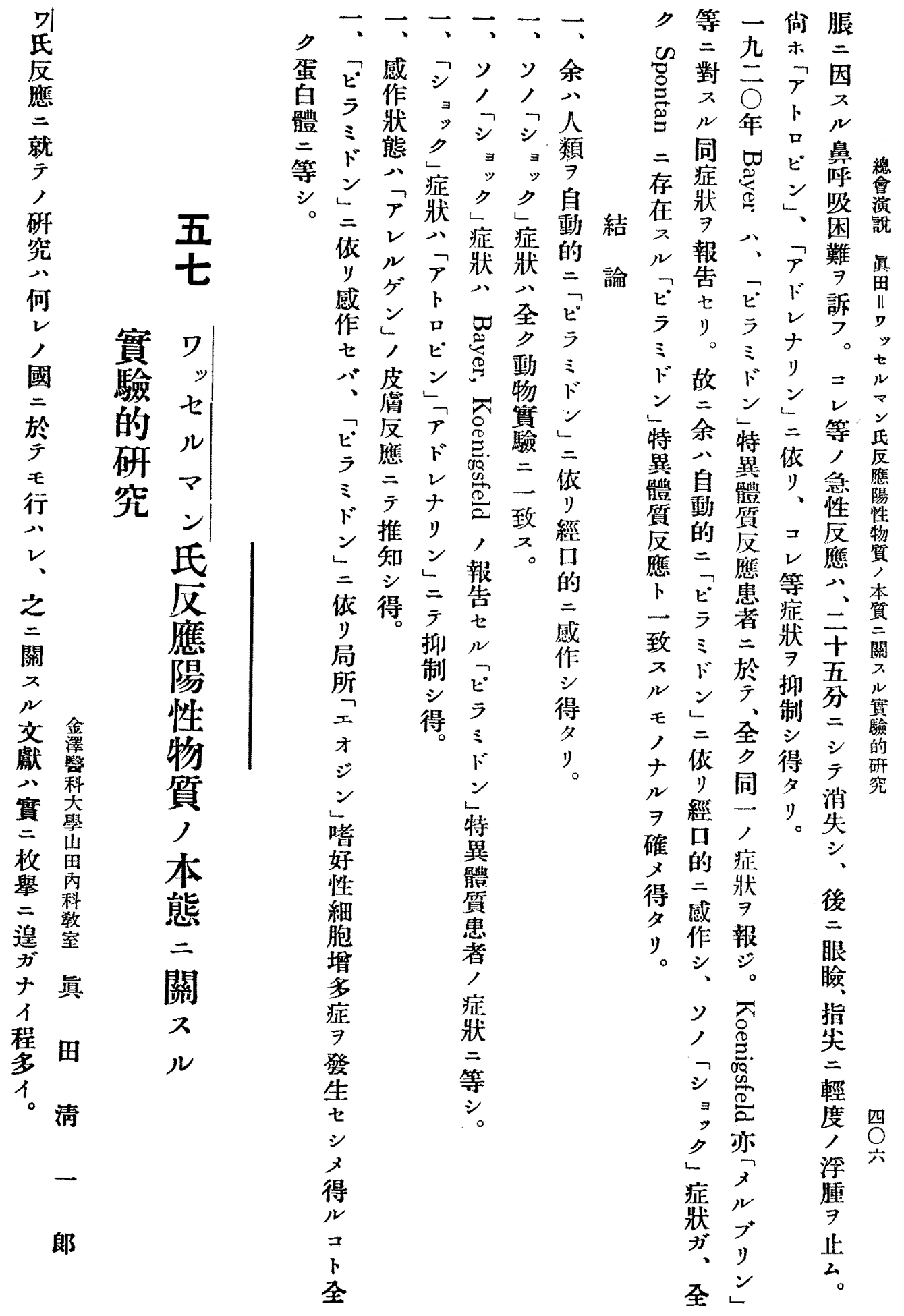




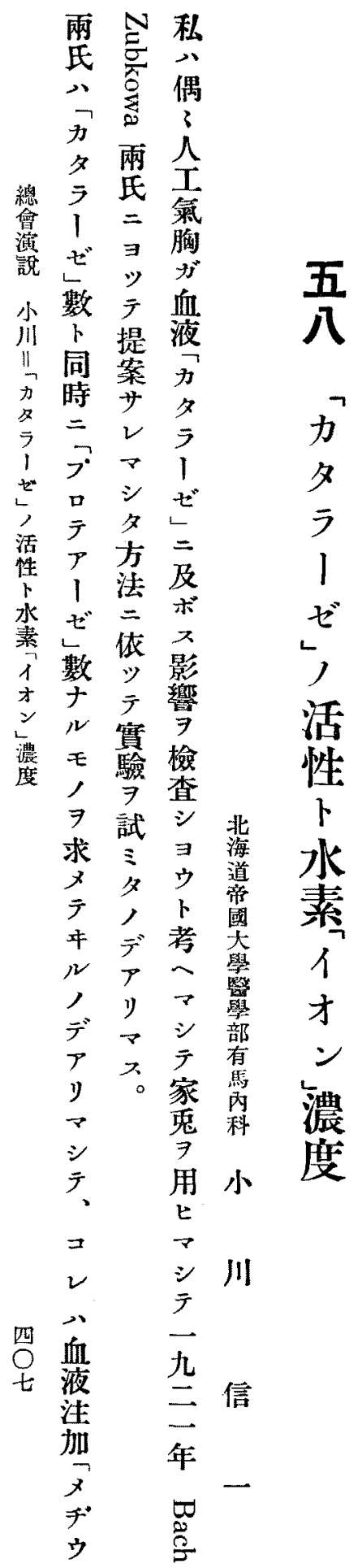

モ, 血ポソ性所染私荮人而 , 事清イ, 狀謂七人三本シ 二貫,

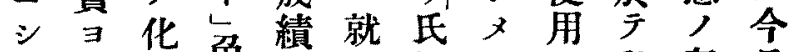

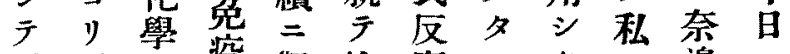

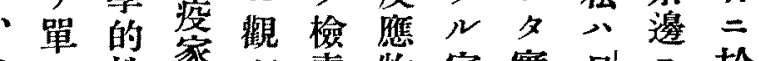

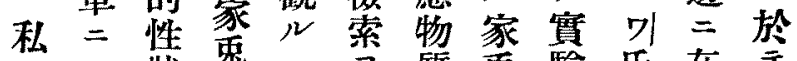
只牀鬼二息質兔驗氏在

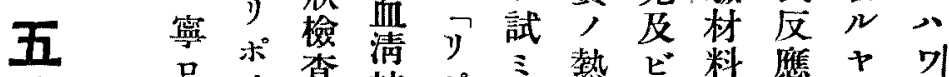

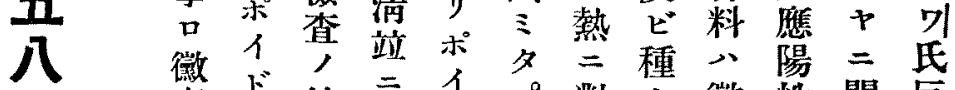

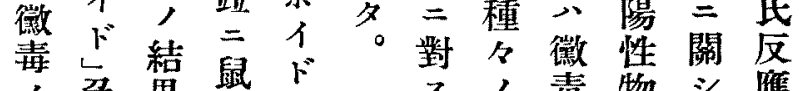

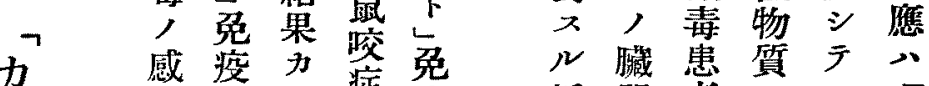

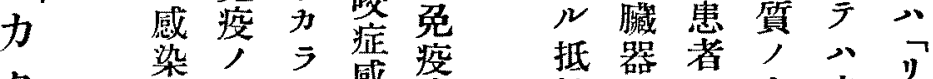

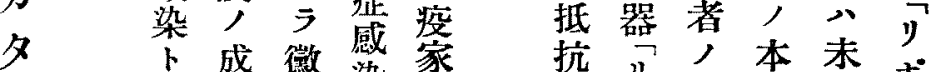
○立毒染鬼性 す外態多

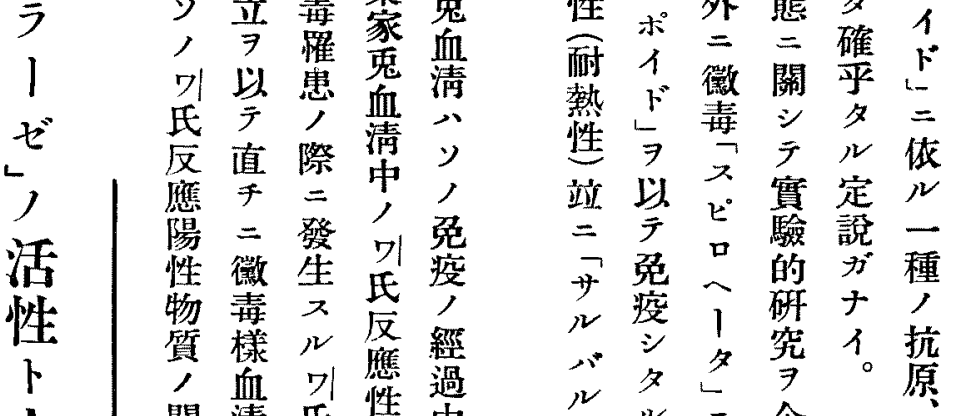

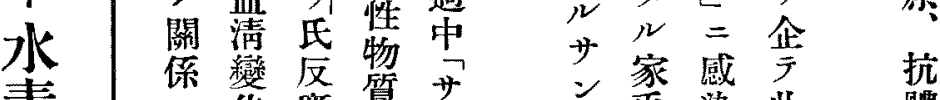

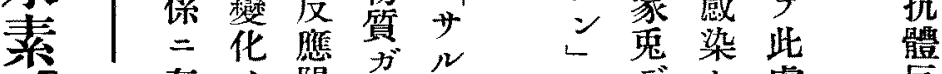
在, 陽 本性熱心゙ 對・シ モ態物對 , $\Rightarrow$ 質對

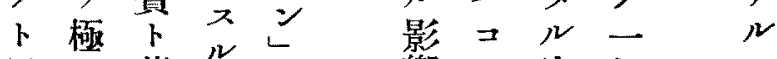
思叉著抵, 響レ家部コ

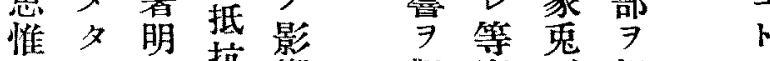

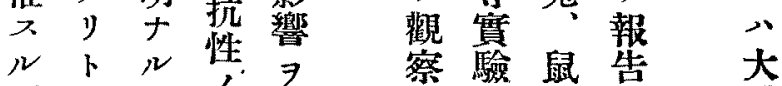
。唱差極全涶動咬七體 ᄀ畫極余次物症 $ン$ 承 ル

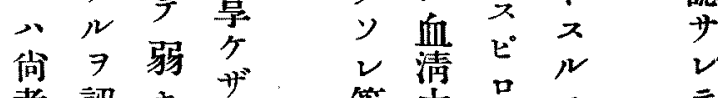
考認キザ等中只正年

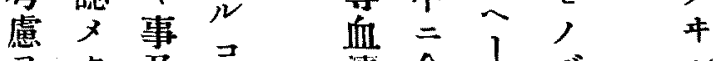

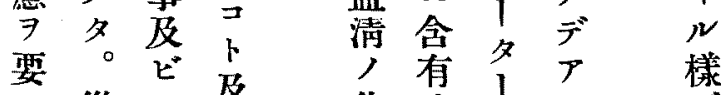
要從

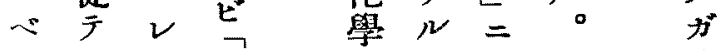

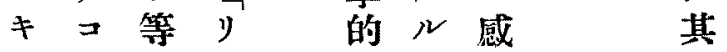




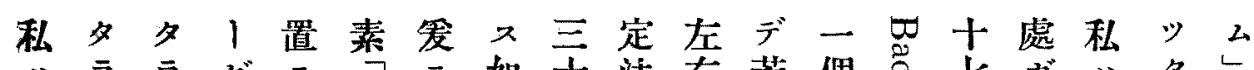

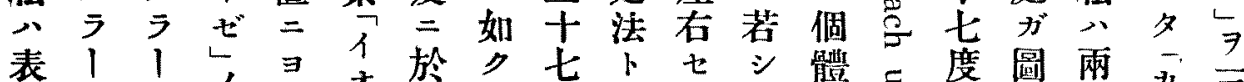

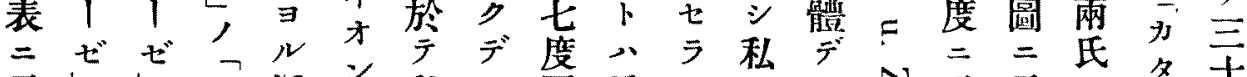

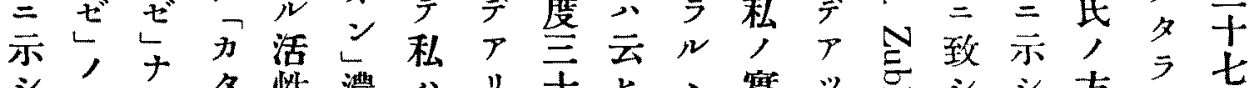

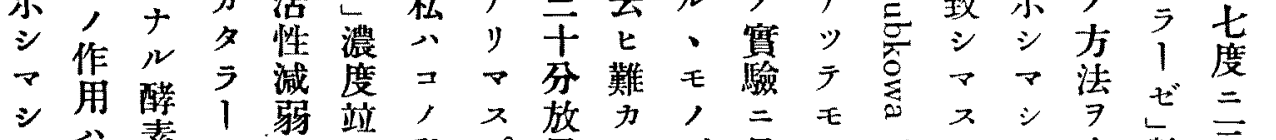

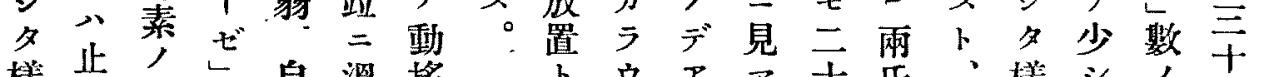

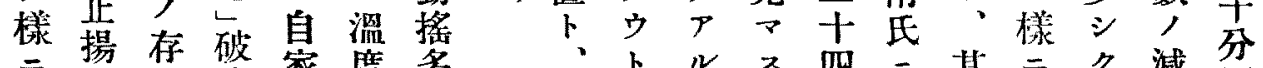
比在壤家度多 比为篗破卜车 較、認焦壞, 所 的 モ 認用箩關謂 多, 天過抑㷛

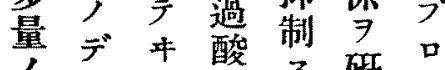

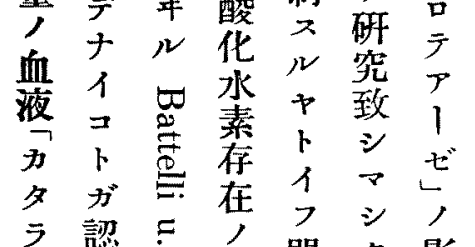
1 怘有閶 。影

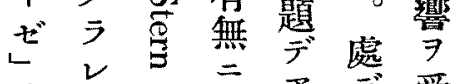
$=レ$ 雨關厂梁受 過方兩關り先年 酸年氏僁、法ザ 化, 研 $\neq$ 及問, 水 $テ ゙$ 究 素 $\checkmark$ 热品分件 $\exists y$ 於 7 芯過

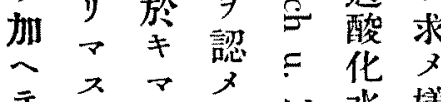
厂。寻 $\mathrm{N}$ 水様

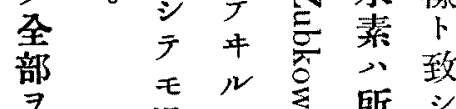
分過，离所 分解 酸 デ兩 謂 七化 $>$ 氏 $7^{\circ}$ 冰り $=$ 口 丈素穴依 テ カ

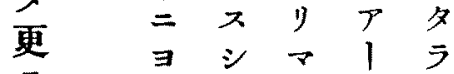

之 渦学学点作活 酸至 化 $\neq \neq \bar{广}$ 即 水办只放 水

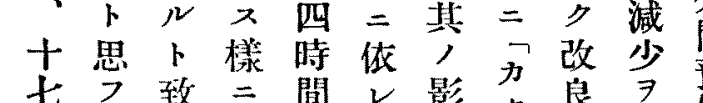

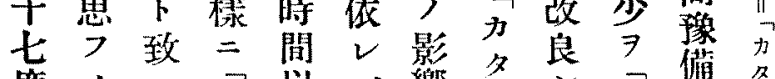

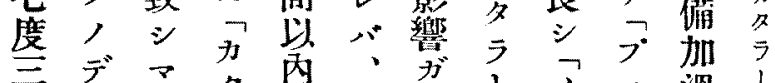

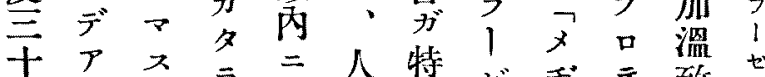

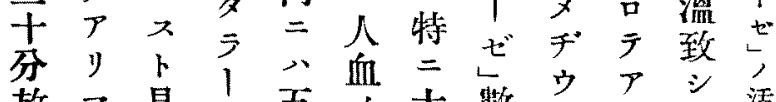

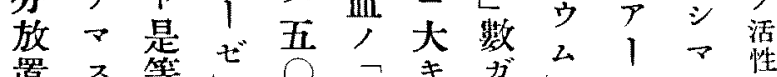
置

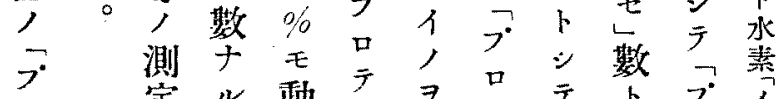

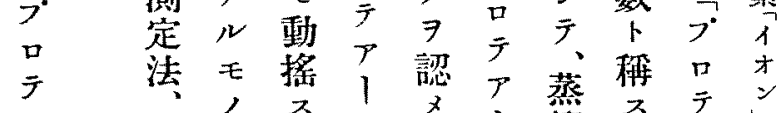

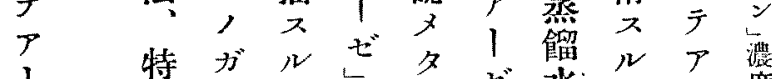

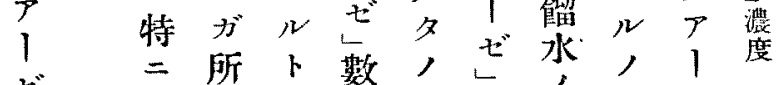
ゼ言所会數光數代ジぜ

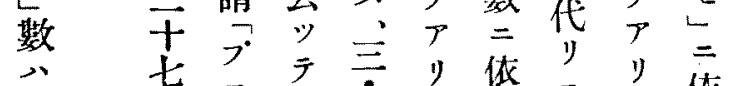

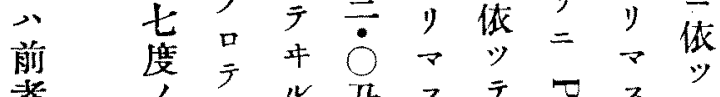

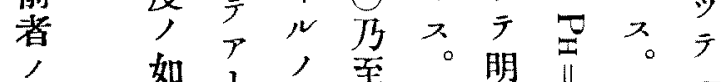

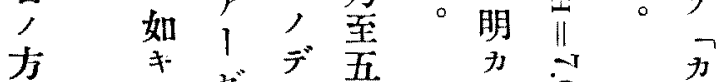

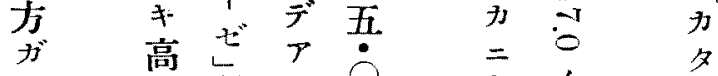
後㳑数”年左

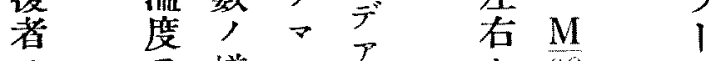

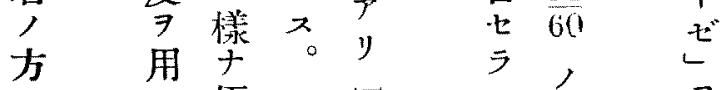

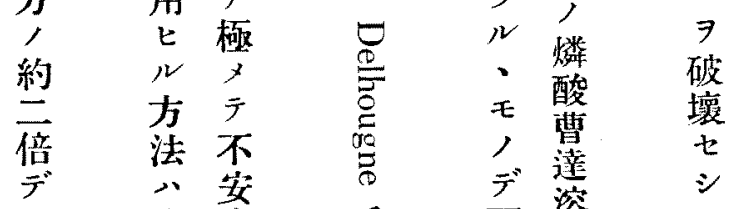
$>$ 決整氏而富名四

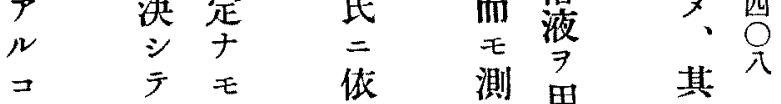
卜 完, 管用其 全二又温旨名

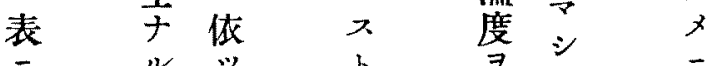
示測兴卢点名。起 
己タ中零最ン十り而於三其 7 反 ゙零次加素

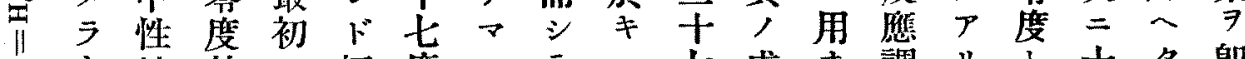
$\infty 1$ 㕸放, 恒度

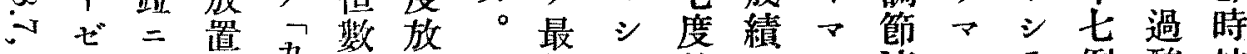

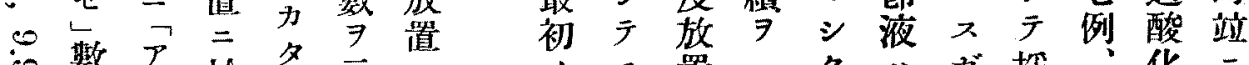

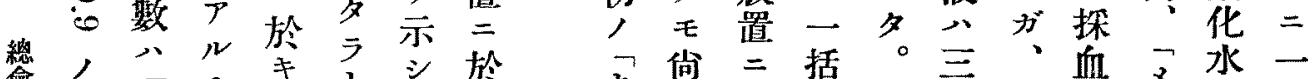
會如

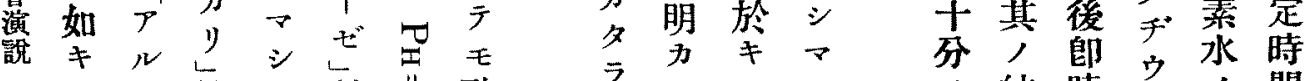

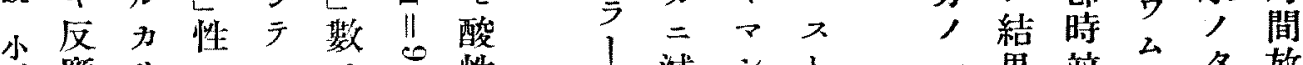

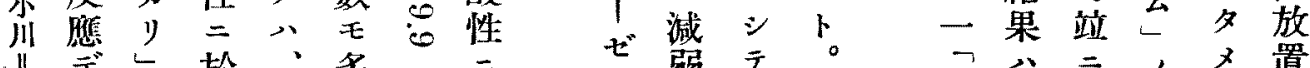
, 力八性方酸少於進数 シ 八

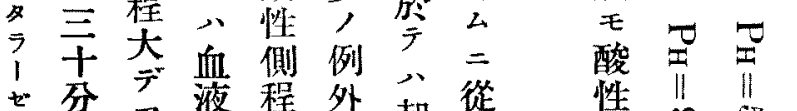

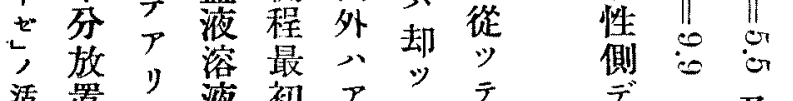

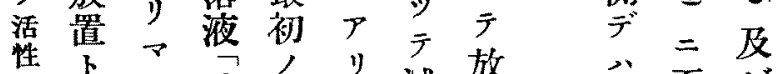

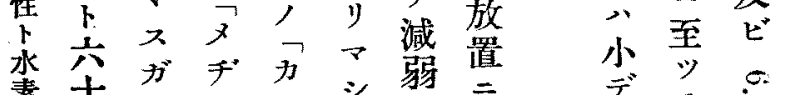

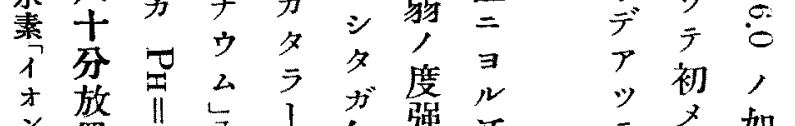
漲䈯 度 $゙$, 加数酸場減性恒酸 八方直 $カ ゙$ 性合弱減数性

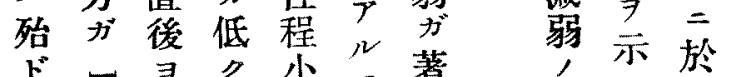

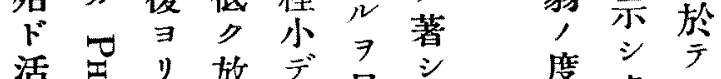

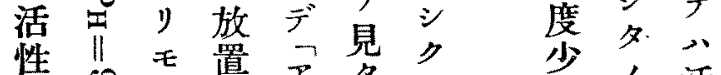
性 :

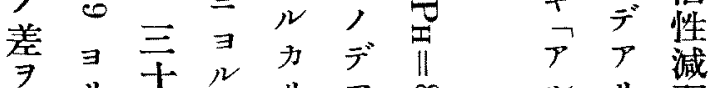
認，焦活 邓幾放性性り名名

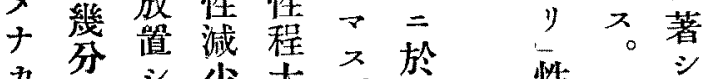
力分沙大 於 夺夕少夸。 タ方方著采言

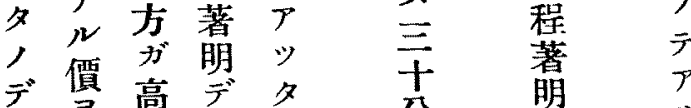

$\curlyvee$ 寻價

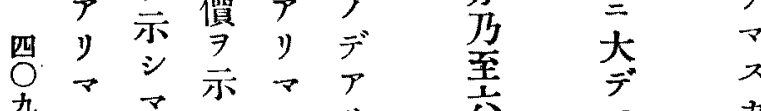

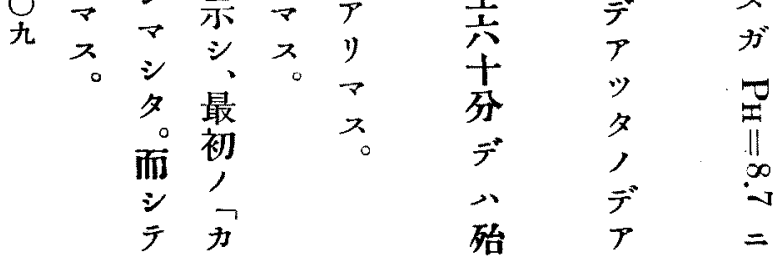
圖 血 反 = 後 二液 應 制 加 , 示溶 $\rightrightarrows$ 止 辚 大夜 七 酸 樣 无 曹 デぞ, レテ

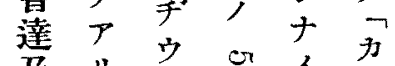
芨

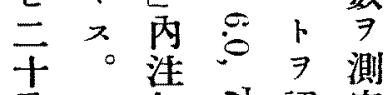
分 架它認定

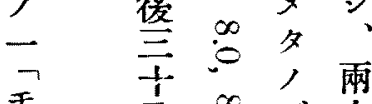

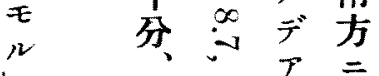
，六: 吾 十 $\rightarrow$ 等 y 分、等 九 $t=$ I 分分品

卜 放 测 二 置 定 ゔ 十後溫响

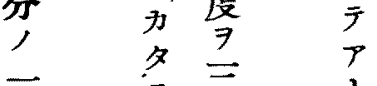
替 今卉 1

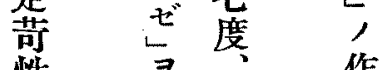
曹測十莋 達定七忍 混淁度 合夕芨初 


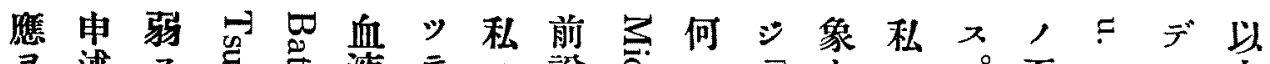

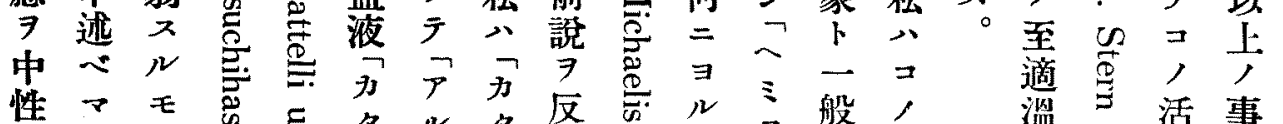

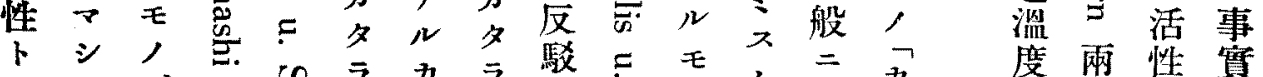
スタデ 及焉

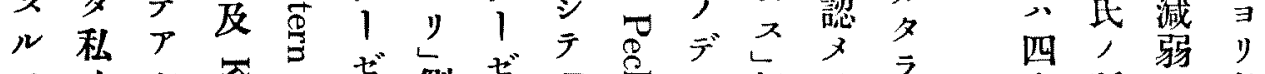

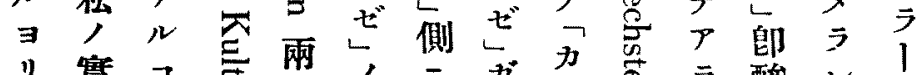

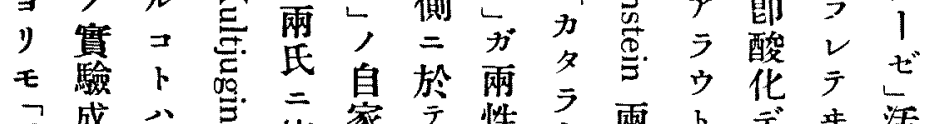

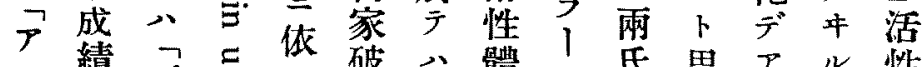

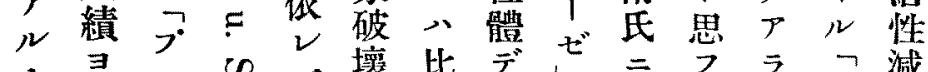
カ

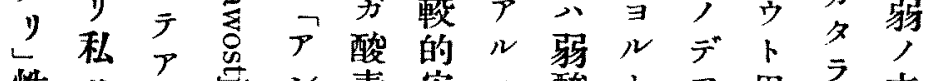

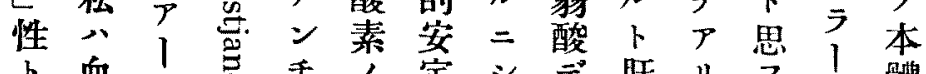

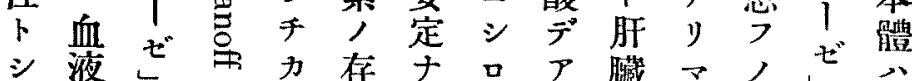

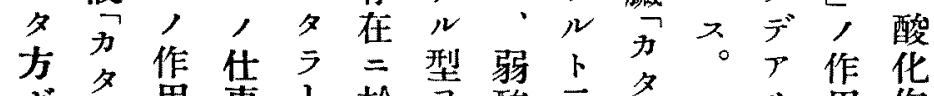

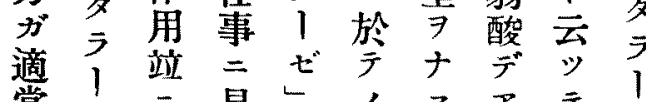

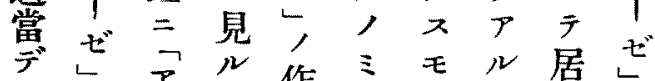
测 $ノ$ 如作起,

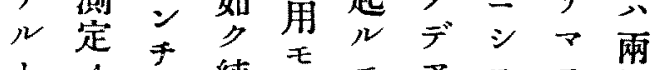

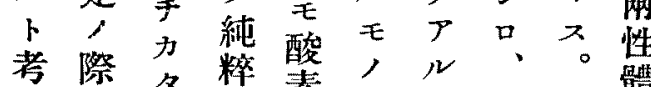

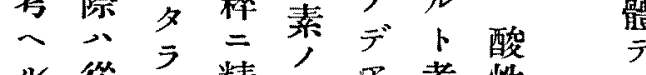

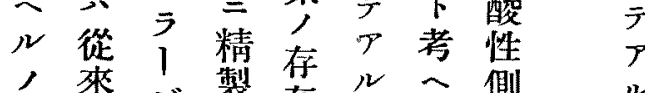

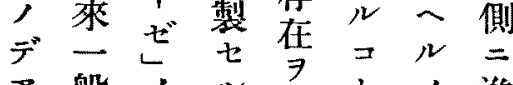
般在必占人䛧 当使丕召要 ×角隽名占高y

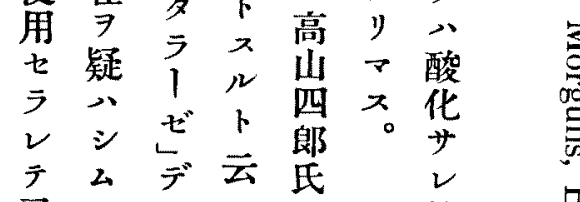
居 こモッ易

樣足䈯示碚究狀

$=\mu=\mu=$ 小, 斗学 ‡゙デッデル カ

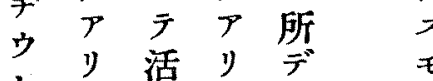

,

反。減。又学

y用作

$\rightarrow$ 用

天同 時 7

反 $=\mu$ 㤅行

二八考

$\exists$ 等

$2, \pi$

活濄

性酸 デ

上減华

臀素?

差 $=$

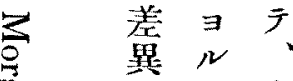

㗊盆尚

另多

多四、作

要多方放十又用亏

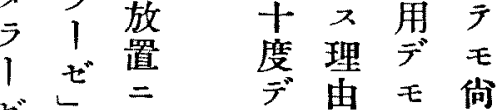

ぎさ首寻

人體”

荷, 裂

電 破 活

狀壞性

乔等態点葴

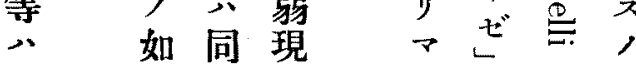

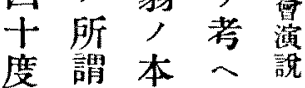

方䠌、小

至之メス叫

突手恐三坚

度多》名多

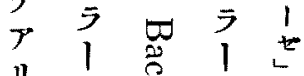

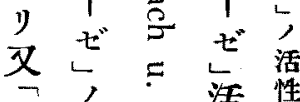

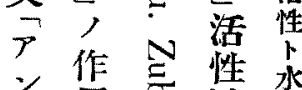

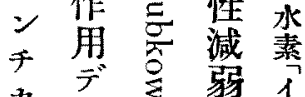
名毛为势 亏 1, 氐惟歷

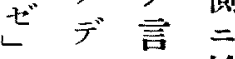
至亏方放 適户如 ? 度考宁 辛文号震 度卜1於 第中ゼキ 至 $シ$, ? テ著四

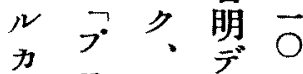
亏号又下 $\overrightarrow{\bar{F}} \bar{\gamma}$

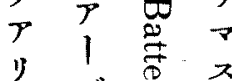


少 私 \%更，又二二測零私 力 召测 以

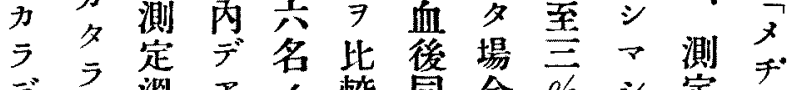
デ

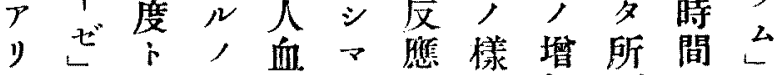

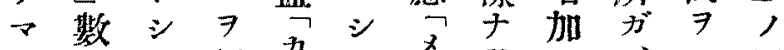

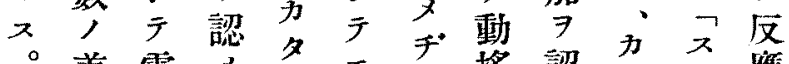
。美零メ

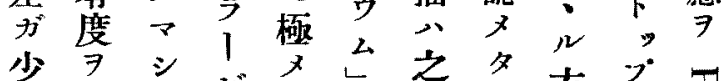
少使 多 用角致 7 同茟 テ 時 $シ$ 㧼二度ナッ旱千

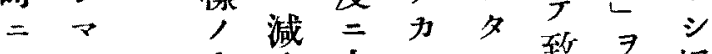
方方少六ツ, 致

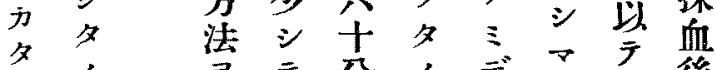

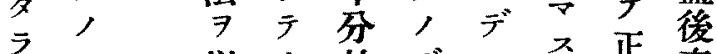

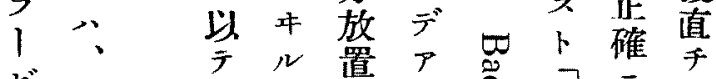
ビカ 测, 当

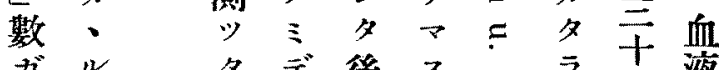

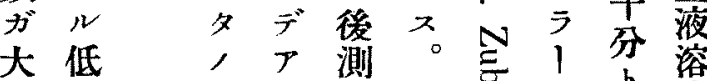

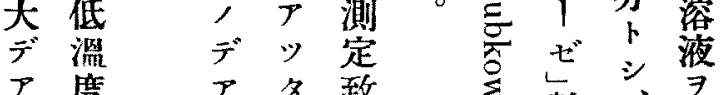

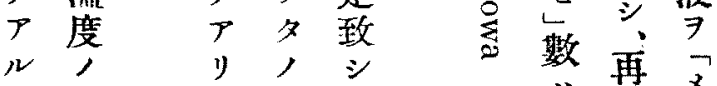

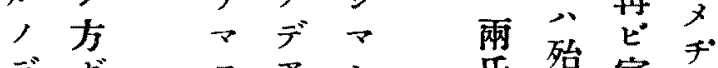

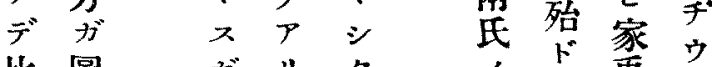

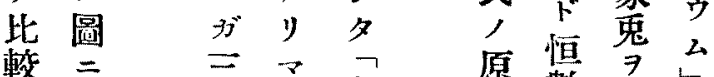

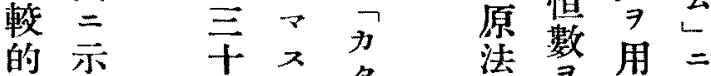
= 分

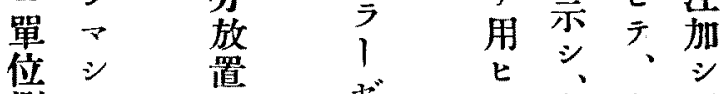
测多 ゼ息人三 定栐六数，場色工十 溫 +1 合素氣分

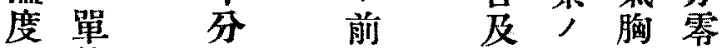
, 位放述 ビ増 前度

動 温

搖 度

對 二

ㅈ

ル

影 テ

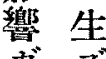

琶

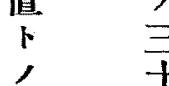

症务

晎放

八置

0

五.
监
七
U
モ
測 加 後 二

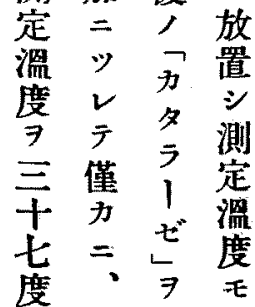




\section{第 一 表 確認試驗}

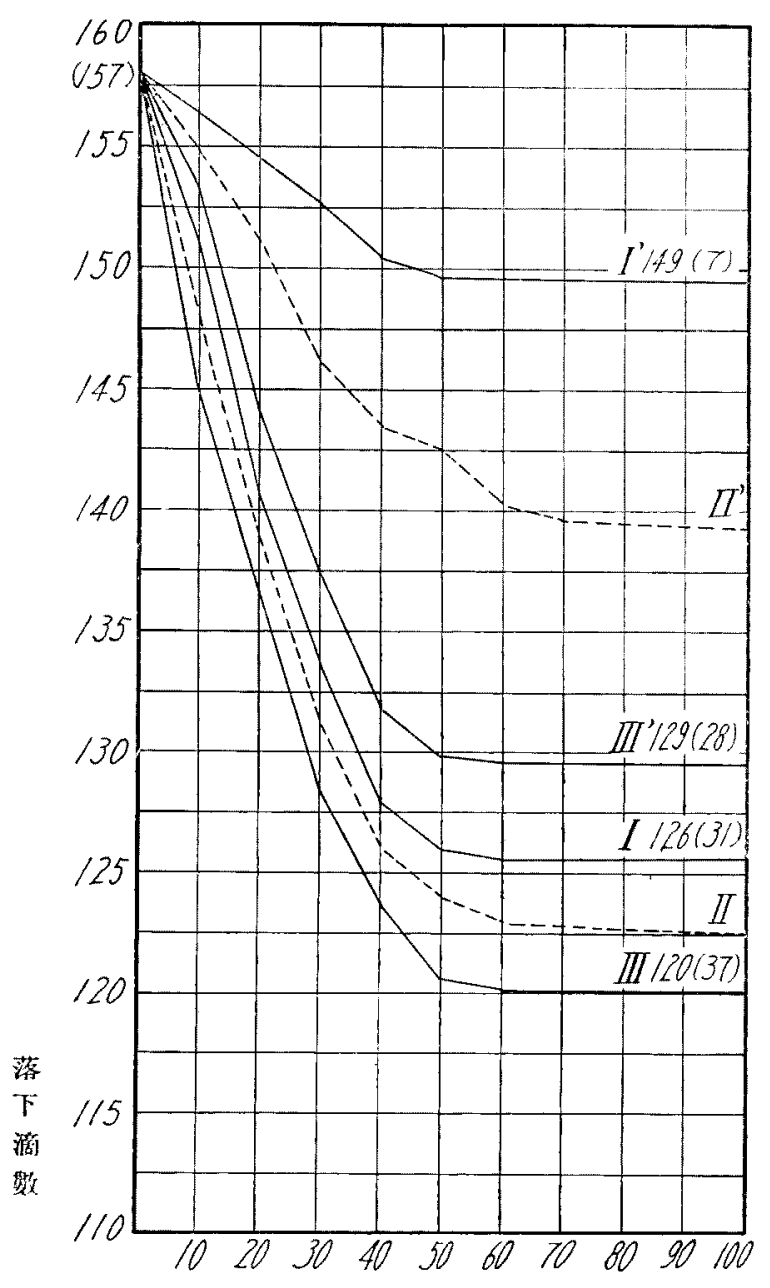

經 過 時間
ル度著

故毒八

二 物 先

先 =

产 對 滲

滲 7 出

出 液

液 感及

二 受 漏

就性 出

丰等 液

厂, 中

述

$\approx$,

浑 バ常

出

液 七

二研

敦 索

₹ 1

テ交ゼ

八可，

y 缺 存

, , 在

相 諸

違點 ル

七 $==$

就卜

點 $\neq \Rightarrow$

于 確 科

ミ、㒛

此 シ 酒

述, 、井 心雨次內 、当犁 一 ジ 室

一り落測定シ ニ, カ液確っフ致门至阙 五演 九媦 滲計

瓷

出 $八$

液 1 關

及

漏じ踟

出二的

液 關 究

リ

パ $ル$

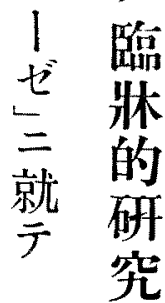

第

回

表 下定法之就㴚否中認。限儿セ水

下 滴 $邓 \exists=\neq$ 溜力二試り點 7 素

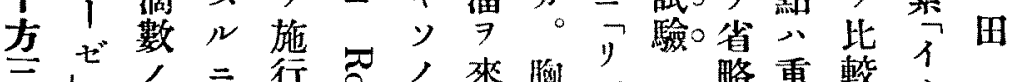

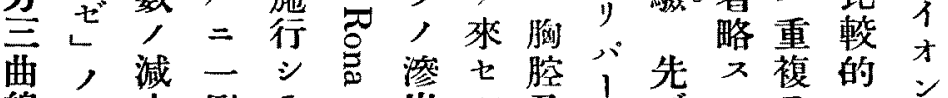

線存少例テ出 $ル$ 及

、在、, 引㿥患腹ゼ果。避觀濃訓

此当換例心

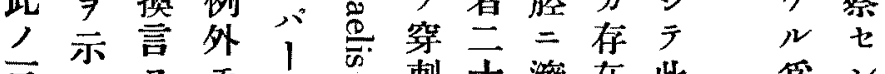

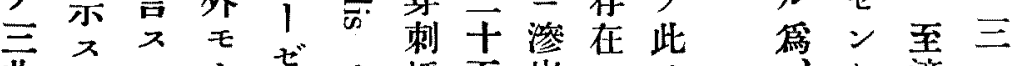

豊レナゼ, 探五出ス, 卜適

線第 ゙ク 
ゼ就疾。雨別期 第五超三就雨。 價 亿患液診 墨第 比見關只法二表示想 7 雨少限夕㚐全, 厂五

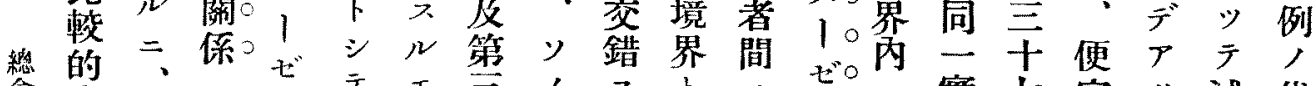

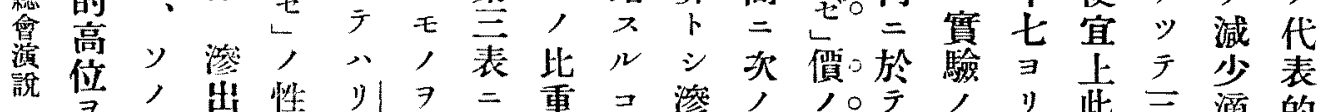

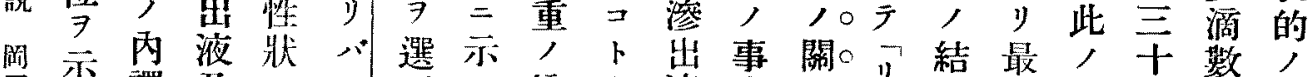
田七譯及, $及$ 无 $\checkmark n$ 、漏差夕夕如

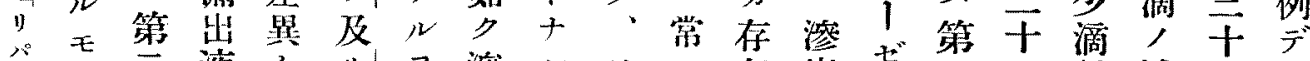

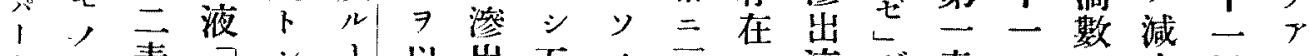
ゼ,表りシ

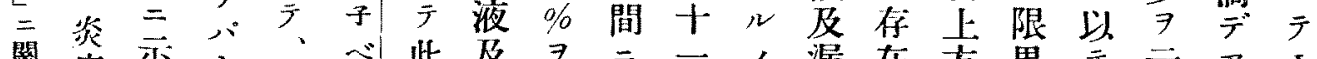

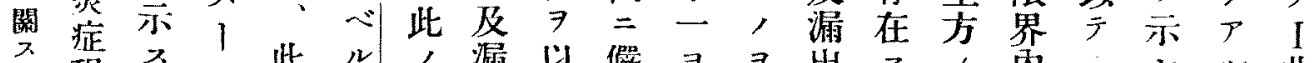
程希ゼ此

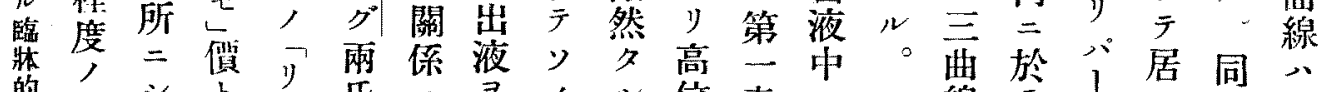
的比 究輘テ、該 的疾疾ゼ應光 $ス ゙$ 白界示り=示心價斯田滴

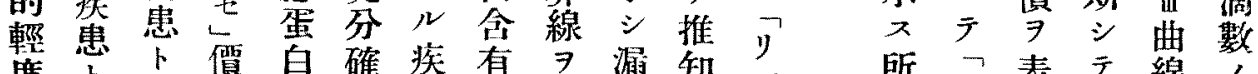
度:5 價皇確疾有 $尹$ 漏知

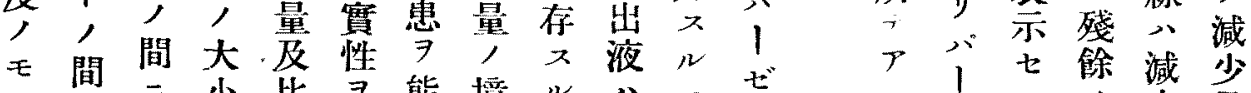

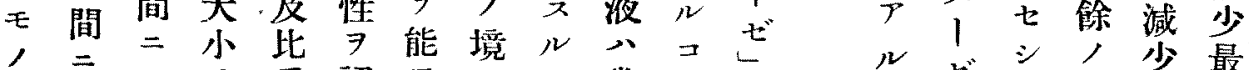

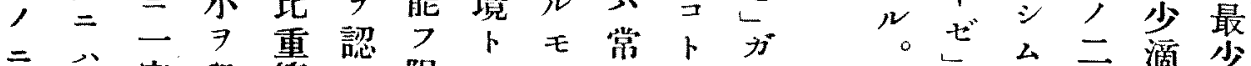
多特定舉等 メ限七, 二ガ存 ク殊關デ゙ガ

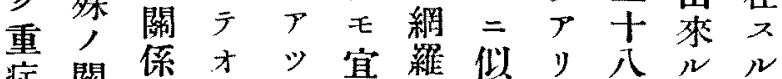
症關係才为宜羅似り、公少,

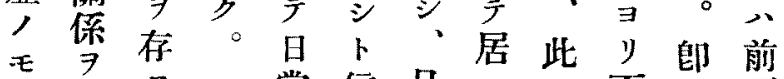
, 認 $x$ 常信且心, 为項 二認ル臨ズ爻。關位此迅 アナ赤林儿同而係 \% 否上”一州示雨夕

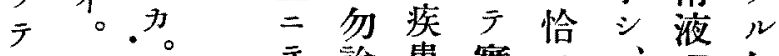
、唯先 今 論患實毛雨当如

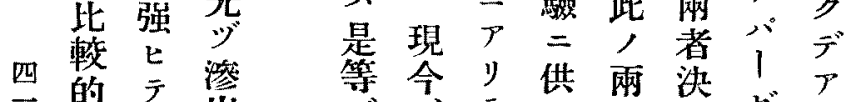
三的云冏留令

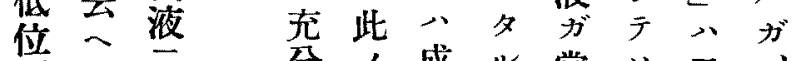
デ 方分, 成少常ソ三。 フ十古雨先 症二, ル五要花可例一限八, 此

郎存乞主數少 千在心゙三最り 漏 $入$ 例多 出ル市ガ先代 液卜。同 II y, 二。同豊泉

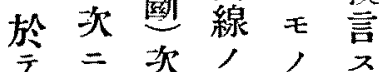
八同人如換

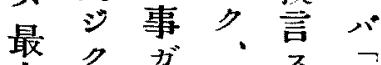

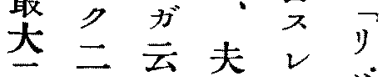

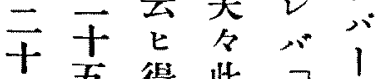
入冽得此马゙

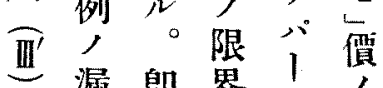
淈罢異ゼ最 》液淩二了聚 最三出位最子 小就液 $三$ 火 七亿中广 
第 三表漏出液「リバーゼ」

\begin{tabular}{|c|c|c|c|c|c|}
\hline \multirow{2}{*}{$\begin{array}{l}\text { 症 } \\
\text { 例 }\end{array}$} & \multirow{2}{*}{ 病 } & \multicolumn{2}{|c|}{$\begin{array}{l}\text { 1リ゚゚- } \\
\text { ゼ,偵 } \\
\end{array}$} & \multirow{2}{*}{$\begin{array}{l}\text { 此 } \\
\text { 重 }\end{array}$} & \multirow{2}{*}{$\begin{array}{l}\text { 蛋 } \\
\text { 白 }\end{array}$} \\
\hline & & $\begin{array}{l}\text { 蟿出 } \\
\text { 液 }\end{array}$ & 血清 & & \\
\hline 1 & 癌 & 28 & 41 & 1015 & $5 \%$ \\
\hline 2 & " & 26 & 40 & 1015 & " \\
\hline 3 & 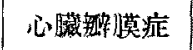 & 21 & 46 & 1008 & 2 \\
\hline 4 & 肝硬等症 & 25 & 46 & 1015 & 3 \\
\hline 5 & パン千比病 & 23 & 43 & 1015 & 3 \\
\hline 6 & 肝硬篴症 & 55 & 45 & 1015 & 3 \\
\hline 7 & 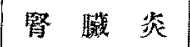 & 18 & 46 & 1010 & 2 \\
\hline 8 & 心独膜症 & 25 & 46 & 1010 & 2 \\
\hline 9 & 肝硬變症 & 23 & 44 & 1012 & 3 \\
\hline 10 & " & 28 & 48 & 1015 & 8 \\
\hline 11 & |「子フローゼ」 & 7 & 43 & 1003 & 1 \\
\hline 12 & , & 8 & 44 & 1005 & 1 \\
\hline 13 & 腎 瀻 瓷 & 19 & $4 ?$ & 1013 & 2 \\
\hline 14 & 心知膜症 & 24 & 44 & 1010 & 2 \\
\hline 15 & 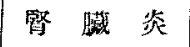 & 22 & 43 & 1012 & 2 \\
\hline 16 & 「チフローゼ! & 7 & 42 & 1008 & 1 \\
\hline 17 & 肝硬㯨症 & 24 & 43 & 1015 & 3 \\
\hline 18 & 㴔 & 27 & 40 & 1015 & 5 \\
\hline 19 & 肝硬謷症 & 23 & 43 & 1013 & 3 \\
\hline 20 & 心躲膜症 & 23 & 42 & 1013 & 3 \\
\hline 21 & 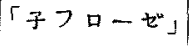 & 7 & 43 & 1008 & 1 \\
\hline 22 & 癌 & 27 & 42 & 1015 & 5 \\
\hline 23 & , & 28 & 43 & 1015 & 5 \\
\hline 24 & , & 28 & 40 & 1015 & 5 \\
\hline 25 & ,. & 28 & 41 & 1015 & 5 \\
\hline
\end{tabular}

第 二 表 滲出液「リバーゼ」

\begin{tabular}{|c|c|c|c|c|c|}
\hline \multirow{2}{*}{$\begin{array}{l}\text { 症 } \\
\text { 例 }\end{array}$} & \multirow{2}{*}{ (1) } & \multicolumn{2}{|c|}{$\begin{array}{l}\text { 1リパ- } \\
\text { ゼ」偠 } \\
\end{array}$} & \multirow{2}{*}{$\begin{array}{l}\text { 比 } \\
\text { 重 }\end{array}$} & \multirow{2}{*}{$\begin{array}{l}\text { 蛋 } \\
\text { 白 }\end{array}$} \\
\hline & & 滀出 & 血清 & & \\
\hline 1 & $\begin{array}{l}\text { 鹪出性肋膜 } \\
\text { 恶 }\end{array}$ & 35 & 46 & 1021 & 6 \\
\hline 2 & " & 33 & 42 & 1019 & 6 \\
\hline 8 & , & 34 & 45 & 1020 & 5 \\
\hline 4 & , & 34 & 44 & 1020 & 5 \\
\hline 5 & ", & 33 & 44 & 1019 & 5 \\
\hline 6 & " & 34 & 46 & 1020 & 5 \\
\hline 7 & " & 34 & 42 & 1020 & 5 \\
\hline 8 & ", & 35 & 43 & 1021 & 6 \\
\hline 9 & $\begin{array}{l}\text { 滲出性助腹 } \\
\text { 膜岕 }\end{array}$ & 38 & 49 & 1019 & 5 \\
\hline 10 & $\begin{array}{l}\text { 淬出性肋膜 } \\
\text { 资 }\end{array}$ & 83 & 41 & 1019 & 5 \\
\hline 11 & ", & 33 & 42 & 1019 & 5 \\
\hline 12 & " & 38 & 46 & 1019 & 5 \\
\hline 13 & $"$ & 32 & 45 & 1018 & 7 \\
\hline 14 & " & 32 & 46 & 1018 & 5 \\
\hline 15 & . & $\therefore 2$ & 44 & 1018 & 5 \\
\hline 16 & " & 82 & 44 & 1018 & 5 \\
\hline 17 & ", & 32 & 43 & 1018 & 5 \\
\hline 18 & ". & 32 & 42 & 1018 & 5 \\
\hline 19 & ", & 31 & 44 & 1017 & 5 \\
\hline 20 & ". & 31 & 42 & 1017 & 5 \\
\hline 21 & $\begin{array}{l}\text { 㳂出性:腹膜 } \\
\text { 悠 }\end{array}$ & 37 & 44 & 1025 & 8 \\
\hline 22 & ". & 32 & 43 & 1018 & 5 \\
\hline 23 & ,. & 87 & 43 & 1026 & 8 \\
\hline 24 & 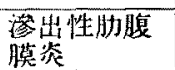 & 35 & 46 & 1021 & 6 \\
\hline 25 & 沴出性肍膜 & 26 & 45 & 1023 & 7 \\
\hline
\end{tabular}


第四表 至適水素「イオン」浱度

(其 一)

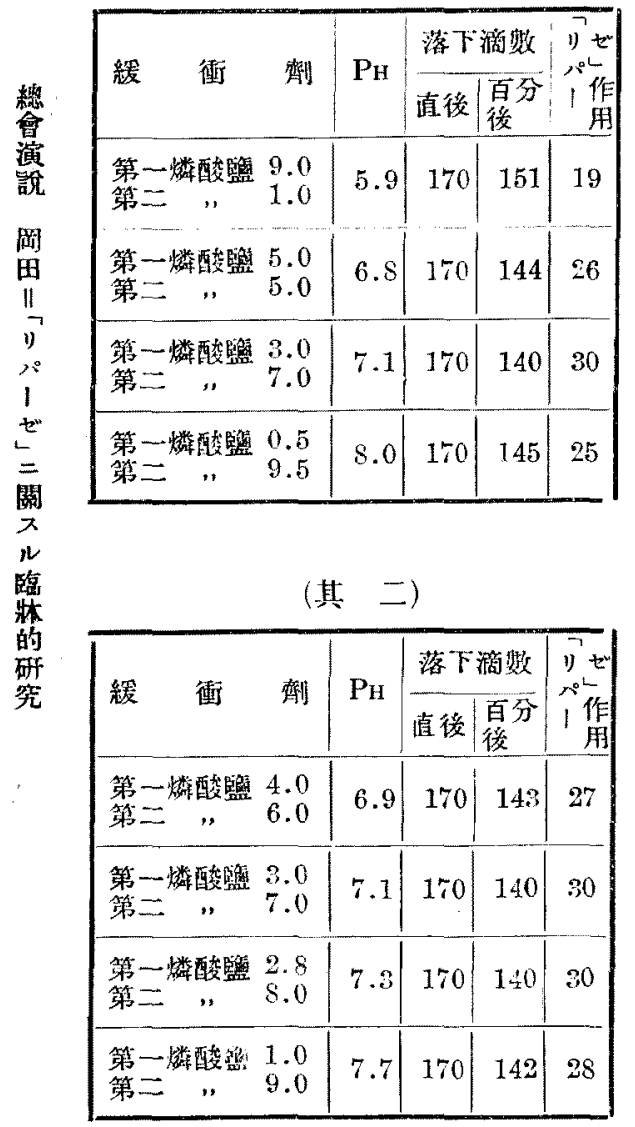

度 $尹$ ビ第濃當シ掩與酰

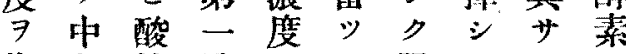

作心性及 $尹$ 为阴 $ン 山$

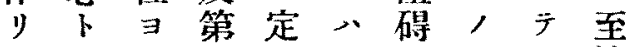

ソシリ三メ必 大僅始適

, テ燐ナズルカメ,

各適厂酸ケソ。, 宁水

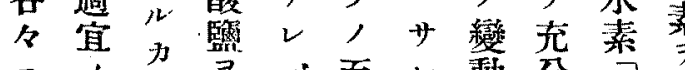

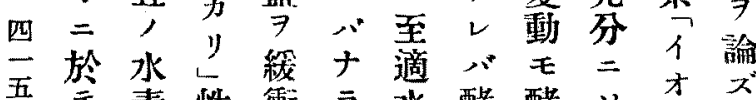

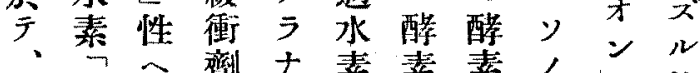

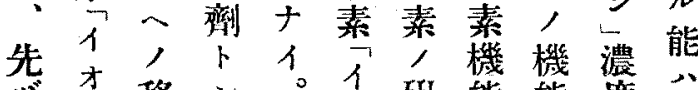

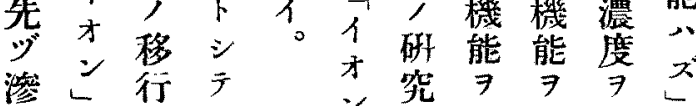

出濃罡選
云至。位血○高比○人示モ

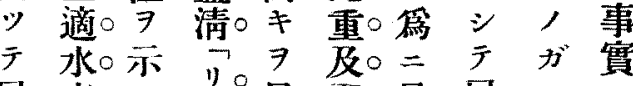

居素○シパ見蛋。最居アハ

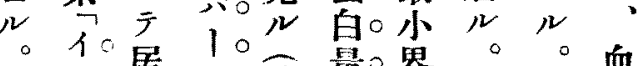

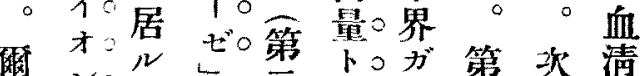

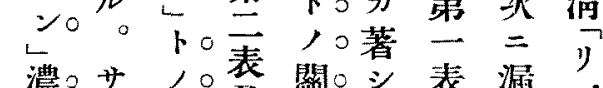

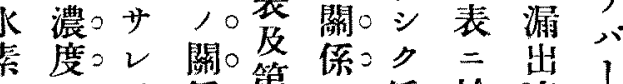

亿西牦第多等出!

才素y雨表多少七漏就傮

學, 液拍, 心出需,

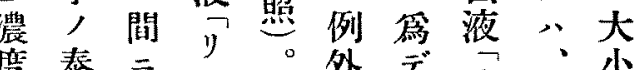

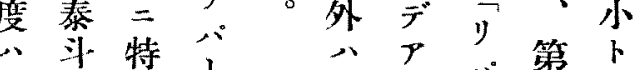

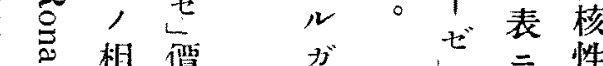

大 價二性

影關测體少尔

笠官係定 限如,

八下於界》豫

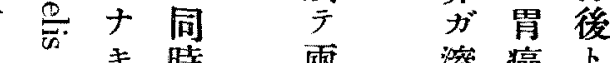

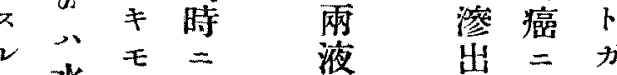

永, 测液就大

，䇣，定车方體

デイ如シ 比夫大一

オク重二影䡒致

ツンデル 及比高ス

于澧〉該蛋位ル

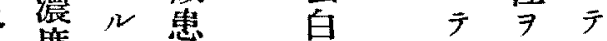

著量著示

度

'

血多多要

清

)

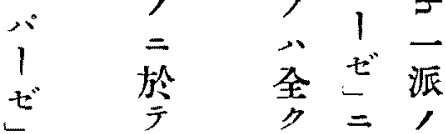

價可此於說

總 八人

稳 1 子著再

テ ゼ フ ク相

遙價只低通

$=\quad \varepsilon$

高亦 
第五表 至適温度

(其 - )

\begin{tabular}{|c|c|c|c|}
\hline \multirow{2}{*}{$\begin{array}{l}\text { 潈度 } \\
\text { (c) }\end{array}$} & \multicolumn{2}{|c|}{ 落下临 数 } & \multirow{2}{*}{ 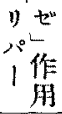 } \\
\hline & 直後 & 百分後 & \\
\hline 0 & 143 & 143 & 0 \\
\hline 10 & 145 & 144 & 1 \\
\hline 20 & 152 & 147 & 5 \\
\hline 80 & 158 & 150 & 8 \\
\hline 40 & 166 & 144 & 22 \\
\hline 50 & 175 & 170 & 5 \\
\hline 60 & 184 & 182 & 2 \\
\hline 70 & 182 & 181 & 1 \\
\hline 80 & 185 & 185 & 0 \\
\hline
\end{tabular}

(其 二)

\begin{tabular}{|c|c|c|c|}
\hline \multirow{2}{*}{$\begin{array}{l}\text { 溜筧 } \\
\text { (C) }\end{array}$} & \multicolumn{2}{|c|}{ 落下湖站 } & \multirow{2}{*}{ 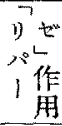 } \\
\hline & 值崚 & 百分後 & \\
\hline 32 & 164 & 154 & 10 \\
\hline 34 & 164 & 148 & 21 \\
\hline 36 & 165 & 139 & 26 \\
\hline 38 & 165 & 139 & 26 \\
\hline 40 & 166 & 144 & 22 \\
\hline 42 & 168 & 153 & 15 \\
\hline 44 & 170 & 162 & 8 \\
\hline 46 & 173 & 167 & 6 \\
\hline 48 & 175 & 170 & 5 \\
\hline
\end{tabular}

利對毒○デテ用度至っっレ檢淮

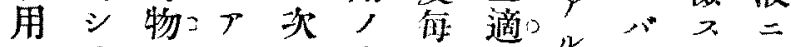
七 $\bar{\gamma}=0 N=$ 出二㵽。弱 $N$ 就

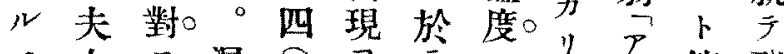

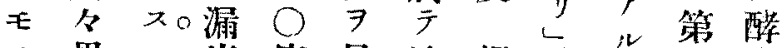

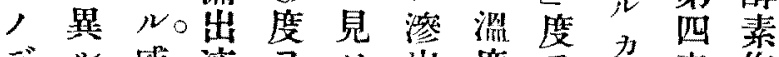
デル威。液 $、 y$ 出度 $\ni$ 態受。亦中 $v$ 液モ以乞其用演

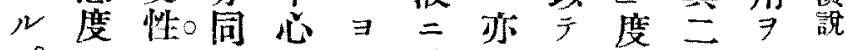

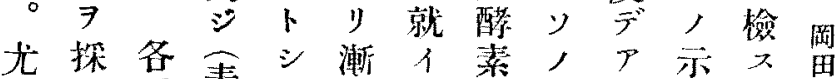
モル種昶 $テ$ 次, 至ルスル 近 コ省更曙、機適。如卜》 来、り略二强》能水漏》七パ

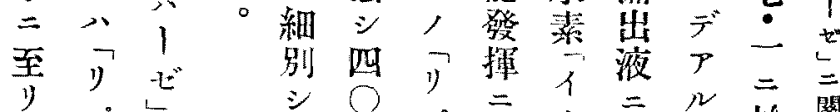

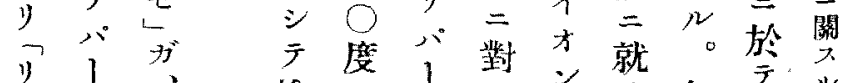

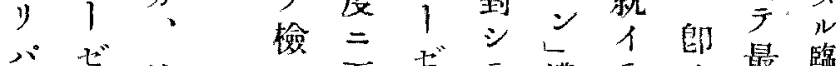

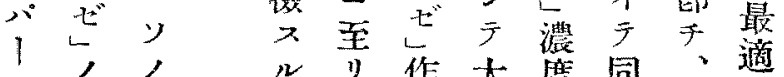

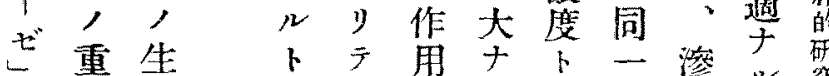

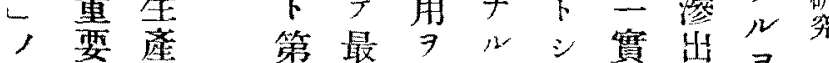
毒大毒五强拾影 $テ$ 驗液

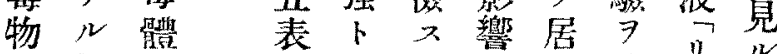
二性 $\exists$ 其十 對狀異 三り卜有コ行少 x =

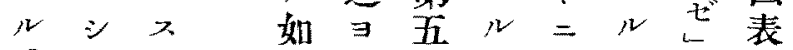
威 $テ ル y$ 表モ悢二, 其 受り二デ再其人秋至二

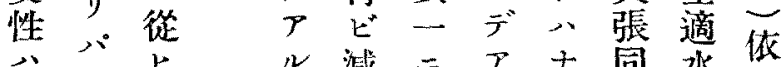

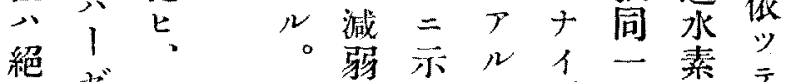

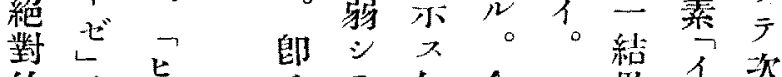

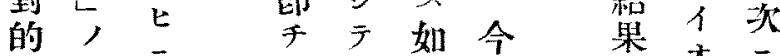
, 診二八刀攝、

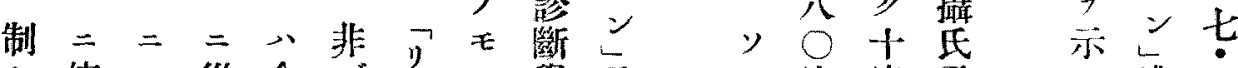
七佊ン從今 ズ, 分學及

ラ 9 及

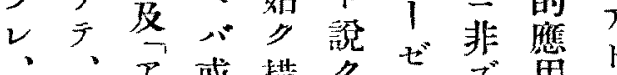

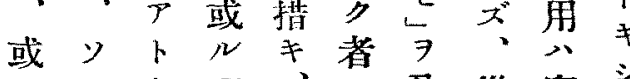

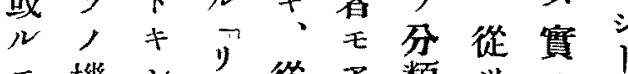
モ機 $シ ハ$ 従 $r$ 類 $ツ=1$ , 能 1 只柬 八 ル 境ドル之, , 何著七七゙カ、心三特雨 等 人夕存口、人常り性物 影抑在七所說 $=テ 7=$
, 度 答

至 二 三 度

適至於寻

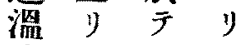

度

졷

三名植 度

六消微二

少先金 至不

三。醍

公依素各 度当作十
又濃 一

表度

省公中 略七心

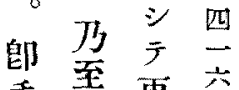
手至更 兩三細 液 換 分 共 三 弱 ス 
第 七 表 毒物二對スル感受性

\begin{tabular}{|c|c|c|c|c|c|}
\hline \multirow{2}{*}{ 菲 } & \multirow{2}{*}{ 物 } & \multicolumn{2}{|c|}{ 落下洏数 } & \multirow{2}{*}{$\begin{array}{l}\text { リゼ } \\
\text { 代 } \\
\text { 1作 } \\
\text { 用 }\end{array}$} & \multirow{2}{*}{$\begin{array}{l}\text { 影 } \\
\text { 堙 }\end{array}$} \\
\hline & & 直後 & 百分徭 & & \\
\hline 蕟罶 水 & 期) & 155 & 185 & 30 & 無 \\
\hline \multirow{3}{*}{ 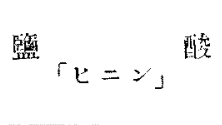 } & $0.1 \mathrm{~ms}$ & 155 & 140 & 15 & 弱抑制 \\
\hline & 1.0. & 155 & 146 & 9 & 独抑制 \\
\hline & 10.0. & 155 & 151 & 4 & ", \\
\hline \multirow{3}{*}{ 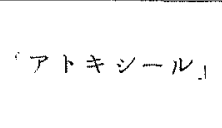 } & $0.1 \mathrm{mg}$ & 155 & 151 & 14 & 弱抑制 \\
\hline & $10 \quad$. & 155 & 174 & 8 & 强拥制 \\
\hline & 10.0, & 155 & 149 & 6 & , \\
\hline \multirow{3}{*}{ 非 化 聙 達 } & $0.1 \mathrm{mg}$ & 155 & 132 & 23 & 弱抑制 \\
\hline & $1.0 \ldots$ & 155 & 146 & 9 & 强抑制 \\
\hline & $10.0 .$. & 155 & 150 & 5 & $"$ \\
\hline \multirow{3}{*}{ 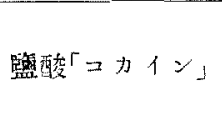 } & $0.1 \mathrm{mg}$ & 155 & 134 & 21 & 弱抑制 \\
\hline & 1.0, & 155 & 146 & 9 & 强抑制 \\
\hline & 10.0. & 155 & 148 & 7 & $"$ \\
\hline \multirow{3}{*}{ 硝 } & $0.1 \mathrm{mg}$ & 155 & 141 & $1 J_{x}$ & 弱抑制 \\
\hline & 1.0, & 155 & 148 & 7 & 强抑制 \\
\hline & $10.0 .$, & 155 & 152 & 3 & $"$ \\
\hline
\end{tabular}

第六表「リパーゼ」分類

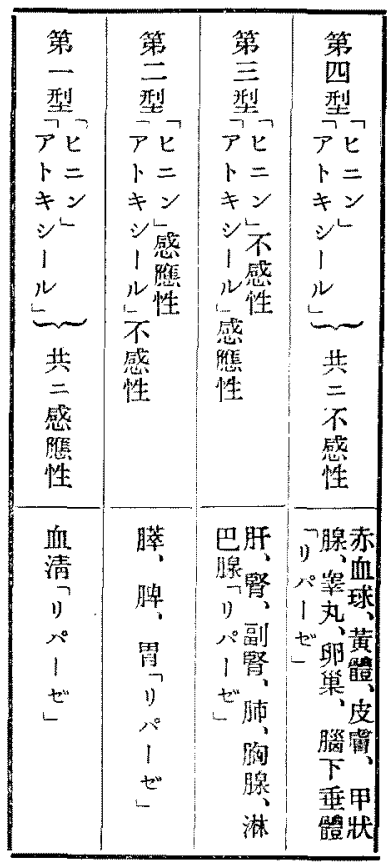

總ッニ示ア上数, 是出キス檢り $ォ$ 而ズ制響

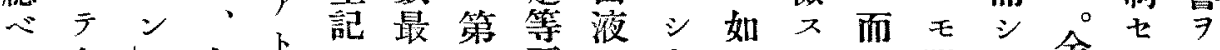

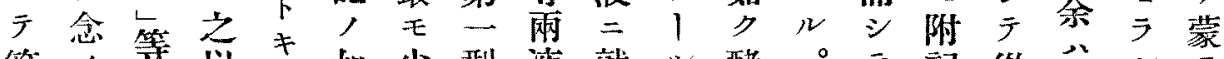

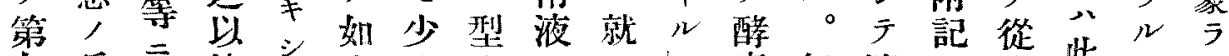

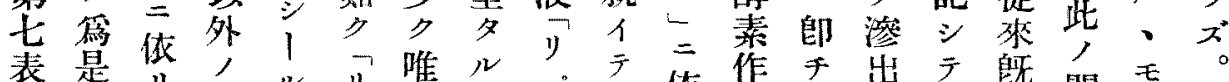

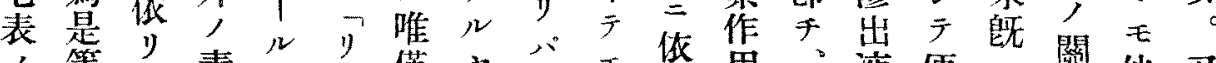
示, 等毒 青更物的

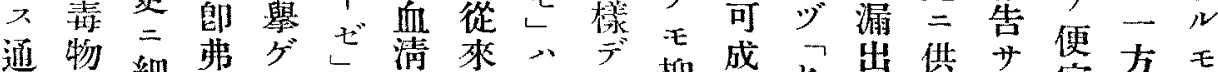

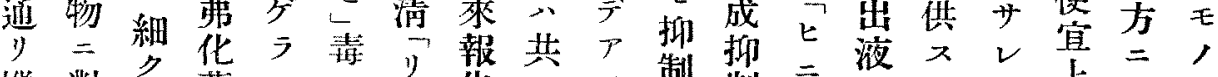

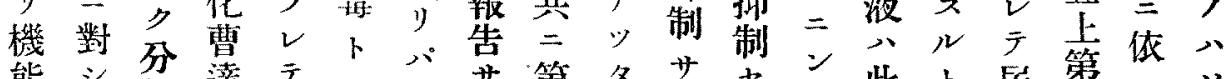

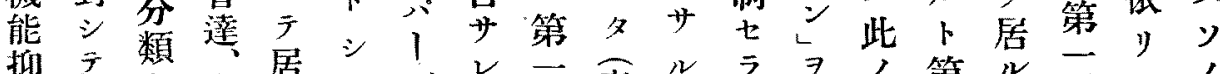
抑

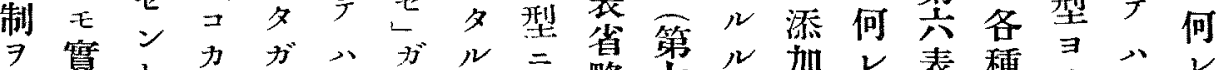

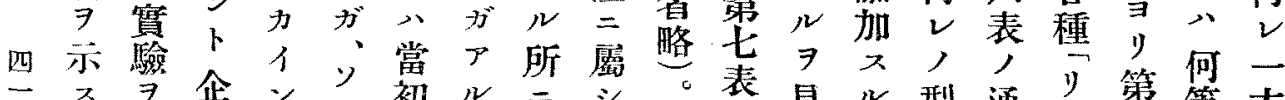

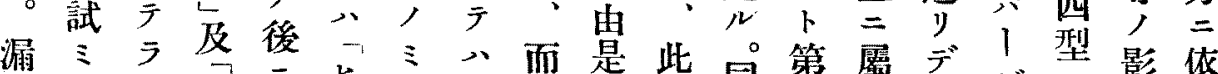

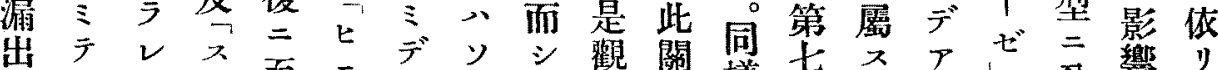

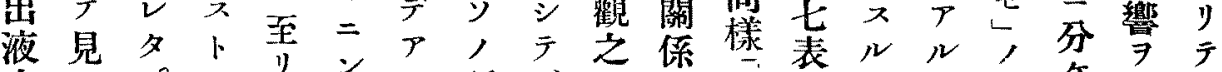

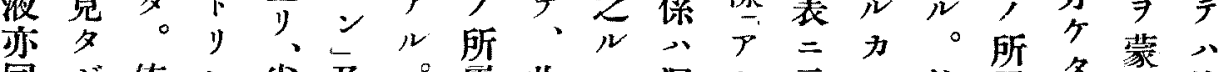

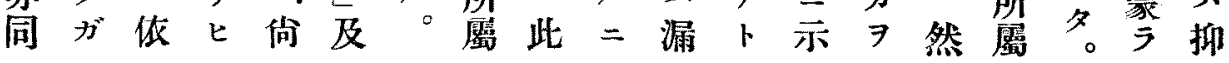


期サ而緒。

及 $レ$ シ 言。

ビルテ

勞 非筋 筋

作 酸 收 肉

後 化 縮 勞

向過, 作

回程際,

復>際

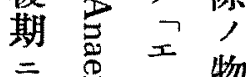

於兽尒貿

ケず帒

酸〔门謝

化 , 就

作 品 根 亏

用 $=$ 源

$=$ 在

寻少寻

再 $卜$

艺昘以

貯 $\bar{~}$ 前

藏居突少

レ等多

此, 多

事此研,

二筋究 學

ナ肉二者

。勞 $\exists=$

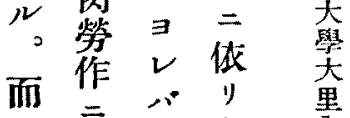

* $=$ 牲

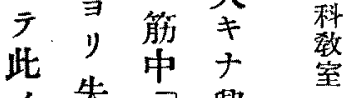

，失 分興

エ

$\begin{array}{lll}2 & 2 & 7 \\ 2 & 3 & \end{array}$

ギル年本里

1 エ

々于 学等

筒乳亏龍 俟

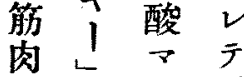

人, ラ゙居 雄吾

ナ勞分少。

シ 作 解
溫数二附。境的總。， ジ

水

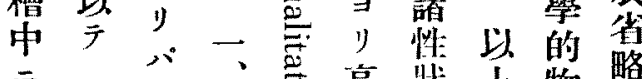
於り 、本焉高狀志物略 テうせ題二, ‘

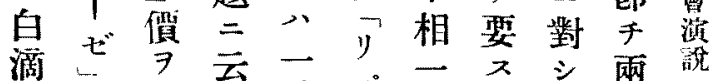
스 榈 二㑩表フ致ハ致ルテ液火 满表ス所ジ゙ス二抑方里

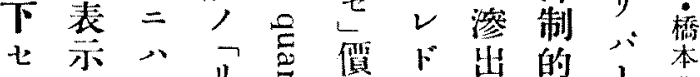

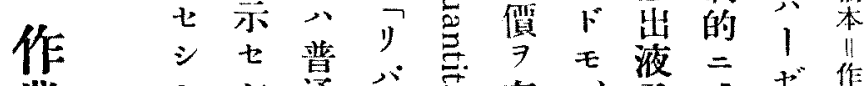

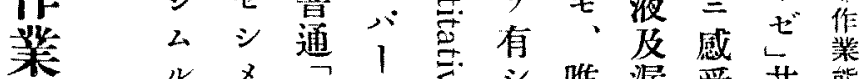
能 モタブゼをシ、唯漏受共熊

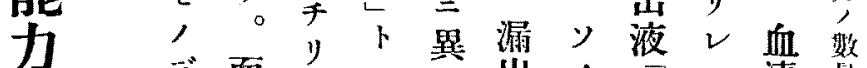

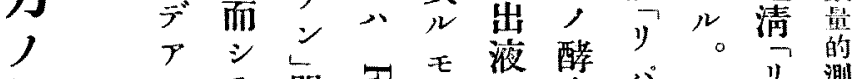

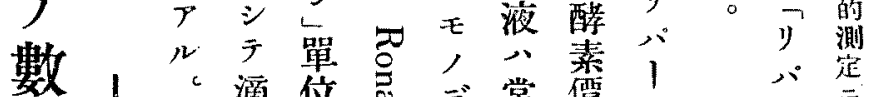

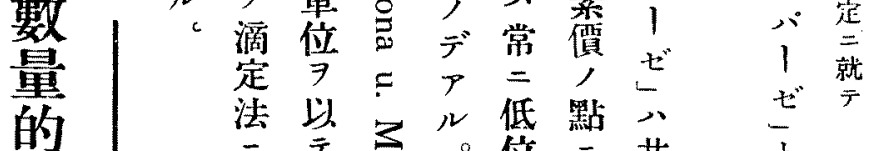
定 法号觉。低駔共 使 $x$ 景, 至共 同

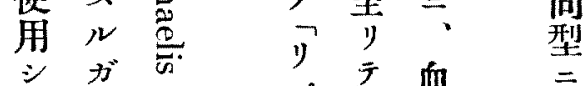

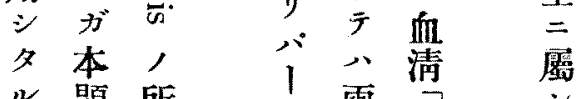
少題所 ビ雨 す ピテ價間

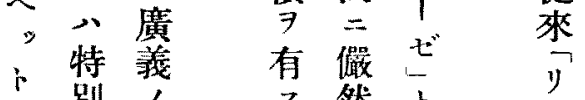
×別人齐然占只

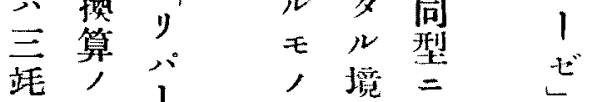

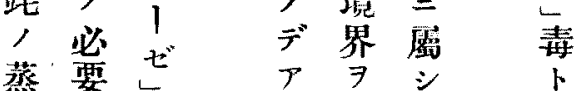
ᄀ 7 \% 餾モデル存、シ

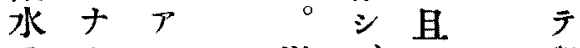
$\exists$ ケ 以・举 攝レ・上櫒雨品四 氏萑出者 $5 \overrightarrow{\text { 八 }}$ 声便宣言液 八上 $上$ 常, 儿 度隇壬二醉總 


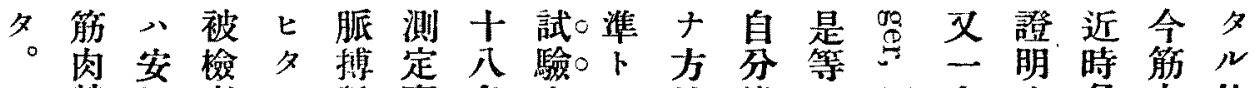
勞静者り數事名方。ナ法達, 方方各肉仕

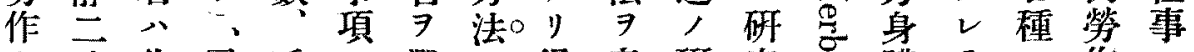
卜時先尿呼八選得索研究急體テ, 作二

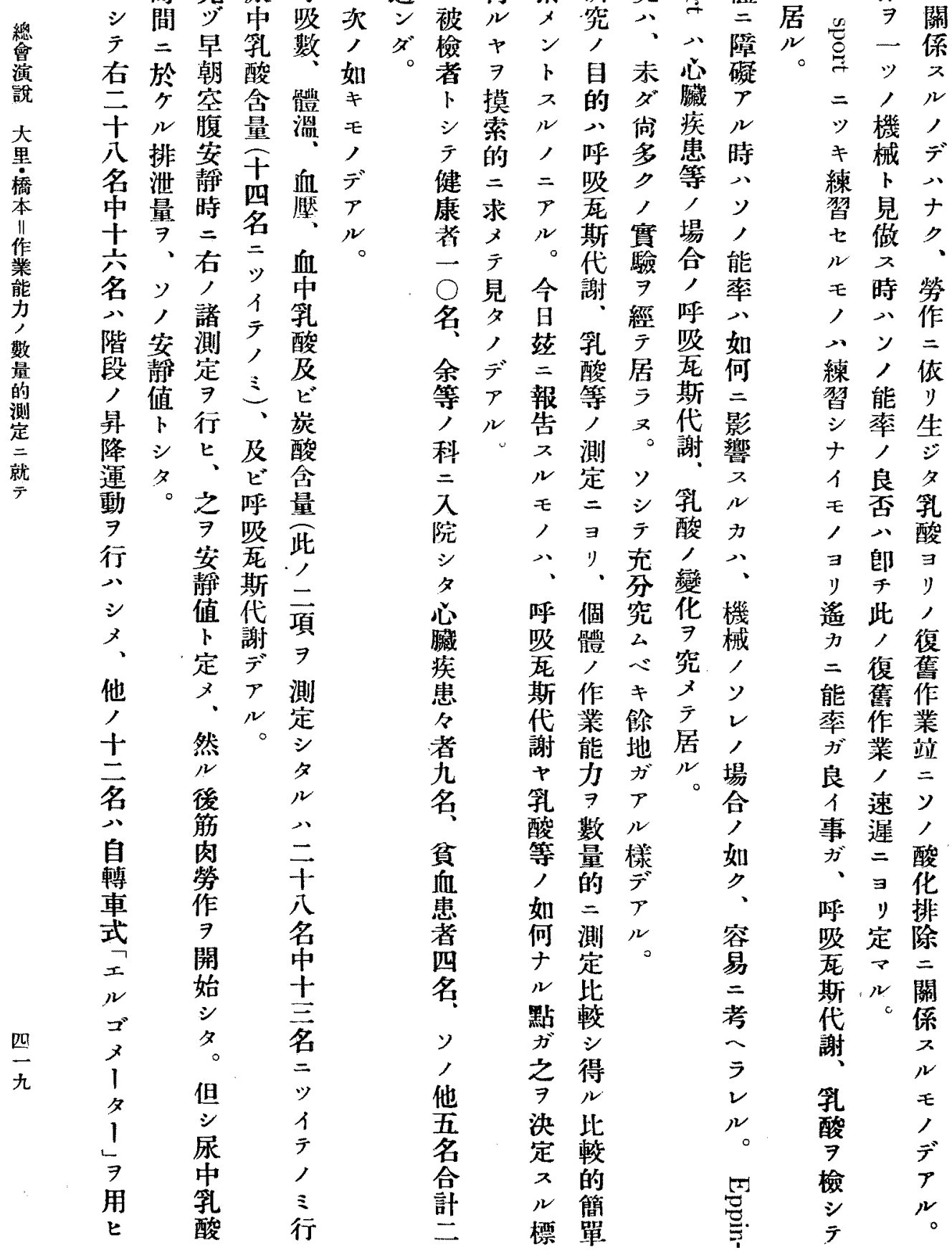




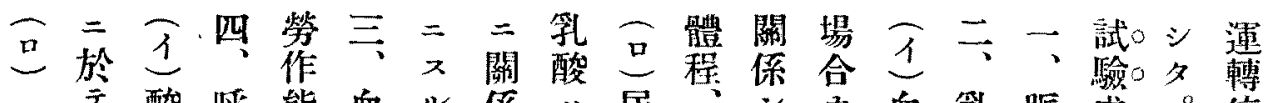

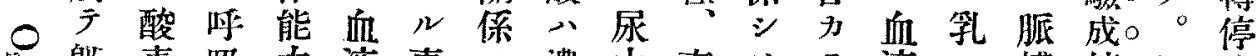

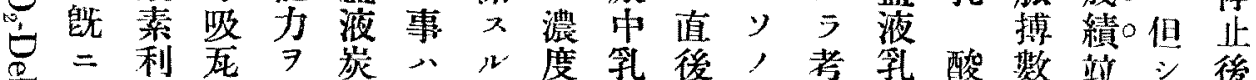

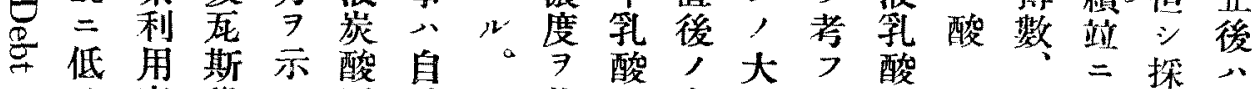

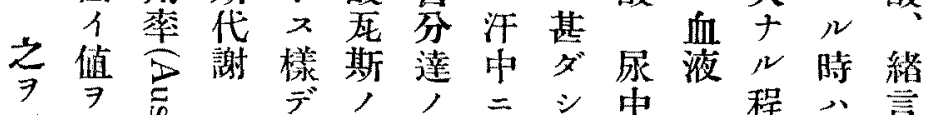

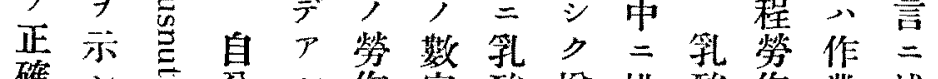
確言分公作学酸獒排酸作業述

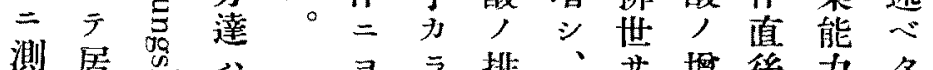

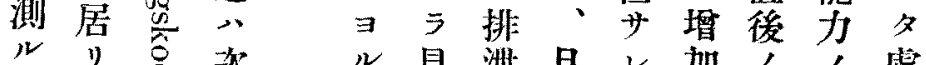
事策总次見池且上加, 處

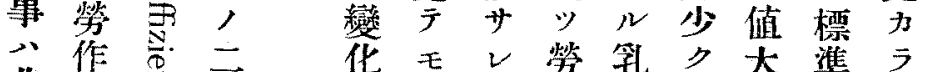

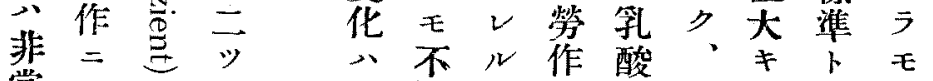
常 $\exists$ 點太適事後, 等, 勞

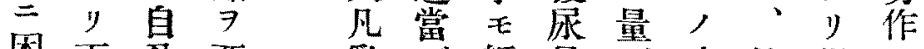
困更分要乳害既量 量時且得= 難三達約酸子知夏、間 \%依 $\vec{Y}$ 低,,$儿$, 墄勞的y事》

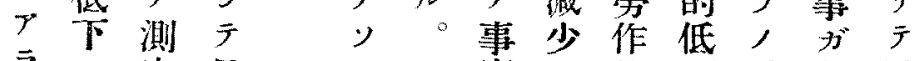
今定見 2 賔三能下低考瞥 ウ。其人等關力

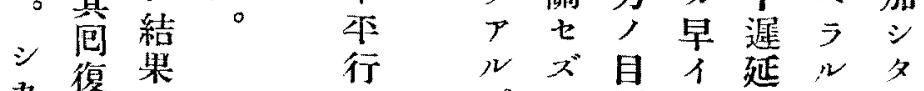
为蕧果

首才—

尊光般 達

只怘

作疾

糋患

思標

等开

等, 健

業得康

績壬著

ラ、ラ゙些

勞? 晏

作少。静

$$
\text { x }
$$

s

事

知

䓡

夕

ソ层云就

市。京

广

Y

乳

八排三出

乳泄》ラ

酸量算云

平

行業, 榷

号尔核

微

妙
'量,

貝票大尿
不。血

筫 液

* 際笔

王直 酸

同尔

同洼 排

量試,

, 歌 僬

勞 = 速

作於 心

テ 学

、E

ソ 、個

, 血 體

勞 液

作笔引

能 酸 續

力八

第 䇨

大作作

F,

量

個 $=$
味考。血直䉥 吸菜。面直演 蹬試徭再大 溫 羷三

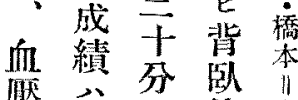
盟 後位作

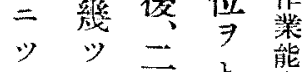

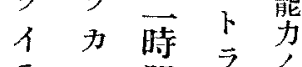
$\bar{\gamma}=$ 䦖 分盈後 学量 徥 戸三直测

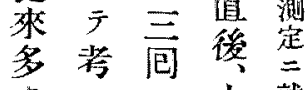
）二止妿 齐見名得 䠞多。文二 厂尿十 v中分 , 箝 後 デ酸 三 聯運辜 ․ 動 分 盼 始 分等 後 時 等唯 數 步 後 字示 持 表間間 示排後

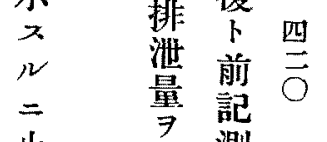
此 测 测 年定定

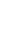

$=$ 


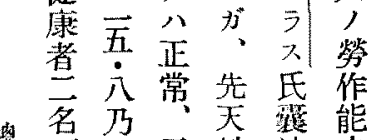

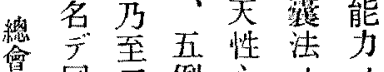

演同云例心,

留夕例 シ 名偑

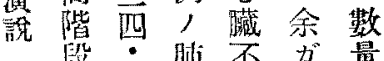

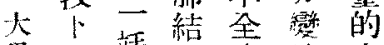

里降㲎核症法表

摩,

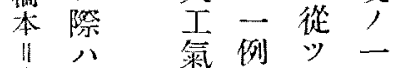

作八胸 デテッ

業乃鼠八測夕

能至 者云定兄

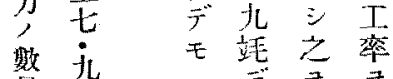

量起

的同般 T 䍋 測

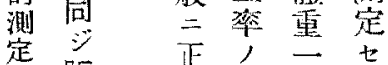

定距 焉低宜

就䍊籍下相卜

本園 篦 シ

面 デ示量テ。

步省光高

行古暧算

只症比九

× 特 心 較 米

名呼点多段

時吸门口。

六換氏健一

亲氮脑康分

七量男間

万苋氣女,

至進管六速

六 枝名 鬲

弃示㟨 デデ

空 息八倪

竓名愽一睨

渻例㪙八不

葓 亏゙休 三 際

正 $\mathbb{E}$ 常

四常時吕要

当㖞至

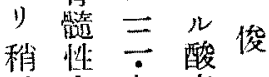

增白元素

大血犝消郎

示各 消 量

夕自合

呈

+ 分 $=$

ラ洼

ㄱ 可

更此 +

$=$,

都賽 $\exists$

合驗 ク

追寻 学他

作 简 關

業 多係

加能少師

少不 $千$

測 備 疲

定, 勞

標整

準 $\boldsymbol{\gamma}$ 他

+2,

ナ。關

令係

力 日

小大

今凡芫

後自为

，分個

研 澾 體

然心,

二 一作

俟定 業

夕人能

夕標 打

r準

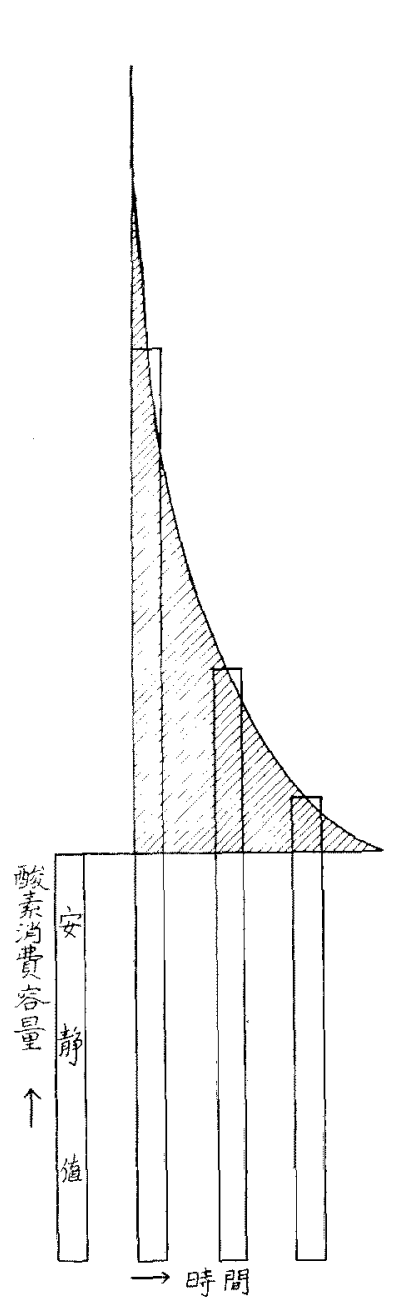

又 際

事 酸

7 溸

知

消

テ 費

又 7 -

居》

儿得致

自直

八高

便 值

直

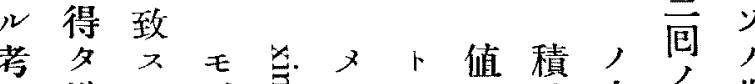

人倳儿、总テシ

デ二樣個自、践 プ法吸線

ア思二體, 名仕二フラ゙竖心

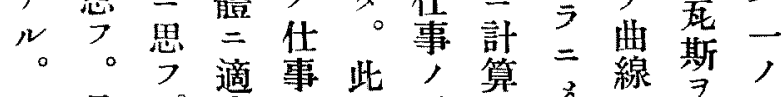

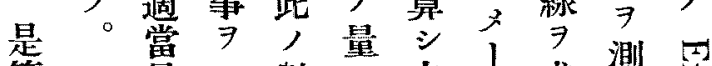

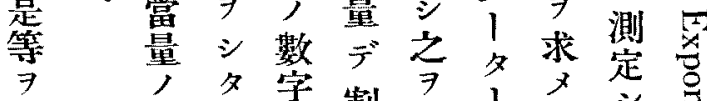

如仕場学割假 ᄂ 、 、

何事合素 = 至圖之寻

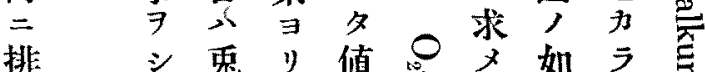

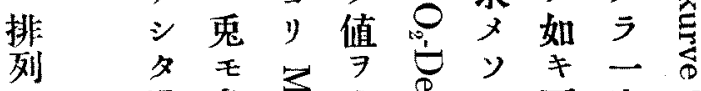

シ一費

湯角求总, 面定 